ISSN: 2306-9716 (Print) ISSN: 2664-6110 (Online)

МІНІСТЕРСТВО ЗАХИСТУ ДОВКІЛЛЯ ТА ПРИРОДНИХ РЕСУРСІВ УКРАЇНИ ДЕРЖАВНА ЕКОЛОГІЧНА АКАДЕМІЯ ПІСЛЯДИПЛОМНОЇ ОСВІТИ ТА УПРАВЛІННЯ

\title{
ЕКОЛОГІЧНI НАУКИ
}


Екологічні науки : науково-практичний журнал / Головний редактор Бондар О.I. - К. : Видавничий дім «Гельветика», 2021. - № 6(39). - 224 с.

Головний редактор: Бондар О.І., доктор біологічних наук

Заступник головного редактора: Нагорнева Н. А.

Науковий редактор: Машков О.А., доктор технічних наук

Відповідальний редактор: Сікачина В. Г.

\section{Редакційна колегія:}

Гандзюра В.П., доктор біологічних наук

Єрмаков В.М., доктор технічних наук

Захматов В.Д., доктор технічних наук

Іващенко Т.Г., кандидат технічних наук

Коніщук В.В, доктор біологічних наук

Лукаш О.В., доктор біологічних наук,

Машков В.А., доктор технічних наук

Михайленко Л.С., доктор біологічних наук

Нецветов М.В., доктор біологічних наук

Ольшевський С.В., доктор технічних наук

Риженко Н.О., доктор біологічних наук

Рудько Г.І., доктор геолого-мінералогічних наук,

доктор географічних наук, доктор технічних наук

Улицький О.А., доктор геологічних наук

Фінін Г.С., доктор фізико-математичних наук

Шматков Г.Г., доктор біологічних наук

На підставі Наказу Міністерства освіти і науки України № 409 від 17.03.2020р. (додаток 1) журнал внесений до Переліку наукових фахових видань України (категорія «Б») у галузі біологічних наук (091 - Біологія), природничих наук (101 - Екологія, 103 - Науки про Землю) та технічних наук (183 - Технології захисту навколишнього середовища).

Журнал публікує (після рецензування та редагування) статті, які містять нові теоретичні та практичні здобутки в галузі екологічних наук.

Статті у виданні перевірені на наявність плагіату за допомогою програмного забезпечення StrikePlagiarism.com від польської компанії Plagiat.pl.

Журнал включено до міжнародної наукометричної бази Index Copernicus International (Республіка Польща) 


\section{MICT}

ЕКОЛОГІЯ І ВИРОБНИЦТВО

Бондар О.І., Гаєвський В.Р., Кочмарський В.З., Филипчук В.Л. Вплив ефективності роботи оборотних систем охолодження ТЕС на величину викидів діоксиду азоту ........................................

Козій І.С., Жиленко Т.І., Трунова I.O., Батальцев Є.В., Макаренко Н.О. Критерії вибору

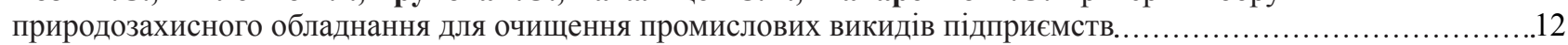

Красовський В.В., Черняк Т.В. Поступова реконструкція пришляхових насаджень у населених пунктах........19 Фатеєв А.І., Ясинецький А.О., Лазарєв Є.С. Екологічні аспекти використання вугілля з підвищеним вмістом натрію та хлору.

Бондар О.І., Закорчевна Н.Б., Крилова І.І. Фінансування сталого розвитку сфери водопостачання

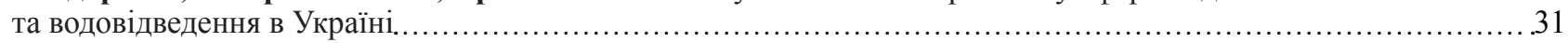

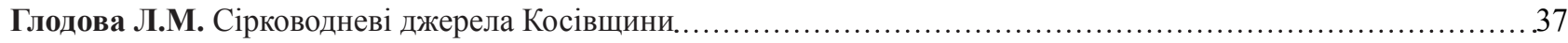

Ігнатишин В.В., Малицький Д.В., Іжак Т.Й., Вербицький С.Т., Ігнатишин А.В., Ігнатишин М.Б. Гідрогеологічний аспект екологічного стану Закарпаття за 2020 рік ................................................42

Курбатова І.М., Захаренко М.О., Тупицька О.М. Еколого-токсикологічна оцінка природних водойм

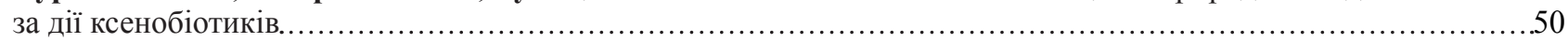

Степова О.В., Гах Т.О., Тягній Л.М. Стан поверхневих водних об’єктів Полтавської області.......................58

ЕКОЛОГІЯ ТА ЕКОНОМІКА ПРИРОДНИХ РЕСУРСІВ

Блінова Н.К., Філатьєва Е.М., Скарга В.В. Визначення параметрів зсуву земної поверхні

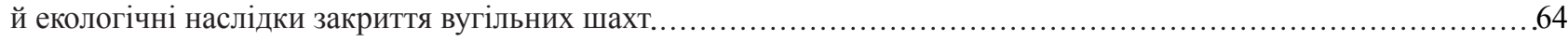

Борецька I.Ю., Джура Н.М., Романюк О.І. Фіторемедіація техногенно забруднених грунтів

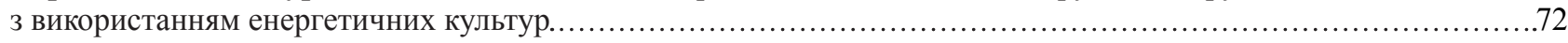

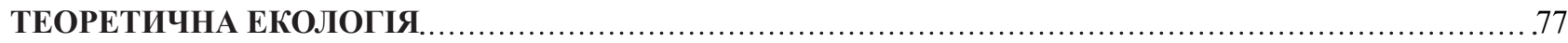

Kuznyetsov S.I., Maljejev V.O., Sevenchenko O.O., Bezpalchenko V.M. Thermal conversion of nitrogen oxides

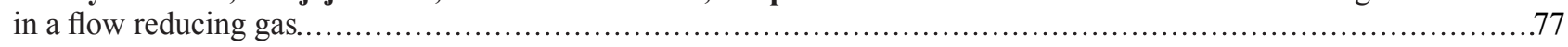

Матіс Є.О., Крот О.П. Модель формування методів оцінки екологічних ризиків для окремих складних систем. ..... 81

Романенко О.В., Груша М.М. Біоетичні аспекти методології гідробіологічних досліджень...........................91

Руда М.В., Шибанова А.М., Паславський М.М., Джумеля Е.А. Моделювання станів складного

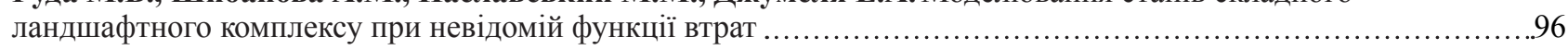

Русин І.Б., Медведєв О.В., Дячок В.В. Конструювання мультиелектродних електро-біосистем з Lemna minor.......103

Юнгін О.С., Прекрасна Є.П., Ластовецька Л.О., Маслак В.І., Кудіна С.В. Дослідження

фізіолого-біохімічних особливостей та біоплівкоутворення бактерій, виділених

із судинних рослин Антарктики......

БІОЛОГІЧНА БЕЗПЕКА

Колісник А.В. Оцінка канцерогенного ризику хронічної інтоксикації населення від забрудненого атмосферного повітря.

Мазур Т.Г., Загоруй Л.П., Димань Т.М., Богатко Н.М., Гриневич Н.Є. Особливості організації екологічно безпечного харчування студентів за різних форм навчання в умовах COVID-19.

Сараненко I.I., Шадура К.О. Вплив вихлопних газів автотранспорту на генеративні органи представників роду Acer $\mathrm{L}$

Чепель А.Є., Кофанова О.В., Свтєєва Л.І. Оцінювання ризику для здоров'я дітей і дорослого населення міст від шкідливого впливу викидів автотранспорту.. 
Гунько С.О., Володько Д.А. Міграція мангану в грунтах біогеоценозів степового Придніпров’я (на прикладі Дніпропетровської області).

Красовський С.А., Ковров О.С., Клімкіна І.І. Визначення фізико-хімічних параметрів вугільного відвалу ДТЕК ШУ «Героїв Космосу».

Луцишин О.3., Гілета Л.А. Міське садівництво в умовах Львівської урбоекосистеми: можливості та переваги......141

Маркіна Л.М., Жолобенко Н.Ю., Ушкац С.Ю., Плахтіна О.І. Визначення напрямів екологічних проблем,

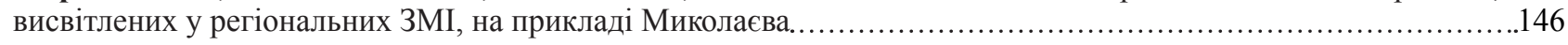

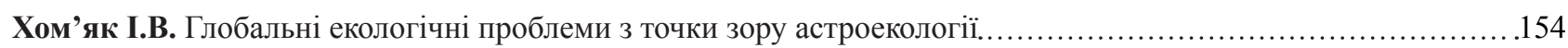

ЗМІНА КЛІМАТУ.

Польовий А.М., Овчарук В.А., Вольвач О.В., Кущенко Л.В., Толмачова А.В. Агрокліматична оцінка посушливості вегетаційного періоду в Причорноморській зоні надзвичайно низької водності.

Коцюба І.Г., Лефтер Ю.О., Нонік Л.Ю., Сльнікова Т.О., Герасимчук О.Л. Аналіз сучасного досвіду та напрямів вирішення проблем управління твердими комунальними відходами. ....

Голік Ю.С., Смоляр Н.О., Остапенко П.О., Чепурко Ю.В. Особливості розподілу територій і об’ єктів природно-заповідного фонду Полтавської області в умовах нового

адміністративно-територіального устрою України.

Герман Н.В. Природний феномен Полісся Рівненщини.

Зубровська О.М. Індукція захисних реакцій у рослин Zea mays L. (Poaceae) в умовах посухи..

Клименко Т.К., Ісмагілова А.Є. Участь інвазійних видів рослин у формуванні рослинних угруповань у процесі відновлювальних сукцесій. .

Котюк Л.А., Іващенко І.В., Рахметов Д.Б., Борисюк Б.В. Сезонні ритми розвитку рослин Dracocephalum Moldavica за інтродукції в умовах Центрального Полісся України.....

Павлишак Я.Я., Кречківська Г.В. Синантропні рослини в урбанофлорі міста Новий Розділ Львівської області.

Хом’як І.В., Гарбар Д.А., Андрійчук Т.В., Костюк В.С., Власенко Р.П. Динаміка відновлюваної рослинності піщаних кар'єрів Житомирського Полісся..

Бондар О.І., Коцар О.М., Филипчук В.Л., Курилюк М.С., Лі Цзюнь. Розроблення та запровадження «зелених» технологій ревіталізації забруднених вод, повітря та порушених грунтів і запобігання їх виснаженню з використанням відновлювальних природних ресурсів та енергії сонця. ....

ОСВІТА ДЛЯ СТАЛОГО РОЗВИТКУ.

Дух О.І., Цицюра Н.І., Галаган О.К. Особливості формування у студентської молоді знань про зміни клімату......214 


\section{CONTENTS}

ECOLOGY AND PRODUCTION

Bondar O., Gayevskii V., Kochmarskii V., Fylypchuk V. Influence of the efficiency of the operation of the cooling systems of the TPP on the value of emissions of nitrogen dioxide.

Kozii I., Zhylenko T., Trunova I., Bataltsev Y., Makarenko N. Criteria for choosing environmental equipment for cleaning industrial emissions of enterprises.

Krasovsky V., Cherniak T. Progressive reconstruction of nearby plantations in settlements......

Fateiev A., Yasynetskyi A., Lazariev Ye. Environmental aspects of coal use with high sodium and chlorine content...24

ECOLOGY OF WATER RESOURCES.

Bondar O., Zakorchevna N., Krylova I. Financing sustainable development of water supply and wastewater

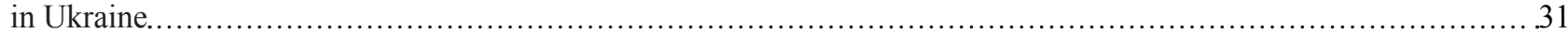

Glodova L. Hydrogen sulfur sources of Kosiv region. .

Ihnatyshyn V., Malytskyi D., Ihnatyshyn A., Izsák T., Ihnatyshyn M., Verbytskyi S. Hydrogeological aspect of Transcarpathia's ecological state in 2020 .

Kurbatova I., Zakharenko M., Tupytska O. Ecological and toxicological assessment of natural waters under the action of xenobiotics....

Stepova O., Gakh T., Tyagniy L. Condition of surface water objects of Poltava region................................58

ECOLOGY AND ECONOMICS OF NATURAL RESOURCE USE. .

Blinova N., Filatieva E., Skarha V. Determination of shiftstates of earth surface and ecological consequences of closing of coal mines.

Boretska I., Dzhura N., Romanyuk O. Phytoremediation of technogenically contaminated soils by means of energy crops

THEORETICAL ECOLOGY

Kuznyetsov S.I., Maljejev V.O., Sevenchenko O.O., Bezpalchenko V.M. Thermal conversion of nitrogen oxides in a flow reducing gas.

Matis Y., Krot O. Model of assessment environmental risks methods formation for individual complex systems.........81

Romanenko O., Hrusha M. Bioethical aspects of hydrobiological research methodology..........................91

Ruda M., Shybanova A., Paslavskyi M., Dzhumelia E. Modeling of states of a compound landscape complex with an unknown loss function.

Rusyn I., Medvediev O., Djachok V. Design of multi-electrode electro-biosystems with Lemna minor. ....

Yunhin O., Prekrasna Ye., Lastovetska L., Maslak V., Kudina S. Research of physiological and biochemical characteristics and biofilm formation of bacteria isolated from vascular plants of Antarctica.

Kolisnyk A. Assessment of carcinogenic risk of chronic intoxication of the population from polluted air. 110

Mazur T., Zahoruy L., Dyman T., Bogatko N., Grynevych N. Peculiarities of the organization of environmentally safe meals for students in different forms of study in the conditions of COVID 19

Saranenko I., Shadura K. Influence of vehicle exhaust gases on generative bodies of Acer L.

Chepel A., Kofanova O., Yevteyeva L. Assessment of the risk to the health of children and adults from the harmful effects of the motor transport emissions in cities.

Hunko S., Volodko D. Migration of manganese in the soils of biocenosis of steppe Pridnieprovie (on the example of Dnipropetrovsk Oblast)..... 
Krasovskyi S., Kovrov O., Klimkina I. Determination of physico-chemical characteristics of the coal dump "Heroiv Kosmosy".

Lutsyshyn O., Hileta L. City gardening in the conditions of Lviv urban ecosystem: opportunities and benefits.

Markina L., Zholobenko N., Ushkats S., Plakhtina O. Determination of directions of environmental problems covered in regional media on the example of Mykolayev.

Khomiak I. Global environmental problems in terms of astroecology.

Polevoy A., Ovcharuk V., Volvach O., Kushchenko L., Tolmachova A. Agroclimate assessment of vegetation drought period in the extremely insufficient low water content in the Black sea zone.

Kotsiuba I., Lefter Yu., Nonik L., Yelnikova T., Herasymchuk O. Analysis of current experience and directions of solving problems of solid municipal waste management......

Holik Yu., Smolyar N., Ostapenko P., Chepurko Iu. Peculiarities of distribution of objects and territories of the nature reserve fund of Poltava region in the conditions of the new administrative-territorial structure.

Herman N. Natural phenomenon of Polissya, Rivne region.

Zubrovska O. Induction of protective reactions in plants of Zea mays L. (Poaceae) under drought conditions.

Klymenko T., Ismagilova A. Participation of invasive plant species in the formation of plant communities during regenerative successions.

Kotiuk L., Ivashchenko I., Rakhmetov D., Borysiuk B. Seasonal rhythm of development of Dracocephalum Moldavica introduced in Central Ukrainian Polissya..

Pavlyshak Y., Krechkivska G. Synanthropic plants in the urban flora of Novy Rozdil, Lviv region.

Khomiak I., Harbar D., Andriichuk T., Kostiuk V., Vlasenko R. Dynamics of restoration vegetation of sand quarries of Zhytomyr Polissya.

INNOVATIVE ASPECTS OF THE LEVEL INCREASE OF ENVIRONMENTAL SAFETY

Bondar A., Kotsar E., Fylypchuk V., Kuryliuk M., Li Jun. Development and implementation “green" technologies revitalization polluted water, air and soil with violations of renewable natural resources and energy of sun and depletion of prevention.

EDUCATION FOR SUSTAINABLE DEVELOPMENT.

Dukh O., Tsytsyura N., Galagan O. Peculiarities of forming the student youth's knowledge about climate change...... 


\title{
ВПИИВ ЕФЕКТИВНОСТІ РОБОТИ ОБОРОТНИХ СИСТЕМ ОХОАОДЖЕННЯ ТЕС НА ВЕАИЧИНУ ВИКИДІВ ДІОКСКДУ АЗОТУ
}

\author{
Бондар О.І. ${ }^{1}$, Гаєвський В.Р. ${ }^{2}$, Кочмарський В.3. ${ }^{2}$, Филипчук В.Л. ${ }^{2}$ \\ ${ }^{1}$ Державна екологічна академія післядипломної освіти та управління \\ вул. Митрополита Василя Липківського, 35, корп. 2, 03035, м. Київ \\ ${ }^{2}$ Національний університет водного господарства та природокористування \\ вул. Соборна, 11, 33028, м. Рівне \\ dei2005@ukr.net, v.r.haievskyi@nuwm.edu.ua,
}

В Україні за 2020 рік частка ТЕС та теплоелектроцентралей (ТЕЦ) у виробництві електроенергії становила $36,2 \%$. Зменшення енергоємності таких об'єктів означає загальне істотне зменшення екологічних ризиків навколишнього середовища. Для екологічної роботи ТЕС необхідне раціональне використання оборотних систем охолодження (ОСО), оскільки підвищення температури оборотної води ОСО зменшує величину вакууму в конденсаторі турбіни і таким чином знижує потужність турбіни, що призводить до збільшення споживання палива та води.

Під час спалювання палива на ТЕС в атмосферу потрапляє значна кількість шкідливих речовин, зокрема тверді частинки (зола), діоксид азоту $\left(\mathrm{NO}_{2}\right)$, діоксид сірки $\left(\mathrm{SO}_{2}\right)$, оксид і діоксид вуглецю $\left(\mathrm{CO}, \mathrm{CO}_{2}\right)$ та викиди тепла. Діоксид азоту є шкідливою токсичною сполукою, належить до 3-го класу небезпеки і відноситься до парникових газів. Надлишок $\mathrm{NO}_{2}$ безпосередньо викликає респіраторно-легеневі захворювання, разом з іншими речовинами призводить до синергетичного негативного ефекту і тому потребує видалення з різних газових середовищ. $\mathrm{NO}_{2}$ утворюється під час спалювання вугілля завдяки окисленням атомарного азоту, що міститься у вугіллі, а також молекулярного азоту, що міститься в атмосфері. Зменшення утворення $\mathrm{NO}_{2}$ можна досягти різними технологічними режимами горіння та хімічними методами очищення.

Здійснено розрахунок викидів діоксиду азоту на прикладі TЕС потужністю $2500 \mathrm{MB}$, що спалює $6 \cdot 10^{9}$ кг вугілля марки АСШ за рік та зроблена оцінка наслідків недостатньо ефективної роботи ОСО. Для розрахунку викидів $\mathrm{NO}_{2}$ використано методику, що враховує особливості технології спалювання палива. Розрахунками визначено, що валові викиди $\mathrm{NO}_{2}$ становлять 38,48 тис. т за рік, а контамінаційний еквівалент енергії (КЕЕ) - 0,307 кг на один ГДж виробленої електроенергії. За номінальною потужністю турбін і річними затратами вугілля марки АСШ розраховано, що недогрів води ОСО лише на $1^{\circ} \mathrm{C}$ призведе до надлишкових викидів $\mathrm{NO}_{2} 0,385$ тис. т на рік.

Порівнюючи концентрацію $\mathrm{NO}_{2}$ у димових газах із ГДК робочої зони (для $\mathrm{NO}_{2}$ ГДКрз $=2$ мг/м³), визначено рівень ступеня очищення димових газів до необхідних санітарно-гігієнічних норм, що має становити 99,8\%. Такий результат засвідчує необхідність глибокого очищення димових газів ТЕС від $\mathrm{NO}_{2}$ з використанням комплексних технологій. Ключові слова: теплоелектростанції, оборотні системи охолодження, викиди двоокису азоту, гранично допустимі концентрації робочої зони, ефективність очищення.

Influence of the efficiency of the operation of the cooling systems of the TPP on the value of emissions of nitrogen dioxide. Bondar O., Gayevskii V., Kochmarskii V., Fylypchuk V.

In Ukraine, in 2020, the share of thermal power plants (TPP) and combined heat and power plants (CHP) in electricity production was $36.2 \%$. A decrease in the energy intensity of such facilities means an overall significant reduction in environmental risks of the environment. For the ecological operation of TPP, the rational use of circulating cooling systems (CCS) is necessary, since an increase in the temperature of the circulating water CCS reduces the amount of vacuum in the turbine condenser and thus reduces the turbine power, which in turn leads to an increase in fuel and water consumption.

When fuel is burned at TPPs, many harmful substances are released into the atmosphere, such as particulate matter (ash), nitrogen dioxide $\left(\mathrm{NO}_{2}\right)$, sulfur dioxide $\left(\mathrm{SO}_{2}\right)$, carbon monoxide and dioxide $\left(\mathrm{CO}, \mathrm{CO}_{2}\right)$ and heat emissions. Nitrogen dioxide is a harmful toxic compound, belongs to the 3rd hazard class and belongs to greenhouse gases. Excess $\mathrm{NO}_{2}$ directly causes respiratory and pulmonary diseases, together with other substances leads to a synergistic negative effect and therefore requires removal from different gas media. $\mathrm{NO}_{2}$ is formed during the combustion of coal due to the oxidation of atomic nitrogen contained in coal, as well as due to the oxidation of molecular nitrogen contained in the atmosphere. Reducing the formation of $\mathrm{NO}_{2}$ can be achieved by various technological modes of combustion and chemical cleaning methods.

In this work, the calculation of nitrogen dioxide emissions was carried out using the example of a thermal power plant with a capacity of $2500 \mathrm{MW}$, which burns $6 \cdot 109 \mathrm{~kg}$ of ASH coal per year, and an assessment of the consequences of insufficiently effective operation of the CCS was made. To calculate $\mathrm{NO}_{2}$ emissions, a methodology was used that takes into account the peculiarities of fuel combustion technology. Calculations have established that the gross $\mathrm{NO}_{2}$ emissions are 38.48 thousand tons per year, and the contaminated energy equivalent (CEE) is $0.307 \mathrm{~kg}$ per one GJ of generated electricity. Based on the nominal power of the turbines and the annual consumption of ASH coal, it is calculated that the underheating of the CCS water by only $1{ }^{\circ} \mathrm{C}$ will lead to excess $\mathrm{NO}_{2}$ emissions of 0.385 thousand tons per year. 
Comparing the concentration of $\mathrm{NO}_{2}$ in flue gases with the MPC of the working area (for $\mathrm{NO} 2 \mathrm{MPCwa}=2 \mathrm{mg} / \mathrm{m}^{3}$ ), an assessment was made of the degree of purification of flue gases to the necessary sanitary and hygienic standards, which should be $99.8 \%$. This result indicates the need for deep cleaning of flue gases from TPP from $\mathrm{NO}_{2}$ using complex technologies. Key words: thermal power plants, circulating cooling systems, nitrogen dioxide emissions, maximum permissible concentrations of the working area, cleaning efficiency.

Постановка проблеми. Однісю 3 найбільш забруднюючих атмосферу галузей промисловості $\epsilon$ теплова енергетика, і тому зменшення емісії шкідливих газів, зокрема діоксиду азоту, є важливою екологічною проблемою. Відповідно, режим експлуатації теплових електричних станцій (ТЕС) має відповідати екологічним нормативам [1]. В Україні за 2020 рік згідно із [2] частка ТЕС та теплоелектроцентралей (ТЕЦ) становила $36,2 \%$, і тому зменшення енергоємності таких об'єктів означає загальне істотне зменшення екологічних ризиків навколишнього середовища в країні.

Аналіз останніх досліджень і публікацій. Для ефективної роботи ТЕС необхідне постійне відведення тепла (отримання 1 Дж електричної енергії вимагає відведення 1,5 Дж тепла). Тепло на ТЕС відводиться за допомогою оборотних систем охолодження (ОСО), і тому основним ресурсом, необхідним для роботи електростанцій, окрім палива, $є$ вода. У середньому на 1 МВт·год. виробленої електроенергії витрачається для різних типів ТЕС $150-300 \mathrm{~m}^{3}$ води. На вироблення електроенергії у 2020 році ТЕС України використали мінімум 5,9 млрд м ${ }^{3}$ води, 3 якої близько 90-95\% припадає на ОСО. Із систем охолодження близько 3-5\% від обсягу оборотної води скидається у навколишне середовище. Крім цього, ТЕС створюють теплові, вуглекислотні $\left(\mathrm{CO}_{2}\right)$ та азотисті $\left(\mathrm{NO}_{x}\right)$ викиди (див. рис.). Величина цих викидів залежить від ефективності роботи ОСО, яка впливає на раціональне використання палива та водних ресурсів і, відповідно, на стан навколишнього середовища. Підвищення тем- ператури оборотної води ОСО зменшує величину вакууму в конденсаторі турбіни і таким чином знижує потужність турбіни, що у свою чергу збільшує споживання палива і води.

Загальна кількість великих ТЕС в Україні близько 15, ї потужності перебувають у межах від 275 МВт до 3600 МВт. Загалом вироблена на них електроенергія становила у 2020 році близько $39,55 \cdot 10^{9}$ кВт год. Кількість відведеного тепла є значною, що суттєво впливає на екологічний стан навколишнього середовища. ТЕС на 1000 МВт виробленої електроенергії спалює за рік 2,3 млн т антрациту або 1,6 млн т нафти чи 1,9 млрд м ${ }^{3}$ газу. Під час спалювання палива в атмосферу надходить величезна кількість шкідливих речовин, що розповсюджуються на десятки і сотні кілометрів. Щодо згоряння палива, то основна частина викидів шкідливих речовин ТЕС припадає на паросилову частину (див. рис.). Такими викидами є: тверді частинки (зола), діоксид азоту $\left(\mathrm{NO}_{2}\right)$, діоксид сірки $\left(\mathrm{SO}_{2}\right)$, оксид та діоксид вуглецю $\left(\mathrm{CO}, \mathrm{CO}_{2}\right)$ і викиди тепла.

Однією з найбільш шкідливих токсичних сполук є діоксид азоту, який належить до 3-го класу небезпеки [3] 3 гостроспрямованим механізмом дії, що потребує автоматизованого контролю за його вмістом у повітрі і видалення з різних газових середовищ. $\mathrm{NO}_{2}$ утворюється під час спалювання вугілля, що містить атомарний азот. За різних умов азот може утворювати 3 киснем низку сполук $\left(\mathrm{N}_{2} \mathrm{O}\right.$, $\mathrm{NO}, \mathrm{N}_{2} \mathrm{O}_{3}, \mathrm{NO}_{2}, \mathrm{~N}_{2} \mathrm{O}_{4} \mathrm{i} \mathrm{N}_{2} \mathrm{O}_{5}$ ), властивості яких різні. $\mathrm{У}$ кінцевому результаті всі речовини перетворю-

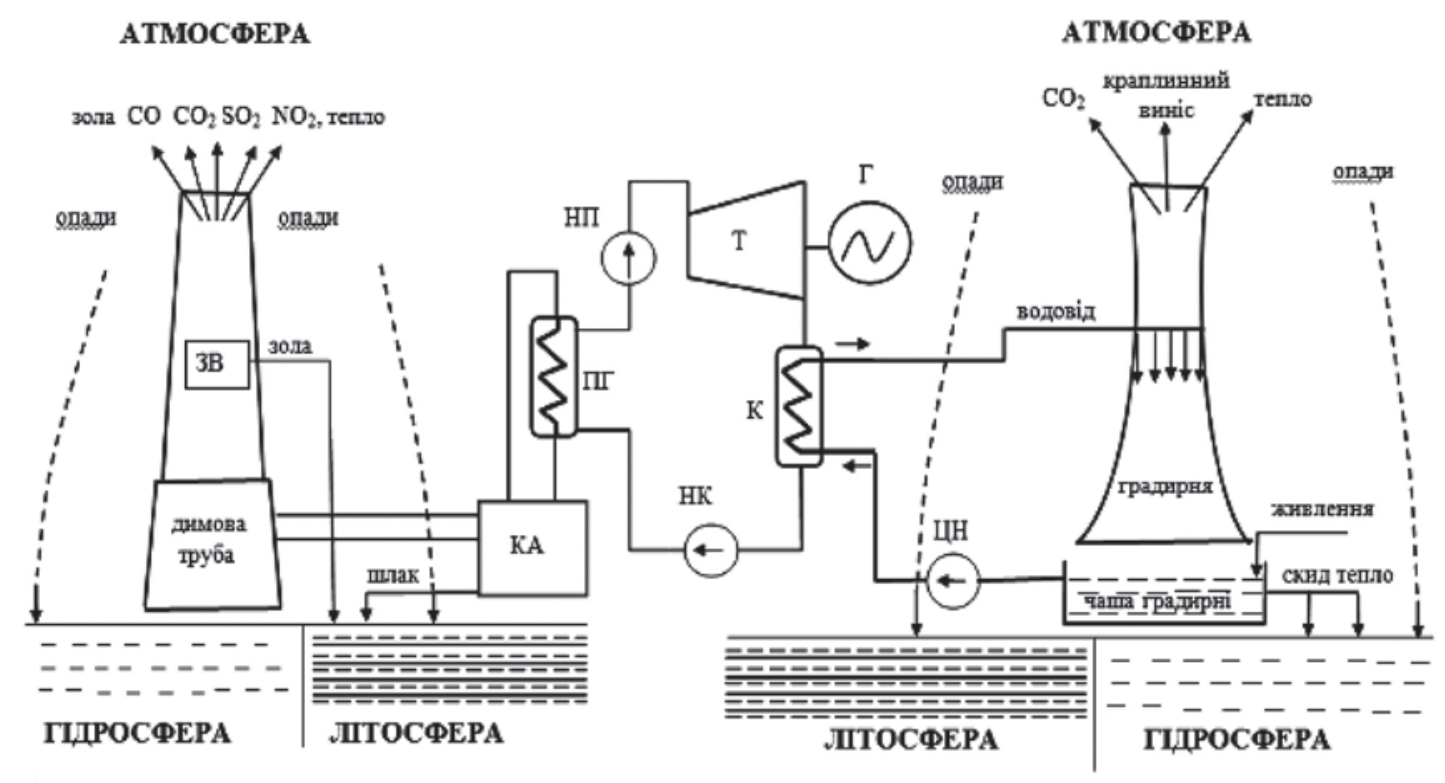


Бондар O.I., Гаєвський В.P. ...

ються в $\mathrm{NO}_{2}$. Концентрація викидів $\mathrm{NO}_{2}$ залежить від технології спалювання палива і може істотно відрізнятися для різних котлоагрегатів. Діоксид азоту належить до парникових газів, сприяє утворенню парникового ефекту і руйнуванню озонового шару. Крім того, оксиди азоту негативно впливають на ріст зелених насаджень і лісів, а також ініціюють виникнення кислотних дощів. Надлишок $\mathrm{NO}_{2}$ безпосередньо викликає респіраторно-легеневі захворювання [4], а також разом 3 іншими речовинами викликає синергетичний негативний ефект [5].

Під час горіння вугілля азот, що знаходиться в повітрі, поєднуючись із киснем, утворює NO, загальна ланцюгова схема реакції якого запропонована Я.Б. Зельдовичем, П.Я. Садовниковим та Д.А. Франк-Каменецьким [6]:

$$
\begin{gathered}
\mathrm{O}_{2}+\mathrm{M} \rightarrow \mathrm{O}+\mathrm{O}+\mathrm{M}-494 \text { кДж/моль; } \\
\mathrm{O}+\mathrm{N}_{2} \rightarrow \mathrm{NO}+\mathrm{N}-314 \text { кДж/моль; } \\
\mathrm{N}+\mathrm{O}_{2} \rightarrow \mathrm{NO}+\mathrm{O}+134 \text { кДж/моль; } \\
\mathrm{O}+\mathrm{O}+\mathrm{M} \rightarrow \mathrm{O}_{2}+\mathrm{M}+494 \text { кДж/моль, }
\end{gathered}
$$

де $\mathrm{M}$ - молекула довільної речовини.

Незважаючи на складний механізм ланцюгової реакції утворення NO, у дослідженні [6] показано, що кінетика його утворення добре описується рівнянням оборотної реакції

$$
\mathrm{N}_{2}+\mathrm{O}_{2} \leftrightarrow 2 \mathrm{NO}-180 \text { кДж/моль. }
$$

Реакції (5) відповідає кінетичне рівняння

$$
\frac{\mathrm{dC}_{\mathrm{NO}}}{\mathrm{dt}}=\mathrm{K}_{1} \cdot \mathrm{C}_{\mathrm{N}_{2}} \cdot \mathrm{C}_{\mathrm{O}_{2}}-\mathrm{K}_{2} \cdot\left(\mathrm{C}_{\mathrm{NO}}\right)^{2} \text { Equation. 3, (6) }
$$

де $\mathrm{CO}_{2}, \mathrm{CN}_{2}, \mathrm{C}_{\mathrm{NO}}$ - актуальні концентрації компонентів газової суміші, $\mathrm{K}_{1}$ i $\mathrm{K}_{2}$ - кінетичні константи прямої і зворотної реакцій відповідно. Після утворення NO миттєво переходить у діоксид азоту за реакцією $2 \mathrm{NO}+\mathrm{O}_{2}=2 \mathrm{NO}_{2}$. Зменшення утворення $\mathrm{NO}$ можна досягти різними технологічними режимами горіння [7], а також хімічними методами очищення [8].

Метою роботи $\epsilon$ розрахунок викидів діоксиду азоту на прикладі ТЕС потужністю 2500 МВт, що спалює $6 \cdot 10^{9}$ кг вугілля марки АСШ за рік, оцінка наслідків недостатньо ефективної роботи ОСО для паросилової частини ТЕС та необхідного ступеня очищення димових газів від $\mathrm{NO}_{2}$.

Викладення результатів досліджень. Визначення викидів і необхідної ефективності очищення відхідних газів здійснювалося відповідно до схеми екологічного впливу паросилової частини ТЕС на довкілля.

Викиди діоксиду азоту. Нині є декілька методик розрахунку викидів NOx. Оскільки у [9] більшість коефіцієнтів рекомендується визначати експериментально і вона повніше враховує технологічні особливості котлів, ми застосуємо таку методику. Щодо інших, то необхідно зазначити, що вони не повною мірою враховують технологічні особливості котлів, а отже, є наближено усередненими. Згідно 3 [9]

\section{ВПАИВ ЕФЕКТИВНОСТІ РОБОТИ...}

питомі викиди оксидів азоту $\mathrm{m}_{\mathrm{NO} 2}{ }^{\text {тв }}$ (кг/МДж) визначаються за формулою:

$$
\mathrm{m}_{\mathrm{NO}_{2}}=\mathrm{m}_{\mathrm{NO}_{2}}^{\text {пал }}+\mathrm{m}_{\mathrm{NO}_{2}}^{\text {пов }},
$$

де $\mathrm{m}_{\mathrm{NO} 2}$ пал - викиди від згорання палива, $\mathrm{m}_{\mathrm{NO} 2}{ }^{\text {пов }}$ - викиди від азоту, що знаходиться у повітрі.

Валові річні викиди $\mathrm{M}_{\mathrm{NO} 2}$ будуть визначатися за формулою:

$$
\mathrm{M}_{\mathrm{NO}_{2}}=\mathrm{m}_{\mathrm{NO}_{2}} \cdot \mathrm{B} \cdot \mathrm{Q} \text {, }
$$

де В - витрати палива, кг/рік; Q - теплота згоряння палива, Мдж/кг.

Для твердого палива $\mathrm{m}_{\mathrm{NO} 2}{ }_{\text {пал }}$ визначається за формулами [9]:

$$
\mathrm{m}_{\mathrm{NO}_{2}}^{\text {пал }}=0,7 \cdot \mathrm{N}_{\text {пал }} \cdot \beta_{\alpha_{1}} \cdot \beta_{\alpha_{1}} \cdot \beta_{\alpha_{1}} \cdot \beta_{\mathrm{z}_{1}} \cdot \beta, \beta_{\mathrm{cm}} \cdot
$$

Величини у співвідношенні (9) визначаються за формулами:

$$
\mathrm{N}_{\text {пал }}=10 \cdot \frac{\mathrm{C}_{\mathrm{N}}}{\mathrm{Q}},
$$

де $\mathrm{C}_{\mathrm{N}}$ - вміст азоту в паливі у \% на робочу масу; $\mathrm{Q}$ - теплота згоряння палива, МДж/кг. Коефіцієнт надлишку повітря $\beta_{\text {от }}$ визначається за формулою:

$$
\beta_{\alpha_{\mathrm{r}}}=\left(0,53 \alpha_{\mathrm{r}}+0,12\right)^{2},
$$

де $\alpha_{\text {г }}-$ коефіцієнт надлишку повітря в пальнику, значення якого знаходяться у діапазоні $0,9 \div 1,3$.

Коефіцієнт впливу частки первинного повітря в пальнику $\beta_{\text {опा }}$ визначається за формулою:

$$
\beta_{\alpha_{\mathrm{r}}}=1,73 \alpha_{\Pi п}+0,48,
$$

де $\alpha_{\text {пा }}$ - частка первинного повітря щодо теоретично необхідного, значення якого знаходяться у діапазоні $0,15 \div 0,55$.

Коефіцієнт впливу рециркуляції димових газів у первинне повітря $\beta_{\text {тт }}$ визначається за формулою:

$$
\beta_{\text {ст }}=1-1,6 \cdot 10^{-2} \sqrt{\mathrm{r}_{\mathrm{r}}},
$$

де $\mathrm{r}_{\text {г }}$ - ступінь рециркуляції димових газів через пальники (\%), значення якого знаходяться у діапазоні $0 \div 30 \%$.

Коефіцієнт впливу максимальної температури на ділянці утворення паливних оксидів азоту $\beta_{\Theta}$ визначається за формулою:

$$
\beta_{\sim}=0.11\left(T_{A \Gamma}-1100\right)^{1 / 3},
$$

де $\mathrm{T}_{\mathrm{Aг}}$ - температура за зоною активності горіння, що знаходиться у діапазоні $1250 \div 2050(\mathrm{~K})$.

Коефіцієнт впливу сумішоутворення в корені факелу для прямоструменевих горілок $\beta_{\text {см }}$ визначається за формулою:

$$
\beta_{\mathrm{cm}}=0,98 \mathrm{~W}_{\mathrm{cm}}-0,47,
$$

де $\mathrm{W}_{\mathrm{cm}}$ - коефіцієнт, значення якого знаходяться у діапазоні $1.4 \div 4.0$ [10].

Повітряні оксиди азоту $\mathrm{m}_{\mathrm{NO} 2}{ }^{\text {тв }}$ визначаються за рівнянням Зельдовича: 


$$
\mathrm{m}_{\mathrm{NO}_{2}}^{\text {пов }}=1.54 \cdot 10^{16} \sqrt{\frac{\alpha_{\mathrm{A \Gamma}}-1}{\alpha_{\mathrm{A} \Gamma}}} \cdot \frac{\exp \left(-\frac{60000}{\mathrm{~T}_{\mathrm{A \Gamma}}}\right)}{\mathrm{T}_{\mathrm{A \Gamma}}},
$$

де $\alpha_{\mathrm{Aг}}-$ коефіцієнт, що визначається за формулою:

$$
\alpha_{\mathrm{A} \Gamma}=\alpha_{\mathrm{A}}+0,5 \cdot \alpha_{\mathrm{A} \Gamma},
$$

де $\Delta \alpha_{\mathrm{T}}-$ присоси в топку, що можна визначити за формулою

$$
\Delta \alpha_{\Gamma}=0,1 \cdot \alpha_{\Gamma} .
$$

Визначимо питомі викиди $\mathrm{NO}_{2}$ викидів від згоряння палива $\left(\mathrm{m}_{\mathrm{NO} 2}{ }^{\text {пал }}\right)$ для середнього необхідного надлишку повітря для горіння $\left(\alpha_{\Gamma}=1,15\right.$ i $\beta_{\alpha \mathrm{T}}=$ 0,532), а також для Донецького вугілля марки АСШ $\left(\mathrm{Q}=20,89 \mathrm{MДЖ/кг,} \mathrm{C}_{\mathrm{N}}=0,6 \%\right.$ [11]) і для середніх значень інших коефіцієнтів: $\beta_{\alpha п п}=1,085$ (для $\alpha_{\text {пп }}=$ $0,35) ; \beta_{\mathrm{rт}}=0,938$ (для $\mathrm{r}_{\Gamma}=15 \%$ ); $\beta_{\Theta}=0,901$ (для середнього значення $\mathrm{T}_{\mathrm{Aг}}$, що можна рахувати як $\left.1900 \mathrm{~K}\right)$; для прямоструменевих горілок $\beta_{\text {см }}=2,176$ (для $\mathrm{W}_{\text {см }}=2,7$ ). Тоді, згідно 3 (9), $\mathrm{m}_{\mathrm{NO} 2}$ пал $=0,242$ кг/ГДж. Визначимо для цих же умов $\left(\alpha_{\mathrm{r}}=1,15\right.$ та $\left.\mathrm{T}_{\mathrm{A \Gamma}}=1900 \mathrm{~K}\right)$ питомі викиди повітряних оксидів азоту $\left(\mathrm{m}_{\mathrm{NO} 2}{ }^{\text {пов }}\right)$. Оскільки 3 (17) $\alpha_{\mathrm{A \Gamma}}=1,208$ та (18) $\Delta \alpha_{\mathrm{T}}=0,115$, то згідно 3 (16) $\mathrm{m}_{\mathrm{NO} 2}{ }^{\text {пов }}=0,065$ кг/ГДж. Видно, що для цих умов $\mathrm{m}_{\mathrm{NO} 2}{ }^{\text {пов }}$ становить близько 27\%. Таким чином, у результаті наших розрахунків можна стверджувати, що повні питомі викиди $\mathrm{NO}_{2}$, які будемо вважати рівними контамінаційному еквіваленту енергії (KЕE), становлять 0,307 кг/ГДж. Валові річні викиди згідно 3 (8) будуть становити $\mathrm{M}_{\mathrm{NO} 2}=\left(0,307\right.$ кг/ГДж) $\left(6 \cdot 10^{9}\right.$ кг/рік) $\left(20,89 \cdot 10^{-3}\right.$ ГДж/кг) $=38,48$ тис. т/рік.

Для прикладу проаналізуємо викиди для ТЕC, що складається із 5 блоків по 500 МВт. За неефективної роботи ОСО, що призводить до підвищення температури конденсату, наприклад, iз $30^{\circ} \mathrm{C}$ до $31^{\circ} \mathrm{C}$, зниження вакууму становить 0,25 кПа, що призведе до падіння потужності кожної турбіни потужністю 500 МВт на $\Delta \mathrm{N}=1,0$ МВт і, відповідно, всієї ТЕС на 5,0 МВт, що буде становити $0,2 \%$ втрат потужності і за необхідності стабільного виробітку електроенергії на такий же відсоток збільшить витрати палива, а отже, кількість викидів шкідливих речовин. Неефективна робота ОСО, що спричиняє підвищення температури в конденсаторі лише на $1^{\circ} \mathrm{C}$, призведе до надлишкових викидів діоксиду азоту 77,0 т/рік. Такий результат відображає суттєві негативні екологічні наслідки недостатньо ефективної роботи ОСО (таблиця).

Необхідна ефективність очищеення. Для визначення ефективності очищення визначимо концентрацію $\mathrm{NO}_{2}$ у димових газах під час спалювання вугілля марки АШ (АСШ). Порівняємо цю величину із гранично допустимою концентрацією у повітрі робочої зони (ГДКрз), тобто з нормативною концентрацією, яка під час щоденної роботи протягом усієї трудової діяльності не викликає захворювань або відхилень у стані здоров'я [12]. Зауважимо, що ГДКрз є однією iз найважливіших екологічних характеристик роботи підприємства, яка нормує вміст шкідливих речовин у викидах і скидах. Згідно з [3] ГДКрз для $\mathrm{NO}_{2}$ становить $2 \mathrm{мг} / \mathrm{M}^{3}$.

Таблиця

\section{Валові річні викиди, контамінаційний еквівалент енергії (КЕE) та валові викиди за рахунок недогріву води ОСО для ТЕС потужністю 2500 МВТ}

\begin{tabular}{|c|c|c|c|}
\hline $\begin{array}{c}\text { Шкідлива } \\
\text { речовина }\end{array}$ & $\begin{array}{c}\text { Валові } \\
\text { викиди, } \\
\text { тис. т/рік }\end{array}$ & $\begin{array}{c}\text { КЕЕ } \\
\text { кг/ГДж }\end{array}$ & $\begin{array}{c}\text { Валові викиди за } \\
\text { рахунок недогріву води } \\
\text { ОСО на 1 }{ }^{\circ} \mathbf{C} \text { т/рік }\end{array}$ \\
\hline $\mathrm{NO}_{2}$ & 38,48 & 0,307 & 77,0 \\
\hline
\end{tabular}

Для дотримання ГДКрз по $\mathrm{NO}_{2}$ необхідно підтримувати відповідну їх концентрацію у димових газах, і тому таку ефективність очищення (ЕО) для $\mathrm{NO}_{2}$ ми пропонуємо визначати за співвідношенням:

$$
(\mathrm{EO})_{\mathrm{NO}_{2}}=\left(1-\frac{(\text { ГДЗр3 })_{\mathrm{NO}_{2}}}{\mathrm{C}_{\mathrm{NO}_{2}}}\right) \cdot 100, \%,
$$

де $(\text { ГККр })_{\mathrm{NO} 2}$ у г/м³ $\mathrm{CO}_{\mathrm{NO} 2}-$ концентрація $\mathrm{NO}_{2}$ у димових газах $\left(г / \mathrm{M}^{3}\right)$, що визначається за формулою, вказаною у [9]:

$$
\mathrm{C}_{\mathrm{NO}_{2}}=\frac{\mathrm{M}_{\mathrm{NO}_{2}}}{\mathrm{~B} \cdot \mathrm{V}_{3 \Gamma}} \text { Equation. 3, } \Gamma / \mathrm{M}^{3} \text {, }
$$

де $\mathrm{M}_{\mathrm{NO} 2}-$ викиди $\mathrm{NO}_{2}$, г/c; В - витрата палива, кг/с; $\mathrm{V}_{\text {зг }}$ - питомий об'єм димових газів від згоряння палива $\left(\mathrm{M}^{3} / \kappa г\right)$, який розраховуємо за формулою, наведеною у [13]:

$$
\begin{gathered}
\mathrm{V}_{3 \Gamma}=\frac{\mathrm{C}^{\mathrm{P}}+0.375 \cdot \mathrm{S}_{\mathrm{op}+\mathrm{x}}^{\mathrm{P}}}{0,54 \cdot\left(\mathrm{RO}_{2}+\mathrm{CO}\right)}, \\
\mathrm{RO}_{2}=\frac{21}{(1+\beta) \cdot \alpha} .
\end{gathered}
$$

Коефіцієнт $\beta$ визначається за співвідношенням:

$$
\beta=2,37 \cdot \frac{\mathrm{H}^{\mathrm{P}}-0,126 \cdot \mathrm{O}^{\mathrm{P}}}{\mathrm{C}^{\mathrm{P}}+0,375 \cdot \mathrm{S}_{\mathrm{O}+\mathrm{K}}^{\mathrm{P}}} .
$$

Відповідно, величина СО обраховується за виразом:

$$
\mathrm{CO}=\frac{\left(21-\beta \cdot \mathrm{RO}_{2}\right)-\left(\mathrm{RO}_{2}+\mathrm{O}_{2}\right)}{0,65+\beta}
$$

Враховуючи, що для наших умов коефіцієнт надлишку повітря $\alpha=1,15$, тоді $\mathrm{O}_{2}=2.2 \%$. Далі за (24) розрахуємо кількість викидів СО для характеристик палива марки АШ (АСШ) на робочу масу $\left(\mathrm{X}^{\mathrm{p}}\right)$ : вміст вуглецю $\mathrm{C}^{p}=63,8 \%$; вміст загальної сірки $\mathrm{S}_{\mathrm{op}+\mathrm{k}} \mathrm{p}=1,7 \%$; вміст водню $\mathrm{H}^{\mathrm{p}}=1,8 \%$; вміст кисню $\mathrm{O}^{\mathrm{p}}=1,3 \%$ [11], а також розраховані за (23) $\beta=0,06$; за (22) $\mathrm{RO}_{2}=16,5 \%$, за (21) визначаємо питомий об'єм димових газів, що рівний $\mathrm{V}_{\text {зг }}=6,63 \mathrm{~m}^{3} /$ кг. Отже, враховуючи, що $\mathrm{M}_{\mathrm{NO} 2}=38,48$ тис. тон/ рік $=1,22 \cdot 10^{3} \Gamma / \mathrm{c}$, a $B=6 \cdot 10^{9} \kappa г /$ рік $=190 \kappa г / \mathrm{c} \mathrm{i}$ Vзг $=6,63 \mathrm{~m}^{3} / \kappa г$, за (20) визначаємо концентрацію $\mathrm{NO}_{2}$, що рівна $\mathrm{CONO}_{2}=0,968 \Gamma / \mathrm{M}^{3}=968 \mathrm{мг} / \mathrm{M}^{3}$. 
Бондар О.I., Гаєвський В.P. ...

Оскільки, згідно з [3], (ГДКрз) $\mathrm{NO}_{2}=2$ мг/м³ , то за (19) ефективність очищення становить 99,8\%, що потребує глибокого очищення димових газів від діоксиду азоту для забезпечення санітарно-гігієнічних вимог робочої зони ТЕС за умов, розглянутих у цій роботі.

\section{ВПАИВ ЕФЕКТИВНОСТІ РОБОТИ...}

Отже, результати дослідження засвідчують важливість ефективного функціонування оборотних систем охолодження і необхідність використання глибокого очищення димових газів від $\mathrm{NO}_{2}$ для забезпечення санітарно-гігієнічних вимог робочої зони ТЕС.

\section{Література}

1. Про Основні засади (Стратегію) екологічної політики України на період до 2030 року: Закон України від від 28 лютого 2019 року № 2697-VIII/ Верховна Рада України. Відомості Верховної Ради Украйни. 2019. № 16. Ст. 70.

2. Інформаційне агенство Мінпром. Київ, 2020. URL: http://minprom.ua/.

3. ГОСТ 12.1.005-88. Общие санитарно-гигиенические требования к воздуху рабочей зоны. Межгосударственный стандарт. Москва: Стандартинформ, 2008.

4. Barck, C., Sandstrom, T. Lundahl, J., Hallden, G, Svartengren, M., Strand, V., Rak, S., Bylin, G. Ambient level of $\mathrm{NO}_{2}$ augments the inflammatory response to inhaled allergen in asthmatics. Respiratory Medicin. 2002. Volume 96. Issue 11. P. $907-917$.

5. Farraj, Aimen K., Malik, Fatiha; Haykal-Coates; Najwa; Walsh, Leon; Winsett, Darrell; Terrell, Dock; Thompson, Leslie C., Cascio, Wayne E., Hazari, Mehdi S. Morning $\mathrm{NO}_{2}$ exposure sensitizes hypertensive rats to the cardiovascular effects of same day $\mathrm{O}_{3}$ exposure in the afternoon. Inhalatin Toxicology. 2016. Volume 28. Issue 4. P. 170-179.

6. Зельдович Я.Б. Избранные труды. Химическая физика и гидродинамика. Москва: Наука, 1984. 374 с.

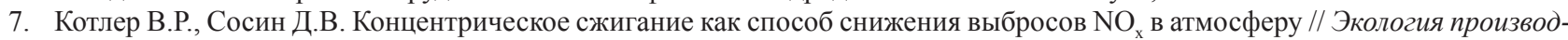
ства. 2008. №3, прил. Энергетика. С.7-8.

8. Кузнецов И.Е. Защита атмосферного воздуха от загрязнений. Симферополь: Таврия, 1973. 124 с.

9. РД. 34.02.304-95. Методические указания по расчету выбросов оксидов азота с дымовыми газами котлов тепловых электростанций. Москва, 1996. 14 с.

10. Руководящие указания. Проектирование топок с твердым шлакоудалением. Ленинград: НПО ЦКТИ, вып. 42, 1981.

11. Роддатис К.Ф., Полтарецкий А. Н. Справочник по котельным установкам малой производительности / Под ред. К.Ф. Роддатиса. Мосва: Энергоатомиздат, 1989. 488 с.

12. Снітинський В.В., Екотоксикологія: Навчальний посібник/ В.В. Снітинський, П.Р. Хірівський, П.С. Гнатів, Г.Л. Антоняк, Н.С. Панас, М.А. Петровська. Херсон: Олді-плюс, 2011. 330 с.

13. Тепловой расчет котлов (Нормативный метод). Издание третье перераб. идополн. Санкт-Петербург: Изд-во НПО ЦКТИ, 1998. $256 \mathrm{c}$. 


\title{
КРИТЕРІЇ ВИБОРУ ПРИРОДОЗАХИСНОГО ОБААДНАННЯ ДИЯ ОЧИЩЕННЯ ПРОМИСАОВИХ ВИКИДІВ ПІДПРИЕМСТВ
}

\author{
Козій I.C., Жиленко Т.І., Трунова I.О., Батальцев Є.В., Макаренко Н.О. \\ Сумський державний університет \\ вул. Римського-Корсакова, 2, 40007, м. Суми \\ i.koziy@ecolog.sumdu.edu.ua
}

\begin{abstract}
Розглянуто питання оптимального вибору ефективного пилогазоочисного обладнання з урахуванням реальних умов середовища і характеристик забруднюючих речовин. Для обгрунтування використано програмне середовище Gephi, на основі алгоритму зниження розмірності - методики UMAP.

Господарська діяльність людини призводить до порушення рівноваги у навколишньому середовищі. У зв'язку 3 недосконалістю технологічних процесів і незадовільною роботою очисного обладнання на підприємствах енергетики та хімічної промисловості в атмосферу надходять гази, що містять різні за токсичністю сполуки. Осадження забруднюючих речовин із газових викидів призводить до забруднення грунтів і міграції важких металів у підземні і поверхневі води, тому питання оптимального вибору ефективного природозахисного обладнання становить актуальність дослідження. Проблема обгрунтованого вибору оптимального пилогазоочисного обладнання повинна враховувати параметри забруднюючих речовин і умови середовища проведення процесу очищення, що може бути виконано з використанням математичного апарату.

Для побудови графу в роботі сформовано бази даних досліджуваних параметрів системи вибору пилогазоочисного обладнання (ВПО) у вигляді матриць елементів. Вибір забруднюючої речовини визначається з матриці забруднюючих речовин з урахуванням вихідних умов певного технологічного об’єкту. Вибір умов перебігу процесу визначається на підставі матриці параметрів середовища, яка формується на основі вихідних даних технологічного процесу або інших прогнозованих параметрах.

У статті за допомогою алгебри висловлень сформульовано поступовість і наслідування роботи алгоритмічної програми розрахунку оптимального ВПО на підставі параметрів забруднюючих речовин та умов середовища. Аналіз графу дає змогу отримати швидке алгоритмічне пояснення орієнтованого оптимального вибору певних типів очисного обладнання. На підставі аналізу і візуалізацій ієрархічної будови схеми вибору пилогазоочисного обладнання можна зробити висновок про зручну оцінку ефективності проведення процесу очищення. Ключові слова: технології захисту навколишнього середовища, забруднюючі речовини, пилогазоочисне обладнання, матриці даних.
\end{abstract}

Criteria for choosing environmental equipment for cleaning industrial emissions of enterprises. Kozii I., Zhylenko T., Trunova I., Bataltsev Y., Makarenko N.

The optimal choice of effective dust and gas cleaning equipment considering pollutants' natural environmental conditions and characteristics is considered. The UMAP method used the Gephi software environment for substantiation based on the dimensional reduction algorithm.

Human economic activity leads to an imbalance in the environment. Due to the imperfection of technological processes and unsatisfactory operation of treatment equipment in the energy and chemical industries, gases containing compounds with different toxicity enter the atmosphere. Deposition of pollutants from gaseous emissions leads to soil contamination and migration of heavy metals into groundwater and surface water, so the question of optimal choice of effective environmental equipment is relevant to the study. The problem of reasonable selection of optimal dust and gas cleaning equipment should consider the parameters of pollutants and environmental conditions of the cleaning process, which can be done using a mathematical apparatus.

An article formed databases of the studied parameters of the selection system of dust and gas cleaning equipment (IDP) in the form of matrices of elements. The choice of pollutant is determined from the matrix of contaminants, taking into account the initial conditions of a particular technological object. Determined the choice of process conditions based on the matrix of environmental parameters formed based on the initial data of the technical process or other predictable parameters.

The article uses the algebra of expressions to formulate the gradualness and imitation of the algorithmic program for calculating the optimal IDP based on the parameters of pollutants and environmental conditions. Graph analysis allows obtaining a quick algorithmic explanation of the optimal oriented choice of certain types of treatment equipment. Based on the research and visualizations of the hierarchical structure of the scheme of selection of dust and gas cleaning equipment, it is possible to conclude a convenient assessment of the effectiveness of the cleaning process. Key words: environmental protection technologies, pollutants, dust and gas cleaning equipment, data matrices.

Постановка проблеми. Збільшення масштабів господарської діяльності людини призводить до посилення антропогенного впливу і порушення рівноваги у навколишньому середовищі. За ступенем хімічної небезпеки для людини забруднення атмосферного повітря посідає перше місце [1]. 3 метою оцінки ступеня техногенного навантаження на навколишнє середовище суттєва увага приділяється дослідженню викидів забруднюючих речовин як визначальному фактору формування зон екологічного неблагополуччя.

Одним із основних чинників, що впливають на санітарний стан атмосфери, є викиди підприємств енергетики та хімічної промисловості $[2,3]$. У зв'язку з недосконалістю технологічних процесів і незадовільною роботою очисного обладнання [4] 
Козій І.С., Жиленко Т.І., Трунова I.О. ...

на цих підприємствах в атмосферу надходять гази, що містять різні за токсичністю сполуки, дрібнодисперсні зважені краплі рідини, тверді частки (пил) вихідної сировини й продукції тощо.

Актуальність дослідження.

Осадження забруднюючих речовин із газових викидів призводить до забруднення грунтів і міграції важких металів у підземні і поверхневі води [5-9], тому питання оптимального вибору ефективного природозахисного обладнання становить актуальність дослідження. Проблема обгрунтованого вибору оптимального пилогазоочисного обладнання повинна враховувати параметри забруднюючих речовин і умови середовища проведення процесу очищення, що може бути виконано з використанням математичного апарату.

Зв'язок авторського доробку із важливими науковими та практичними завданнями. Робота виконувалася за плановими науково-дослідними проєктами кафедри прикладної екології Сумського державного університету за темою «Зменшення техногенного навантаження на навколишнє середовище підприємств хімічної, машинобудівної промисловості та теплоенергетики» згідно із науково-технічною програмою Міністерства освіти і науки України (№ державної реєстрації 0116U006606).

Аналіз останніх досліджень і публікацій. Традиційно на більшості промислових підприємств енергетичної та хімічної галузі схеми пилогазоочищення представлені апаратами сухого та мокрого типу $[10,11]$.

Як апарати сухого очищення в основному використовують циклони, едектрофільтри та рукавні фільтри [12, 13]. Зазначені види апаратів сухого очищення використовуються для уловлення зважених твердих часток, але вони не спроможні ефективно працювати з потоками газу, що містять легкозлипливі та смолисті речовини і дисперсний пил.

Апарати мокрого пилогазоочищення представлені в основному розпилюючими та тарілчастими скруберами, апаратами вихрового типу та іншими конструкціями [14]. Зазвичай мокре очищення не вимагає додаткової підготовки газів, дозволяє одночасно проводити очищення як від газових викидів, так і дисперсних часток. Мокре пилоочищення має високу ефективність при вловленні дрібнодисперсного пилу, але проблема очистки газів від легкозлипливих та смолистих речовин виключає можливість ефективного використання апаратів мокрого типу [15].

Аналіз основних типів пилогазоочисного обладнання широко представлено у науковій літературі [16, 17], але питання оптимального вибору певних конструкцій апаратів з урахуванням реальних умов середовища і характеристик забруднюючих речовин потребує подальшого дослідження.

Виділення не вирішених раніше частин загальної проблеми, котрим присвячусться
КРИТЕРІЇ ВИБОРУ ПРИРОДОЗАХИСНОГО...

означена стаття. Використання ефективного обладнання для очищення газових викидів підприємств від певних забруднюючих речовин суттєво зменшує негативний вплив на довкілля. Тому завдання математично обгрунтованого вибору оптимального природозахисного обладнання з урахуванням як параметрів досліджуваного процесу очищення викидів, так і параметрів забруднюючих речовин становить новизну роботи.

Методологічне або загальнонаукове значення. Одним із сучасних математичних інструментів аналізу і спрощення інформації є побудова графів [18]. Граф - це метод графічних даних та відношень між ними (рис. 1).

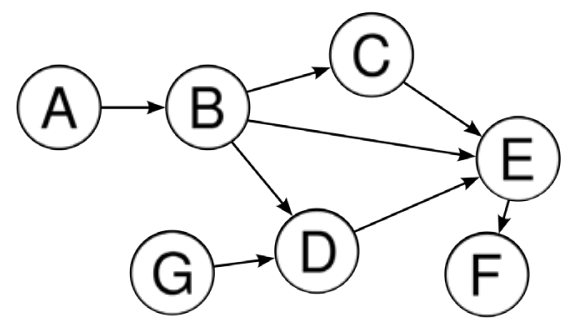

Рис. 1. Направлений ациклічний граф

Мета побудови графів - представити різні типи складних даних для їх адекватного опису в тексті або алгоритмі. Об'єкти розглядаються як вершини, або вузли графу, а зв'язки - як дуги, або ребра. Для різних галузей види графів можуть відрізнятися орієнтованістю, обмеженнями на кількість зв'язків і додатковими даними про вершини або ребра.

Побудову графу в роботі виконано в програмному середовищі Gephi на основі алгоритму зниження розмірності, а саме за допомогою методики UMAP (Uniform Manifold Approximation and Projection) [19].

Цей алгоритм побудовано на засадах ріманової геометрії і топологічної алгебри. UMAP зберігає найбільшу частину глобальної структури з чудовою продуктивністю під час його виконання [19]. До параметрів алгоритму належать: кількість сусідів, мінімальна відстань, метрика відстані, розмірність кінцевого простору.

Виклад основного матеріалу. Для побудови графу сформуємо бази даних досліджуваних параметрів системи вибору пилогазоочисного обладнання (ВПО) у вигляді матриць елементів.

Матриия забруднюючих речовин (3Р). Матриця забруднюючих речовин сформована у вигляді двомірної матриці розміром $i$ х $j$ (рис. 2) (де $i$ - кількість ЗР у матриці; $j$ - кількість різних за фізикохімічними характеристиками різновидів певної ЗР у матриці) і містить інформацію про певний перелік ЗР, включаючи їх можливі різновиди і фізико-хімічні параметри. Інформація формується 3 матеріалів даних інвентаризації, умов технологічних процесів та довідникових даних за певними 3В. 
Кожна комірка $x_{i j}$ двомірної матриці являє собою характеристику $i$-ӧ̈ ЗР (порядковий номер у матриці по горизонталі) $j$-ого різновиду (порядковий номер у матриці по вертикалі) і включає такі параметри:

Zrij - назва (код) i-ої 3Р ј-варіації, на підставі даних матеріалів джерел викидів;

Asij - агрегатний стан i-oї 3Р j-варіації (твердий 0 , рідкий, газоподібний -1$)$;

Dsij - дисперсність i-ої 3Р j-варіації, мкм (обмежує використання апаратів де частинки можуть «проскакувати», див. базу обладнання);

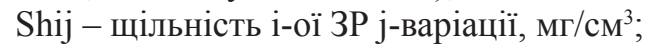

Fmij - форма частинок i-ої 3Р ј-варіації (ізометрична частинка -3 , пластинка -2 , волокно -1 );

Knij - клас небезпечності і-ої ЗР ј-варіації (I - IV);

Vhij - вплив на організм людини i-ої 3Р j-варіації (респіраторний / фіброгенна дія - 2, подразнення / пошкодження шкіри - 3, дуже отруйна / канцероген - 1);

Chij - хімічний склад i-ої 3Р j-варіаціі;

Gkij - гранично-допустима концентрація i-ої 3Р

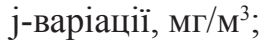

Zpij - злипливість часток і-ої 3Р ј-варіації через розривну міцність шару частинок, Па (ознаку вказали у базі обладнання);

Gpij - горючість часток i-ої 3P j-варіації (горючі 1 , негорючі - 0); може бути обмеженням для використання обладнання яке містить горючий матеріал;

Zmij - змочуваність часток і-ої ЗР ј-варіації,
Rvij - розчинність у воді і-ої ЗР ј-варіації (розчинна -2 , слаборозчинна - 1, нерозчинна - 0 (може бути використане обладнання як для сухого так і мокрого очищення);

Saij - здатність до поглинання i-ої 3Р ј-варіації (сорбція) компонентів середовища (так - 1, ні - 0);

Crij - здатність i-ої $3 \mathrm{P}$ j-варіації вступати у хімічну реакцію (так -1, ні -0$)$.

Для узагальнення інформації щодо матриці забруднюючих речовин наведемо базу даних для певних забруднюючих речовин підприємств теплоенергетики та хімічної промисловості (табл. 1).

Матриия параметрів середовища. За аналогією сформуємо матрицю параметрів середовища (умов перебігу процесу) під час надходження викидів і-ої 3Р ј-варіації у навколишнє середовище від джерела утворення, яка враховує такі параметри:

Pserij - параметр середовища (умови перебігу процесу), який характеризує умови під час викиду ЗР в певному випадку;

Uvoli - умова за вологовмістом викиду 3Р (1 - вологий (3Р викидаються із значним супутнім вологовмістом викиду (можуть летіти мокрі включення), 0 - сухий (може розглядатися для газоподібних і твердих 3Р, викид яких не містить вологу));

Unai - умова максимального обсягу викидів, $\mathrm{m}^{3} /$ год (максимально можливий об'єм, який потрібно буде очищувати - обмежує вибір апарата);

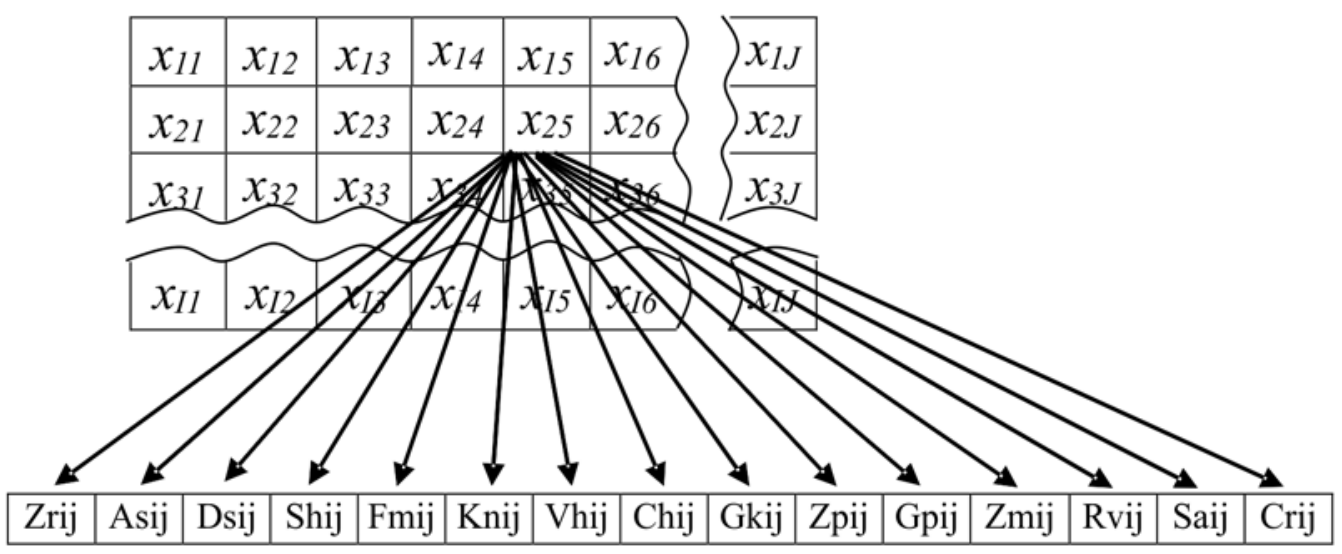

Рис. 2. Матриця об'єктів підмножини ЗР

Таблиця 1

Зразок матриці забруднюючих речовин

\begin{tabular}{|c|c|c|c|c|c|c|c|c|c|c|c|c|c|c|}
\hline $\mathbf{Z r i j}$ & $\mathbf{A s}_{\mathbf{i j}}$ & $\mathbf{D s}_{\mathbf{i j}}$ & $\mathbf{S h}_{\mathbf{i j}}$ & $\mathbf{F m}_{\mathbf{i j}}$ & $\mathbf{K n}_{\mathbf{i j}}$ & $\mathbf{V h}_{\mathbf{i j}}$ & $\mathbf{C h}_{\mathbf{i j}}$ & $\mathbf{G k}_{\mathbf{i j}}$ & $\mathbf{Z p}_{\mathbf{i j}}$ & $\mathbf{G p}_{\mathbf{i j}}$ & $\mathbf{Z m}_{\mathbf{i j}}$ & $\mathbf{R v}_{\mathbf{i j}}$ & $\mathbf{S a}_{\mathbf{i j}}$ & $\mathbf{C r}_{\mathbf{i j}}$ \\
\hline $\begin{array}{c}\text { Аерозоль } \\
\text { двоокису титану }\end{array}$ & 0 & 0,26 & 2920 & 3 & 4 & 2 & $\mathrm{TiO}_{2}$ & 10 & 780 & 0 & 36 & 0 & 0 & 0 \\
\hline Пил ільменіту & 0 & 7,20 & 3600 & 3 & 4 & 2 & $\mathrm{FeTiO}_{3}$ & 10 & 320 & 0 & 72 & 0 & 0 & 0 \\
\hline Сірки діоксид & 1 & - & 2,619 & - & 3 & 2 & $\mathrm{SO}_{2}$ & 10 & - & 0 & - & 2 & 1 & 1 \\
\hline Азоту діоксид & 1 & - & 2,052 & - & 3 & 2,3 & $\mathrm{NO}_{2}$ & 2 & - & 0 & - & 2 & 1 & 1 \\
\hline Сірчана кислота & 1 & - & 1836 & - & 2 & $1,2,3$ & $\mathrm{H}_{2} \mathrm{SO}_{4}$ & 1 & - & 0 & - & 2 & 1 & 1 \\
\hline Двоокис вуглецю & 1 & - & 1,839 & - & 4 & 2 & $\mathrm{CO}_{2}$ & 3 & - & 0 & - & 2 & 1 & 1 \\
\hline
\end{tabular}




\section{Козій І.С., Жиленко Т.І., Трунова I.О. ...}

Utemi - умова максимального значення температури викиду $3 \mathrm{P},{ }^{\circ} \mathrm{C}$ (температура викиду, який потрібно буде очищувати, обмежує вибір апарату);

Uidi - умова наявності інших домішок окрім певної ЗР у викиді (1 - так (може ускладнювати процес очистки речовин, які вступають у хімічну реакцію, потребує «як варіант» більш комплексних апаратів для очистки), 0 - ні (може були використано обладнання для очистки однокомпонентної домішки 3Р).

Узагальнення матриці параметрів середовища наведено в табл. 2.

Таблиця 2

Матриця параметрів середовища

\begin{tabular}{|c|c|c|c|c|}
\hline Pserij & Uvoli & Unaij & Utemi & Uidi \\
\hline 1 варіант & 0 & 3000 & 100 & 0 \\
\hline 2 варіант & 0 & 30000 & 250 & 0 \\
\hline 3 варіант & 1 & 300000 & 400 & 1 \\
\hline n варіант & 0 або 1 & $\ldots$ & $\ldots$ & 0 або 1 \\
\hline
\end{tabular}

Матриия пилогазоочисного обладнання. Завершальним блоком дослідження $є$ формування матриці пилогазоочисного обладнання, яке може бути використане для очищення від ЗР (наявного на об'єкті дослідження або потенційно можливого для використання) і враховує такі параметри:

Gouij - назва очисного обладнання;

Tsmij - сухий чи мокрий тип очищення газу (1 - мокре (підійде для усіх агрегатних станів 3Р, важливо для розчинних у воді 3 Р але також підійде для вловлення твердих часток); 0 - сухе (підійде лише для твердого агрегатного стану 3Р));

Gnaij - максимальне навантаження по газовій фазі, м³/год;

Gpaij - гідравлічний опір апарату, Па;

Kmnij - концентрація 3Р на вході (максимальна), г/ $\mathbf{M}^{3}$;

\section{КРИТЕРІЇ ВИБОРУ ПРИРОДОЗАХИСНОГО...}

Kmkij - концентрація 3Р на виході (макси-

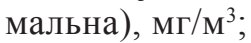

Efpij - ефективність вловлення за фракційним складом часток (мінімальний розмір), мкм (цей критерій більше характеризує тверді 3Р, які мають певний розмір і можуть бути вловлені в певному очисному апараті);

Tmaij - верхня температурна межа роботи апарату, ${ }^{\circ} \mathrm{C}$ (може бути використано як температурне обмеження для різних умов середовища);

Vgaij - максимальна швидкість газу в перетині апарату, м/с;

Lnrij - витрата рідини, м $^{3} /$ год;

Ezpij - можливість роботи із злипливими частинками ЗР (1 - так (може вловлювати злипливі тверді частинки; 0 - взагалі не може ефективно працювати зі злипливими частинками).

Узагальнення матриці пилогазоочисного обладнання наведено в табл. 3 .

Теоретичні основи обтрунтування вибору очисного обладнання. Вибір лінійної структури системи очищення викидів забруднюючих речовин однозначно задається у символьній формі:

$$
\text { Zrij; Pserij; Gouij, }
$$

де Zrij - вибір 3Р; Pserij - вибір умов перебігу процесу; Gouij - вибір пилогазоочисного обладнання.

Вибір ЗР визначається 3 матриці забруднюючих речовин з урахуванням вихідних умов певного технологічного об'єкту. Вибір умов перебігу процесу визначається на підставі матриці параметрів середовища, яка формується на основі вихідних даних технологічного процесу або інших прогнозованих параметрів.

Наступний крок в утворенні структури - це підбір пилогазоочисного апарату, який буде відповідати умовам проведення процесу очищення викидів певних 3Р, з оптимальними показниками відповідності (матриця пилогазоочисного обладнання).

Таблиця 3

Матриця пилогазоочисного обладнання

\begin{tabular}{|c|c|c|c|c|c|c|c|c|c|c|}
\hline Gouij & Tsmij & Gnaij & Gpaij & Kmnij & Kmkij & Efpij & Tmaij & Vgaij & Lnrij & Ezpij \\
\hline $\begin{array}{c}\text { Електрофільтр типу ЕГУ } \\
\text { (ЕГУ 1-7/400-4-4/2.56-2-11.2) }\end{array}$ & 0 & 36200 & 200 & 90 & 50 & 0,1 & 330 & 1 & - & 1 \\
\hline $\begin{array}{c}\text { Електрофільтр типу ЕГУ } \\
\text { (ЕГУ 80/400-18-6/3.84-3-576) }\end{array}$ & 0 & 1969900 & 200 & 90 & 50 & 0,1 & 330 & 1 & - & 1 \\
\hline $\begin{array}{c}\text { Електрофільтр КХП } \\
\text { ЕСТ-11,4-4-Ш } \\
\end{array}$ & 0 & 40500 & 200 & 6 & 20 & 0,1 & 330 & 1 & - & 1 \\
\hline Рукавний фільтр ФРІР-25 & 0 & 2400 & 2000 & 10 & 20 & 0,3 & 135 & 0,55 & - & 0 \\
\hline Рукавний фільтр ФРІР-1200 & 0 & 110000 & 2000 & 10 & 20 & 0,3 & 135 & 0,55 & - & 0 \\
\hline $\begin{array}{l}\text { Двоступінчастий фільтр тонкого } \\
\text { очищення СРФ5КР*6 (6 секцій) }\end{array}$ & 0 & 30000 & 2500 & 120 & 1 & 1 & 240 & 0,15 & - & 0 \\
\hline $\begin{array}{c}\text { Батарейний циклон БЦ-512 } \\
\text { (односекційний) }\end{array}$ & 0 & 6500 & 1300 & 75 & 10000 & 10 & 400 & 4 & - & 1 \\
\hline $\begin{array}{l}\text { Мокрий скрубер Вентурі } \\
\text { СВ 150/90-800 } \\
\end{array}$ & 1 & 7000 & 1200 & 30 & 500 & 1 & 400 & 5 & 7 & 1 \\
\hline Апарат з КДПТ ( $\mathrm{d}_{\mathrm{o}}=0,06$ м) & 1 & 40000 & 1200 & 20 & 50 & 0,3 & 400 & 3,5 & 10 & 1 \\
\hline
\end{tabular}




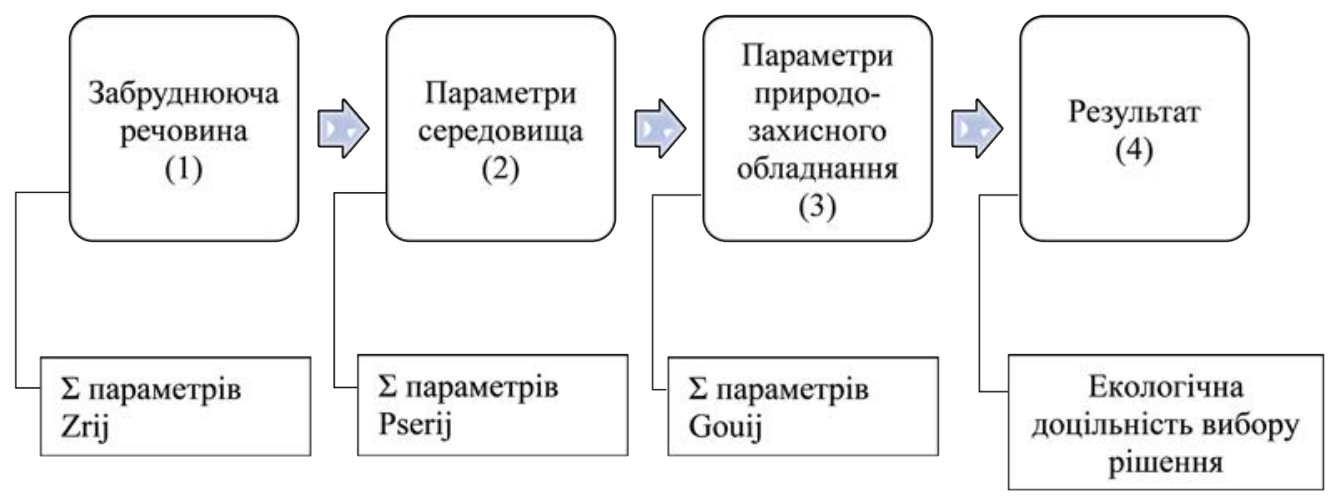

Рис. 3. Морфологічна схема прочеесу підбору пилогазоочисного обладнання для уловлення забруднюючих речовин

Такі взаємозв'язки доцільно представити у вигляді морфологічного графа (рис. 3), який дозволяє відобразити одночасне перетворення. Для цього необхідні чіткі умови, що однозначно описують можливість наслідування структурних елементів та варіантних особливостей у сукупності предметного переліку.

Сукупність параметрів (елементів) груп Zrij, Pserij, Gouij формується на підставі матриць (табл. 1-3).

3 огляду на кількість елементів в кожній групі, можна очікувати значної кількостї комбінацій ключових характеристик і варіантів вибору пилогазоочисного обладнання. В якості попереднього кроку нам необхідно визначити основні правила, за якими об'єкти можуть бути згруповані разом. Ми будемо використовувати закони математичної логіки для викладу загальних підходів до формування теорії вибору пилогазоочисного обладнання, будуючи висловлювання за допомогою логічних відносин. У цьому разі доцільність вибору певного апарату складається 3 елементів графа морфологічних ознак, а в формалізованій формі кожен тип системи ВПО буде являти собою складне висловлювання, яке складається 3 простих елементів за допомогою дій, які можуть бути змістовно виражені як «і» (з’єднання), відоме як кон'юнкція; «або» (заміна), відоме як диз'юнкція.

Далі аналізуються параметри ЗР та умови середовища на відповідність певному варіанту пилогазоочисного обладнання. На мові математичної логіки це означає, що необхідно врахувати одночасно значення цих трьох складників. Для цього скористаємося логічною операцією «і» (як показано на зразку далі

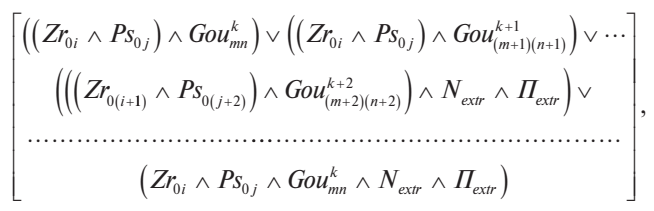

де $\mathrm{i}, \mathrm{j}, \mathrm{k}, \mathrm{l}, \mathrm{m}, \mathrm{n}, \mathrm{p}=1,2,3, \ldots$; - обсяг викидів; максимальне навантаження по газовій фазі.
Наприклад, для очистки викидів аерозолів двоокису титану обсягом $30000 \mathrm{~m}^{3} /$ год за умов не перевищення температури середовища вище $400^{\circ} \mathrm{C}$ ми використовуємо апарат з КДПТ (0,06 м) (який також підійде з урахуванням обмеженням по дисперсності частинок ЗР):

$$
\left[\left(\left(\left(Z r_{01} \wedge P s_{02}\right) \wedge G o u_{9}^{0}\right) \wedge N_{30000} \wedge \Pi_{40000}\right)\right] .
$$

Таким чином, за допомогою алгебри висловлень сформульовано поступовість і наслідування роботи алгоритмічної програми розрахунку оптимального ВПО на підставі параметрів ЗР та умов середовища проведення процесу очищення.

Наведений математичний запис обгрунтування ВПО представляє поступові перетворення між його складниками. Такі взаємозв'язки доцільно представити у вигляді графа, який дозволяє відобразити одночасне перетворення однієї складової частини в декілька інших за допомогою відповідної кількості ребер графа, які виходять із однієї вершини. Порядок відображення вершин графа повинен бути однозначним, щоб забезпечувати послідовність зміни як константних, так і варіантних елементів.

Результат застосування програми представлено на такому графі (рис. 4).

Візуалізації графа вказують на вибір більш оптимального технологічного обладнання для очищення певних 3Р з урахуванням умов параметрів середовища, де повинен відбуватися цей процес.

Головні висновки. У роботі проведено аналіз баз даних параметрів забруднюючих речовин, умов проведення процесу очищення викидів та параметрів пилогазоочисного обладнання. За допомогою графів отримано швидке алгоритмічне пояснення орієнтованого оптимального вибору певних типів очисного обладнання. На підставі аналізу і візуалізацій ієрархічної будови схеми вибору пилогазоочисного обладнання можна зробити висновок про зручну оцінку ефективності проведення процесу очищення. 


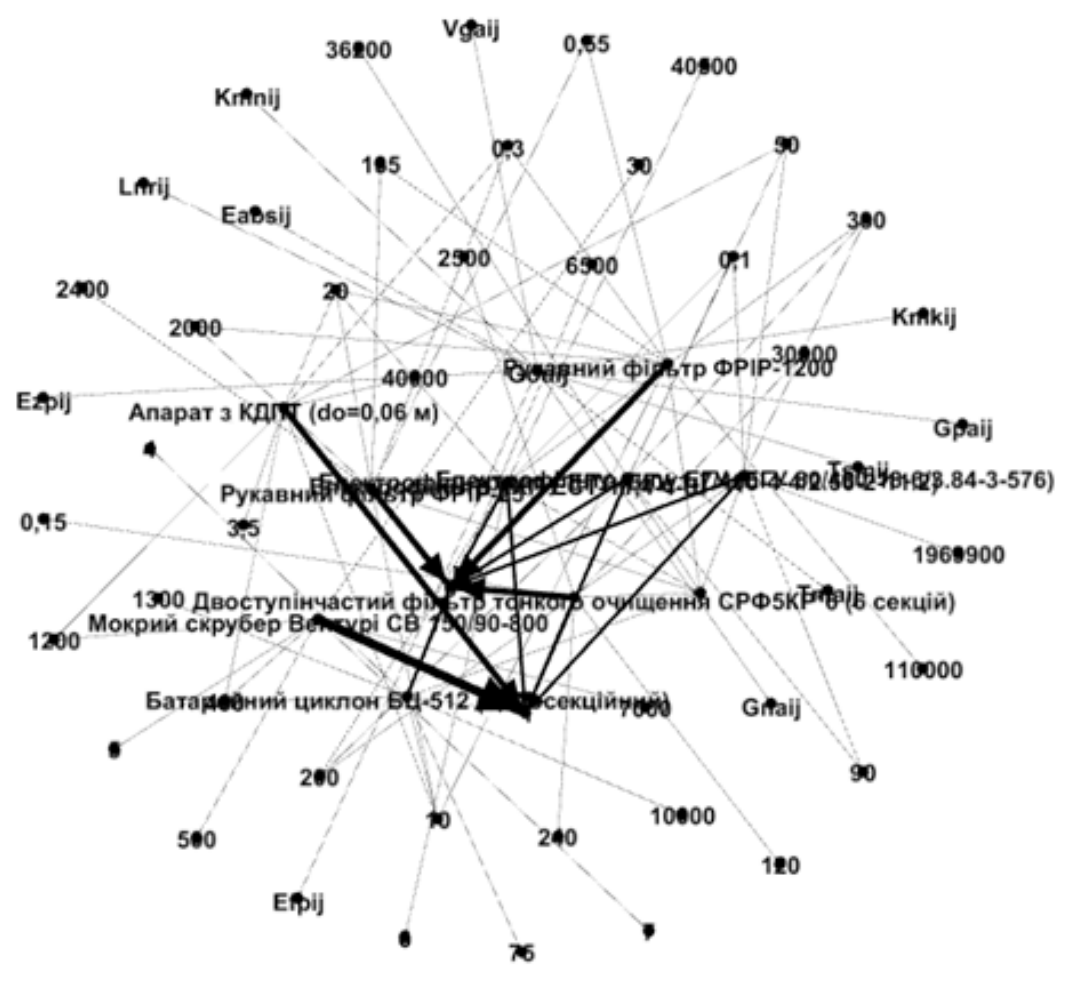

Рис. 4. Направлений граф прочесу обтрунтування вибору пилогазоочисного обладнання

Перспективи використання результатів дослідження. У подальшому планується представити програмний застосунок для більш зручного вибору пилогазоочисного обладнання на підставі аналізу баз даних забруднюючих речовин та умов середовища (місцевості, пори року). Це дозволить оперативно вирішувати питання прийняття технологічних рішень для зменшення техногенного навантаження на довкілля.

\section{Література}

1. Ambient air pollution: a global assessment of exposure and burden of disease / director of Public Health, Environmental and Social Determinants of Health, Dr. M. Neira. Geneva, Switzelend: WHO Document Production Services, 2016, 132 p.

2. Hurets L., Miakaieva H., Kozii I. Directions of the environmental protection processes optimization at heat power engineering enterprises. Журнал інженерних наук. 2017. T. 4. №2. C. G12-G16.

3. Kozii I., Plyatsuk L., Hurets L. Distribution of the Dispersed Phase in the Gas Cleaning Equipment with Pulsating Plug. Problemele Energeticii Regionale. 2021. Vol. №1(49). P. 29-38.

4. Гурец Л.Л., Козий И.С., Пляцук Д.Л. Газоочистное оборудование для комплексной очистки газов. Deutschland, Lambert academic publishing: OmniScriptum GmbH\&Co. KG, 2014. 57 c.

5. Abdul-Wahab S.A., Jupp B.P. Levels of heavy metals in subtidal sediments in the vicinity of thermal power/desalination plants: a case study. Desalination. 2009. Vol. 244, P. 261-282.

6. Cicek A., Koparal A.S. Accumulation of sulfur and heavy metals in soil and tree leaves sampled from the surroundings of Tunçbilek Thermal Power Plant. Chemosphere. 2004. Vol. 57. P. 1031-1036.

7. Mohammad A., Mujahid A.K. Effects of coal-fired thermal power plant discharges on agricultural soil and crop plants. Environmental Research. 1986. Vol. 39, P. 405-417.

8. Alper B. Geochemical Assessment of Environmental Effects of Ash from Yatagan (Mugla-Turkey) Thermal Power Plant. Water, Air, and Soil Pollution. 2003. Vol.144. P. 3-18.

9. Raja R., Nayak A. K., Shukla A. K., Rao K. S. Impairment of soil health due to fly ash-fugitive dust deposition from coal-fired thermal power plants. Environmental Monitoring and Assessment. 2015. Vol. 187, P. 679.

10. Ветошкин А.Г. Аппаратурное оформление процессов защиты атмосферы от газовых выбросов : учебное пособие по проектированию. Москва: Инфра-Инженерия, 2017. 244 с.

11. Швыдкий В.С., Ладыгичев М.Г. Очистка газов: Справочное издание. Москва: Теплоэнергетик, 2002. 640 с.

12. Вальдберг А.Ю., Александров В.П. Фильтры для очистки промышленных газов. Москва: МГУИЭ, 2009. 204 с.

13. Санаев Ю.И. Обеспылевание газов электрофильтрами. Семибратово: Кондор-Эко, 2009. 163 с.

14. Молчанов В.Н., Лисянский Ю.А., Молчанов А.В. Методы, аппараты и системы промышленной очистки газов. Бушин: EKOLTRONIK CZECH s.r.o., 2011. 680 c. 
15. Plyatsuk L., Hurets L., Kozii I., Vaskin R. Industrial research studies of gas treatment device with a large hole sieve trays. Науковий вісник НГУ. 2016. Вип. №3, С. 95-100.

16. Kerry F.G. Industrial gas handbook: Gas separation and purification. Boca Raton, FL: CRC Press, 2007. 550 p.

17. Lieberman N.P., Lieberman E.T. A working guide to process equipment. NY, NY: McGraw-Hill, 2014. 751 p.

18. Bacciu D., Bruno A. Deep tree transductions - a short survey. In Recent Advances in Big Data and Deep Learning. 2020. P. $236-245$.

19. Wu D., Yeong J., Tan G., Chevrier M., Loh J., Lim T., Chen J. Comparison Between UMAP and t-SNE for MultiplexImmunofluorescence Derived Single-Cell Data from Tissue Sections. bioRxiv. 2019. 20 p. 


\title{
ПОСТУПОВА РЕКОНСТРУКЦІЯ ПРИШАЯХОВИХ НАСАДХЕНЬ У НАСЕАЕНИХ ПУНКТАХ
}

\author{
Красовський В.В., Черняк Т.В. \\ Хорольський ботанічний сад \\ вул. Кременчуцька, 1/79, оф. 46, 37800, м. Хорол, Полтавська область \\ horolbotsad@gmail.com
}

\begin{abstract}
Показано, що деревні насадження, які зростають в населених пунктах уздовж вулиць, на смузі землі між тротуаром і проїжджою частиною дороги, становлять економічну, соціальну та культурну цінність, адже виконують санітарну функцію, вносять певну різноманітність у місцевий ландшафт, прикрашають вулиці і водночас позитивно впливають на емоційний стан водіїв, пасажирів та пішоходів.

Зазначено, що сучасний стан більшості пришляхових насаджень визначається тривалим антропогенним навантаженням. Оцінка стану пришляхових насаджень не може здійснюватися на єдиній методологічній основі, бо під час створення пришляхових насаджень використовують деревні рослини різних видів чи лісових порід, плодових та декоративних культур із красивими кронами і листям, які зростають у різних грунтово-кліматичних умовах залежно від регіону, можуть мати притаманні виду грибкові, бактеріальні, вірусні хвороби та шкідників.

Відзначено, що дерева живуть та старіють і у пришляхових насадженнях не можуть культивуватися до досягнення вікової межі через те, що їх дуже рідко формують або взагалі не формують (за винятком порід, які не переносять формувального обрізання), з часом вони стають перерослими, хворіють, втрачають декоративні властивості, набувають ознак аварійності і є загрозою для людей, транспортних засобів, повітряних ліній електропередач, i, як невідворотна реальність, розпочинається реконструкція насаджень.

Підкреслено, що під час реконструкції на урбанізованих територіях пришляхових насаджень із системною заміною дерев невирішеною проблемою залишається втрата на тривалий час санітарних функцій насаджень.

Проведене дослідження полягає в удосконаленні способів реконструкції пришляхових насаджень у населених пунктах, а саме в обгрунтуванні та впровадженні у практику способу поступової реконструкції пришляхових насаджень, що скорочує проміжок часу від видалення старих насаджень до поновлення експлуатаційних характеристик нових насаджень, тобто не зменшує санітарне значення і ступінь озеленення локації у процесі реконструкції насадження.

Запропоновано новий спосіб поступової реконструкції пришляхових насаджень, що включає видалення старих та висадку саджанців нових дерев, який відрізняється тим, що старі перерослі дерева глибоко кронують, а молоді висаджують у ряд між ними. Перші видаляють лише після досягнення молодими деревами більш зрілого віку. Представлений спосіб поступової реконструкції пришляхових насаджень у населених пунктах простий у реалізації, проте може мати обмеження у разі зростання старих перерослих дерев, що не підлягають кронуванню. Ключові слова: населені пункти, пришляхові насадження, реконструкція.
\end{abstract}

Progressive reconstruction of nearby plantations in settlements. Krasovsky V., Cherniak T.

It is shown that tree plantations that grow in settlements along the streets, on the strip of land between the sidewalk and the roadway, are of economic, social and cultural value, because they perform a sanitary function, add some diversity to the local landscape, decorate the streets and positively affect emotional state of drivers, passengers and pedestrians.

It is noted that the current state of most roadside plantations is determined by long-term anthropogenic load. Assessment of the condition of roadside plantations cannot be carried out on a single methodological basis because when creating roadside plantations use woody plants of different species or forest species, fruit and ornamental crops with beautiful crowns and leaves, they grow in different soil and climatic conditions depending on the region. species of fungal, bacterial, viral diseases and pests.

It is noted that trees live and age and in roadside plantations can not be cultivated until the age limit due to the fact that they are very rare or not formed at all (except for species that do not tolerate formative pruning), over time they become overgrown, sick, lose decorative properties, acquire signs of emergency and are a threat to people, vehicles, overhead power lines and, as an inevitable reality, begins the reconstruction of plantations. It is emphasized that during the reconstruction of roadside plantations in urban areas with the systematic replacement of trees, the long-term loss of sanitary functions of plantations remains an unsolved problem.

The study is to improve the methods of reconstruction of roadside plantations in settlements, namely the justification and implementation of the method of gradual reconstruction of roadside plantations, which reduces the time from removal of old plantations to restoration of new plantations, ie does not reduce planting. A new method of gradual reconstruction of roadside stands has been proposed, including the removal of old and planting of new trees, characterized in that old overgrown trees are deeply crowned and young ones are planted in a row between them and the first are removed only when young trees reach a more mature age. The presented method of gradual reconstruction of roadside plantations in settlements is easy to implement, but may have limitations in the case of growth of old overgrown trees that are not subject to crowning. Key words: settlements, roadside plantings, reconstruction.

Постановка проблеми. Суспільство та природа 3 найдавніших часів тісно пов'язані між собою, тому не є чимось особливим успадковане від багатьох поколінь штучне залучення великої кількості дерев- них рослин у населені пункти як життєвого середовища й елементу довкілля.

Деревні насадження, що зростають у містах, селищах та селах вздовж вулиць, на смузі землі між 
тротуаром і проїжджою частиною дороги, себто пришляхові, становлять економічну, соціальну та культурну цінність, адже виконують санітарну функцію, вносять певну різноманітність у місцевий ландшафт, прикрашають вулиці і водночас позитивно впливають на емоційний стан водіїв, пасажирів та пішоходів.

У кожній природно-кліматичній зоні країни є власні традиційні породи дерев, які використовують як пришляхові насадження. Існують види високих і ширококронних деревних рослин, яким необхідний простір для зростання. Серед них - клен гостролистий (Acer platanoides L.), клен сріблястий (Acer saccharinum L.), липа дрібнолиста (Tilia cordata Mill.), липа широколиста (Tilia platyphyllos Scop.), горобина звичайна (Sorbus aucuparia L.), горобина скандинавська (Sorbus intermedia (Ehrh.) Pers.), береза повисла (Betula pendula Roth), гіркокаштан звичайний (Aesculus hippocastanum L.), клен несправжньоплатановий (Acer pseudoplatanus L.) тощо [1]. Ці ж види найчастіше використовують у Лісостеповій зоні України, тому під час висадки враховуються їхні розміри у майбутньому.

Сучасний стан більшості пришляхових насаджень визначається тривалим антропогенним навантаженням. Оцінка стану пришляхових насаджень не може здійснюватися на єдиній методологічній основі, бо під час створення пришляхових насаджень використовують деревні рослини різних видів чи лісових порід, плодових та декоративних культур iз красивими кронами і листям, які зростають у різних грунтово-кліматичних умовах залежно від регіону, можуть мати притаманні виду грибкові, бактеріальні, вірусні хвороби та шкідників.

Важливо відзначити, що дерева живуть та старіють і у пришляхових насадженнях не можуть культивуватися до досягнення вікової межі через те, що їх дуже рідко формують або взагалі не формують (за винятком порід, які не переносять формувального обрізання), з часом вони стають перерослими, хворіють, втрачають декоративні властивості, набувають ознак аварійності і є загрозою для людей, транспортних засобів, повітряних ліній електропередач, i, як невідворотна реальність, розпочинається реконструкція насаджень.

Під час реконструкції на урбанізованих територіях пришляхових насаджень із системною заміною дерев невирішеною проблемою залишається втрата на тривалий час санітарних функцій насаджень.

Зв'язок авторського доробку із важливими науковими та практичними завданнями. Авторський доробок безпосередньо пов'язаний із діяльністю Хорольського ботанічного саду, де проводяться дослідження 3 інтродукції, акліматизації, селекції рослин, здійснюються роботи зі збереження біологічного різноманіття, охорони рослинного світу, екологічного моніторингу, ландшафтного проєктування та садово-паркового будівництва. Важливим у діяль- ності ботанічного саду $є$ поширення результатів досліджень за межі ботанічного саду.

Аналіз останніх досліджень і публікацій. Добре відомо, що будь-яка реконструкція деревних насаджень будь-якого об'єкта озеленення, зокрема пришляхових насаджень у населених пунктах, є процесом поетапним. При цьому конкретні заходи щодо реконструкції визначаються станом об'єкта і включають, зокрема, формувальне, санітарне, омолоджувальне обрізання крони дерев, підсадку або посадку нових та видалення старих, хворих, вражених шкідниками або аварійних дерев. Також відомо та очевидно, що під час підсадки саджанців до вже наявних вуличних насаджень необхідно створити умови для нормального та безпечного розвитку саджанців, зокрема достатнє освітлення та простір для їхнього росту. Такі умови забезпечуються обрізанням крони зростаючих дерев, що розташовані поряд із місцем посадки нових [2-5].

У галузі зеленого будівництва найбільшого розповсюдження набули однорядні насадження дерев по обидві сторони дороги, розташовані прямими лініями паралельно осі дороги. Відстань між деревами і віддаленість їх від полотна дороги можуть бути різними в межах смуги відведення та залежно від породи дерев. Також підбирають породи дерев, що найбільше підходять для зростання в конкретній локації [6-10].

Необхідно визнати, що процес розвитку і росту дерев у пришляхових насадженнях відбувається переважно в складних умовах, де підвищена температура повітря i грунту, грунт ущільнений, повітря загазоване і задимлене, зі вмістом пилу. Несприятливі умови урбанізованого середовища населених пунктів призводять до передчасного старіння насаджень і зниження їхньої життєдіяльності, отже, передчасно застарілі, хворі, а також вражені шкідниками і паразитами дерева необхідно видаляти. Також показником потреби у заміні деревних пришляхових насаджень $є$ їх критичний біологічний вік. Велику загрозу для пішоходів, транспорту та різних споруд становлять пришляхові перерослі дерева через велику вітрильність крони, адже під час буревіїв такі дерева або окремі їх скелетні гілки стають аварійними за можливого падіння. Під час капітального ремонті вулиці, а саме розширення дорожнього полотна або тротуарних шляхів, заміни підземних комунікаційних мереж тощо, коренева система дерев зазнає пошкоджень, що може призвести до їх загибелі. Це один $з$ аргументів на користь того, щоб із проведенням ремонтів одночасно проводити повну заміну дерев, однак у такому разі значно зросте відновлювальна вартість зелених насаджень.

Отже, для реконструкції пришляхових насаджень із старих, перерослих, хворих, а також дерев iз дуплами або таких, що мають загрозливий аварійний уклін, необхідні роботи, спрямовані на відновлення їхніх експлуатаційних характеристик, 
що включають видалення старих та посадку нових дерев. Водночас очевидно, що для поновлення експлуатаційних характеристик щойно висаджених саджанців деревних порід потрібен певний час.

Варто окремо вказати на впроваджений у практику реконструкції пришляхових насаджень спосіб омолодження старих перерослих дерев шляхом спилу стовбура на пень, що спричинює швидкий ріст кореневої порості, з якої формують одностовбурне дерево. Описану операцію доцільно виконувати $з$ видами дерев, які після пошкодження здатні відновлювати цілісність організму, та в місцях, де мешканці населеного пункту звикли до певного виду дерев, адже такі устої необхідно зберігати. Проте цей спосіб не дозволяє створювати нові пришляхові насадження з інших, більш стійких у змінених умовах середовища декоративних видів, крім тих, що раніше зростали.

Новизна роботи полягає в удосконаленні способів реконструкції пришляхових насаджень у населених пунктах, а саме обгрунтуванні та впровадженні у практику способу поступової реконструкції пришляхових насаджень, що скорочує проміжок часу від видалення старих насаджень до поновлення експлуатаційних характеристик новими, тобто не зменшується санітарне значення та ступінь озеленення локації у процесі реконструкції насадження.

Методика досліджень. У роботі використано такі загальнонаукові методи дослідження живої матерії, як логістичний, пояснювальний та експериментальний.

Виклад основного матеріалу. В останні роки у процесі експлуатації пришляхових насаджень у населених пунктах застосовують прийом радикального зменшення висоти або зміни форми крони перерослих дерев, де перепилюють стовбур дерева на висоті 3,5-4,0 м, а гілки, розміщені на його залишку, вкорочують. Такий прийом застосовують до листяних порід із сплячими бруньками, які зберігають життєздатність протягом багатьох років, адже 3 них у разі пошкодження частини дерева розвиваються пагони. Хоча крона у таких дерев відновиться швидко і розташовуватиметься значно нижче від попередньої, як і планувалося, проте у порід із м'якою деревиною 3 великою ймовірністю значно скоротиться тривалість життя через загнивання серцевини стовбура, починаючи від зрізу й опускаючись вниз. Водночас вагомим аргументом застосування такого прийому є виключення аварійності перерослих дерев. Принаймні нині такий прийом глибокого кронування перерослих дерев, що є доцільним кроком, широко застосовується на центральних вулицях міста Хорол Полтавської області (рис. 1).

Оскільки пришляхові насадження покращують санітарно-гігієнічні умови околиці, позитивно впливають на створення мікроклімату, а отже, спрямовані на забезпечення сприятливих умов життєдіяльності населення, під час реконструкції пришляхових наса- джень ставиться завдання максимально скоротити проміжок часу від початку видалення старих насаджень до початку набуття експлуатаційних характеристик новими. Спосіб, за якого не зменшують ступінь озеленення пришляхових насаджень безпосередньо у процесі їх реконструкції, має беззаперечну перевагу, адже потрібно немало часу, щоб висаджені саджанці досягли необхідних розмірів і задовольняли експлуатаційні потреби населеного пункту.

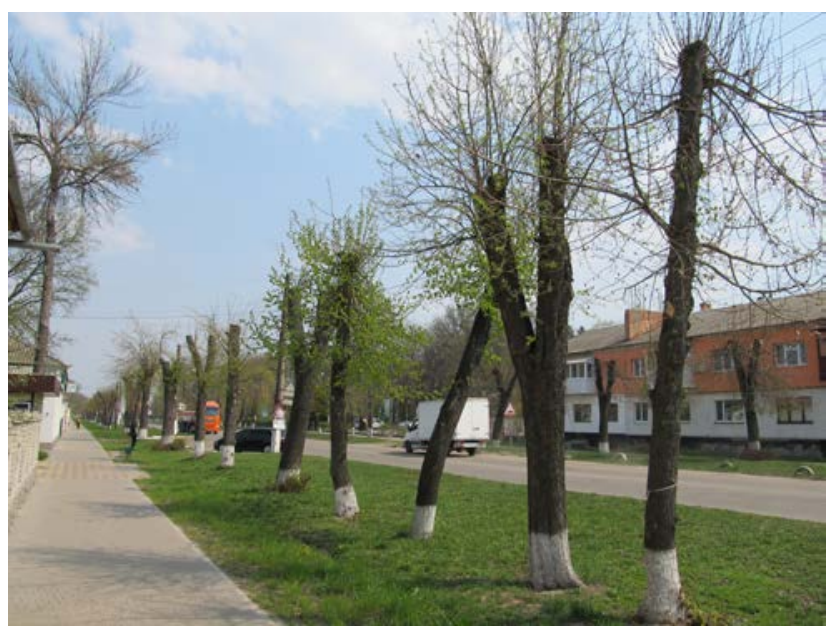

Рис. 1. Пришляхові глибококроновані дерева породи липа, м. Хорол, Полтавська обл., вул. Небесної сотні, квітень 2019 p.

Нині завдання щодо невеликого розбігу у часі між видаленням існуючих насаджень і набуттям експлуатаційних характеристик новими можливо вирішити висадкою крупномірних дерев із великим комом грунту. Проте цей спосіб дороговартісний, спеціальна механізована техніка не завжди є навіть у великих містах. Під час пересадки крупноміру на допомогу може прийти компроміс: зменшити ком грунту до мінімальних розмірів, пересадити полегшене дерево, а потім у процесі догляду компенсувати можливий ризик випадання дерев посиленим поливом із додаванням біостимуляторів росту та розвитку.

3 урахуванням викладеного ми пропонуємо вирішувати вищепоставлене завдання способом поступової реконструкції пришляхових насаджень, що включає видалення старих та висадку саджанців нових дерев, який відрізняється тим, що старі перерослі дерева глибоко кронують, а молоді висаджують в ряд між ними і перші видаляють лише після набуття саджанцями стану більш зрілого віку.

Спосіб поступової реконструкції пришляхових насаджень у населених пунктах випробовується працівниками ботанічного саду у співпраці з КП «Комунсервіс» в м. Хорол Полтавської обл. на частині вулиці Небесної Сотні біля ПрАТ «Хорольський механічний завод», де між глибококронованими деревами видів липа серцелиста (Tilia cordata Mill.), горобина скандинавська (Sorbus 
intermedia (Ehrh.) Pers.) та гіркокаштан звичайний (Aesculus hippocastanum L.) висаджено 28 трирічних саджанців гіркокаштана м'ясочервоного (Aesculus $x$ carnea Hayne.). Варто зазначити, що у процесі такої реконструкції нові насадження, на відміну від попередніх, висаджені у чітку лінію із стандартною відстанню між саджанцями для цієї породи дерев (рис. 2). Крім того, гіркокаштан м'ясочервоний, на противагу гіркокаштану звичайному, не вражається мінуючою міллю каштановою (Cameraria ohridella Deschka \& Dimic) - шкідником гіркокаштанів. Станом на 01.10.2021 р. саджанці гіркокаштана м'ясочервоного мали середню висоту 1,6 м.

Нині у лісостеповій зоні України як пришляхові насадження переважно використовують аборигенні види дерев, які тисячоліттями пристосовувалися до грунтово-кліматичних умов місцевості, і дендрологи мають значний досвід у їх підборі для кожної окремої локації населеного пункту. Водночас використання інтродукованих видів у зазначених насадженнях $є$ більше винятком, ніж правилом, адже, за даними науковців, аборигенний дуб

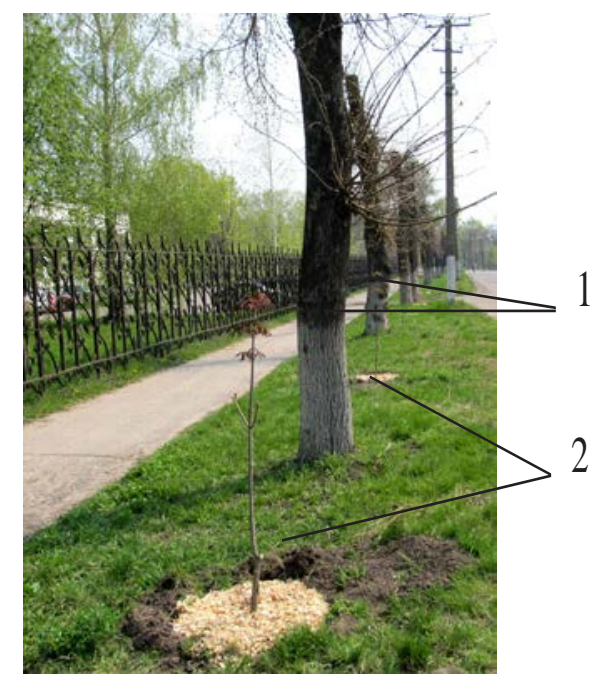

Рис. 2. Пришляхові насадження, м. Хорол,

Полтавська обл., вул. Небесної сотні, квітень 2019 р.

1 - старі глибококроновані насадження,

2 - молоді саджанцеві насадження черешковий (Quercus robur L.) навіть у міських умовах доживає до 100-150 років, а інколи - до 300-400 років, водночас дуб червоний (Quercus rubra L.) показує значно меншу довговічність (до 100 років). Двохсотрічний досвід інтродукції деревних рослин в Україні показав, що зазвичай довговічність екзотів у культурі в 1,5-2,0 рази менша, ніж у природних умовах [11].

Зважаючи на викладене та оцінюючи сучасні глобальні зміни клімату, на наш погляд, особливого значення в насадженнях населених пунктів доречно надавати використанню жаро- та посухостійких плодових культур, які мають і декоративне значення [12-14]. 3 цією метою під час запровадження способу поступової реконструкції пришляхових насаджень у лісостеповій зоні України для заміни існуючих насаджень на жаро- та посухостійкі варто використовувати такі інтродуценти, як зизифус справжній (Zizyphus jujuba Mill.) та мигдаль звичайний (Amygdalus communis L. forma amara DS). За даними наших досліджень із використанням методів оцінки декоративності деревних рослин [15], Z. jujuba за ступенем оцінки декоративності дерев і чагарників належить до другої групи декоративності, що відповідає високій декоративності, A. communis forma amara - до третьої групи декоративності, що відповідає посередній декоративності.

Головні висновки. Запропоновано новий спосіб поступової реконструкції пришляхових насаджень у населених пунктах, який зараз проходить державну реєстрацію в ДП «Український інститут інтелектуальної власності» як корисна модель, а отже, охоронятиметься відповідним патентом (автор В. Красовський) [16].

Дослідження спрямовані на розв'язання проблеми скорочення проміжку часу від початку видалення старих перерослих дерев пришляхових насаджень до поновлення експлуатаційних характеристик нових насаджень.

Запропонований спосіб поступової реконструкції пришляхових насаджень у населених пунктах простий у реалізації, проте може мати обмеження у разі зростання старих перерослих дерев, що не підлягають кронуванню.

\section{Література}

1. Кушнір А.І., Карпов Ю.Р., Кушнір О.А. Використання у ландшафтному будівництві м. Києва нових сортів та форм листяних щеплених декоративних рослин. Вищі навчальні заклади - Києву : матер. наук.-практ. конференції. Київ., 2004. С. 39-41.

2. Порядок видалення дерев, кущів, газонів і квітників у населених пунктах : затв. постановою Кабінету Міністрів України від 1 серпня 2006 р. № 1045.

3. Правила утримання зелених насаджень у населених пунктах України : затв. наказом М-ва будівництва, архітектури та житлово-комунального господарства України від 10 квіт. 2006 р. № 105.

4. Методическое руководство и технические условия по реконструкции городских зеленых насаждений. Москва : МГУЛ, $2001.58 \mathrm{c}$

5. Озеленение населенных мест : справочник / Ерохина В.И. и др. ; под ред. В.И. Ерохиной. Москва : Стройиздат, 1987.480 с.

6. Гончаровська І.В., Кузнєцов В.В., Антонюк Г.О. Використання біорізноманіття плодових рослин для збереження існуючих і створення нових декоративних композицій. Біорізноманіття Украӥни в контексті сучасних природних умов середовища : матеріали Міжнар. наук.-практ. конф., 4-5 червня 2020 р. Тернопіль : Крок, 2020. С. 16-19. 
Красовський В.В., Черняк Т.В.

7. Дендрофлора України. Дикорослі та культивовані дерева і кущі. Покритонасінні. Частина І. Довідник / Кохно М.А. та ін.; за ред. М.А. Кохна. Київ : Фітосоціоцентр, 2002. 448 с.

8. Збереження та збагачення рослинних ресурсів шляхом інтродукції, селекції та біотехнології : монографія / Черевченко Т.М., Рахметов та ін. ; за ред. Т.М. Черевченко. Київ : Фітосоціоцентр, 2012. 432 с.

9. Колесников А.И. Декоративные формы древесных пород. Москва : Изд-во мин-ва коммун. хоз. РСФСР, 1958. 278 с.

10. Миколайчук В.Г., Чернова А.В. Декоративна дендрологія та квітникарство : метод. реком. Миколаїв, 2019.60 с.

11. Масальський В.П., Кузнєцов С.І. Аборигенна дендрофлора покритонасінних - основа паркобудування в Лісостепу України. Науковий вісник НЛТУ Украӥни. 2018. № 8, т. 28. С. 14-18.

12. Карпун Ю.Н. Субтропическая декоративная дендрология : справочник. Санкт-Петербург, 2010. 580 с.

13. Меженський В.М., Меженська Л.О. Малопоширені плодові культури : навчальний посібник. Київ : ЦП «Компринт», 2016. $544 \mathrm{c}$.

14. Шайтан И.М., Мороз П.А., Клименко С.В. Интродукция и селекция южных и новых плодовых растений. Київ : Наукова думка, 1983. 216 с.

15. Власенко А.С. Оцінка декоративності дендросозоекзотів ех situ Степу України. Науковий вісник Східноєвропейського наиіонального університету ім. Лесі Украӥнки. 2016. № 7 (332). С. 27-35.

16. Рішення про державну реєстрацію корисної моделі «Спосіб поступової реконструкції пришляхових насаджень в населених пунктах». Реєстраційний номер заявки а 201904795 від 06.05.2019. МПК (2021.01) A01C 14/00, A01G 23/02 (2006.01). Лист ДП «Український інститут інтелектуальної власності» 17.11.2021 № 14675/3У/21. 


\title{
ЕКОАОГІЧНІ АСПЕКТИ ВИКОРИСТАННЯ ВУГІМЯ З ПІДВИЩЕНИМ ВМІСТОМ НАТРІЮ ТА ХАОРУ
}

\author{
Фатеєв А.І., ${ }^{1}$ Ясинецький А.О., ${ }^{1}$ Лазарєв С.С. ${ }^{2}$ \\ ${ }^{1}$ Інститут теплоенергетичних технологій Національної академії наук України \\ вул. Андріївська, 19, 04070, м. Київ, \\ ${ }^{2}$ Національний технічний інститут України «Київський політехнічний інституту \\ імені Ігоря Сікорського» \\ вул. Політехнічна, 6, 03056, м. Київ \\ antonfateev86@gmail.com, aoyasin@gmail.com, stalkerov14091998@gmail.com
}

\begin{abstract}
Солоне вугілля українських родовищ у переліку непроєктних палив є перспективним джерелом енергії в Україні. Це пов'язано насамперед із високими енергетичними (паливними) характеристиками цього вугілля, а також умовами залягання та запасами. Основні перепони використання родовищ солоного вугілля пов'язані із підвищеним вмістом у ньому домішок $(\mathrm{Na}$ та $\mathrm{Cl}$ ). Ці домішки, з одного боку, можуть призводити до низки проблем під час спалювання (шлакування, корозія, екологічні проблеми), але й можуть мати позитивний ефект у разі використання такого вугілля у сумішах з іншим, менш реакційним паливом. Встановлено, що під час спалювання композиційного палива солоного та пісного вугілля відбувається не тільки зменшення загального вмісту натрію у суміші, а й утворення нових, більш складних та насамперед тугоплавких мінеральних фаз золи (в основному нефелінів), що унеможливлюють надмірне шлакування поверхонь нагріву. Найбільш оптимальний вміст солоного вугілля у суміші при цьому не більше $50 \%$. Однак використання суміші солоного вугілля 3 іншим видом палива не забезпечує дотримання вимог із викиду хлору. У зв'язку з цим пропонується одночасне зв'язування сполук хлору та сірки у установці десульфуризації димових газів із використанням кальцієвих сорбентів, таких як вапно та вапняк. Експериментально доведено, що за одночасного контакту реагенту з хлороводнем та діоксидом сірки першим зв'язуватися буде саме хлороводень. Ця особливість пов'язана із більшою реакційною здатністю хлороводню порівняно із сірчистою кислотою. Для забезпечення повного зв'язування хлору без зниження ефективності сіркоочищення димових газів рекомендовано збільшити мольну витрату кальцієвих реагентів на величину половини мольного вмісту хлору у димових газах. Ці рекомендації дозволяють ефективно, безпечно та екологічно використовувати солоне вугілля в енергетичній галузі, що дасть змогу розширити паливну базу та підвищить енергетичну безпеку України. Ключові слова: солоне вугілля, натрій, хлор, суміш, сіркоочищення, десульфуризація димових газів.
\end{abstract}

Environmental aspects of coal use with high sodium and chlorine content. Fateiev A., Yasynetskyi A., Lazariev Ye.

Salt coal of Ukrainian deposits in the list of non-project fuels is a promising source of energy in Ukraine. This is primarily due to the high energy (fuel) characteristics of this coal, as well as conditions and reserves. The main obstacles to the use of salt coal deposits are associated with the increased content of impurities $(\mathrm{Na}$ and $\mathrm{Cl}$ ). These impurities on the one hand can lead to a number of combustion problems (slag, corrosion, environmental problems), but can also have a positive effect when using such coal in mixtures with other less reactive fuels. It is established that the combustion of composite fuel of salt and lean coal not only reduces the total sodium content in the mixture, but also the formation of new more complex and primarily refractory mineral phases of ash (mainly nepheline), which prevents excessive slagging of heating surfaces. The most optimal content of salt coal in the mixture is not more than $50 \%$. However, the use of a mixture of salted coal with other fuels does not ensure compliance with chlorine emissions. In this regard, it is proposed to simultaneously bind chlorine and sulfur compounds in a flue gas desulfurization plant using calcium sorbents such as lime and limestone. It has been experimentally proven that hydrogen chloride will be the first to bind when the reagent is in simultaneous contact with hydrogen chloride and sulfur dioxide. This feature is due to the greater reactivity of hydrogen chloride compared to sulfuric acid. To ensure complete binding of chlorine without reducing the efficiency of flue gas desulphurization, it is recommended to increase the molar consumption of calcium reagents by half the molar content of chlorine in flue gases. These recommendations allow for efficient, safe and environmentally friendly use of salted coal in the energy sector, which will expand the fuel base and increase Ukraine's energy security. Key words: salt coal, sodium, chlorine, mixture, flue gas desulfurization.

Споживання первинних енергоресурсів безперервно зростає, що змушує країни залучати до енергетичного використання все менш якісне паливо (вуглецевмісні відходи, торф, низькоякісне низькокалорійне вугілля, вуглецеві суміші різного походження тощо). Водночас протягом останніх 20 років пильна увага світової громадськості спрямована до питань екології. Україна є членом Європейського Енергетичного співтовариства (СЕС) та взяла зобов'язання дотримуватися умов Договору СЕС та його Додатків. Згідно З Додатком II до Договору всі великі установки повинні були після 31.12.2017 р. відповідати вимогам Директиви
2001/80/EC [1] про обмеження викидів деяких забруднюючих речовин в повітря, але через великий обсяг робіт та обмежені фінансові ресурси ці вимоги виконані не були. Національний план скорочення викидів відтермінував дію директиви 2001/80/EC, однак наступна директива 2010/75/EC [2] про промислові викиди ще посилила вимоги СС до викидів діоксиду сірки, оксидів азоту та пилу.

Жорсткіші вимоги щодо викидів шкідливих речовин поставили перед вугільною енергетикою нові економічні та технологічні завдання і водночас відкрили нові можливості для пошуку та впрова- 
дження інноваційних розробок у галузі переробки альтернативних видів палива. Відомо, що за більш ніж 200 років експлуатації вугільних басейнів країни потужні і доступні вугільні пласти вже відпрацьовані, а ті, що залишилися, мають малу потужність $(0,8-1,2$ м), залягають на глибинах понад 1000 м, а також характеризуються здебільшого високим вмістом сірки. Тому залучення доступних джерел позабалансових енергоресурсів залишається вельми актуальним. Таким енергоресурсом може стати вугілля з підвищеним вмістом лужних і лужноземельних металів, яке має загальну назву «солоне вугілля», що займає чинне місце серед резервних джерел енергії не тільки в Україні, але й у багатьох країнах світу. Поклади солоного вугілля України мають надзвичайно потужний потенціал, основні поклади розташовані в Західному та Північному Донбасі, розвідані запаси близько 10-12 млрд т (прогнозні - до 25 млрд т). Нині це вугілля не видобувається, хоча поклади вугілля характеризуються невеликими глибинами залягання (300-600 м), значними потужностями пластів (інколи до 3-5 м), прийнятну теплоту згоряння (близько 7000 ккал/кг на суху беззольну масу) і помірну зольність (10-15\%) [3-4].

Основні перепони освоєння і використання родовищ солоного вугілля пов'язані підвищеним вмістом у ньому низки шкідливих домішок. Такими домішками є усі легкоплавкі сполуки натрію та хлору (насамперед галіт), які ускладнюють експлуатацію котлоагрегатів, сприяючи швидкому шлакуванню та корозії поверхонь нагріву. Хлор поряд із сіркою виступає як основний кородуючий агент, а також такий, що забруднює навколишнє середовище.

Аналіз літературних даних останніх років свідчить, що дослідження 3 розроблення ефективної та економічно доцільної технології використання солоного вугілля продовжуються і сьогодні. Серед розробок, що стосуються залучення солоного вугілля до реального енергобалансу країни, які нині активно продовжуються, можна виділити дослідження китайських учених [5-10]. Ними за останні роки були запропоновані кілька методів вирішення проблеми використання солоного вугілля, таких як: газифікація та піроліз (визначено можливість та перспективність газифікації/піролізу солоного вугілля родовища Zhundong) [6-7]; використання різних добавок, що дають змогу перевести $\mathrm{Na}$ та Са у більш тугоплавкі сполуки [8]; попереднє відмивання водою або обробка різними хімічними розчинами (вилуговування) [9] та спалювання у суміші з іншим вугіллям [10].

Розглядаючи питання сумісного спалювання, нещодавні публікації випробування сумісного спалювання солоного вугілля родовища Zhundong провінції Xinjiang (Китай) з його потужними покладами свідчать, що, знаючи мінеральний склад солоного вугілля, можна знайти оптимальні співвідношення солоного вугілля і типового кам'яного (бітумінозного) вугілля, за яких проблеми шлакування та корозії не виникатимуть.

Усвідомлюючи актуальність та перспективність використання у тепловій енергетиці сумішевих палив, а також зважаючи на високі енергетичні (паливні) характеристики солоного вугілля перспективним шляхом використання солоного вугілля $\epsilon$ його спільне спалювання з іншим вугіллям, яке має вищу температуру плавлення золи та не викликає надмірного шлакування поверхонь нагріву. Під час спалювання сумішей тільки деколи спостерігаються адитивні залежності реакційної здатності від їхнього складу, а значно частіше - ефекти синергізму або антагонізму [11]. Це зумовлює необхідність експериментального дослідження взаємного впливу вугілля одне на одного. Важливими факторами впливу тут $\epsilon$ співвідношення компонентів, реакційна здатність обох палив (структура органічної маси, метаморфізм) та склад мінеральної частини.

Для визначення змін мінеральної складової частини солоного вугілля в процесі взаємодії з іншим вугіллям, що входить у суміш, були проведені дослідження сумісного спалювання $з$ наступним аналізом мінералів зольних залишків за допомогою дифрактометра ДРОН-4М ( $\mathrm{Cu}(\mathrm{Co}) \mathrm{K} \alpha-$ випроміненням). Напівкількісний фазовий аналіз дифрактограм проводився за допомогою програмного забезпечення МАТСН!

У таблиці 1 наведені характеристики (елементний та технічний аналіз) зразків солоного вугілля та пісного вугілля, що були використані у дослідах.

Були відібрані два зразки солоного вугілля Богданівського родовища, що мали середній та високий вміст $\mathrm{Na}_{2} \mathrm{O}$ в золі $~ 3,6 \%$ та $\sim 7 \%$ відповідно. Ці зразки характеризуються невисокою зольністю $10 \%$ та $5 \%$ та значним вмістом $\mathrm{Cl} \sim 1 \%$. Для проведення експерименту зразки вугілля були подрібнені до фракції 0-0,2 мм. Після чого наважки зразків солоного та пісного вугілля (окремо), а також їх сумішей піддавалися термічній обробці у прямокутних лодочках протягом 3 годин (1 година нагрівання до $850{ }^{\circ} \mathrm{C}$, 2 години витримки при $\left.850^{\circ} \mathrm{C}\right)$. Порівнюючи отримані в результаті експерименту маси золи сумішей із теоретично розрахованими за правилом адитивності було встановлено, що зольного залишку із сумішей в експерименті утворюється більше, ніж теоретично розраховано. Тобто має місце відчутний, хоч і невеликий, синергетичний ефект, що може свідчити про утворення у процесі термолізу сумішей нових мінеральних сполук.

Аналіз дифрактограм мінеральних фаз золи зразків солоного вугілля показав, що більшість

Таблиця 1

Характеристика солоного вугілля та пісного

\begin{tabular}{|c|c|c|c|c|c|c|c|c|c|c|}
\hline \multirow{2}{*}{ Родовище } & \multicolumn{5}{|c|}{ Елементний склад,\% } & \multicolumn{3}{|c|}{ Технічний аналіз,\% } & \multirow{2}{*}{$\begin{array}{c}\mathrm{Na}_{2} \mathrm{O} \text { y } \\
\text { золі }\end{array}$} & \multirow{2}{*}{ Cl } \\
\hline & $\mathbf{C}^{\text {daf }}$ & $\mathbf{H}^{\mathrm{daf}}$ & $\mathbf{N}^{\text {daf }}$ & $S^{\text {daf }}$ & $\mathbf{O}^{\text {daf }}$ & $\mathbf{W}^{\mathbf{a}}$ & $\mathbf{V}^{\text {daf }}$ & $\mathbf{A}^{\mathbf{d}}$ & & \\
\hline Богд. (№ 1) & 68,2 & 5,4 & 1,3 & 3,3 & 21,9 & 9,6 & 41,0 & 10,2 & $3,32-3,89$ & 0,91 \\
\hline Богд. (№ 2) & 70,9 & 5,2 & 2,4 & 1,3 & 20,5 & 12,7 & 42,8 & 5,07 & $6,62-7,22$ & 0,8 \\
\hline Пісне & 87,1 & 4,2 & 2,3 & 0,41 & 6,0 & 1,1 & 17,9 & 12,2 & 0,7 & 0,042 \\
\hline
\end{tabular}


інтенсивних рефлексів відповідають мінеральним фазам, що відносяться до групи оксидів $\left(\mathrm{SiO}_{2}, \mathrm{Fe}_{2} \mathrm{O}_{3}\right.$, $\left.\mathrm{Fe}_{3} \mathrm{O}_{4}, \mathrm{Al}_{2} \mathrm{O}_{3}\right)$. У значній кількості також виявлено ангідрит $\mathrm{CaSO}_{4}$ та алюмосилікат $\mathrm{Al}_{2} \mathrm{Si}_{2} \mathrm{O}_{5}$, в меншій кількості силікати, складні силікати та сульфати. Основна частина $\mathrm{Na}$ перебуває у вигляді сульфатів $\mathrm{Na}_{2} \mathrm{SO}_{4}, \mathrm{Na}_{2} \mathrm{~S}_{2} \mathrm{O}_{6}$ та силікатів $\mathrm{Na}_{2} \mathrm{SiO}_{3}, \mathrm{Na}_{2} \mathrm{Si}_{4} \mathrm{O}_{9}$, $\mathrm{Na}_{2} \mathrm{SiO}_{4}$, що мають низькі температури плавлення i $є$ основними чинниками, що викликають шлакування. Аналіз дифрактограми пісного вугілля дозволив встановити такі групи мінеральних фаз, що сформувалися в процесі термолізу вугілля: оксиди $\mathrm{SiO}_{2}, \mathrm{Al}_{2} \mathrm{O}_{3}$ (найбільш інтенсивні рефлекси), $\mathrm{Fe}_{2} \mathrm{O}_{3}$ (менш інтенсивні рефлекси), різноманітні силікати - $\mathrm{Al}_{2} \mathrm{SiO}_{5}, \mathrm{MgSiO}_{3}$ та складні алюмосилікати $\mathrm{KAl}_{3} \mathrm{Si}_{3} \mathrm{O}_{11}, \mathrm{Ca}_{3} \mathrm{Al}_{2}\left(\mathrm{SiO}_{4}\right)_{3}$.

Аналіз дифрактограм (рис. 1) зольних залишків сумішей дозволив установити, що більшість інтенсивних рефлексів відповідають мінеральним фазам, що відносяться до групи оксидів - $\mathrm{SiO}_{2}$, $\mathrm{Fe}_{2} \mathrm{O}_{3}, \mathrm{Fe}_{3} \mathrm{O}_{4}$ та $\mathrm{Al}_{2} \mathrm{O}_{3}$. У значній кількості визначені ангідрит $\left(\mathrm{CaSO}_{4}\right)$, силікат кальцію $\left(\mathrm{CaSiO}_{3}\right)$, алюмосилікат $\left(\mathrm{Al}_{2} \mathrm{SiO}_{5}\right)$. Однак найбільшої уваги заслуговують результати з визначення мінеральних фаз, до яких входить $\mathrm{Na}$. У порівнянні $з$ аналізом дифрактограми Богд. № 1 та Богд. № 2 у зольному залишку суміші спостерігається значно менша кількість силікату натрію $\left(\mathrm{Na}_{2} \mathrm{SiO}_{4}\right)$ та сульфату натрію $\left(\mathrm{Na}_{2} \mathrm{SO}_{4}\right)$. Натомість констатуємо появу більш складних та насамперед тугоплавких мінералів - нефеліну $\left(\mathrm{NaAlSiO}_{4}, \mathrm{KNa}_{3}\left(\mathrm{AlSiO}_{4}\right)_{4}\right)$ та ультрамарину $\left(\mathrm{Na}_{7} \mathrm{Al}_{6} \mathrm{Si}_{6} \mathrm{O}_{24} \mathrm{~S}_{3}\right)$, а також інших сполук - комбіту $\left(\mathrm{NaCaSiO}_{4}\right)$ та алюмінату натрію $\left(\mathrm{NaAlO}_{2}, \mathrm{Na}_{2} \mathrm{Al}_{2} \mathrm{O}_{4}\right)$.

Отримані результати з утворення нефелінів, ультрамаринів та інших мінералів підтверджуються дослідженнями вчених інших країн. Так, у роботі [12] описано механізм утворення подібних мінералів під час спалювання солоного вугілля родовища Xinjiang:

1) нефеліну: $2 \mathrm{Al}_{2} \mathrm{SiO}_{5}+\mathrm{Na}_{2} \mathrm{SO}_{4} \rightarrow 2 \mathrm{NaAlSiO}_{4}+$ $\mathrm{Al}_{2} \mathrm{O}_{3}+\mathrm{SO}_{3}(\mathrm{~g})$

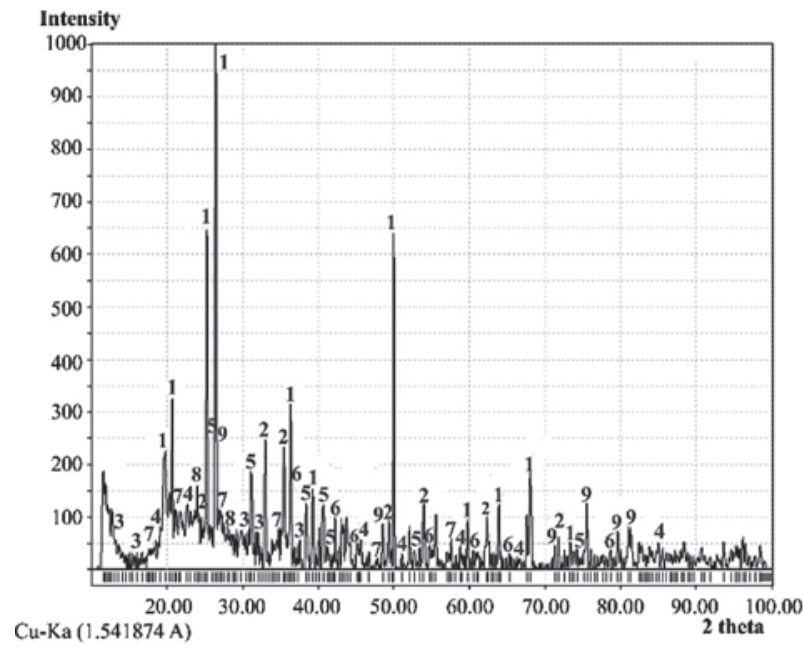

$a$

Рис. 1. Дифрактогр. сумішей (50:50) Богд. № 1: Пісне (а) та Богд. № 2: Пісне (б)

$1-\mathrm{SiO}_{2} ; 2-\mathrm{Fe}_{2} \mathrm{O}_{3} \mathrm{ma} \mathrm{Fe}_{3} \mathrm{O}_{4} ; 3-\mathrm{Na}_{2} \mathrm{SiO}_{4} ; 4-\mathrm{Na}_{2} \mathrm{SO}_{4} ; 5-\mathrm{CaSO}_{4} ; 6-\mathrm{Ca}_{2} \mathrm{SiO}_{4}$; $7-(\mathrm{Na}, \mathrm{K}) \mathrm{AlSiO}_{4} ; 8-\mathrm{Na}_{7} \mathrm{Al}_{6} \mathrm{Si}_{6} \mathrm{O}_{24} \mathrm{~S}_{3} ; 9-\mathrm{Al}_{2} \mathrm{Si}_{2} \mathrm{O}_{5} ; \mathrm{O}-\mathrm{Na}_{2} \mathrm{CaSiO}_{4}$
2) утрамарину: $6 \mathrm{NaAlSiO}_{4}+\mathrm{Na}_{2} \mathrm{SO}_{4} \rightarrow$ $\mathrm{Na}_{8} \mathrm{Al}_{6} \mathrm{Si}_{6} \mathrm{O}_{24} \mathrm{SO}_{4}$

3) алюмінату натрію: $\mathrm{Al}_{2} \mathrm{O}_{3}+\mathrm{Na}_{2} \mathrm{O} \rightarrow \mathrm{Na}_{2} \mathrm{Al}_{2} \mathrm{O}_{4}$

При варіації співвідношення солоного та пісного вугілля (40:60, 60:40) спостерігається превалювання тих чи інших сполук. Так, у суміші, де переважає солоне вугілля, поряд зі значною кількістю мінералів, до складу яких входить $\mathrm{Al}$ та $\mathrm{Si}$, виявлені досить значні рефлекси, що відповідають мінералам, до яких входить Fe та Са. Водночас у суміші, де превалює пісне вугілля, основні піки відповідають силікатам та алюмосилікатам, а піки, до яких входять $\mathrm{Fe}$ та $\mathrm{Ca}$, мають значно меншу інтенсивність. Що стосується сполук, до яких входить $\mathrm{Na}$, кількість утворених нових мінералів залежить від вмісту $\mathrm{Na}$ у суміші. Так, у суміші, де превалює солоне вугілля, виявлені подібні мінерали, як і у суміші 50 на 50, а також мінерали 3 іншою структурою, а саме більшим вмістом $\mathrm{Na}$ $\left(\mathrm{Na}_{2} \mathrm{AlSiO}_{3}\right.$ та $\left.\mathrm{Na}_{8} \mathrm{Al}_{6} \mathrm{Si}_{6} \mathrm{O}_{24} \mathrm{SO}_{4}\right)$. Тобто зі збільшенням вмісту $\mathrm{Na}$ у суміші його кількість, що переводиться у тугоплавкі з'єднання, також збільшується. У суміші, де превалює пісне вугілля, подібна ситуація, за рахунок меншого вмісту Na відбувається утворення меншої кількості мінералів (нефелінів та ультрамаринів).

Одержані результати дають реальні підстави вважати, що перспективним напрямом використання вітчизняного солоного вугілля може стати його спільне спалювання $з$ іншим вугіллям, яке не має в своєму складі підвищеного вмісту $\mathrm{Na}$ та $\mathrm{Cl}$. При цьому вирішуються такі питання, як зниження у паливній суміші загального вмісту солей, формування під час спалювання тугоплавких натрієвих сполук та підвищення загальної реакційної здатності сумішевого палива.

Однак навіть під час спільного спалювання солоного вугілля із звичайним викиди хлору будуть підвищеними. Першочергово вони залежать від кількох факторів - початкового вмісту хлору у суміші палива, умов горіння (температура, час перебування в зоні

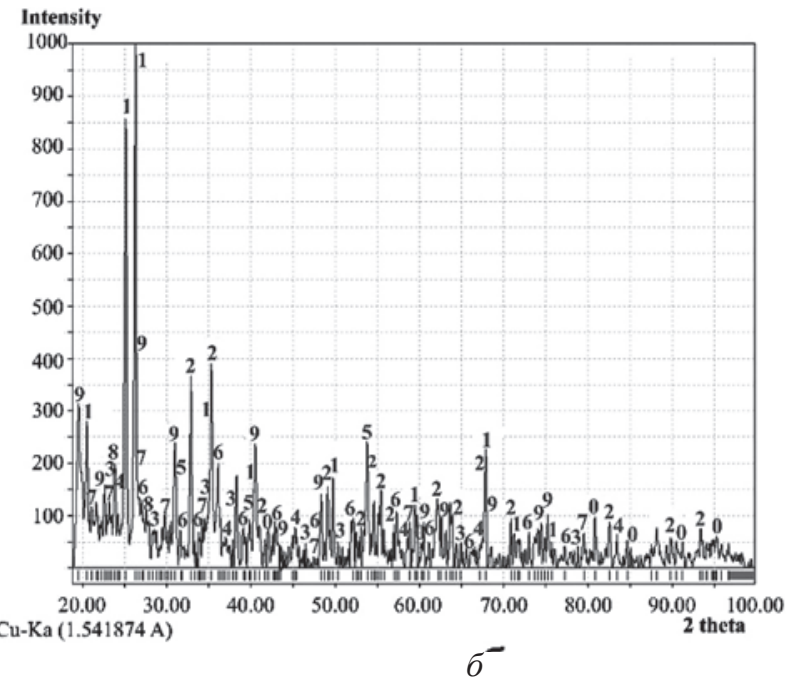


Фатеєв А.I., Ясинецький А.О., Лазарєв G.С.

горіння тощо) - та використання різних технологій очищення димових газів. Ефективними заходами для скорочення викидів хлору під час спалювання палива $\epsilon$ технології контролю викидів діоксиду сірки або технології десульфуризації димових газів (ДДГ), у яких хлор поглинається разом із сірчистим ангідридом [13].

Поширеними технологіями ДДГ як для комунальних, так і для промислових котлів є системи, що використовують у кальцієві сорбенти вапно або вапняк. Димовий газ вступає у контакт з розпиленим вапняним розчином або суспензією вапняку та відбуваються зв'язування діоксиду сірки за таким механізмом:

1. Абсорбція діоксиду сірки технологічною водою, що вводиться у реакційну. Утворення сірчистої кислоти та ii двостадійна дисоціація з утворенням аніонів гідросульфіту та сульфіту:

$$
\mathrm{SO}_{2(2)}+\mathrm{H}_{2} \mathrm{O}_{(p)} \leftrightarrow \mathrm{H}_{2} \mathrm{SO}_{3(p-r)}-
$$

утвор. сірчистої кислоти у краплі;

$$
\mathrm{H}_{2} \mathrm{SO}_{3} \leftrightarrow \mathrm{H}^{+}+\mathrm{HSO}_{3}^{-}-
$$

1 стадія дисоціації сірчистої кислоти;

$$
\mathrm{HSO}_{3}^{-} \leftrightarrow \mathrm{H}^{+}+\mathrm{SO}_{3}^{2-}-
$$

2 стадія дисоціації сірчистої кислоти.

2. Дисоціація у розчині гідроксиду кальцію, що міститься у гашеному вапні, або розчинення під дією кислого середовища карбонату кальцію, що міститься у вапняку з утворенням іонів кальцію:

2. Дисоціація у розчині гідроксиду кальцію, що міститься у гашеному вапні або розчинення під
ЕКОАОГІЧНІ АСПЕКТИ ВИКОРИСТАННЯ ВУГІАЯ...

дією кислого середовища карбонату кальцію, що міститься у вапняку з утворенням іонів кальцію:

$$
\begin{gathered}
\mathrm{Ca}(\mathrm{OH})_{2(p-\mu)} \leftrightarrow \mathrm{Ca}^{2+}+2 \mathrm{OH}^{-} \\
\mathrm{CaCO}_{3(m \varepsilon)}+2 \mathrm{H}^{+} \leftrightarrow \mathrm{Ca}_{(p-\mu)}^{2+}+2 \mathrm{HCO}_{3(p-\mu)}^{-}
\end{gathered}
$$

3. Реагування іонів кальцію 3 іонами сульфіту та гідросульфіту з утворенням сульфіту та гідросульфіту кальцію:

$$
\begin{gathered}
\mathrm{Ca}^{2+}+\mathrm{SO}_{3}^{2-} \leftrightarrow \mathrm{CaSO}_{3(p-\mu)} \\
\mathrm{Ca}^{2+}+\mathrm{HSO}_{3}^{-} \leftrightarrow \mathrm{Ca}\left(\mathrm{HSO}_{3}\right)_{2(p-\mu)}
\end{gathered}
$$

У мокрих технологіях ДДГ димові гази спочатку можна промивати в попередньому скрубері, що зупиняє потенційне накопичення хлоридів у циркуляційному контурі абсорбера ДДГ. У попередньому скрубері більшість летючої золи та розчинних газів, таких як $\mathrm{HCl}$, уловлюється, а стоки видаляються на станцію очищення стічних вод [13].

Для дослідження процесів взаємодії діоксиду сірки 3 кальцієвими реагентами у присутності хлороводню було проведено цикл експериментальних досліджень на установці мокрого газоочищення (рис. 2) [14]. Основою установки мокрого газоочищення $\epsilon$ реактор-барботер 7, в якому відбуваються абсорбція діоксиду сірки 3 модельного газу та хімічна реакція з розчином або суспензією реагенту. Модельний газ, що подається у реакторбарботер з балона $1, \epsilon$ сумішшю азоту з $\mathrm{SO}_{2}$. Витрата модельного газу балона регулюється за допомогою газового редуктора 2 та контролюється манометром 3. Витрата модельного газу вимірюється реометром 5.

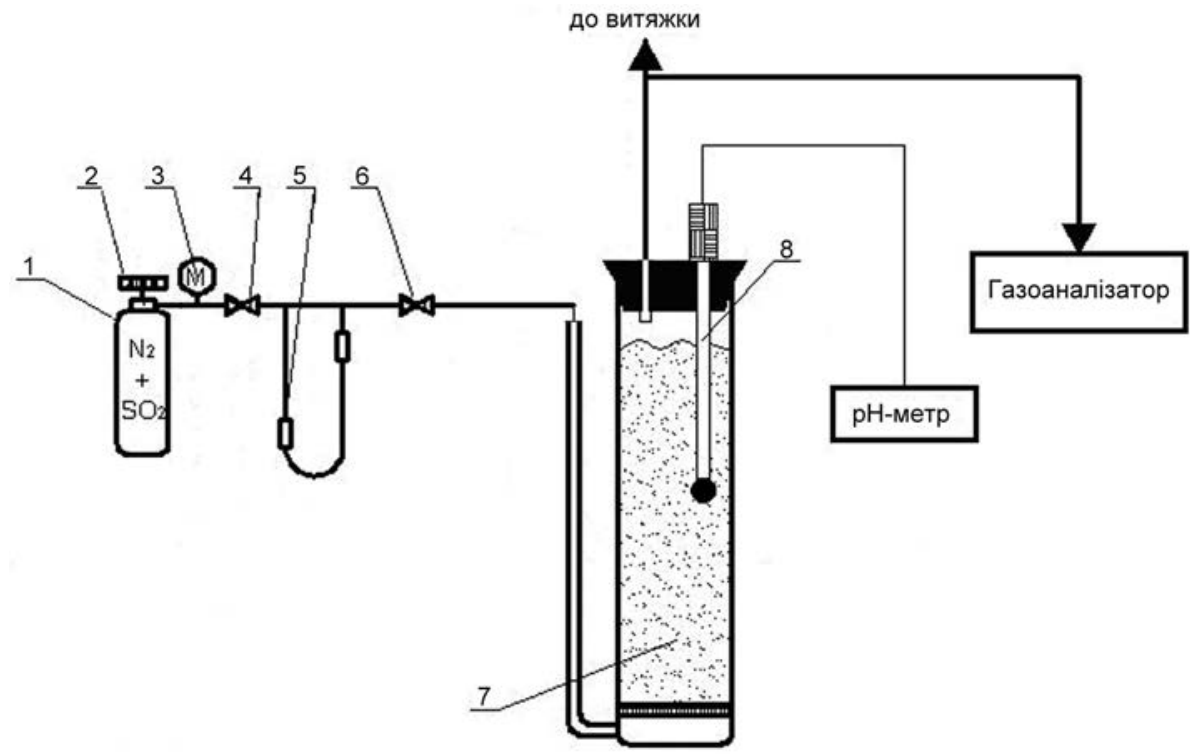

Рис. 2. Схема установки мокрого газоочищення

1 - балон з газовою сумішшю, 2 - редуктор балона, 3 -манометр,

4 -кран-регулятор, 5 -реометр, 6-кран, 7 - реактор-барботер,

8 - електрод $\mathrm{pH}$-метра 
Після регулюючих та вимірювальних пристроїв модельний газ подається у нижню частину реактора-барботера через пористий скляний фільтр (для розпилення газу на дрібні бульбашки) та потрапляє у розчин або суспензію реагенту. Як реагент використовується $\mathrm{CaCO}_{3}$ або $\mathrm{Ca}(\mathrm{OH})_{2}$, що додаються у реактор. Маса наважки реагентів була вибрана таким чином, щоб забезпечити однакову кількість кальцію у реакторі незалежно від вибору реагенту. Для визначення впливу хлороводню на ефективність зв'язування сірчистого ангідриду були проведені експериментальні дослідження, у яких дистильована вода були замінена на водний розчин $\mathrm{HCl}$. Після проходження реактора газ подається до газоаналізатора, у якому вимірюється вихідна концентрація $\mathrm{SO}_{2}$, лишокйоговідводиться до витяжки. Датчикіономіра 9 дає можливість реєструвати у часі показник $\mathrm{pH}$ та температуру розчину. Всі основні параметри експериментів наведені у табл. 2. Схема процесу абсорбції при всіх способах контакту реагентів може бути представлена таким чином: зустрічаються потоки газу та рідини; є межа розділу фаз; компоненти переносяться через поверхню розділу фаз. Реакція протікає у рідкій фазі. При цьому немає принципової різниці між способами контакту фаз «газ - рідина»: чи відбувається барботаж (диспергований газ у вигляді бульбашок піднімається у шарі рідини) або зрошення (диспергована у вигляді крапель рідина рухається у газовому середовищі). Лабораторна модель у газовій фазі є моделлю реактора ідеального витіснення, у рідкій фазі - моделлю реактора ідеального перемішування. Час контакту «газ - рідина» є часом підйому бульбашки.

Проведені шість експериментів: по три для кожного реагенту. Перший i четвертий експерименти дали можливість побачити проходження процесу зв'язування діоксиду сірки без наявності $\mathrm{HCl}$ у розчині. Другий і п'ятий дали змогу побачити зміну у процесі поглинання $\mathrm{SO}_{2}$ за наявності хлороводню у реакторі. Третій і шостий дали можливість оцінити проходження процесу поглинання діоксиду сірки при наявності хлороводню за збільшення сорбенту у 2 рази.

У результаті проведених експериментів було отримано характер зміни у часі вихідної концентрації діоксиду сірки (рис. 3 та рис. 5) та зміни показника $\mathrm{pH}$ розчину (рис. 4 та рис. 6) у разі використання як сорбенту відповідно $\mathrm{Ca}(\mathrm{OH})_{2}$ та $\mathrm{CaCO}_{3}$.

Як можна побачити $з$ наведених вище рисунків, наявність $\mathrm{HCl}$ суттєво зменшує ступінь поглинання діоксиду сірки. Це підтверджується відсутністю зони повного поглинання $\mathrm{SO}_{2}$ (рис. 3, рис. 5). Iз графіків зміни показника $\mathrm{pH}$ видно, що показник $\mathrm{pH}$ за наявності $\mathrm{HCl}$ знижується за рахунок його реагування $з$ лужними реагентами за реакціями:

$$
\begin{gathered}
\mathrm{Ca}(\mathrm{OH})_{2}+2 \mathrm{HCl} \leftrightarrow \mathrm{CaCl}_{2}+2 \mathrm{H}_{2} \mathrm{O} \\
\mathrm{CaCO}_{3}+2 \mathrm{HCl} \leftrightarrow \mathrm{CaCl}_{2}+\mathrm{CO}_{2}+\mathrm{H}_{2} \mathrm{O}
\end{gathered}
$$

Таблиця 2

\begin{tabular}{|c|c|c|c|c|c|c|}
\hline Параметр & \multicolumn{6}{|c|}{ Значення } \\
\hline Реагент & \multicolumn{3}{|c|}{$\mathrm{Ca}(\mathrm{OH})_{2}$} & \multicolumn{3}{|c|}{$\mathrm{CaCO}_{3}$} \\
\hline № експерименту & 1 & 2 & 3 & 4 & 5 & 6 \\
\hline Маса наважки, г & 0,06 & 0,06 & 0,12 & 0,08 & 0,08 & 0,16 \\
\hline Кількість $C a$ у реакторі, моль & \multicolumn{2}{|c|}{$8 \cdot 10^{-4}$} & $1,6 \cdot 10^{-3}$ & \multicolumn{2}{|c|}{$8 \cdot 10^{-4}$} & $1,6 \cdot 10^{-3}$ \\
\hline Концентрація $\mathrm{HCl}$ у реакторі, г/л & 0 & \multicolumn{2}{|c|}{0,425} & 0 & \multicolumn{2}{|c|}{0,425} \\
\hline Об'єм рідини у реакторі, л & \multicolumn{6}{|c|}{0,12} \\
\hline Витрата модельного газу, л/хв & \multicolumn{6}{|c|}{1,2} \\
\hline Концентрація $\mathrm{SO}_{2}$ у мод. газі, ppm & \multicolumn{6}{|c|}{1978} \\
\hline Температура у реакційній зоні, ${ }^{\circ} \mathrm{C}$ & \multicolumn{6}{|c|}{$15 \ldots 25$} \\
\hline
\end{tabular}

Основні параметри експериментів

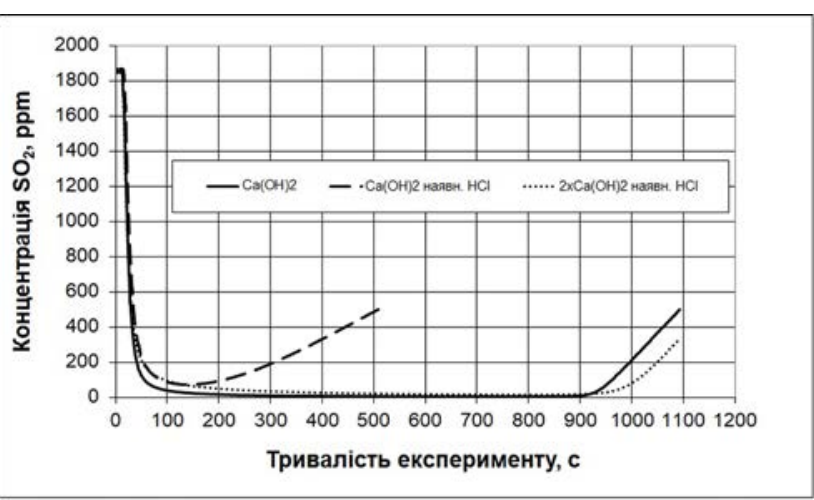

Рис. 3. Зміна у часі вихідної кониентрації діоксиду сірки при використанні як сорбенту $\mathrm{Ca}(\mathrm{OH})_{2}$.

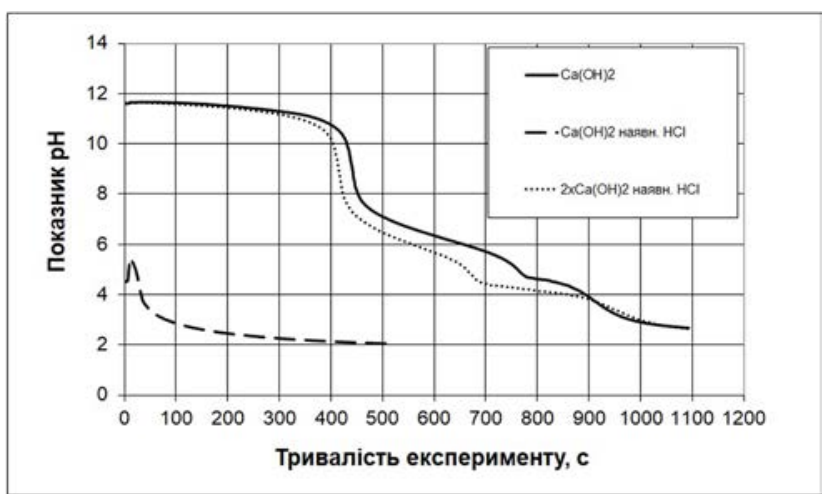

Рис. 4. Зміна у часі показника рН розчину при використанні як сорбенту $\mathrm{Ca}(\mathrm{OH})_{2}$. 
Фатеєв А.I., Ясинецький А.О., Лазарєв G.C.

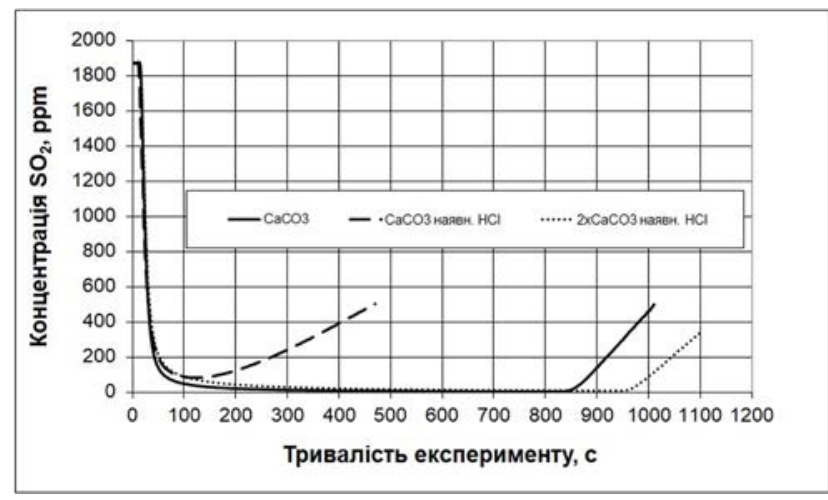

Рис. 5. Зміна у часі вихідної концентрації діоксиду сірки при використанні як сорбенту $\mathrm{CaCO}_{3}$.

Цей процес відбувається за рахунок того, що хлороводень є сильною кислотою, а $\mathrm{H}_{2} \mathrm{SO}_{3} є$ кислотою середньою. Відповідно, іони кальцію будуть першочергово хімічно зв'язані з хлором, а потім будуть зв'язувати сірчистий ангідрид за реакціями (6) та (7). Кількість зв'язаного хлороводнем кальцію буде відповідно до реакцій (8) та (9) удвічі менша, ніж кількість $\mathrm{HCl}$. Для оцінки залишкового кальцію для зв'язування 3 діоксидом сірки були проведені розрахунки, представлені у табл. 3. Оскільки кількість $C a$ у реакторі не залежала від типу реагенту, розрахунки представлені для трьох пар експериментів.

Таблиця 3

Розрахунок кальцію для зв'язування з $\mathrm{SO}_{2}$

\begin{tabular}{|c|c|c|c|}
\hline Параметр & \multicolumn{3}{|c|}{ Значення } \\
\hline № експерименту & $1 \mathrm{\text {та } 4}$ & 2 та 5 & 3 та 6 \\
\hline Кількість $C a$ у реакторі, моль & $8 \cdot 10^{-4}$ & $8 \cdot 10^{-4}$ & $1,6 \cdot 10^{-3}$ \\
\hline Кількість $H C l$ у реакторі, моль & 0 & $1,4 \cdot 10^{-3}$ & $1,4 \cdot 10^{-3}$ \\
\hline $\begin{array}{c}\text { Залишок } C a \text { після реагування з } \\
H C l \text {, моль }\end{array}$ & $8 \cdot 10^{-4}$ & $10^{-4}$ & $9 \cdot 10^{-4}$ \\
\hline
\end{tabular}

Тобто у експериментах 1 та 4 і 3 та 6 кількість кальцію для зв'язування діоксиду сірки майже однакова. 3 рис. 3 та рис. 5 видно, що реєстрація на виході 3 реактора $\mathrm{SO}_{2}$ у експериментах без додавання $\mathrm{HCl}$ та 3 подвоєним вмістом реагенту відбувається майже одночасно, що підтверджує першочергове реагування кальцію з $\mathrm{HCl}$.

Тому під час спалювання палива 3 підвищеним вмістом хлору першочергово рекомендується забезпечити установку спалювання заходами боротьби з викидами діоксиду сірки. Однак для виключення
ЕКОАОГІЧНІ АСПЕКТИ ВИКОРИСТАННЯ ВУГІАЯ...

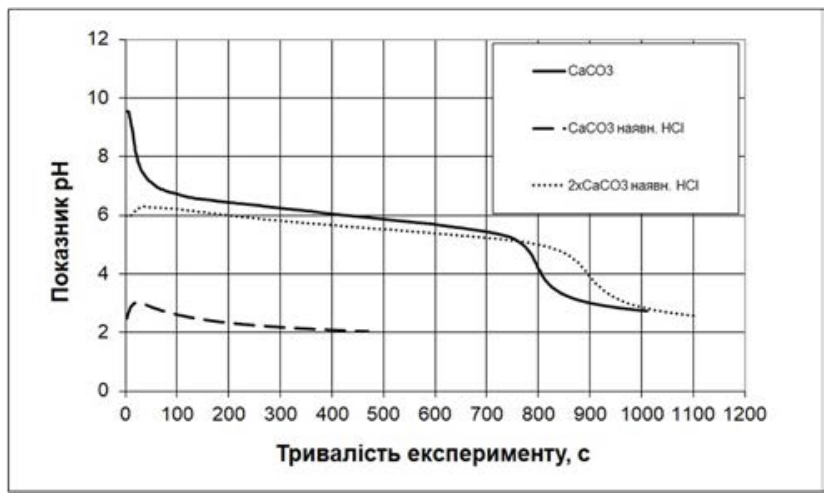

Рис. 6. Зміна у часі показника рН розчину при використанні як сорбенту $\mathrm{CaCO}_{3}$.

негативного впливу хлору на ефективність десульфуризації димових газів кальцієвими реагентами рекомендується підвищити мольну витрату кальцію у системі ДДГ на величину половини мольного вмісту хлору у димових газах. Ця рекомендація забезпечить повне поглинання хлору у системі ДДГ без зниження ефективності сіркоочищення.

\section{Висновки:}

1. Залучення солоного вугілля до паливної бази $\epsilon$ актуальним завдяки його високим енергетичним характеристикам та значним покладам на території України. Однак його використання пов'язане з утворенням забруднень на теплообмінних поверхнях, що призводить до зниження ефективності процесу теплообміну, а також погіршення екологічних показників, що пов'язано з викидом хлору.

2. Перспективним напрямом використання вітчизняного солоного вугілля може стати його спільне спалювання з іншим вугіллям, яке не має в своєму складі підвищеного вмісту $\mathrm{Na}$ та $\mathrm{Cl}$. Доцільним буде вміст солоного вугілля у суміші до $50 \%$.

3. Однак навіть під час спалювання суміші солоного та звичайного вугілля викиди хлору будуть підвищеними. У світовій практиці ефективними заходами для скорочення викидів хлору під час спалювання палива $є$ технології контролю викидів діоксиду сірки.

4. Рекомендується підвищити мольну витрату кальцієвого реагенту у системах сіркоочищення на величину половини мольного вмісту хлору у димових газах. Це дасть змогу забезпечити повне поглинання хлору у системі ДДГ без зниження ефективності зв'язування $\mathrm{SO}_{2}$.

\section{Література}

1. Directive 2001/80/EC of the European Parliament and of the Council of 23 October 2001 on the limitation of emissions of certain pollutants into the air from large combustion plants. / Official Journal of the European Communities. L 309. 27.11.2001. P. 1-21.

2. Directive 2010/75/EU of the European Parliament and of the Council of 24 November 2010 on industrial emissions (integrated pollution prevention and control). Official Journal of the European Union, L 334. Vol.53. 17.12.2010. P.17-119.

3. Іванова А.В. Генезис і еволюція солоного вугілля України та проблеми його освоєння: Дис. на здобуття наукового ступеня доктора геологічних наук: 04.00.01. Київ. 2016. 336 с.

4. Шендрик Т.Г., Саранчук В.И. Соленые угли. ДонГТУ, Донецк: «Східний видавничий дім», 2003. 296 с. 
5. Guoliang Song, Xiaobin Qi, Shaobo Yang, Zhao Yang. Investigation of ash deposition and corrosion during circulating fluidized bed combustion of high-sodium, high-chlorine Xinjiang lignite, Fuel. 2018. Volume 214. p. 207-214.

6. K. Zhang, Y. Li, Z.H. Wang, Q. Li, R. Whiddon, Y. He, K.F. Cen. 2016. Pyrolysis behavior of a typical Chinese sub-bituminous Zhundong coal from moderate to high temperatures, Fuel. Volume 185. p. 701-708.

7. Yukui Zhang, Haixia Zhang. Gasification Characteristics and Sodium Transformation Behavior of High-Sodium Zhundong Coal. Energy Fuels. 2017. 31. p. 6435-6444.

8. Dai B, Wu X, De Girolamo A, Zhang L. Inhibition of lignite ash slagging and fouling upon the use of a silica-based additive in an industrial pulverised coal-fired boiler. Part 1. Changes on the properties of ash deposits along the furnace. Fuel. 2015 Volume 139. p. $720-732$.

9. Yaxin Gao, Lizhi Ding, Xian Li, Wenhui Wang, Yi Xue, Xianqing Zhu, Hongyun Hu, Guangqian Luo, Ichiro Naruse, Zongqing Bai, Hong Yao. $\mathrm{Na} \& \mathrm{Ca}$ removal from Zhundong coal by a novel $\mathrm{CO}_{2}$-water leaching method and the ashing behavior of the leached coal. Fuel. 2017. Volume 210. p. 8-14.

10. Renhui Ruan, Houzhang Tan, Xuebin Wang, Yan Li, Shuaishuai Li, Zhongfa Hu, Bo Wei, Tao Yang. Characteristics of fine particulate matter formation during combustion of lignite riched in AAEM (alkali and alkaline earth metals) and sulfur $i .2018$. Volume 211. p. 206-213.

11. David Tillman, Dao Duong and N. Stanley Harding. Solid Fuel Blending. Principles, Practices, and Problems. Publisher Elsevier/ Butterworth Heinemann. 2012. 352 p.

12. Bo Wei, Xuebin Wang, Houzhang Tan, Limeng Zhang, Yibin Wang, Zhao Wang. Effect of silicon-aluminum additives on ash fusion and ash mineral conversion of Xinjiang high-sodium coal. Fuel. 2016. Volume 181. p. 1224-1229.

13. T. Lecomte, J. Félix Ferrería de la Fuente, F. Neuwahl, M. Canova, A. Pinasseau, I. Jankov, T. Brinkmann, S. Roudier, L. Delgado Sancho. Best Available Techniques (BAT) Reference Document for Large Combustion Plants. 2017. P. 940

14. Вольчин І.А., Мезин С.В., Руденко Л.Н., Ясинецкий А.А. 2015 Исследование поглощения диоксида серы в растворе карбамида. Энергетик. № 6. С. 24-26. 


\title{
ЕКОАОГІЯ ВОДНИХ РЕСУРСІВ
}

\author{
УДК 351:628.1:331](477) \\ DOI https://doi.org/10.32846/2306-9716/2021.eco.6-39.5
}

\section{ФІНАНСУВАННЯ СТААОГО РОЗВИТКУ СФЕРИ ВОДОПОСТАЧАННЯ ТА ВОДОВІДВЕДЕННЯ В УКРАЇНІ}

\author{
Бондар О.І., Закорчевна Н.Б., Крилова I.I. \\ Державна екологічна академія післядипломної освіти та управління \\ вул. Митрополита Василя Липківського, 35, корп. 2, 03035, м. Київ \\ dei2005@ukr.net
}

Розглянуті питання фінансування сталого розвитку сфери водопостачання та водовідведення в Україні. Для досягнення Цілей сталого розвитку 2030, прийнятих у вересні 2015 року на саміті ООН, до яких приєдналася Україна, адаптувавши їх до українських реалій, зокрема у сфері водопостачання та каналізації (ціль 6), необхідні значні кошти. Сфера водопостачання та водовідведення України потребує неабияких інвестицій для оновлення основних фондів підприємств водопостачання та водовідведення, реконструкції і розвитку інженерної інфраструктури, упровадження новітніх технологій, поліпшення якості послуг тощо. Однак приватне фінансування у сфері водопостачання та водовідведення в Україні не було успішно залучене. Ефективні фінансові механізми, які задіяні у розвинутих країнах, не застосовуються в Україні через різні перешкоди. Окрім того, існують проблеми, що обмежують можливості мобілізації інвестицій для цієї сфери, зважаючи на політичну, економічну та соціальну ситуації, високі транзакційні затрати та непрозорість регуляторного середовища. За даними ООН та ОЕСР для розширення загального доступу до основних ресурсів питної води та санітарії до 2030 року необхідно подвоїти поточні річні темпи зростання. Майбутні потреби в інвестиціях також зростатимуть, і вони будуть неймовірно високими.

Відображені наявні механізми інвестиційного фінансування потреб сфери водопостачання та водовідведення в Україні, проаналізовані обсяги та джерела інвестицій ліцензіатів НКРЕКП у сфері централізованого водопостачання та водовідведення у 2020 р., запропоновані шляхи та інструменти вдосконалення фінансово-економічного механізму державного регулювання сфери водопостачання та водовідведення в Україні. Ключові слова: водопостачання, водовідведення, цілі сталого розвитку, інвестиції, фінансово-економічні механізми, державне регулювання.

Financing sustainable development of water supply and wastewater in Ukraine. Bondar O., Zakorchevna N., Krylova I.

The article is devoted to the issue of financing sustainable development of water supply and wastewater in Ukraine. To achieve the 2030 Sustainable Development Goals, adopted in September 2015 at the UN summit, to which Ukraine joined and which were adapted to Ukrainian realities, in particular in the field of water supply and sanitation (goal 6), significant investments are required. The sphere of water supply and wastewater of Ukraine requires significant investments in updating the fixed assets of water supply and wastewater enterprises, reconstruction and development of engineering infrastructure, introduction of the latest technologies, and improvement of the quality of services. However, private financing in the field of water supply and wastewater in Ukraine has not been successfully attracted, financial mechanisms that are effective for developed countries are not used in Ukraine due to existing barriers. In addition, there are several issues that limit the ability to mobilize investment in this area, including difficult political, economic and social situations, high transaction costs, and a lack of transparency in the regulatory environment. According to the UN and OECD, achieving shared access to basic drinking water and sanitation by 2030 will require doubling the current annual rate of progress, and future investment needs will be incredibly high. The authors describe the existing mechanisms for financing the investment needs of the water supply and wastewater sector of Ukraine by sources of raising funds, analyze the volumes and sources of investments of the NEURC licensees in the field of centralized water supply and wastewater in 2020. The authors suggest ways and tools to improve the financial and economic mechanism of state regulation of the water supply and wastewater sector in Ukraine. Key words: water supply, wastewater, sanitation, sustainable development goals, investments, financial and economic mechanisms, regulation.

Постановка проблеми. Сфера водопостачання та водовідведення в Україні потребує значних інвестицій на оновлення основних фондів підприємств водопостачання та водовідведення, реконструкцію та розвиток інженерної інфраструктури, впровадження новітніх технологій, поліпшення якості послуг тощо. За підрахунками Мінрегіону України, потреба в капітальних інвестиціях у сферу водопостачання та водовідведення в Україні (не враховуючи поточні витрати на підтримання інфраструктури в робочому стані) становить 19 млрд дол. США (3 яких: 7,6 млрд дол. США необхідні для ремонту водопровідних мереж; 9,9 млрд. дол. США - на ремонт каналізаційних мереж; 463 млн дол. США приведення якості питної води відповідно до норм; 1,3 млрд дол. США - зменшення енергоємності подачі води) [20; 24; 25]. На жаль, за тридцять років Незалежності та за десять років державного економічного регулювання сфери водопостачання та водовідведення в країні не вироблені ефективні механізми залучення інвестицій у цю галузь.

Актуальність дослідження. Водні ресурси та водопровідно-каналізаційне господарство посідають чільне місце у забезпеченні сталого 
функціонування економіки країни та розвиткові регіонів. Більшість басейнів річок, які майже на 80\% забезпечують питне водопостачання в Україні, згідно з гігієнічною класифікацією водних об'єктів за ступенем забруднення можна віднести до забруднених та дуже забруднених [21]. Забруднення водних об'єктів - джерел питного водопостачання - за неповноцінної бар'єрної ролі діючих водоочисних споруд та неефективного екологічного регулювання спричиняє погіршення якості питної води, що подається споживачам. Отже, можна констатувати, що сфера водопостачання та водовідведення в Україні знаходиться в критичному стані.

Дефіцит фінансування поглиблює проблеми доступності послуг водопостачання та водовідведення, якісної питної води та санітарії в країні. Підвищення ефективності діяльності систем централізованого водопостачання та водовідведення тісно пов'язане з розв'язанням комплексу взаємопов'язаних проблем, що передбачають запобігання забрудненню водних джерел на основі організації моніторингу за їх станом та застосування інноваційних технологій очищення води; підтримання у відповідному стані та оновлення основних фондів водопровідно-каналізаційного господарства тощо. Природно, що це неможливо здійснити без залучення значних інвестиційних ресурсів та їх ефективного використання. Повне відшкодування витрат за надання послуг, а також деякі інвестиційні витрати на водопостачання та водовідведення має забезпечувати тарифна політика. Система формування тарифів, що склалася нині, не створює стимулів для ефективної роботи комунальних підприємств, не сприяє ресурсозбереженню. У статті автори окреслили шляхи пошуку науково обгрунтованих та практично значущих напрямів розв'язання проблеми інвестиційного забезпечення розвитку однієї із пріоритетних галузей народного господарства.

Відсутність ефективних механізмів та інструментів інвестиційного забезпечення, необхідність формування належної тарифної політики у сфері водопостачання та водовідведення, їі соціальна значущість, а також вагомість підприємств для економіки регіонів та підвищення рівня добробуту населення визначають актуальність цієї праці.

Зв'язок авторського доробку з важливими науковими та практичними завданнями. Здійснене дослідження наукових поглядів на проблеми фінансування сфери водопостачання та водовідведення в Україні спрямовує на подальше вивчення такої проблеми із зосередженням зусиль учених на розв'язанні ще не вирішених завдань. Практичне значення праці полягає у системному узагальненні та аналізі сучасного стану й особливостей інвестування у сферу водопостачання та водовідведення в Україні.

Аналіз останніх досліджень і публікацій. Застосування фінансово-економічних механізмів у житлово-комунальному господарстві країни знайшло своє відображення у працях вітчизняних науковців і практиків державного управління: О. Білянського [8], Л. Бражнікової [10], Г. Крамаренко [19], О. Ігнатенко [16], Н. Олійник [22], В. Полуянова [23], В. Бодрова [9], І. Розпутенка, Л. Ільченко-Сюйви, О. Кілієвич [26], І. Запатріної [14], Ю. Кірсанова [18] та інших. Проте вони розглядалися без урахування специфіки сфери водопостачання та водовідведення.

Виділення не вирішених раніше частин загальної проблеми, яким присвячується означена стаття. Мета праці - вивчення стану впровадження сучасних фінансово-економічних механізмів державного регулювання в галузі водопостачання та водовідведення в Україні та розроблення науково обгрунтованого підходу до формування інвестиційної та тарифної політики у сфері водопостачання та водовідведення з урахуванням соціальних, економічних, екологічних, технічних факторів та реалій.

Виклад основного матеріалу. У 2015 році всі держави-члени Організації Об'єднаних Націй $(\mathrm{OOH})$ прийняли Порядок денний сталого розвитку на період до 2030 року, що передбачає 17 цілей сталого розвитку (ЦСР), у тому числі присвячені сфері питної води та санітарії ЦСР 6) [27]. Головна мета забезпечення універсального доступу до безпечних, надійних, стійких та доступних послуг із водопостачання та водовідведення. Резолюцією № 64/292 Генеральної Асамблеї ООН від 28 червня 2010 р. було чітко визначено: вільний доступ до питної води $\epsilon$ правом людини, а водопостачання та водовідведення - важливими послугами для реалізації прав людини [5; 6].

Дані докладу Генерального Секретаря ООН про досягнення ЦСР від 2019 р. свідчать про те, що досягнення загального доступу до основних ресурсів питної води та санітарії до 2030 року потребуватиме подвоєння поточних річних темпів прогресу [7]. За даними звіту ОЕСР від 2018 року досягнення ЦСР, для виконання Паризької угоди та реалізації права людини на воду та санітарію необхідне значне збільшення інвестицій у розвиток та управління водними ресурсами та водними послугами [4]. Отже, світ напрацьовуватиме нові підходи та засоби фінансування сфери водопостачання та водовідведення, які будуть корисними в регіонах, на місцях [3].

Україна також приєдналася до виконання глобальних завдань, адаптувавши ЦСР до українських реалій. Як наслідок, у 2017 році було видано Національну доповідь «Цілі сталого розвитку: Україна», у якій було адаптовано 17 глобальних ЦСР 3 урахуванням специфіки національного розвитку. У 2020 році було прийнято Указ Президента України «Про Цілі сталого розвитку України на період до 2030 року» та підготовлено Добровільний звіт із досягнення ЦСР, згідно з яким результат досягнення ЦСР 6 визнано загалом прогресивним, «але недостатнім у зв'язку з браком фінансування як на державному, так і на місцевому рівнях» [13]. 


\section{Бондар O.I., Закорчевна Н.Б., Крилова I.I.}

Підтримання інфраструктури водопостачання та водовідведення у робочому стані потребує постійних капітальних вкладень, а іiі поліпшення - значного збільшення цих вкладень. Наприклад, щоб розширити водопостачання і досягти ЦСР 6, країнам, що розвиваються, необхідно збільшити витрати до 18 млрд дол. США на рік. Крім того, їм доведеться підтримувати наявну водогосподарську інфраструктуру, що збільшить капітальні витрати до 54 млрд дол. США на рік. Переваги поліпшення діяльності у галузі водопостачання та водовідведення величезні. Наприклад, один долар США інвестицій у цю сферу економить від 4 до 12 дол. США затрат на охорону здоров'я людини $[1 ; 2]$. Глобальні капітальні витрати на підтримку і розвиток інфраструктури водопостачання та водовідведення в країнах OЕСР, країнах БРІКс оцінюються в межах від 0,35 до 1,2\% їх ВВП, що відповідає загальним прогнозованим річним потребам у розмірі близько 1037 млрд дол. США до 2025 р. порівняно з поточними витратами на інфраструктуру водопостачання в розмірі 576 млрд дол. США в рік. У країнах із перехідною економікою потреба в підтримці і модернізації наявної інфраструктури водопостачання та водовідведення «поєднується» із інституційною неефективністю і погіршенням бази активів [2].

Для фінансування інфраструктурних проєктів у сфері водопостачання та водовідведення можна використовувати різні ресурси та механізми. Кошти на розвиток сфери водопостачання та водовідведення надходять із кількох типів джерел, які можуть бути державними або приватними (рис. 1).

Окремі механізми фінансування інвестиційних потреб сфери водопостачання та водовідведення, що відображені на рис. 1, використовуються в Україні, зокрема: місцеві та державні цільові програми; регіональні угоди щодо соціально-економічного розвитку; оренда/концесія комунального майна; місцеві гарантії; кредити міжнародних фінансових організацій; міжнародна технічна допомога; гранти. А деякі - мають певні обмеження та перешкоди до застосування, наприклад державно-приватне партнерство (не виправдало очікування, відсоток залучення приватних інвестицій в інфраструктурні проєкти в Україні досить низький за наявності достатньо високих технічних, юридичних та економічних ризиків); податки та збори (міська влада має обмежені можливості використання такого механізму фінансування

\section{ФІНАНСУВАННЯ СТААОГО РОЗВИТКУ...}

потреб місцевого економічного розвитку, передусім за наявності високого рівня фінансової централізації та обмежені фіскальні повноваження); корпоратизація комунальних підприємств (відсутня нормативно-правова база); облігаційні та безоблігаційні позики (на сучасному етапі основною характерною рисою українського ринку муніципальних запозичень загалом та українського ринку муніципальних облігацій $є$ його «заморожування», оскільки частка контрактів за ними становить $0 \%$ ); ендавмент (цільові фонди, призначені для використання у некомерційних цілях, зазвичай з метою фінансування організацій та ініціатив у соціальних цілях, що наповнюються за рахунок благодійних пожертв, не утворюються).

Динаміка капітальних інвестицій у сферу водопостачання та водовідведення (включаючи сферу поводження $з$ відходами) зображена на рис. 2.

Отже, за всієї різноманітності наведених джерел єдиним реальним фактором фінансування інвестиційних потреб сфери водопостачання та водовідведення в України нині є кошти, залучені від споживачів (тариф). Повне відшкодування витрат на надання послуг, а також деякі інвестиційні затрати на водопостачання та водовідведення має забезпечувати тарифна політика. Проте система формування тарифів, що склалася в країні, не стимулює підвищення ефективності роботи комунальних підприємств, не стимулює ресурсозбереження, не забезпечує збереження та цільове спрямування інвестиційної складової тарифу [20].

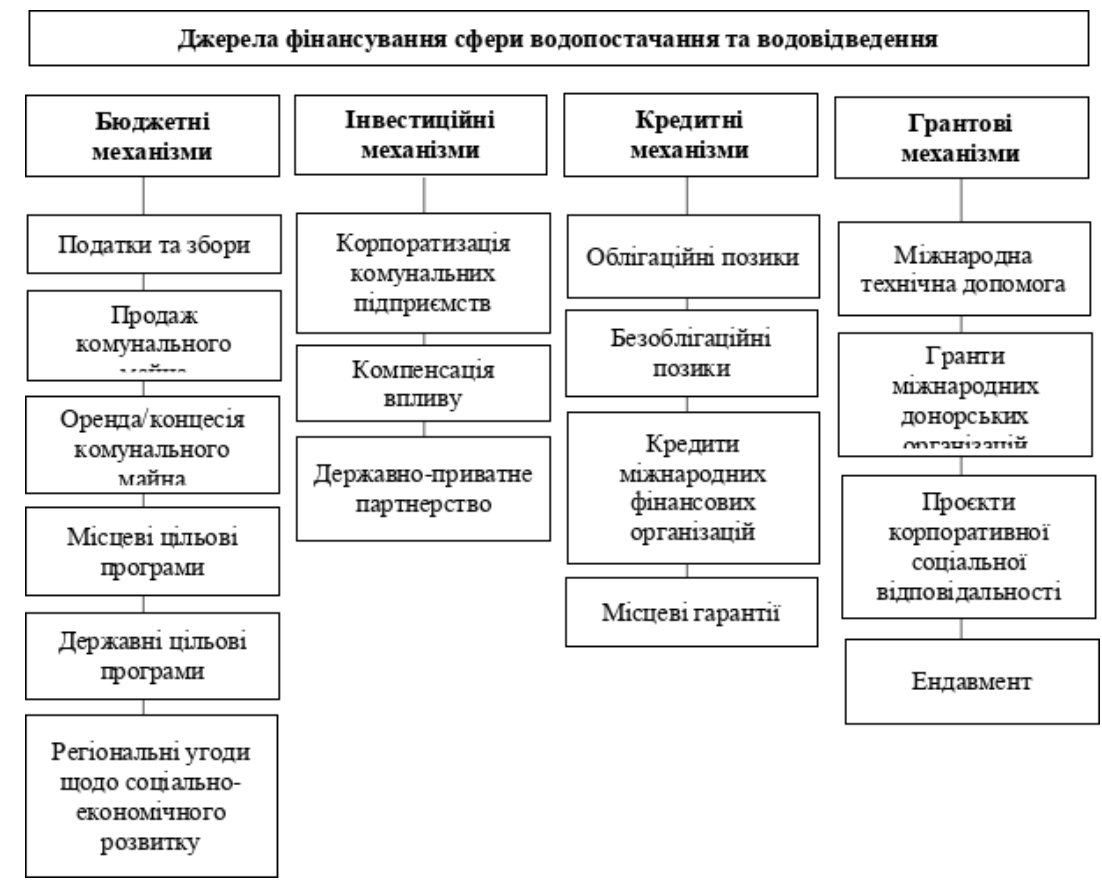

Рис. 1. Механізми фінансування інвестиційних потреб сфери водопостачання та водовідведення України (за джерелами залучення коштів)

Джерело: складено на основі [11, с. 14-15; 12, с. 68 ] 


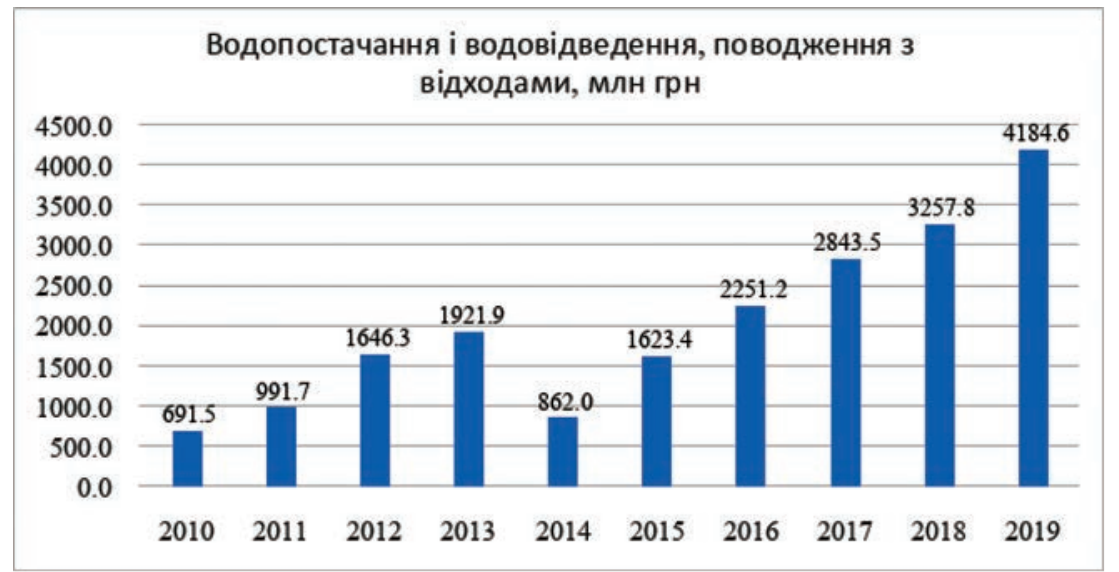

Рис. 2. Динаміка капітальних інвестицій у сферу водопостачання та водовідведення за 2010-2019 рр.

Джерело: розроблено за [17].

Зокрема, упродовж 2020 року до НКРЕКП (здійснює державне регулювання $3 \%$ підприємств водопостачання та централізованого водовідведення України, на діяльність яких припадало $75 \%$ національного ринку послуг у цій сфері) було подано на розгляд та схвалення 49 інвестиційних програм ліцензіатів у галузі централізованого водопостачання та централізованого водовідведення, що дорівнює 96\% від 51 ліцензіата. Рішеннями НКРЕКП було схвалено та опубліковано 48 інвестиційних програм на 2020 рік на загальну суму 3627,45 млн грн, що на $20 \%$ більше, ніж плановані обсяги інвестування в попередньому році. Такі інвестиційні програми визнані достатньо обгрунтованими та такими, що спрямовані на підвищення ефективності виробництва та охорону довкілля [15].

Структура планованих обсягів фінансування заходів інвестиційних програм на 2020 рік за джерелами фінансування наведена в табл. 1.

Таблиця 1

Планові обсяги та джерела інвестицій ліцензіатів НКРЕКП у сфері централізованого водопостачання та водовідведення на 2020 рік

\begin{tabular}{|c|c|c|}
\hline Джерела інвестицій & $\begin{array}{c}\text { Обсяг } \\
\text { інвестицій, } \\
\text { млн грн }\end{array}$ & $\begin{array}{c}\text { Структура } \\
\text { інвестицій за } \\
\text { ї джерелами, } \\
\text { \% }\end{array}$ \\
\hline Амортизація & 959,46 & 26,5 \\
\hline $\begin{array}{c}\text { Виробничі інвестиції } \\
\text { з прибутку }\end{array}$ & 573,18 & 15,8 \\
\hline $\begin{array}{c}\text { Невикористані кошти } \\
\text { попередніх періодів }\end{array}$ & 139,02 & 3,8 \\
\hline Бюджетні кошти & 54,97 & 1,5 \\
\hline Інші залучені кошти & 6,66 & 0,2 \\
\hline $\begin{array}{c}\text { Позики, що підлягають } \\
\text { поверненню }\end{array}$ & 1894,16 & 52,2 \\
\hline $\begin{array}{c}\text { Усього за 48 інвестиційними } \\
\text { програмами }\end{array}$ & 3627,45 & 100,0 \\
\hline
\end{tabular}

Джерело: [15]
У 2020 році більше половини $(52,2 \%)$ коштів усіх джерел фінансування інвестиційних програм припадає на запозичення згідно 3 угодами, укладеними 3 міжнародними фінансовими організаціями. Крім того, у 2020 році, як і в попередні роки, вагомим джерелом інвестицій була амортизація, передбачена у структурі тарифів на централізоване водопостачання та централізоване водовідведення. Амортизаційні кошти становлять $63 \%$ від обсягу інвестування, передбаченого тарифами 2020 року. У розрізі всіх джерел інвестицій частка амортизації становить 26,5\%. Також кошти залучалися за рахунок прибутку, передбаченого у структурі тарифів ліцензіатів для фінансування виробничих інвестицій, обсяг яких визначається в розмірах, необхідних для поступового відновлення мереж (поліпшення функціонування підприємств водопровідно-каналізаційного господарства) та з урахуванням потреб щодо виконання фінансових зобов'язань ліцензіатів перед міжнародними фінансовими організаціями. Так, станом на кінець 2020 року вісім ліцензіатів НКРЕКП у межах цього проєкту освоїли 75,3 млн дол. США, а загальна сума субкредитних договорів ліцензіатів НКРЕКП за проєктом становить 271,9 млн дол. США [15].

3 виробничих об'єктів водопровідно-каналізаційних господарств гостро потребують поліпшення мережі водопостачання та водовідведення. Ïх стан істотно впливає на якість надання послуг та довкілля. Проте вартість відновлення мереж $\epsilon$ настільки високою, що лише за рахунок амортизації здійснити його неможливо - тривалість перевищила б сотні років. Наприклад, в Україні загальна довжина мереж водопостачання ліцензіатів НКРЕКП становить 55,3 тис. км, 3 них ветхі та аварійні - 47\%. Кошти підприємств, що можуть бути використані для цілей відновлення (річний обсяг амортизації), становлять близько 473, а вартість відновлення вища у 475 разів) [15].

Очевидно, що наявних методів фінансування інвестиційних потреб у сфері водопостачання та водовідведення недостатньо, а тому галузь потребує впровадження різних інноваційних підходів, перегляду політик та використання нових інструментів та механізмів. Необхідний обсяг інвестицій для підтримки й модернізації сфери водопостачання та водовідведення не може бути забезпечений лише за рахунок тарифів, необхідні також пряма і непряма бюджетна підтримка, чітко визначена в межах прийнятої довгострокової стратегії розвитку сфери водопостачання та водовідведення. 


\section{Бондар O.I., Закорчевна Н.Б., Крилова I.I.}

Отже, вдосконалення фінансово-економічного механізму державного регулювання сфери водопостачання та водовідведення в Україні має здійснюватися шляхом використання, зокрема, таких інструментів, як: чітке визначення стратегічних цілей розвитку сфери водопостачання та водовідведення, виражене в конкретних цифрах, прикріплене до конкретних індикаторів та показників, створення системи атрибутів, індикаторів та критеріїв ефективного регулювання; перегляд механізму формування тарифів на послуги з водопостачання та водовідведення. Вони мають бути обгрунтовані 3 фундаментальними економічними показниками (коефіцієнт доступності послуг; рівень інфляції; індекс цін на ремонтно-будівельні роботи; середній дохід домогосподарства в країні; платоспроможність домогосподарств; обсяг реалізованої продукції; коефіцієнт зміни середнього доходу домогосподарств тощо) та містити граничну норму інвестиційних відрахувань на оновлення основних фондів підприємства; створення системи цін на викиди вуглецю на основі потужностей низьковуглецевих джерел, що мають мінімальний вихід парникових газів викидів у біосферу; зміни порядків прямого і непрямого оподаткування (ПДВ, акцизи, мита тощо, що закладені в цінах на всі види товарів та послуг); зменшення або спрощення податків, надання пільг, створення бази даних інвестиційних проєктів, забезпечення верховенства закону тощо; упровадження технічних та фінансових інновацій.

Використання зазначених інструментів, на наш погляд, забезпечить: прозорість фінансово-економічних механізмів державного регулювання сфери водопостачання та водовідведення; створення об'єктивних умов і передумов ефективного функціонування галузі, що відображатимуть динаміку та рівень тарифного навантаження на споживачів, ефективність споживання, інвестиційний потенціал); збереження та посилення державного регулювання з державною фінансовою підтримкою та впровадження певних інструментів ринкового регулювання з приватними інвестиціями.

Окрім того, кращий інвестиційний клімат у сфері водопостачання та водовідведення (як і в країні загалом) може бути забезпечений за рахунок розбудови стійкої інституціональної бази, у складі якої: справедлива судова система, система стримувань та противаг у владі, сприяння незалежності регулюючих органів, оптимізація практики тарифоутворення з урахуванням інтересів держави, споживачів, підприємств за допомогою прозорих процесів економічного регулювання, що підвищить передбачуваність інвестицій та знизить політичні, економічні, екологічні та соціальні ризики.

Головні висновки. Забезпечення збалансованого розвитку сфери водопостачання та водовідведення в Україні потребує значних інвестицій на оновлення основних фондів підприємств водопостачання та водовідведення, реконструкції та розвитку інженерної інфраструктури, впровадження новітніх технологій, поліпшення якості послуг тощо. Обмеженість фінансових можливостей у сфері водопостачання

\section{ФІНАНСУВАННЯ СТАЯОГО РОЗВИТКУ...}

та водовідведення, розвитку об'єктів водопровідно-каналізаційного господарства зумовлює необхідність пошуку і використання нових форм і методів організації інвестицій. Діяльність систем водопостачання та водовідведення має регіональний характер, тому заходи державного економічного регулювання, насамперед тарифоутворення, стосуються не тільки фінансової діяльності підприємств водопостачання та водовідведення, але й соціально-економічного розвитку регіонів. Тарифна політика повинна забезпечувати повне відшкодування витрат на надання послуг (включаючи соціальні, екологічні актори впливу), а також деякі інвестиційні затрати на утримання та розвиток сфери водопостачання та водовідведення. Проте наявна система тарифоутворення не стимулює підвищення ефективності роботи комунальних підприємств, ресурсозбереження. Амортизаційних коштів, а це 63\% від обсягу інвестування, недостатньо для ефективної інвестиційної політики підприємств. Інвестиційна складова частина тарифу незахищена і може змінюватися залежно від стану підприємств. Можливість використання підприємствами водопостачання та водовідведення власного прибутку як джерело капіталовкладень незначна, оскільки підприємства в основному є збитковими. У 2020 році збільшилася частка фінансування інвестиційних програм у сфері водопостачання та водовідведення за рахунок кредитних коштів міжнародних фінансових організацій, які потім відшкодовуватимуться за рахунок тарифів. Зважаючи на необхідність вжиття заходів щодо формування додаткових джерел фінансування інвестицій, запропоновано таке: визначення стратегічних цілей розвитку сфери водопостачання та водовідведення, виражене в конкретних цифрах, із прив'язкою до конкретних індикаторів та показників; перегляд механізму тарифоутворення на послуги за водопостачання та водовідведення мають бути обгрунтовані фундаментальними економічними показниками (коефіцієнт доступності послуг; рівень інфляції; індекс цін на ремонтно-будівельні роботи; середній дохід домогосподарства в країні; платоспроможність домогосподарств; обсяг реалізованої продукції; коефіцієнт зміни середнього доходу домогосподарств тощо); визначення граничної норми інвестиційних відрахувань на оновлення основних фондів підприємств водопостачання та водовідведення; удосконалення методів прямого та непрямого економічного регулювання сфери тощо. Фінансування першочергових інвестицій може здійснюватися підприємствами водопостачання та водовідведення за рахунок власних коштів, у разі використання тарифів для населення, обмежених їх прийнятністю та доступністю, за умови дотримання базового рівня збирання платежів, бюджетної прямої та непрямої підтримки, збереження та посилення державного регулювання iз державною фінансовою підтримкою та впровадження певних інструментів ринкового регулювання з приватними інвестиціями. 


\section{Лiтература}

1. Launch of the OECD Report «Managing Water for All: an OECD Perspective on Pricing and Financing», 2009. OECD. URL: https://www.oecd.org/environment/launchoftheoecdreportmanagingwaterforallanoecdperspectiveonpricingandfinancing.htm (accessed on 21.10.2021).

2. Meeting the Challenge of Financing Water and Sanitation. Tools and approaches. 2011. OECD Studies on Water. OECD. URL: https://www.pseau.org/outils/ouvrages/ocde_meeting_the_challenge_of_financing_water_and_sanitation_2013.pdf (accessed on 21.10.2021).

3. OECD. Financing Water, Investing in Sustainable Growth; Policy Perspectives. OECD Environment Policy Paper No. 11; OECD: Paris, France, 2018. URL: chrome-extension://efaidnbmnnnibpcajpcglclefindmkaj/viewer.html-?pdfurl=https $\% 3 \mathrm{~A} \% 2 \mathrm{~F} \% 2 \mathrm{Fwww}$. oecd.org\%2Fwater\%2FPolicy-Paper-Financing-Water-Investing-in-Sustainable-Growth.pdf\&clen=1794084\&chunk=true (accessed on 23.10.2021).

4. OECD. Making Blended Finance Workfor Water and Sanitation: Unlocking Commercial Finance for SD G6; OECD Studies on Water; OECD: Paris, France, 2019. URL: https://www.oecd.org/env/resources/making-blended-finance-work-for-sdg-6-5efc8950-en.htm (accessed on 21.10.2021).

5. Resolution adopted by the General Assembly on 28 July 2010 № 64/292. The human right to water and sanitation. United Nations Official Document. URL: https://www.un.org/en/ga/search/view_doc.asp?symbol=A/RES/64/292 (accessed on 23.10.2021).

6. UN. The Critical Role of Water in Achieving the Sustainable Development Goals: Synthesis of Knowledge and Recommendations for Effective Framing, Monitoring, and Capacity Development. 2015. URL: https:/sustainabledevelopment.un.org/content/ documents/6185Role\%20of\%20Water\%20in\%20SD\%20Draft\%20Version\%20February\%202015.pdf (accessed on 21.10.2021).

7. UN. Report of the Secretary-General on SDG Progress 2019. URL: chrome-extension://efaidnbmnnnibpcajpcglclefindmkaj/ viewer.html?pdfurl=https $\% 3-\mathrm{A} \% 2 \mathrm{~F} \% 2 \mathrm{Fsustainabledevelopment.un.org} \% 2 \mathrm{~F}$ content $\% 2 \mathrm{Fdocuments} \% 2 \mathrm{~F} 24978 \mathrm{Report}$ of the SG_on_SDG_Progress_2019.pdf\&clen=12684827\&chunk=true (accessed on 23.10.2021).

8. Білянський О.М. Організаційно-фінансовий механізм розвитку житлово-комунального господарства: дис. ... канд. екон. наук: спец. 08.10.01 / Білянський О. М. Харків, 2006. 189 с.

9. Бодров В.Г., О.П. Ігнатенко Удосконалення фінансово-економічних механізмів державного регулювання сфери благоустрою населених пунктів. Інвестиції: практика та досвід : наук.-практ. журн. 2015. № 3. С. 105-109.

10. Бражнікова Л.М. Стратегічне управління фінансовою діяльністю підприємств ЖКГ: автореф. дис. ... д-ра екон. наук : спец. 08.00.04. Маріуполь, 2011. 36 с.

11. Джерела та механізми фінансування місцевого економічного розвитку: навч. пос. / В. Мамонова, Н. Балдич, Н. Гринчук, Л. Чорний, К. Рубановський, М. Борода. Проєкт «Місцевий економічний розвиток міст України». Київ: Центр громадської експертизи, 2013. 176 с.

12. Дзезик С.С., Кучеренко В.Р. Стратегії розвитку комунального сектору міського господарства. Одеса, 2009. 154 с.

13. Добровільний національний огляд щодо Цілей сталого розвитку в Україні. URL: https://ukraine.un.org/uk/151096dobrovilnyy-natsionalnyy-ohlyad-shchodo-tsiley-staloho-rozvytku-v-ukrayini (дата звернення: 22.10.2021).

14. Запатріна I.B. Публічно-приватне партнерство в Україні: перспективи застосування для реалізації інфраструктурних проектів та надання публічних послуг. 2010. URL: file://C:/Users/original/Downloads/-econprog_2010_4_8\%20(2).pdf (дата звернення: 24.10.2021).

15. Звіт про результати діяльності НКРЕКП у 2020 році. URL: https://www.nerc.gov.ua/?id=61765 (дата звернення: 15.10.2021).

16. Ігнатенко О.П. Державне регулювання сфери благоустрою населених пунктів: дисертація ...доктора 3 держ. упр-я: спец: 25.00.02. Київ: НАДУ, 2016. 471 с.

17. Капітальні інвестиції за видами промислової діяльності за 2010-2019 роки. База даних Держстат України. URL: http://www.ukrstat.gov.ua/-operativ/menu/menu_u/ioz.htm (дата звернення: 30.10.2021).

18. Кірсанова Ю.В. Фінансово-економічні аспекти утримання системводопостачання та водовідведення в неприбуткових обслуговуючих кооперативах// Вчені записки університету «КРОК». Серія: Економіка. 2013. Вип. 33. С. 100-107.

19. Крамаренко Г.О. Організаційно-економічний механізм управління житлово-комунальним комплексом :автореф. дис. ... д-ра екон. наук: спец. 08.06.01. Донецьк, 1998. 36 с.

20. Крилова І.І. Державне регулювання сфери водопостачання та водовідведення в Україні. дис. ... доктра наук держ упр.: спец. 25.00.02 / Крилова I.І. Київ: НАДУ, 2021. 717 с.

21. Національна доповідь про якість питної води та стан питного водопостачання в Україні у 2019 році. База даних: Мінрегіон України. URL: https://www.minregion.gov.ua/wp-content/uploads/2020/12/naczionalna-dopovid-za-2019-rik.pdf (дата звернення: 21.10.2021).

22. Олійник Н.І. Державне регулювання ринку житла в Україні: дис. ... д-ра наук з держ. упр.: спец. 25.00.02. Київ, 2011. 391 с.

23. Полуянов В.П. Організаційно-економічний механізм підвищення ефективності підприємств житлово-комунального господарства: автореф. дис. ... д-ра екон. наук: спец. 08.06.01. Донецьк, 2005. 29 с

24. Стан водопровідно-каналізаційного господарства. Презентація Мінрегіону України (доп. Медведь Т.А.) від 16.02.2016 p. База даних: «Центр ресурсоефективного та чистого виробництва». URL: http://recpc.kpi.ua/images/eap_-green/-16.02.16_ Forum_Kуіv (дата звернення: 20.10.2021).

25. Технічний стан водопровідно-каналізаційного господарства. Презентація Мінрегіону України (доповідач Хоцянівська Н.) від 13.09.2018 p. База даних: «Львівводоканал». URL:http://eco-forum-lviv.com.ua/wp-content/ uploads/2018/10/4_2-Khotsianivska.pdf (дата звернення: 22.10.2021).

26. Фінансово-економічні механізми державного управління формуванням та розвитком внутрішнього ринку України : навч. посіб. / авт. кол.: І.В. Розпутенко, Л.В. Ільченко-Сюйва, О.І. Кілієвич та ін. Київ: НАДУ, 2014. 60 с.

27. Цілі сталого розвитку: Україна. Національна доповідь 2017. URL: http://un.org.ua/images/SDGs_NationalReportUA_Web_1. pdf (дата звернення: 21.10.2021). 


\title{
СІРКОВОДНЕВІ ДХЕРЕАА КОСІВЩИНИ
}

\author{
Глодова Л.М. \\ Національний природний парк «Гуцульщина» \\ вул. Дружби, 84, 78601, м. Косів, Івано-Франківська область \\ liubovglodova@gmail.com
}

\begin{abstract}
На території Косівщини виявлено та детально описано шістдесят вісім джерел, із яких тільки п'ять - це сірководневі джерела («Джерело коло Грибка», «Бухтєнка», «Джерело на Петричєлі», «Джерело на ділянці Глигул», «Сірководневе джерело у м. Косів»). Вода, насичена сірководнем, має унікальні цілющі властивості і користується популярністю у місцевих жителів та гостей краю. Унікальні властивості джерел, зазвичай віддалене від людських поселень та мальовниче їх розташування, легенди та перекази про джерела підвищують рекреаційну привабливість місць локації джерел та краю загалом. У статті наведена детальна інформація про сірководневі джерела, складено паспорти джерел із зазначенням висоти їх розташування, координат, рельєфу, експозиції схилу, площі водного дзеркала, розмірів, глибини, дебіту, запаху, смаку, ширини витоку, температури, описана рослинність на берегах джерела тощо. Також визначена туристично-рекреаційна цінність кожного із джерел та ситуація із їх облагородженням.

НПП «Гуцульщина» проведений хімічний аналіз води у сірководневих джерелах за десятьма показниками (амоній-іони, залізо, загальна твердість, кальцій, магній, загальна лужність, хлориди, нітрити, сульфати, мідь). Визначено, що кожне сірководневе джерело володіє своїм набором елементів з унікальними пропорціями, що є важливим складником у разі інтенсивного рекреаційного та потенційного лікувального застосування. 3 метою попередження замулення природних джерел, їх пересихання чи прокладання через місце витоку джерела об'єктів антропогенного характеру визначений перелік заходів, необхідних для збереження цих природних ресурсів регіону та їх активного рекреаційного застосування.

Відзначено, що запорукою ефективного рекреаційного використання та водночас збереження джерел як об'єктів природної спадщини Косівщини є взаємодія між органами місцевої влади, національним природним парком «Гуцульщина» та надавачами еко-рекреаційно-туристичних послуг на території краю. Ключові слова: сірководневі джерела, паспорти джерел, хімічний склад води, рекреація, збереження, національний природний парк «Гуцульщина».
\end{abstract}

Hydrogen sulfur sources of Kosiv region. Glodova L.

Sixty-eight sources have been identified and described in detail in the Kosiv region. Only five of sources are hydrogen sulfide sources ("Dzherelo kolo Hrybka", "Bukhtenka", "Dzherelo na Petrycheli”, "Dzherelo na plotu Glygul”, "Sulfur hydrogen source in c. Kosiv"). Saturated with hydrogen sulfide water has unique healing properties and is popular with locals and visitors to the region. The unique properties of sources, usually remote from human settlements and their picturesque location, legends and legends about sources increase the recreational attractiveness of the location of sources and the region in general. The article provides detailed information about hydrogen sulfide sources, source passports with their location, coordinates, relief, slope exposure, water surface area, size, depth, flow rate, odor, taste, source width, temperature, described vegetation on the banks of the source, etc. The tourist and recreational value of each of the sources and the situation with their improvement are also determined.

NPP "Hutsulshchyna" conducted a chemical analysis of water in hydrogen sulfide sources on ten indicators (ammonium ions, iron, total hardness, calcium, magnesium, total alkalinity, chlorides, nitrites, sulfates, copper). It is determined that each hydrogen sulfide source has its own set of elements with unique proportions, which is an important component in the case of intensive recreational and potential therapeutic applications. In order to prevent siltation of natural springs, their drying or laying through the source of the source of anthropogenic objects, a list of measures necessary for the conservation of these natural resources of the region and their active recreational use.

It is noted that the key to effective recreational use and, at the same time, preservation of sources as objects of natural heritage of Kosiv region is the interaction between local authorities, Hutsulshchyna National Nature Park and providers of eco-recreational and tourist services in the region. Key words: hydrogen sulfide sources, source passports, chemical composition of water, recreation, preservation, Hutsulshchyna National Nature Park.

Постановка проблеми. Природна спадщина кожного регіону по-своєму унікальна. Збереження, популяризація в рекреаційних та оздоровчих цілях цікавих із погляду туристичної привабливості цінних природних комплексів та об'єктів є важливим аспектом економічного розвитку територіальних громад, а також потенційним важелем поповнення бюджетів регіону загалом [1]. Внутрішній туризм, який набуває все чіткіше вираженого характеру, провокує розвиток пропозицій для вибагливого відвідувача та водночас вносить корективи в аспекти збереженості автентичності та природних ресурсів краю. Тому збереження природних об'єктів $є$ справою пріоритету, що має багато законодавчих важелів, які передбачають як фінансування напрямів подібного характеру, так і певні алгоритми презентування та оприлюднення інформації про об'єкт.

Актуальність дослідження. Станом на 1.01.2021 р. співробітниками Національного природного парку «Гуцульщина», що на Косівщині, виявлено і задокументовано 68 джерел природного походження [2]. Ці місця проінвентаризовані науковцями парку, описані стандартні для цих випадків характеристики водного об'єкта, здійснюються систематичні перевірки на предмет потенційної захаращеності водних дзеркал та прилеглих біля них територій, а також у міру необхідності та першочерговості проводяться роботи з облагородження 
території джерела та розробляються, знакуються й інформативно насичуються маршрути, що пролягають до або біля таких джерел, за умови, що вони не локалізовані в заповідній зоні парку. Слід відзначити, що наявна систематизована інформація про 68 джерел, із них тільки 5 - це джерела, вода яких насичена сірководнем, а тому має унікальні цілющі властивості і користується популярністю у місцевих жителів та гостей Косівщини як момент гідротерапіі. Незвичайний смак та дещо специфічний аромат води із цих джерел із давніх-давен породив численні легенди про причини походження таких смакових якостей, які дійшли до нас [3]. Сумарно з унікальними властивостями, зазвичай віддаленим від людських поселень та мальовничим розташуванням джерел легенди та перекази створюють неповторну ауру та магнетизм місця, що є важливим атрибутом рекреаційної привабливості та конкурентоспроможності краю [4]. Водночас, враховуючи негативні екологічні тенденції та кліматичні зміни в усьому світі, такі природні об'єкти потребують систематичного моніторингу та періодичного дослідження якостей води. Це необхідно з метою попередження замулення природних джерел, унеможливлення, у разі пересихання, прокладання через місце витоку джерела об'єктів антропогенного характеру тощо.

Зв'язок авторського доробку з важливими науковими та практичними завданнями. Відповідно до Орхуської конвенції [5] та директиви 98/83/СС [6] про якість води, призначеної для споживання людиною, у суспільства є право на отримання інформації про якість води. Доступність такої інформації дасть змогу підвищити обізнаність населення щодо необхідності ощадливого та бережливого водоспоживання. Проведені дослідження також є частиною наукового доробку лабораторії екологічного моніторингу Національного природного парку «Гуцульщина» та виконуються в межах Програми Літопису природи, розділу 3.2. «Гідрологія», який затверджений до виконання на території природно-заповідного фонду Міністерством екології та природних ресурсів України та Національною академією наук України від 25.11.2002 [7].

Аналіз останніх досліджень та публікацій. Інформація, присвячена питанням джерел на території НПП «Гуцульщина», висвітлена в окремих томах Літописів природи НПП «Гуцульщина», які $€$ формою щорічної наукової звітності Парку перед Міндовкіллям [2]. Окремі фрагментарні відомості популярного характеру про сірководневі джерела згадані у праці [4]. Через вагому рекреаційну цінність сірководневих джерел інтернет-ресурси рясніють значною кількістю інформації популярного характеру [8]. Цей факт суттєво підвищує рейтинги відвідуваності самих джерел, що негативно відображається на стані їх збереженості. 3 цією метою важливо задокументувати поточні характеристики джерел, які стануть еталонними під час фіксації потенційних змін, спричинених антропогенними, рекреаційними навантаженнями чи впливами іншого характеру.

Виділення не вирішених раніше частин загальної проблеми, котрим присвячусться стаття. Зважаючи на фрагментарність даних про сірководневі джерела на території Косівщини, відсутність інформації про хімічний склад води в них, рекреаційний стан і навантаження, а також значну кількість інформації ненаукового характеру, є потреба провести комплексні дослідження джерел та систематизувати і стандартизувати відомості про ці гідрологічні перлини Косівщини. Новизна. У межах публікації узагальнено інформацію щодо основних характеристик сірководневих джерел, виявлених на території Косівщини, а також вперше проведений хімічний аналіз складу води. Метою дослідження є фіксація та опис сірководневих джерел, виявлених на території парку, особливостей їх розташування, ідентифікація видового складу прибережної рослинності та інших деталей, притаманних місцевості, визначення компонентного складу води заради отримання даних, достатніх для порівняльного моніторингу в майбутньому - фіксування змін чи стабільності показників, що стане запорукою, у разі необхідності, швидкого реагування та усунення негативу відносно джерела.

Викладення основного матеріалу. Дослідження проведені упродовж 2018-2020 рр. Описи джерел проведені у місці їх знаходження (табл. 1), аналіз води (табл. 2) здійснений у лабораторії екологічного моніторингу НПП «Гуцульщина» згідно 3 нормативними документами, рекомендованими службами Міністерства захисту довкілля та природних ресурсів України, в яких визначені норми - гранично допустимі концентрації тих чи інших сполук у воді.

Встановлено, що всі джерела добре відомі місцевому населенню. Хоча до більшості з них і не промарковані маршрути, вони є часто відвідуваними, деякі $з$ них облагороджені. Так, приміром, воду із «Джерела коло Грибка» використовують для лікування хвороб шлунково-кишкового тракту. На пагорбі, на скелі над джерелом знаходиться альтанка, збудована, згідно зі свідченнями місцевих жителів, на початку 80-х років, перекрита у 1993-1994 рр. У 1996 році біля альтанки зведений паркан (рис. 1.1).

Воду із джерела «Бухтєнка» також використовують у лікувальних цілях місцеві жителі. Джерело не облагороджене (рис. 1.2.). «Джерело на Петричєлі» є місцем частого відвідування, біля джерела зведена альтанка, яка активно використовується людьми, що приходять по воду. Також встановлено роз'яснювальний щит (рис. 1.3). «Джерело на ділянці Глигул» (рис. 1.4.) відоме не тільки місцевим жителям, воно є туристичним об'єктом гостей краю, які приходять до джерела по сірководневу воду. Оскільки джерело розташоване близько біля потоку, то під час проливних дощів вода з потоку може частково або повністю заливати джерело. Однак цілісність джерела не пошкоджується, склад води швидко відновлюється. 
Таблиця 1

Сірководневі джерела Косівщини

\begin{tabular}{|c|c|c|c|c|c|}
\hline \multirow[b]{2}{*}{ Характеристики } & \multicolumn{5}{|c|}{ Назва водного об'єкта } \\
\hline & $\begin{array}{c}\text { «Джерело коло } \\
\text { Грибка» }\end{array}$ & «Бухтєнка» & $\begin{array}{c}\text { «Джерело } \\
\text { на Петричслі» }\end{array}$ & $\begin{array}{c}\text { «Джерело на участку } \\
\text { Глигул» }\end{array}$ & $\begin{array}{c}\text { «Сірководневе } \\
\text { джерело у м. Косів» }\end{array}$ \\
\hline Адреса & $\begin{array}{l}\text { с. Шешори. } \\
\text { Шешорське } \\
\text { ПНДВ }\end{array}$ & $\begin{array}{c}\text { c. Шешори. } \\
\text { Шешорське } \\
\text { ПНДВ }\end{array}$ & $\begin{array}{c}\text { с. Прокурава. Шешорське } \\
\text { ПНДВ }\end{array}$ & $\begin{array}{c}\text { с. Шешори. } \\
\text { Шешорське ПНДВ. }\end{array}$ & м. Косів \\
\hline Автор(и) знахідки & $\begin{array}{l}\text { Глодова Л.М, } \\
\text { Соколюк В.В. }\end{array}$ & $\begin{array}{l}\text { Глодова Л.М., } \\
\text { Соколюк В.В. }\end{array}$ & $\begin{array}{c}\text { Глодова Л.М., Олексюк } \\
\text { І.В., Удудяк С.В. } \\
\end{array}$ & $\begin{array}{l}\text { Глодова Л.М., Якібчук } \\
\text { П.М., Якібчук І.М. } \\
\end{array}$ & $\begin{array}{l}\text { Глодова Л.М., Пліхтяк } \\
\text { В.П. } \\
\end{array}$ \\
\hline Дата & 16.10 .2019 & 28.10 .2019 & 5.11 .2019 & 23.09 .2020 & 22.10 .2018 \\
\hline Час (год.) & 10.25 & 9.30 & 11.55 & 10.25 & 10.00 \\
\hline Абсолютна висота (м) & 594 & 598 & 649 & 452 & 687 \\
\hline Координати & $\begin{array}{l}\text { N: } 48^{\circ} 18^{\prime} 19,3 ", \\
\text { E: } 024^{\circ} 57^{\prime} 13,8^{\prime \prime}\end{array}$ & $\begin{array}{l}\text { N: } 48^{\circ} 18^{\prime} 19,0^{\prime \prime}, \\
\text { E: } 024^{\circ} 56^{\prime} 56,4^{\prime \prime}\end{array}$ & $\begin{array}{l}\text { N: } 48^{\circ} 20^{\prime} 25,3^{\prime \prime}, \\
\text { E: } 024^{\circ} 55^{\prime} 10,2^{\prime \prime}\end{array}$ & $\begin{array}{l}\text { N: } 48^{\circ} 18^{\prime} 44,0^{\prime \prime}, \\
\text { E: } 024^{\circ} 58^{\prime} 17,5^{\prime \prime}\end{array}$ & $\begin{array}{l}\text { N: } 48^{\circ} 19^{\prime} 21,0^{\prime \prime}, \\
\text { E: } 025^{\circ} 03^{\prime} 07,2^{\prime \prime}\end{array}$ \\
\hline Рельєф & Скелястий & Скелястий & Скельний & Глиняно-кам'янистий & Глиняно-кам'янистий \\
\hline $\begin{array}{l}\text { Ухил поверхні } \\
\text { (град) }\end{array}$ & $30^{\circ}$ & $40^{\circ}$ & $55^{\circ}$ & $40^{\circ}$ & $40^{\circ}$ \\
\hline Експозиція схилу & Пн & Пн & $3 x$ & $3 x$. & Північний. \\
\hline $\begin{array}{l}\text { Положення у } \\
\text { мезорельєфі }\end{array}$ & $\begin{array}{l}\text { Нижня частина } \\
\text { схилу }\end{array}$ & $\begin{array}{c}\text { Верхня частина } \\
\text { схилу } \\
\end{array}$ & Середня частина схилу & Нижня частина схилу & $\begin{array}{c}\text { Верхня частина схилу } \\
\text { хребта }\end{array}$ \\
\hline $\begin{array}{l}\text { Сучасні природно- } \\
\text { географічні процеси }\end{array}$ & Немає & $\begin{array}{c}\text { Джерело зна- } \\
\text { ходиться біля } \\
\text { потоку } \\
\end{array}$ & Немає помітних & Невеликі зсуви & Невеликі зсуви \\
\hline $\begin{array}{c}\text { Кам'янистість поверх- } \\
\text { нева (\%) }\end{array}$ & 80 & 40 & 60 & 30 & 30 \\
\hline $\begin{array}{c}\text { Форма кам'яних } \\
\text { утворень }\end{array}$ & Ізометричні & Ізометричні & Неокатані & Неокатані, ізометричні & Неокатані \\
\hline $\begin{array}{l}\text { Розмір кам'ян. } \\
\text { утворень (см) }\end{array}$ & $20-50,50-100$ & $20-50,50-100$ & 20-50, 50-100 і більші & $2-5,50-100$ & $2-5 \mathrm{~cm}$ \\
\hline Місце розташування & Лic & Ліс. г. Брусний & Ліс. г. Петричєла & $\begin{array}{l}\text { Лic, біля гирла річки } \\
\text { Глигулєнка }\end{array}$ & У лісі \\
\hline $\begin{array}{c}\text { Площа водного } \\
\text { дзеркала }\left(\mathrm{M}^{2}\right)\end{array}$ & 0,16 & 0,24 & Чітких меж немає & 0,07 & 0,075 \\
\hline Довжина (м) & 0,4 & 0,6 & $\begin{array}{c}\text { Вода виливається у потік, } \\
\text { далі в річку }\end{array}$ & 0,35 & 0,25 \\
\hline Ширина (м) & 0,4 & 0,4 & $\begin{array}{c}\text { Полотном шириною } 0,5 \\
\text { метра вода пробивається } \\
\text { iз недр землі. }\end{array}$ & 0,2 & 0,30 \\
\hline Глибина джерела (м) & 0,12 & 0,25 & невідома & 0,1 & 0,1 \\
\hline Дебіт (л/ хв) & 0,86 & $\begin{array}{c}\text { Середній } \\
\text { (близько 2-2,5) }\end{array}$ & Важко простежити & $\begin{array}{c}\text { Дуже слабкий, на час } \\
\text { обстеження майже } \\
\text { непомітний. }\end{array}$ & 0,350 л/хв \\
\hline $\mathrm{T}^{0}$ води $\left({ }^{\circ} \mathrm{C}\right)$ & 6 & 8 & 2 & $7^{\circ} \mathrm{C}$ & $10^{\circ} \mathrm{C}$ \\
\hline $\mathrm{T}^{0}$ повір’я $\left({ }^{\circ} \mathrm{C}\right)$ & 9 & 22 & 19 & $15^{\circ} \mathrm{C}$ & $12^{\circ} \mathrm{C}$ \\
\hline Запах & $\begin{array}{l}\text { Тухлий, } \\
\text { сірчистий }\end{array}$ & Сірководневий & $\begin{array}{c}\text { Сірководневий, дуже } \\
\text { насичений }\end{array}$ & Сірчистий & Тухлий \\
\hline Смак & Сірководневий & Терпко-солодка & $\begin{array}{c}\text { Специфічний, властивий } \\
\text { цій воді }\end{array}$ & Сірководневий & $\begin{array}{l}\text { Приторно- } \\
\text { тухло-гнилий }\end{array}$ \\
\hline Ширина витоку (м) & 0,25 & 0,2 & 0,5 & 0,1 & 0,2 \\
\hline Особливості & & $\begin{array}{c}\text { Джерело не } \\
\text { облаштоване, } \\
\text { пробилося між } \\
\text { камінням. }\end{array}$ & $\begin{array}{c}\text { Вода сірководнева, } \\
\text { лікувальна, лікує хвороби } \\
\text { кишково-шлункового } \\
\text { тракту. Місцевими жите- } \\
\text { лями закладена труба, для } \\
\text { зручності набору води у } \\
\text { посуду і викладено каміння. } \\
\text { Воду приходять набирати } \\
\text { дуже часто (а це в основ- } \\
\text { ному жителі Прокурави), як } \\
\text { літом, так і зимою. } \\
\end{array}$ & $\begin{array}{c}\text { Джерело облаштоване. } \\
\text { Джерело облаго- } \\
\text { роджене кам'яними } \\
\text { глибами, вода витікає } \\
\text { з берега, днище } \\
\text { - кремениця. }\end{array}$ & $\begin{array}{c}\text { Джерело позначено } \\
\text { знаком. Вода витікає } \\
\text { зі скелі }\end{array}$ \\
\hline Рослинність & & $\begin{array}{c}\text { Бук, граб, ялиця, } \\
\text { папороть, мати-й } \\
\text { мачуха, кропива, } \\
\text { зеленчук жов- } \\
\text { тий, горлянка } \\
\text { повзуча. }\end{array}$ & Бук, чорниця & $\begin{array}{c}\text { Граб звичайний, ялиця } \\
\text { біла, ялина європей- } \\
\text { ська (смерека), вільха } \\
\text { сіра, бузина чорна, } \\
\text { яглиця звичайна, } \\
\text { підбіл звичайний, } \\
\text { тирлич ваточниковид- } \\
\text { ний, бучина лісова, } \\
\text { печіночниця звичайна, } \\
\text { жовтець шерстистий, } \\
\text { осока лісова, підлісник } \\
\text { європейський, жабрій } \\
\text { чотиригранний, глуха } \\
\text { кропива пурпурова. }\end{array}$ & $\begin{array}{c}\text { Ліс: ялиця біла, бук } \\
\text { лісовий, клен, явір. } \\
\text { Рослинний покрив: } \\
\text { бузина чорна, кропива } \\
\text { глуха, папороть }\end{array}$ \\
\hline
\end{tabular}


До «Сірководневого джерела у м. Косів» (рис. 1.5.) систематично приходять місцеві жителі набрати сірководневої води. До цього джерела веде промаркована еколого-пізнавальна стежка, тому воно відоме за межами району i $€$ туристичною атракцією Косівщини.
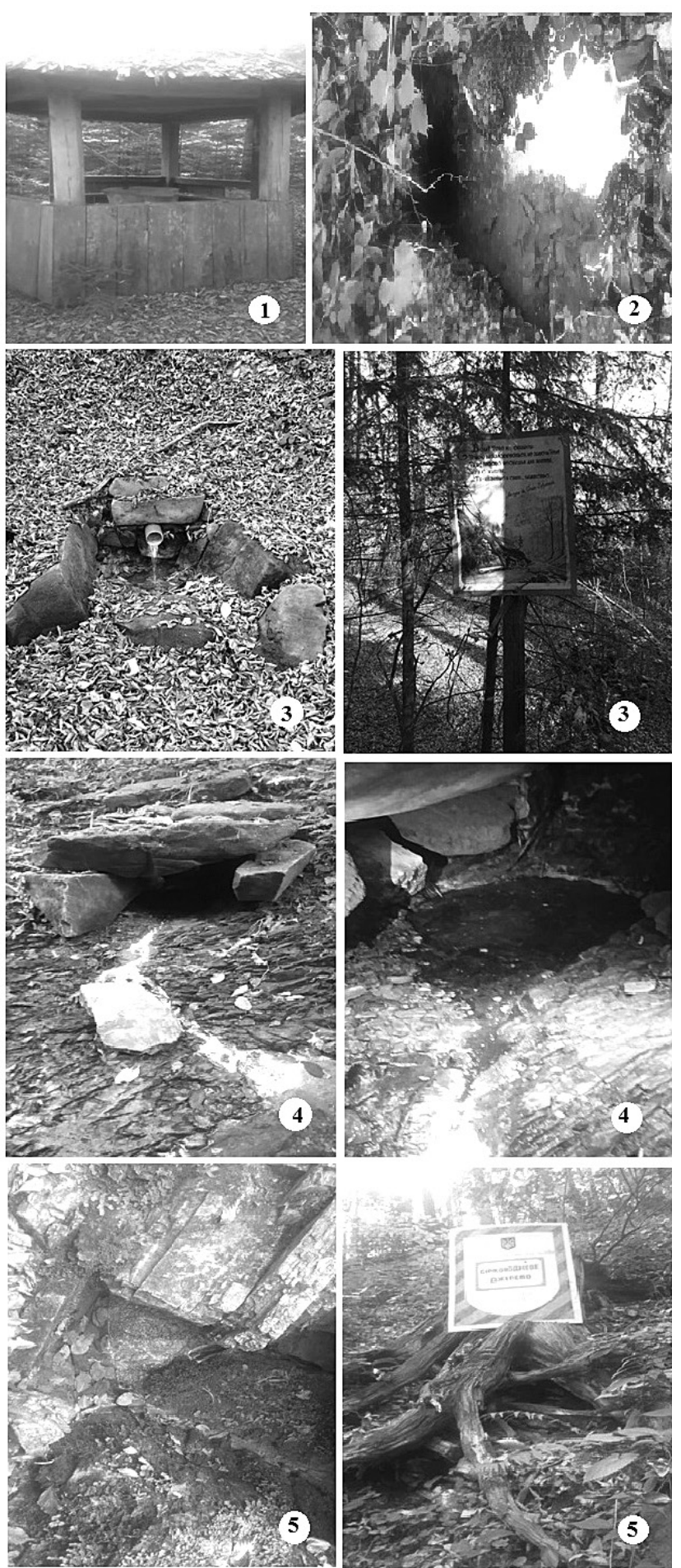

Рис. 1. Сірководневі джерела Косівщини

Примітки: 1, 2, 3, 4, 5 - «Джерело коло Грибка», «Бухтєнка», «Джерело на Петричєлі», «Джерело на ділянці Глигул», «Сірководневе джерело у м. Косів» відповідно.
Таблиця 2

Хімічні показники води сірководневих джерел Косівщини

\begin{tabular}{|c|c|c|c|c|c|}
\hline $\begin{array}{c}\text { Показник / } \\
\text { одиниці } \\
\text { вимірювання }\end{array}$ & $\begin{array}{c}\text { «Джерело } \\
\text { коло } \\
\text { Грибка» }\end{array}$ & $\begin{array}{c}\text { «Бух- } \\
\text { тєнка» }\end{array}$ & $\begin{array}{c}\text { «Джерело } \\
\text { на } \\
\text { Петричєлі» }\end{array}$ & \begin{tabular}{|c} 
Джерело \\
на \\
ділянці \\
Глигул»
\end{tabular} & \begin{tabular}{|c|} 
«Сірко- \\
водневе \\
джерело у \\
м. Косів»
\end{tabular} \\
\hline $\begin{array}{c}\text { Амоній-іони / } \\
\text { мг/дм }{ }^{3} \\
\end{array}$ & $\begin{array}{c}\text { не } \\
\text { виявлено } \\
\end{array}$ & 0,028 & 0,022 мг/дм ${ }^{3}$ & $\begin{array}{c}\text { не } \\
\text { виявлено } \\
\end{array}$ & 0,04 \\
\hline Залізо / мг/дм³ & 0,09 & $\begin{array}{c}\text { не } \\
\text { виявлено } \\
\end{array}$ & 0,16 & 0,184 & $\begin{array}{c}\text { не } \\
\text { виявлено }\end{array}$ \\
\hline $\begin{array}{c}\text { Загальна } \\
\text { твердість / } \\
\text { мГ-екв./дм }\end{array}$ & 3,7 & 2,0 & 3,7 & 1,9 & 4,0 \\
\hline $\begin{array}{c}\text { Кальцій / мг/ } \\
\text { дм }^{3} \\
\end{array}$ & 44,088 & 36,07 & 44,09 & 28,056 & 68,14 \\
\hline $\begin{array}{c}\text { Магній / мг/ } \\
\text { дм }^{3} \\
\end{array}$ & 18,9 & 2,52 & 18,9 & 6,30 & 7,56 \\
\hline $\begin{array}{c}\text { Загальна } \\
\text { лужність / } \\
\text { мг-екв/дм }{ }^{3}\end{array}$ & 1,4 & 2,0 & 2,7 & 1,1 & 0,6 \\
\hline $\begin{array}{c}\text { Хлориди / } \\
\text { мг/дм }{ }^{3}\end{array}$ & 48,0 & 41,0 & 6,0 & 8,0 & 3,0 \\
\hline $\begin{array}{c}\text { Нітрити / мг/ } \\
\text { дм }^{3} \\
\end{array}$ & 1,66 & 0,36 & 0,82 & 0,087 & 0,02 \\
\hline $\begin{array}{c}\text { Сульфати / мг/ } \\
\text { дм }^{3} \\
\end{array}$ & $\begin{array}{c}\text { не } \\
\text { виявлено } \\
\end{array}$ & 35,14 & 52,17 & 60,205 & 39,25 \\
\hline Мідь / мг/дм³ & 0,01 & $\begin{array}{c}\text { не } \\
\text { виявлено }\end{array}$ & 0,118 & 0,018 & 0,14 \\
\hline
\end{tabular}

Аналізуючи хімічний склад води з різних джерел, слід відзначити, що кожне джерело має свій унікальний компонентний склад, що важливо під час його потенційного рекреаційного та лікувального застосування. 3 цією метою слід облагородити територію біля джерел, прокласти цікаві та інформативні екомаршрути, розробляти та застосовувати заходи промоції місць локації джерел, а також залучити місцеву владу в межах іiі компетенцій до питань врегулювання туристичних потоків, туристичного збору, несанкціонованого викидання сміття на шляхах пролягання існуючих маршрутів. Кожне із джерел $€$ потенційно комерційно привабливим рекреаційним об'єктом за умов належної промоції, співпраці відповідних за реалізацію цієї промоції структур та за виконання умови збереження самого джерела як природної спадщини.

Головні висновки. У статті описані 5 сірководневих джерел, розташованих на території Косівського району. Складено паспорти джерел, визначена їх туристично-рекреаційна цінність. Проведений хімічний аналіз води у джерелах, визначено, що кожне джерело володіє своїм набором елементів із унікальними пропорціями, що є важливим складником у разі інтенсивного рекреаційного та потенційного лікувального застосування.

Визначений перелік заходів, необхідних для збереження цих природних ресурсів регіону та їх активного рекреаційного застосування.

Перспективи використання результатів досліджень. Отримані результати важливі для рекреаційно-туристичної галузі краю та повинні бути враховані під час планування різного роду заходів i розроблення документів, спрямованих на збереження природної спадщини. 


\section{Література}

1. Стратегія розвитку Івано-Франківської області на 2021-2027 роки. / Затверджено Рішенням обласної ради від 21.02.2020 № 1381-34/2020. С. 1-99.

2. Літопис природи Національного природного парку «Гуцульщина». Т. XVI/за ред. Ю.П. Стефурака. Косів, 2020. С. 102-108 с.

3. Пелипейко I.А. Містечко над Рибницею / Косів: «Писаний Камінь», 2004. 572 с.

4. Національний природний парк "Гуцульщина" / В.В. Пророчук, Ю.П. Стефурак, В.П. Брусак.; за ред. В.В. Пророчука. Львів: НФК «Карпати і атласи», 2013. 408 с.

5. Конвенція про доступ до інформації, участь громадськості в процесі прийняття рішень та доступ до правосуддя 3 питань, що стосуються довкілля (Орхуська конвенція). URL: https://zakon.rada.gov.ua/laws/show/994_015\#Техt (дата звернення 28.10.2021).

6. Директива Ради 98/83/ЄС від 3 листопада 1998 р. про якість води, призначеної для споживання людиною. URL: https://zakon.rada.gov.ua/laws/show/994_0963\#Text (дата звернення 28.10.2021).

7. Наказ «Про затвердження Програми Літопису природи» від 25.11.2002 № https://zakon.rada.gov.ua/rada/show/v465_737-02\#Text (дата звернення 20.10.2021).

8. Джерела на Косівщині 21.03.2020 https://huculia.info/kosiv-region-wellsprings/ (дата звернення 20.10.2021). 


\title{
ГІДРОГЕОАОГІЧНИЙ АСПЕКТ ЕКОАОГІЧНОГО СТАНУ ЗАКАРПАТТЯ ЗА 2020 PIK
}

\author{
Ігнатишин В.В. ${ }^{1,2}$, Малицький Д.В. ${ }^{3}$, Іжак Т.Й. ${ }^{2}$, Вербицький С.Т. ${ }^{1}$, \\ Ігнатишин А.В. ${ }^{1}$, Ігнатишин М.Б. ${ }^{1}$ \\ ${ }^{1}$ Інститут геофізики імені С.I. Субботіна Національної академії наук України \\ вул. Ярославенка, 27, 79011, м. Львів \\ rgstrs1962@i.ua, sergever@gmail.com, Adalbert_Ihnatisin@i.ua, sitkomonika@i.ua; \\ 2 Закарпатський угорський інститут імені Ференца Ракоці II \\ пл. Кошута, 6, 90202, м. Берегове, Закарпатська область \\ izsak.tibor@kmf.org.ua; \\ ${ }^{3}$ Карпатське відділення Інституту геофізики імені C.I. Субботіна \\ Національної академії наук України \\ вул. Наукова, 3-Б, 79060, м. Львів \\ dmalytskyy@gmail.com
}

\begin{abstract}
Деформометричні спостереження в зоні Оашського глибинного розлому та Берегівського горбогір'я відмітили характер сучасних горизонтальних рухів кори - розширення кори зі швидкостями, що збігаються з рухами кори в Карпато-Балканському регіоні. Виявлено період знакозмінних рухів, які супроводжуються підвищенням сейсмічної активності регіону. Вивчення сейсмотектонічних процесів у Закарпатському внутрішньому прогині важливе, оскільки територія є сейсмогенеруючою: тут періодично відбуваються місцеві землетруси. Більшість землетрусів мають малу енергію, проте реєструються і відчутні місцеві землетруси. Важливо знати геодинаміку регіону в різних його частинах, проте деформометричними спостереженнями охоплені тільки Берегівське горбогір'я та зона Оашського глибинного розлому. Стиснення порід у регіоні супроводжується підняттям рівня води у свердловині глибиною 530 метрів, розрядкою геомеханічної енергії. Аналіз результатів гідрогеологічного стану в регіоні та сейсмічності у 2020 році: зазначено кореляцію кривих варіацій спостережуваних параметрів. Зростання рівня води супроводжується інтенсифікацією місцевої сейсмічної активності. Відмічено кореляцію вікових ходів сучасних горизонтальних рухів кори в зоні Оашського глибинного розлому та варіацій рівня води у свердловині глибиною 530 метрів, на відміну від варіацій рівня води в неглибокій свердловині глибиною 8 метрів на території режимної геофізичної станції «Тросник» Відділу сейсмічності Карпатського регіону Інституту геофізики імені С.І. Субботіна Національної академії наук України, яка реагує на інші типи рухів кори, зокрема сезонні. Актуальність проведення систематичних спостережень рівня води в цих свердловинах пов'язана з тим фактом, що варіації рівня води у свердловинах можна використати під час вивчення геодинамічного стану в місцевостях із наявними свердловинами. Ключові слова: гідрогеологічний стан, сейсмічний стан, землетруси, Закарпатський внутрішній прогин, зона Оашського глибинного розлому, рухи кори, рівень води у свердловинах.
\end{abstract}

Hydrogeological aspect of Transcarpathia's ecological state in 2020. Ihnatyshyn V., Malytskyi D., Ihnatyshyn A., Izsák T., Ihnatyshyn M., Verbytskyi S.

Deformation monitoring observations in the Oas deep-seated fault area and Berehove Hills revealed the character of modern lateral movements of the Earth's crust with speeds that correspond to the movements of the Earth's crust in the Carpathian-Balkan region. The period of alternating movements accompanied by increased seismic activity in the region has been determined. The study of seismotectonic processes in the Transcarpathian Inner Trough is significant since the territory is seismogenic: local earthquakes are regular here. The majority of earthquakes are low-energy ones, however perceptible local earthquakes are also registered. It is of great significance to know the region's geodynamics in its various parts; however, deformation monitoring observations cover only Berehove Hills and the Oaș deep-seated fault. Rock compression in the region is accompanied by increased water level in a $530 \mathrm{~m}$ deep well and geomechanic energy discharge. Analysis of results of the region's hydrogeological state seismicity in 2020: the correlation of variation curves of the observed parameters has been determined. Increased water level is accompanied by intensification of local seismic activity. The authors revealed the correlation of secular variations of modern lateral movements of the Earth's crust in the Oaş deep-seated fault area and variations of water level in a $530 \mathrm{~m}$ deep well, unlike the variations of water level in a shallow $8 \mathrm{~m}$ deep well on the territory of monitoring geophysical station "Trosnyk" of the Seismicity Department of the Carpathian region of S.I. Subbotin Institute of Geophysics of the National Academy of Sciences of Ukraine that reacts to other types of movements of the Earth's crust, seasonal ones in particular. The topicality of conducting systematic observations of water level in these wells is related to the fact that variations of water level in wells can be used to study the geodynamic state in the localities with available wells. Key words: hydrogeological state, seismic state, earthquakes, Transcarpathian Inner Trough, Oaș deep-seated fault, movements of Earth's crust, water level in wells.

Постановка проблеми. На території Закарпатського внутрішнього прогину діють низка геофізичних та сейсмологічних пунктів спостережень Карпатської дослідно-методичної геофізич- ної та сейсмологічної партії відділу сейсмічності Карпатського регіону та Карпатського відділення Інституту геофізики ім. C.I. Субботіна НАН України, на яких у безперервному режимі проводиться 
Ігнатишин В.В., Малицький Д.В., Іжак Т.Й. ...

моніторинг геофізичних полів, геодинамічного та сейсмічного станів. Деформометричні спостереження в зоні Оашського глибинного розлому та Берегівського горбогір'я відмітили характер сучасних горизонтальних рухів кори - розширення кори зі швидкостями, що збігаються з рухами кори в Карпато-Балканському регіоні. Також виявлено період знакозмінних рухів, які супроводжуються підвищенням сейсмічної активності регіону. Тому необхідно мати інформацію про стан рухів верхніх шарів земної кори і на інших ділянках Закарпатського внутрішнього прогину. Цю інформацію можна отримати завдяки вивченню варіацій параметрів метеорологічного та гідрогеологічного станів.

Актуальність дослідження. Вивчення сейсмотектонічних процесів у Закарпатському внутрішньому прогині важливе, оскільки територія $\epsilon$ сейсмогенеруючою: тут періодично відбуваються місцеві землетруси. Більшість землетрусів мають малу енергію, проте реєструються і відчутні місцеві землетруси, періодичність яких коливається в межах 1-3 років. Важливість вивчення геодинамічних процесів у регіоні полягає в тому, що останнім часом відчутних місцевих землетрусів реєструється менше, що свідчить про акумуляцію енергії напружено-деформованого стану порід. Важливо знати геодинаміку регіону в різних його частинах, проте деформометричними спостереженнями охоплені тільки Берегівське горбогір'я та зона Оашського глибинного розлому. Частини Закарпаття, яким властиві сейсмічні прояви, не охоплені дослідженнями рухів кори, тому вивчення зв'язку рухів кори з варіаціями геофізичних полів розширить спектр методів вивчення геомеханічних рухів.

Зв'язок авторського доробку 3 важливими науковими та практичними завданнями. Питання дослідження екологічно небезпечних явищ, пов'язаних 3 аномальними гідрологічними процесами, висвітлено в багатьох наукових працях, зокрема й пов'язаних із катастрофічними повенями, що відбувалися на теренах Закарпаття в останні десятиліття. Проте $є$ ще один напрям досліджень, орієнтованих на вивчення екологічного стану регіону, - дослідження геологічних процесів, що супроводжують наведені вище процеси і також можуть зробити суттєвий внесок у погіршення екологічного стану регіону. Ідеться про сейсмологічні явища та явища, пов'язані з геодинамічним станом досліджуваного регіону. Усі вони в сукупності проливають світло на процеси, що протікають у таких місцях, 3 метою їх дослідження та побудови моделі геологічних процесів, можливості майбутнього їх прогнозування, покращення екологічного стану регіону.

Аналіз останніх досліджень і публікацій. Серед дієвих механізмів зняття негативних наслідків урбанізації необхідно вказати на раціональне використання природних ресурсів, особливо відновлюваних на основі інтенсивних і ефективних технологій, своє-
ГІДРОГЕОАОГІЧНИЙ АСПЕКТ ЕКОАОГІЧНОГО..

часне виявлення і прогнозування глобальних (зовнішніх) і регіональних (внутрішніх) екологічних загроз на базі наукових досліджень в екологічній сфері, які покликані забезпечити декомпенсуючу протидію наслідкам екологічних загроз [1]. Запропоновано новий метод визначення місця розташування штучних гідрогеологічних вікон у покрівлі та підошві водоносного горизонту через використання факторного аналізу хімічного складу підземних вод водоносного горизонту, що є важливим під час визначення джерел забруднення водоносних горизонтів; пропонується використання цього методу в районах розташування старих родовищ нафтових, газових та нафтогазоконденсатних родовищ [2].

Побудовано графіки залежності між геоакустикою і деформаціями, магнітудою й енергетичним класом, а також наведено гістограму сейсмічної активності Закарпатського регіону за період 2002-2016 рр., підтверджено залежність магнітуди від енергетичного класу, підтверджено взаємозв'язок між геоакустичними і деформаційними даними, що необхідно для виявлення впливу сейсмічності на зміну інших параметрів середовища, зокрема температури, характеристик вогнищ землетрусів, важливо для побудови діючої моделі сейсмічності Закарпатського регіону [3]. Проведено теоретичне визначення та моделювання критичних значень напружено-деформованого стану грунтового масиву під впливом навантажень, що дозволяє передбачити характер впливу механічних процесів на екологогеофізичний стан навколишнього середовища та дослідити стійкість інженерних споруд; досліджено напружено-деформаційні процеси гірського масиву, які викликають надзвичайні ситуації природного та техногенного характеру [4]. Метод радарної інтерферометрії дозволяє здійснювати моніторинг зміщень земної поверхні для оцінки динаміки розвитку зсувів у межах зсувонебезпечних територій, у поєднанні з даними літолого-стратиграфічних, геоморфологічних і структурно-тектонічних досліджень дає надійні результати, необхідні для прогнозування розвитку цих процесів і зменшення їхнього негативного впливу на природно-техногенні системи [5]. Аналіз за останні десятиріччя показав, що температура вийшла на основну позицію за впливом на режим грунтових вод, що пояснює прояви порушень циклічності в режимі грунтових вод, які можуть відбуватися під впливом потепління клімату; вплив антропогенних чинників на підвищення температури, що $є$ важливим під час пошуків закономірних періодичностей у змінах показників гідрогеологічного режиму і балансу на теренах інших водозбірних басейнів [6]. Запропоновано використання методу інверсії хвильових форм для визначення механізмів вогнищ для подій, які відбуваються в регіонах із малою сейсмічністю, за даними обмеженої кількості сейсмічних станцій. Отриманий результат може бути використаний для вивчення, дослідження й індентифікації відносно слабких 
сейсмічних подій на основі даних малої кількості станцій [7]. Аналіз часових рядів абсолютних річних мінімумів стоку води для всієї сукупності річок у межах басейнів та суббасейнів України показав наявність періодичності, що являє собою послідовну зміну в часі досліджуваної стокової характеристики з відносно великими та малими їхніми значеннями, зокрема, у сучасний період спостерігається спадна тенденція [8]. Для оцінювання потенційної небезпеки від сейсмічних коливань грунту під час землетрусів необхідно використовувати максимальну кількість розрахункових параметрів, якими характеризують сейсмічну небезпеку конкретних ділянок та які застосовують для визначення сейсмостійкості будинків і споруд: розрахунковими акселерограмами, сейсмограмами та велосиграмами [9]. Показано, що за результатами дослідження на 34 метеостанціях України за період 1991-2020рр. екологічний стан довкілля, кліматичні умови з вираженою сезонністю та мінливістю, аномальна літня спека та регіональні прояви змін клімату мають певний негативний вплив на добробут, здоров'я та комфортність життя населення країни [10]. У [11] модель тимчасового ряду застосовано для виявлення статистичного зв'язку між частотою і глибиною виникнення землетрусів, а також статистичної залежності цих даних від гравіметричних варіацій, для визначення закономірностей у зміні рівнів ряду і побудови його моделі з метою прогнозування та дослідження взаємозв'язків між геофізичними явищами. У сучасних дослідженнях динамічну поведінку середовища, що розташоване в сейсмогенеруючій зоні на межі тектонічних плит, розглядають як поведінку складної відкритої системи, що перебуває у стані самоорганізованої критичності. Це зумовлено самими закономірностями генерації землетрусів та складною будовою цієї зони, а мережа розломів і тріщин зумовила суттєву неоднорідність і фрагментованість зони [12]. Важливими характеристиками сейсмічного процесу в Закарпатті є енергетичні параметри місцевих землетрусів - магнітуда, інтенсивність, енергетичний клас, які покладено в основу сейсмічного районування. Використовувані методики, за допомогою яких визначають енергетичні параметри місцевих землетрусів, не повною мірою враховують впливи глибин гіпоцентрів і регіональні особливості шляхів поширення сейсмічних хвиль [13]. Відомо, що грунтові масиви можуть підсилювати або послаблювати сейсмічні хвилі, генеровані землетрусами. Актуальне завдання дослідження впливу грунтових товщ на проходження сейсмічних хвиль важливе 3 позиції експлуатації споруд та проєктування нових сейсмостійких об'єктів [14]. Проведено вивчення густинної неоднорідності земної кори України і суміжних регіонів на основі детальних тривимірних гравітаційних моделей земної кори різного масштабу таких тектонічних регіонів і окремих структур, які побудовано з використанням комплексу геологічних, петрофізичних $\mathrm{i}$ сейсмічних даних уздовж геотраверсів, профілів ГС3, сучасних сейсмічних досліджень методами WARR і розраховано із застосуванням комплексу автоматизованої інтерпретації потенціальних полів GMT-Auto, у результаті отримано нові відомості стосовно розподілу густини в земній корі [15]. Завдяки численним дослідженням методами електромагнітного моніторингу землетрусів отримані деякі важливі результати, з'явилося багато нової інформації про можливі електромагнітні провісники землетрусів [16]. Показано, що магнітні та радонові аномальні поля є суттєвими геофізичними чинниками довкілля, які великою мірою визначають його екологічний стан. Найбільш небезпечні ділянки, у межах яких локалізовані розломи, з якими у верхній частині розрізу земної кори пов'язані аномалії радону [17]. Зменшення сонячної активності супроводжується зменшенням кількості магнітних бур на Землі, а в роки великої сонячної активності збільшуються негативні варіації від зовнішніх джерел поля, зазначено, що вікові варіації визначають як різницю між середньорічними значеннями поля, вплив зовнішніх джерел поля підвищується зі зростанням сонячної активності [18]. Моніторинг геофізичних процесів у Закарпатському внутрішньому прогині довів зв'язок гідрогеологічного та сейсмотектонічного станів - зміни параметрів гідрологічного стану супроводжувалися інтенсивними варіаціями параметрів геодинамічного стану [19]. Аналіз результатів геофізичних досліджень у сейсмогенеруючому регіоні, яким є Закарпаття, приводить до важливих висновків, що підтверджують гідрогеологічний аспект аномальних варіацій геодинамічного та сейсмічного станів [20]. На території Карпатського геодинамічного полігону впродовж багатьох років проводяться геофізичні спостереження, а саме: метеорологічні, гідрогеологічні й аерофізичні спостереження. За результатами аналізу часових рядів спостережень зазначено зв'язок варіацій метеорологічних параметрів, сучасних горизонтальних рухів кори та проявів місцевої сейсмічної активності [21].

Виділення не вирішених раніше частин загальної проблеми, яким присвячусться стаття. Під час вивчення екологічного стану Закарпатського внутрішнього прогину важливе дослідження геомеханічних процесів, що можуть супроводжуватися проявом вивільнення енергії пружно-деформованого стану порід. Численні дослідження впливу чинників завад на перебіг сейсмотектонічних процесів, зв'язку геофізичних полів у період сейсмічної активізації відмітили важливість результатів вимірювання сучасних горизонтальних рухів кори в регіоні. Відомості про характер рухів верхніх шарів земної кори отримують за допомогою нахиломірів, деформометрів, для яких необхідні спеціальні умови - місце, метеорологічні параметри. Встановлення таких приладів передбачає наявність спеціальних підземних приміщень і унікального обладнання. Тому необхідно 
Ігнатишин В.В., Малицький Д.В., Іжак Т.Й. ...

мати джерело інформації про геодинамічний стан регіону, яке є більш доступним. Такими параметрами можуть стати характеристики гідрогеологічного стану регіону.

Новизна. У даному дослідженні під час вирішення поставлених завдань, а саме вивчення зв'язку гідрогеологічних параметрів із параметрами геодинамічного та сейсмічного станів, було використано варіації рівнів грунтових вод у свердловинах різних глибин. Аналізували кореляцію кривих рівнів води у свердловині та просторово-часовий розподіл місцевої сейсмічності, зазначено високий ступінь їх кореляції. Пропонується використання вимірювання рівня води у свердловинах у висвітленні питання характеру горизонтальних рухів кори.

Методологічне, або загальнонаукове, значення. Представлене дослідження має велике методоло-

\section{ГІДРОГЕОАОГІЧНИЙ АСПЕКТ ЕКОАОГІЧНОГО...}

гічне значення, оскільки відкриває нові можливості для розширення спектра геофізичних досліджень у сейсмонебезпечних регіонах. Щодо загальнонаукового значення проведених досліджень та їхніх результатів, необхідно відмітити важливість виявлених особливостей, а саме високого ступеня кореляції варіацій параметрів гідрогеологічного стану та параметрів динаміки сучасних горизонтальних рухів кори. Банк даних геодинамічного стану регіону можна збільшити завдяки використанню нових методів дослідження.

Виклад основного матеріалу. На території режимної геофізичної станції «Тросник» $є$ свердловина глибиною 530 м. Тривалий період за допомогою цієї свердловини проводилися вимірювання акустичної емісії, температури води на глибині 530 м, теплового потоку та гамма-випромінювання.

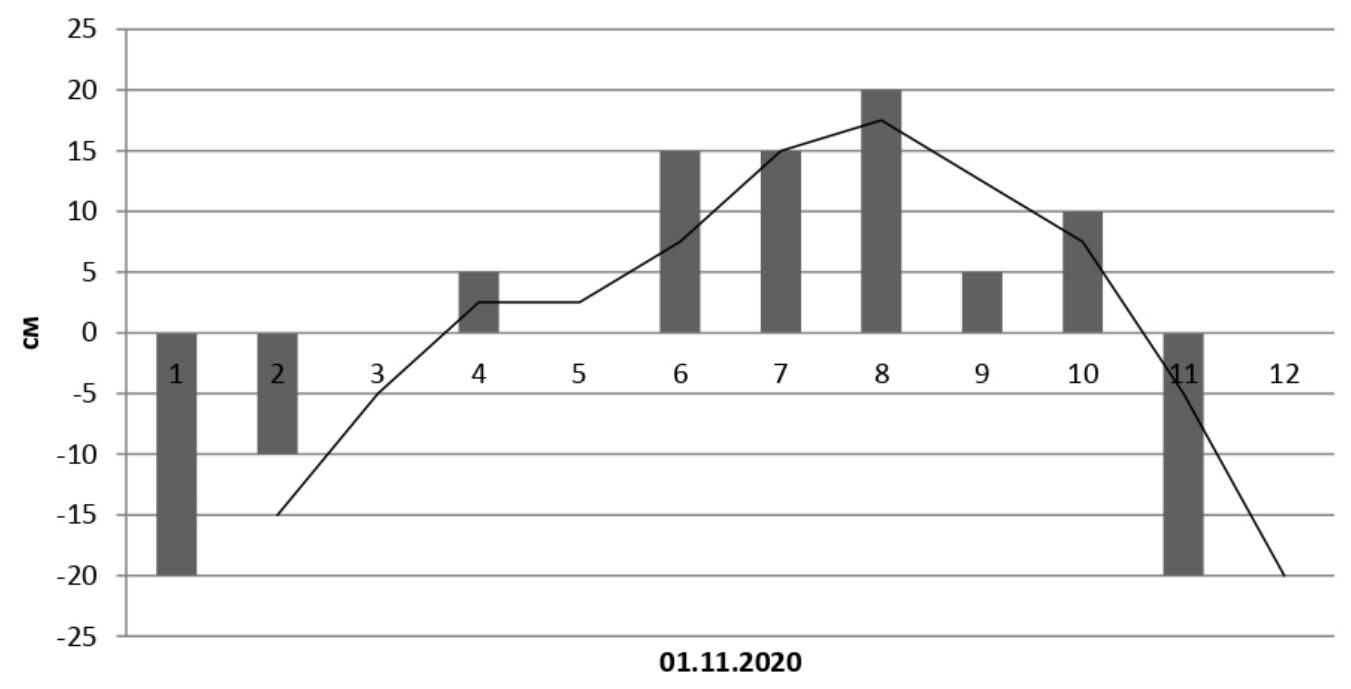

Рис. 1. Варіації рівня води у свердловині глибиною 530 м на РГС «Тросник» (середньомісячні величини)

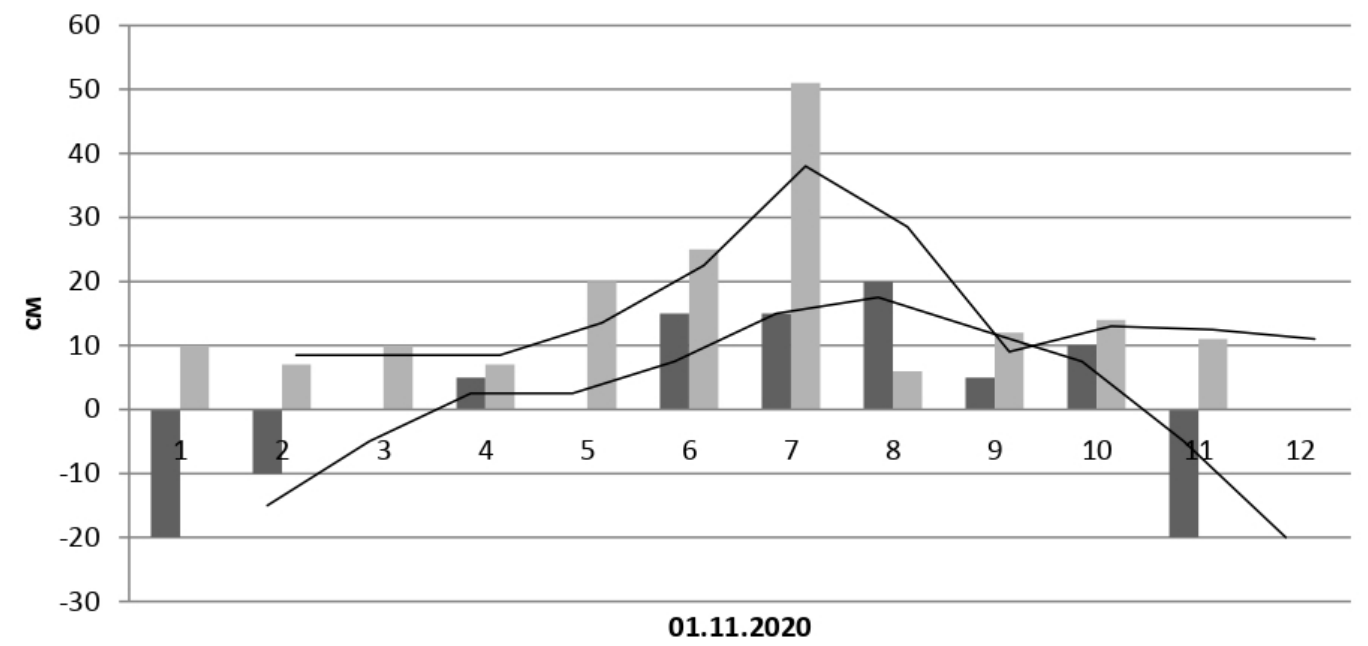

Рис. 2. Варіації рівня води у свердловині (діаграма сірого кольору) та місиева сейсмічність (діаграма чорного кольору) у 2020 р. Закарпатський внутрішній прогин 
Результати дослідження відмічали кореляцію сучасних горизонтальних рухів кори, а саме їх вікового ходу, з рівнем води у свердловині глибиною 530 м: стиснення порід викликало підняття рівня води у глибокій свердловині. Результати вимірювань рівня води у свердловині показують характер рухів кори. Рухи кори пов'язані із сейсмічністю регіону, тому важливо вивчати зміну рівня води у свердловинах для дослідження сейсмотектонічних процесів у Закарпатському внутрішньому прогині. Проведено дослідження зв'язку рівня води у свердловині та сейсмічності у 2020 р., порівняно з рухами кори й іншими геофізичними полями. На відміну від свердловини глибиною 8 м, у свердловині глибиною 530 м рівень води змінюється інтенсивніше. Землетруси реєструються в періоди мінімумів рівнів води у свердловині глибиною 530 м. У лютому 2020 р. рівень води у свердловині характерний коливаннями, відмічено 4 максимуми. У лютому на території Закарпаття зареєстровано 7 місцевих землетрусів у періоди як підняття рівня води у свердловині, так і зниження рівня води у свердловині, що відповідає розширенню та стисненню порід. Сейсмогенеруючі інтервали часу корелюються 3 періодами знакозмінних процесів рівня води у свердловині. Серії землетрусів у регіоні відбуваються в період стиснення порід, що викликає підвищення рівня води у свердловині на режимній геофізичній станції «Тросник». Представлено зміну рівня води у свердловині глибиною 530 м (рисунок 1).

Рівень води у свердловині зростає до серпня місяця (включно), далі спостерігається зниження рівня води. Представлено зв'язок зміни рівня води у свердловині та сейсмічну активність регіону (рисунок 2).

Проведено вивчення впливу динаміки рівня води у свердловині глибиною 530 м та місячних величин горизонтальних рухів земної кори в зоні Оашського глибинного розлому за 2020 р. Дослідження рухів кори в центральній частині Закарпатського внутрішнього прогину (у штольні пункту деформографічних спостережень «Королеве») за 2020 р. показало незначне стиснення порід, яке можна порівняти з нульовим віковим ходом деформацій земної кори, подібно до 2014 р. Отже, фактичний зв'язок рівня води у свердловинах та в річках регіону важливий для розуміння впливу динаміки гідрогеологічного стану регіону на сейсмотектонічні процеси на сейсмонебезпечних територіях країни. Представлено варіації рівня води у свердловині № 831 (глибина - 530 м, РГС «Тросник») у місячному діапазоні (рисунок 3). Порівняно з рухами кори в зоні Оашського глибинного розлому, розраховано місячні величини зміщень земної кори за сучасних горизонтальних рухів кори.

Якщо вважати основними геофізичними процесами геомеханічні, то представлені залежності повинні були корелюватися: стиснення порід мало спричиняти підняття рівня води у свердловині. Спостерігається кореляція рухів кори та зміни рівня води у свердловині: стиснення порід супроводжується динамічним зниженням рівня води у свердловині, за винятком червня та жовтня 2020 р. Також зауважимо, що глибока свердловина реагує на вікові рухи кори в зоні Оашського глибинного розлому. Показано зв'язок просторово-часового розподілу місцевої сейсмічності в Закарпатському внутрішньому прогині з варіаціями рівня води у свердловині та місячними рухами кори, виміряними на ПДС «Королеве» за досліджуваний період (рисунок 4).

У результаті проведеного аналізу представлених вище залежностей варто зазначити зв'язок досліджуваних геофізичних полів. Корелюють гідрогеологічний стан регіону та місцева сейсмічність: підняття рівня води у свердловині, яке супроводжується сейсмічною активізацією регіону, імовірно, спричинене стисненням верхніх шарів земної кори за сучасних горизонтальних рухів земної кори. Отже, у результаті проведеного аналізу варіацій рівня води у свердловині важливо зазначити, що досліджувані параметри реагують на вікові рухи кори, виміряні на деформометричній станції, змонтованій у штольні смт Королеве (Берегівський район Закарпатської області). Аналіз результатів гідрогеологічного стану

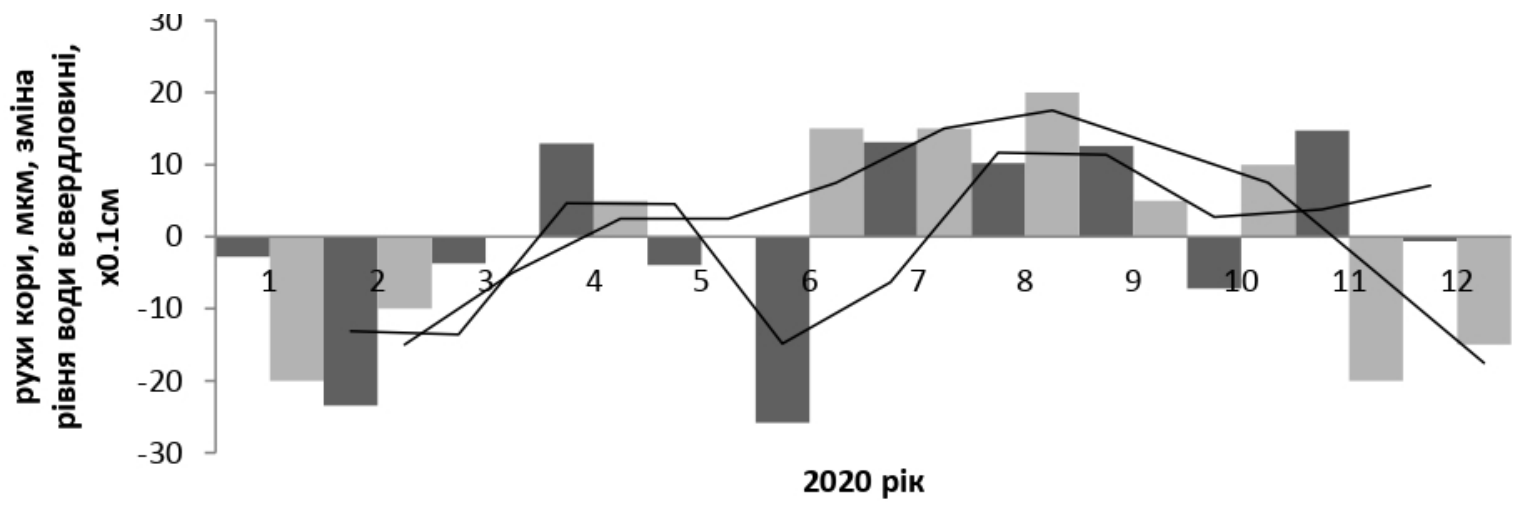

Рис. 3. Варіації рівня води у свердловині № 831 на РГС «Тросник» (діаграма сірого кольору), сучасні рухи кори в зоні Оашського глибинного розлому (діаграма чорного кольору). 2020 р. 
Ігнатишин В.В., Малицький Д.В., Іжак Т.Й. ...

в регіоні та сейсмічності у 2020 р.: відмічено кореляцію кривих варіацій спостережуваних параметрів. Зростання рівня води супроводжується інтенсифікацією місцевої сейсмічної активності. Стиснення порід у регіоні супроводжується підняттям рівня води у свердловині глибиною 530 м, розрядкою геомеханічної енергії. Представлено залежності досліджуваних параметрів за 2020 р. (рисунок 5).

Річний хід рівня води у свердловині становить +3 см. За 1-12.2020 р. зареєстровано на території Закарпатського внутрішнього прогину 188 місцевих землетрусів (рисунок 6). Підняття води у свердловині свідчить про річне стиснення порід у зоні Оашського глибинного розлому.

Частота землетрусів припадає на періоди, коли рівень води піднімається. Важливий геодинамічний аспект гідрогеологічних процесів у регіоні, для цього представлено динаміку сучасних горизонтальних рухів кори, виміряну на ПДС «Королеве» за 2020 р. (рисунок 7).

\section{ГІДРОГЕОАОГІЧНИЙ АСПЕКТ ЕКОАОГІЧНОГО...}

Віковий хід рухів кори за 2020 р. - стиснення порід незначної величини. Сейсмічність регіону припадає на періоди стиснення порід, що деякою мірою супроводжується підняттям рівня води у свердловині.

Головні висновки. За 2020 р. на території Закарпатського внутрішнього прогину зареєстровано 188 місцевих землетрусів. 23 січня 2020 р. на Виноградівщині в околицях смт Вилок зареєстровано відчутний місцевий землетрус ( $\mathrm{I}=4,5$ бали за шкалою MSK-64). Сейсмічна активність як результат геомеханічних процесів представлена періодами, які супроводжують інтервали часу, за яких рівень води підвищений, тобто як результат стиснення порід. Стиснення порід у регіоні супроводжується підняттям рівня води у свердловині глибиною 530 м, розрядкою геомеханічної енергії. Аналіз результатів гідрогеологічного стану в регіоні та сейсмічності у 2020 р.: наявна кореляція кривих варіацій спостережуваних параметрів. Зростання рівня води

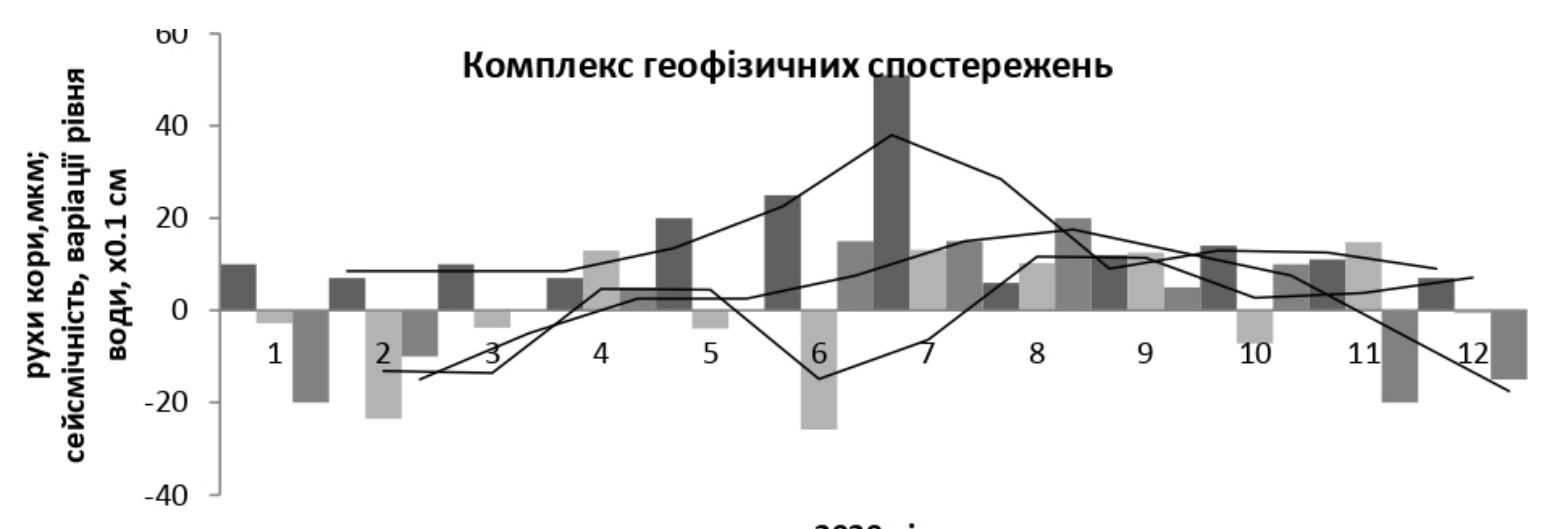

2020 рік

Рис. 4. Комплекс геофізичних спостережень: сейсмічний стан (діаграма чорного кольору), геодинаміка регіону (діаграма світло-сірого кольору), гідрогеологічний стан регіону (діаграма сірого кольору). 2020 р. Закарпатський внутрішній прогин

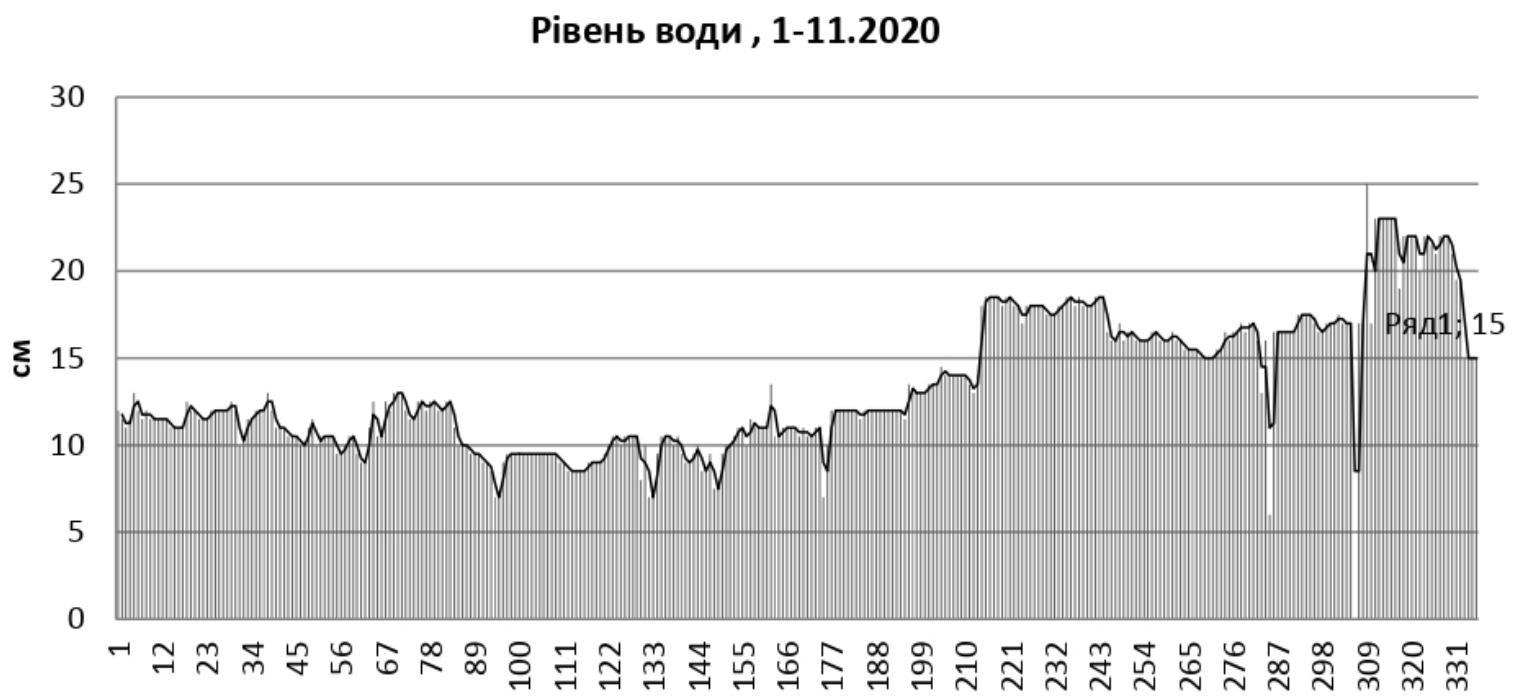

Рис. 5. Варіації рівня води у свердловині глибиною 530 м. РГС «Тросник» 


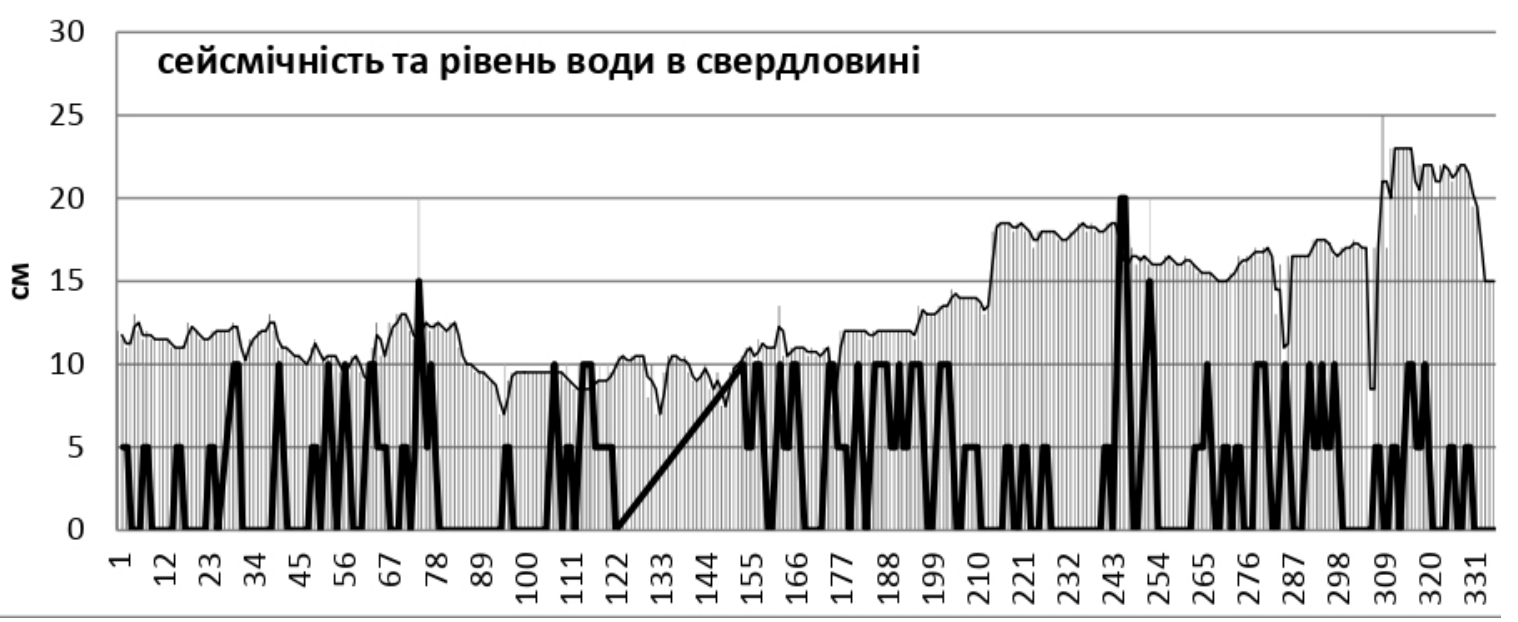

Рис. 6. Сейсмічність регіону (діаграма сірого кольору) та варіації земної кори (діаграма чорного кольору) у 2020 р. Закарпатський внутрішній прогин

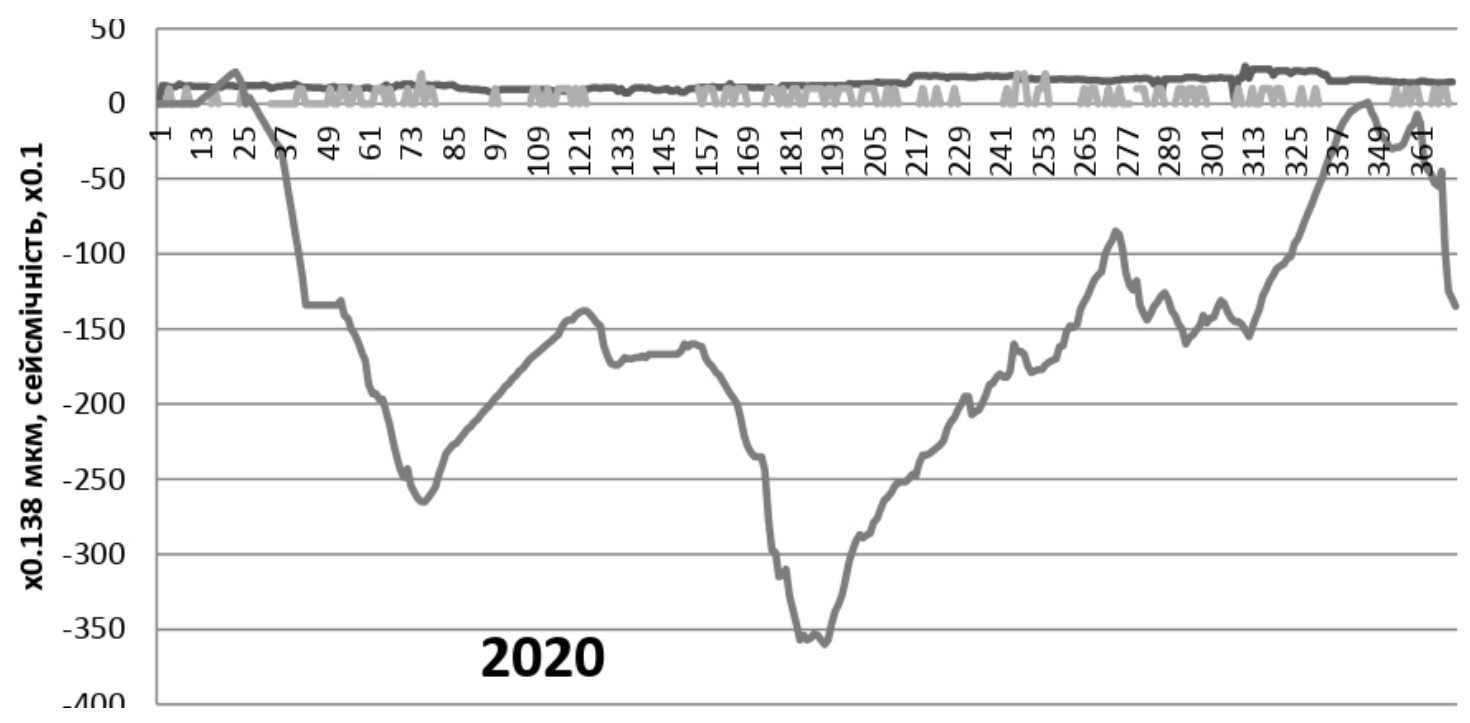

Рис. 7. Рухи кори в зоні Оашського глибинного розлому (крива сірого кольору); сейсмічність регіону (діаграма світло-сірого кольору); варіації рівня води у свердловині № 831 (глибина -530 м) на РГС «Тросник». 2020 p.

супроводжується інтенсифікацією місцевої сейсмічної активності. Відмічено кореляцію вікових ходів сучасних горизонтальних рухів кори в зоні Оашського глибинного розлому та варіацій рівня води у свердловині глибиною 530 м, на відміну від варіацій рівня води в неглибокій свердловині глибиною 8 м на території режимної геофізичної станції «Тросник» відділу сейсмічності Карпатського регіону Інституту геофізики ім. C.I. Субботіна НАН України, яка реагує на інші типи рухів кори, зокрема й сезонні. Актуальність проведення систематичних спостережень рівня води в цих свердловинах пов'язана $з$ тим фактом, що варіації рівня води у свердловинах корелюються із сучасними горизонтальними рухами кори, зокрема в зоні Оашського глибинного розлому.

Отже, проведенням спостереження рівня води у свердловинах можна отримати відомості про характер сучасних горизонтальних рухів кори, особливо в тих місцях, де деформометричні спостереження вкрай важливі, але немає можливості проводити такі спостереження через низку причин, як-от унікальність деформометричних спостережень, пов'язаних із вибором місця спостереження, умов їх проведення. Порівняно 3 можливостями проведення вимірювання сучасних рухів кори за допомогою кварцових деформометрів, для встановлення яких необхідні особливі умови - штольні, глибини їх пролягання, стабільність внутрішньої температури приміщення, доступність та забезпечення сучасними приладами, методи вивчення рухів кори, пов’язаних із свердловинами, є більш перспективними та доступними. У краї в наявності багато свердловин різної глибини, які залишилися після пошукових гідрогеологічних робіт та які можна використати для моніторингу рівня води. 
Ігнатишин В.В., Малицький Д.В., Іжак Т.Й. ...

Перспективи використання результатів дослідження. Важливі продовження проведення гідрогеологічних та геодинамічних спостережень у Закарпатському внутрішньому прогині та розширення точок спостережень. Отримані результати дослідження зв’язків параметрів гідрогеологічного стану з характеристиками сучасних горизонтальних рухів кори можуть бути використані в дослідженні динаміки сейсмотектонічних процесів у сейсмо-

\section{ГІДРОГЕОАОГІЧНИЙ АСПЕКТ ЕКОАОГІЧНОГО...}

небезпечних регіонах України. Вони спрощують методики вивчення рухів кори через використання низкигідрогеологічних параметрів та висновків, отриманих на основі цих досліджень. Оскільки на території Закарпаття не досить пунктів деформометричних спостережень, залучення до геофізичного моніторингу вимірювання гідрологічних параметрів у свердловинах поповнить банк даних, необхідних для вирішення проблем екологічного стану регіону.

\section{Література}

1. Обгрунтування доцільності застосування геоінформаційних систем у ландшафтно-екологічному моніторингу / В. Зацерковний та ін. Вісник Київського наџіонального університету імені Тараса Шевченка. Серія «Геологія». 2020. № 1 (88). C. 98-105. DOI: 10.17721/1728-2713.88.14.

2. Чомко Д., Чомко Ф., Черкашина Н. Штучні гідрогеологічні вікна як забруднення Бучацько - Канківського водоносного горизонту на північному сході України. Вісник Київського начіонального університету імені Тараса Шевченка. Серія «Геологія». 2020. № 2 (89). С. 110-114.

3. Регресійний аналіз сейсмічних і геофізичних параметрів та його застосування для дослідження сейсмічності Закарпатського регіону / М. Хом'як та ін. Вісник Київського національного університету імені Тараса Шевченка. Серія «Геологія». 2020. № 3 (90). С. 49-53.

4. Стародуб Ю., Гаврись А., Козіонова О. Моделювання впливу еколого-геофізичного стану грунтів на інженерні мостобудівні об'єкти. Вісник Киїського національного університету імені Тараса Шевченка. Серія «Геологія». 2020. № 3 (90). C. 97-103.

5. Углицьких Є., Вижва С., Іванік О. Моніторинг вертикальних зміщень земної поверхні території Закарпаття за даними радарної інтерферометрії. Вісник Київського начіонального університету імені Тараса Шевченка. Серія «Геологія». 2020. № 4 (91). С. 94-99.

6. Мінливі ритми в режимі грунтових вод та їхній зв'язок із кліматичними чинниками / О. Шевченко та ін. Вісник Київського національного університету імені Тараса Шевченка. Серія «Геологія». 2021. № 2 (93). С. 71-81.

7. Малицький Д., Нікулін В. Механізм вогнища Литовського землетрусу на основі інверсії хвильових форм. Вісник Київського національного університету імені Тараса Шевченка. Серія «Геологія». 2021. № 2 (93). С. 46-52.

8. Багаторічна мінливість абсолютних річних мінімумів стоку води річок України / О. Ободовський та ін. Вісник Київського національного університету імені Тараса Шевченка. Серія «Геологія». 2019. № 4 (87). C. 89-95. DOI: 10.17721/1728-2713.87.13.

9. Кендзера О., Семенова Ю. Сейсмічна реакція різних за будовою ділянок території Києва на сейсмічні навантаження. Геофізичний журнал. 2021. № 43 (5). С. 150-164. DOI: 10.24028/gzh.v43i5.244077.

10. Бойченко С., Забарна О., Кучма Т. Комфортні кліматичні умови на території України за період 1991-2020 рр. Геофізичний журнал. 2021. № 43 (4). С. 91-104. DOI: 10.24028/gzh.v43i4.239961.

11. Аналіз часових рядів на прикладі реєстрації варіацій гравітаційного поля / Р. Буртієв та ін. Геофізичний журнал. 2021. № 43 (4). C. 76-90. DOI: 10.24028/gzh.v43i4.239960.

12. Микуляк С., Куліч В., Скуратівський С. Про подібність зсувного деформування гранульованого масиву та фрагментованого середовища в сейсмоактивній зоні. Геофізичний журнал. 2021. № 43 (3). С. 161-169. DOI: 10.24028/gzh.v43i3.236386.

13. Визначення енергетичних параметрів сейсмічних подій Закарпатського прогину з урахуванням добротності земної кори / Ю. Андрущенко та ін. Геофізичний журнал. 2021. № 43 (2). C. 218-226. DOI: 10.24028/gzh.v43i2.230201.

14. Сейсмічна реакція шаруватої грунтової товщі з включеннями / О. Кендзера та ін. Геофізичний журнал. 2021. № 43 (2). C. 3-13. DOI: 10.24028/gzh.v43i2.230186.

15. Макаренко I. Густинна неоднорідність земної кори України і суміжних регіонів за даними тривимірного гравітаційного моделювання. Геофізичний журнал. 2021. № 43 (2). C. 45-95. DOI: https://doi.org/10.24028/gzh.v43i2.230190.

16. Пірісв Р. Ефективність електромагнітного моніторингу при вивченні землетрусів. Геофізичний журнал. 2021. № 43 (2). C. 166-177. DOI: 10.24028/gzh.v43i2.230195.

17. Магнітні та радонові аномалії на території міста Києва: екологічний аспект / М. Орлюк та ін. Геофізичний журнал. 2021. № 43 (1). C. 227-250. DOI: 10.24028/gzh.0203-3100.v43i1.2021.225551.

18. Sumaruk T., Sumaruk Р. Відображення хейлівських циклів сонячної активності у вікових варіаціях геомагнітного поля. Геофізичний журнал. 2020. № 42 (5). C. 183-192. DOI: 10.24028/gzh.0203-3100.v42i5.2020.215081.

19. Зв'язок гідрогеологічного та сейсмотектонічного станів у Закарпатському внутрішньому прогині / В. Ігнатишин та ін. Інноваційні пріоритети в розвитку науки : збірник наукових матеріалів XXVII Міжнародної науково-практичної інтернет-конференції, 18 лютого 2019 р., м. Вінниця. Ч. 1. 76 с. С. 61-67.

20. Ігнатишин В. Дослідження гідрогеологічного аспекту сейсмотектонічних процесів в Закарпатському внутрішньому прогині. Географія в Київському начіональному університеті імені Тараса Шевченка: 85 років - досягнення та перспективи $(G T S N U)$ : матеріали Міжнародної науково-практичної конференції, присвяченої 85-річчю географічного факультету Київського національному університеті імені Тараса Шевченка, м. Київ, 30-31 березня 2018 р. / гол. редкол. Я. Олійник ; КНУ імені Тараса Шевченка. Київ : Прінт-Сервіс, 2018. С. 265-269.

21. Метеорологічні аспекти геодинамічного стану Закарпатського внутрішнього прогину / В. Ігнатишин та ін. Науковий вicник Херсонського державного університету. Серія «Географічні науки». № 10. С. 137-145. DOI: 10.32999/KSU2413-7391. 


\title{
ЕКОАОГО-ТОКСИКОАОГІЧНА ОЦІНКА ПРИРОДНИХ ВОДОЙМ ЗА ДІЇ КСЕНОБІОТИКІВ
}

\author{
Курбатова I.М., Захаренко М.О., Тупицька О.М. \\ Національний університет біоресурсів і природокористування України \\ вул. Героїв Оборони, 15, 03041, м. Київ \\ innakurbatova@ukr.net
}

\begin{abstract}
Узагальнено критерії оцінки екологічного стану водойм, що базуються на дослідженні структури водних екосистем, показників біорізноманіття, функціональних особливостей представників фіто- та зоопланктону, біопродуктивності об'єктів аквакультури, морфометричних ознак, морфологічних показників у безхребетних і риб, окремих компонентів пластичного обміну у тканинах. Основними показниками іхтіофауни, що рекомендовано використовувати як біоіндикатори якості води і стану гідроекосистем, є наявність хромосомних мутацій, зміна кількості та форми хромосом, міксоплоїдія, лінійно-вагові показники, співвідношення статей, плодючість, асиметрія, видове, трофічне та таксономічне розмаїття. Найбільш доцільними виявились дослідження структури ДНК, яка може змінюватись у відповідь на дію полютантів. Більш доступним способом біоіндикації якості води $є$ популяційний рівень, який включає контроль за лінійним розмаїттям особин, співвідношенням статей у популяції, наявністю особин із морфологічними відхиленнями й абсолютною плодючістю риб. Для біоіндикації водних об’єктів 3 використанням іхтіофауни розроблено спеціальні схеми, які включають морфологічні, генетичні, популяційні та біоценотичні характеристики риб. Біотестування якості води з використанням водоростей базується на дослідженні впливу токсикантів на кількість клітин, їхню морфологію, ультраструктуру та процеси фіксації азоту. Гідроекологічну оцінку стану водних екосистем рекомендують проводити за фізичними показниками та хімічним складом води, а також її біологічною складовою частиною. Як критерії екологічного стану водойм рекомендують використовувати склад і розповсюдження представників зообентосу, стан якого контролюють за чисельністю і біомасою окремих видів, видовим розмаїттям, наявністю рідкісних і зникаючих видів.

Рекомендовані основні показники іхтіофауни для використання як біоіндикаторів якості води і стану гідро екосистем та ряд біологічних маркерів, які характеризують біохімічні процеси в організмі як біотести екологічного стану водойм. Ключові слова: екологічний стан, водойми, ксенобіотики, токсикологічна оцінка, біотестування, біоіндикація, маркери.
\end{abstract}

Ecological and toxicological assessment of natural waters under the action of xenobiotics. Kurbatova I., Zakharenko M., Tupytska O.

The criteria for assessing the ecological status of water bodies based on the study of the structure of aquatic ecosystems, biodiversity indicators, functional features of phyto- and zooplankton, bioproductivity of aquaculture objects, morphometric features, morphological indicators in invertebrates and fish, individual tissue components are summarized. The main indicators of ichthyofauna recommended for use as bioindicators of water quality and hydroecosystems are the presence of chromosomal mutations, changes in the number and shape of chromosomes, myxoploidy, linear weights, sex ratios, fertility, asymmetry, species, trophic and taxonomic diversity. The most appropriate were studies of the structure of DNA, which can change in response to the action of pollutantsA more accessible method of bioindication of water quality is the population level, which includes control over the linear diversity of individuals, the sex ratio in the population, the presence of individuals with morphological abnormalities and the absolute fertility of fish. Special schemes have been developed for the bioindication of water bodies using ichthyofauna, which include morphological, genetic, population and biocoenotic characteristics of fish. Bioassay of water quality using algae is based on the study of the effect of toxicants on the number of cells, their morphology, ultrastructure and nitrogen fixation processes. Hydroecological assessment of aquatic ecosystems is recommended for physical indicators and chemical composition of water, as well as its biological component. As criteria for the ecological status of water bodies, it is recommended to use the composition and distribution of zoobenthos, the condition of which is controlled by the number and biomass of individual species, species diversity, the presence of rare and endangered species.

The main indicators of ichthyofauna are recommended for use as bioindicators of water quality and the state of hydro ecosystems and a number of biological markers that characterize biochemical processes in the body as bioassays of the ecological state of water bodies. Key words: ecological condition, reservoirs, xenobiotics, toxicological assessment, biotesting, bioindication, markers.

Постановка проблеми. Структура водних екосистем, окрім природних чинників, залежить від значної кількості зовнішніх факторів, які впливають на стан популяцій, міжвидові зв'язки, склад і властивості водного середовища, фізіолого-біохімічні процеси в гідробіонтів, видовий склад і чисельність іхтіофауни $[5 ; 6 ; 9 ; 21 ; 26]$.

Однак, незважаючи на низку природоохоронних заходів, антропогенний тиск на водні екосистеми посилюється внаслідок збільшення скиду у природні та штучні водойми значних обсягів техноло- гічних стічних вод промислових підприємств і енергетичних об’єктів, а останнім часом також і великих комплексів із виробництва продукції тваринництва, переробних підприємств харчової промисловості, об'єктів ветеринарної медицини $[2 ; 3 ; 6 ; 8]$.

Відходи цих підприємств містять значну кількість забруднювачів води і здатні порушувати функціонування природних екосистем не тільки в зоні їхньої виробничої діяльності [2], але й поза ііі межами, коли потрапляють зі стічними водами у грунти, підземні та поверхневі води [21-23]. 


\section{Курбатова I.М., Захаренко М.О., Тупицька О.М.}

Погіршення гідрологічного режиму водних об'єктів, порушення видового складу компонентів, зміна структурно-функціональної організації водних екосистем під впливом гідромеліоративних робіт, атмосферних опадів, радіонуклідів, пестицидів, комунально-побутових стоків, рідких відходів підприємств і тваринницьких об'єктів, органічних і мінеральних добрив, засобів захисту рослин, діатомових водоростей, гельмінтів, дрейсени, адвентизації іхтіофауни, ксенобіотиків впливає на ембріональний розвиток та виживаність личинок, морфологічні показники крові, пластичний обмін у тканинах риб, що робить необхідним виявлення низки нових критеріїв біотестування водойм рибогосподарського призначення.

Матеріали та методи. Аналіз літературних джерел свідчить про існування значної кількості критеріїв оцінки екологічного стану водойм, заснованих на дослідженнях стану популяцій фіто- і зооценозів, морфометричних ознак, морфологічних показників у безхребетних і риб, окремих компонентів пластичного обміну у тканинах. Що ж стосується оцінки екологічного стану водойм у зоні діяльності тваринницьких підприємств, то вона потребує подальших пошуків ефективних критеріїв, заснованих на дослідженнях стану іхтіоценозів.

Обговорення. Антропогенний вплив на водні екосистеми протягом тривалого часу змінив їхній екологічний стан і значною мірою визначив подальшу еволюцію біологічних складників, особливо взаємодії гідробіонтів 3 абіотичним середовищем $[1 ; 16]$. Екологічний стан природних водойм оцінюють шляхом біоіндикації, яка грунтується на дослідженні структури водних екосистем, показників біорозмаїття, функціональних особливостей представників фіто- та зоопланктону, біопродуктивності об'єктів аквакультури $[1 ; 7 ; 14 ; 16]$. Зі збільшенням техногенного навантаження на природні водойми роль біоіндикації в оцінці їхнього екологічного стану зростає. Для оцінки якості води, окрім характеристики водяних безхребетних, водоростей i вищих водяних рослин, використовують популяційні та ценотичні характеристики іхтіофауни [1;9]. Для біоіндикації водних об'єктів із використанням іхтіофауни розроблено спеціальні схеми, які включають морфологічні, генетичні, популяційні та біоценотичні характеристики риб $[1 ; 5]$.

Із цією метою використовують загальноприйняту екологічну класифікацію поверхневих вод України [16]. Згідно $з$ даною класифікацією поверхневі води України поділено на п'ять класів і сім категорій, які враховують цілу низку фізичних показників, хімічний склад, трофічність, сапробність та санітарногігієнічну характеристику [16].

Навантаження на навколишнє середовище, яке зроста із року в рік, різними хімічними токсикантами, зокрема й антропогенного походження, передбачає використання сучасних методів контролю екологічного стану водойм, який передбачає врахування негативного впливу забруднювачів на організм тварин, людей i різних видів гідробіонтів, оскільки здебільшого вони володіють мутагенними й ембріотоксичними властивостями $[1 ; 5 ; 14]$. Негативний вплив токсикантів різного механізму дії на тварин може проявлятися не тільки шляхом зміни фізіологічних функцій організму [7; 16], але й безпосередньо на структурі клітин, окремих іiі компонентів [32], ланок або, загалом, на метаболізм клітини через зміну активності ензимів [25].

Основними ж показниками іхтіофауни, що рекомендовано використовувати як біоіндикатори якості води і стану гідроекосистем, $є$ наявність хромосомних мутацій, зміна кількості та форми хромосом, міксоплоїдія, лінійно-вагові показники, співвідношення статей, плодючість, асиметрія, видове, трофічне i таксономічне розмаїття та деякі інші [16; 32]. Наведені генетичні, морфологічні та ценотичні характеристики іхтіофауни здебільшого дають можливість правильно оцінити екологічний стан водного об'єкта, намітити перспективи його оздоровлення в разі виявлення суттєвих відхилень від норми. Так, зміна кількості і структури хромосом, соматичних клітин може відбуватися внаслідок негативного впливу різних ксенобіотиків водного середовища на іхтіофауну і неспроможності останньої елінімувати ці чинники за допомогою імунної системи [7].

Такі зміни на генетичному рівні в соматичних клітинах риб під дією токсикантів, які можуть бути інтегральним показником розвитку і гомеостазу, характеризують наявність мутагенних чинників водних середовищ і ефективність імунної системи риб [1]. Зміна кількості та структури хромосом впливає на генетичний апарат соматичних клітин, що веде до порушення метаболічних процесів у тканинах.

Зважаючи на генотоксичніть багатьох забруднювачів води, було рекомендовано використовувати низку біологічних маркерів, які характеризують біохімічні процеси в організмі, як біотести екологічного стану водойм [27]. Найбільш доцільними виявились дослідження структури ДНК, яка може змінюватись у відповідь на дію полютантів [27].

Зміна послідовності або руйнування (випадання) нуклеотидів у ланцюзі ДНК може бути одним iз важливих тестів негативного впливу токсикантів, зокрема води, на гідробіонтів. Найбільший інтерес щодо виявлення цього впливу на організм становлять показники, що характеризують ступінь пошкодження молекули ДНК, який установлюють за допомогою методу ДНК-комет [10; 27$].$

Останнім часом велике значення для оцінки якості води надають дослідженню наночастинок, виробництво яких із року в рік зростає значними темпами [33]. Показано вплив різних наночастинок на різні біологічні об'єкти, зокрема риб, земноводних i людей. Окрім того, проведеними дослідженнями встановлено, що додавання іонів або наночастинок міді у воду викликає деструктивні зміни молекули 
ДНК зябер і травної залози двостулкового молюска (Mytilus trossalus L.), що свідчить про негативний вплив наночастинок міді на гідробіонтів [10; 11].

Дослідженнями встановлено, що в молюсків, виловлених із морських прибережних акваторій, які зазнають постійного антропогенного навантаження, встановлені значні пошкодження молекули ДНК, тоді як у тварин із чистої зони вказані зміни не спостерігались [10]. Індекс генетичного пошкодження виявився найвищим у молюсків і гребінців iз забрудненої полютантами зони порівняно з аналогічним показником у тварин із чистої зони. На основі проведених досліджень був зроблений висновок про пошкодження ДНК клітин зябер молюсків, що вказує на виникнення патологічних змін у досліджуваному органі. Одержані дані підтверджують зроблений висновок про негативний вплив забруднювачів води на структуру молекул ДНК, що в кінцевому підсумку викликає появу мутацій і руйнування клітин [10].

Більш доступним способом біоіндикації якості води і стану гідроекосистем є популяційний рівень, який включає контроль за лінійним розмаїттям особин, співвідношенням статей у популяції, наявністю особин із морфологічними відхиленнями (асиметрія), абсолютною плодючістю риб [1]. Вплив ксенобіотиків різного механізму дії на вищевказані характеристики пов'язують із відхиленнями маси тіла та лінійних промірів риб різних вікових груп від стандарту, зміною співвідношення статей у популяції, кількості променів і пелюсток у зябрових дугах, грудних і черевних плавцях, кількості лусок у бічній лінії різних сторін тулуба. Окрім того, до уваги беруть кількість особин із вираженою асиметрією органів, показниками асиметрії відповідних вікових груп особин у популяції, а також кількість ікринок у яєчниках самок $[1 ; 12]$.

Біоіндикацію якості води і стану водних екосистем на ценотичному рівні рекомендують проводити за видовим і таксономічним розмаїттям, трофічним розмаїттям груп риб, різноманіттям риб із різним ступенем стено- і еврибіонтності, різноманітністю риб iз морфологічною асиметрією та деякими іншими характеристиками популяцій гідробіонтів [1; 14; 16]. Уважають, що вищенаведені показники будуть мати значення в риб різних популяцій за оптимальних для них характеристик якості води $[1 ; 16]$.

Для різних трофічних угруповань водних екосистем дуже чисті води, брудні і дуже брудні, які відносять до оліготрофних, олігосапробних, гіпертрофних і полісапробних, є небажаними, оскільки вони негативно впливають на ценотичні характеристики іхтіофауни $[16 ; 20 ; 28 ; 32]$. Максимальне трофічне розмаїття характерне зазвичай для водних екосистем за середніх показників якості води [14]. 3 погіршенням якості води внаслідок надходження у водойми ксенобіотків частка видів риб з асиметричними ознаками зростає, що свідчить про погіршення екологічного стану водних екосистем.
На основі вищевикладеного можна зробити висновок, що зі зростанням забрудненості, трофності та сапробності води співвідношення окремих угруповань риб буде змінюватись через зниження кількості особин стенобіотичних видів.

Гідроекологічну оцінку стану водних екосистем низка авторів рекомендують проводити за комплексною характеристикою, в основу якої покладено фізичні показники і хімічний склад води, а також i біологічну складову частину [16; 25], що значною мірою відповідає нормативним документам країн Європейського Союзу (далі - СС) [4]. Згідно з вимогами директиви СС пріоритетною в оцінці екологічного стану водних екосистем повинна залишатись біологічна складова частина, яка включає характеристику різних угруповань водного об'єкта. Як критерії екологічного стану водойм рекомендують використовувати склад і розповсюдження представників зообентосу [4], стан якого контролюють за чисельністю і біомасою окремих видів, видовим розмаїттям, наявністю рідкісних і таких, що зникають, видів відповідно до методичних рекомендацій. Окрім того, для оцінки якості води гідроекосистем рекомендовано використовувати індекс Вудівіса [25], який характеризує стан розмаїття водних угруповань індикаторних груп деякої макрофауни.

Використання сучасних методик оцінки екологічного стану природних водойм із різним рівнем антропогенного тиску показало їхню перспективність i ефективність [25]. За характеристиками показників макрофауни безхребетних, а саме: їхньою чисельністю, біомасою, видовим розмаїттям, індексом Вудівіса, запропоновано класифікацію екологічного стану водойм урбанізованих територій за допомогою спеціальної шкали. Автори рекомендують для більш точної характеристики екологічного стану природних водойм одержані результати порівнювати $з$ референтними характеристиками даного водного об'єкта до здійснення антропогенного тиску на гідроекосистему.

Характеристику референтних умов для різних видів водних об'єктів рекомендовано проводити за спеціальними таблицями, запропонованими River Quality Biologal Assesment (RQBA). Отже, за допомогою кількісних характеристик і показників біорозмаїття бентосних та фітофільних угруповань можна здійснити оцінку екологічного стану природних водойм та запропонувати ефективні методи їх відновлення за дії антропогенних чинників.

Метод біотестування широко використовується і для оцінки екологічного стану морських акваторій, особливо в зоні скиду великих об'ємів води річками, забрудненими промисловими та комунальними стічними водами. Найбільш чутливими до дії ксенобіотиків води є різні види ракоподібних [16]. Найменш стійкими до таких забруднювачів води, як важкі метали, нафтопродукти, феноли, є мізиди (Crustacea: 


\section{Курбатова I.М., Захаренко М.О., Тупицька О.М.}

Mysidacea), на відміну від веслоногих ракоподібних, личинок і молоді креветок, молоді риб [16].

Для виявлення характеру забруднень, їхньої інтенсивності та тривалості надходження у водні об'єкти низка авторів рекомендують використовувати мікробіологічні тести [30]. Із цією метою у воді контролюють чисельність сапрофітних гетеротрофних бактерій, бактерій групи кишкової палички, фенолрезистентних і вуглеводноокиснювальних бактерій. Причому найбільш ефективним тестом під час установлення забруднення води $є$ співвідношення кількості грампозитивних до грамнегативних бактерій. У чистих водоймах число грампозитивних бактерій значно переважає кількість грамнегативних. У разі антропогенного забруднення води число грамнегативних бактерій значно зростає [30]. У разі надходження у воду органічних забруднювачів у ній збільшується кількість паличкоподібних форм, а під час їх розпаду на завершальній стадії - коковидних форм бактерій [30]. Виявлено, що індикатором накопичення важкомінералізованих органічних сполук $\epsilon$ поява у воді фенолрезистентних бактерій. Видовий склад та чисельність мікроорганізмів $є$ складовою частиною чинних стандартів із класифікації й оцінки якості води водойм і водостоків за мікробіологічними показниками.

Антропогенний вплив на водні екосистеми пов'язують із дією ксенобіотиків органічного і неорганічного походження, які змінюють хімічний склад i гідробіологічний режим води, перебіг біологічних процесів у природних водоймах [14; 34]. Вищеперелічені критерії значною мірою визначають якість води та іï придатність до використання [23]. Гідробіонти, які використовують воду як середовище існування, впливають на динамічну рівновагу фізичних і хімічних чинників, а також біологічні процеси у водоймі. Екотоксикологічну оцінку природних водойм проводять декількома сучасними методами, заснованими на дослідженнях якості води та природних угруповань, зокрема й індикаторних організмів водойми [20]. Останніми роками для оцінки антропогенного навантаження на природні водойми запропоновано метод екотоксикологічної оцінки, який включає цілий комплекс досліджень [20; 24]. Із цією метою рекомендовано використовувати різні бактерії родів Pseudomonas, Escherichia, Aeromonas, Bacillus, Vibria, Coribacter тощо; водорості: Chlorella vulgaris, Selenastrum capricornutum, Ankistrodesmus falcatus, Scenedesmus acutus; безхребетні: Daphnia magna, Daphnia pulex, Ceriodaphnia affinis, C. reticulata; риб: Carassius auratus, Cyprinus carpio, Lepomis macrochirus, Oncorhinchus mykiss та інші [15; 25].

Токсичні властивості різних ксенобіотиків, що містять стічні води, установлюють за нітрифікаційною здатністю Nitrobacter, а також за інтенсивністю процесів люмінесценції Fotobacterium phosphoreum. Для виявлення мутагенних властивостей токсикантів стічних вод використовують біотест із Salmonella typhimurium i Esherichia coli.

\section{ЕКОАОГО-ТОКСИКО ОГІЧНА ОЦІНКА...}

Біотестування якості води 3 використанням водоростей базується на дослідженні впливу токсикантів на кількість клітин, їхню морфологію, ультраструктуру, процеси фіксації азоту [23]. Дослідження гострої та хронічної токсичності ксенобіотиків за допомогою безхребетних включає визначення $\mathrm{LC}_{50}$, а також цілої низки фізіологічних, морфологічних і генетико-цитологічних параметрів. У біотестуванні для встановлення механізмів негативного впливу токсикантів на живі організми використовують різні види іхтіофауни [35]. У гострому експерименті на рибах визначають летальну та напівлетальну дози токсиканта, а у хронічному - його вплив на фізіологічні функції, метаболічні процеси, морфологічні та генетичні параметри. Основними тестами $\epsilon$ дослідження лінійних промірів, маси тіла, зовнішніх ознак риб, стану зябер, кількості дихальних рухів, ударів серця, поведінки, гематологічних, морфологічних, гістологічних показників, активності ензимів, процесів росту, відтворення тощо [20]. Як основні об'єкти під час дослідження механізмів впливу токсикантів на іхтіоценози рекомендують використовувати прісноводних риб: Oncorhinchus mykiss, Carassius auratus, Cyprinus carpio, Labeo rohita macrochirus тощо [20; 24]. Основними показниками в риб, за якими оцінюють екологічний стан водних об'єктів, є морфологічні показники крові, поведінка, виживаність, ріст, розвиток, відтворення, а також зміни біохімічних показників крові, гепатопанкреаса і зябер [2; 35].

Окрім представників іхтіофауни, деякі дослідники рекомендують екологічну оцінку водойм у разі ïx забруднення ксенобіотиками антропогенного походження проводити за деякими представниками зообентосу і паразитами риб. На основі досліджень впливу токсикантів на риб були встановлені ГДК різних ксенобіотиків у водоймах, які використовуються в рибогосподарських цілях [17].

Біоіндикація, як спосіб оцінки якості води, передбачає також контроль стану цілої низки компонентів гідроекосистем. Вона включає дослідження стану мікрофлори, перифітона, фіто- і зоопланктона, макрофітів, зообентоса [20]. Вказані критерії покладені в основу експертної оцінки екологічного стану водних об'єктів, який включає видовий склад, чисельність, біорозмаїття, співвідношення видів різної екологічної валентності, характеристику їхньої сапробності та функціональні характеристики водних угруповань [20; 31].

Запропоновані такі стани водних екосистем: фоновий, антропогенно екологічно напружений i антропогенно екологічний регрес. Ці стани водних екосистем побудовані на історії екологічних модифікацій, основою якої є розмежування стану екосистем за інтенсивністю метаболізму. Відповідно до стану водних угруповань запропоновано такі градації якості води: чиста, слабо забруднена, помірно забруднена і забруднена [22]. 
Оцінка якості води за методом екотоксикологічної діагностики грунтується на використані біотестування як основного способу накопичення інформації про відносну токсичність ксенобіотиків, а також біоіндикації, що характеризує стан угруповань водних екосистем. Вказаний метод дає можливість виявити токсичну дію, механізми і вплив токсикантів на водні угруповання [13; 20].

Для екологічної оцінки гідроекосистем запропоновано низку цитологічних, фізіологічних, молекулярних показників, які характеризують стан популяції й угруповань $[15 ; 16 ; 31]$. Однак загальних критеріїв оцінки екологічного стану водних екосистем нині не існує, оскільки механізми впливу різних ксенобіотиків, зокрема важких металів, гербіцидів, радіонуклідів, органічних забруднювачів, стічних вод промислових, комунальних і тваринницьких підприємств, на гідробіонтів значно різняться, а їхня дія залежить від сезону року, тривалості впливу, концентрації та багатьох інших чинників [3]. Незважаючи на те, що водні екосистеми характеризуються відносною стабільністю, наявністю енергетичних потоків, а також селективністю токсичних агентів, більшість забруднювачів води здатні порушувати міжвидові відносини та сприяти виникненню стресових навантажень на гідробіонтів [16; 26].

Тривалий час для об'єктивної оцінки екологічного стану водних екосистем використовують методи патофізіологічних досліджень риб. Із цією метою використовують значну кількість клінічних, патологоанатомічних, гістологічних, цитогенетичинх i біохімічних досліджень, які проведені на рибах із забруднених річок. Окрім значної кількості фізіолого-біохімічних показників, які змінюються в риб у відповідь на дію забруднювачів води, більшість із них рекомендовані як критерії для оцінювання екологічного стану водойм. Останнім часом також поширилися методи, засновані на контролі клінічного стану та патологоанатомічних досліджень, які застосовуються у практиці ветеринарної медицини [22].

До уваги в цьому разі беруть стан шкіряного покриву (наявність слизу), пігментів шкіри, плавців, анального отвору, зябрових кришок, дуг, пелюсток, ротового отвору, рота, ока й осьового скелета. Досліджують пружність м'язів, стан та розміщення внутрішніх органів - серця, печінки, нирок, шлунка, кишечника, особливо слизової оболонки, наявність крововиливів, ексудату, їхній розмір, колір і консистенцію [22].

У риб із річок, забруднених стоками промислових підприємств, спостерігали помутніння рогівки ока, зміну забарвлення поверхні тіла, гіперплазію пелюсток зябер, збільшення розмірів серця, нирок, зміну кольору печінки, утворення перетинок на гонадах, міопатію, порушення формування кісток черепа.

Вплив ксенобіотиків на риб, за даними численних досліджень, проявляється в руйнуванні волокон і м'язів серця, дистрофією м'язових волокон, жировою інфільтрацією міокарда, гіперплазією пелюсток зябер, зміною їхнього кольору, злущенням епітелію пелюсток, застійними явищами в судинах, дегенеративними змінами хрящової тканини зябер.

У риб унаслідок дії токсикантів води часто спостерігаються міопатія м'язів, асинхронний розвиток ікри, ліпідне і сполучнотканинне переродження яєчників і сім'яників, резорбція і дегенерація ооцитів, лізис їхніх оболонок, утворення кістозних вузлів [29]. Часто в риб реєструють некроз паренхіми печінки, надмірний розвиток сполучної тканини, руйнування ядер гепатоцитів, надлишкову проліферацію сполучної тканини, крововиливи, ліпідну дегенерацію, вакуольну жирову дистрофію паренхіми, новоутворення. Зареєстровано значні порушення функції нирок у риб під впливом різних ксеноіотиків. У таких риб діагностують порушення структури сечовивідних канальців, гіперплазію, нефропатію і розростання паренхіми нирок.

Розвиток токсикозу у риб під дією ксенобіотиків різного механізму дії, який умовно ділять на окремі стадії: контакту, мобілізації, дестабілізації і деградації, проявляється спочатку значними змінами гематологічних показників, перед появою інших видів патологій [21].

Вплив токсикантів води на кровотворні органи риб є одним із механізмів їхньої адаптації до зміни екологічного стану водного об'єкта, а морфологічний склад крові може бути важливим діагностичним тестом під час оцінювання екологічного стану водойм [21].

У разі довготривалої дії токсичного чинника на риб спостерігають незворотні зміни в системі кровотворення. За дії підвищених доз ксенобіотиків у риб розвивається анемія, яка супроводжується дегенеративними змінами у кровотворних органах, печінці, нирках та зябрах $[21 ; 22]$.

Виходячи із наведених даних, низка авторів [21] рекомендують як чутливий індикатор негативного впливу токсикантів води на ранніх стадіях вести контроль гематологічних показників. У риб це пов'язано 3 тим, що саме кровоносна система реагує на зміну екологічного стану водного об'єкта однією з перших шляхом руйнування клітин крові та появою їхніх незрілих форм [21]. 3 огляду на ці зміни крові риб, метод гематологічного аналізу є одним 3 основних під час вивчення впливу токсикантів на риб і оцінки екологічного тиску на природні водойми.

Негативний вплив токсикантів на гідробіонтів пов'язаний із змінами морфофункціональної організації органів і тканин, а також дегенеративними процесами, які виникають у їхньому організмі. Найбільш суттєві зміни гістоструктури під впливом різних ксенобіотиків у риб зареєстровано з боку паренхіматозних органів [22]. У печінці риб, які тривалий час перебували у воді, забрудненій органічними ксенобіотиками, токсичними сполуками чи 
Курбатова I.М., Захаренко М.О., Тупицька О.М.

важкими металами, діагностували деструкцію клітин паренхіми печінки - гепатоцитів, розростання сполучної тканини, ліпідну дегенерацію. У нирках риб за дії токсикантів спостерігали гіперемію, дистрофічні зміни епітелію канальців і капсули, некробіоз тканин, які характеризували як інтерстиціальний нефрит, посилений нефрокальцитозом сечовивідних шляхів [13]. Однак найбільше забруднюючі речовини водойм впливають на зябровий апарат риб, який забезпечує зв'язок організму з водним середовищем. Установлено, що вплив токсикантів води на зябра риб пов'язаний із набуханням респіраторного епітелію, гіперемією пелюсточок, крововиливами, некрозом і злущуванням епітеліальних клітин [22; 23]. Токсиканти води змінюють роботу серцево-судинної системи риб, викликають розширення і переповнення кров'ю шлуночків і судин серця, дрібні крововиливи в міокарді, дистрофічні зміни м'язових волокон, білкову дистрофію м'язів, жирове переродження тканин серця [22].

Ксенбіотики різного походження порушують водно-сольовий обмін у риб, впливають на засвоєння макро- і мікроелементів організмом риб із води через зябра, особливо кальцію. Це є однією із причин остеопорозу або сколіозу в риб за дії токсикантів [8].

У риб, які тривалий період часу перебували під впливом органічних ксенобіотиків, забруднювачів неорганічного походження, стоків промислових підприємств, зареєстровано порушення відтворювальної здатності, що пов'язують із переродженням яєчників через збільшення ліпоїдних включень та розростанням сполучної тканини [29]. Ці зміни призводять до порушення функції яєчників і сім'яників, резорбції і дегенерації ооцитів, виникнення кістозних утворень, появи гермафродитних особин [29].

Останніми роками все більше уваги під час екотоксикологічного оцінювання забруднення природних водойм приділяють біохімічним показникам, які $€$ основними критеріями для виявлення механізмів впливу токсикантів на риб. Дію токсикантів на метаболічні процеси у тканинах і органах пов'язують із впливом на ендокринну систему риб шляхом збільшення кількості адреналіну, норадреналіну і катехоламінів, а також активацією гіпоталамо-гіпофізно-наднирникової системи, що викликає збільшення вмісту кортикостероїдів і АТФ [18]. За невеликих концентрацій ксенобіотиків у воді основними кількісними ознаками виникнення токсикозу в організмі риб є підвищення активності ключових ферментів лізосом, вмісту жирних кислот, особливо низькомолекулярних, вільних амінокислот, триацилгліцеридів, жовчних кислот, активності ензимів тощо [6]. Більшість цих показників рекомендовано використовувати в біотестуванні екологічного стану водойм [6].

Метаболічну відповідь риб на тривалу дію токсикантів пов'язують також з активацією енергетичних процесів завдяки стимуляції реакцій гліколізу, гальмуванням синтезу замінних амінокислот і білків,

\section{ЕКОАОГО-ТОКСИКО АОГЧНА ОЦІНКА...}

посиленням катаболізму глікогену, ліпідів і білків [22]. На основі одержаних даних запропоновано загальну схему розвитку токсикозу в риб під впливом різних доз ксенобіотиків. Так, за гострої токсичності забруднюючих речовин в органах і тканинах риб відбуваються незворотні зміни структури і функції клітин, що веде до загибелі організму. Хронічну дію токсичних агентів пов'язують із мобілізацією захисних систем організму риб, посиленням енергетичного обміну, детоксикаційної функції печінки, зміною гематологічних показників [22; 23]. За незначних концентрацій токсикантів у воді риби адаптуються до їхнього впливу зміною фізіолого-біохімічних процесів в організмі. У такому разі захисні системи організму риб компенсують руйнівну дію токсикантів, але водночас можуть з'являтись перші ознаки захворювань організму. Наслідком цього може бути адаптація риб до дії токсикантів або подальша деградація в органах і системах, що часто використовується для оцінки екологічного стану водойм.

Узагальнюючи наведені дані, можна зробити висновок, що найбільш доступними в оцінці екологічного стану природних водойм є методи клінічного і патолого-анатомічного дослідження риб. Вони можуть бути використані як експрес-методи під час екологотоксиклогічнї оцінки водних екосистем за дії рідких відходів тваринних підприємств та промислових об'єктів.

Для оцінки токсичності різних забруднювачів води рекомендовано використовувати активність ряду ензимних систем крові і тканин риб, зокрема лужної фосфатази, аланін- і аспартатамінотрансферази, а також різні види оксигеназ, які беруть участь у знешкодженні ксенобіотиків у тканинах [36]. До останніх відносять такі ферменти, як: цитохром $\mathrm{P}_{450}$, гідроксилази і ксантиноксидази. Вказані ферменти відіграють ключову роль у перетворенні ксенобіотиків в організмі, в основному на водорозчинні сполуки, які здатні утворювати кон'югати з іншими метаболітами і виводитись через нирки із сечею або 3 печінки із жовчю [19]. До групи оксидаз, які беруть участь у знешкодженні ксенобіотиків, відносять флавіновмістимі оксігенази, молібденоксігенази, до яких входять альдегідоксидаза і ксантиноксидаза, простагландин-Р-синтетаза, ліпоксігеназа, амінооксидаза, альдегідрогеназа [19]. Проведеними дослідженнями підтверджено участь ксантиоксидази і ксантиндегідрогенази в метаболізмі ксенобіотиків у тканинах, активність яких значно знижується.

Головні висновки та перспективи досліджень. Отже, критерії оцінки екологічного стану водойм базуються на дослідженні структури водних екосистем, показників біорозмаїття, функціональних особливостей представників фіто- та зоопланктону, біопродуктивності об'єктів аквакультури, морфометричних ознак, морфологічних показників у безхребетних і риб, окремих компонентів пластичного обміну у тканинах. 


\section{Література}

1. Антоновский А.Г., Демченко В.А., Демченко Н.А. Перспективы использования особей, популяции и сообществ рыб в системе биоиндикации качества воды и состояния гидроэкосистем. Вісник Запорізького національного університету. 2008. № 1. С. 30-34.

2. Афанасьев С.А., Гродзинский М.Д. Методика оценки экологических рисков, возникающих при воздействии источников загрязнения на водные объекты. Киев : Ай-Би, 2004. С. 60.

3. Екологічна оцінка стану довкілля в зонах виробництва продукції птахівництва / В.П. Бородай та ін. Сучасне птахівництво. 2014. № 4 (137). С. 22-25.

4. Водна рамкова Директива СC 2000/60/ЕС. Основні терміни та їх визначення / EU Water Framwork Directive 2000/60/EC. Definitions of Main Terms. Київ : 2006. 240 с

5. Дятлов С.Е. Роль и место биотестирования в комплексном мониторинге морской среды. Экология моря. 2000. № 51. С. $83-87$.

6. Жиденко А.А. Особенности пластического обмена карпа разного возраста под действием гербицидов. Bicник Дніпропетровського національного університету імені Олеся Гончара. Серія «Біологія. Екологія». 2008. № 1 (16). С. 84-92.

7. Захаров В.М. Здоровье среды: методика оценки. Москва : Центр экологической политики России, 2000. 68 с.

8. Земнов Г.В., Журавлева Г.Ф. Кинетика патологических изменений при кумулятивном токсикозе в организме как критерий сопротивляемости популяции рыб. Экология животных. 2004. № 1. С. 41-47.

9. Изменчивость признаков осевого скелета у сеголеток плотвы после воздействия токсических веществ в период раннего индивидуального развития / А.Н. Касьянов и др. Вопросы ихтиологии. 2001. № 41 (4). С. 495-503.

10. Оценка генотоксичности наночастиц на морских гидробионтах с помощью метода ДНК-комет / С.П. Кукла и др. Современные методы исследования состояния поверхностных вод в условиях антропогенной нагрузки : материалы $\mathrm{V}$ Всероссийской конференции по водной экотоксикологии, Борок, 28 октября - 1 ноября 2014 г. Ярославль : Из-во ООО «Филигрань, 2014. II. С. 65-69.

11. Курбатова I.M., Тупицька О.М. Вплив абіотичних факторів на організм прісноводних риб (літературний огляд). Вісник Запорізького начіонального університету. Серія «Біологічні науки». 2015. № 2. С. 99-108.

12. Курбатова I.M., Тупицька О.М., Смоленський О.О. Вплив антропогенних чинників на якість води рибогосподарської водойми ЗАТ «Антонов» с. Круглик. Питання біоіндикації та екологіï. 2014. № 19 (1). С. 107-115.

13. Лукин А.А., Шамрова Ю.Н. Оценка качества вод на основе гистологических исследований (на примере Кенозеро). Водные ресурсы. 2004. № 4. С. 481-489.

14. Биологический контроль окружающей среды: биоиндикация и биотестирование / О.П. Мелехова и др. Москва : Академия, 2007. 288.

15. Мелехова О.П., Сарапульцева Е.И., Евсеєва И.Т. Биологический контроль окружающей среды. Биоиндикация и биотестирование. Москва : ИЦ «Академия», 2010. 288 с.

16. Методи гідроеклогічних досліджень поверхневих вод / за ред. В.Д. Романенка. Київ : Логос, 2006. 408 с.

17. Методические указания по установлению эколого-рыбохозяйственных нормативов (ПДК и ОБУВ) загрязняющих веществ для воды водных объектов, имеющих рыбохозяйственное значение / под ред. О.Ф. Филенко. Москва : Из-во ВНИИРО ; Борок, 1998. $46 \mathrm{c}$.

18. Микряков Д.В., Микряков В.Р. Влияние гормона стресса кортизона на лейкоциты крови карася Carassius carrasius L. Биология внутренних водоемов. 2005. № 4. С. 90-94.

19. Миронюк М.О., Арсан О.М., Хоменчук В.О. Вплив сирої нафти і дизпалива на активність сукцинатдегідрогенази та цитохромоксидази в організмі коропа (Cурrinus carpio L.). Гідробіологічний журнал. 2011. № 47 (2). С. 112-118.

20. Биологические методы оценки качества вод. Биоиндикация / Т.И. Моисеенко и др. Вестник Тюменского государственного университета. 2010. № 7. С. 20-40.

21. Моисеенко Т.И. Гематологические показатели рыб в оценке их токсикозов. Вопросы ихтиологии. 1998. № 2. С. 371-380.

22. Моисеенко Т.И., Лукин А.А. Патологии рыб в загрязненных водоемах и их диагностика. Вопросы ихтиологии. 1999. № 4. С. 535-547.

23. Моисеенко Т.И., Соромотин А.В., Шалабодов А.Д. Качество вод и методология нормирования загрязнения. Вестник Тюменского государственного университета. 2010. № 7. С. 5-19.

24. Немова Н.Н., Высоцкая Р.У. Биохимическая индикация состояния рыб. Москва : Наука, 2004. 215 с.

25. Биоиндикация экологического состояния водоёмов в черте г. Киева / В.Д. Романенко и др. Гидробиологический журнал. 2010. № 46 (2). С. 3-23.

26. Романенко В.Д. Медовик Д.В. Видовий склад та екологічна характеристика іхтіофауни малих річок урбанізованих територій. Гідробіологічний журнал. 2017. № 53 (4). С. 3-12.

27. Слободскова В.В., Кукла С.П., Челомин В.П. Кометный анализ как тест на гентотоксичность морских прибрежных акваторий. Современные методы исследования состояния поверхностных вод в условиях антропогенной нагрузки : материалы V Всероссийской конференции, Борок, 28 октября - 1 ноября 2014 г. Ярославль : Из-во ООО «Филигрань», 2014. С. $160-163$.

28. Тупицкая О.Н., Смоленский О.О., Курбатова И.Н. Биохимические показатели крови карпа (Cuprinus carpio L.) под воздействием алифатических аминов. Вестник Тверского государственного университета. 2015. № 4. С. 33-40.

29. Шатуновский М.И., Акимова Н.В., Рубан Г.И. Реакция воспроизводительной системы на антропогенное воздействие. Вопросы ихтиологии. 1996. № 36 (2). С. 229-247.

30. Шорникова Е.А., Хайрулова Т.И., Шведюк Т.О. Микробиологические исследования в мониторинге антропогенно нарушенных участков реки Оби в акватории города Сургута. Современные методы исследования состояния поверхностных вод в условиях антропогенной нагрузки : сборник материалов VI Всероссийской конференции, Борок, 14-17 сентября 2017 г. Ярославль : Из-во ООО «Филигрань», 2017. С. 117-120.

31. Шулидов А.В., Хорунжа Т.А. Методы токсикологической оценки загрязнения экосистем. Москва : Гидрометеоиздат, 1994.124 с. 


\section{Курбатова I.М., Захаренко М.О., Тупицька О.М.}

32. Щербак В.І., Семенюк Н.С. Індикація впливу урбанізацій на водойми за різноманіттям фітопланктону. Доповіді Наиіональної академії наук України. 2006. № 12. С. 170-175.

33. Copper Oxide Are Highly Toxin between Metal Oxide Nanoparticles and Carbon Nanotubes / H.L. Karlson et al. J. Chem. Research Toxicology. 2008. № 21 (5). P. 1726-1732.

34. Zakharenko M., Tupitska O., Yaremchuk O., Chepil L. Effect of antibiotics, hormones and anthelmintic on high molecular weight protein fractions in the common carp / I. Kurbatova et al. Ukrainian Journal of Ecology. 2020. № 10 (2). P. 76-80.

35. Niimi A.J. Review of biochemical method and other indicators to assess fish health in aquatic ecosystems containing toxic chemicals. J. Great Lakes Research. 1990. № 16. P. 529-541.

36. Water quality. Determination of the inhibition of the mobility Daphnia magna Straus (Cladocera, Crustacea) Acute toxicity test. ISO 6341. 1996. 


\title{
СТАН ПОВЕРХНЕВИХ ВОДНИХ ОБ'СКТІВ ПОАТАВСЫКОї ОБААСТI
}

\author{
Степова О.В., Гах Т.О., Тягній Л.М. \\ ${ }^{1}$ Національний університет «Полтавська політехніка імені Юрія Кондратюка» \\ пр. Першотравневий, 24, 36011, м. Полтава \\ alenastepovaja@gmail.com, tanigah@ukr.net, tjagnij94@gmail.com
}

\begin{abstract}
У роботі проведено дослідження екологічної оцінки стану поверхневих водних об'єктів Полтавської області, проаналізована динаміка інтегрального критерію забрудненості водойм протягом 2000-2019 років за допомогою показника КЗ. 3'ясовано, що одним із факторів, що спричинив щорічне погіршення екологічного стану водойм Полтавщини, $є$ зростання техногенного навантаження водогосподарського комплексу на водні об'єкти внаслідок поступового виснаження і забруднення поверхневих джерел води за рахунок зношеності та застарілих технологій очищення, що призводить до суттєвого хімічного і бактеріального забруднення та підвищує ризики виникнення надзвичайних ситуацій. Рівень техногенного впливу водогосподарського комплексу оцінено за показниками забруднення та виснаження водних об'єктів. Виконано аналіз регіонального водогосподарського комплексу Полтавської області, який включає аналіз показників забору води, показників водовідведення, визначення рівнів техногенного впливу на водноресурсний потенціал. У поверхневі водойми Полтавської області постійно здійснюється скидання стічних вод. Для визначення причин забруднення поверхневих водойм проведено аналіз інтенсивності водокористування за галузями економіки, обсягів загального водовідведення та кількість користувачів-забруднювачів. 3'ясовано причини негативного екологічного стану поверхневих вод і розроблено рекомендації з поліпшення стану водогосподарського комплексу. Для усунення недоліків водовідведення доцільне розроблення та впровадження технологічних схем упорядкування наявного водовідведення, які забезпечать керовану екологічно безпечну та ефективну систему відведення всіх видів стічних вод населених пунктів з можливістю збалансування за рахунок впровадження безводних, маловодних та водозберігаючих технологій у всіх галузях економіки. Ключові слова: водогосподарський комплекс, поверхневі води, забруднення води.
\end{abstract}

Condition of surface water objects of Poltava region. Stepova O., Gakh T., Tyagniy L.

The ecological assessment of the state of surface water bodies of Poltava region is performed in the work, the dynamics of the integrated criterion of water pollution during 2000-2019 is analyzed with the help of indicator. It was found that one of the factors that caused the annual deterioration of the ecological condition of water bodies of Poltava region is the growth of man-caused load of the water complex on water bodies, due to gradual depletion and pollution of surface water sources due to wear and obsolete treatment technologies, which leads to significant chemical and bacterial contamination and increases the risk of emergencies. The level of technogenic impact of the water complex is assessed by indicators of pollution and depletion of water bodies. The analysis of the regional water management complex of Poltava region is performed, which includes the analysis of water intake indicators, drainage indicators, determination of levels of technogenic impact on water resource potential. Sewage is constantly discharged into the surface reservoirs of Poltava region. To determine the causes of surface water pollution, an analysis of the intensity of water use by industry, the volume of total drainage and the number of users of pollutants. The causes of the negative ecological condition of surface waters are clarified and recommendations for improving the condition of the water management complex are developed. To eliminate the shortcomings of sewerage, it is advisable to develop and implement technological schemes for streamlining the existing sewerage, which will provide a managed environmentally safe and efficient system of drainage of all types of wastewater settlements with the possibility of balancing through the introduction of waterless, low-water and water-saving technologies in all sectors. Key words: water management complex, surface waters, water pollution.

Постановка проблеми. Проблема водних ресурсів для України, зокрема Полтавської області, надзвичайно актуальна. Серед основних природноресурсних факторів регіонального розвитку важливу роль відіграють водний режим і водні ресурси, які визначають умови та беруть участь в усіх видах господарської діяльності людини. Залежно від природних та економічних умов освоєння водних ресурсів утворюються регіональні водогосподарські комплекси. Проблема стану водних ресурсів є однією 3 найактуальніших проблем розвитку всієї економіки України на найближчі роки, особливо у разі необхідності забезпечення питних потреб.

Актуальність дослідження. Інтенсифікація господарської діяльності - одна 3 обов'язкових умов подальшого розвитку людського суспільства - супроводжується безумовним посиленням антропогенного впливу на довкілля. Однією із найбільш вразливих його ланок $\epsilon$ води місцевого стоку - малі річки та водотоки.

Одним із наслідків високого антропогенного впливу $є$ евтрофікація водойм. Це складний процес у прісних і морських водах, де бурхливий розвиток певних типів мікроводоростей порушує водні екосистеми і являє собою загрозу тваринам і здоров'ю людини.

Погіршення екологічної ситуації річкових систем у Полтавській області внаслідок нераціонального використання водних ресурсів, значного техногенного впливу є вкрай відчутною проблемою і несе приховану небезпеку для нинішнього і майбутніх поколінь. 


\section{Степова О.В., Гах Т.О., Тягній Л.М.}

Водогосподарський комплекс Полтавщини створений у 60-70-х роках минулого століття та призначений для гарантованого забезпечення галузей економіки та населення водними ресурсами необхідної якості та кількості.

Натепер водогосподарська обстановка змінюється, змінилися економічні можливості щодо використання водних ресурсів, змінилися природні умови річкового стоку, пов'язаного як 3 кліматичними умовами, так і $з$ антропогенним фактором.

Екологічні ризики від господарської діяльності, що проводиться в Полтавській області, зумовлюють необхідність застосування комплексного підходу для вивчення тенденцій зміни якісних показників поверхневих вод.

Таким чином, зв'язок авторського доробку із важливими науковими та практичними завданнями за оцінкою та аналізом екологічного стану поверхневих водних об'єктів, використання водних ресурсів у Полтавській області є надзвичайно актуальним дослідженням сьогодення.

Роботу виконано відповідно до «Основних засад (стратегії) державної екологічної політики України на період до 2020 року», затверджених Законом України від 21.12.2010 р. № 2818-VI.

Аналіз останніх досліджень і публікацій, в яких започатковано розв'язання такої проблеми, на які спираються автори. Дослідженню екологічного стану поверхневих водних об'єктів України, вивченню вмісту та стоку біогенних речовин у річки України присвячено багато праць відомих учених, а саме О. Алмазова [1], А. Денисової [2], Е. Нахшиної [3]. Дані про потрапляння біогенних речовин до поверхневих вод присутні у роботі А. Коненко, I. Гарасевич, I. Енакі [4]. Дослідження біогенних елементів для Нижнього Дніпра подане в роботі Л. Журавльової [5], а особливості формування вмісту біогенних речовин та характеристик їх стоку у річках басейну Дніпра у роботі С. Сніжка [6]. Аналізу якісного стану поверхневих водних джерел Полтавської області присвячені наукові праці [7-9].

На актуальність дослідження та прогнозування стану поверхневих водних об'єктів наголошено в роботах закордонних учених $[10 ; 11]$. $€$ безліч методів та методик, за допомогою яких можна оцінити екологічний стан водойм. Проте оцінити якісно стан поверхневих вод, що перебуває під впливом людської діяльності, є досить складним завданням, оскільки він визначається багатьма факторами. Визначення одночасно всіх показників не завжди $€$ необхідним та економічно доцільним. Практично залежно від мети досліджень оцінка якості поверхневих вод грунтується на вибраних репрезентативних показниках, величини яких мають визначатися за уніфікованими методами аналізу якості компонентів довкілля.

Виділення не вирішених раніше частин загальної проблеми, яким присвячується зазначена стаття.

\section{СТАН ПОВЕРХНЕВИХ ВОДНИХ ОБ’ЄКТІВ...}

Проведений аналіз праць науковців, як вітчизняних, так і закордонних, у вивченні стану поверхневих водойм та процесів, що в них відбуваються, вказує на те, що проблема забруднення поверхневих водойм триває. Стан поверхневих водойм у світі погіршується внаслідок збільшення техногенного навантаження. Внаслідок поступового виснаження і забруднення поверхневих джерел води, незадовільного технічного стану та зношеності систем водовідведення, застосування застарілих технологій очищення стічних вод погіршується якість вод поверхневих водойм, підвищуються ризики виникнення надзвичайних ситуацій техногенного та епідемічного характеру, що становить загрозу національній безпеці держави.

Новизна. Ефективна система моніторингу екологічного стану поверхневих водойм, зокрема водних об'єктів Полтавської області, $є$ актуальною проблемою сьогодення, розв'язання якої сприятиме визначенню оптимальних та раціональних заходів поліпшення екологічного стану водних об'єктів Полтавської області.

Важлива особливість вивчення водогосподарського комплексу полягає у своєрідності об'єкта досліджень, що включає природничу водноресурсну та господарську складові частини, i, як наслідок, потребує його розгляду як природно-територіального комплексоутворення.

Методологічне або загальнонаукове значення. За оцінкою екологічного стану регіонального водогосподарського комплексу, яка включає оцінку екологічного стану водних об'єктів Полтавської області та оцінку поводження 3 водними ресурсами на регіональному рівні, можливе формування ефективного моніторингу та виявлення нагальних екологічних проблем.

Виклад основного матеріалу. Рівень техногенного впливу водогосподарського комплексу можна оцінити за показниками стану поверхневих водних джерел, показниками забруднення та показниками виснаження водних ресурсів.

Однією з природничих складових частин водогосподарського комплексу Полтавщини є поверхневі водойми. Водойми одночасно використовують як джерело водопостачання, для скиду стічних вод, тому використання водних ресурсів має бути скореговане в інтересах усіх учасників водогосподарського комплексу.

Річкова мережа Полтавської області включає: велику річку - Дніпро, яка протікає в межах області на ділянці довжиною 145 км, 8 середніх річок загальною протяжністю 1360 км та 1771 малих річок, водотоків і струмків загальною протяжністю 11501 км, у тому числі малих річок завдовжки понад 10 км в області нараховується 137, їх загальна довжина - 3596 км.

Основними джерелами водних ресурсів області $є$ річки Сула, Псел, Ворскла, Оріль та їхні притоки, а також Кременчуцьке та Дніпродзержинське водосховища на річці Дніпро. У межах області 
формується стік таких трьох річок, як: Сліпорід, Говтва, Тагамлик.

Аналіз сучасного екологічного стану водних джерел Полтавської області свідчить, що негативні процеси на річках, водосховищах і ставках тривають. Більшість річок і водотоків забруднені хімічними речовинами, які потрапили у водойми внаслідок скиду стічних вод промислових підприємств, втратили своє природне значення. Проблема якісного виснаження водних ресурсів 3 кожним роком стає більш гострою. Основні труднощі у разі використання поверхневих водних джерел пов'язані із забрудненням та евтрофікацією водойм.

Проведено оцінку якісного стану поверхневих водних джерел Полтавської області за коефіцієнтом забруднення (К3) за період 2009-2019 рр. з урахуванням таких гідрохімічних показників, як: загальне залізо, нітрити, азот сольовий, аміак, фосфати, БСК, хлориди, сульфати, нафтопродукти [7].
За результатами оцінки якості річкових вод Полтавської області за середніми значеннями показника забруднення води (КЗ) у Полтавській області станом на 2019 рік якість води водойм перебуває у скрутному екологічному стані (рис. 1). Загалом рівень забруднення поверхневих водойм Полтавської області близький до рівня екологічної катастрофи [9].

Відповідно до класифікації водойм за середніми значеннями показника К3 найбільш забрудненими вважаються річки Оржиця $($ К3= 3,97), Омельник $(\mathrm{K} 3=2,3)$, Ворскла $($ К3= 4,96).

Причин негативного екологічного стану поверхневих вод Полтавщини досить, одними з яких $є$ надмірне неефективне використання водних ресурсів.

Полтавщина має складний водогосподарський комплекс. Найбільшими споживачами води Полтавської області $\epsilon$ житлово-комунальне господарство, сільське господарство, промисловість, яка поєднує підприємства: гірничо-збагачувальні, сталеливарні, машинобудівні та підприємства харчової промисловості.

Загалом динаміка забору води 3 природних джерел має тенденцію до зменшення (рис. 2).

Створений в області багатогалузевий господарський комплекс потребує значних обсягів води. Найбільші валові потреби у воді населення та галузей економіки відзначені в 1990 р. і дорівнювали 485 млн м³, у 2000 р. зменшилися до 294,7 млн м³ на $42 \%$, а в 2014 - близько 250 млн м³. Задовольняються ці потреби водозабором 3 поверхневих джерел, підземних горизонтів i за рахунок вод, залучених в оборотні і повторно-послідовні системи. У поверхневі водойми Полтавської області постійно здійснюється скид стічних вод. Інтенсивність водовикористання за галузями економіки охарактеризована на рис. 3 .

Найбільше свіжої води використовується у житлово-комунальному i побутовому господарстві - 44,47 млн м ${ }^{3}$, що менше ніж у попередньому році на $\quad 0,8 \% \quad$ (у $2018 \quad-$ 44,81 млн м ${ }^{3}$ ), та у промисловості - 27,50 млн м ${ }^{3}$ (зменшення порівняно з 2018 роком на $6,5 \%$ від 29,44 млн м ${ }^{3}$.

Рис. 2. Динаміка забору та споживання води з природних водних джерел Полтавської області за 1990-2019 роки 


\section{Степова О.В., Гах Т.О., Тягній Л.М.}

Найбільшими споживачами води є підприємства сільського господарства (майже $61,0 \%$ всієї використаної води) та комунальне господарство $(23,8 \%)$. Частка промисловості у загальному водоспоживанні продовжує зменшуватися з $18 \%$ у 2011 році до $14,7 \%$ у 2014 році (2012 рік - 16,5\%). Серед галузей промисловості найбільшими споживачами $€$ підприємства чорної металургії (50,8\%), харчової промисловості $(19,4 \%)$ та енергетики (15,3\%). Втрати води під час транспортування мають стабільну тенденцію до зростання. Такі втрати мають місце у комунальному і побутовому водопостачанні через зношеність та незадовільний стан мереж водопостачання. Ключовою проблемою такої сфери $є$ незадовільний технічний стан водопровідних мереж - понад 80,3\% труб мають зношеність більше $45,23 \%$, що призводить до погіршення якості послуг 3 водопостачання, щороку збільшується кількість аварійних ситуацій [12].

Однією 3 основних характеристик рівня екологічної безпеки регіону є обсяги загального водовідведення стічних вод у поверхневі водні об'єкти, зокрема обсяги скидання забруднених стоків (рис. 4). У поверхневі водні об'єкти скинуто очисними спорудами 49 підприємств області 68,72 млн м ${ }^{3}$ стічних вод, що на 2,48 млн м $^{3}$, або на $3,5 \%$, менше ніж у 2018 році (49 підприємствами - 71,2 млн м $\left.{ }^{3}\right)$. Зменшення відбулося за рахунок зниження скидів ТОВ «Мало-коханівський кар'єр», КП «Кременчукводоканал» та відсутності скиду ПрАТ «Полтавський ГЗК».

Кількість водокористувачів-забруднювачів 3 кожним роком зменшується, в основному через припинення роботи деяких промислових підприємств (рис. 5). Основними водокористувачами-забруднювачами в області є: комунальне підприемство «Глобинське» Глобинської міської ради; КП «Лубни-водоканал» Лубенської міської ради; житловокомунальне підприємство c. Петрівка-Роменська Гадяцького району; КП Полтавської обласної ради «Полтававодоканал»;Машівська дільниця «Пирятинські госпрозрахункові очисні споруди» м. Пирятин; Карлівська дільниця КП «Житлово-експлуатаційна організація» Терешківської сільської ради Полтавського району;

\section{СТАН ПОВЕРХНЕВИХ ВОДНИХ ОБ'СКТІВ...}

сільське комунальне підприємство «Сяйво» с. Засулля Лубенського району; ТОВ «Оржицький молокозавод»; ТОВ «Метро Кеш енд Кері Україна».

Маса забруднюючих речовин, скинутих за рік у поверхневі водні об'єкти, становила 28,23 тис. т (у розрахунку щодо сухого залишку), що на 3,95 тис. тонн менше (або 12,3\%) ніж у попередньому році (2018 р. - 32,18 тис. т, 2017 р. 33,87 тис. т, 2016 р. $-33,46$ тис. т) [8].

Незважаючи на те, що останнім часом спостерігається тенденція до зниження обсягів використання води на потреби галузей народного господарства, а отже, і зменшення обсягів загального водовідведення, частка забруднених стоків у зворотних водах $\epsilon$ досить високою, що викликає в кінцевому рахунку суттєве забруднення водойм стічними водами.

Необхідність охорони водних ресурсів викликається недостатньою потужністю очисних споруд, неефективністю їх роботи внаслідок перевантаження та спрацювання обладнання.

Нагальною натепер залишається проблема очистки стічних вод, особливо підприємствами

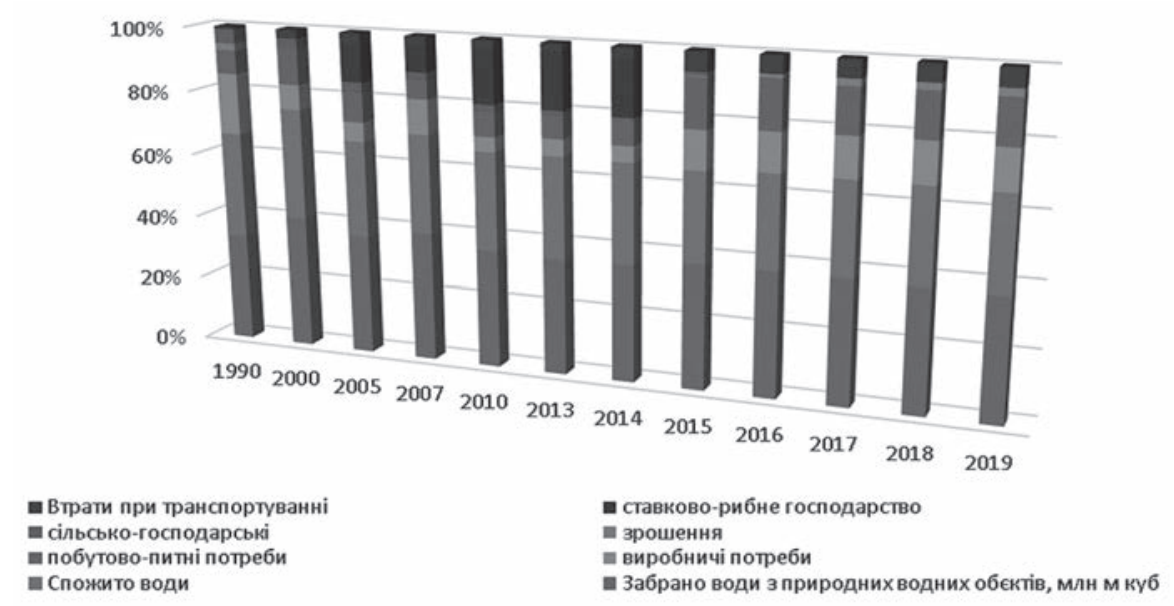

Рис. 3. Динаміка водокористування за галузями економіки протягом 1990-2019 рр.

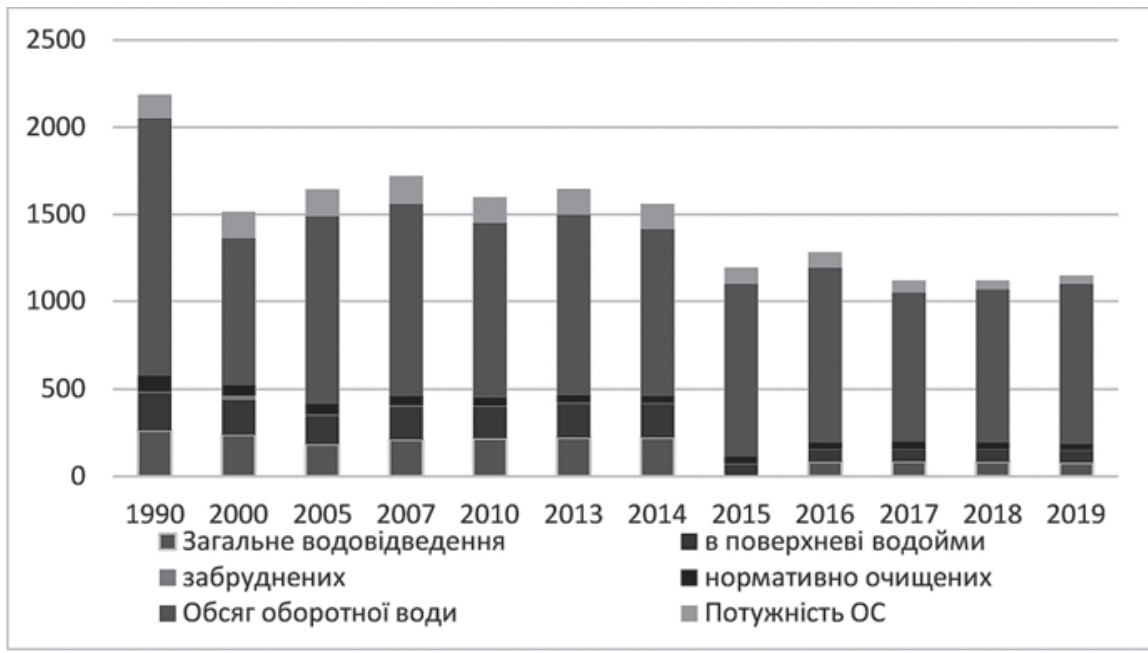

Рис. 4. Структура водовідведення в Полтавській області за 1990-2019 роки, млн. м³ 


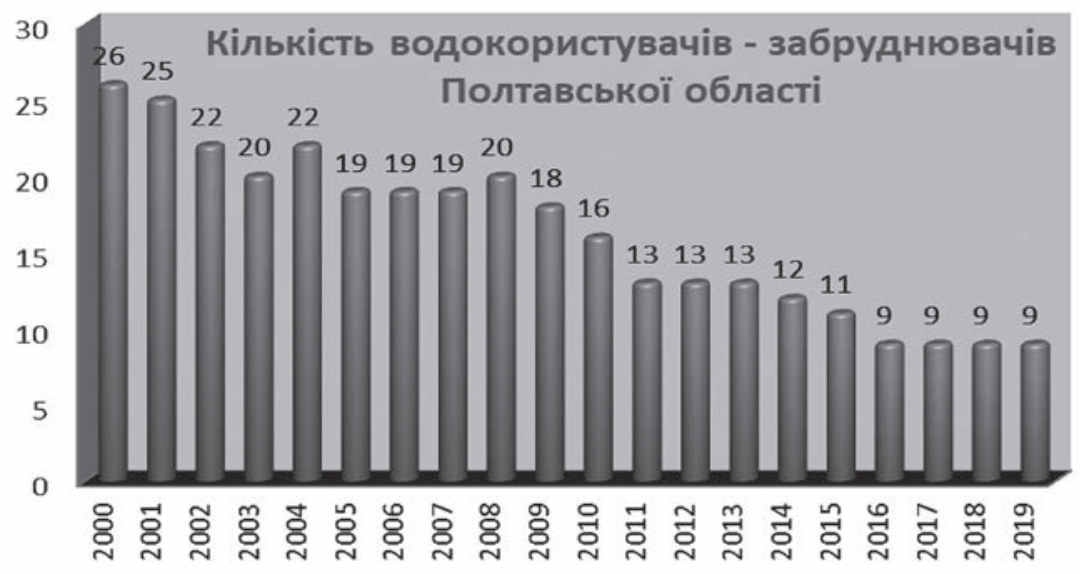

Рис. 5. Динаміка водокористувачів-забруднювачів Полтавської області протягом 2000-2019 років

комунальної сфери у зв'язку зі зношеністю та фізичною застарілістю комплексів очисних споруд.

Через незавершення робіт з реконструкції та капітального ремонту очисних споруд триває скидання не досить очищених стічних вод у поверхневі водні об'єкти області. Наявна система водовідведення не забезпечує стабільну роботу очисних біологічних споруд населених пунктів у відповідності до проєктних показників. Ці споруди є беззахисними перед надходженням на них виробничих стічних вод, забруднених понад вимоги біологічного способу очищення. В аварійних ситуаціях на промислових підприємствах залпові скиди дуже забруднених виробничих стічних вод можуть суттєво погіршити роботу споруд біологічної очистки. Відновлення ïx роботи потребує тривалого часу. Під час налагодження роботи очисних біоспоруд скид стічних вод у водні об'єкти здійснюється в аварійному режимі з порушенням вимог водного законодавства.

Крім того, частина поверхневих стічних вод скидається у поверхневі водні об'єкти не досить очищеними або зовсім без очищення. Це призводить до суттєвого хімічного та бактеріального забруднення водних об'єктів.

Таким чином, у процесі водокористування господарський вплив на якісні та кількісні характеристики водних ресурсів не балансується з їхньою самовідновлювальною здатністю.

Оцінка водокористування свідчить про нераціональність та наявність скиду забруднених стоків у природні водні об'єкти в результаті використання зношеного водозабезпечуючого та водоохоронного обладнання, спрацьованого обладнання очисних станцій, наявності каналізаційних мереж в аварійному стані, низької ефективності роботи очисних споруд.

Першочерговими заходами, спрямованими на оздоровлення басейну річки Дніпро, є: заміна аварійних каналізаційних мереж та відпрацьованого обладнання очисних станцій; використання сучасних методів утилізації стоків; зменшення забруднення, забезпечення стабільного використання води, охорони водного середовища, поліпшення стану водних екосистем, запобігання забрудненню підземних вод; збір та обробка інформації про забруднення річок (джерела забруднення, захворюваність населення, що 3 цим забрудненням пов'язана, технологічні заходи, які дозволяють зменшити рівень забрудненості тощо); підвищення рівня інформованості громадськості щодо рівня забрудненості поверхневих водойм; залучення недержавних та громадських організацій у разі реалізації екологічної політики.

Головні висновки. Аналіз результатів оцінки стану водогосподарського комплексу Полтавщини свідчить про те, що збалансування можливе за рахунок впровадження безводних, маловодних та водозберігаючих технологій у всіх галузях економіки, максимальне залучення води у системи оборотного водопостачання; заміни фізично та морально зношеного водозабезпечуючого і водоохоронного обладнання; підвищення ефективності роботи очисних споруд, впровадження сучасних технологій очищення та заміни аварійних каналізаційних мереж і спрацьованого обладнання очисних станцій; повного припинення скидання у водні об'єкти забруднених стічних вод; дотримання водоохоронного законодавства.

Перспективами використання результатів дослідження є застосування у формуванні системи моніторингу екологічного стану поверхневих водойм, зокрема водних об'єктів Полтавської області, та контролю за якістю поверхневих водойм.

\section{Література}

1. Алмазов О.М. Стік розчинний: солей та біогенних речовин, які виносяться річками УРСР в Чорне море. Наукові записки Одеської біологічної станиії, 1961. Вип. 3. С. 99-107.

2. Денисова А.И. Многолетние изменения в стоке биогенных и органических веществ при зарегулировании Днепра. Гидробиологический журнал, 1978. Т. 14. № 2. С. 80-86.

3. Нахишна Е.П. Ионный и биогенный сток рек басейна Верхнего Днепра. Гидрохимические материальl, 1981. Т. 78. С. $57-64$.

4. Коненко А.Д., Гарасевич И.Г., Енаки И.Г. Азот, фосфор и калий в воде рек правобережного Украинского Полесья. Гидробиологический журнал, 1974. Т. 10. № 5. С. 14-20.

5. Журавлёва Л.А. Гидрохимия устьевой области Днепра и Южного Буга в условиях зарегулированного стока. Киев : Наук. думка, 1988. 175 с. 
Степова О.В., Гах Т.О., Тягній Л.М.

6. Снежко С.И. Особенности формирования речного стока биогенных веществ (на примере бассейна р. Днепр в пределах УССР) : автореф. дисс. канд. географ. наук, Ростов-на-Дону, 1989. 24 с.

7. Сніжко С.І. Оцінка та прогнозування якості природних вод : підручник. Київ : Ніка-Центр, 2001. 264 с.: іл.

8. Регіональна цільова програма розвитку водного господарства та екологічного оздоровлення басейну річки Дніпро в Полтавській області на період до 2021 року. Полтава, 2013. 162 с.

9. Степова О.В., Гах Т.О. Екологічний стан поверхневих водойм Полтавської області. Екологічні науки : науково-практичний журнал / Головний редактор О.І. Бондар. Київ : ДЕА, 2020. № 2(29). Т. 2. С. 87-91.

10. Liao Wengeng, Li Jinxiu, Peng Jing. Discussions on the several quantification problems in the planning of water resources protection in China. Water Power, 2002. No. 5. Pp. 8-10.

11. Huang Zhenli, Li Yuliang. Prediction of water quality and calculation of environmental capacity in the Three Gorges Reservoir. Beijing : China Water Power Press, 2004. Pp. 24-195.

12. Голік Ю.С., Ілляш О.Е., Степова О.В. На шляху до інтегрованого управління водними ресурсами Полтавщини. Збірник наукових статей IV Всеукраїнського з '̈зду екологів з міжнародною участю (Екологія/Есоlogy-2013), м. Вінниця, 25-27 вересня 2013 р. С. 219-221. 


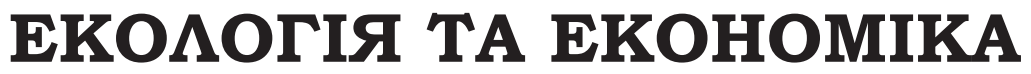 ПРИРОДНИХ РЕСУРСІВ
}

УДК 502: 504

DOI https://doi.org/10.32846/2306-9716/2021.eco.6-39.10

\section{ВИЗНАЧЕННЯ ПАРАМЕТРІВ ЗСУВУ ЗЕМНОЇ ПОВЕРХНI Й ЕКОАОГІЧНІ НАСАІДКИ ЗАКРИТТЯ ВУГІАЬНИХ ШАХТ}

\author{
Блінова Н.К., Філатьсва Е.М., Скарга В.В. \\ Східноукраїнський національний університет імені Володимира Даля \\ пр. Центральний, 59-А, 93400, м. Сєвєродонецьк, Луганська область \\ blinovan.k@ukr.net, elafilatyeva@gmail.com, skargaviktoria@gmail.com.
}

\begin{abstract}
Розглянуті негативні екологічні наслідки на довкілля під час експлуатації вугільних шахт та в разі їх ліквідації. У результаті діяльності шахт відбувається зміна рельєфу земної поверхні під впливом ііі підробки очисними виробками, а також зміна водного балансу між поверхневими та підземними водами. Тривала експлуатація шахт на Донбасі спочатку призвела до утворення квазістаціонарної екосистеми «шахтні води - мінеральний скелет». Це призвело до зміни природної конфігурації та спрямованості потоків підземних вод, техногенного посилення активності взаємозв’язку з поверхневими водами та зміни структур джерел формування їхніх ресурсів. Закриття шахт пов'язане з відновленням природних рівнів підземних вод, що були здреновані під час експлуатації. До основних негативних екологічних наслідків закриття шахт відносять підтоплення та заболочування земної поверхні, зміну хімічного складу підземних та поверхневих вод, активізацію зсуву земної поверхні над виробками, погіршення фізико-механічних властивостей гірських порід.

Можливість затоплення осілих ділянок земної поверхні грунтовими, атмосферними та паводковими водами в нормативних документах не розглядається. Для часткового вирішення цієї проблеми розглянуті питання теоретичного обгрунтування умов початку зсуву земної поверхні й утворення плоского дна мульди зрушення на земній поверхні. Розроблені критерії оцінки закінчення процесів зсуву порід та осідання земної поверхні. Встановлені особливості впливу повторної підробки через 50-80 років на параметри мульди зсуву земної поверхні. Встановлена тривалість процесів зрушення підроблених порід та умови можливого відновлення природного стану земної поверхні. Ключові слова: вугільна шахта, закриття, наслідки, екологія, підтоплення, земна поверхня, підробка, заболочування, води, підземні, поверхневі, породи, активізація, зсув, початок, мульда зрушення, плоске дно, тривалість, природний стан, відновлення.
\end{abstract}

Determination of shiftstates of earth surface and ecological consequences of closing of coal mines. Blinova N., Filatieva E., Skarha V.

Negative ecological consequences for the environment at operation of coal mines and at their liquidation are considered. As a result of the activity of mines there is a change in the relief of the earth's surface under the influence of its forgery by treatment works, as well as a change in the water balance between surface and groundwater. Prolonged operation of mines in the Donbass initially led to the formation of a quasi-stationary ecosystem "mine water - mineral skeleton". This has led to changes in the natural configuration and direction of groundwater flows, man-made increased activity of the relationship with surface waters and changes in the structures of sources of formation of their resources. Closure of mines is associated with the restoration of natural groundwater levels that were drained during operation. The main negative environmental consequences of mine closures include flooding and waterlogging of the earth's surface, changes in the chemical composition of groundwater and surface water, increased landslides over workings, deterioration of physical and mechanical properties of rocks.

The possibility of flooding of the earth's surface by ground, atmospheric and flood waters is not considered in the regulations. To partially solve this problem, the issues of theoretical substantiation of the conditions of the beginning of the landslide and the formation of a flat bottom of the displacement trough on the earth's surface are considered. Criteria for assessing the completion of rock landslides and subsidence of the earth's surface have been developed. The peculiarities of the influence of repeated forgery in 50-80 years on the parameters of the landslide trough are established. The duration of the processes of shifting of rocks and the conditions of possible restoration of the natural state of the earth's surface have been established. Key words: coal mine, closure, consequences, ecology, flooding, earth's surface, forgery, waterlogging, water, underground, surface, rocks, activation, shift, beginning, trough shift, flat bottom, duration, natural state, recovery.

Постановка проблеми. Експлуатація вугільних шахт спричиняс негативні екологічні наслідки для довкілля. У період активної діяльності вугільних підприємств основними чинниками, що визначають стан екосистеми, є викиди в атмосферу пило- та газоподібних речовин. Вони видаляються з гірничих виробок вихідними вентиляційними струменями та дегазаційними системами. Окрім цього, негативний вплив мають породні відвали, які в багатьох випадках є палаючими. Такі екологічні наслідки не є основними під час закриття шахт та їх затоплення. У Донбасі з 1996 по 2014 р. затоплення шахт призвело до підтоплення від 20 до 40\% прилеглих до них територій [1]. Це стало наслідком вилучення корисних копалин і попутного видалення з надр породи та води. Унаслідок такої діяльності відбулася зміна рельєфу земної поверхні 
Блінова Н.К., Філатьєва Е.М., Скарга В.В.

під впливом іiі підробітку очисними виробками, а також зміна водного балансу між поверхневими та підземними водами. У цьому випадку тривала експлуатація шахт на Донбасі спочатку призвела до утворення квазистаціонарної екосистеми «шахтні води мінеральний скелет». Це призвело до зміни природної конфігурації та спрямованості потоків підземних вод, техногенного посилення активності взаємозв'язку 3 поверхневими водами та зміни структури джерел формування їхніх ресурсів [2]. Закриття шахт пов'язане з відновленням природних рівнів підземних вод, що були здреновані під час експлуатації. До основних негативних екологічних наслідків закриття шахт належать підтоплення та заболочування земної поверхні, зміна хімічного складу підземних та поверхневих вод, активізація зсуву земної поверхні над виробками, погіршення фізико-механічних властивостей гірських порід, а також видавлювання шахтних газів [3].

Актуальність дослідження. Можливість затоплення осілих ділянок земної поверхні грунтовими, атмосферними та паводковими водами в нормативному документі [4] не відображена. Із цієї причини дослідження, що пов'язані 3 теоретичним обгрунтуванням початку зсуву земної поверхні, умовами утворення плоского дна мульди та розробленням критеріїв оцінки закінчення процесів зсуву порід і осідання земної поверхні належать до актуальних

\section{ВИЗНАЧЕННЯ ПАРАМЕТРІВ ЗСУВУ...}

завдань. Їх рішення необхідне для встановлення остаточних екологічних наслідків експлуатації та закриття вугільних шахт, а також розроблення емпіричних залежностей для інженерних розрахунків зміни рельєфу земної поверхні.

Метою роботи є вивчення умов виникнення, розвитку та згасання процесів зсуву підроблених порід і земної поверхні під впливом очисних виробок та встановлення залежності параметрів цих процесів від гірничо-геологічних та гірничотехнічних умов ведення гірничих робіт.

Зв'язок авторського доробку з важливими науковими та практичними завданнями. Для досягнення мети послідовно розглянуті такі питання: зони впливу очисної виробки під час відпрацювання пологих вугільних пластів; встановлення початку зсуву земної поверхні; умови утворення плоского дна мульди зсуву земної поверхні; критерії оцінки закінчення процесів зсуву земної поверхні; вплив повторного підробітку на параметри мульди зсуву земної поверхні; тривалість зрушення й умови можливого відновлення природного стану земної поверхні.

Аналіз останніх досліджень і публікацій. Узагальнення даних, що наведені в роботах [4-7], разом із результатами досліджень [8-10] дають деякі уявлення [11] про утворення можливих зон із різним напруженим станом на момент закінчення процесів зміщення підроблених порід і земної поверхні (рис. 1).

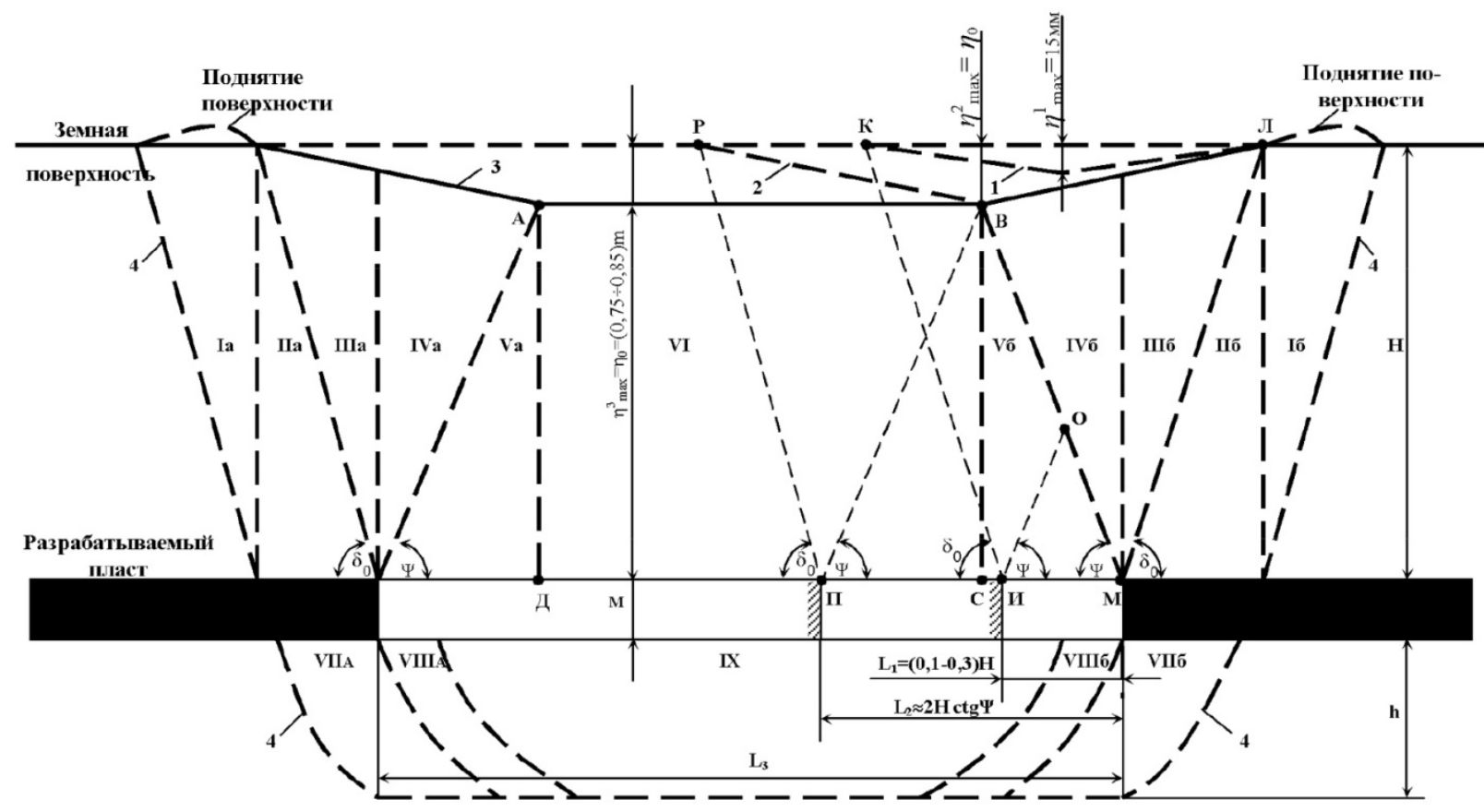

Рис. 1. Зони впливу очисної виробки згідно з узагальненими даними [5-10]

1, 2, 3 -мульди зсуву земної поверхні відповідно за розмірів виробки $L_{1}, L_{2} i L_{3}$; 4 -межа впливу очисної виробки за повної підробки земної поверхні з урахуванням ії можливого підняття згідно з [8; 9]; $L_{1}, L_{2} i L_{3}-$ розміри очисної виробки, щя відповідають зсуву земної поверхні $\left(\eta_{\text {мах }}^{1}=15 \mathrm{мм}\right)$, досягненню ї̈ повної підробки

$\left(\eta^{2}{ }_{\text {мах }}=\eta_{0}\right)$ і утворенню плоского дна мульди $\left(\eta_{\text {мах }}^{3}=\eta_{\text {мах }}^{2}=\eta_{0}\right) ; \eta_{0}-$ максимальне осідання земної поверхні після

ї̈ повної підробки (глибина плоского дна); $m$ - потужність пласта, щчо розроблясться; Н - глибина залягання

пласта; $h$ - відстань, на якій позначається вплив виробки в надпрацьованих породах; $\delta_{0}-$ граничний кут;

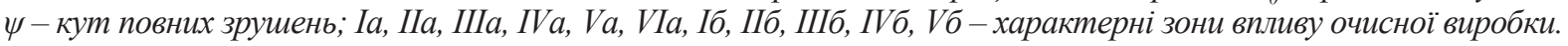


В умовах повної підробки земної поверхні (появі плоского дна мульди) і процесів зрушення, що закінчилися, з позицій можливого порушення природної рівноваги можна виділити такі зони впливу виробок (рис. 1):

- підняття порід та земної поверхні (Ia, Iб) унаслідок їх вигину [8; 9]. Максимальне підняття земної поверхні в умовах Західного Донбасу досягає 12 мм і відбувається на відстані 0,85 Н попереду очисного вибою;

- стиснення (ІІа, ІІб) порід (опорного тиску) [5-7]. Порожнини розшарування закриваються [12], що впливає на десорбований газ, перехід його в новий стан залежно від властивостей вміщуючих порід [13]; знакозмінних деформацій (IIIa, IIIб). Відзначаються як розтягування і стиск за нормаллю до напластування [5]. Залежно від гірничо-геологічних умов і властивостей міцності порід під впливом розтягування можуть утворюватися тріщини, що доходять до земної поверхні [12];

- найбільшого прогину (IVa, IVб) з високою ймовірністю тріщиноутворення [5]. Висота поширення водо- та газопровідних тріщин залежить від співвідношення властивостей міцності порід і величини напруг, що виникають у них. Характеризується можливим інтенсивним газовиділенням у виробки;

- повних зрушень (Va, Vб) та розвантаження від гірського тиску [4; 5-8];

- відновлення гірського тиску (VI), у разі достатнього розмірі виробки наближається до природного [5], породи ущільнюються, тріщини закриваються.

У породах підошви пласта також відбувається перерозподіл напруг [5] з утворенням зон опорного тиску (стиснення VIIa, VIIб), нерівномірних (VIIIa, VIIIб) та рівномірних (IX) піднять (розвантаження від гірського тиску).

Новизна. Наукові результати отримані на підставі узагальнення експериментальних даних про зсув підробленої вуглепородної товщі та земної поверхні під час експлуатації вугільних шахт більш ніж за п'ятдесят останніх років. На їх основі розроблені теоретичне визначення початку зрушення земної поверхні, умови утворення плоского дна мульди зрушення, критерії оцінки закінчення процесів зрушення підроблених порід і земної поверхні. Це дозволяє об’єднати в єдиний логічний ланцюжок утворення квазістаціонарної системи під час роботи вугільних підприємств, а потім під час відновлення природного рівня підземних вод після ліквідації шахт. Отримані результати необхідні для розроблення методик встановлення остаточного рельєфу місцевості та відновлення рівня підземних вод після затоплення шахт у регіонах.

Викладення основного матеріалу. За сучасного розвитку науки і техніки практично неможливо за допомогою приладів зафіксувати початок зсуву земної поверхні під час їі підробки вугільними пластами. Із цієї причини це питання досі залишається практично невивченим. Найбільш перспективним напрямом прогнозу параметрів зсуву земної поверхні є математичне моделювання. Згідно з відомими математичними моделями [14], що описують процеси тільки над очисним вибоєм, що рухається, не представляється можливим встановити початок зрушення земної поверхні в разі розвитку очисних робіт для конкретних гірничотехнічних і гірничо-геологічних умов. Актуальність питання пов'язана $з$ розробленням рекомендацій із ліквідації або зведення до мінімуму негативного впливу на земну поверхню відпрацювання вугільних пластів.

Встановлено [15], що в одних гірничо-геологічних умовах максимальне осідання земної поверхні $\eta_{m}$ практично функціонально залежить від ступеня розвитку очисних робіт. Це свідчить про те, що в гірничо-геологічних умовах однієї шахти головним чинником, що впливає на параметри зсуву земної поверхні, є розміри очисної виробки (виробленого простору). Інші чинники, як-от: потужність розроблюваного пласта $(m)$, глибина ведення гірничих робіт $(H)$ і міцнісні властивості підроблених порід $(f)$, залишаються постійними або змінюються незначно. Підтвердженням викладеного є графіки залежності $\eta_{m}=\varphi(L)$ (рис. 2).

Ці залежності для шахт, що розглядаються, добре описуються експоненціальними рівняннями. Кореляційні відносини перебували в діапазоні $0,940 \div 0,998$. Точки перетину графіків рівнянь із віссю абсцис $\left(\eta_{m}=0\right)$ відповідають початку зсуву земної поверхні. Для кожної із шахт визначили лінійний розмір очисної виробки $\left(L_{\mu}\right)$, який відповідає початку зсуву земної поверхні.

Знання процесів утворення мульди зсуву земної поверхні та пов'язаного 3 ними ущільнення підроблених порід після виймання вугільних пластів необхідне для вирішення завдань захисту об'єктів на земній поверхні, а також визначення ступеня відновлення вихідного природного стану підробленого масиву. Дослідження в цій галузі [5-6] були проведені в період часу, що безпосередньо був пов'язаний із веденням гірничих робіт. Відповідно до чинних нормативних документів тривалість процесів зсуву порід визначається 3 урахуванням глибини ведення гірничих робіт та швидкості просування очисного вибою. Спостереження припинялися, коли сумарні осідання земної поверхні протягом шести місяців не перевищували 10\% максимальних, але не більше ніж 30 мм. 3 іншого боку, відомо, що тривалість зсуву порід над зупиненим очисним вибоєм може в кілька разів перевищувати період їхнього зсуву над рухомим. Процеси ущільнення порід під плоским дном мульди зрушення земної поверхні раніше практично не вивчалися. 3 урахуванням викладеного, розгляд теоретичних основ утворення плоского дна мульди зрушення земної поверхні й експериментальна їх перевірка $є$ актуальними не лише для вугільної промисловості, а й для інших галузей господарської діяльності.

Відповідно до [5] дном мульди зсуву називають середню іiі частину, у якій точки земної поверхні мають найбільші осідання, причому подальше збільшення площі підробки не призводить до збільшення осідань цих точок.

Площа мульди в головному перерізі $\left(S_{\eta_{0}}\right)$ повинна прагнути до площі перерізу вийнятого пласта $\left(S_{m}=B \cdot m\right)$. Умовою повного відновлення вихідного стану підроблених порід після закінчення деякого періоду часу під плоским дном мульди має бути рівність глибини мульди $\left(\eta_{0}\right)$ і потужності пласта, що розробляється $(m)$. Отже, критерієм закінчення 


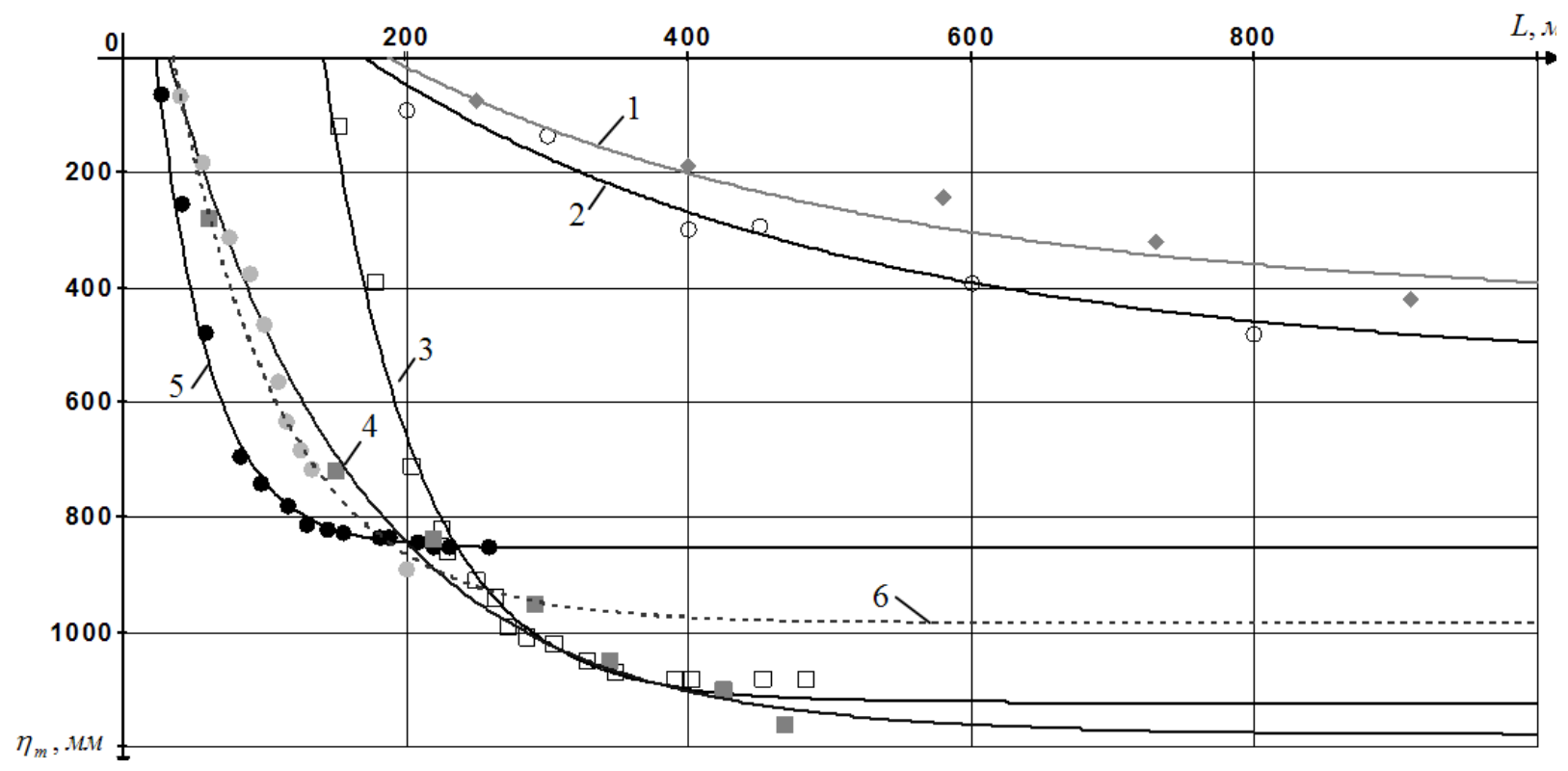

Рис. 2. Графік залежності максимального осідання земної поверхні $\left(\eta_{m}\right)$ в разі зміни одного з геометричних розмірів виробленого простору $(L)$ для різних гірничо-геологічних та гірничотехнічних умов.

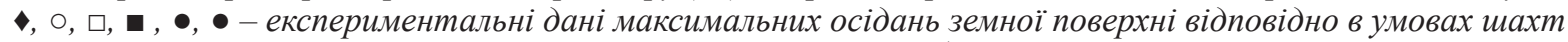
ім. М.В. Фрунзе (пласт $h_{8}$ ) [16], ім. П.Л. Войкова (пласт $\left.k_{5}^{1}\right)$ [17], однієї з польських шахт [18], ім. Г.Г. Капустина (пласт $\left.m_{3} н\right)$ [6], «Степової» (пласт $C_{8}$ ) [19], «Ювілейної», пласт $C_{6}^{\prime}$ [20]; 1, 2, 3, 4, 5, 6-емпіричні залежності максимальних осідань земної поверхні

процесів ущільнення порід під плоским дном мульди зсуву є близькість відношення $\eta_{0} / m$ до одиниці, а для всієї мульди (усіх зон впливу очисної виробки) аналогічним критерієм може бути відношення $S_{\eta_{0}} / \mathrm{Sm}$.

3 урахуванням можливості повного відновлення гірського тиску в разі неповного підроблення земної поверхні [21], площа мульди в головному перерізі $\left(S_{\eta_{m}}\right)$ через деякий час має досягти значення площі вийнятого пласта $\left(S_{m}\right)$. Визначили значення цих площ:

$$
\begin{gathered}
S_{\eta_{m}}=\eta_{m} \cdot L=\eta_{m} \cdot\left[H \operatorname{ctg} \delta_{0}+\left(H-\eta_{m}\right) \operatorname{ctg} \psi_{0}\right], \\
S_{m}=m \cdot B=2 m \cdot\left(H-\eta_{m}\right) \operatorname{ctg} \psi_{0}
\end{gathered}
$$

Для спрощення розрахунків прийняли $H-\eta_{m} \approx H$. Таке припущення можливе, виходячи зі співвідношення аналізованих величин $H>>\eta_{m}$. Прирівнявши після цього праві частини рівнянь (1 та 2), отримали вираз визначення $\eta_{m}$ :

$$
\eta_{\mathrm{m}}=\frac{2 \cdot \mathrm{m} \cdot \operatorname{ctg} \Psi_{0}}{\operatorname{ctg} \delta_{0}+\operatorname{ctg} \Psi_{0}}
$$

Виходячи $з$ геометричних побудов та фізичного сенсу, завжди має дотримуватися співвідношення $\eta_{m}<m$. Воно можливе лише за умови, якщо $\psi_{0}>\delta_{0}$. За $\psi_{0}=\delta_{0}$ згідно з рівнянням (3) $\eta_{m}=m$, тобто такі рівності $€$ обов'язковими умовами утворення плоского дна мульди зсуву на земній поверхні та свідчать про відновлення вихідного стану підроблених порід. Після закінчення процесів зсуву й ущільнення порід максимальне осідання земної поверхні $\eta_{m}$ у разі неповної підробки може дорівнювати глибині мульди зсуву $\eta_{0}$.

Аналіз (табл. 1) для різних гірничо-геологічних умов показав, що значення $\eta_{m} / m$ змінюється в широкому діапазоні від 0,19 до 0,95.
Експериментальні дані свідчать про те, що в багатьох випадках процеси зсуву порід та земної поверхні після припинення очисних робіт далекі від свого завершення і не відповідають припущенням, визначеним у нормативному документі [4]. Найбільш близьким співвідношення $\eta_{m} / m$ до одиниці $(0,95)$ спостерігалося в разі виїмки пласта низького ступеня метаморфізму (марка Г) та незначної глибини ведення гірничих робіт (110 м). Таке значення $\eta_{m} / m$, в умовах шахти «Степової» [19], вказує на високий ступінь ущільнення порід, але не свідчить про відновлення земної поверхні, бо в аналогічних умовах утворюються тріщини шириною до 0,8 м та глибиною понад 4,0 м [12].

\begin{tabular}{|c|c|c|c|c|c|c|c|}
\hline \multirow[b]{2}{*}{ № } & \multirow[b]{2}{*}{$\begin{array}{c}\text { Шахта, пласт, } \\
\text { джерело }\end{array}$} & \multicolumn{5}{|c|}{ Умови спостережень } & \multirow[b]{2}{*}{$\begin{array}{l}\eta_{m} / m, \\
\text { частки }\end{array}$} \\
\hline & & $\begin{array}{c}\text { m, } \\
\text { м }\end{array}$ & $\begin{array}{c}\eta_{m}, \\
\text { град }\end{array}$ & $\begin{array}{c}\boldsymbol{H}_{c p}, \\
\mathbf{M}\end{array}$ & 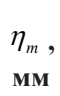 & $\begin{array}{l}\text { Марка } \\
\text { вугілля }\end{array}$ & \\
\hline 1. & Ясинівська, $l_{6}$ [22] & 0,80 & 4 & 307 & 250 & $\mathrm{~K}, \mathrm{OC}$ & 0,31 \\
\hline 2. & Глибока, $h_{6}$ [23] & 1,15 & 5 & 541 & 800 & $\mathrm{OC}, \mathrm{T}$ & 0,70 \\
\hline 3. & $\begin{array}{c}\text { Комісарівська, } \\
\ell_{1}^{0}[24]\end{array}$ & 0,90 & 6 & 260 & 533 & $\mathrm{~T}$ & 0,59 \\
\hline 4. & Україна, $K_{7}^{\prime}$ [24] & 0,65 & -* & 540 & 122 & OC, $\mathrm{T}$ & 0,19 \\
\hline 5. & $\begin{array}{l}\text { ім. 50-річчя } \\
\text { СРСР, } i_{3}^{\prime} \text { [25] }\end{array}$ & 1,00 & 4 & 692 & 465 & ж & 0,47 \\
\hline 6. & $\begin{array}{c}\text { Ворошилівська, } \\
i_{3}^{\prime} \text { [26] }\end{array}$ & 1,00 & 4 & 500 & 410 & A & 0,41 \\
\hline 7. & Степова, $C_{8}[19]$ & 0,91 & 4 & 110 & 865 & $\Gamma$ & 0,95 \\
\hline
\end{tabular}

Таблиця 1

Гірничо-геологічні умови визначення параметра $\eta_{m} / m$

Примітка: *- немає даних. 
В умовах шахт «Глибока» та ім. 50-річчя СРСР на деяке збільшення відношення $\eta_{m} / m$ вплинуло відпрацювання кількох пластів (табл. 1).

У разі ведення очисних робіт на глибині понад 250 м значення $\eta_{m} / m$ не перевищують 0,6 , що підтверджує значне заниження загальної тривалості процесів зсуву підроблених порід та земної поверхні згідно із [4]. Ці рекомендації базуються на геометричних параметрах зон впливу очисних виробок для конкретної глибини та швидкості посування очисного вибою. Ураховуючи продовження процесу зсуву порід після припинення очисних робіт, вплив $v_{\text {оч}}$, очевидно, має зменшитися, а інших чинників зрости. Зміни співвідношення ступеня впливу окремих чинників підтверджуються експериментальними даними [27].

До головних чинників, що впливають на закінчення процесів зсуву порід та їх ущільнення після припинення очисних робіт, імовірно, можна віднести глибину ведення гірничих робіт, властивості міцності порід і потужність пласта, що розробляється.

Протягом останніх кількох десятків років на Донбасі вугільні пласти зазвичай відпрацьовували в низхідному порядку, тому в багатьох випадках земна поверхня до ведення очисних робіт на глибших горизонтах неодноразово підроблялася. На вищерозташованих горизонтах вугілля видобували 50-80 років тому.

Вплив наступних підробок через тривалий період на зміни параметрів мульд зрушення земної поверхні не вивчався. Досі відсутні експериментальні та теоретичні дослідження, на підставі яких можна було б оцінити спільну дію відпрацювання кількох пластів у різний час на стан земної поверхні. Знання розглянутих питань необхідне для розроблення заходів iз захисту об'єктів на земній поверхні й у гірничих виробках, а також вирішення інших завдань, що пов'язані із проявом гірського тиску і зрушенням підроблених порід.
Дослідження проводилися під час відпрацювання пластів $l_{2}{ }^{6}, l_{2}{ }^{H}, K_{7}{ }^{H}$ У різний час шахтою «Княгинінська» ДП «Донбасантрацит». Виймана потужність і середня глибина відпрацювання пластів відповідно становили 1,$25 ; 0,75 ; 0,75$ та 275; 280; 575 м; кут падіння - 3-6․ Виїмкові ділянки 5-ї та 6-ї східних лав по пласту $K_{7}{ }^{4}$ експлуатувалися в 1987-1988 pр. У підроблюваній ними області були очисні виробки по пласту $l_{2}{ }^{6}$, у яких 31936 по 1941 р. добували вугілля. Проміжок між відпрацюванням пластів від 46 до 53 років. Розрахункова тривалість процесів зсуву порід після їх підробки пластом $l_{2}{ }^{6}$ мала становити приблизно 13 місяців. Передбачалося, що ці процеси на початок виїмки пласта $K_{7}{ }^{\mu}$ завершилися і породи значно ущільнилися.

Профільна лінія I простягалася не в головному перерізі мульди зрушення, її проєкція практично збігалася з лінією падіння пласта. Графіки осідання реперів цієї профільної лінії показали (рис. 3), що процеси зсуву й ущільнення порід тривали через вісім років після їх підробки пластом $K_{7}^{\mu}$. Осідання над масивом вугілля пласта за чотири останні роки спостережень становило понад 100 мм. За весь період після підробки максимальне осідання земної поверхні досягло 175 мм і знаходилося над виробленим простором лав відпрацьованого пласта $l_{2}{ }^{6}$ у $1939-1941$ рр. Це свідчить про те, що виїмка пласта викликала активізацію зсуву раніше підроблених порід пластом $l_{2}^{6}$.

Більш суттєві осідання земної поверхні спостерігалися на реперах 31-61 профільної лінії II. Вона розташовувалась у головному перерізі мульди зрушення земної поверхні після відпрацювання 5-ї та 6-ї східних лав. Зафіксовано абсолютне максимальне осідання земної поверхні за період спостережень - 305 мм, а останні чотири роки - приблизно 200 мм (рис. 4). Експериментальні дані порівняли 3 розрахунковими параметрами осідання земної поверхні [4]. Розрахункові максимальні осідання земної поверхні в разі першочергового

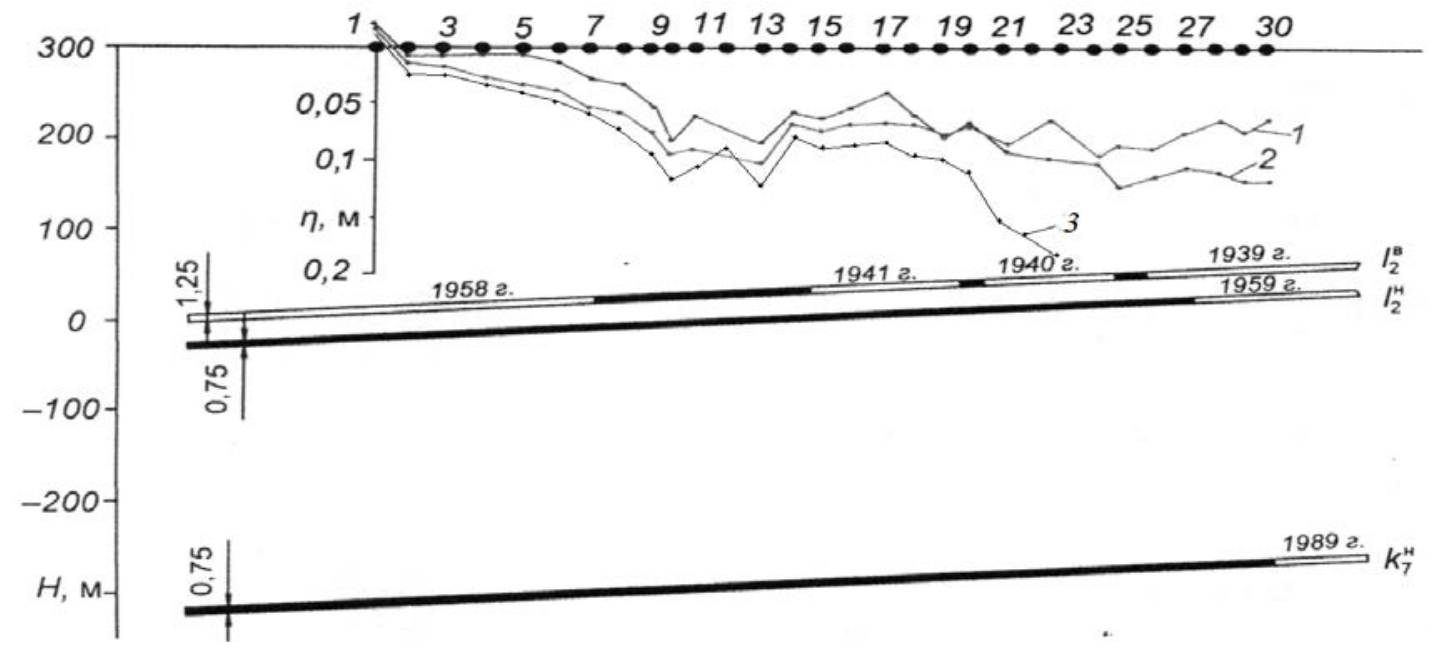

Рис. 3. Вертикальний переріз за профільною лінією реперів 1-30 в разі відпращювання 5-ї та 6-ї східних лав у 1987-1988 рр.

1, 2 і 3 -осідання реперів п на земній поверхні відповідно

13 квітня 1992 р., 26 квітня 1994 р. і 10 червня 1996 р. 


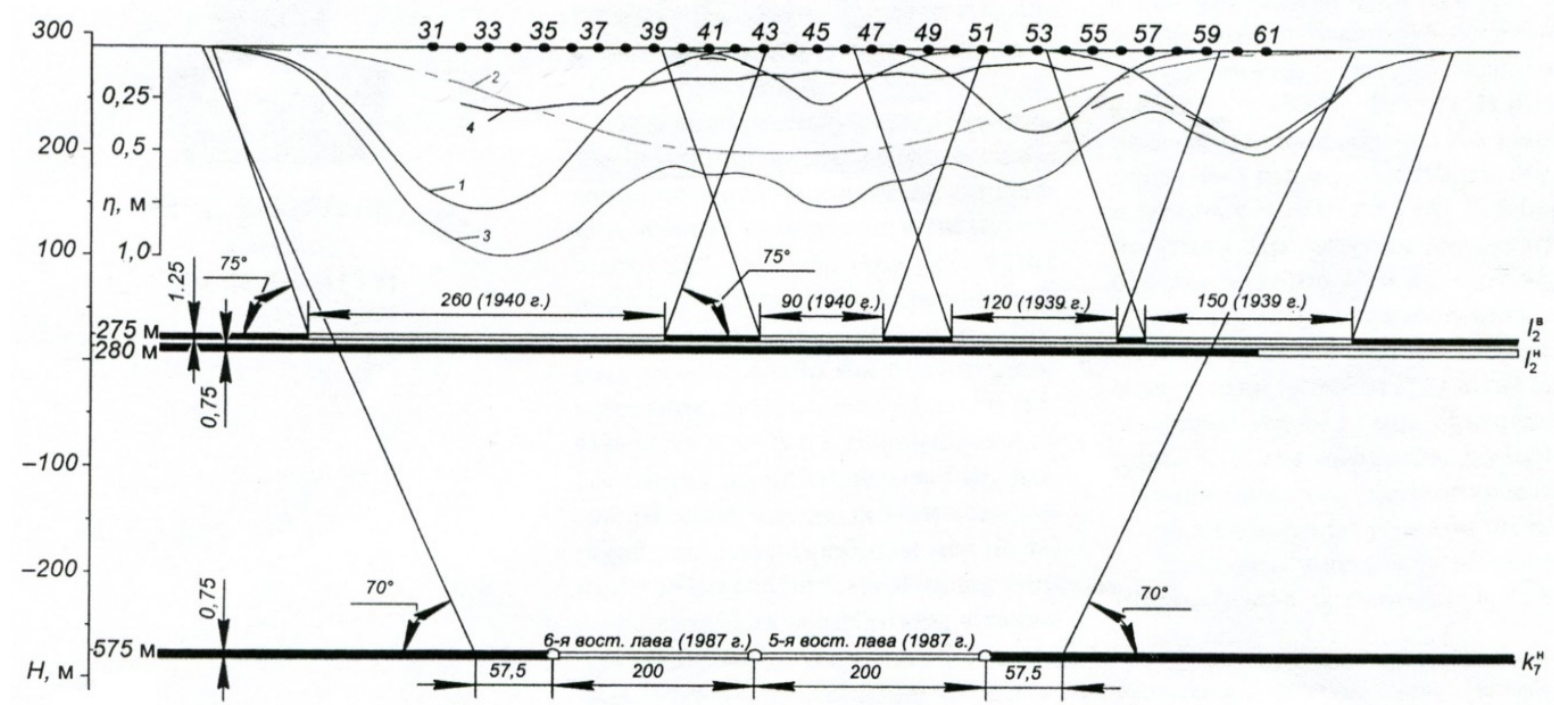

Рис. 4. Вертикальний переріз підробленої товщі порід за профільною лінією II, що сумішений із графіками осідань п реперів 31-61

1 і 2 - розрахункові мульди осідання земної поверхні під час ї̈ підробки пластами $l_{2}{ }^{8} i K_{7}{ }^{\mu}$;

3 - сумарна розрахункова мульда осідань земної поверхні за спільного відпрацювання пластів $l_{2}{ }^{B}$ та $K_{7}{ }^{\mu}$; 4 - фактична мульда осідання земної поверхні за повторної ї̈ підробки пластом $K_{7}{ }^{{ }^{2}}$.

відпрацювання пласта $l_{2}{ }^{6}$ над виробленим простором шириною 260 м становили 0,78 м, над виробленим простором шириною 90 м - 0,27 м, над виробленим простором шириною 120 м - 0,41 м, над виробленим простором шириною 150 м - 0,48 м (рис. 4).

Максимальне розрахункове осідання земної поверхні - 0,51 м, у припущенні першочергового відпрацювання пласта $K_{7}^{{ }^{t}}$, розташоване над серединою вироблених просторів 5-ї та 6-ї східних лав, а максимальне фактичне осідання (305 мм) відбулося над серединою виробленого простору пласта $K_{7}{ }^{{ }^{\prime}}$ довжиною 260 м у вертикальному перерізі. Це вказує на відмінні особливості формування мульди зсуву земної поверхні за її повторної підробки.

Вплив наслідків відпрацювання вугільних пластів на земну поверхню оцінюється нині лише з позицій охорони споруд та об'єктів від руйнування чи забезпечення їхнього функціонування в нормальному режимі [4].

Можливість відновлення природного стану земної поверхні (повного чи часткового) нормативними документами не розглядається. Знання цього питання необхідне для вирішення екологічних проблем. Наприклад, відновлення водного балансу поблизу земної поверхні та пов'язаного з ним рослинного світу.

Можливість відновлення гірського тиску в разі неповної підробки земної поверхні [28] дає підстави припускати, що через деякий час площа мульди в головному перерізі $\left(S_{\eta_{m}}\right)$ має досягти значення площі перерізу вийнятого пласта $\left(S_{m}\right)$. Для спрощення розрахунків криволінійні проєкції напівмульд замінили прямолінійними відрізками і визначили значення площ:

$$
\begin{gathered}
S_{\eta_{m}}=\eta_{m}^{\prime} B+\eta_{m}^{\prime} \cdot H \cdot \operatorname{ctg} \delta_{o}, \\
S_{m}=m \cdot B .
\end{gathered}
$$

Прирівнявши праві частини рівнянь (4 та 5), отримали формулу для визначення максимально можливого значення $\eta_{m}^{\prime}$ за відновлення вихідного природного стану земної поверхні:

$$
\eta_{m}^{\prime}=\frac{B \cdot m}{B+H \cdot \operatorname{ctg} \delta_{\mathrm{O}}^{\prime}}
$$

Відповідно до [25] процеси зсуву земної поверхні й ущільнення порід проходять три стадії - початкову, інтенсивного розвитку та загасання. Виходячи 3 технічних можливостей, спостереження [23; 25; 29-32] проводилися практично на стадії інтенсивного перебігу процесів. До початку спостережень фіксувалися суттєві осідання підроблених порід та земної поверхні $\left(\eta_{m}=93 \ldots 430 \mathrm{Mм}\right)$, а швидкість ï зсуву становила 5...68 мм/міс. Максимальні значення цих параметрів за період спостережень для різних об'єктів перебували відповідно в межах $100 \ldots 1600$ мм та від $5 \mathrm{mм} /$ міс до $100 \mathrm{мм} /$ добу. Повний період спостережень, залежно від завдань і гірничо-геологічних умов, становив від чотирьох до двадцяти місяців. Спостереження припинялися, коли середня швидкість осідання підроблених порід, земної поверхні йінших об'єктів зменшувалася до $5 . .60 \mathrm{mм} /$ міс. Процеси зрушення під час спостережень були далекі від завершення, що підтверджується незначними (табл. 2) значеннями $\eta_{m}$ щодо потужності пласта $\left(\eta_{m} / m=0,08 \ldots 0,82\right)$.

3 віддаленням від розроблюваного пласта величина максимального осідання порід і земної поверхні зменшується і становить деяку частку від потужності пласта $[23 ; 25 ; 29-32]$. Статистична обробка експериментальних даних [33] показала, що під час ведення очисних робіт на глибині приблизно 1000 м середнє значення $\eta_{m}$ дорівнює 0,15 м. Істотно зменшується і середня швидкість осідання порід та 
Відомості про умови проведення експериментів [23; 25; 29-32] та розрахункові дані про можливу тривалість процесів зсуву й ущільнення порід $\left(T_{o}\right)$.

\begin{tabular}{|c|c|c|c|c|c|c|c|c|c|}
\hline \multirow[b]{2}{*}{$\begin{array}{c}\text { Літературне } \\
\text { джерело }\end{array}$} & \multirow[b]{2}{*}{ Шахта, пласт } & \multirow[b]{2}{*}{$\mathbf{m}, \mathbf{M}$} & \multirow[b]{2}{*}{$h / H$, м } & \multirow[b]{2}{*}{$\begin{array}{c}\eta_{m} \\
\mathbf{M M}\end{array}$} & \multirow[b]{2}{*}{$\begin{array}{c}\eta_{m} / m, \\
\text { частки }\end{array}$} & \multirow[b]{2}{*}{ 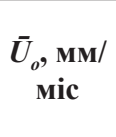 } & \multicolumn{3}{|c|}{ Тривалість процесів, міс } \\
\hline & & & & & & & $T_{6}$ & $\boldsymbol{T}_{\text {наб̆ }}$ & $\begin{array}{c}T_{o}= \\
T_{b}+T_{\text {наб }}\end{array}$ \\
\hline \multirow{2}{*}[31]{} & \multirow{2}{*}{ Нововолинська, $\mathrm{n}_{8}$} & 1,50 & 345 & 722 & 0,48 & 18 & 14,9 & 13,0 & 27,9 \\
\hline & & 1,50 & 345 & 755 & 0,50 & 25 & 9,4 & 13,0 & 22,4 \\
\hline$[32]$ & Павлоградська, $\mathrm{C}_{8}$ & $2,10 \ldots 2,20$ & 94 & 1600 & 0,74 & $400 * *$ & $(-0,3) *$ & 4,0 & 4,0 \\
\hline$[32]$ & № 1 Новогродівська, $\mathrm{k}_{8}$ & 1,00 & 33 & 820 & 0,82 & 60 & 2,2 & 5,5 & 7,7 \\
\hline \multirow{3}{*}[25]{} & \multirow{3}{*}{ Оріхівська, $\mathrm{k}_{2}$} & 1,70 & 520 & 465 & 0,27 & 15 & 44,9 & 9,0 & 53,9 \\
\hline & & 1,70 & 200 & 800 & 0,47 & 35 & 17,9 & 9,0 & 26,9 \\
\hline & & 1,70 & $220 \ldots 520$ & 400 & 0,24 & 30 & 33,7 & 9,0 & 32,7 \\
\hline \multirow{3}{*}[23]{} & \multirow{3}{*}{ Глибока, $\mathrm{h}_{6}$} & 1,15 & 541 & 800 & 0,70 & 17 & $(-1,7) *$ & 20,0 & 20,0 \\
\hline & & 1,15 & 541 & 720 & 0,63 & 36 & 1,4 & 20,0 & 21,4 \\
\hline & & 1,15 & 115 & 860 & 0,75 & 32 & 5,5 & 20,0 & 25,5 \\
\hline \multirow{3}{*}[30]{} & \multirow{3}{*}{ Шахтарська - Глибока, $\mathrm{h}_{8}$} & 1,30 & 1005 & 107 & 0,08 & 6 & 68,8 & 19,6 & 88,4 \\
\hline & & 1,30 & 1005 & 100 & 0,08 & 5 & 84,0 & 19,6 & 103,6 \\
\hline & & 1,30 & 1005 & 123 & 0,09 & 6 & 66,2 & 19,6 & 85,8 \\
\hline
\end{tabular}

Примітка: * - у подальших розрахунках прийнято $\mathrm{T}_{\mathrm{B}}=0 ;$ ** - середня швидкість осідання за період спостережень.

земної поверхні $(\bar{U})$ у разі віддалення підроблюваних об'єктів $(h)$ від пласта. Така залежність, у першому наближенні, задовільно описується рівнянням:

$$
\bar{U}=16399 \cdot h^{-1,06}, \mathrm{MM} / \mathrm{Mic} .
$$

Підтвердженням цьому є суттєве значення теоретичного кореляційного відношення $\mathrm{R}=0,79$, його достовірність $\mathrm{m}_{\mathrm{R}}=0,10$ та значимість $\mathrm{t}_{\mathrm{R}}=7,86$.

Якщо на стадії ведення очисних робіт у конкретних гірничо-гелогічних умовах визначено фактичні значення $\eta m$, то згідно з рівнянням (6), у разі закінчення процесів ущільнення підроблених порід, можна розрахувати гранично-можливу величину $\eta_{m}^{\prime}$.

За різницею цих величин, за допомогою даних про середню швидкість осідання підроблених об'єктів, на стадії згасання процесів зсуву $\left(\bar{U}_{o}\right)$ оцінили тривалість відновлення $\left(T_{6}\right)$ природного стану земної поверхні та порід:

$$
\mathrm{T}_{\mathrm{B}}=\frac{\eta_{m}^{\prime}-\eta_{m}}{\bar{U}_{\hat{\imath}}}, \text { мic. }
$$

Значення $\eta_{m}^{\prime}$ визначили за фактичними параметрами $B$ і $H$ та значеннями граничних кутів $\delta_{\hat{\imath}}^{\prime}$, що рекомендуються нормативними документами. Результати розрахунку можливого періоду відновлення природного стану підроблених порід та земної поверхні після закінчення очисних робіт $\left(T_{b}\right)$, а також загальної тривалості процесів $\left(T_{o}\right)$ наведено в таблиці 3 .

Залежно від гірничо-геологічних умов можливий період відновлення природного стану після закінчення очисних робіт $\left(T_{g}\right)$ перебував у широкому діапазоні. Виходячи з фізичних уявлень, головними чинниками, що впливають на тривалість відновлення вихідного стану, $є$ міцнісні властивості порід і глибина ведення очисних робіт $(H)$ або відстань від пласта, що розробляється, до підроблюваних об'єктів (h). Так, наприклад, в умовах шахти «Павлоградська» за глибини 94 м і низьких властивостей міцності вміщаючих порід природний стан відновлювався практично відразу після закінчення очисних робіт. У разі відпрацювання антрацитових пластів на глибоких горизонтах і більш міцних вміщуючих порід загальна тривалість процесів становила 7-10 років.

Наявні експериментальні дані та результати розрахунку загальної тривалості процесів зсуву й ущільнення порід $\left(T_{o}\right)$ дозволили встановити ï залежність від глибини $(H)$ ведення очисних робіт (відстань до підроблюваних об'єктів $h)$.

$$
T_{o}=0,085 \cdot H(h)+0,7, \text { мic. }
$$

Рівняння (9) характеризується високим значенням парного коефіцієнта кореляції $(\mathrm{r}=0,91)$, його значимістю $\left(\mathrm{t}_{\mathrm{r}}=17,4\right)$ та надійністю $\left(\mathrm{m}_{\mathrm{r}}=0,05\right)$. Це свідчить про можливість застосування залежності в першому наближенні у практичних розрахунках за глибини ведення очисних робіт понад сто метрів.

Головні висновки за результатами роботи:

- значення розмірів виробок, за яких починалося зрушення земної поверхні, перебували в діапазоні 23-187 м. Вони залежали від потужності пластів, що розробляються, глибини ведення гірничих робіт, міцнісних властивостей порід, що підробляються, і швидкості просування очисних вибоїв;

- фактична тривалість процесів зрушення порід, що підробляються, і земної поверхні значно перевищує рекомендовану нормативним документом. У разі відпрацювання антрацитового пласта вона становила понад десять років;

- максимальне осідання земної поверхні відбувається над серединою виробленого простору раніше відпрацьованих лав, що свідчить про активізацію зсуву порід через 40-50 років після їх первинної підробки. Після повторної підробки максимальне осідання земної поверхні переважно залежить від розмірів виробленого простору раніше відпрацьованих пластів;

- процеси, що визначають екологічні наслідки під час експлуатації вугільних шахт та після їх закриття, суттєво відрізняються один від одного. Під час експлуатації вугільних шахт цей вплив визначається 


\section{Блінова Н.К., Філатьєва Е.М., Скарга В.В.}

відкачуванням води 3 гірничих виробок і іï дренуванням 3 порід, які підробляються, що призводить до зниження рівня підземних вод. Ліквідація шахт викликає відновлення цього рівня у змінених умовах стану підроблених порід та рельєфу земної поверхні.

\section{ВИЗНАЧЕННЯ ПАРАМЕТРІВ ЗСУВУ..}

Перспективи використання результатів дослідження. Отримані результати необхідні для розроблення методики впливу діючих шахт на стан навколишнього середовища, що суттєво змінюється після лівідації шахт і їх затоплення.

\section{Література}

1. Фомин В.О. Прогнозирование изменения притока подземных вод в ликвидированную шахту. Уголь Украины. 2007. № 2. C. 31-33.

2. Сляднев В.А., Яковлев Е.А., Юркова Н.А. Шахтные воды как фактор техногенного риска изменения состояния геологической среды. Уголь Украиныл. 2007. № 3. С. 43-46.

3. Заборин М.С., Богун Л.Д., Воевода Б.И. Геодинамика и её влияние на восстановление гидрогеологических условий в пределах закрытых шахт. Уголь Украиныл. 2007. № 2. С. 31-33.

4. ГСТУ 101.001592226.001 - 2003. Правила підробки будівель, споруд і природних об'єктів при видобуванні вугілля підземним способом. Вид. офіц. Київ, 2004. 128 с.

5. Сдвижение горных пород при подземной разработке угольных и сланцевых месторождений / А.Г. Акимов и др. Москва : Недра, 1970. 224 с.

6. Иофис М.А., Шмелёв А.И. Инженерная геомеханика при подземных разработках. Москва : Недра, 1985. 248 с.

7. Петухов И.М., Линьков А.М. Механика горных ударов и выбросов. Москва : Недра, 1983. 280 с.

8. Фисенко Г.Л. Предельные состояния горных пород вокруг выработок. Москва : Недра, 1976. 272 с.

9. Ларченко В.Г. Стадии деформирования и зоны сдвижения подработанной толщи пород. Вестник Международной академии наук экологии и безопасности. 2001. № 1 (37). С. 127-130.

10. Озеров И.Ф. Сдвижение земной поверхности и геомеханические процессы в толще горных пород. Уголь Украины. 2001. № 5. С. 51-54.

11. Дубовик А.И., Филатьев М.В., Филатьева Э.Н. Инженерная геомеханика при отработке угольных пластов. Лисичанск : ДонГТУ, 2017. 250 с.

12. Ларченко В.Г. Факты, подтверждающие теорию механизма сдвижения толщи горных пород. Вестник Международной академии наук экологии и безопасности. 2002. Т. 7 . № 7 (55). С. 70-73.

13. Ставрогин А.Н., Протесеня А.Г. Прочность горных пород и устойчивость выработок на больших глубинах. Москва : Недра, 1985. $271 \mathrm{c}$.

14. Кулибаба С.Б., Рожко М.Д., Хохлов Б.В. Характер развития процесса сдвижения земной поверхности во времени над движущимся очистным забоем. Наукові праці Украӥнського держсавного науково-дослідногоі проєктно-конструкторського інституту гірничої геології, геомеханіки і маркшейдерської справи Начіональної академії наук України. 2010. № 7. С. 40-54.

15. Филатьев М.В. Влияние степени развития очистных работ на максимальное оседание земной поверхности. Уголь Украины. 2011. № 4. C. 12-16.

16. Аверин Г.А., Кирьязев Н.Н., Доценко О.Г. Влияние слоистости на оседание земной поверхности. Уголь Украины. 2010. № 10. C. 34-35.

17. Борзых А.Ф., Горовой Е.П. Влияние ширины выработанного пространства на активизацию сдвижения угленосного массива. Уголь Украиныл. 1999. № 9. С. 26-30.

18. Бабенко Е.В. Настройка модели для моделирования сейсмических событий техногенной природы. Проблеми гірського тиску / Донецький національний технічний університет. 2009. № 17. С. 67-93.

19. Ларченко В.Г. Влияние подземной разработки угольных пластов на состояние земной поверхности. Вестник Международной академии наук экологии, безопасности человека и природы. 1998. № 4 (12). С. 39-41.

20. Назаренко В.О., Пилипенко П.П. Розвиток осідань земної поверхні при відході лави від розрізної печі. Вісник Житомирського державного технологічного університету. 2012. № 1 (60). С. 126-129.

21. Епишев Г.П., Новичихин И.А. О возможности восстановления горного давления при неполной подработке земной поверхности. Уголь Украины. 1981. № 1. С. 7-8.

22. Исследование закономерностей сдвижения массива горных пород при отработке угольных пластов / Б.И. Мягкий и др. Уголь Украиныл. 1972. № 10. С. 11-12.

23. Выемка предохранительного целика под действующим вертикальным стволом / С.Б. Кулибаба и др. Уголь Украиныл. 1991. № 8. C. $28-31$.

24. Борзых А.Ф., Желтиков Ю.А. Прогнозирование максимальных оседаний пород в пределах подрабатываемой угленосной толщи. Уголь Украины. 1989. № 7. С. 9-10.

25. Опыт расконсервации околоствольных целиков с применением гармонической отработки пластов / С.Б. Кулибаба и др. Уголь Украины. 1989. № 7. С. 7-8.

26. Борзых А.Ф., Аверин Г.А., Князьков О.В. Прогнозирование максимальных оседаний пород подработанного угленосного массива. Вестник Международной академии наук экологии, безопасности человека и природы. 2004. Т. 9. № 7 (79). С. 34-38.

27. Борзых А.Ф., Тыняный В.И. Смещение пород на линии остановленного очистного забоя. Уголь Украиныl. 1985. № 5. С. $12-13$.

28. Епишев Г.П., Новичихин И.А. О возможности восстановления горного давления при неполной подработке земной поверхности. Уголь Украины. 1981. № 1. С. 7-8.

29. Опыт подработки автодорожного моста в Западном Донбассе / И.Е. Головчанский и др. Уголь Украины. 1983. № 12. С. 36-37.

30. Кулибаба С.Б., Голдин С.В., Крюченков А.Ф. Подработка вертикального ствола в условиях объединения Шахтёрскуголь. Уголь Украины. 1993. № 12. С. 39-41.

31. Бейлинов Я.И., Шевелев В.Б. Опыт подработки Нововолынского кирпичного завода. Уголь Украиныл. 1972. № 7. С. $51-52$.

32. Белан Н.А. Деформирование пород над очистной выработкой. Уголь Украиныл. 1984. № 3. С. 38-39.

33. Филатьев М.В., Антощенко Н.И., Сятковский С.Л. Влияние глубины ведения очистных работ на максимальное сдвижение земной поверхности при отработке угольных пластов. Школа підземної розробки : IV Міжнародна науково-практична конференція, 12-18 вересня 2010 р. Дніпропетровськ : НГУ, 2010. С. 39-45. 


\title{
ФІТОРЕМЕДІАЦІЯ ТЕХНОГЕННО ЗАБРУДНЕНИХ ГРУНТІВ З ВИКОРИСТАННЯМ ЕНЕРГЕТИЧНИХ КУАЬТУР
}

\author{
Борецька I.Ю. ${ }^{1}$, Джура Н.М. ${ }^{1}$, Романюк О.І. ${ }^{2}$ \\ ${ }^{1}$ Львівський національний університет імені Івана Франка \\ вул. Грушевського, 4, 79005, Львів \\ ${ }^{2}$ Відділення фізико-хімії горючих копалин Інституту фізико-органічної хімії і вуглехімії \\ імені Л.М. Литвиненка Національної академії наук України \\ вул. Наукова, 3А, 79022, м. Львів \\ ira.boretska2017@gmail.com
}

\begin{abstract}
У статті розглядаються проблеми антропогенної трансформації грунтів, забруднених важкими металами, радіонуклідами, пестицидами, нафтою і нафтопродуктами. Відновлення родючості грунтів та захист їх від забруднення є складними науковими завданнями сучасності, що потребують проведення комплексу фізико-хімічних і біологічних заходів. Важливим теоретично-прикладним аспектом є розроблення нових способів ремедіації для зниження процесів деградації грунтів за впливу хімічного забруднення. Проаналізовано екологічні особливості енергетичних культур: Camelina sativa L., Melilotus officinalis L., Brassica napus L., Switchgrass - Panicum virgatum L., Miscanthus giganteus L., Salix L., Pориlus L., які можна використовувати для фіторемедіації техногенно забруднених грунтів. Енергетичні рослини спеціально вирощують для використання як палива або для виробництва на їх основі біопалива. Вагомим аргументом для розвитку зеленої енергетики є те, що енергетичні культури здатні рости на малородючих грунтах і нагромаджувати за таких умов велику кількість біомаси. Коренева система за довготривалого вирощування культури на одному місці збагачує вміст органічної речовини у грунті, тим самим підвищуючи його родючість. Окреслено переваги енергетичних рослин як фіторемедіантів. Фіторемедіаційна технологія об'єднує багато методів, які базуються на процесах фітостабілізації (іммобілізації органічних і неорганічних забруднювачів шляхом адсорбції коренями рослин і перетворення полютантів у нерозчинні, малорухомі форми грунтового комплексу); фітоекстракції (поглинання полютантів коренями і переміщення у надземну частину, акумуляції у різних органах; використовують для очищення грунтів, забруднених важкими металами й радіонуклідами); фітовипаровування (вилучення токсикантів із грунту рослинами і виділення в атмосферу летких нетоксичних сполук); фітостимуляції (збільшення мікробного метаболізму у ризосфері). Узагальнено і систематизовано матеріал про використання енергетичних культур для відновлення деградованих грунтів. Наведено перелік енергетичних рослин та обгрунтовано доцільність їх вирощування як перспективну фітотехнологію підвищення агрономічної ефективності грунтів. Ключові слова: фіторемедіація, техногенно забруднені грунти, важкі метали, пестициди, радіонукліди, нафтозабруднені грунти, енергетичні культури.
\end{abstract}

Phytoremediation of technogenically contaminated soils by means of energy crops. Boretska I., Dzhura N., Romanyuk O.

The article considers the issue of anthropogenic transformation of soils contaminated with heavy metals, radionuclides, pesticides, oil and petroleum products. Restoring soil fertility and protecting it from pollution is a complex scientific task of our time, which requires taking physical, chemical and biological measures. An important theoretical and applied aspect is the development of new remediation methods to reduce soil degradation under the influence of chemical pollution. Ecological features of the following energy crops were analyzed: Camelina sativa L., Melilotus officinalis L., Brassica napus L., Switchgrass - Panicum virgatum L., Miscanthus giganteus L., Salix L., Populus L. They can be used for phytoremediation of technogenically contaminated soils. Energy crops are grown to be used as solid fuels or for the production of biofuels. A strong argument in favour of green energy is that energy crops can be grown on low-fertile soils and can accumulate a large amount of biomass under such conditions. In the process of longterm cultivation of such crops in one place, the root system enriches the amount of organic matter in the soil, thereby increasing its fertility. The benefits of energy plants as phytoremediants are outlined in the article. Phytoremediation technology combines many methods that are based on the processes of phytostabilization (immobilization of organic and inorganic pollutants which are absorbed by plant roots and transformed into insoluble, sedentary forms of the soil complex); phytoextraction (pollutants are absorbed by roots, moved to the aboveground part and accumulated in various organs; used for cleaning soils contaminated with heavy metals and radionuclides); phytovolatilization (toxicants are removed from the soil by plants and then the non-toxic volatile compounds are released into the atmosphere); phytostimulation (increase of microbial metabolism in the rhizosphere). The advantages of growing energy plants as a promising phytotechnology for restoring degraded soils and increasing their agronomic efficiency are substantiated. The article systematizes and generalizes information on the use of energy crops for the restoration of degraded soils. The list of energy crops is provided together with the justification of their cultivation as a promising phytotechnology used to increase the agronomic efficiency of soils. Key words: phytoremediation, technogenically contaminated soils, heavy metals, pesticides, radionuclides, oilcontaminated soils, energy crops.

Постановка проблеми. Відновлення деградованих земель є складним, а інколи неможливим завданням, оскільки втрата їх природної родючості тісно пов'язана 3 порушенням низки процесів і явищ, що відбуваються за участі рослин та інших грунтових організмів. Вирощування енергетичних культур на забруднених та деградованих грунтах - перспективний варіант уникнення використання орних земель сільськогосподарського призначення з такою метою, зменшення конкуренції між продовольчим та біоенер- 
Борецька I.Ю., Джура Н.М., Романюк О.I.

гетичним землекористуванням. Актуальним є пошук нових потенційних енергетичних культур для виробництва рідкого та твердого біопалива та дослідження фіторемедіаційних можливостей таких рослин на забруднених землях. Проте літературних даних та наукових досліджень про ремедіаційну здатність енергетичних культур сьогодні бракує. Не повною мірою вивчено й особливості використання енергетичних культур для фіторемедіації забруднених земель на фоні різних забруднювачів.

Актуальність дослідження. Відновлення родючості грунтів, охорона їх від забруднення є однією 3 найскладніших наукових проблем сучасності, що потребує проведення комплексу фізико-хімічних i біологічних заходів. Актуальним та важливим як у теоретичному, так і в прикладному аспектах $є$ розроблення нових способів ремедіації забруднених грунтів. Фіторемедіація є одним із найефективніших методів дезактивації забруднюючих речовин у грунті за допомогою рослин. Фіторемедіація не вимагає екскавації грунту, сприяє збереженню й відновленню навколишнього середовища, сприяє поліпшенню якості грунтів, захисту їх від ерозії, може застосовуватися на великих площах $[5,11,13,14]$.

Вагомим аргументом для розвитку зеленої енергетики є те, що енергетичні культури здатні рости на малородючих грунтах і нагромаджувати за таких умов велику кількість біомаси. Коренева система за довготривалого вирощування культури на одному місці збагачує вміст органічної речовини у грунті, тим самим підвищуючи його родючість. Після вегетації надземна біомаса рослин може підлягати відповідній переробці і бути додатковим джерелом кольорових металів, біопаливом для енергетичних цілей. Висока продуктивність біомаси енергетичних культур може перетворити технологію фіторемедіації у прибуткову галузь для біоенергетичної промисловості $[4,6,15]$.

Зв'язок авторського доробку із важливими науковими та практичними завданнями. Узагальнено і систематизовано матеріал про використання енергетичних культур для відновлення деградованих грунтів. Наведено перелік енергетичних рослин-фіторемедіантів та обгрунтовано доцільність їх практичного використання на забруднених територіях. Робота проводиться в межах науково-дослідної теми кафедри екології Львівського національного університету імені Івана Франка «Екологічний моніторинг абіотичних і біотичних компонентів середовища в умовах антропогенно-техногенного впливу на довкілля» (номер державної реєстраціï - 0119U002396).

Аналіз останніх досліджень і публікацій. Техногенне забруднення довкілля має глобальний характер. Господарська діяльність людини призвела до деградації земель, їх забруднення пестицидами, радіонуклідами та важкими металами. До земель несільськогосподарського призначення належать
ФІТОРЕМЕДІАЦІЯ ТЕХНОГЕННО ЗАБРУДНЕНИХ...

забруднені грунти поблизу гірничодобувних і металургійних виробництв; кар'єри, полігони твердих побутових відходів та інші маргінальні території, особливістю яких $є$ перевищення ГДК неорганічних (важкі метали: $\mathrm{Pb}, \mathrm{Cr}, \mathrm{Al}, \mathrm{Zn}, \mathrm{Ni}$ та ін.) та органічних (поліциклічні ароматичні вуглеводні, пірен, фенатрен, поліфенольні сполуки та ін.) сполук [7, 8, 11, 12, 14].

Серед основних джерел забруднення $є$ коксохімічне виробництво, установки спалювання викопного палива - ТЕС, ГЕС, котельні, чорна й кольорова металургія, хімічна промисловість, виробництво будівельних матеріалів, целюлозно-паперова, нафтохімічна, паливна промисловості, а також транспорт, комунальне й сільське господарство [4]. Нафтовидобувна і нафтопереробна галузі промисловості за наслідками впливу на природне середовище створюють багатопланові проблеми. Узагальнено матеріал про вплив полютантів на деградацію грунтів (табл. 1).

Ступінь деградації грунтів великий, а процес ремедіації - складний, дорогий і повільний. Грунтознавці стверджують, що для відновлення продуктивності виснаженого і пошкодженого грунту необхідні значні інвестиції. Здійснення рекультивації забруднених земель необхідно розпочинати з розроблення способів їх використання в агропромисловому виробництві, що дало би змогу швидко відновлювати такі землі та отримувати з них безпечну продукцію [2].

Виклад основного матеріалу. Очищення забруднених грунтів є надзвичайно важливою проблемою для України. Рослини здатні накопичувати ксенобіотики у біомасі, піддавати їх метаболічним перетворенням і сорбувати на своїй поверхні. Саме тому перспективним і сучасним методом для відновлення деградованих хімічно забруднених грунтів різного генезису у промислово розвинених країнах є фimoремедіація. Як динамічно розвинений напрям відновлення властивостей, екологічних функцій та якостей грунту фіторемедіація об'єднує значну кількість методів, які базуються на процесах: фітостабілізації (іммобілізації органічних і неорганічних забруднювачів шляхом адсорбції коренями рослин, часточками грунту або осадження в прикореневій зоні; передбачає перетворення полютантів у нерозчинні, малорухомі форми і подальше підтримання їх у такому стані завдяки сполукам, що виділяються кореневою системою рослин у грунтовий комплекс; запобігає переміщенню полютантів у грунті, грунтових водах або повітрі, зменшує ерозію, винос і вилуговування, сприяє відновленню екосистем і біорозмаїття); фітоекстракції (поглинання забруднювачів кореневою системою рослин разом із поживними речовинами і транслокація їх у надземні органи; по завершенні вегетації й транслокаційних процесів надземні органи рослин скошують і піддають відповідній переробці; використовують для очищення грунтів і водойм, забруднених важкими металами й радіонуклідами); фітостимуляції (збільшує мікробний метаболізм у рослинній ризосфері, 


\section{Вплив забруднення на грунтові екосистеми}

\begin{tabular}{|c|c|}
\hline Пестициди & $\begin{array}{l}\text { За дії пестицидів змінюється мікробіоценоз грунту, кількісні та якісні показники популяцій } \\
\text { грунтових мікроорганізмів, що може спричинити погіршення процесів самоочищення [19]. } \\
\text { Негативні наслідки застосування пестицидів: зменшення біологічної продуктивності, порушення } \\
\text { функціонування грунтових мікробіоценозів, накопичення залишків пестицидів та їх похідних у } \\
\text { поверхневих грунтових водах, перешкоджання відновленню родючості, зменшення харчової цінності } \\
\text { сільськогосподарської продукції тощо. Інтенсивність шкідливого впливу залежить від технології } \\
\text { застосування пестицидів, способів обробки грунту або рослин. Пестициди бувають не тільки } \\
\text { токсичними, а і стійкими. Найстійкішими є хлорорганічні пестициди. Період напіврозпаду деяких } \\
\text { пестицидів, що містять миш'як, свинець або ртуть, може затягтися до } 20 \text { років. У грунті відбувається } \\
\text { фотохімічне та біохімічне руйнування препаратів: випаровування в атмосферу, адсорбція частинами } \\
\text { грунту та гумусу, поглинання і трансформація грунтовими організмами, перехід у рослини тощо. } \\
\text { Сукупність цих процесів визначає стабільність агрохімікатів у грунті [20]. }\end{array}$ \\
\hline $\begin{array}{c}\text { Важкі метали } \\
\text { та їхні сполуки }\end{array}$ & $\begin{array}{l}\text { Найнебезпечніші забруднювачі грунту, які характеризуються значною стабільністю, високою } \\
\text { токсичністю, вираженими акумулятивними властивостями, що згубно впливають на живі організми. } \\
\text { Викиди відпрацьованих газів автомобільного транспорту містять токсичні сполуки кадмію і свинцю. } \\
\text { Забруднення грунтів вздовж автомагістралей цими важкими металами є тривалим і стійким [7]. } \\
\text { Сільськогосподарські угіддя забруднюються важкими металами внаслідок атмосферних викидів } \\
\text { підприємств, відходів тваринницьких ферм та застосування мінеральних добрив і пестицидів. } \\
\text { Органічні добрива - гній і компост - можуть містити велику кількість важких металів. У результаті } \\
\text { внесення у грунт органіки у ньому зростає концентрація свинцю, кадмію, міді, цинку, заліза, марганцю } \\
\text { [1, 7]. Значна кількість кадмію надходить у довкілля із продуктами горіння. Вміст кадмію у деревній } \\
\text { золі коливається у межах від } 2 \text { до } 30 \text { мг/кг, а в золі із соломи сягає } 10 \text { мг/кг. Значне забруднення кадмієм } \\
\text { атмосфери, грунту і води відбувається під час лісових пожеж. Оскільки зола має лужну реакцію, наявний } \\
\text { у їі складі кадмій нерозчинний у воді і погано засвоюється рослинами, проте він накопичується у грунті } \\
\text { і під час закислення стає доступним для рослин [1]. }\end{array}$ \\
\hline Радіо & $\begin{array}{l}\text { Особливістю Чорнобильської аварії є стійке, довготривале, нерівномірне, плямисте радіоактивне } \\
\text { забруднення великих територій цезієм, стронцієм і плутонієм. Одним із найважчих наслідків } \\
\text { аварії є радіоактивне забруднення сільськогосподарських угідь. Із користування було виведено } \\
\text { близько } 5 \text { млн га (50 тис. км²) земель, з яких } 3,5 \text { млн - орних і } 1,5 \text { млн га - ліси. Радіонукліди } \\
\text { стають складовими частинами загального колообігу речовин, мають здатність нагромаджуватися у } \\
\text { грунті, воді, організмах. Нині радіаційна ситуація в Україні на забруднених територіях порівняно } 3 \\
\text { раннім постчорнобильським періодом покращилася внаслідок: природного радіоактивного розпаду, } \\
\text { фіксації і перерозподілу радіонуклідів у грунті; проведення комплексу контрзаходів, спрямованих на } \\
\text { посилення біогеохімічних бар’єрів із метою блокування радіонуклідів у грунтах. Особлива небезпека } \\
\text { радіоактивно забрудненої продукції зберігається на пасовищах і сіножатях забруднених зон, що } \\
\text { розташовані на лучно-болотних і торфово-болотних перезволожених грунтах, для яких характерні } \\
\text { високі коефіцієнти переходу }{ }^{137} \text { Сs у рослини [12]. }\end{array}$ \\
\hline $\begin{array}{c}\text { Нафта і } \\
\text { нафтопро-дукти }\end{array}$ & $\begin{array}{l}\text { Нафта і нафтопродукти - це рідкі забруднювачі, які активно мігрують у грунті. Висока рухливість } \\
\text { полютантів визначає не тільки небезпеку їхнього поширення на значних площах під час виникнення } \\
\text { аварійних ситуацій, але й потрапляння в грунтово-підземні і поверхневі води. Шкідливий } \\
\text { екологічний вплив смолянисто-альфальтенових компонентів на грунтові екосистеми полягає не в } \\
\text { хімічній токсичності, а в порушенні водно-повітряного балансу, зменшенні вологоємності грунту, } \\
\text { блокуванні доступності мінеральних речовин унаслідок гідрофобізації поверхні грунтових частинок } \\
\text { важкими фракціями вуглеводнів, пригніченні біологічних процесів. Якщо нафта просочується } \\
\text { згори, її смолянисто-асфальтенові компоненти сорбуються у верхньому гумусовому горизонті, } \\
\text { міцно цементуючи його. При цьому зменшується поровий простір грунтів. Чорне забарвлення } \\
\text { нафтозабруднених грунтів призводить до надмірного поглинання сонячної радіації }[3,9,10] \text {. }\end{array}$ \\
\hline
\end{tabular}

що важливо для процесу очищення); фimoдеградаиіiі і фітотрансформації (розкладання ксенобіотиків до нетоксичних сполук, базується на значному потенціалі метаболізму і біорозмаїтті рослин); фітовипаровуванні (вилучення токсикантів із грунту рослинами і виділення в атмосферу летких неотруйних сполук); ризофільтрації (вилучення рослинами розчинених форм токсикантів із рідкої фази завдяки значній поглинальній здатності кореневої системи рослин); ризодеградаціï (розкладання ксенобіотиків у ризосферній зоні рослин за допомогою мікроорганізмів) $[4,11,13,14]$.
Актуальними залишаються питання розроблення методів екологічної ремедіації забруднених грунтів, пов'язаних зі здатністю різних фіторемедіантів оптимізувати та відновлювати природний стан (структуру та функціï) грунту, швидко формувати потужну кореневу систему та надземну вегетативну масу, проявляти високий коефіцієнт біоакумуляції. Широкий спектр видів рослин має потенціал для використання в біоенергетичних та фіторемедіаційних цілях на основі їх екосистемних властивостей для встановлення кращого зв’язку між фітотерапією грунту - віднов- 
Борецька I.Ю., Джура Н.М., Романюк О.I.

лення та виробництва біопалива. Особливої уваги заслуговують енергетичні культури - рослини, які спеціально вирощують для використання як палива або ж для виробництва на їх основі біопалива. Вони здатні накопичувати неорганічні забруднювачі в кореневій системі та розкладати стійкі органічні забруднювачі у грунті, тому ці види рослин $є$ оптимальними для фітостабілізації та фітодеструкції [15]. Найбільш поширеними енергетичними культурами $є$ : міскантус, верба, тополя, світчграс, сорго, еспарцет, рижій, буркун тощо.

Сьогодні досліджено велику кількість рослин із можливістю використання їх як енергетичних, але тільки деякі види досягли комерційного рівня та вирощуються на великих площах $[4,6$, 8]. Екологічні особливості деяких енергетичних

ФІТОРЕМЕДІАЦІЯ ТЕХНОГЕННО ЗАБРУДНЕНИХ...

культур наведемо у таблиці 2. Ми вивчаємо фіторемедіаційні можливості енергетичних культур на техногенно забруднених грунтах.

Попередні дослідження показали, що нафтозабруднені грунти пригнічували ростові показники Miscanthus giganteus. Застосування гуматів (гуміфілд форте і фульвітал плюс) - обприскування надземної частини у процесі вегетації - покращувало загальну життєздатність міскантусу в умовах нафтового забруднення: рослини активно нагромаджували біомасу, розвивали потужну кореневу систему і надземну частину, у листках збільшувався вміст фотосинтетичних пігментів. Проведені дослідження можуть бути використані для підвищення стресостійкості й урожайності міскантусу в умовах нафтового забруднення та під час розроблення фіторемедіаційних технологій відновлення нафтозабруднених територій $[9,10]$.

Таблиця 2

Екологічні особливості енергетичних культур Одно- та дворічні насінні трав'янисті рослини

\begin{tabular}{|c|c|}
\hline $\begin{array}{l}\text { Рижій посівний } \\
\text { (Camelina sativa L.) }\end{array}$ & $\begin{array}{l}\text { Олійна рослина родини капустяні з коротким вегетаційним періодом (80-85 днів), } \\
\text { можна вирощувати в усіх регіонах України, що дає змогу не лише ефективно } \\
\text { використовувати запаси вологи осінньо-зимових опадів, а й сформувати врожай. } \\
\text { Перевагою рижіює те, що він практично не заселяється шкідниками та не уражується } \\
\text { хворобами, а це дає можливість значно знизити рівень витрат на його вирощування; } \\
\text { невибагливий до родючості грунту [17]. }\end{array}$ \\
\hline $\begin{array}{l}\text { Буркун лікарський } \\
\text { (Melilotus officinalis L.) }\end{array}$ & $\begin{array}{l}\text { Дворічна трав’яниста рослина з родини бобових, найкращий азотфіксатор, добре } \\
\text { підходить для сівозмін півдня. Иого можна культивувати як однорічну рослину } \\
\text { (сходить, цвіте та плодоносить у рік посіву)і як дворічну-сходи рослини з’являються } \\
\text { навесні або восени, зимують і формують насіння на другий рік. Дворічний буркун } \\
\epsilon \text { більш продуктивним. Рослину можна використовувати як сидерат, а це збагачує } \\
\text { грунт азотом [17]. }\end{array}$ \\
\hline $\begin{array}{l}\text { Ріпак } \\
\text { (Brassica napus L.) }\end{array}$ & $\begin{array}{l}\text { Однорічна олійна рослина родини капустяні (Brassicaceae). Розрізняють } 2 \text { форми } \\
\text { ріпаку: ярий (кольза) й озимий. Ріпак озимий має основне значення, добре } \\
\text { адаптований до умов України, сидерат, може забезпечити збільшення органічної } \\
\text { речовини в грунті у кількості, еквівалентній внесенню 10-15 т/га гною. Має високу } \\
\text { врожайність і продуктивність, зимостійкий. Завдяки кореневій системі ріпаку } \\
\text { знижується інтенсивність ерозії грунтів, покращується структура грунту [18]. }\end{array}$ \\
\hline \multicolumn{2}{|r|}{ Багаторічні культури } \\
\hline $\begin{array}{l}\text { Світчграс, або } \\
\text { лозоподібне просо } \\
\text { (Switchgrass - } \\
\text { Panicum virgatum L.) }\end{array}$ & $\begin{array}{l}\text { Багаторічна трав’яниста злакова посухостійка культура, розмножується насінням, } \\
\text { може рости на всіх типах грунтів, невимоглива до вмісту вологи та поживних } \\
\text { речовин у грунті, стійка до шкідників та хвороб; корінь розвинений і може сягати до } \\
2 \text { м у глибину; добре переносить спеку в літні місяці; на одному місці може рости } \\
\text { протягом 10-15 років [6]. }\end{array}$ \\
\hline $\begin{array}{l}\text { Міскантус гігант- } \\
\text { ський (Miscanthus } \\
\text { giganteus L.) }\end{array}$ & $\begin{array}{l}\text { Багаторічна злакова культура, триплоїд має стерильний пилок, тому розмножується } \\
\text { вегетативно, кореневищами (ризомами); має дуже розгалужену кореневу систему, } \\
\text { тому його можна вирощувати на деградованих, піщаних, супіщаних грунтах; на } \\
\text { одному місці може рости протягом } 25 \text { років. Рослина містить 64-71\% целюлози, } \\
\text { вміст золи становить 2,2\%; погано переносить високу кислотність і високий рівень } \\
\text { грунтових вод [17]. }\end{array}$ \\
\hline $\begin{array}{l}\text { Енергетична верба } \\
\text { (Salix L.) }\end{array}$ & $\begin{array}{l}\text { Найбільш розповсюджена енергетична культура у світі: генотип верби - один із } \\
\text { найбагатших після рису, і це дає можливість створювати нові сорти та гібриди для } \\
\text { різноцільового використання. Продуктивність верби - } 10-15 \text { т/га (за сприятливих } \\
\text { грунтово-кліматичних умов урожайність зростає до } 25-30 \text { т/га) сухої маси в рік, що } \\
\text { перевищує за продуктивністю традиційні лісові насадження у } 14 \text { разів [8]. }\end{array}$ \\
\hline $\begin{array}{l}\text { ична тополя } \\
\text { L.) }\end{array}$ & $\begin{array}{l}\text { Багаторічна деревовидна енергетична культура, маловибаглива, росте практично } \\
\text { на всіх типах грунтів, порівняно швидко накопичує біомасу, погано переносить } \\
\text { підвищену кислотність грунту [8]. Останнім часом насадження тополі все активніше } \\
\text { використовують як регенеративне джерело енергії для виробництва біопалива. } \\
\text { Ïї деревина досить легка, широко використовується з технічною метою. }\end{array}$ \\
\hline
\end{tabular}


Багаторічні енергетичні культури здатні швидко утворювати надземну фітомасу та формувати потужну кореневу систему, що дозволяє їм акумулювати важкі метали із грунту, бути новими й важливими рослинами для фіторемедіації. Встановлено, що енергетичні культури, зокрема світчграс і міскантус, є гіперакумулянтами - активно поглинають важкі метали і частково акумулюють їх у своїй підземній та надземній частинах. По завершенні вегетації надземна вегетативна маса цих рослин може підлягати відповідній переробці, що є додатковим джерелом кольорових металів або вироблення біопалива для енергетичних цілей [11].

Висновки. Розроблення нових способів ефективної ремедіації техногенно забруднених грунтів вимагає вирішення питань методичного, технологічного і правового змісту та потребує розроблення і проведення комплексу фізико-хімічних і біологічних заходів, спрямованих на зниження інтенсивності процесів деградації таких грунтів. Фіторемедіація ефективна й економічно вигідна технологія відновлення грунту, заснована на використанні рослин i асоційованих із ними мікроорганізмів-деструкторів, які здатні видаляти токсичні речовини із середовища або перетворювати їх у безпечні метаболіти.

Вирощування енергетичних культур як фіторемедіантів на забруднених та деградованих грунтах вважаємо перспективним напрямом, що дозволить не лише знизити рівень деградації, а й підвищити агрономічну цінність цих грунтів. Висока продуктивність біомаси енергетичних культур може перетворити технологію фіторемедіації у прибуткову галузь для біоенергетичної промисловості.

\section{Література}

1. Брощак І.С., Венглінський М.О., Гаврилюк В.Б. Періодична доповідь про стан грунтів на землях сільськогосподарського призначення України. Львів, 2015. 94 с.

2. Грабак Н.Х., Будикіна Ю.І. Техногенно забруднені землі та шляхи їх безпечного використання в агропромисловому виробництві. Наукові праці : наук.-метод. журнал. Миколаїв : Вид-во ЧДУ ім. Петра Могили, 2014. Т. 232. Вип. 220. Екологія. С. 83-87.

3. Джура Н.М., Подан І.Ю. Екологічні наслідки довготривалого нафтовидобутку на Старосамбірському родовищі. Вісник Львівського університету. Сер. біол. 2017. Вип. 76. С. 120-127.

4. Кулик М.І., Падалка В.В. Розвиток біоенергетики на основі рослинного енергетичного ресурсу (на прикладі Полтавської області). Управління стратегіяли випереджсаючого інновачійного розвитку: монографія / за ред. к.е.н., доц. Н. С. Ілляшенко. Суми : Триторія, 2020. С. 109-118.

5. Ласло О.О. Відновлення порушених земель сільськогосподарського призначенння за допомогою біоремедіації. Вісник Начіонального університету водного господарства та природокористування : зб. наук. пр. Рівне, 2014. С. 94-100.

6. Мандровська С.М., Петриченко С.М., Герасименко Г.С., Гончарук Г.С., Литвенюк В.В. Перспективи вирощування світчграсу як альтернативного джерела енергії в Україні. Цукрові буряки. 2011. С. 13-14.

7. Параняк Р.П., Васильцева Л.П., Макух Х.І. Шляхи надходження важких металів у довкілля та їх вплив на живі організми. Біологія тварин. 2007. С. 1-6.

8. Пацула О.І., Фецюх А.Б., Буньо Л.В. Використання Salix viminalis L. для фіторемедіації грунтів, забруднених важкими металами. Екологічні науки. 2018. Т. 2, № 20. С. 101-106.

9. Подан I.І., Джура Н.М. Вплив нафтового забруднення і гуматів на ріст рослин міскантусу. Екологічні науки. 2019. № 2 (25). С. 182-186.

10. Подан I.I., Джура Н.М. Діагностика і фіторемедіація нафтозабруднених природних і штучних наземних екосистем Старосамбірського нафтового родовища / Scientific developments of Ukraine and EU in the area of natural sciences : Collective monograph. Riga : Izdevnieciba «Baltija Publishing», 2020. P. 2. C. 541-556 .

11. Самохвалова В.Л. Біологічні методи ремедіації грунтів, забруднених важкими металлами. Біологічні студї̈.2014. С.217-236.

12. Радіоактивно забруднені землі. Юридична енциклопедія : в 6 т. / за ред. кол. Ю.С. Шемшученко. Київ : «Українська енциклопедія» ім. М.П. Бажана, 2003. Т. 5.736 с.

13. Basumatary B., Saikia R., Bordoloi S. Phytoremediation of crude oil contaminated soil using nut grass Cyperus rotundus. Journal of Environmental Biology. 2012. Vol. 33, №5. P. 891-896.

14. Moubasher H.A., Hegazy A.K., Mohamed N.H., Moustafa Y.M., Kabiel H.F., Hamad A.A. Phytoremediation of soils polluted with crude petroleum oil using Bassia scoparia and its associated rhizosphere microorganisms. International Biodeterioration \& Biodegradation. 2015. Vol. 98, P. 113-120.

15. Pandey, Vimal Chandra \& Bajpai, Omesh \& Singh, Nandita, 2016. Energy crops in sustainable phytoremediation. Renewable and Sustainable Energy Reviews, Elsevier. 2016. Vol. 54(C), Р. 58-73.

16. Офіційний веб-ресурс ДУ «Інститут охорони грунтів України» URL : http://www.iogu.gov.ua/monitorynh-objektiv-dovkillya/ vazhki-metaly/

17. Офіційний веб-ресурс Biowatt. URL : http:/www.biowatt.com.ua/informatsiya/ bioenergetichni-kulturi-polissya/

18. Офіційний веб-ресурс компанії Агроресурс URL : http://www.agro.kr.ua/uk/ozimiy-ripak-si-marten

19. Офіційний веб-ресурс ООО «Информационное агентство Инфоиндустрия» URL https://infoindustria.com.ua/shlyah-u-zonu-ekologichnoyi-katastrofi/

20. Офіційний веб-ресурс Професійної Асоціації Екологів України (ПАEУ). URL https://ecolog-ua.com/news/pro-shkodu-pestycydiv 


\title{
ТЕОРЕТИЧНА ЕКОАОГІЯ
}

\author{
UDC 66.094.8: 661.5 \\ DOI https://doi.org/10.32846/2306-9716/2021.eco.6-39.12
}

\section{THERMAL CONVERSION OF NITROGEN OXIDES IN A FLOW REDUCING GAS}

\author{
Kuznyetsov S.I., Maljejev V.O., Sevenchenko O.O., Bezpalchenko V.M. \\ Kherson National Technical University \\ Beryslavske highway, 24, 73008, Kherson \\ ksieko@rambler.ru,mahnoveccs@gmail.com,oksana.semenchenko@gmail.com, bezpalchenkov@ukr.net
}

\begin{abstract}
Air pollution, even in very low doses, seriously damages human health. Nitrogen oxides combine with water vapor in the atmosphere to form acids, which in the form of acid rain fall into the soil and acidify it. We have investigated the process of thermal decomposition of nitrogen oxides in a laboratory setup in the presence of gaseous and solid reducing agents. The possibility of sanitary neutralization of nitrogen oxides by their thermal decomposition without the use of expensive catalysts used in industry has been shown. A method and design of a reactor for the thermal decomposition of nitrogen oxides $\left(\mathrm{N}_{\mathrm{x}} \mathrm{O}_{\mathrm{y}}\right)$ in the presence of reducing agents has been developed. The essence of the method we have developed is as follows: natural gas is burned in a reactor, and a mixture of nitrous gas with oxygen or air is used as an oxidizer for burning natural gas. The amount of natural gas supplied for combustion must be calculated so that the temperature of the gas mixture reaches $1100-1200^{\circ} \mathrm{C}$ and the minimum amount of oxygen remains in the gas. At this temperature, a significant part of the nitrogen oxides decomposes. After the reactor, in the presence of a solid reducing agent (coke), the final decomposition of the residual nitrogen oxides takes place. The degree of decomposition of nitrogen oxides in the first zone of the reactor in the presence of natural reducing gas is $85.0-88.7 \%$, and in the second zone in the presence of a reducing agent-coke is 97.4-99.5\%. The concentration of nitrogen oxides at the outlet of the laboratory installation does not exceed $0.02-0.05 \%$. To achieve the above indicators, the following technological regime must be observed: temperature in I and II zones $-1000{ }^{\circ} \mathrm{C}$, combustion gas consumption $-3-4 \%$ of the total volume of gas and air supplied for combustion, coke consumption $0.25 \mathrm{~kg}$ per $1 \mathrm{~kg}$ of oxides nitrogen entering the second zone of the reactor. Key words: air pollution, nitrogen oxides, thermal method, degree of purification.
\end{abstract}

Термічна конверсія оксидів азоту у потоку газу-відновника. Кузнєцов С.І., Малєєв В.О., Семенченко О.О., Безпальченко В.М.

Забруднення повітря навіть у малих дозах завдає серйозної шкоди здоров’ю людей. Оксиди азоту, з'єднуючись в атмосфері із парами води, утворюють кислоти, які у вигляді кислотних дощів потрапляють у грунт та закислюють його. Нами досліджено процес термічного розкладання оксидів азоту на лабораторній установці у присутності газоподібних та твердих відновників. Показано можливість санітарного знешкодження оксидів азоту шляхом їх термічного розкладання без застосування коштовних каталізаторів, що використовуються у промисловості. Розроблено метод та конструкцію реактора для термічного розкладання оксидів азоту $\left(\mathrm{N}_{\mathrm{x}} \mathrm{O}_{\mathrm{y}}\right)$ у присутності відновників. Сутність розробленого методу: у реакторі спалюється природний газ; у якості окислювача для спалювання природного газу застосовують суміш нітрозного газу з киснем або повітря. Кількість газу, що подається на спалювання, розраховується таким чином, щоб температура газової суміші досягала $1100-1200^{\circ} \mathrm{C}$ і в газі залишалася мінімальна кількість кисню. За цієї температури відбувається розкладання значної частини оксидів азоту. Після реактора у присутності твердого відновника (коксу) відбувається остаточне розкладання залишків оксидів азоту. Ступінь розкладання оксидів азоту у першій зоні реактора у присутності газу-відновника (метан) становить $85,0-88,7 \%$, у другій зоні у присутності коксу - 97,4-99,5\%. Концентрація оксидів азоту на виході лабораторної установки становить 0,02-0,05\%. Для досягнення наведених показників необхідно дотримуватися такого технологічного режиму: температура в I та II зоні$1000{ }^{\circ} \mathrm{C}$; витрата пального газу - 3-4\% від повного обсягу газу та повітря, що подається на згоряння; витрата коксу 0,25 кг на 1 кг оксидів азоту, що надходять у другу зону реактора. Ключові слова: забруднення атмосферного повітря, оксиди азоту, термічний метод, ступінь очищення.

Formulation of the problem. Air pollution, even in very small doses can bring serious harm to human health [1]. On air pollution, in particular, suffer breathing human organs. Nitrogen oxides, combining with water vapor in the atmosphere, form acids, which in the form of acid rain fall into the soil and acidify it [2]. Restoring fertility acidified soils requires great costs. Acid rain also has a negative impact on water bodies (lakes, rivers, bays, ponds). This process increases the acidity of water to a level at which flora and fauna die [3]. The bulk of man-made pollution is formed when organic fuel is burned. A significant part of these pollutants is accounted for by nitrogen oxides [4]. The neutralization of these emissions is a very urgent task.
Analysis of recent research and publications. There are various methods for cleaning gases from nitrogen oxides. Some of them have been introduced into production, others are under development and laboratory testing. The purification of waste gases from nitrogen oxides is based on oxidation, reduction and sorption processes. Oxidative methods are based on the preliminary oxidation of $\mathrm{NO}$ to $\mathrm{N}_{2} \mathrm{O}_{3}$ and $\mathrm{NO}_{2}$ followed by the absorption of oxidized nitrous gases by various sorbents $[5,6]$. Reduction methods are based on catalytic or thermal reduction of oxides to neutral substances. A wide variety of methods is associated with various technological processes in which nitrous gases 
are released into the atmosphere. These emissions differ in the number, content of nitrogen oxides, $\mathrm{NO}$ oxidation, oxygen and other impurities, temperature and other characteristics. There are optimal treatment methods for different emissions [7, 8]. At a high (more than $3 \%$ ) oxygen content in the purified gas, it is advisable to use thermal reduction. The most effective issue of neutralizing nitrogen oxides is solved in the production of nitric acid [9]. For this - of the process was developed and implemented a method of catalytic gas cleaning over a palladium catalyst. Nevertheless, of the catalytic - cue method associated with the installation of sophisticated equipment and the use of expensive catalyst [10]. The catalytic method of decomposition of nitrogen oxides is advisable for gases containing no more than $1 \%$ $\mathrm{NO}_{2}$ and up to $4-5 \%$ oxygen. In addition, catalysis

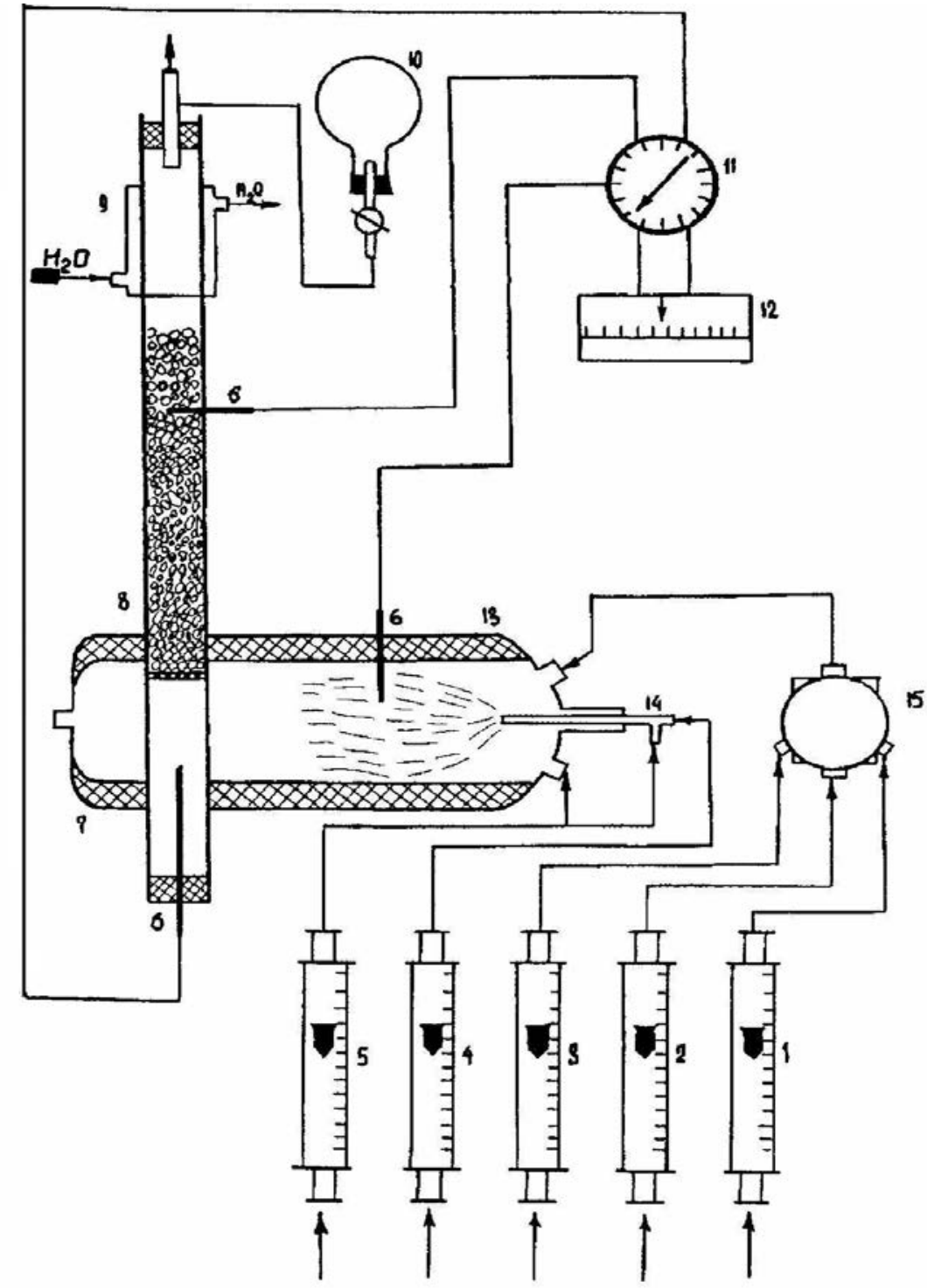

Fig. 1. Laboratory installation for thermal decomposition of nitrogen oxides 1 -rotameter (for $\mathrm{NO}$ ), 2 -rotameter (for $\mathrm{N}_{2}$ ), 3, 5 -rotameters (for air), 4 -rotameter (for $\mathrm{CH}_{4}$ ), 6 -thermocouple, 7 -reactor, 8 -layer coke, 9 - heat exchanger, 10 - flask, 11, 12 -thermometers,

13 - primary reaction zone, 14 - nozzle, 15 - mixer is effective at high pressures. In industry there are a large number of sources emitting nitrous gas into the atmosphere, containing up to $3-5 \%$ nitrogen oxides and up to $10-20 \%$ oxygen. These systems include off-gases from the production of oxalic acid, which contain 2.0-2.5\% nitrogen oxides and about $10 \%$ oxygen [11]. The catalytic method of neutralization is unacceptable for such systems. Other well-known methods, for example, alkaline ones, which are bulky and have a low degree of purification (about $60-70 \%$ ), also turn out to be ineffective under these conditions. Currently, the question of neutralizing nitrogen oxides in the production of oxalic acid remains open.

The purpose of the research was to develop a method for the thermal decomposition of nitrogen oxides, which ensures the purification of waste gases to maximum permissible concentrations.

Main material. A method and design of a reactor for the thermal decomposition of nitrogen oxides $\left(\mathrm{N}_{\mathrm{x}} \mathrm{O}_{\mathrm{y}}\right)$ in the presence of reducing agents has been developed .

The essence of the method we have developed is as follows: natural gas is burned in the reactor (first zone), and a mixture of nitrous gas with oxygen or air is used as an oxidizer for burning natural gas. The amount of natural gas supplied for combustion must be calculated so that the temperature of the gas mixture reaches $1100-1200^{\circ} \mathrm{C}$ and the minimum amount of oxygen remains in the gas. At this temperature, a significant part of the nitrogen oxides decomposes. Further, the gas mixture enters the second zone, where the decomposition of residual nitrogen oxides occurs in the presence of a solid reducing agent - coke.

To test the working hypothesis of the developed method of thermal decomposition of nitrogen oxides, a laboratory pilot installation was made, the diagram of which is shown in fig. 1.

The reactor for thermal decomposition of nitrogen oxides 7 is made of quartz glass. It consists of two zones: in the first zone, the gas mixture is heated and nitrogen oxides are reduced in the presence of a gaseous reducing agent 13; in the second zone, nitrogen oxides are reduced in the presence of a solid reducing agent - coke 8 . The reactor has a nozzle 14 for burning combustible gas and a connection for supplying air and nitrous gas. The installation is equipped with rotameters $1-5$ for measuring 
the flow rates of individual components of the gas mixture and thermocouples 6 with devices 11, 12 for measuring the temperature at various points of the reactor. In addition, a gas mixer 15, a heat exchanger 9 and a sampling point for gas analysis 10 are set in the installation.

Experimental technique. Air, nitrogen and nitrous gas were mixed in a certain proportion in the mixer 15 and fed into the reactor. Natural gas is also supplied here through the nozzle 14. As a result of natural gas combustion, the temperature in the first zone rises to $1100-1200{ }^{\circ} \mathrm{C}$. The concentration of nitrogen oxides at the inlet was determined by calculation by the number of dosed components. The second zone of the reactor 8 is loaded with coke. Hot gases passing through the second zone interact with coke, resulting in the decomposition of residual nitrogen oxides. The concentration of nitrogen oxides at the outlet was determined by the method of evacuated flasks. The degree of decomposition of nitrogen oxides was determined from the content of nitrogen oxides at the inlet and outlet.

The optimal technological mode of the process of thermal decomposition of nitrogen oxides, namely the consumption of combustible gas, temperature, the amount of solid reducing agent, and the volumetric velocity of gases, has been established experimentally. To reach a temperature of $1100^{\circ} \mathrm{C}$, a mixture of the following composition was fed into the reactor: air $-2.22 \mathrm{~m}^{3} / \mathrm{h}(94 \%)$, methane $-0.082 \mathrm{~m}^{3} / \mathrm{h}(3.61 \%)$, nitrogen oxides $-0.04 \mathrm{~m}^{3} / \mathrm{h}(1.99 \%)$. Total $-2,351 \mathrm{~m}^{3} / \mathrm{h}$ $(100 \%)$. After achieving stable operation of the reactor, the concentration of nitrogen oxides at the outlet was determined. Since the research was carried out in relation to waste gases from the production of oxalic acid, the content of oxides in them was maintained at the level of $2.0-2.5 \%$. To achieve such a percentage of nitrogen oxides in the gas mixture, $46 \mathrm{dm}^{3} / \mathrm{h}$ NO was supplied to the unit. The consumption of other components was controlled so that the temperature in the reactor did not drop below $1000-1100^{\circ} \mathrm{C}$. In this case, a minimum amount of oxygen was supplied to the reactor, since its presence in the gas is associated with the occurrence of a side reaction $\mathrm{C}+\mathrm{O}_{2}=\mathrm{CO}_{2}+\mathrm{Q}$ which entails additional consumption of coke.

It should be noted that the ratio between the components adopted by us ensures the achievement of the specified temperature. An increase or decrease in the consumption of components at a constant consumption of the combustible gas leads to a decrease in the temperature in the reactor and, consequently, to a violation of the operating mode of the installation. The results of studies on the thermal decomposition of nitrogen oxides in the first zone of the laboratory unit are shown in table 1.

From the data in the table it can be seen that the degree of decomposition of nitrogen oxides at their initial concentration in the gas mixture of $2.0-2.2 \%$ is $85.0-88.7 \%$. Subsequently, this gas is directed to the second zone of the reactor, where there is a complete decomposition of nitrogen oxides in the presence of a solid reducing agent - coke (table 2).

Table 1

Thermal decomposition of nitrogen oxides in the first zone of the reactor

\begin{tabular}{|c|c|c|c|c|c|}
\hline \multirow{2}{*}{$\begin{array}{c}\text { Test } \\
\text { number }\end{array}$} & \multirow{2}{*}{$\begin{array}{c}\text { Gas consumption, } \\
\mathbf{m}^{\mathbf{3} / \mathbf{h}}\end{array}$} & $\begin{array}{c}\text { The concentration of nitrogen oxides } \\
\text { in the gas mixture, \% }\end{array}$ & \multirow{2}{*}{$\begin{array}{c}\text { Decomposition of nitrogen } \\
\text { oxides, \% }\end{array}$} & $\begin{array}{c}\text { Temperature, } \\
\text { exit }\end{array}$ \\
\cline { 3 - 5 } & & entrance & $\mathbf{C}$ & 1000 \\
\hline 1 & 2.35 & 2.0 & 0.30 & 85.0 & 1000 \\
\hline 2 & 2.35 & 2.1 & 0.305 & 85.5 & 1000 \\
\hline 3 & 2.35 & 2.1 & 2.29 & 86.0 & 1000 \\
\hline 4 & 2.35 & 2.05 & 2.295 & 85.6 & 1000 \\
\hline 5 & 2.35 & 2.1 & 2.29 & 86.2 & 1000 \\
\hline 6 & 2.35 & 2.2 & 2.29 & 86.8 & 1000 \\
\hline 7 & 2.35 & 2.2 & 2.25 & 88.7 & 1000 \\
\hline 8 & 2.35 & 2.18 & 2.25 & 88.5 & \\
\hline
\end{tabular}

Data on the decomposition of nitrogen oxides in the second zone of the reactor

\begin{tabular}{|c|c|c|c|c|c|c|}
\hline \multirow{2}{*}{ № test } & \multirow{2}{*}{$\begin{array}{c}\text { Gas consumption, } \\
\mathbf{m}^{\mathbf{3} / \mathbf{h}}\end{array}$} & $\begin{array}{c}\text { The concentration of nitrogen } \\
\text { oxides in the gas mixture, \% }\end{array}$ & $\begin{array}{c}\text { Decomposition } \\
\text { in the second zone, } \%\end{array}$ & $\begin{array}{c}\text { Temperature, } \\
{ }^{\circ} \mathbf{C}\end{array}$ & $\begin{array}{c}\text { General degree } \\
\text { of decompo-sition, \% }\end{array}$ \\
\cline { 3 - 6 } & entrance & exit & & 1000 & 99.5 \\
\hline 1 & 2.35 & 0.300 & 0.01 & 96.6 & 1000 & 97.4 \\
\hline 2 & 2.35 & 0.305 & 0.05 & 98.3 & 1000 & 98.3 \\
\hline 4 & 2.35 & 2.290 & 0.03 & 90.0 & 1000 & 99.5 \\
\hline 5 & 2.35 & 2.295 & 0.01 & 96.5 & 1000 & 98.5 \\
\hline 6 & 2.35 & 2.290 & 0.01 & 96.5 & 1000 & 98.0 \\
\hline 7 & 2.35 & 2.290 & 0.04 & 86.0 & 1000 & 99.3 \\
\hline 8 & 2.35 & 2.250 & 0.01 & 92.0 & 1000 & 99.2 \\
\hline
\end{tabular}


From the data in table 2 it can be seen that the degree of decomposition of nitrogen oxides in the second zone is $97.4-99.5 \%$. The specific consumption of coke was $0.25 \mathrm{~kg}$ per $1 \mathrm{~kg}$ of nitrogen oxides entering the second zone. The concentration of nitrogen oxides at the outlet of the laboratory installation does not exceed $0.02-0.05 \%$.

Main conclusions. We have investigated the process of thermal decomposition of nitrogen oxides in a laboratory setup in the presence of gaseous and solid reducing agents. The degree of decomposition of nitrogen oxides in the first zone of the reactor in the presence of a reducing agent-natural gas is $85.0-88.7 \%$, and in the second zone in the presence of a reducing agent-coke - 97.4-99.5\%. The concentration of nitrogen oxides at the outlet of the laboratory installation does not exceed $0.02-0.05 \%$. To achieve the above indicators, the following technological regime must be observed: temperature in I and II zones $-1000{ }^{\circ} \mathrm{C}$, combustion gas consumption $-3-4 \%$ of the total volume of gas and air supplied for combustion, coke consumption $0.25 \mathrm{~kg}$ per $1 \mathrm{~kg}$ of oxides nitrogen entering the second zone of the reactor. The possibility of sanitary neutralization of nitrogen oxides by their thermal decomposition without the use of expensive catalysts used in industry is shown.

Prospects for the use of research results. Investigations carried out in laboratory conditions have shown the high efficiency of the method of thermal decomposition of nitrogen oxides in the neutralization of concentrated nitrous gases. The next stage of research will be the verification of the developed method in industrial conditions, for example, for cleaning the entire volume of waste gas in the production of oxalic acid.

\section{References}

1. Air Pollution / World Health Organization. - Geneva: Palais des Nations, 1998. 468 p.

2. Acid Rain, What It Is - How You Can Help. - Washington: DC, National Wildlife Federation, 1982.

3. Ігнатенко М.Г., Малєєв В.О., Пилипенко Ю.В. Основи економіки природокористування. Херсон : Олді-плюс, 2007. 312 с.

4. Кузнецов, И.Е. Оборудование для санитарной очистки газов : Справочник / И.Е. Кузнецов, К.И. Шмат, С.И. Кузнецов. К. : Техника, 1989. 304 с.

5. Кузнецов, С.И. Очистка отходящих газов известково-обжиговых печей Вестник ХНТУ. 2007. №3(29). С. $74-86$.

6. Кузнецов, С.И., Злотникова, К.Н. Нейтрализация оксидов азота. Proceedings of the Conference 2018 : The development of technical sciences: problems and solutions. Brno. C. 117-121.

7. Старк, С.Б. Газоочистные аппараты и установки в металлургическом производстве. М.: Металлургия, 1990. 400 с.

8. В.О. Малєєв, Кузнєцов С.І., Карманов В.В., Безпальченко В.М. Наукові основи раціонального використання ПРП території Херсонської області: монографія. Херсон, 2018. 336 с.

9. Кузнецов, И.Е. Новые методы очистки газов от окислов азота. Киев: Укр. НИИТИ. 1971. 42 с.

10. Резніченко Г.М., Бутенко А.М. Забезпечення захисту атмосферного повітря шляхом досконалення технології переробки вольфрамовмісної вторинної сировини. Техногенно-екологічна безпека. 2017. № 2. С. 61-66.

11. Кузнецов, С. И. Защита атмосферного воздуха от оксидов азота при производстве щавелевой кислоты. Матеріали Всеукраїнської науково-практичної конференції: Сучасні хімічні технологї̈: екологічність, інноваиії, ефективність. Херсон, 2017. С. 32-39. 


\title{
МОДЕАЬ ФОРМУВАННЯ МЕТОДІВ ОЦІНКИ ЕКОАОГІЧНИХ РИЗИКІВ ДАЯ ОКРЕМИХ СКААДНИХ СИСТЕМ
}

\author{
Матіс Є.O., Крот О.П. \\ Харківський національний університет будівництва та архітектури \\ вул. Сумська, 40, 61002, м. Харків \\ matis19ev@gmail.com; krot.olga@kstuca.kharkov.ua
}

\begin{abstract}
У статті розглянуто і систематизовано сучасні методичні підходи з оцінювання екологічності промислових підприємств і фактори впливу хімічної галузі, а саме метод ризик-аналізу, та проаналізовано економічні, екологічні і соціальні (економічний аспект ризик-аналізу визначається оцінкою рівня техногенного навантаження на НС у вигляді екологічних збитків; екологічний аспект ризик-аналізу визначається як імовірнісна характеристика реалізації настання або відсутності негативного впливу техногенних факторів на компоненти НПС і здоров'я населення; соціальний аспект ризик-аналізу полягає у дослідженні дії негативних факторів на стійкість промислових підприємств, рівень здоров'я населення) інструменти визначення рівня екологічної безпеки, які використовуються для оцінки впливу хімічної промисловості на навколишнє середовище та суспільство. Зроблена оцінка прямих збитків від техногенного явища та визначення наслідків від екологічних збитків. Методика буде цікава фахівцям у галузі екології, хімії та суміжних наук. Дослідження наводить на думку про необхідність створення нового підходу до комплексної оцінки екологічності системних об'єктів. Оцінку діяльності хімічних підприємств за екологічною і соціальною складовими частинами пропонується проводити на основі методу ризик-оцінки. Актуальним науково-практичним завданням екологічної оцінки виробництва хімічної галузі є розроблення інформаційно-алгоритмічного забезпечення оцінювання екологічності і безпечності промислових об’єктів на основі удосконалення теоретичних, методичних положень комплексного екологічного аналізу щодо стану діяльності підприємств. Поставлені завдання можуть бути вирішені на основі поетапного формування системи інтегральної оцінки екологічності з урахуванням ризику негативних порушень у соціальній, економічній і екологічній системі, що дасть змогу надати загальну характеристику впливу на об’єкти НПС і встановити небезпечні ризик-фактори для здоров'я населення. Комплексний підхід у дослідженні рівня екологічності промислових підприємств дає змогу обгрунтувати методичні засади для врахування екологічних, економічних і соціальних показників в управлінні якістю НПС. Ключові слова: екологічні ризики, методика багатокритеріальної оцінки, хімічні підприємства, екологічна стійкість.
\end{abstract}

Model of assessment environmental risks methods formation for individual complex systems. Matis Y., Krot $\mathbf{O}$.

The article considers and systematizes modern methodological approaches of assessing the environmental friendliness of industrial enterprises and factors influencing the chemical industry, being more specific it is the method of risk analysis and we have analyzed economic, environmental and social (economic aspect of risk analysis is determined by assessing the level of man-made impact in the form of environmental damage; environmental aspect of risk analysis is defined as the probable characteristics of the occurrence or absence of negative impact of man-made factors on natural environment and public health, the social aspect of risk analysis is to study the impact of negative factors on the sustainability of industrial enterprises, levels of environmental safety) which are used to assess the impact of the chemical industry on the environment and society. The estimation of direct losses caused by the technogenic phenomenon and determination of consequences of ecological damages has been made. The method will be of interest to specialists in the field of ecology, chemistry and related sciences. The study suggests the need to create a new approach to comprehensive assessment of the environmental friendliness of system facilities. It is proposed to evaluate the work of chemical enterprises in terms of environmental and social components on the basis of the risk assessment method. An urgent scientific and practical task of environmental friendly assessment of the chemical industry is the development of information and algorithmic assessment of environmental friendliness as well as safety of industrial facilities based on improving the theoretical and methodological provisions of comprehensive environmental analysis of the state of enterprises. The set tasks can be solved on the basis of step-by-step formation of the system of integrated environmental assessment taking into account the risk of negative infringements in the social, economic and ecological system, that will enable to give general characteristic of impact on natural environment and define risk-factors for public health. An integrated approach to the study of the level of environmental friendliness of industrial enterprises allows to substantiate the methodological principles for taking into account environmental, economic and social indicators in the quality management of natural environment. Key words: environmental risk, multi-criteria assessment methodology, chemical industry, ecological sustainability.

Постановка проблеми. Оцінка екологічних ризиків промислового об'єкта розраховується для визначення небезпек, отримання якісних та кількісних показників рівнів та наслідків дії небезпечних і шкідливих факторів на об'єкти впливу та визначення ймовірності наслідків для попередження несприятливих подій і для обгрунтування управлінських рішень щодо зменшення рівня ризику. Процедура оцінки екологічних ризиків полягає у виконанні взаємопов'язаних етапів та має три найважливіші складники, такі як: ідентифікація небезпек, оцінка ризику впливів та характеристика ризику (рис. 1) [1, с. 488; 2, с. 1141].

У загальному визначенні екологічний ризик це імовірність несприятливих для НС наслідків від будь-яких змін у природних об'єктах.

Прийняття управлінського рішення щодо зниження рівня екологічного ризику пов'язано 3 імовірністю 
виникнення техногенних аварій, що завдають істотної шкоди природному середовищу і здоров'ю людей.

Під час визначення екологічного ризику вихідною інформацією $є$ дані про порушення стану, функціональності об'єкта, небезпечні антропогенні явища та процеси; рівень захворюваності населення за умови прояву небезпечних явищ.

Відповідно до завдань сталого розвитку ризик розглядається у трьох аспектах - економічному, соціальному й екологічному [3, с. 111].

Економічний аспект ризик-аналізу визначається оцінкою рівня техногенного навантаження на НПС у вигляді екологічних збитків.

Для конкретного стану об'єкта навколишнього середовища визначають ступінь негативного впливу 3 урахуванням небезпечних факторів дії на об'єкт i на його складники, що становить екологічний аспект ризик-аналізу.

Екологічний ризик є імовірнісною характеристикою визначення негативного впливу техногенних факторів на компоненти НПС і здоров'я населення (екологічний аспект).

Соціальний аспект ризик-аналізу полягає у дослідженні дії негативних факторів на стійкість природнотериторіальних комплексів (ПТК), рівень здоров'я населення. Визначення ризику проводиться з урахуванням стану і процесів у системі дослідження, враховуються наслідки впливу техногенного об'єкта на складники НПС і людину.

Оцінка екологічного ризику має комплексний характер, заснований на різнорідних даних. Для розрахунку оцінки необхідно визначити структуру збитків, факторів, що їх викликають, і привести всі показники до єдиної нормованої шкали оцінок. Структура екологічного ризику становить ієрархічну модель, початкова вершина якої відповідає комплексній оцінці ризику, висячі вершини - різним очікуваним збиткам за видами факторів, що їх викликають. Кожній дузі у відповідність ставиться ймовірність виникнення цього типу збитку (рис. 2).

Ієрархічна модель оцінки екологічного ризику враховує вплив основних компонентів навколишнього середовища: атмосферного повітря (ЗА), води (3В), грунту (ЗГ). Для отримання комплексної оцінки ризику необхідно привести значення показників збитку до єдиної дискретної шкалою оцінок за п'ятирівневою шкалою, яка включає такі показники збитку:

$$
\mathrm{U}=\left\{\mathrm{u}_{1}, \mathrm{u}_{2}, \mathrm{u}_{3}, \mathrm{u}_{4}, \mathrm{u}_{5}\right\},
$$

де $\mathrm{u}_{1}-$ несуттєвий; $\mathrm{u}_{2}-$ малий; $\mathrm{u}_{3}-$ середній; $\mathrm{u}_{4}-$ великий; $\mathrm{u}_{5}$ - катастрофічний.

Визначення показників негативного впливу грунтується на аналізі чинників, що їх викликають. Для цього проводиться вимірювання концентрацій забруднюючих речовин, нормування оцінок відповідно до функціоналу нормування величин або визначення інтегральних показників.

У результаті формується комплексна оцінка:

$$
K^{*}=\sum_{i}\left[C_{i}^{*}, O_{i}^{*}, g_{y i}\right], i \in I_{s},
$$

де $C_{i}^{*}-$ значення концентрації; $O_{i}^{*}-$ проста оцінка, що визначається стандартними методиками (індекс забруднення атмосфери (IЗА), індекс забруднення грунтів (ІЗГ), питомий комбінаторний індекс забруднення води (ПКІЗВ)); $I_{s}$ - множина індексних характеристик; $\mathrm{g}_{\mathrm{yi}}-$ вага показника.

Екологічний ризик визначається як імовірність настання несприятливої події з урахуванням його наслідків, викликаних небезпечними природними або антропогенними факторами протягом певного

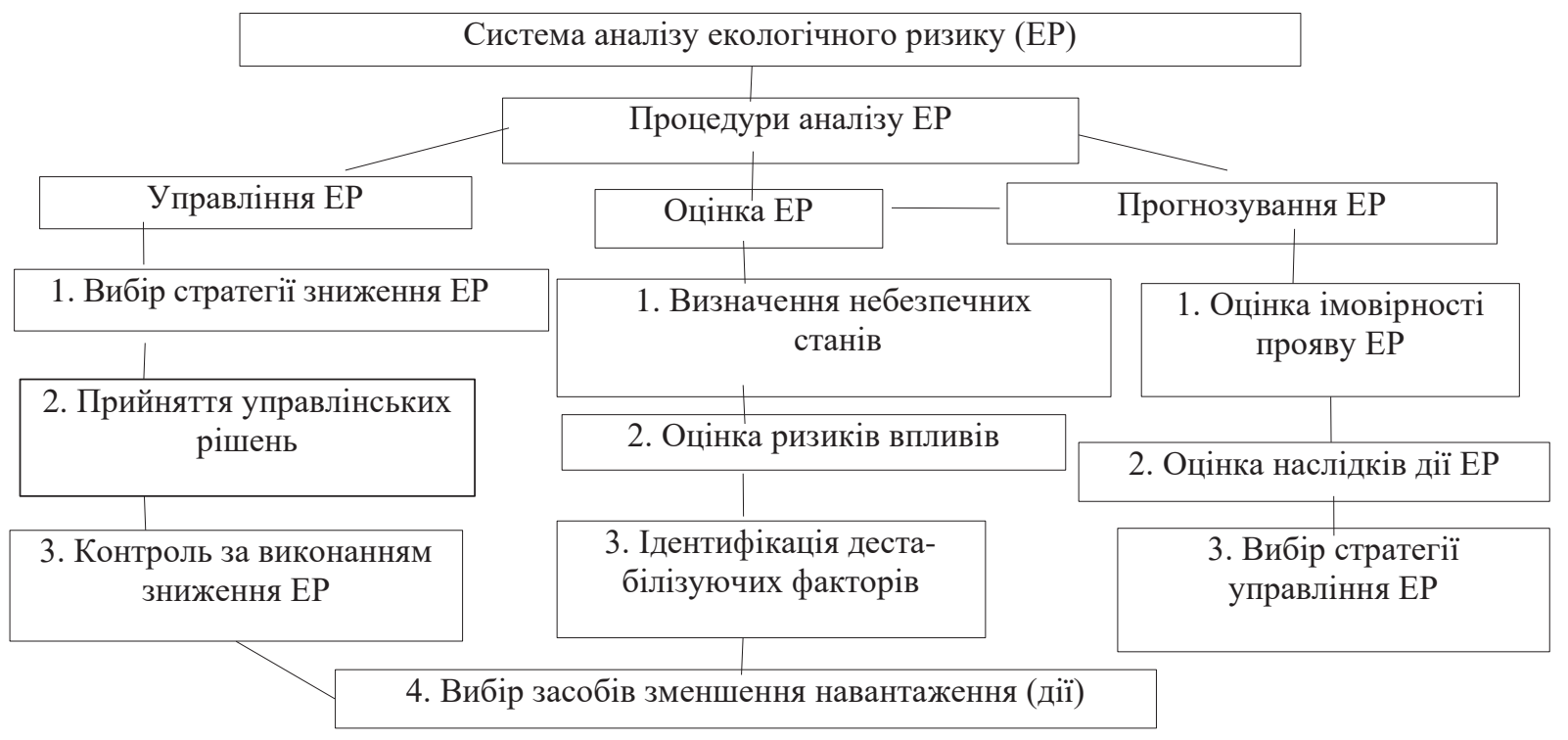

Рис. 1. Схема аналізу ризику 


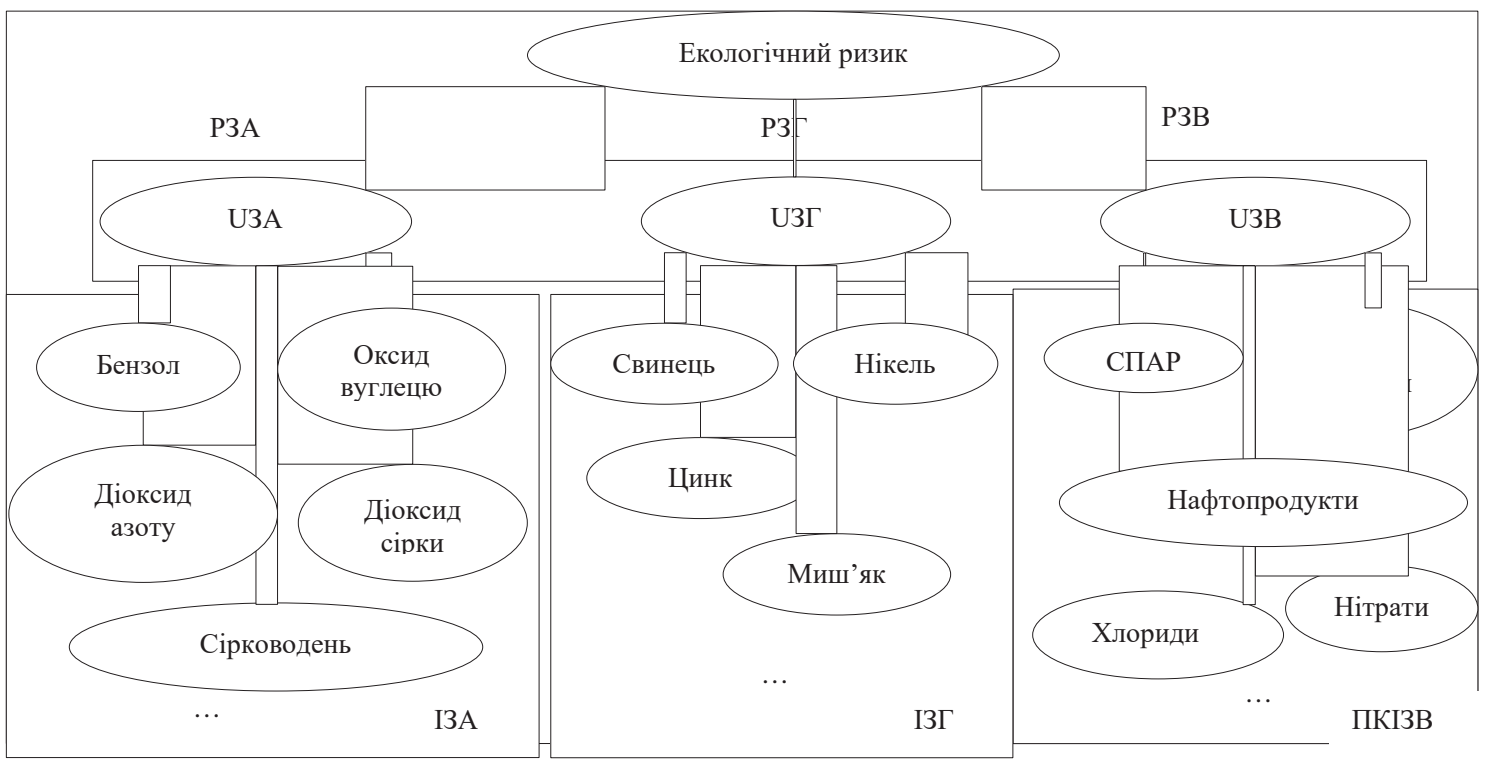

Рис. 2. Ієрархічна модель оцінки екологічного ризику

Таблиця 1

Заходи щодо запобігання шкідливому впливу за категоріями екологічного ризику

\begin{tabular}{|c|c|c|}
\hline Категорія ризику & Оцінка & Заходи \\
\hline Незначний & $1-3$ & Заходи не потребуються \\
\hline Малий & $4-6$ & Заходи не обов'язкові. За ситуацією треба стежити, щоб ризик був керованим \\
\hline Середній & $7-9$ & $\begin{array}{c}\text { Необхідно здійснити заходи щодо зниження ризику. Якщо ризик має серйозні наслідки, } \\
\text { необхідно більш точно обчислити вірогідність небезпечної події }\end{array}$ \\
\hline Високий & $10-16$ & Обов'язкові термінові заходи щодо зниження ризику \\
\hline Катастрофічний & $17-25$ & $\begin{array}{c}\text { Обов'язкові заходи щодо ліквідації ризику. Робота в умовах ризику повинна бути негайно } \\
\text { припинена і відновлена тільки після ліквідації ризику }\end{array}$ \\
\hline
\end{tabular}

періоду часу. Імовірність настання небезпечної події і виникнення збитків визначається на основі статистичних даних. П'ятирівнева шкала рівня ймовірності виникнення збитків включає такі показники:

$$
\mathrm{P}=\left\{\mathrm{p}_{1}, \mathrm{p}_{2}, \mathrm{p}_{3}, \mathrm{p}_{4}, \mathrm{p}_{5}\right\}
$$

де $\mathrm{p}_{1}$ - практично виключено; $\mathrm{p}_{2}$ - малоймовірно; p3 - ймовірно; p4 - можливо; p5 - неминуче. Оцінка екологічного ризику здійснюється за видами збитку відповідно до матриці ризику. Матриця ризику показує залежність рівня ризику від співвідношення ймовірності події та тяжкості шкоди (рис. 3).

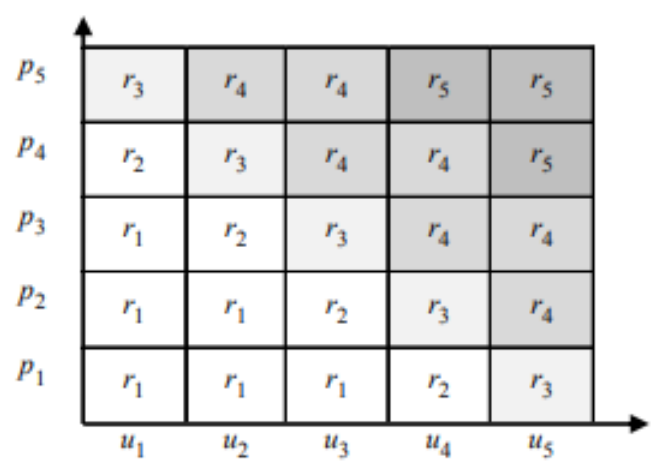

Рис. 3. Матриця екологічних ризиків
Залежно від отриманого значення оцінки введені такі категорії ризиків: $\mathrm{R}=\left\{\mathrm{r}_{1}, \mathrm{r}_{2}, \mathrm{r}_{3}, \mathrm{r}_{4}, \mathrm{r}_{5}\right\}$, де $r_{1}$ - незначний ризик; $r_{2}$ - малий ризик; $r_{3}$ - середній ризик; $\mathrm{r}_{4}-$ високий ризик; $\mathrm{r}_{5}-$ катастрофічний ризик. Залежно від розрахованого значення ризику визначається необхідність проведення заходів щодо запобігання шкідливого впливу на об'єкти НПС або ліквідації наслідків відповідно до таблиці 1.

Кількісна міра ризику може визначатися абсолютним або відносним рівнем втрат. В абсолютному вираженні ризик може визначатися величиною можливих втрат у натуральному (фізичному) або вартісному вираженні. У відносному вираженні ризик визначається як величина можливих втрат, яка порівнюється з базовими (фоновими) значеннями (повсякденний ризик смерті для людини оцінюється величиною дії на людину за рік або інший час), відсоток біологічних видів екосистеми, на яких позначиться шкідливий вплив). Таким чином, екологічний ризик одночасно враховує дві характеристики несприятливого події - ймовірність його настання і величину завданої шкоди, тобто $\epsilon$ комплексним показником. Він відображає інформацію про середні збитки, які об'єкт понесе при постійній стратегії поведінки в тих чи інших умовах розвитку негативної дії. 3 точки зору кількісної оцінки поняття 
«екологічний ризик» може бути сформульовано як відношення величини можливого збитку від впливу шкідливого екологічного фактора за певний інтервал часу до нормованої інтенсивності цього фактора.

У загальному випадку ймовірність природного i антропогенного впливу на біосферу визначається не одним, а безліччю факторів, найважливішими з яких є два:

- небезпечне явище (природні і техногенні катастрофи, різного роду порушення, забруднення НПС), що визначає ймовірність дестабілізації природної рівноваги, до якої адаптувалася людина;

- вразливість населення (ступінь підготовленості до цих явищ, реакція на них), що визначає ймовірність агресивного впливу факторів НПС безпосередньо на людину, яка може привести до погіршення здоров'я, смерті, зниження життєздатності популяції.

Ризики порушення стійкості й екологічності екосистем і ризики здоров'ю населення визначають на макро- і мікрорівні діяльності промислового об'єкта, враховуючи стаціонарність і динамічність природних процесів. Система оцінки детермінованого екологічного ризику використовує фіксовані значення токсичності і концентрацій забруднювачів у природних об'єктах. Показником детермінованого ризику є співвідношення токсичності та концентрації. Імовірнісний підхід відповідає класичному визначенню поняття ризику і дає змогу врахувати варіабельність і невизначеність розподілу негативного фактору впливу у НПС. Результатом оцінки такого ризику є розрахована ймовірність настання несприятливих наслідків за період негативної дії (рис. 4).

Загальна модель оцінки екологічного ризику на мікрорівні має вигляд:

$$
M=\left\{q_{p} \mid p=\overline{1, n}\right\},
$$

де: $M$ - множина чинників ризику; $q_{p}$ - чинник $p$-го типу ризику.

Для оцінки екологічного ризику доцільно використовувати системний аналіз багатофакторних ризиків для $i-x$ компонентів НПС в узагальненій формі, який обумовлює можливість адаптації до конкретних умов.

Кожний $j$-й показник $x_{i j} q_{p}-$ чинника ризику визначається інформаційним вектором $I_{i p j}$ :

$$
I_{i j}=\left\{x_{i j}\left|x_{i j}=x_{j q}\right| q=\overline{1, n_{i j}} ; x_{i j k} \in Z_{i j k} ; j \in N_{p}\right\} .
$$

Кожний чинник ризику $q_{p}$ характеризується показником антропогенного навантаження $H_{p}$ та природними чинниками.

Антропогенне навантаження як причина порушення стійкості екосистем пов'язується 3 ј-ою кількістю показників $h_{p j}[4$, с. 635]:

$$
H_{p}=\left\{h_{p j} \mid p \in N ; j=\overline{1, n_{p}}\right\}, N \in[1, n],
$$

де: $H_{p}$ - сучасний рівень антропогенного навантаження на $i$-й компонент НПС, що викликає р-й вид ризику появи негативних наслідків для екосистеми; $N$ - кількість чинників $p$-го виду ризику впливу антропогенного навантаження на $i-\breve{u}$ компонент НПС.

Безумовно, екологічний ризик $(P)$ на макрорівні як ймовірність порушення стійкості екосистем залежить від існуючого стану компонентів екосистеми $\left(K_{i}\right)$ та впливу сучасного або потенційного антропогенного навантаженням $\left(H_{i}\right)$ і може бути виражена функцією $P=f_{i}\left(K_{i}, H_{i}\right)$

В загальному вигляді ймовірність порушення екологічної стійкості та початку деградаційних процесів і-го компоненту навколишнього середовища під впливом негативних чинників визначається за формулою [4, с. 635]:

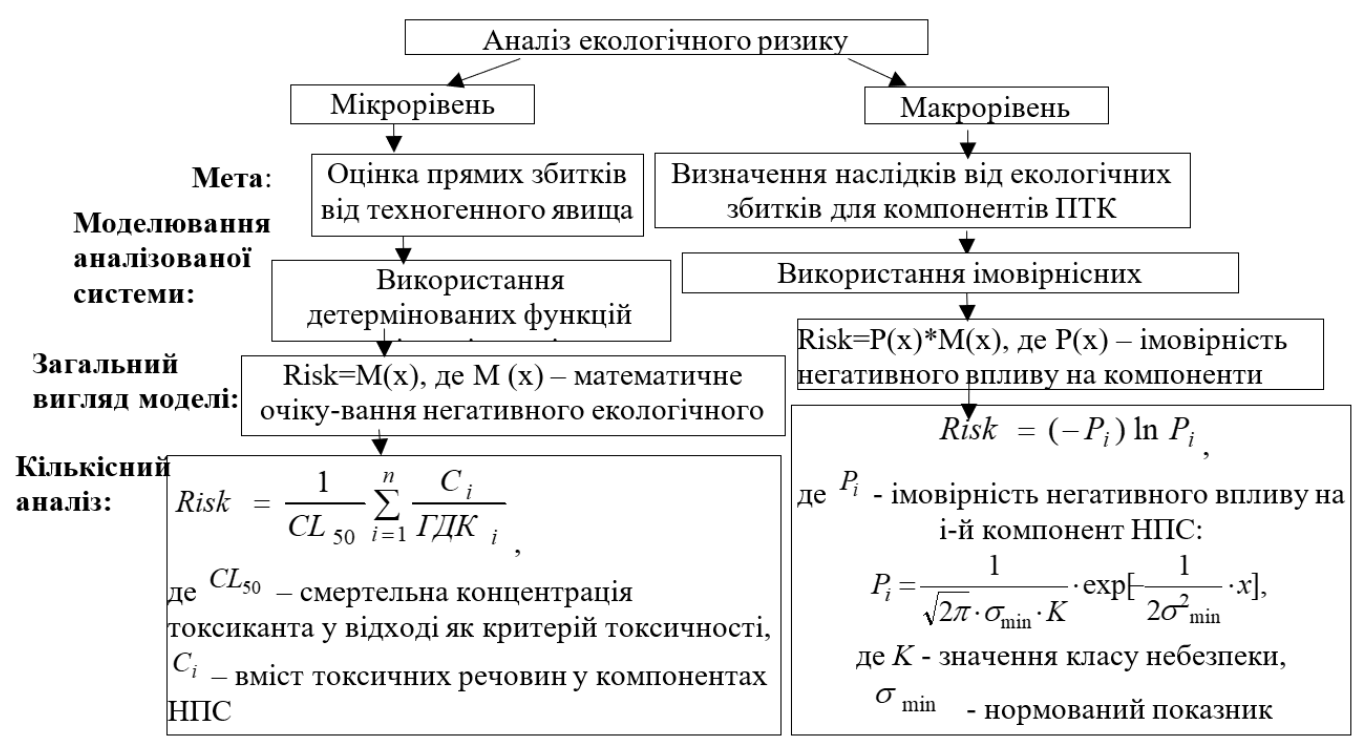

Рис. 4. Схема аналізу екологічного ризику на мікро- і макрорівнях 
Матіс 6.O., Крот О.П.

$$
P=1-\prod_{i=1}^{k}\left(1-P_{i}\right)
$$

де: $P_{i}$ - ймовірність порушення стійкості екосистем залежить від існуючого стану $i$ - $x$ компонентів екосистеми;

Оцінка екологічного ризику при сучасному стані $i$-го компоненту НПС визначається за формулою:

$$
P_{i}^{c}=f_{i}\left(K_{i}^{c}, H_{i}^{c}\right),
$$

де: $K_{i}^{c}$ - сучасний стан $i$-го компоненту навколишнього середовища;

$H_{i}^{c}$ - сучасний рівень антропогенного навантаження від впливу негативних чинників на $i$-й компонент навколишнього середовища.

Актуальність дослідження. Актуальним науково-практичним завданням екологічної оцінки виробництва хімічної галузі $є$ розроблення інформаційно-алгоритмічного забезпечення оцінювання екологічності і безпечності промислових об'єктів на основі удосконалення теоретичних, методичних положень комплексного екологічного аналізу щодо стану діяльності підприємств. Методика оцінки екологічного ризику на макрорівні (державному рівні) передбачає ідентифікацію регіонів (областей) України 3 найбільшим рівнем екологічної небезпеки на основі оцінки екологічного ризику стану компонентів довкілля та визначення пріоритетності екологічних проблем у регіонах 3 найбільшим рівнем екологічної небезпеки. На регіональному рівні необхідним є вирішення таких завдань: ідентифікація антропогенних чинників, що є причиною підвищеного екологічного ризику погіршення стану компонентів НПС; визначення переліку найбільш небезпечних підпиємств-природокористувачів; удосконалення регіональних програм ыз метою формування природоохоронних заходів щодо зниження екологічного ризику; науково-практичне обгрунтування рівня прийнятності екологічного ризику погіршення стану компонентів навколишнього природного середовища.

\section{МОДЕАЬ ФОРМУВАННЯ МЕТОДІВ...}

Зв'язок авторського доробку із важливими науковими та практичними завданнями. На мікрорівні (місцевому) впровадження методики оцінки екологічного ризику передбачає оцінку технологічних та економічних можливостей підприємства по реалізації заходів, спрямованих на мінімізацію ризику з урахуванням економічної оцінки екологічного ризику, що дозволяє визначити умови, за яких ризик залишається прийнятним, для чого він зіставляється із соціально-економічними перевагами [5, с. 21].

Викладення основного матеріалу. Економічна характеристика екологічного ризику надає таке трактування: ймовірність антропогенного впливу на біосферу залежить від різних чинників, кожен з яких володіє конкретною величиною ризику, необхідно для узагальнення оцінки екологічного ризику підсумувати ризики за окремими факторами:

$$
R=\sum_{n=1} P_{i} \times X_{i}
$$

де $\mathrm{R}$ - кількісна міра ризику (середній ризик), що виражається в тих же показниках, що і збитки (математичне очікування збитку), які об'єкт понесе при постійній стратегії поведінки за період (середньомісячний, середньорічний)); $\mathrm{P}_{\mathrm{i}}$ - ймовірність отримання збитків розміром $\mathrm{X}_{\mathrm{i}}$ в результаті настання несприятливої події; $\mathrm{X}_{\mathrm{i}}$ - величина збитку, виражена у відповідних показниках (прийнятих в економіці, як правило, у вартісному вираженні); n - число можливих варіантів збитків, які можуть мати місце при настанні несприятливої події, включаючи і нульову шкоду.

Таким чином, екологічний ризик є комплексною характеристикою і допускає оцінки можливих негативних наслідків для об'єкта управління і варіативну ймовірність їх настання. Цим він відрізняється від загальноприйнятої концепції оцінки екологічної безпеки, заснованої на законі Лібіха про мінімальне значення екологічних факторів.

Уявлення про ризик тих чи інших втрат (збитків) дає крива розподілу ймовірностей втрати (залежність ймовірності втрат від їх величини) (рис. 5). Ïї побудова являє собою складну задачу.

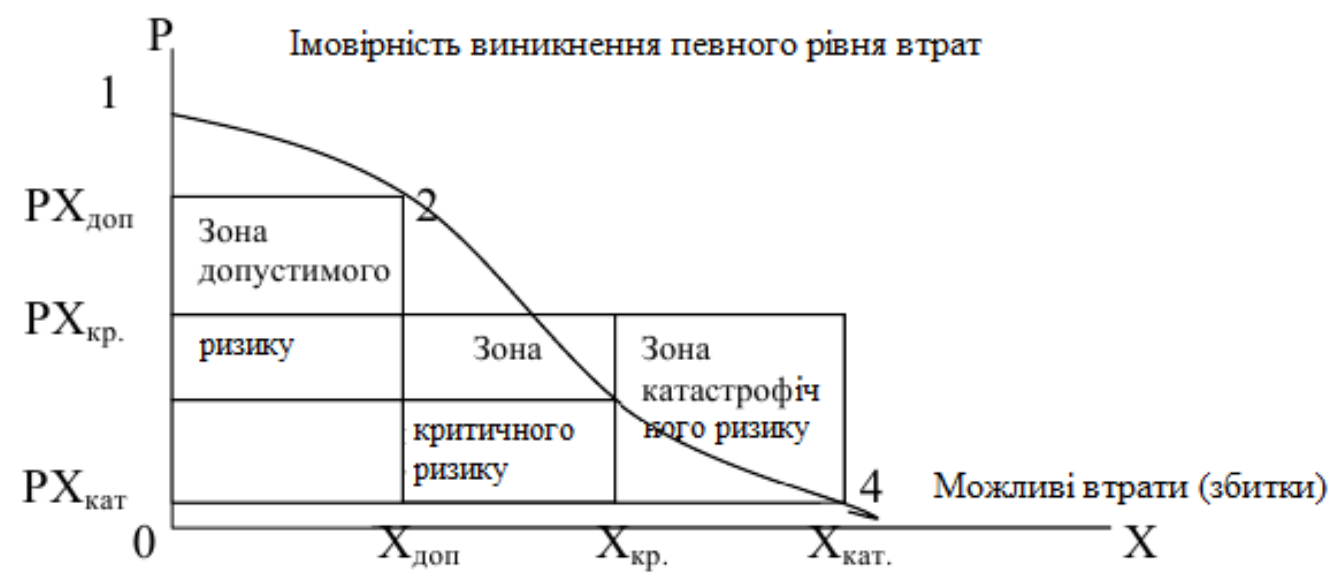

Рис. 5. Типова крива розподілу ймовірності виникнення певного рівня шкоди 
Побудова кривої дає змогу визначити «зони ризику» у функції від величини збитку (X), а саме: безризикового, допустимого, критичного та катастрофічного ризику. Безризиковою вважається область, якій відповідають незначні порушення екосистем, що не приводять до екологічних відмов. Під зоною допустимого ризику слід розуміти область, в межах якої вплив джерела небезпеки здійснюється відповідно до екологічно обгрунтованого ризику (наприклад, скиди не перевищують гранично допустимих, визначених 3 урахуванням асиміляційної ємності екосистеми), тобто збиток не перевищує запланованого $\left(\mathrm{X}_{\text {доп }}\right)$.

Зона критичного ризику характеризується небезпекою відмов, переходом системи в стан надзвичайної екологічної ситуації або кризовий. При цьому збиток $\left(\mathrm{X}_{\text {кр }}\right)$ має величину значно більшу, ніж запланований.

Зона катастрофічного ризику відрізняється небезпекою виникнення екологічної катастрофи (від локального до регіонального масштабу - повна відмова екосистеми). У межі збиток $\left(\mathrm{X}_{\text {кат }}\right)$ може досягати величини, що перевищує дохід цього підприємства, що здійснює небезпечні скиди/викиди (регіональний або національний дохід залежно від масштабів екологічної катастрофи).

Тенденція застосування концепції прийнятного ризику стає все більш стійкою у всіх промислово розвинених країнах. Оцінка прийнятного ризику особливо важлива під час прийняття рішень про інвестиції. Рівень ризику вважається прийнятним, якщо його величина (ймовірність реалізації або можливі збитки) настільки незначні, що заради одержуваної при цьому вигоди у вигляді матеріальних або соціальних благ людина або суспільство загалом готові піти на ризик.

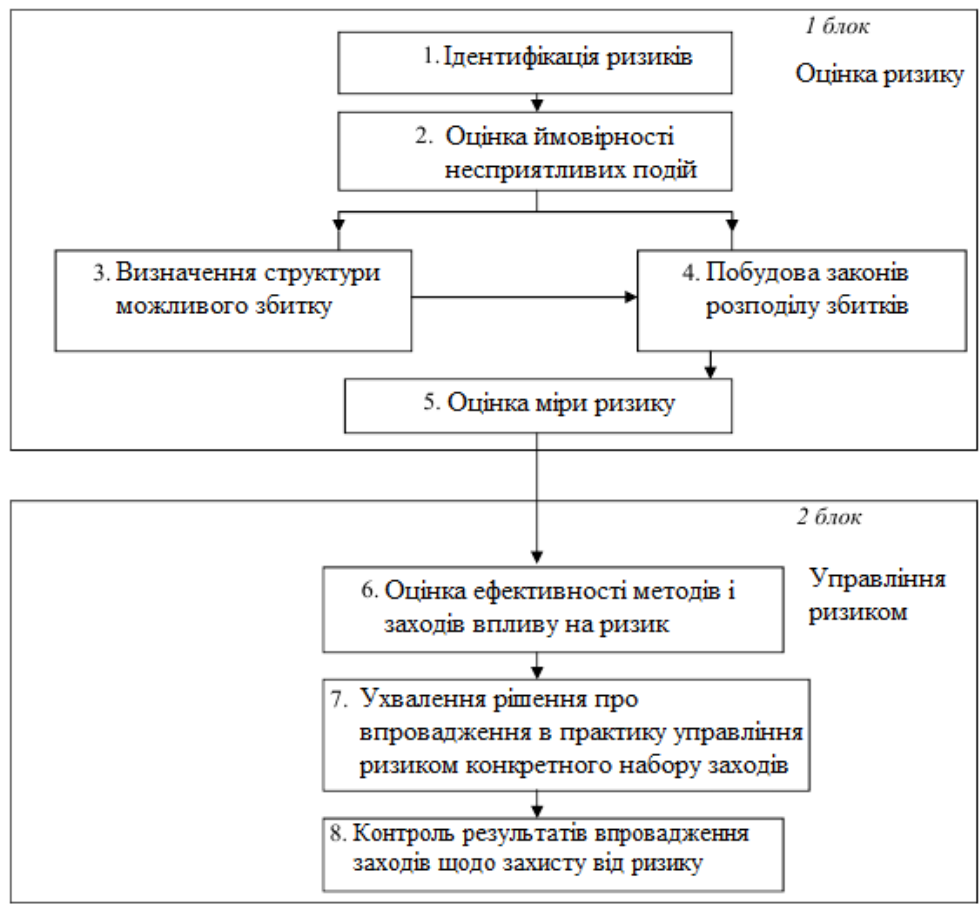

Рис. б. Блок-схема етапів ризик-аналізу
Ризик-аналізом називають будь-яку діяльність із виявлення, аналізу, систематизації факторів ризику (рис. 6).

Блок «Оцінка ризику». Оцінка ризику - це аналіз походження і масштаби ризику в конкретній ситуації. Будучи аналітичним інструментом, оцінка ризику дозволяє визначити фактори ризику для здоров'я людини, їх співвідношення і на цій основі визначити пріоритети діяльності по мінімізації ризику.

Метою оцінки є формування умовного розподілу ймовірностей збитків на однотипних об'єктах для несприятливої події з урахуванням її впливу.

Методичний блок «Оцінка ризику» включає послідовне проведення таких етапів.

1. Ідентифікація ризиків грунтується на виявленні небезпеки, встановленні джерел і чинників ризику, а також об'єктів їх потенційного впливу, на основі чого визначається склад (перелік) негативних подій, що викликають погіршення якості навколишнього середовища і прямо або побічно (через це погіршення) завдають економічної шкоди промисловому підприємству. При цьому вивчаються сценарії можливих впливів на НПС як еволюційного, так і аварійного характеру.

2. Оцінка ймовірності прояву (схильності), тобто реального впливу фактора ризику на людину і навколишнє середовище; виконується тільки щодо тих подій, які віднесені до розряду ризикових (аварійних) 3 урахуванням тимчасового чинника; оцінка дається за допомогою різних методів: інженерних, моделювання, експертних, соціологічних.

3. Визначення структури можливого збитку пов'язане 3 аналізом впливу чинників ризику на населення і навколишнє середовище, визначенням стійкості людини й екосистеми щодо впливу певного дестабілізуючого чинника. Найчастіше проводиться в двох формах: у натуральному вигляді і в вартісному вираженні. Натуральний (фізичний) збиток вимірюється кількісними характеристиками (число загиблих дерев, пошкоджених машин, забруднених гектарів грунту тощо). Вартісна форма вираження називається збитком. Збитки поділяються на прямі (безпосередні втрати об'єкта: здоров'я, життя людини, майно населення або юридичних об'єктів тощо) і непрямі, що виникають як наслідок неможливості для об'єкта вести нормальну діяльність, яку він здійснював до прояву події (до них відносять упущену вигоду, втрату іміджу тощо). Збитки визначаються різними методами: нормативними, розрахунковими, ринковими тощо.

4. Побудова кривої розподілу ймовірностей втрат.

5. Заключний етап - оцінка міри ризику проводиться з метою виявлення та 


\section{Матіс G.O., Крот О.П.}

формування кількісних показників ризику для прийняття управлінських рішень.

Таким чином, для визначення величини ризику відповідно до виразу (9) необхідно мати інформацію, яка відображатиме відповідність значень Р і значенням $\mathrm{X}_{\mathrm{i}}$. Така інформація в найпростішому випадку визначає закон розподілу ймовірностей в просторі збитків. У процесі обробки вихідних даних для отримання висновку про наявність чи відсутність ризику, його форми, оцінки характеристик повинні розглядатися концентрація забруднювача, його токсичність, доза і тривалість дії. Потребує також визначення ступінь точності оцінки екологічного ризику.

На практиці для природних екосистем найчастіше розраховують екологічний ризик антропогенного забруднення. Якщо не враховувати аварійні екологічні ситуації, а обмежитися тільки еволюційним аспектом зміни стану ОПС внаслідок антропогенного впливу, то під час оцінки екологічного ризику необхідно виділяти три його складники:

- оцінка впливу забруднюючих речовин на здоров'я людини (населення);

- оцінка стан біоти за біологічними інтегральними показниками;

- оцінка впливу забруднюючих речовин на компоненти навколишнього природного середовища.

Найбільш достовірно можна оцінити екологічний ризик за його першим складовій - стану здоров'я людини, при визначенні екологічного ризику головна увага має бути направлена на аналіз співвідношення шкідливих екологічних наслідків, що закінчуються смертельними наслідками, і кількісну оцінку сумарного шкідливого впливу на НС, оскільки для цього показника є досить надійні статистичні дані.

Оцінити екологічний ризик за другим і третім його складниками значно важче - показникам екологічної небезпеки властива стохастичність (невизначеність) через прояви різних ефектів, до яких відносяться:

- кумулятивний ефект будь-яких довгострокових впливів на природні об'єкти (організми, екосистеми), істотне збільшення і накопичення за часом часто призводить до різких якісних змін шляхом сумації слабких кількісних зрушень;

- нелінійність дозових ефектів впливів на живі організми виражається у вигляді непропорційно сильних біологічних ефектів від невеликих доз впливу, що пов'язано з підвищеною чутливістю організмів до слабких (інформаційним) впливів. Слабкі впливу призводять до змін поведінки живих істот. Впливи середньої інтенсивності викликають стресову реакцію i, як правило, включають механізми опору організму. Сильні впливи порушують життедіяльність, підвищують ймовірність смерті;

- синергетична (спільна) дія різних факторів середовища на живі організми, яка нерідко призводить до несподіваних ефектів, не є сумою відповідей на надані дії; дія одного чинника може, як поси- лювати, так і послаблюватися або якісно змінювати ефекти впливів інших.

Блок «Управління ризиком». Стратегія управління екологічною безпекою заснована на концепції ненульового, тобто прийнятного ризику, коли визнається факт недостатності абсолютної безпеки. Управління екологічними ризиками безпосередньо пов'язано з екологічним менеджментом. Воно розуміється як процес прийняття рішень, коли враховується оцінка екоризику, а також технологічні та економічні можливості його запобігання (зниження). Основна мета управління ризиком полягає у визначенні шляхів запобігання небезпечної ситуації або мінімізації ймовірності розвитку такої ситуації (зведення ризику до прийнятного рівня).

Досягнення поставленої мети здійснюється шляхом розроблення управлінських рішень, у яких вказуються методи впливу на ризик (правові, економічні, інформаційні, технологічні).

Під час управління ризиком можна виділити два процеси:

- регулювання ризику - процес нагляду та контролю за джерелами небезпеки, спостереження за станом навколишнього середовища і його змінами під впливом людської діяльності, перевірка виконання планів і заходів з охорони НПС, раціонального використання природних ресурсів, оздоровлення навколишнього середовища, дотримання вимог природоохоронного законодавства i нормативів якості навколишнього середовища. Цей процес здійснюється спеціально уповноваженими державними органами;

- оптимізація витрат на захист - процес зниження ризику з метою досягнення такого його рівня, який є розумним і досяжним з погляду економічних і соціальних факторів.

Основою для вибору методів впливу на ризик $\epsilon$ дані блоку «Оцінка ризику», який розглядається як перша ланка управління ризиком.

6. Оцінка ефективності методів і заходів впливу на ризик. Оскільки нейтралізація ризику (повна або часткова) за допомогою набору відповідних заходів пов'язана з витратами, які можуть значно відрізнятися за своїми розмірами, важливо визначити на цьому етапі «прийнятність» ризику. Це дозволяє більш достовірно оцінювати ефективність методів і заходів впливу на ризик. «Прийнятність» ризику визначається в межах методології системного аналізу у відповідності до положень класичної теорії оптимізації, що дозволяє під час вибору варіантів знаходити тільки одне компромісне рішення. При цьому ризик обов'язково зіставляється 3 низкою соціально-економічних чинників. Процес порівняння здійснюється на основі критерію «витрати-вигоди» («вартість-ефективність»), оцінюються:

- вигоди від того чи іншого виду господарської діяльності;

- втрати, зумовлені використанням виду діяльності; 
- наявність і можливості регулюючих заходів 3 метою зменшення негативного впливу на природне середовище та здоров'я людини.

Чиста вигода визначається з умови:

$$
B=U-\left(P+X+Y_{1}+Y_{2}\right),
$$

де U - загальна вигода, що включає вартість виробленого продукту; Р - основні виробничі витрати (будівлі, обладнання, вартість експлуатації і т.п. без урахування захисних заходів); $\mathrm{X}$ - витрати на досягнення того чи іншого рівня безпеки, що включають природоохоронні витрати і витрати на заходи техніки безпеки; $\mathrm{Y}_{1}-$ виражена в грошових одиницях величина збитку в результаті даного виду діяльності, що завдається навколишньому середовищу; $\mathrm{Y}_{2}$ - виражена в грошових одиницях величина збитку в результаті даного виду діяльності, що наноситься здоров'ю людей.

Діяльність виправдана, якщо В>0. Можливі три варіанти прийняття рішення:

- ризик може бути повністю допустимий (низький, нижче середнього і середній);

- частково допустимий (вище середнього);

- повністю неприпустимий (високий, зона відчуження).

У разі неможливості отримання вартісної характеристики ризику використовується метод зіставлення рівнів ризику, встановлених відповідними нормативами, тобто витрат, необхідних на його зниження в розрахунку на одиницю ризику, і вигод, виражених у вартісній формі.

7. Прийняття рішення про впровадження в практику управління ризиком конкретного набору заходів. Управління ризиками передбачає визначення і впровадження в практику «оптимального» (раціонального) набору методів, які дозволяють зменшити сукупні витрати, зумовлені забрудненням навколишнього середовища ( «чисті ризики») або отримати максимально можливу в такій ситуації вигоду.

При цьому йдеться про два види управління екологічним ризиком:

- аварійним технологічним ризиком у разі «стрибкоподібної» техногенної катастрофи;

- неаварійним промисловим ризиком у процесі «нормальної» виробничої діяльності.

Таким чином, етап прийняття регулювального рішення пов'язує всі попередні етапи оцінки ризику та управління ним. Його реалізація можлива за допомогою інструменту екологізації виробництва, а саме екологічного менеджменту, практичні системи якого інтегруються в загальну систему управління підприємством. Схеми створення і функціонування систем екологічного менеджменту теоретично засновані на «принципі постійного поліпшення Е. Демінга», а практична методологія їх використання викладена в стандартах ISO 14001 та 14004.

8. Контроль результатів впровадження заходів щодо захисту від ризику. Специфічним є останній етап ризик-аналізу, а саме: контроль за результатами усунення неприйнятного (надмірного) ризику або зменшення прийнятного, частково прийнятного (недоцільного) ризику. У процесі управління ризиком він здійснюється шляхом безперервного або регулярного моніторингу стану НПС; оцінки впливу на навколишнє природне середовище (ОВНС), що виконується на стадії проектування будівництва підприємства; екологічної експертизи запланованій господарської діяльності; екологічного аудиту, який використовується для перевірки й оцінки реальної (експлуатаційної) діяльності промислових об'єктів. Правильний вибір «типового» методу контролю у процесі ризик-аналізу є окремим важливим завданням.

Обидва розглянутих блоку «Оцінка ризику» й «Управління ризиком» мають як загальну базу, так і відмінні риси. Загальним в оцінці та управлінні ризиком є те, що вони являють собою дві стадії єдиного процесу прийняття рішення, заснованого на мінімізації ризику. Різниця полягає в тому, що оцінка ризику будується на фундаментальному дослідженні джерел і чинників ризику, схильності до ризику з урахуванням особливостей екологічної обстановки, а управління ризиком спирається на екологічний та соціологічний аналіз.

Прийняття та реалізація управлінських рішень повинні грунтуватися на системному підході до вирішення проблеми за допомогою екологічного менеджменту та на загальних принципах «екорозвитку», закладених у концепції сталого еколого-економічного розвитку:

- прийнятність ризику екологічної небезпеки;

- домінанта соціального ефекту забезпечення екологічної безпеки;

- оцінка ступеня небезпеки розвитку природних і техногенних процесів;

- збалансоване поєднання централізованих та децентралізованих структур управління, а також компенсаційних економічних механізмів забезпечення екологічної безпеки;

- планування i розвиток виробництва відповідно до місткості і здатності природних екосистем до самовідновлення;

- еколого-економічна збалансованість суспільного розвитку;

- економічне стимулювання екологічно чистих технологій і обладнання.

На основі проаналізованих методів оцінки екологічних ризиків розроблене інформаційне забезпечення оцінки екологічного ризику, яке передбачає вивчення процесів трансформації і міграції речовин у суміжних середовищах довкілля і враховує оцінку різних компонентів НПС (рис. 7).

Таким чином, для визначення оптимального методу оцінки екологічного ризику необхідно враховувати походження фактора негативного впливу (явище), процеси у екологічній системі, якій 


\section{Матіс G.O., Крот О.П.}

нанесені збитки, кінцевий стан екосистеми (наслідки дії негативного фактора для компонентів НПС і здоров'я населення) (рис. 8).

Використання методики визначення екологічних ризиків для окремих складних систем (еколого-економічна, соціально-екологічна, соціально-економічна) показує необхідність створення нового під-

\section{МОДЕАЬ ФОРМУВАННЯ МЕТОДІВ..}

ходу до комплексної оцінки екологічності системних об'єктів (рис. 9).

\section{Перспективи використання результатів} дослідження.

Таким чином, пропонується комплексне використання методів оцінки екологічних ризиків, заснованих на показниках небезпечності явищ і джерел

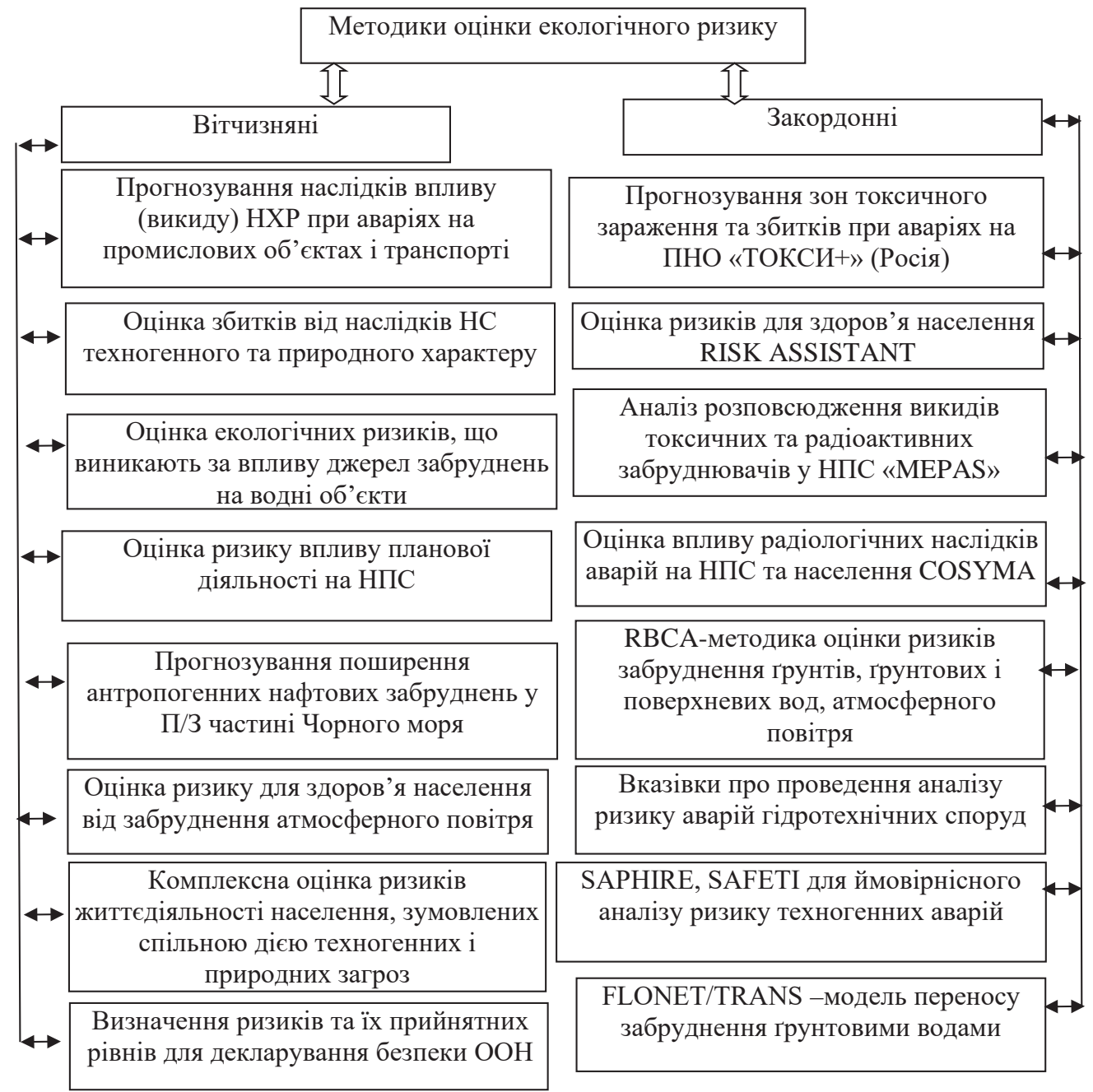

Рис. 7. Закордонні системи інформаційного забезпечення оцінки ЕР

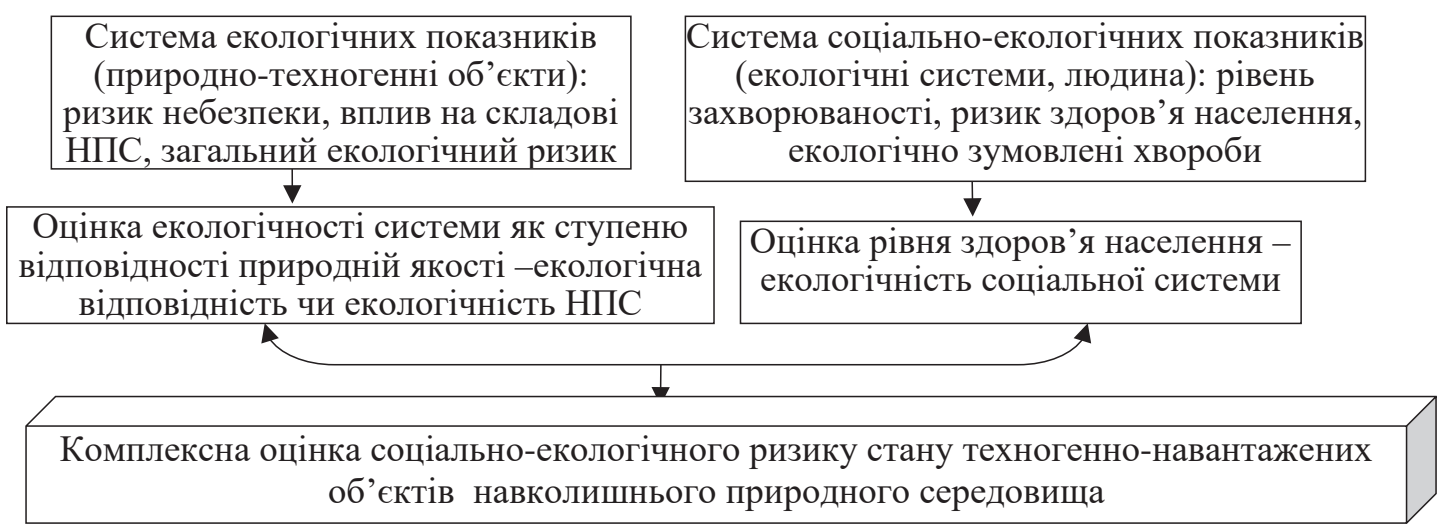

Рис. 8. Модель комплексної оцінки екологічного ризику стану ПТК 


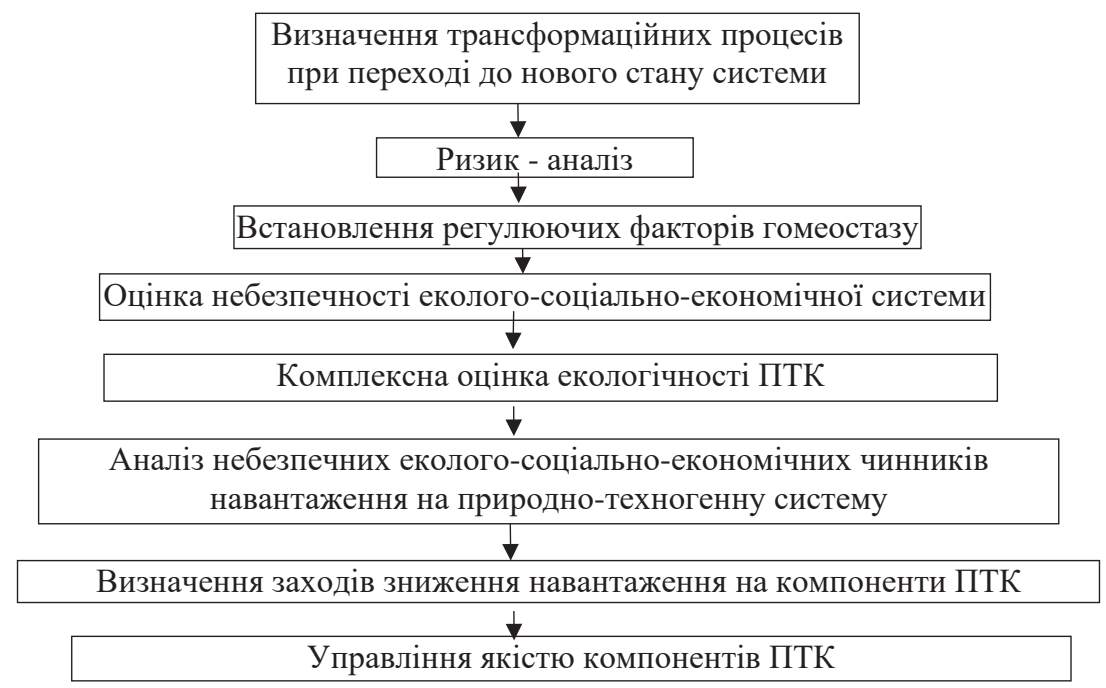

Рис. 9. Схема комплексної оцінки екологічності системних об'єктів

ïх виникнення, екологічних збитків, негативного впливу на здоров'я населення, стійкості території до техногенного впливу 3 урахуванням початкового стану об’єкта негативного впливу [6, с. 288]. Доцільність розроблення методики багатокритеріальної оцінки екологічності підприємств хімічної галузі пов'язана із запровадженням додаткових аспектів дослідження у методичне та інформаційне забезпечення існуючих методик 3 контролю якості моніторингових систем. Необхідність удосконалення робочих методик, застосованих на практиці 3 визначення екологічності підприємств хімічної промисловості, зумовлена розширенням вузькоспеціалізованих завдань відповідно до обгрунтованості аналізу з функціональності та ефективності досліджених систем [7, с. 52].

\section{Література}

1. Lettenmeier M., Liedtke C., Rohn H. Eight Tons of Material Footprint—Suggestion for a Resource Cap for Household Consumption in Finland. 2014. Vol. 3. 488-515 p.

2. Liedtke C, Buhl J, Ameli N. Microfoundations for Sustainable Growth with Eco-Intelligent Product Service-Arrangements. Sustainability. 2013. Vol. 5. 1141-1160 p.

3. Майорова Л.П. Оценка экологичности технологических процессов. Вестник Томского гос. ун-та. 2009. Том 2 (Вип. 13). С. 111-116.

4. Dennis J. Paustenbach Human and ecological risk assessment. Theory and practice: text. New York: 2002. 635 p.

5. Manuilova A. Methods and Tools for Assessment of Environmental Risk. Product Stewardship \& Sustainability. Akzo Nobel Surface Chemistry AB. 2003. 21 p.

6. Матіс Є.О., Крот О.П. Дослідження показників екологічності підприємств хімічної промисловості. Науковий вісник будівництва. 2020. Т. 100 (Вип. 2). С. 288-294. URL: http://nbuv.gov.ua/UJRN/Nvb_2020_100_2 47 (дата звернення: 11.12.2021).

7. Матіс, С.О., Крот О.П. Метод оцінки життєвого циклу продукту як ефективний комплекс дій щодо екобезпеки хімічної галузі. 2021. Technogenic and ecological safety, National University of Civil Defence of Ukraine. Том 9 (Вип. 1). C. 52-57. URL: http://repositsc.nuczu.edu.ua/handle/123456789/12989 (дата звернення: 11.12.2021). 


\title{
БІОЕТИЧНІ АСПЕКТИ МЕТОДОАОГIї ГІДРОБІОАОГІЧНИХ ДОСАІДЖЕНЬ
}

\author{
Романенко О.В., Груша М.М. \\ Національний медичний університет імені О.О. Богомольця \\ пр. Перемоги, 34, 03057, м. Київ \\ g_mykhaylo@meta.ua
}

\begin{abstract}
У статті висвітлюється розвиток уявлень про біоетичні аспекти дослідницької діяльності. Враховуючи актуальність розроблення моделей, що характеризують перебіг процесів у гідроекосистемах загалом, а також в окремих гідробіонтах, потребу у вивченні механізмів адаптації організмів до чинників навколишнього середовища, у з'ясуванні характеру біотичних зв'язків у екосистемах, у впровадженні методів біотестування та біоіндикації, авторами розглядаються застосування норм і принципів біоетики в методології гідробіолоігчних досліджень, сучасні вимоги до умов використання в науковій та освітній роботі водяних тварин. Акцентується увага на питаннях планування і проведення відповідних досліджень 3 урахуванням дотримання ключових біоетичних аспектів організації наукової діяльності, з якими мають кореспондуватися: наукові або освітні цілі роботи і її спрямування на забезпечення потреб у підтриманні належного стану навколишнього природного середовища, представників тваринного світу, в отриманні нових знань у галузях гідроекології та гідробіології; мета експерименту й обгрунтування вибору виду, джерела та кількості водяних тварин для його проведення; передбачені експериментальні процедури і способи мінімізації та попередження дискомфорту, больових відчуттів, тривалого погіршення функціонального стану в досліджуваних водяних тварин; вибір гуманних кінцевих точок експерименту; необхідні для проведення експериментального дослідження обізнаність персоналу, інфраструктура, ресурси тощо. Обговорюються запропоновані міжнародною науковою спільнотою новітні вимоги до методології експериментальної роботи з використанням хребетних і безхребетних тварин, а також змістовне наповнення рекомендацій із цього питання. Деталізується значення документування дотримання біоетичної складової частини під час планування та проведення наукових досліджень, а також оприлюднення їх результатів. Обговорюються сучасні тенденції щодо розширення переліку таксономічних груп водяних безхребетних тварин, включення яких у дослідження має супроводжуватися дотриманням чинних норм і принципів біоетики. Ключові слова: гідробіологічні дослідження, методологія, біоетика, водяні тварини, ракоподібні.
\end{abstract}

Bioethical aspects of hydrobiological research methodology. Romanenko O., Hrusha M.

The article highlights the development of conception about bioethical aspects of research. Given the relevance of developing models that characterize the processes in hydroecosystems in general, as well as in individual aquatic animals, the need to study the mechanisms of adaptation of organisms to environmental factors, to clarify the nature of biotic relationships in ecosystems, to implement methods of biotesting and bioindication, the authors consider the application of norms and principles of bioethics in the methodology of hydrobiological research, modern requirements for the conditions of use in scientific and educational work of aquatic animals. Emphasis is placed on planning and conducting relevant research, taking into account compliance with key bioethical aspects of the organization of scientific activities, which should correspond, inter alia: scientific or educational goals of research and its direction to meet the needs of maintaining the proper environment, wildlife, gaining new knowledge in the fields of hydroecology and hydrobiology; the purpose of the experiment and justification of the choice of species, source and number of aquatic animals for its implementation; experimental procedures and methods of minimization and prevention of discomfort, pain, long-term deterioration of the functional state in the studied aquatic animals are provided; selection of humane endpoints of the experiment; infrastructure, resources, staff awareness necessary for the experimental study. The latest requirements to the methodology of experimental work with the use of vertebrates and invertebrates proposed by the international scientific community are discussed, as well as the content of recommendations on this issue. The importance of documenting compliance with the bioethical component in the planning and conduct of research, as well as the publication of their results is detailed. Current trends to expand the list of taxonomic groups of aquatic invertebrates, the inclusion of which in the study should be accompanied by compliance with modern norms and principles of bioethics, are discussed. Key words: hydrobiological research, methodology, bioethics, aquatic animals, crustaceans.

Для розроблення моделей, що характеризують перебіг процесів у гідроекосистемах загалом, а також в окремих організмах гідробіонтів, актуальним є використання результатів відповідних експериментальних досліджень $[1,2]$. Вони необхідні для з'ясування особливостей фізіологічних і біохімічних процесів у водяних тварин, зокрема пов'язаних 3 адаптацією організмів до чинників навколишнього середовища, для моделювання відносин між гідробіонтами в екосистемах, для розроблення і впровадження методологій біотестування та біоіндикації тощо.
Оскільки практична спрямованість відповідних наукових напрямів і сучасної біологічної та екологічної освіти передбачає використання водяних тварин в експериментальній роботі, особливої актуальності набувають питання, пов'язані з біоетичними аспектами проведення досліджень у галузях гідробіології та гідроекології $[3,4]$. Такі дослідження мають бути етично виправданими і відбуватися лише після попереднього науково обгрунтованого визначення необхідного для досягнення відповідних наукових або освітніх цілей мінімуму кількості залучених тварин. 
При цьому ключовим питанням організації згаданих досліджень має бути забезпечення заподіювання якомога меншого болю та/або страждань останнім. Виходячи з відзначеного вище, безпосереднє використання тварин в експериментальній роботі та в освітньому процесі зумовлює необхідність урахування та безумовного дотримання у структурі відповідних досліджень саме сучасних біоетичних норм, спрямованих, зокрема, на уникнення використання хребетних тварин, за можливості застосування інших методичних підходів, а якщо за останнього саме досягнення планованих цілей дослідження неможливе, тоді потрібно спрямувати зусилля на удосконалення його протоколу з метою мінімізації як чисельності піддослідних тварин, так і больових відчуттів і страждань у них $[5,6]$. На ці питання ми звертали увагу в наших попередніх працях [3, 4], проте стрімкий розвиток науково обгрунтованих уявлень про особливості життєдіяльності представників тваринного світу, чутливості водяних тварин до широкого кола чинників навколишнього середовища актуалізує необхідність подальшого обговорення проблеми дотримання біоетичних норм у плануванні та проведенні експериментальних досліджень із використанням хребетних та безхребетних тварин.

Окрім вже згаданих принципів, що мають братися до уваги як на етапі планування дослідницької роботи, так і на етапі безпосереднього проведення експериментів із використанням водяних тварин, варто звернути увагу і на інші питання, які безпосередньо пов'язані зі згаданими вище. До них можна віднести: 1) наукові або освітні цілі, досягнення яких передбачається $з$ використанням піддослідних тварин; 2) урахування відповідності експерименту потребам підтримання здоров'я чи добробуту людей, стану навколишнього природного середовища, належних умов існування тварин; 3) вдосконалення екологічних та біологічних знань тощо. Окрім того, 3 метою зменшення кількості залучених до проведення експериментальної роботи водяних тварин варто визначити можливість їх повторного використання. Водночас останнє не повинно супроводжуватися збільшенням рівня стресового навантаження на тварин. 3 метою запобігання впливу на тварин чинників, здатних викликати в них стресові реакції, під час планування експериментальної роботи, розроблення та виконання іiї протоколу необхідно спиратися на ті методи, що дозволяють уникнути болю або мінімізувати біль, дискомфорт, страждання, тривале погіршення функціонального стану в досліджуваних організмів, при цьому слід звернути увагу й на можливості сучасних методів анестезії водяних тварин $[3,4]$. Також у разі обмеження рухової активності тварин, виникнення в них дискомфорту внаслідок змін температурного режиму навколишнього середовища або хімічного складу останнього необхідним $€$ врахування потреби в обгрунтованій мінімізації впливу на організм стресогенного чинника. Окрема увага повинна надаватися тим передбаченим протоколом дослідження процедурам у кінцевих точках експерименту, за досягнення яких відбувається виведення водяних тварин зі стану тимчасового знерухомлення, анестезії, а за певних умов може відбуватися процедура евтаназії [7]. За відсутності чітко визначених і затверджених цілей та умов проведення експериментального дослідження 3 використанням водяних тварин варто переглянути його дизайн, звернувши увагу на пов'язані з ним ключові біоетичні аспекти, з якими мають, зокрема, кореспондуватися: 1) наукові або освітні цілі дослідження з урахуванням відповідності експерименту потребам підтримання здоров'я чи добробуту людей, належного стану навколишнього природного середовища, представників тваринного світу, отриманню нових знань в галузі екології та біології тощо; 2) мета розроблення плану експерименту, включаючи обгрунтування вибору виду, джерела та кількості тварин для проведення дослідження, урахування можливості їх повторного використання у подальшому; 3) детальний опис експериментальних процедур; 4) передбачені методи уникнення або мінімізації болю, дискомфорту, страждань або тривалого погіршення функціонального стану досліджуваних водяних тварин, наприклад методи анестезіі; 5) вибір гуманних кінцевих точок та остаточного розпорядження досліджуваними тваринами, включаючи за необхідності методи евтаназіі; 6) необхідні для виконання експериментального дослідження інфраструктура або ресурси (наприклад, відповідне обладнання), компетентність персоналу, який буде брати участь в його забезпеченні [7].

Відповідність планування, організації та проведення експериментальної роботи сучасним біоетичним нормам є обов'язковою умовою не лише для виконання безпосередньо наукового дослідження, а й для можливості оприлюднення його результатів у подальшому. У сучасних тенденціях розвитку методології досліджень із залученням тварин можна простежити акцентуацію уваги на надійності експериментальних методів, на відтворюваності отриманих 3 їх застосуванням даних, на адекватності використання біологічного матеріалу, на валідизації результатів наукових пошуків, на ресурсах для покращення дизайну дослідження. 3 метою стандартизації методології проведення дослідницької роботи на тваринах та подальшого представлення отриманих даних у наукових виданнях групою вчених у 2010 році було запропоновано низку рекомендацій, відомих як The ARRIVE Guidelines-2010 [8]. Відзначається, що обізнаність із ними науковців зумовила ширше використання біоетичних норм під час планування та проведення відповідних експериментальних досліджень, а також під час аналізу отриманих результатів [9]. Водночас у низці наукових праць, присвячених аналізу проблем звітності за результатами експериментальної роботи з біоло- 


\section{Романенко О.В., Груша М.М.}

гічними об'єктами та підготовки до оприлюднення отриманих даних, звертається увага на недостатній рівень обізнаності частини виконавців із біоетичними аспектами планування та проведення дослідницької роботи з використанням тварин та на негативні наслідки цього [10-13].

Нещодавно оприлюднений оновлений варіант згаданих вище рекомендацій: The ARRIVE guidelines 2.0: Updated guidelines for reporting animal research [14]. За змістовим наповненням в ньому виділяються дві частини: "ARRIVE Essential 10" та "ARRIVE Recommended Set":

- в частині “ARRIVE Essential 10" наведено мінімальний перелік вимог, виконання яких $є$ необхідною умовою для проведення оцінки надійності отриманих за результатом експериментальної роботи даних і зроблених на цій підставі висновків [14]. До нього входять описи деталей проєкту наукового дослідження, у тому числі обгрунтування вибору тварин для його проведення, розміру відповідної вибірки, заходів з об'єктивізації отримуваних даних (зокрема критерії включення та виключення тварин із відповідних груп дослідження, рандомізації тощо), методів статистичної обробки отримуваних даних, експериментальних процедур; також наводяться результати дослідження. При цьому акцентується увага на приналежності вибраних для дослідження організмів певній таксономічній групі (виду, штаму тощо), на їх статі, віку або стадії розвитку, а крім того, за потреби також і на їхній вазі; важливе місце займає інформації про походження тварин, їх стан здоров'я чи імунний статус, генотип та особливості їх генетичної модифікації за умови наявності такої, про процедури, яким тварини піддавалися раніше. Також для кожної групи тварин, що бере участь в дослідженні, наводяться детальні описи тих процедур, до яких вони залучаються в ньому, що дає можливість відтворення останніх. При цьому звертається увага на доцільності проведення кожної 3 таких процедур із чітким формулюванням іiі мети та обгрунтованості;

- у частині "ARRIVE Recommended Set" акцентується увага дослідників на пов'язаних з експериментальною роботою із тваринами, яка планується до виконання, Заяві про дотримання в ній біоетичних норм, а також на Декларації стосовно можливого конфлікту інтересів, на питаннях, пов'язаних із уточненням реєстрації протоколу дослідження та з регламентом доступу до первинних даних, із деталізацією інформації про методологію експериментальної роботи та про особливості утримання досліджуваних тварин, догляду за ними [14]. При цьому окремій увазі підлягає детальний опис в експериментальних протоколах втручань та дій, спрямованих на зменшення можливості болю та страждань у досліджуваних тварин, визначення гуманних кінцевих точок окремо для кожного досліду, ознак, за якими відбувається контроль їх досягнення, і частоти відпо-

\section{БІОЕТИЧНІ АСПЕКТИ МЕТОДОАОГІЇ...}

відного моніторингу (за відсутності визначення для дослідження гуманних кінцевих точок необхідним $\epsilon$ пояснення причини цього). Схвалення на використання в дослідженні конкретного виду тварин надається відповідним комітетом 3 етичного контролю (або аналогічною за повноваженнями структурою), а за відсутності такої ухвали в тій заяві, що стосується дотримання дослідниками біоетичних норм, виконавці роботи мають аргументувати можливість проведення дослідження за їі відсутності (наприклад, у разі залучення до дослідження саме тих безхребетних тварин, на використання яких у наукових цілях на цей час не поширюються відповідні визнані міжнародною науковою спільнотою обмеження). Таким чином, вже на етапі планування структури дослідження мають бути науково обгрунтованим його контекст і пояснені потреба у використанні експериментального підходу для вирішення проблеми, якій воно присвячене, та залучення для цього конкретного виду тварин, що має кореспондуватися 3 визначеними науковими цілями дослідження і відповідати сучасним нормам біоетики. Водночас будьякі очікувані або несподівані несприятливі події, що виникають під час проведення досліду, підлягають реєстрації.

Під час підготовки протоколу проведення наукової роботи увага його розробників має бути акцентованою на таксономічній приналежності запланованих для дослідження тварин, зважаючи й на те, що з нею пов'язане застосування комплексу заходів біоетичного змісту, передбачених відповідними документами, до яких належать, зокрема, Закон України «Про захист тварин від жорстокого поводження», «Європейська конвенція про захист хребетних тварин, що використовуються для дослідних та інших наукових цілей», «Договір про функціонування Свропейського Союзу», Директива Європейського Парламенту та Ради 2010/63/EU про захист тварин, що використовуються у наукових цілях, а також інші нормативні акти $[5,15-18]$. Вони містять конкретні положення стосовно практичного застосування норм і принципів біоетики. Причому, як підкреслюється в одному зі згаданих вище документів, під дію останніх підпадає «будь-яка жива хребетна тварина, яка не належить до людського роду, включаючи непаразитуючі та/або відтворюючі личинкові форми» [5], більше того, певні положення відносяться «до будь-якої тварини, що використовується або призначена для використання у будь-якій дослідній або іншій науковій процедурі, якщо така процедура може спричинити біль, страждання, занепокоєння чи завдати тривалої шкоди» [5].

У зв'язку з наведеним вище звернемо увагу, що чинною Директивою Європейського Парламенту та Ради 2010/63/EU про захист тварин, що використовуються у наукових цілях [18], розширено визначений раніше, у 1999 році, «Європейською конвенцією про захист хребетних тварин, що використовуються 
для дослідних та інших наукових цілей» [5] перелік таксономічних груп, на представників яких поширюються норми і принципи біоетики, шляхом включення до нього таксону Круглороті (Cyclostomata), а крім того, таксону Головоногі молюски (Cephalopoda). Внесення до названого переліку представників головоногих молюсків пов'язане зі з'ясуванням розвитку в цих водяних безхребетних тварин когнітивних функцій на достатньо високому рівні [19].

3 огляду на тенденції до розвитку сучасних уявлень щодо чутливості безхребетних тварин до різноманітних екологічних чинників, можна передбачати розширення переліку таксономічних груп, на представників яких будуть поширюватися відповідні норми і принципи біоетики в майбутньому. При цьому звернемо увагу на ракоподібних з ряду Десятиногі (Decapoda). 3 урахуванням біологічних особливостей цих водяних безхребетних тварин, зручності їх вилову в дикій природі, їхньої відносної невибагливості до умов культивування [20-22] представники ряду Десятиногі (Decapoda) широко використовуються в гідробіологічних, гідроекологічних, екофізіологічних, екотоксикологічних, біохімічних дослідженнях як модельні організми [23-30], причому чинними законодавчими нормами не передбачено обмежень на використання згаданих тварин у наукових чи освіт- ніх цілях [31]. Проте отримані останнім часом дані 3 вивчення особливостей реагування представників ракоподібних з ряду Десятиногі (Decapoda) на низку подразників свідчать на користь можливості перегляду такого положення. Так, у цих тварин були зареєстровані захисні поведінкові реакції у відповідь на подразнення ударом електричного струму, спрямовані на уникнення цього [32], а також захисні рухові реакціï, спричинені нанесенням на окремі ділянки їхнього тіла агресивних хімічних агентів [33], що в сукупності може розглядатися як свідчення притаманності больових відчуттів десятиногим ракам. 3 урахуванням наведених вище даних, особливостей функціонування нервової системи та поведінки ракоподібних 3 ряду Десятиногі (Decapoda) у наукових колах обговорюється питання про внесення цих тварин до переліку організмів, на яких поширюються законодавчо закріплені норми і принципи біоетики [34].

Таким чином, під час планування та проведення наукових досліджень, а також під час організації освітнього процесу у сферах гідробіології та гідроекології необхідним є безумовне дотримання прийнятих міжнародною науковою спільнотою підходів, що базуються на засадах чинних уявлень про біоетику, враховуючи при цьому сучасні погляди на розвиток цього питання.

\section{Література}

1. Методи гідроекологічних досліджень поверхневих вод / О.М. Арсан, О.А. Давидов, Т.М. Дьяченко та ін.; за ред. В.Д. Романенка. Київ: ЛОГОС, 2006. 408 с.

2. Романенко О.В., Арсан О.М., Кіпніс Л.С., Ситник Ю.М. Екологічні проблеми київських водойм і прилеглих територій; за ред. О.В. Романенка. Київ: Наукова думка. 2015. 192 с.

3. Романенко О.В., Груша М.М. Біоетичні аспекти іхтіологічних та екофізіологічних досліджень. Наукові записки Тернопільського національного педагогічного університету імені Володимира Гнатюка. Серія: Біологія. Спеціальний випуск "Гідроекологія", 2010. № 2 (43). С. 420-423.

4. Романенко О.В., Груша М.М. Біоетичні аспекти гідроекологічних досліджень. Наукові записки Тернопільського національного педагогічного університету імені Володимира Гнатюка. Серія: Біологія. Спеціальний випуск: Гідроекологія. 2015. № 3-4 (64). C. 572-575.

5. European convention for the protection of vertebrate animals used for experimental and other scientific purposes. Official Journal of the European Communities. 24 August 1999. No L 222. P. 31-37.

6. Russell W.M.S., Burch R.L. The Principles of Humane Experimental Technique (Special edition). South Mimms: UFAW, 1992. $238 \mathrm{p}$.

7. OIE - Terrestrial Animal Health Code, Twenty-eighth edition. Paris: WORLD ORGANISATION FOR ANIMAL HEALTH, 2019. $491 \mathrm{p}$.

8. Kilkenny C., Browne W., Cuthill I. C. et al. Animal research: Reporting in vivo experiments: The ARRIVE guidelines. Br. J. Pharmacol. 2010; Vol. 160, No 7. P. 1577-1579.

9. Reichlin T. S., Vogt L., Wurbel H. (2016). The researchers' view of scientific rigor-survey on the conduct and reporting of in vivo research. PLoS One. 2016. Vol 11. DOI: https://doi.org/10.1371/jornal.pone.0165999.

10. Reproducibility and reliability of biomedical research: improving research practice. London: Academy of Medical Sciences, $2015.78 \mathrm{p}$.

11. Hurst V., Percie du Sert N. The ARRIVE guidelines survey. Open Science Framework. 2017 DOI: https://doi.org/10.17605/ OSF. $\mathrm{IO} / \mathrm{G} 8 \mathrm{~T} 5 \mathrm{Q}$.

12. Fraser H., Parker T., Nakagawa S., Barnett A., Fidler F. Questionable research practices in ecology and evolution. PLoS One. 2018. Vol 13. DOI: https://doi.org/10.1371/jornal.pone.0200303.

13. Hair K., Macleod M. R., Sena E. S. et al. A randomised controlled trial of an intervention to improve compliance with the ARRIVE guidelines (IICARus). Res. Integr. Peer Rev. 2019. Vol. 4, No 12. DOI: https://doi.org/10.1186/s41073-019-0069-3.

14. Percie du Sert N., Ahluwalia A., Alam S. et al. Reporting animal research: Explanation and elaboration for the ARRIVE guidelines 2.0. PLoS Biol. 2020. Vol. 18, No 7. DOI: https://doi.org/10.1371/journal.pbio.3000411.

15. Про захист тварин від жорстокого поводження: Закон України від 21.02.2006 № 3447-IV. Вiдомості Верховної Ради України. 2006. № 27. - Ст. 230.

16. Bate M., Chippendale C., Lucas A. Australian code for the care and use of animals for scientific purposes, 8th edition. Canberra: NHMRC, 2013. $92 \mathrm{p}$. 
17. Consolidated versions of the Treaty on European Union and on the Treaty on the Functioning of the European Union. Official Journal of the European Union. 30 March 2010. No C 83. P. 1-388.

18. Directive 2010/63/EU of the European Parliament and of the Council of 22 September 2010 on the protection of animals used for scientific purposes. Official Journal of the European Union. 2010. No L 276. P. 33-79

19. Darmaillacq A., Dickel L., Mather J. Cephalopod Cognition. Cambridge: CUP, 2014. 247 p.

20. Elwood R. Evidence for pain in decapod crustaceans. Anim. Welf. 2012. Vol. 21. P. 23-27.

21. Hauton C. The scope of the crustacean immune system for disease control. J. Invertebr. Pathol. 2012.Vol. 110. P 251-260.

22. McGaw I.J. The decapod crustacean circulatory system: A case that is neither open nor closed. Microsc. Microanal. 2005. Vol. 11. P. 18-36.

23. Derby C.D., Sorensen, P.W. Neural processing, perception, and behavioral responses to natural chemical stimuli by fish and crustaceans. J. Chem. Ecol. 2008. Vol. 34. P. 898-914.

24. Derby C., Thiel M. Nervous systems and control of behavior. The natural history of the crustacea. New York, Oxford University Press, 2014. Vol. 3. P. 263-292.

25. Reynolds J.D., Souty-Grosset C. Management of freshwater biodiversity: crayfish as bioindicators. Cambridge: Cambridge University Press, 2011. 384 p.

26. Stensmyr M.C., Erland S., Hallberg E. et al., Insect-like olfactory adaptations in the terrestrial giant robber crab. Curr. Biol. 2005. Vol. 15. P. 116-121.

27. Vogt G. Functional anatomy in biology of freshwater crayfish. / Ed.Holdich, D.M. Oxford: Blackwell Science, 2000. P. 53-151.

28. Belanger R.M., Lahman S.E., Moore P.A. Chapter 6. Crayfish: An experimental model for examining exposure to environmental contamination. Ecotoxicology and genotoxicology: Non-traditional aquatic models. / Ed. M.L. Larramendy. Cambridge: Royal Society of Chemistry, 2017. P. 124-156.

29. El Assal F. M., Abdel-Meguid Z. A. Impact of heavy metal pollution on Procambarus clarkii (Crustacea: Decapoda) from Egypt. Int. J. Waste Resour. 2017. Vol. 7. P. 1-4.

30. Zhang F., Wei J., Li Q. et al Effects of perfluorooctane sulfonate on the immune responses and expression of immune-related genes in Chinese mitten-handed crab Eriocheir sinensis. Comp. Biochem. Physiol. C Toxicol. Pharmacol. 2015. Vol. 172. P. 13-18.

31. Elwood R. W., Barr, S., Patterson, L. Pain and stress in crustaceans? Appl. Anim. Behav. Sci. 2009. Vol. 118. P. 128-136.

32. Magee B., Elwood R. W. Trade-offs between predator avoidance and electric shock avoidance in hermit crabs demonstrate a nonreflexive response to noxious stimuli consistent with prediction of pain. Behav. Process. 2016. Vol. 130. P. 31-35.

33. Elwood R. W., Dalton N., Riddell G. Aversive responses by shore crabs to acetic acid but not to capsaicin. Behav. Process. 2017. Vol. 140. P. 1-5.

34. Passantino A., Elwood R. W., Coluccio P. Why protect decapod crustaceans used as models in biomedical research and in ecotoxicology? Ethical and legislative considerations. Animals. 2021. Vol. 11, No. 1. DOI: https://doi.org/10.3390/ani11010073. 


\title{
МОДЕАЮВАННЯ СТАНІВ СКААДНОГО ААНДШАФТНОГО КОМПАЕКСУ ПРИ НЕВІДОМІЙ ФУНКЦІї ВТРАТ
}

\author{
Руда М.В. ${ }^{1}$, Шибанова А.М. ${ }^{1}$, Паславський М.М. ${ }^{2}$, Джумеля Е.А. ${ }^{1}$ \\ ${ }^{1}$ Національний університет «Львівська політехніка» \\ вул. Степана Бандери, 12, 7900, м. Львів \\ ${ }^{2}$ Національний лісотехнічний університет України \\ вул. Генерала Чупринки, 103, 79057, м. Львів \\ mariia.v.ruda@lpnu.ua, alla.m.shybanova@lpnu.ua, elvira.a.dzhumelia@lpnu.ua; \\ mykhailo.paslavskyi@nltu.edu.com
}

\begin{abstract}
Встановлено, що ризики виникнення і розвитку аварійних ситуацій на реальних об'єктах безперервно змінюються, зумовлюють значні методичні та інструментальні похибки класифікації (розпізнавання) небезпечних ситуацій і під час ідентифікації передаварійних ситуацій знижують вірогідність і однозначність одержуваної інформації. Велика частина досліджень у розглянутій предметній сфері присвячена вирішенню проблем, пов'язаних з управлінням промисловою і екологічною безпекою об'єктів і оптимізацією систем відшкодування збитку від надзвичайних ситуацій. Моделювання функціональних властивостей складного ландшафтного комплексу пропонується розглядати як процес упорядкування організаційних компартментів у взаємозв'язку і взаємодії для підвищення їхньої надійності, стійкості та захисної ефективності. Запропоновано підхід до вирішення проблем моделювання складного ландшафтного комплексу за спостережуваними даними за відсутності можливості точного визначення відповідних функцій втрат (ризиків), який дозволить підвищити ефективність управління промисловою безпекою. Для визначення компартментів складного ландшафтного комплексу застосовано метод регулярної еквіваленції, адаптований із Соціальної Теорії Мереж. Досліджено некласичний підхід до вирішення завдання визначення станів технічної та природної сфери у складному ландшафтному комплексі за спостережуваними даними за відсутності можливості точного визначення відповідних функцій втрат (ризиків) для вирішальних правил. Основна відмінність найкращого вирішального правила станів складного ландшафтного комплексу полягає в тому, що розділююча функція визначається довільним видом функцій втрат із точністю до складеного вектора параметрів, що залежать від спостережуваних даних і часткової апріорної інформації про компартменти складного ландшафтного комплексу. Сформульовано оптимальне в сенсі мінімуму розглянутого некласичного середнього ризику вирішальне правило станів складного ландшафтного комплексу для трьох можливих станів компартментів цього складного ландшафтного комплексу. Встановлено, що запропонований підхід до оцінки стійкості та ризиків втрати компартменту у складного ландшафтного комплексу дає можливість отримати кількісні показники стійкості та ризиків втрати компартменту, що може бути використано як індикатори стану всього складного ландшафтного комплексу. На основі таких показників можливий розрахунок тих порогових величин, поза якими відбуваються негативні явища, прогнозування та моделювання ситуацій, картування джерел ризиків, моніторинг змін, а це дозволить виявити причини цих змін або встановити фактори, що сповільнюють чи стримують наближення складного ландшафтного комплексу до критичного стану, тобто розробити превентивні заходи запобігання катастрофам. Ключові слова: складний ландшафтний комплекс, екологічна безпека, стани, функція втрат.
\end{abstract}

Modeling of states of a compound landscape complex with an unknown loss function. Ruda M., Shybanova A., Paslavskyi M., Dzhumelia E.

It is established that the risks of occurrence and development of emergencies on real objects are constantly changing, cause significant methodological and instrumental errors in the classification (recognition) of dangerous situations and in the identification of pre-emergency situations reduce the reliability and uniqueness of the information obtained. Most of the research in this subject area is devoted to solving problems related to the management of industrial and environmental safety of facilities and optimization of compensation systems for emergencies. Modeling of functional properties of a compound landscape complex is offered to be considered as a process of ordering of compartments in interrelation and interaction for increase of their reliability, stability and protective efficiency. The approach to the decision of issues of modeling of a compound landscape complex on the observed data in the absence of possibility of exact definition of the corresponding functions of losses (risks) which will allow increasing efficiency of management of industrial safety is offered. To determine the compartments of a compound landscape complex, the method of regular equivalence adapted from the Social Theory of Networks was applied. The non-classical approach to the decision of an issue of definition of states of technical and natural sphere in a compound landscape complex on the observed data in the absence of possibility of exact definition of corresponding functions of losses (risks) for decisive rules is investigated. The main difference of the best decisive rule of states of a compound landscape complex is that the separating function is determined by an arbitrary type of loss functions up to a composite vector of parameters depending on the observed data and partial a priori information about the compartments of a compound landscape complex. The optimal in the sense of the minimum of the considered non-classical average risk the decisive rule of states of a compound landscape complex for three possible states of compartments of this compound landscape complex is formulated. It is established that the proposed approach to assessing the resilience and risks of loss of a compartment in a compound landscape complex makes it possible to obtain quantitative indicators of resilience and risks of loss of a compartment, which can be used as indicators of the state of the entire compound landscape complex. Based on such indicators, it is possible to calculate the thresholds beyond which adverse events occur, forecasting and modeling situations, mapping risk sources, monitoring changes, and this will identify the causes of these changes or identify factors that slow or hinder the approach of a compound landscape to a critical state, i.e. to develop preventive measures to prevent disasters. Key words: compound landscape complex, ecological safety, states, loss function. 
Постановка проблеми. Відомо, що сучасний рівень розвитку методології аналізу системних ризиків базується на розгляді небезпечних об'єктів і технологічних процесів як статичних систем із параметрами, що не змінюються в часі [1]. Однак ризики виникнення і розвитку аварійних ситуацій на реальних об'єктах безперервно змінюються, зумовлюють значні методичні та інструментальні похибки класифікації (розпізнавання) небезпечних ситуацій і під час ідентифікації передаварійних ситуацій знижують вірогідність і однозначність одержуваної інформації.

Актуальність дослідження. Велика частина досліджень у розглянутій предметній сфері присвячена вирішенню проблем, пов'язаних 3 управлінням промисловою й екологічною безпекою об'єктів і оптимізацією систем відшкодування збитку від надзвичайних ситуацій $[2,3]$. При цьому в [4] зазначається, що основними причинами низької ефективності управління промисловою безпекою та низької достовірності одержуваних даних є: недостатня повнота статистичних даних і значна методична похибка екстраполяції вхідних даних, що призводить до низької достовірності оцінки небезпечних ситуацій. Вперше можливості оптимального дуального управління на основі теорії статистичних рішень розглядалися в роботах $[5,6]$.

Моделювання функціональних властивостей складного ландшафтного комплексу (СЛК) пропонується розглядати як процес упорядкування організаційних компартментів у взаємозв’ язку і взаємодії для підвищення їхньої надійності, стійкості та захисної ефективності.

Базуючись на гіпотезі, що СЛК можна представити як сукупність компартментів, які мають властивості цілого СЛК, виділено деяку ділянку СЛК одиничної площі. За умовами усі такі ділянки - еквівалентні. Проведено верхню межу досліджуваної системи паралельно поверхні грунту на висоті $\mathrm{H}$, приблизно рівній потроєній висоті дерев $h$. На деякій глибині R за межами шару розміщення кореневої системи проведено нижню грань. Утворений у такий спосіб паралелепіпед і буде розглянутий як об'єкт моделювання. Через бокові грані обмін енергією і речовиною не відбувається, оскільки відсутні відповідні градієнти. У виділений об'єм через верхню грань проникає сонячна радіація і вуглекислий газ, а видаляються, наприклад, пари води. Так само зазначені обмінні процеси відбуваються через нижню грань. Попри це, все, що надходить у систему, відноситься до іiі вхідних впливів, а все що $з$ неї видаляється, - або до втрат, або до відчужуваного кінцевого продукту.

Під час математичного моделювання СЛК розглядають їх екологічний вплив як деякий індекс, який приймається однорідним i ізотропним у горизонтальній площині, а площу СЛК - досить великою для того, щоб можна було знехтувати ефектом «краю поля». У цьому разі всі перетоки енергії і речовини здійснюються тільки у вертикальному напрямі. Понад це, можна також нехтувати ефектом неоднорідності грунту, вважаючи, що описувані процеси можуть бути віднесені до будь-якої частини СЛК. Зрозуміло, однорідних і ізотропних СЛК у природі не існує, однак запропонована ідеалізація дає змогу досягнути необхідну коректність математичних побудов. Отже, неоднорідність модельованої системи проявляється при цьому тільки у вертикальному розміщенні цілей, де важливими є процес і результат моделювання, а модель СЛК має охоплювати прогнозування основних змінних СЛК, бути тим засобом, яким управлінці мають надавати необхідного окреслення поведінці компартментів СЛК та впливу на них. До основних організаційних змінних інформаційної системи (IC) пропонується віднести: складну організаційну структуру (у вигляді дерева цілей, структурних та функціональних схем); динамічну систему показників: надійності, стійкості та захисної ефективності. Все це зумовлює актуальність моделювання СЛК, яке б охоплювало усі рівні організації СЛК у взаємодії із зовнішнім середовищем, насиченим урбаністичними, промисловими та аграрним комплексами. При цьому особливе функціональне значення має специфіка переходу речовинно-енергетичних потоків зі згаданих антропогенних до природних систем і здатність останніх долати ці антропогенні забруднення. А це породжує проблему регулювання стану самого СЛК. Базуючись на сказаному, головне завдання полягає не стільки у скороченні антропогенних забруднювальних викидів, скільки у збереженні ієрархічної структури СЛК та забезпеченні біотичних механізмів регулювання, використання та відтворення СЛК [7]. Для цього необхідне розроблення підходів та методів кількісної оцінки стану СЛК, яка давала би змогу відображати показники їх порушення, стійкості, а відтак створити умови для розрахунку ризиків втрат.

Мета роботи: запропонувати підхід до вирішення проблем моделювання СЛК за спостережуваними даними за відсутності можливості точного визначення відповідних функцій втрат (ризиків), який дозволить підвищити ефективність управління промисловою безпекою.

Аналіз останніх досліджень і публікацій. Для визначення компартментів $(C l)$ СЛК застосовано метод регулярної еквіваленції, адаптований із Соціальної Теорії Мереж [8]. Алгоритм регулярної еквіваленції (доступний у програмі Ucinet 6) оцінює подібність ролей компартментів в СЛК на основі бінарної матриці $A_{n \times n}$ зв'язків між ними. Ієрархічне кластерування [9] вихідної матриці подібності з аналізу регулярної еквіваленції дозволило виділити окремі яруси і підсистеми в досліджуваних компартментах. Більш детально алгоритм регулярної еквіваленції та методи агрегації мереж представлені в роботах Боргатті та Еверета [10], Лужковіча [11] та інших.

Результати досліджень та їх обговорення. Виходячи 3 вищеописаних методів, виділено 
компартмент СЛК $F$, який можна подати як множину характеристик і записати у вигляді:

$$
F_{j i}=\left(G_{i}, T_{j}, S_{p}, I\right),
$$

де $G$ - підмножина гігротопів $\mathrm{G}=\left\{G_{i} \mid i=1,5\right\} ; T-$ підмножина трофотопів $T=\left\{T_{j} \mid j=1,5\right\} ; S_{p}$ - множина видової різноманітності підсистеми компартменту; I - множина інтегральних характеристик, до яких можна віднести стійкість СЛК. Остання множина характеристик також може містити зв'язки між компонентами екосистеми.

Множина $G$ містить 5 елементів, або, інакше кажучи, лісові типологи [12] виділяють 5 видів гігротопів: сухий, свіжий, вологий, сирий, мокрий. 3 кожним елементом пов'язують параметр $W$, який визначає середньорічну глибину рівня грунтових вод (у метрах).

Під час дослідження певної системи необхідно локалізувати місцевість, де проводяться дослідження, та ретельно стежити за основними параметрами, необхідними для досліджень.

Множина Т містить 4 елементи - різновиди трофотопів: бір, субір, суфудок (судіброва), фуд (діброва), які характеризуються агрофізичними та агрохімічними параметрами. До таких властивостей насамперед відносять множину грунтових характеристик $S$.

$$
S=\{\mathrm{Sp}, \mathrm{St}, \mathrm{TD}\},
$$

де $\mathrm{Sp}$ - агрофізичні властивості, $\mathrm{St}$ - тип грунту, TD лісова підстилка, виділена в окремий шар, оскільки знаходиться на поверхні грунту.

Агрофізичні властивості характеризують грунт 3 огляду на фізичні особливості твердої речовини. Тому множину характеристик можна записати у вигляді:

$$
\mathrm{Sp}=\{\mathrm{Vm}, \mathrm{Lm}, \operatorname{Prs}\},
$$

де $\mathrm{Vm}$ - об'ємна маса грунту $\left(г / \mathrm{cm}^{3}\right), \mathrm{Lm}$ - питома

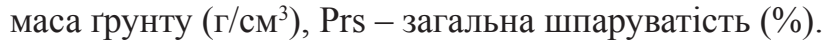

Множина типів грунтів (St) містить у собі підмножини генетичних горизонтів грунтів (Hor), механічного складу грунту $(M c h)$, агрохімічні властивості грунту (Ch).

$$
\mathrm{St}=\{\text { Hor }, \text { Mch, } \mathrm{Ch}\}
$$

У межах формування формалізованих описів генетичних горизонтів прийнято позначати горизонти відповідними символами: основними (великі літери) та допоміжними (малі). Генетичні горизонти Hor є горизонтальними шарами, що якісно відрізняються один від одного. Перехідні зони позначаються назвами двох суміжних горизонтів.

У грунтах СЛК прийнято виділяти такі елементи множини горизонтів [12]:

$$
\text { Hor }=\left\{\mathrm{B}_{\mathrm{hor}}, A_{\mathrm{hor}}, A d\right\},
$$

де $\mathrm{B}_{\mathrm{h} o r}$ - основні горизонти; $A_{\mathrm{hor}}$ - додаткові горизонти; $A d$ - додаткові, відносно відокремлені морфологічні елементи грунту.

$$
\mathrm{B}_{\text {hor }}=\{\mathrm{T}, \mathrm{Ho}, \mathrm{H}, \mathrm{E}, \mathrm{I}, \mathrm{P}\},
$$

де Т - торф'яні, що складаються з рослинних рештків 3 різним ступенем розкладу; Но - органічні акумулятивні, лісова підстилка; Н - гумусові, горизонти, які акумулюють органічні речовини; Е - елювіальні, збіднені в результаті вимивання; I - ілювіальні, збагачені глинистими частинками внаслідок вимивання; Р- материнська порода.

Динаміку функціонування більшості СЛК 3 урахуванням прогнозу їх стану можна представити у вигляді деякого ситуаційного процесу із трьома можливими станами. Перший стан пов'язаний з ситуацією $X_{1}^{0}$, коли стан СЛК повністю відповідає заданим умовам функціонування і в принципі поява екологічної небезпеки (ЕН) малоймовірна. Другий стан пов'язаний із ситуацією $X_{2}^{0}$, коли стан СЛК не відповідає заданим умовам функціонування і може привести до ЕН, але поки не виникає необхідності застосування активних заходів щодо іiі ліквідації. Третій стан пов'язаний із ситуацією $X_{3}^{0}$, коли стан СЛК призводить до появи ЕН, що вимагає застосування активних заходів щодо її ліквідації. При цьому кожна зі згаданих ситуацій з'являється випадково.

Позначимо через $X$ простір розглянутих вище ситуацій ЕН в СЛК. Цей простір розіб'ємо на три області $X_{k}$, де $k=1,2,3$. Для визначення вирішального правила необхідно сформулювати критерій якості класифікації ЕН та небезпечного об'єкта (НО), тобто розпізнавання ситуацій $X_{k}^{0}, k=1,2,3$. Вирішальне правило повинно бути таким, щоб сформульований критерій досягав екстремуму. Це означає, що завдання класифікації станів СЛК полягає в найкращому, в сенсі заданого критерію, розбитті простору ситуацій $X$ на області $X_{k}, k=1,2,3$.

Для конкретизації поняття станів СЛК введено матрицю втрат компартменту:

$$
F(x, c)=\left[\begin{array}{l}
F_{11}(x, c) F_{12}(x, c) F_{13}(x, c) \\
F_{21}(x, c) F_{22}(x, c) F_{23}(x, c) \\
F_{31}(x, c) F_{32}(x, c) F_{33}(x, c)
\end{array}\right],
$$

де $F_{k m}(x, c)$ - функції втрат компартменту для значень $k, m=1,2,3 ; c$ - складова вектора параметрів функцій втрат, що дорівнює $c=\left[c_{1} c_{2} c_{3}\right]$. Функції втрат $F_{k m}(x, c), k, m=1,2,3$ характеризують ризики, пов'язані зі станами СЛК, що виникають при перенесенні ситуаці $X_{k}^{0}$ до класу ситуаці $X_{m}^{0}$ або при потраплянні ситуації $X_{k}^{0}$ в область $X_{m}$

На головній діагоналі матриці (7) розташовано ризики при нейтральних значеннях НО в СЛК, а по обидва боки від головної діагоналі розташовано ризики (втрати) при негативних значеннях станів НО. Будемо вважати, що $F_{k m}(x, c)<0$ для всіх $k$ $=1,2,3$. Такі негативні ризики можна інтерпретувати як деякі виграші при нормальних станах СЛК та мінімальних ризиках втрати компартменту. При цьому ситуація із простору $X$ для кожного класу $X_{k}^{0}$ 


\section{Руда М.В., Шибанова А.М., Паславський М.М. ...}

характеризується умовною щільністю розподілу $p(x / k)=p_{k}(x)$ i апріорною ймовірністю $P_{k}$. 3 огляду на це для розглянутого випадку появи ЕН введемо вектор апріорних даних такого вигляду:

$$
P(x)=\left[p_{1}(x) P_{1}, p_{2}(x) P_{2}, p_{3}(x) P_{3}\right]^{T},
$$

У такому разі середній ризик втрати компартменту у СЛК в умовах ЕН $є$ функціонал меж $\Lambda_{k m}$ між областями $X_{k}$ i $X_{m}$ для всіх $k, m=1,2,3$ і складеного вектора $c$. Для фіксованого складеного вектора $c$ стан СЛК з появою ЕН буде визначатися за межею $\Lambda_{k m}$.

3 метою можливості пошуку оптимальних у сенсі мінімуму середнього ризику виникнення ЕН об'єкту в СЛК меж і складеного вектора скористаємося вектором характеристичних функцій рішень виду:

$$
\Theta(x, c)=\left[\Theta_{1}(x, c) \Theta_{2}(x, c) \Theta_{3}(x, c)\right]^{T} .
$$

У векторі (9) характеристика функції:

$$
\Theta_{m}(x, c)=\left\{\begin{array}{l}
1, \text { якщо } \mathrm{X} \in \mathrm{X}_{\mathrm{m}} \\
0, \text { якщо } \mathrm{X} \notin \mathrm{X}_{\mathrm{m}}, \quad \mathrm{m}=1,2,3
\end{array}\right.
$$

3 урахуванням (7) - (9) величину середнього ризику стану СЛК з ЕН об'єктом можна представити у векторно-матричній формі:

$$
R(c)=\int_{X} \Theta^{T}(x, c) F^{T}(x, c) P(x) d x .
$$

Тоді умова мінімуму середнього ризику (18) буде визначатися прирівнянням градієнта (11) по вектору $c$ до нуля, тобто:

$$
\begin{aligned}
& \bar{\nabla}_{c} R(c)=\int_{X}\left(\bar{\nabla}_{c} \Theta(x, c)\right)^{T} F^{T}(x, c) P(x) d x+ \\
& +\int \Theta^{T}(x, c)\left(\bar{\nabla}_{c} F(x, c)\right)^{T} P(x) d x=0
\end{aligned}
$$

$\mathrm{У}$ виразі (12) матриця $\overline{\mathrm{v}}_{c} F(x, c)$ характеризує чутливість функції втрат (7) по вектору $c$, а вектор $\overline{\mathrm{v}}_{c} \Theta(x, c)$ - вектор чутливості характеристики функцій по вектору $c$.

Вважаючи, що характеристики функції (10), що визначають межі $\Lambda_{k m}$ між областями $X_{k}$ i $X_{m}$, при кожному фіксованому векторі $c$, виражають мінімум середнього ризику (11), їх чутливість повинна бути рівною нулю, і перший інтеграл в рівнянні (12) повинен дорівнювати нулю, тобто

$$
\int_{X}\left(\bar{\nabla}_{c} \Theta(x, c)\right)^{T} F^{T}(x, c) P(x) d x=0 .
$$

Виходячи з рівняння (12), це означає, що другий інтеграл має дорівнювати нулю, тобто:

$$
\int_{X} \Theta^{T}(x, c)\left(\overline{\mathrm{v}}_{c} F(x, c)\right)^{T} P(x) d x=0 .
$$

Оскільки $\bar{v}_{c} \Theta(x, c)$ - вектор багатовимірних $\delta$ - функцій, які за винятком точок, що належать межам $\Lambda_{k m}$ між областями $X_{k}$ і $X_{m}$ для всіх $k, m=1$, 2, 3, дорівнюють нулю, то для заданої межі $\Lambda_{s m}$ між областями $X_{s}$ i $X_{m}$ :

$$
\bar{\nabla}_{c} R(c)=\int_{\Lambda_{s m}} \Delta_{s m}(x, c)^{T} P(x) d x=\int_{\Lambda_{s m}} f_{s m}(x, c) d x=0
$$

\section{МОДЕ ЮЮВАННЯ СТАНІВ...}

У виразі (14) вектор $\Delta_{s m}(x, c)=F_{s}(x, c)-F_{m}(x, c)-$ різниця векторів втрат станів для областей $X_{s}$ i $X_{m}$, які в цьому разі визначаються відповідними (15) і (16) векторами:

$$
\begin{aligned}
F_{s}(x, c) & =\left[F_{1 s}(x, c) F_{2 s}(x, c) F_{3 s}(x, c)\right]^{T}, \\
F_{m}(x, c) & =\left[F_{1 m}(x, c) F_{2 m}(x, c) F_{3 m}(x, c)\right]^{T},
\end{aligned}
$$

У виразі (14) функція $f_{s m}(x, c)=\Delta_{s m}(x, c)^{T} P(x)-$ розподільча функція, знак якої дозволяє виконувати класифікацію станів СЛК. При цьому рівняння:

$$
f_{s m}(x, c)=\Delta_{s m}(x, c)^{T} P(x)=0
$$

визначає поверхню, що розділяє області $\mathrm{X}_{\mathrm{s}} \mathrm{i} X_{m}$.

Характерною відмінністю рівняння (17) $є$ те, що розподільча функція визначається заданим видом функцій втрат із точністю до складеного вектора параметрів, що визначається даними й апріорною інформацією про ЕН в СЛК. 3 огляду на це оптимальний в сенсі мінімуму середнього ризику (11) стан СЛК у цьому разі можна сформулювати в такій формі: дані моніторингу про ЕН СЛК у вигляді $x \in X_{k}$, тобто дані $x$ відносяться до класу $X_{k}^{0}$, якщо $\Delta_{k m}(x, c)^{T} P(x)\langle 0$, для всіх $m=1,2,3$. При цьому вектор $c$ визначається з умови (13).

В окремому випадку, коли за результатами даних моніторингу моделюється два можливих стани СЛК при ЕН об'єкта (ЕН на об'єкті має місце - стан $X_{1}^{0}$ або ЕН на об'єкті відсутній - стан $X_{2}^{0}$ ) оптимальний в сенсі (11) стан СЛК приймає вигляд: $x \in X_{1}$, тобто х відноситься до $X_{1}^{0}$, якщо $f_{12}(x, c)\left\langle 0\right.$ і $x \in X_{2}$, тобто х відноситься до $X_{2}^{0}$, якщо $\left.f_{12}(x, c)\right\rangle 0$.

У цьому разі складник вектора, що входить у функцію, буде визначатися за умови (13) для всіх $k, m=1,2,3$. Вирішальне правило для цієї задачі класифікації ЕО об'єкта відрізняється від традиційних вирішальних правил теорії статистичних рішень використанням не фіксованих функцій втрат, а функцій втрат, що задаються із точністю до відновлюваних параметрів і залежних від спостережуваних даних.

Для ілюстрації узагальнюючого характеру описуваного некласичного підходу розглянемо класичний байєсовський підхід до задачі моделювання станів СЛК при невідомій функції втрат. При класичному підході функції втрат постійні. Це означає, що в цьому разі, виходячи з класичного підходу, в (7) функції втрат для всіх $k, m=1,2$ будуть визначатися у вигляді:

$$
\begin{aligned}
& \left.F_{12}(x, c)=w_{12}\right\rangle 0, F_{11}(x, c)=w_{11}\langle 0, \\
& \left.F_{21}(x, c)=w_{21}\right\rangle 0, F_{22}(x, c)=w_{22}\langle 0 .
\end{aligned}
$$

3 урахуванням функцій втрат (18) середній ризик (11) буде визначатися величиною:

$$
R=w_{11} P_{1} \int_{X_{1}} p_{1}(x) d x+w_{21} P_{2} \beta+w_{12} P_{1} \alpha+w_{22} P_{2} \int_{X_{2}} p_{2}(x) d x,
$$

де $\alpha=\int p_{1}(x) d x$ - умовна ймовірність похибки першого Порялдку, а $\beta=\int_{X_{1}} p_{2}(x) d x-$ умовна ймовірність 
похибки другого порядку. Для прийнятих постійних функцій втрат в (7) $\bar{v}_{c} F(x, c)=0$ і розділяє поверхню (15) буде визначатися функцією такого вигляду:

$$
f_{12}(x, c)=\left(w_{11}-w_{12}\right) P_{1} p_{1}(x)=\left(w_{21}-w_{22}\right) P_{2} p_{2}(x)=0
$$

На підставі (7) оптимальне вирішальне правило класифікації ЕН об'єкта зводиться до традиційного визначення достовірності і порівняння його з порогом, який визначається величиною:

$$
l_{0}=\left(w_{21}-w_{22}\right) P\left[\left(w_{12}-w_{11}\right) P_{1}\right]^{-1}
$$

Оптимальне правило означає, що якщо $l(x)>l_{0}$, то спостережувані дані $x$ відносяться до класу $X_{1}^{0}$ (наявність ЕН на об'єкті в СЛК). Якщо ж $l(x)>l_{0}$, то спостережувані дані відносяться до класу $X_{2}^{0}$ (відсутність ЕН на об'єкті в СЛК).

Під час моделювання СЛК $(S)$ зазначені підсистеми $\left(S S_{i}, i=1,2, \ldots, N\right)$ пропонується описувати вісьмома множинами системних компонент, а саме: $E$ - множина елементів; $V$ - множина показників, притаманних елементам множини $E$, для множини показників $V$ доцільно виділити дві підмножини: $V j-$ підмножина імен показників; $Z j$ - підмножина значень показників, що змінюються у часі; $W$ - множина станів системи, елементи якої визначаються значеннями показників (підмножина $Z j$ ), згідно $з$ їх іменами (підмножина $V j)$, у фіксований момент часу - множина $T ; F$ - множина функцій (дій, операцій), що забезпечують перехід системи від початкового стану до головної мети; $C$ - множина цілей функціонування системи; $R-$ множина відношень, що містить підмножини відношень між самими множинами та між елементами кожної із зазначених множин.

Між цими множинами системної моделі існують такі види відношень: $R_{l}(E, V j)$ - відношення відповідності, яке ставить у відповідність кожному елементу множини $E$ деяку вибірку із $V j ; R_{2}(V j, Z j)$ - відношення відповідності між заданим іменем показника та конкретними його значеннями у момент часу $t ; R_{3}(Z j, W)-$ відношення, яке ставить у відповідність кожному елементу множини $Z j$ підмножину значень елементів множини $W$ у момент часу $t ; R_{4}(W, F)$ - відношення порядку, яке задає послідовність виконання функцій (дій, операцій) у процесі досягнення головної мети $C_{0}$.

Мета, своєю чергою, може формуватися як вимога щодо досягнення конкретних значень показників чи станів ефективності підсистем СЛК та ефективного виконання захисних функцій СЛК загалом. Тобто, моделюючи СЛК, необхідно виділити такі обов'язкові множини компонент $[14,15,16]$, які б забезпечували повноту моделі:

$$
\begin{gathered}
M_{S S}^{S}=\left\{\begin{array}{l}
E^{1}, E_{S S}^{2}, \ldots, E_{S S}^{i}, \ldots, E_{S S}^{N}, V^{1}, V_{S S}^{2}, \ldots V_{S S}^{i}, \ldots, \\
V_{S S}^{N}, W^{1}, W_{S S}^{2}, \ldots, W_{S S}^{i}, \ldots W_{S S}^{N},
\end{array}\right. \\
F^{1}, F_{S S}^{2}, \ldots, F_{S S}^{i}, \ldots, F_{S S}^{N}, C^{1}, C_{S S}^{2}, \ldots C_{S S}^{i}, \ldots C_{S S}^{N}, R^{1}, R_{S S}^{2}, \ldots R_{S S}^{i}, \ldots R_{S S}^{N}, \\
R\left(S S_{1}, S S_{2}\right), R\left(S S_{1}, S S_{3}\right), \ldots, R\left(S S_{i}, S S_{i+1}\right), \ldots \\
\left.R\left(S S_{i+1}, S S_{i}\right), \ldots, R\left(S S_{N}, S S_{N-1}\right)\right\} .
\end{gathered}
$$

Наведені закономірності структуризації та функціонування підсистем СЛК є початковими правилами щодо виділення системи елементів та компартментів СЛК. 3 точки зору повноти системної моделі СЛК, на верхніх рівнях декомпозиції обов'язковим є розгляд у взаємозв'язку таких об'єктів:

$$
E=\left\{E^{1}, E_{S S}^{2}, \ldots, E_{S S}^{i}, \ldots, E_{S S}^{N}\right\},
$$

При декомпозиції елементів множини $E$ для кожного елемента $\left(E^{1}, E_{S S}^{2}, \ldots, E_{S S}^{i}, \ldots, E_{S S}^{N}\right)$ із множини (23), пропонується виділити весь набір системних компонент - $\{V, Z, W, F, C, R\}$. Наступна декомпозиція елементів (23) та їхніх компонент залежить від виду досліджуваної підсистеми $S S i$, де $i=1,2, \ldots, N$. Спільною для них усіх $\epsilon$ ієрархічність структуризації. Це можна формалізувати описом на теоретико-множинній мові у вигляді дерева взаємовідношень, яке може бути абстрактним рівнем ієрархічної моделі СЛК, де задаються одиниці їх характеристик та взаємовідношення між ними. Тому це буде шестиверствне дерево, де перший граф $\left(G_{E}\right)$ - граф елементів, другий $\left(G_{V}\right)$ - граф показників, третій $\left(G_{Z}\right)$ - граф значень показників, четвертий $\left(G_{W}\right)$ - граф станів, п'ятий $\left(G_{F}\right)$ - граф функцій, шостий $\left(G_{C}\right)$ - дерево (граф) цілей. Цей шестиверствний граф може задавати правила формування системної моделі будьякої СЛК [17, 18]. Тому модель СЛК пропонується подавати у вигляді графа, де на рівні першої верстви можуть розміщуватися ієрархічні структури усіх підсистем компартментів СЛК та зовнішнього середовища. Для графічного подання усіх верств графа СЛК пропонується використовувати елементи макро-, мезо- та мікрорівня СЛК. Елементи множин $E^{1}, E_{S S}^{2}, \ldots, E_{S S}^{i}, \ldots, E_{S S}^{N}$ (граф $G$ ) вказують на верхній рівень декомпозиції СЛК та, відповідно, можуть бути описані трирівневими графами.

Висновки. Таким чином, досліджено некласичний підхід до вирішення завдання визначення станів технічної та природної сфери в СЛК за спостережуваним даними за відсутності можливості точного визначення відповідних функцій втрат (ризиків) для вирішальних правил. Основна відмінність найкращого вирішального правила станів СЛК полягає в тому, що розділююча функція визначається довільним видом функцій втрат 3 точністю до складеного вектора параметрів, що залежать від спостережуваних даних і часткової апріорної інформації про компартменти СЛК. Сформульовано оптимальне в сенсі мінімуму розглянутого некласичного середнього ризику вирішальне правило станів СЛК для трьох можливих станів компартментів цього СЛК (інертність, відновлювальність, пластичність). Під час аналізу СЛК компартмент $з$ його підсистемами та ярусами розглядається як рівноцінний компонент відносно інших. Однак, виходячи з основ теорії біотичної регуляції навколишнього середовища, де головним компонентом екосистеми виступає біота, такий підхід вимагає певних корекцій, що витікає 
3 основних властивостей живого, його організації, функціонування. Можна зробити відповідний висновок, що індикатором різноманітності, стану рівноваги та порушення СЛК є рослинність, а регуляторним механізмом його формування, відновлення від початкового до рівноважного стану, стабілізації виступає компартмент. Тому оцінка стану СЛК, його потенціалу, стійкості повинна базуватися на порівняльній оцінці сукцесійних стадій (серій) угруповань в компартменті від початкового до стійкого клімаксового стану.

Виходячи 3 такого розуміння, що грунтується на законах термодинаміки, ключове місце в оцінці ризику посідає дослідження сукцесійного розвитку компартменту. Сукцесія розглядається як такий процес розвитку, що відбувається завдяки реалізації біоти потенційних можливостей перебудови структури компартменту відносно зміни навколишнього середовища. Інакше кажучи, розвиток компартменту описується векторним полем у фазовому просторі. Одночасно такий розвиток супроводжується зміною зовнішніх (кліматичних, гідрологічних, едафічних характеристик), які на виході з СЛК можуть суттєво відрізнятися від фонових (вхідних). Переходи СЛК через послідовну зміну стійких станів іï компартментів розглядаються як атрактори стійкості. Хоча це самоорганізований та самопідтримуючий процес, однак він спрямований у бік удосконалення механізмів акумуляції енергії через адаптаційні властивості видів, зниження енергетичних витрат, а відтак зниження показників ентропії, що означає наближення до стійкого, але водночас і термінального стану, а тому зростає ризик руйнування компартменту. Як вважає Р. Уіттекер [19], у процесі сукцесії підвищується продуктивність компартменту, його біорізноманітність, зростає стійкість. Сукцесія - це не лінійний, не строго детермінований, а стохастичний, імовірнісний процес. Це означає, що кожен ярус підсистеми компартменту (ценопопуляція) може бути заміщений іншим, краще адаптованим до існуючих умов або преадаптованим для наступних можливих змін, і таке заміщення відбувається на всіх етапах процесу, у кожній $з$ підсистем компартменту. Таким чином, показник біотичного різноманіття тих елементів, які можуть взаємозаміщуватися у процесі сукцесії, має ключове значення, оскільки зниження біорізноманіття (або окремих його форм) звужує область стійкості. Хоча компартмент може бути досить стійким і при вузькій області, тобто при досить обмеженій кількості видів (наприклад, букові ліси). Але при цьому можливі варіанти заміщення, і ймовірність формування різноманітності стійких станів звужується.

Врешті, головне завдання полягає в тому, щоб оцінити положення цього компартменту у сукцесійному ряді, і в цьому відношенні в геоботаніці є фундаментальні напрацювання, зокрема щодо оцінки швидкості, етапів розвитку ценозів (сингенез, ендоекогенез, філценогенез), уявлення про різні форми клімаксу, сукцесійні ряди, серії тощо.

Перспективи використання результатів досліджень. Виходячи з цих розробок, запропоновано такі індикаторні ознаки або характеристики, за якими будемо оцінювати дві групи характеристик компартменту: кількісні показники його зміни, тобто швидкість сукцесій $(V)$, та масштабність змін $(S)$, тобто їхній часовий та просторовий стан $f(V, S)$. Причому можуть бути використані як безпосередні, так і опосередковані характеристики. До числа останніх належить, наприклад, наявність у складі ярусів чи підсистем компартменту видів, занесених до Червоної книги, охоронних списків, тобто таких, що підлягають охороні, бо такі види, як правило, пов'язані 3 рідкісними компартментами або надмірно експлуатуються, тобто знаходяться у зоні більшого ризику руйнування, ніж ті, де такі види відсутні. Для такої оцінки важливі і такі характеристики, як показники гемеробії, що відображають здатність видів рослин зростати і поширюватися у різного ступеня перетворених людиною екосистемах: а-, оліго-, мезо-, еу-, по-, лі-, метагемероби. Іншою ознакою є типи стратегій поведінки видів, що відображають їхнє відношення до заселення та утримання компартменту: $R$ - стрес-толеранти заселюють екстремальні екотопи; $S$ - патієнти утримуються за рахунок конкуренції, протидії впливу зовнішніх факторів, тобто характеризують інерційність ценозу; $K$ - експлеренти, що швидко реагують і характеризують ступінь резистентності ценозу.

\section{Література}

1. Абдрахманов Н.Х., Абдрахманова К.Н., Ворохобко В.В., Шайбаков Р. А. Современное состояние разработки методологии анализа системных рисков при проектировании и эксплуатации нефтегазового оборудования опасных производственных объектов. Нефтегазовое дело: электрон. науч. журн. Уфа: УГНТУ, 2014. № 3. C. 359-376. URL: http://ogbus.ru/issues/3_2014/ogbus_3_2014_p359-76_AbdrakhmanovNKh_ru.pdf.

2. Акимов В.А., Лесных В.В., Тимофеева Т.Б. Проблема выбора оптимальной структуры национальной системы возмещения ущерба от природных и технологических чрезвычайных ситуаций. Проблемы безопасности чрезвычайных ситуаций. Х., НУЦЗ Украины, 2006. № 6. С. 15-26.

3. Абдрахманов, Н.Х. Управление промышленной и экологической безопасностью объектов нефтепереработки и нефтехимии на основе анализа рисков. Защита окружающей среды в нефтегазовом комплексе. М.: Открытое акционерное общество Всероссийский науч.-исслед. ин-т организации, управления и экономики нефтегазовой промышленности, 2013. № 3. С. 5-9.

4. Абдрахманов Н.Х., Абдрахманова К.Н., Ворохобко В.В., Шайбаков Р. А. Современное состояние разработки методологии анализа системных рисков при проектировании и эксплуатации нефтегазового оборудования опасных про- 
изводственных объектов. Нефтегазовое дело: электрон. науч. журн. Уфа: УГНТУ, 2014. № 3. C. 359-376. URL: http://ogbus.ru/issues/3 2014/ogbus 3 2014_p359-76_AbdrakhmanovNKh_ru.pdf.

5. Фельдбаум, А.А. Основы теории оптимальных автоматических систем. М.: Наука, 1968.

6. Цыпкин, Я.З. Адаптация и обучение в автоматических системах. М.: Наука, 1968.

7. Li B.-L., Gorshkov V.G., Makarieva A.M. Allometric scaling as an indicator of ecosystem state: a new approach // I. Petrosillo et al. (eds.) Use of Landscape Sciences for the Assessment of Environmental Security, NATO Science for Peace and Security Series C: Environmental Security, Springer, the Netherlands, 2008. P. 107-117.

8. Borgatti, S.P., Everett, M.G., Freeman, L.C. UCINET VI. Software for Social Network Analysis. Natick: Analytic Technologies, 2002.

9. Johnson, S.C. Hierarchical clustering schemes. Psychometrika 32, 1967. 241-253.

10. Borgatti, S.P., Everett, M.G. Two algorithms for computing regular equivalence. Social Networks 15, 1993. 361-376.

11. Luczkovich, J.J. et al., 2003. Defining and Measuring Trophic Role Similarity in Food Webs Using Regular Equivalence. J. Theor. Biol. 220(3), 303-321.

12. Погребняк П.С. Основы лесной типологии. К.: Изд-во АН УССР, 1955. - 456 с.

13. Ткачев Ю.А., Юдович Я.Э. Статистическая обработка геохимических данных. Л.: Наука, 1975.

14. Лавинский Г.В. Построение и функционирование сложных систем управления. - К.: Выща шк. Головное изд-во, 1989.336 с.

15. Методи побудови та вдосконалення організаційних структур URL: http://library.if.ua/book/32/2125.html

16. Организационные структуры управления производством / [Под ред. Б. 3. Мильнера]. Москва: Экономика, 1975.320 с.

17. Курінний O.В. Аналіз методів проектування організаційних структур. URL:: http://www.confcontact.com/2007may/8_kurin.htm

18. Одрехівський М.В. Системний підхід до організаційного моделювання інноваційних підприємств. Розвиток суб'єктів господарювання України: сучасні реалї̈ та перспективи: колективна монографія / за заг. ред. Л.М. Бандоріної, Л.М. Савчук. Дніпро: Пороги, 2017. С. 139-153.

19. Уиттекер Р. Сообщества и экосистемы. Москва, Изд-во Прогресс, 1980. 326 с. 


\title{
КОНСТРУЮВАННЯ МУАЬТИЕАЕКТРОДНИХ EИЕКTPO-БIOCИСTEM 3 LEMNA MINOR
}

\author{
Русин І.Б. ${ }^{1}$, Медведсв О.В. ${ }^{2}$, Дячок В.В. ${ }^{1}$ \\ ${ }^{1}$ Національний університет «Львівська Політехніка» \\ вул. Степана Бандери, 12, 79013, м. Львів \\ ${ }^{2}$ Філія «Науково-дослідний інститут автомобілебудування «Еталон» \\ вул. Городоцька, 174, 79022, м. Львів \\ rib7@i.ua, mov2@ukr.net
}

\begin{abstract}
Конструювання мультиелектродних електро-біосистем є ефективною стратегією у досягненні високих значень електропродуктивності мікробних електро-біосистем та малодослідженим способом для рослинно-мікробних паливних елементів. Біотехнологія рослинно-мікробних електро-біосистем $є$ молодою науковою галуззю, що відокремилася в 2008 році від біотехнології мікробних електро-біосистем. Електро-біосистеми, базовані на рослинах, генерують біоелектрику завдяки електроактивним мікроорганізмам ризосфери рослин. Утилізуючи органічні фотосинтетанти та сполуки субстрату, вони передають електрони і протони на електроди, в результаті чого продукується біоелектрика. Вивчення стекування мультиелектродних модулів рослинно-мікробних електро-біосистем $є$ важливим кроком для підвищення їх потужності. У статті вивчено мультиелектродні електро-біосистеми, базовані на Lemna minor, та досліджено вплив на біоелектричні параметри їх стекування шляхом послідовного з'єднання. Сконструйовано ефективні одиничні мультиелектродні електро-біосистеми з L. minor із середнім вольтажем відкритого кола 0,983 В та 1,170 В відповідно для 4- та 8-електродних електро-біосистем. 4-електродна електро-біосистема виявилася більш економічно вигідною за 8-електродну, оскільки при у 2 рази нижчих затратах на електродні матеріали демонструвала лише в 1,2 раза нижчі біоелектричні параметри для цього об’єму електро-біосистеми. У результаті стекування 7 бюджетних та компактих 4-електродних електро-біосистем шляхом їх послідовного з'єднання досягнуто зростання біоелектричного потенціалу до $6,001 \mathrm{~B}$, при цьому сила струму короткого замикання залишилася на вихідному рівні. Конструювання мультиелектродних електро-біосистем та їх послідовне з'єднання є перспективним способом подолання проблеми низької потужності, способом підвищення їх біоелектричних параметрів та вагомим кроком до широкомасшабного впровадження водних рослинно-мікробних електро-біосистем, базованих на L. minor. Ключові слова: відновлювана енергія, біоелектрика, електрод, електро-біосистема, рослина.
\end{abstract}

Design of multi-electrode electro-biosystems with Lemna minor. Rusyn I., Medvediev O., Djachok V.

The design of multi-electrode electro-biosystems is an effective strategy in achieving of high values of electrical productivity of microbial electro-biosystems and a little-studied method for plant-microbial fuel cells. Biotechnology of plant-microbial electrobiosystems is a young scientific field that separated in 2008 from the biotechnology of microbial electro-biosystems. Plant-based electro-biosystems generate bioelectricity through electro-active microorganisms of the plant rhizosphere. By utilizing organic photosynthetants and substrate compounds, they transfer electrons and protons to the electrodes, resulting in bioelectricity. The study of the stacking of multi-electrode modules of plant-microbial electro-biosystems consider as an important step to increase their capacity. In this paper, we studied multielectrode electro-biosystems based on Lemna minor and investigated the effect on bioelectric parameters of their stacking by series connection. Efficient single multi-electrode electro-biosystems with $L$. minor with an average open-circuit voltage of $0.983 \mathrm{~V}$ and $1.170 \mathrm{~V}$, were designed, for 4- and 8-electrode electro-biosystems, respectively. The 4-electrode electro-biosystem proved to be more cost-effective than the 8 -electrode one, because at 2 times lower costs for electrode materials it showed only 1.2 times lower bioelectric parameters for a given volume of the electro-biosystem. As a result of stacking of 7 budget and compact 4-electrode electro-biosystems by their series connection, an increase in the bioelectric potential to 6,001 V was achieved, while the short-circuit current remained at the initial level. The design of multi-electrode electro-biosystems and their serial connection is a promising way to overcome the problem of low power, a way to increase their bioelectric parameters and a significant step towards large-scale introduction of aquatic plant-microbial electro-biosystems based on L. minor. Key words: renewable energy, bioelectricity, electrode, electro-biosystem, plant.

Постановка проблеми та актуальність дослідження. Стекування електро-біосистем, базованих на мікроорганізмах, у мультиелектродні електро-біосистеми є вагомим способом підвищення їх ефективності й отримання високих значень електропродуктивності та водночас малодослідженим питанням у галузі рослинно-мікробних паливних елементів. Ефективність об'єднання модулів мікробних електро-біосистем, енергоефективність яких була пропорційною до кількості використовуваних одиничних систем, було досліджено $[1,2]$, продемонстровано ефекти паралельного та послідовного їх з'єднання [3].

Аналіз останніх досліджень і публікацій. Перші дослідження об'єднання рослинно-мікробних електро-біосистем представлені в роботах [4-6]. Десять електро-біосистем із мохами були з'єднані в один комплекс для досягнення вищих значень біоелектричних параметрів [4]. Три контейнери з рослинами $A$. africanus та електродними системами були послідовно з'єднані, в результаті чого біоелектричний потенціал зріс в 1,88 раза [6]. Можливість 
використання мультиелектродних електро-біосистем 3 рослинами була показана в роботах $[7,8]$.

Мета та завдання дослідження. Беручи до уваги актуальність проблеми, недостатній рівень іiі вивчення та великі перспективи стекування одиничних електро-біосистем для підвищення їх енергоефективності, ми поставили перед собою завдання розробити ефективну та бюджетну одиничну мультиелектродну електро-біосистему з L. minor та дослідити стекування шляхом послідовного з'єднання iіi 7 модулів в лабораторних умовах із метою підвищення біоелектричних параметрів.

Виклад основного матеріалу.

Методи дослідження. Для проведення експериментів було сконструйовано 4-електродні та 8-електродні електро-біосистеми 3 Lemna minor L., які містилися в контейнерах об'ємом 700 мл із розмірами 120 мм х 95 мм х 60 мм. Схема розташування електродних систем у контейнерах наведена на рис. 1. У кожен контейнер поміщали 200 г піщаного субстрату, отриманого з дна ставка, 600 мл води зі ставка із додаванням свіжої водопровідної води

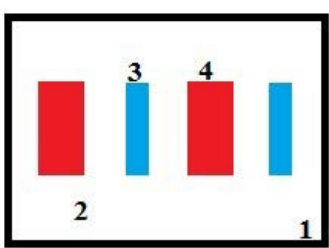

A

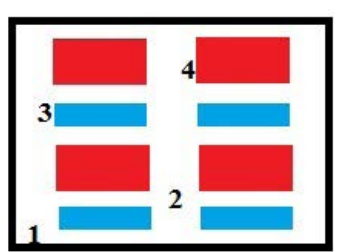

$\mathbf{6}$
Рис. 1 Схема розташування електродів y 4-електродній (A) та 8-електродній

(Б) електро-біосистемах з L. minor:

1-контейнер, 2 -субстрат, 3 -анод, 4-катод

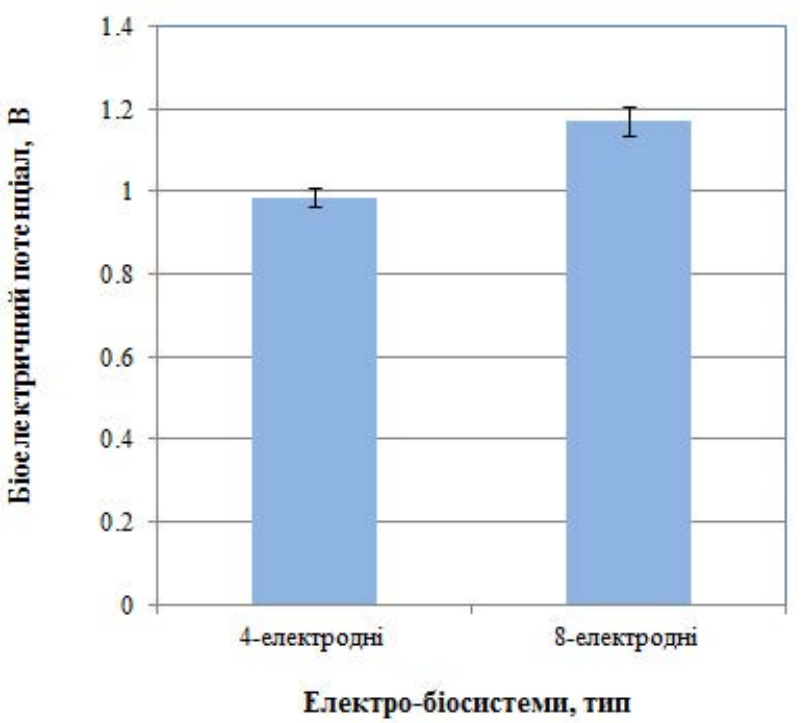

Рис. 2. Вплив збільшення кількості електродів з 4 до 8 на біоелектричний потенціал електро-біосистеми з L. minor $(x \pm S E, n=5)$ та рослину ряску L. minor, отриману із забрудненого ставка поблизу м. Львова в кількості 60 листків/мл у поверхневому шарі. Як електродні системи використовувалися пари електродів [9]: катод 87 мм х 28 мм х 14 мм та анод 78 мм х 36 мм х 1 мм. Електроди занурювали у субстрат в зону коріння рослин.

Дроти, що виходили з катодів на поверхню, об'єднували між собою, аналогічно об'єднували дроти від анодів. Електро-біосистеми розміщували біля вікон, де вони отримували природне освітлення.

Покази біоелектричного потенціалу відкритого кола та силу струму короткого замикання реєстрували за допомогою цифрового мультиметра UT890C UNIT-T. Густину ряски обчислювали шляхом прямого підрахунку кількості листків в 1 мл середовища. Наведені в роботі результати представлені як середнє значення для всіх повторюваних експериментів та їх стандартні похибки (x $\pm \mathrm{SE})$. Статистичну оцінку істотності різниці між середніми значеннями обчислено за допомогою F-тесту для 95\%-го рівня достовірності.

Предметом досліджень були показники біоелектричного потенціалу і сили струму 4- та 8-електродних електро-біосистем з L. Minor, як одиничних систем, так і у разі їх стекування.

Результати дослідження та їх обговорення. Для розроблення ефективної та бюджетної одиничної мультиелектродної електро-біосистеми 3 L. minor та визначення впливу кількості електродів на біоелектричні параметри нами було сконструйовано 4-електродну та 8-електродну електро-біосистеми. У разі збільшення кількості електродів вдвічі біоелектричний потенціал зростав на 0,187 В (рис. 2), а сила струму зростала на 1,311 мА (рис. 3). Незначне зростання біоелектричних показників за збільшення кількості електродів до 8, очевидно, пов'язано 3 майже оптимальною площею електродів на

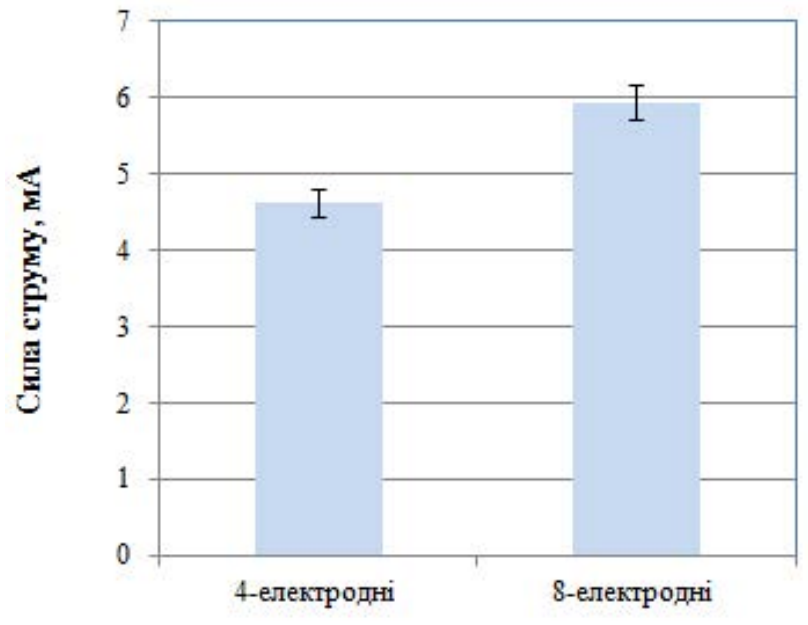

Електро-біосистемп, тип

Рис. 3. Вплив збільшення кількості електродів з 4 до 8 на силу струму електро-біосистем з L. minor $(x \pm S E, n=5)$ 
Русин I.Б., Медведєв О.В., Дячок В.В.

цей об’єм електро-біосистеми у разі 4-електродної електро-біосистеми.

Хоча 8-електродна електро-біосистема характеризувалася суттєво вищими значеннями біоелектрики $(\mathrm{P}<0.05)$, перевищування становило лише 1,2 раза. Враховуючи те, що при цьому для іiі конструювання використано в 2 рази більше електродів, 4-електродну електро-біосистему було обрано як більш бюджетну й ефективну одиничну мультиелектродну електро-біосистему з L. minor для подальших експериментів зі стекуванням.

Послідовне стекування 7 одиничних 4-електродних електро-біосистем привело до зростання біоелектричного потенціалу в 6,10 раза (рис. 4).

Біоелектричний потенціал піднявся з 0,983 В до 6,001 В. Аналогічні тренди зафіксовані у роботах iз грунтовими електро-біосистемами 3 рослинами при послідовному з'єднанні 3 електро-біосистем, базованих на $A$. africanus, де показано ріст біоелектричного потенціалу з 0,690 В до 1,300 В [6], та C. palustris, де показано ріст потенціалу з 1,1 В до 3,23 В [8]. Водночас послідовне з'єднання не мало впливу на струм короткого замикання, який залишився на вихідному рівні, як показано також для електро-біосистем, базованих на мікроорганізмах [3] та рослинах і мікроорганізмах [5,8].

Головні висновки. Сконструйовано компактні мультиелектродні 4- та 8-електродні водні електробіосистеми, базовані на L. Minor, із середнім воль-

\section{КОНСТРУЮВАННЯ МУАЬТИЕАЕКТРОДНИХ...}

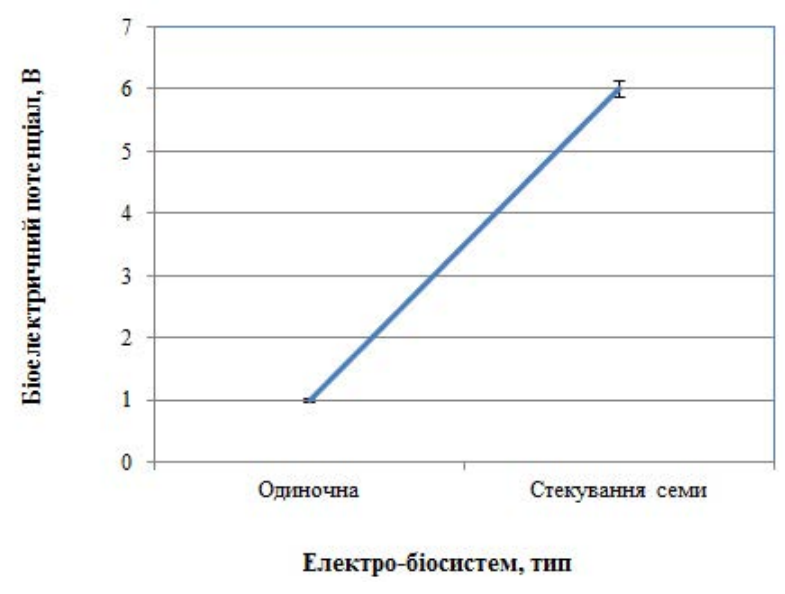

Рис. 4. Вплив послідовного стекування 7 одиничних 4-електродних електро-біосистем з L. minor на біоелектричні параметри $(x \pm S E, n=5)$

тажем відкритого кола 0,983 В та 1,170 В відповідно. Стекування шляхом послідовного з'єднання 7 бюджетних 4-електродних електро-біосистем дозволило досягнути зростання біоелектричного потенціалу в 6,10 раза. Виявлений ефект стекування 4-електродних електро-біосистем відкриває можливості для підвищення значень біоелектричного потенціалу для водних електро-біосистем, базованих на рясці, без потреби у надмірному збільшенні площ та кількості електродів.

\section{Література}

1. Ieropoulos I.A., Stinchcombe A., Gajda I., Forbes S., Merino-Jimenez I., Pasternak G., Sanchez-Herranz D., Greenman J. Pee power urinal - microbial fuel cell technology field trials in the context of sanitation. Environmental Science: Water Research Technology. 2016. Vol. 2. P. 336-343. doi: 10.1039/C5EW00270B

2. Walter X.A., Merino-Jiménez I., Greenman J., Ieropoulos I. PEE POWER ${ }^{\circledR}$ urinal II - Urinal scale-up with microbial fuel cell scaledown for improved lighting. Journal of Power Sources. 2018. Vol. 15, № 392. P. 150-158. doi: 10.1016/j.jpowsour.2018.02.047

3. Aelterman P., Rabaey K., Pham H.T., Boon N., Verstraete W. Continuous electricity generation at high voltages and currents using stacked microbial fuel cells. Environmental Science Technology. 2006. Vol. 40, № 10. P. 3388-3394. doi: org/10.1021/es0525511

4. Bombelli P., Dennis R.J., Felder F., Cooper M.B., Iyer D.M.R., Royles J., Harrison S.T., Smith A.G., Harrison C.J., Howe C.J. Electrical output of bryophyte microbial fuel cell systems is sufficient to power a radio or an environmental sensor. Royal Society Open Science. 2016. Vol. 3, 160249. doi: org/10.1098/rsos.160249

5. Pamintuan K.R.S., Clomera J.A.A., Garcia K.V., Ravara G.R., Salamat E.J.G. Stacking of aquatic plant-microbial fuel cells growing water spinach (Ipomoea aquatica) and water lettuce (Pistia stratiotes) / IOP Conference Series: Earth and Environmental Science 191, 012054. The 4th International Conference on Water Resource and Environment (WRE 2018) 17-21 July 2018, Kaohsiung City, Taiwan. Kaohsiung City: IOP Publishing. doi: 10.1088/1755-1315/191/1/012054(2018)

6. Gomora-Hernandez J.C., Serment-Guerrero J.H., Carreno-de-Leon M.C., Flores-Alamo N. Voltage production in a plant-microbial fuel cell using Agapanthus africanus. Revista Mexicana de Ingenieria Quimica. 2020. Vol. 19, № 1. P. 227-237. doi: 10.24275/ rmiq/IA542

7. Pamintuan K.R.S., Reyes C.S.A., Lat D.K.O. Compartmentalization and polarization studies of a Plant-Microbial Fuel Cell assembly with Cynodon dactylon. E3S Web of Conferences. 2020. Vol. 181, № 01007. doi: 10.1051/e3sconf/202018101007

8. Rusyn I.B., Medvediev O.V., Valko B.T. Enhancement of bioelectric parameters of multi-electrode plant-microbial fuel cells by combining of serial and parallel connection. International Journal of Environmental Science and Technology. 2021. Vol. 18, № 6. P. 1323 - 1334. doi: 10.1007/s13762-020-02934-3

9. Русин І.Б., Медведєв О.В. Спосіб отримання біологічної електрики з глибинних шарів грунту: пат. 112093 Україна: МПК 2016.01, Н05F 7/00, Н01M 8/16; заявл. 9.03.2016; опубл. 12.12.2016. Бюл. № 23. 5 с. 


\title{
ДОСАІДЖЕННЯ ФІЗІОАОГО-БІОХІМІЧНИХ ОСОБАИВОСТЕЙ ТА БІОПИІВКОУТВОРЕННЯ БАКТЕРІЙ, ВИДІАЕНИХ ІЗ СУДИННИХ РОСАИН АНТАРКТИКИ
}

\author{
Юнгін О.С. ${ }^{1}$, Прекрасна Є.П. ${ }^{2}$, Ластовецька Л.О. ${ }^{1}$, Маслак В.І. ${ }^{1}$, Кудіна С.В. ${ }^{1}$ \\ ${ }^{1}$ Київський національний університет технологій та дизайну \\ вул. Немировича-Данченка, 2, 01001, м. Київ \\ ${ }^{2}$ Державна установа «Національний науковий антарктичний центр» \\ бульв. Тараса Шевченка, 16, 01601, м. Київ \\ olgaungin@gmail.com,preckrasna@gmail.com
}

\begin{abstract}
Успішна колонізація земель Антарктики судинними рослинами Deschampsia antarctica та Colobanthus quitensis, ïx адаптація до стресових умов регіону пов'язана не лише з кліматичним змінами, а й із функціонуванням мікробних угруповань філой ендосфери вказаних рослин. Одним із вагомих факторів ефективності колонізації рослини бактеріями є їх здатність утворювати біоплівки на зовнішніх і внутрішніх поверхнях рослини. Внесок мікробіоти з ендосфери (внутрішні тканини рослин) та філосфери (надземної частини листя рослин) у витривалість рослин в умовах Антарктичного півострова та особливостей формування їх біоплівок залишається невивченим. Метою роботи було дослідження фізіолого-біохімічних особливостей і біоплівкоутворення бактерій, асоційованих із судинними рослинами Антарктики Deschampsia antarctica та Colobanthus quitensis. У результаті роботи показана гетеротрофність досліджуваних бактеріальних ізолятів та наявність у них широкого спектра сахаролітичних ферментів для утилізації моно- й дицукрів. Крім того, виявлена здатність культур використовувати молекулярний азот атмосфери як єдине джерело нітрогену, що також $є$ ознакою ріст-стимулювальних властивостей бактерій. Показана здатність культур формувати різні типи біоплівок та їх широкий температурний діапазон культивування. Гетеротрофність бактеріальних ізолятів, виділених із біомаси Deschampsia antarctica та Colobanthus quitensis, наявність у досліджуваних культур широкого спектра сахаролітичних ферментів для утилізації моно- й дицукрів, а також їх здатність фіксувати атмосферний азот свідчать на користь їх участі в рослинно-мікробних взаємодіях і потенціальному стимулюванні росту та розвитку судинних рослин Антарктики. Широкий температурний діапазон досліджуваних культур і їх оптимум культивування може свідчити про оригінальність їх походження та наявність проміжного хазяїна (ссавця та/або птаха) у контексті екосистеми антарктичного півострова. Ключові слова: біоплівки, бактерії філосфери, судинні рослини Антарктики.
\end{abstract}

Research of physiological and biochemical characteristics and biofilm formation of bacteria isolated from vascular plants of Antarctica. Yunhin O., Prekrasna Ye., Lastovetska L., Maslak V., Kudina S.

Successful colonization of Antarctic lands by vascular plants Deschampsia antarctica and Colobanthus quitensis and their adaptation to the stressful environments of the region is associated not only with climate change but also with the functioning of microbial groups of phylo- and endosphere of these plants. One of the important factors in the effectiveness of bacterial plant colonization is their ability to form biofilms on the outer and inner parts of plants. The contribution of plant-associated microbiota to plants development and its biofilm formation aspects remains unexplored. The aim of the research was to study physiological and biochemical characteristics and biofilm formation of bacteria associated with vascular plants of Antarctica Deschampsia antarctica and Colobanthus quitensis. As a result the heterotrophic metabolism of the studied bacteria and a wide range of saccharolytic enzymes for the utilization of mono- and disaccharides were shown. Moreover, the use of atmospheric nitrogen as the sole source of nitrogen for studied bacteria was observed. That was also a sign of the plant growth-stimulating properties of bacteria. The ability of bacteria to form different types of biofilms and their wide temperature cultivation range was shown. Heterotrophic metabolism bacterial isolates from the biomass of Deschampsia antarctica and Colobanthus quitensis, the wide range of saccharolytic enzymes for utilization of mono- and disaccharides, as well as their ability to use atmospheric nitrogen indicate their potential promoting of vascular plants in Antarctica. The wide cultivation range of the studied bacteria and their optimum of cultivation may indicate their origin and the fact of an intermediate host (mammal and/or bird) existance in the context of the Antarctic peninsula ecosystem. Key words: biofilms, bacteria of philosphere, vascular plants of Antarctica.

Постановка проблеми. Мікроорганізми, асоційовані з антарктичними рослинами Deschampsia antarctica та Colobanthus quitensis, задіяні в каскаді біохімічних реакцій, що допомагають рослинам виживати й повноцінно функціонувати в екстремальних грунтово-кліматичних умовах Антарктики. Здатність мікроорганізмів ендо- й філосфери вказаних рослин утилізувати широкий спектр джерел карбону за низьких температур, формувати біоплівки та брати участь у трансформації головних біогенних елементів відіграє важливу роль в адаптації рослин до стресових факторів регіону.

Тож метою роботи було дослідження фізіолого-біохімічних особливостей та біоплівкоутворення бактерій, асоційованих із судинними рослинами Антарктики Deschampsia antarctica та Colobanthus quitensis.

Актуальність дослідження. Зміни клімату, що безпосередньо впливають на Антарктичний півострів, сприяють успішній колонізації вільних від льоду земель двома антарктичними судинними 
Юнгін О.С., Прекрасна Є.П., Ластовецька Л.О. ...

рослинами - Deschampsia antarctica та Colobanthus quitensis. Відомо, що бактерії мають ключове значення для росту й адаптації рослин до екстремальних умов росту та розвитку. Одним із вагомих факторів ефективності колонізації рослини бактеріями $\epsilon$ їх здатність утворювати біоплівки на зовнішніх і внутрішніх поверхнях рослини. Внесок мікробіоти 3 ендосфери (внутрішніх тканин рослин) та філосфери (надземної частини листя рослин) у витривалість рослин в умовах Антарктичного півострова та особливостей формування їх біоплівок залишається невивченим. 3 огляду на кліматичні зміни, що проявляються в Антарктичному півострові [1], актуальним завданням є дослідження мікроорганізмів, асоційованих із судинними рослинами цього регіону.

Зв'язок авторського доробку 3 важливими науковими та практичними завданнями. Робота проводилася в межах завдання 13 «Вивчення походження, біорізноманіття та проведення моніторингу наземних екосистем Антарктики в умовах кліматичних змін» Державної цільової науково-технічної програми проведення досліджень в Антарктиці на 2011-2023 pр., затвердженої постановою Кабінету Міністрів України від 3 листопада 2010 р. № 1002 (у редакції постанови Кабінету Міністрів України від 20 січня 2021 р. № 32).

Аналіз останніх досліджень і публікацій. Біоплівкова форма росту $є$ природною стратегією існування мікроорганізмів у навколишньому середовищі. У контексті рослинно-мікробних взаємодій рослина є не лише організмом-господарем, а й поверхнею для росту та розвитку біоплівок бактерій-ендофітів [2].

Дослідження в Антарктиді, як правило, зосереджені на різноманітті макроорганізмів та генезисі, властивостях і класифікації грунтів. У плані мікробіології найновіші дослідження зосереджувалися на оцінці біотехнологічного потенціалу вторинних метаболітів (антибіотиків, протипухлинних засобів, ферментів тощо), що виробляються культивованими бактеріями (зокрема, актинобактеріями). Мало дослідників вивчали мікробне різноманіття та перспективні рослинно-бактеріальні взаємодії. Застосування молекулярних підходів на основі гена $16 \mathrm{~S}$ рибосомної РНК (рРНК) виявило схожі закономірності бактеріального різноманіття між двома судинними видами рослин (Deschampsia antarctica та Colobanthus quitensis), знайденими в антарктичних екосистемах [3]. Відомо, що мікроорганізми беруть участь у метаболізмі зазначених видів рослин та забезпечують їх функціонування в суворих умовах регіону. Так, нещодавно був опублікований геном бактерії, виділеної з філосфери Deschampsia antarctica, що має антифризні білки та відповідає за інгібування рекристалізації льоду в рослинах за низьких температур [4].

Виділення не вирішених раніше частин загальної проблеми, котрим присвячусться стаття. Великий науковий інтерес до мікроорганізмів, асоційованих із судинними рослинами антарктичного

\section{ДОСАІДЖЕННЯ ФІЗІОАОГО-БІОХІМІЧНИХ...}

регіону, що спостерігається в дослідженнях останніх років, зумовлений не лише поглибленням теоретичних відомостей про рослинно-мікробні взаємодії, а й перспективами зміни клімату у світі та біотехнологічним потенціалом вказаних мікроорганізмів. Антарктичні рослини розробили механізми адаптації, які дають їм змогу успішно переживати екстремальні умови регіону. Деякі ефективні механізми протидії несприятливим стресовим факторам виникають унаслідок встановлення функціонального симбіозу 3 ендофітними мікроорганізмами. Зокрема, велику увагу було приділено вивченню впливу мікроміцетів-ендофітів. Так, дослідження останніх років показали провідну роль мікроміцетів-ендофітів у підвищенні толерантності рослин до ультрафіолетового випромінювання (УФ-В) та мінімізації пошкодження клітин рослин [5]; стимуляції росту рослин за рахунок підвищення мінералізації нітрогену [6]; покращення фізіологічних показників за сольового стресу за рахунок продокування енергії та комплексоноутворення з $\mathrm{Na}^{+}$[7].

Проте майже немає досліджень щодо розвитку та впливу бактеріальних ендофітів судинних рослин антарктичного регіону. У роботі [8] досліджено розмаїття мікробних угруповань ризо-, філо- та ендосфери D. antarctica та C. quitensis. Більшість мікроорганізмів належить до груп Proteobacteria, Bacteroidetes та Actinobacteria та є специфічними для різних частин рослин. За допомогою молекулярно-генетичного аналізу й статистичних обробок даних встановлено, що виявлені бактерії відіграють роль у гетеротрофії, ферментації та відновленні нітратів. Однак потрібні додаткові дослідження для 3'ясування ролі мікроорганізмів в успішній колонізації антарктичними рослинами вільних від льоду земель Антарктики. Бактерії, що живуть у холодному природному середовищі (наприклад, в Антарктиді), реалізують стратегію біоплівкового росту, хоча механізми того, як цей спосіб життя пов'язаний із їх адаптацією до навколишнього середовища в контексті бактеріально-рослинних взаємодій, були не досить досліджені.

Новизна. Уперше оцінено здатність бактеріальних ізолятів, асоційованих із D. antarctica та $C$. quitensis, формувати біоплівки за широкого температурного діапазону, визначено оптимум їх культивування. Уперше показано їх здатність використовувати атмосферний азот як єдине джерело нітрогену та наявність сахаролітичних ферментів.

Методологічне та загальнонаукове значення. У роботі досліджували 12 культур, що виділені 3 D. antarctica та C. quitensis, які були відібрані під час 25-ї Української антарктичної експедиції (січень - квітень 2020 р.) вздовж Західної частини Антарктичного півострова.

В основі роботи лежить комплексний підхід до вивчення здатності мікроорганізмів формувати біоплівки. У його межах були застосовані класичні фізіолого-біохімічний і мікробіологічний підходи, які доцільно використовувати для характеристики нових 
штамів. Так, культури вирощували на мінімальних середовищах із додаванням різних джерел карбону (ряди Гіса) для виявлення цукролітичних особливостей мікроорганізмів [9]. Здатність мікроорганізмів використовувати молекулярний азот атмосфери як єдине джерело нітрогену оцінена $з$ використанням середовища Ешбі [10]. Наявність бактеріального росту фіксували за зміною оптичної густини середовища та оцінювали як + (слабкий ріст), ++ (помірний ріст), +++ (рясний ріст).

Під час вивчення здатності виділених культур бактерій формувати біоплівки частково застосований метод комбінованого дослідження біоплівок [11]. Для отримання біоплівок культури вирощували у статичних закритих мікрокосмах (віалах) із середовищем Nutrient Broth (HiMedia, Ltd.) за температури 4, 22, 37 та $42^{\circ} \mathrm{C}$ протягом 3 діб. Такі температурні режими перекривають можливі варіанти існування бактерій не лише в навколишньому середовищі, а й за умови наявності проміжного хазяїна (ссавця чи птаха). Досліджуваними параметрами були приріст біомаси (продуктивність) і ступінь прикріплення клітин до поверхні, що визначали спектрофотометрично за довжини хвиль 600-620 та 570 нм відповідно. Для визначення прикріплення клітин до поверхні використано метод культивування ізолятів у культиральних 96-лункових планшетах із подальшим фарбуванням кристалічним фіолетовим [12].

Виклад основного матеріалу. У результаті роботи показана гетеротрофність бактеріальних ізолятів, виділених із біомаси Deschampsia antarctica та Colobanthus quitensis, та наявність у досліджуваних культур широкого спектра сахаролітичних ферментів для утилізації моно- й дицукрів (див. табл. 1). Серед запропонованих моноцукрів представлені як гексози, так і пентози; як дицукри представлені лактоза й цукроза. Позначення «+» відображає позитивну реакцію, «+-» - невиражену позитивну реакцію, «-» - негативну реакцію.

Таблиця 1

Здатність утилізувати цукри як сдине джерело карбону

\begin{tabular}{|c|c|c|c|c|c|c|c|c|c|}
\hline \multirow{2}{*}{ Ізолят } & \multicolumn{4}{|c|}{ Гексози } & \multicolumn{2}{c|}{ Пентози } & \multicolumn{2}{|c|}{ Дицукри } \\
\cline { 2 - 11 } & Glu & Fru & Man & Gal & Ara & Xyl & Ryb & Lac & Suc \\
\hline 9.1 & + & - & + & - & - & - & - & - & - \\
\hline 10.1 & + & - & + & + & - & + & + & - & - \\
\hline 10.4 & + & - & + & + & - & + & + & - & - \\
\hline 15.6 & + & - & - & - & - & + & - & - & - \\
\hline 16.7 & + & - & - & - & + & + & - & + & + \\
\hline 23.2 & + & + & + & - & + & + & - & + & + \\
\hline 25.2 & + & + & + & + & - & + & + & + & + \\
\hline 26.2 & + & - & + & + & - & + & - & - & +- \\
\hline 26.4 & + & - & + & + & - & + & - & - & + \\
\hline 26.7 & + & + & + & - & - & - & + & +- & + \\
\hline 39.12 & + & + & - & - & - & - & + & - & - \\
\hline 40.1 & + & + & + & + & + & + & + & +- & + \\
\hline
\end{tabular}

Найбільше ізолятів утилізували глюкозу, манозу та ксилозу. Маноза є ізомером глюкози, компонентом багатьох полісахаридів та змішаних біополімерів рослинного, тваринного й бактеріального походження. Як основна складова частина полімерів ксилану в рослинах ксилоза вважається одним із найпоширеніших вуглеводів на Землі після глюкози. 3 огляду на те, що досліджувані ізоляти асоційовані з рослинами, цілком зрозуміло, що саме вказані цукри можуть бути перспективними для метаболічного використання бактеріями.

Цікаво, що ізоляти 25.2 та 40.1 утилізували найбільшу кількість із представлених цукрів -8 із 9. Найменшу кількість цукрів утилізував ізолят $9.1-2$ з 9 (глюкозу та манозу).

Здатність мікроорганізмів використовувати молекулярний азот атмосфери як єдине джерело нітрогену було виявлено в таких культур: $10.1(+), 10.4(+)$, $25.2(+), 26.2(+), 26.7(+++), 40.1(+++)$. Найбільший приріст біомаси спостерігали в культур 26.7 та 40.1.

Досліджено здатність ізолятів формувати біоплівки за широкого діапазону температур [13]. Також визначали тип біоплівки, що формувалася ізолятами на розділі фаз: ALS - біоплівка на розділі фаз «повітря - рідина - тверда поверхня» (air - liquid solid), LS - біоплівка на розділі фаз «рідина - тверда поверхня» (liquid - solid) [14] (див. табл. 2).

Здатність ізолятів формувати біоплівки за різних температур культивування

\begin{tabular}{|c|c|c|c|c|c|}
\hline \multirow{2}{*}{ Ізолят } & \multicolumn{3}{|c|}{ Ріст за температури } & \multirow{2}{*}{$\begin{array}{c}\text { Тип біоплівки } \\
\text { ка розділі фаз }\end{array}$} \\
\cline { 2 - 5 } & $\mathbf{4}^{\circ} \mathbf{C}$ & $\mathbf{2 6}^{\circ} \mathbf{C}$ & $\mathbf{3 7}^{\circ} \mathbf{C}$ & $\mathbf{4 2}^{\circ} \mathbf{C}$ & \\
\hline 9.1 & - & + & + & + & ALS* \\
\hline 10.1 & - & + & + & + & ALS \\
\hline 10.4 & + & + & + & - & LS** \\
\hline 15.6 & - & + & - & - & LS \\
\hline 16.7 & - & + & - & - & LS \\
\hline 23.2 & - & + & - & - & LS \\
\hline 25.2 & + & + & + & - & ALS \\
\hline 26.2 & + & + & + & + & ALS \\
\hline 26.4 & + & + & + & + & LS \\
\hline 26.7 & + & + & + & + & ALS \\
\hline 39.12 & + & + & + & + & LS \\
\hline 40.1 & - & + & + & + & LS \\
\hline
\end{tabular}

Встановлено, що досліджувані ізоляти мають різний температурний діапазон культивування, що може свідчити про оригінальність їх походження та наявність проміжного хазяїна (наприклад, ссавці та/або птахи). Формування LS біоплівок є важливою ознакою бактерій, асоційованих із судинними рослинами. 3 огляду на функціонування всередині рослини мікроорганізми мають колонізувати тканини рослин у мікроаерофільних умовах.

Цікавим $\epsilon$ розподіл продуктивності культур за різних температурних діапазонів. Так, 
ізоляти $9.1,10.1$ та 40.1 ростуть у діапазоні $26-42^{\circ} \mathrm{C}$, а 10.4 та 25.2 - за діапазону $4-37^{\circ} \mathrm{C}$. Ізоляти 26.2 , 26.4, 26.7 та 39.12 мали найширший температурний діапазон культивування 3-поміж усіх досліджуваних культур $-4-42^{\circ} \mathrm{C}$. Крім того, три культури з усіх досліджуваних - 15.6, 16.7 та 23.2 - формували LS біоплівку та продукували біомасу лише за температури $26^{\circ} \mathrm{C}$. Це, імовірно, може бути пов'язано з функціонуванням цих бактерій як внутрішніх асоціантів судинних рослин.

Головні висновки. Гетеротрофність бактеріальних ізолятів, виділених із біомаси Deschampsia antarctica та Colobanthus quitensis, наявність у досліджуваних культур широкого спектра сахаролітичних ферментів для утилізації моно- й дицукрів, а також їх здатність фіксувати атмосферний азот свідчить про їх участь у рослинно-мікробних взаємодіях та потенціальному стимулюванні росту й розвитку судинних рослин Антарктики. Широкий температурний діапазон досліджуваних культур і їх оптимум культивування може свідчити про оригінальність їх походження та наявність проміжного хазяїна (ссавця та/або птаха) у контексті екосистеми антарктичного півострова.

Перспективи використання результатів дослідження. Дослідження рослинно-мікробних взаємодій антарктичного регіону загалом та мікроорганізмів Антарктики зокрема є важливим не лише для України, а й для світової науки. Антарктичний регіон вважається одним із найбільш перспективних із позиції виділення мікроорганізмів із біотехнологічним потенціалом. Результати дослідження допомагають охарактеризувати бактеріальні ізоляти, асоційовані із судинними рослинами Антарктики, та розширити уявлення про їх роль у контексті рослинно-мікробних взаємодій.

\section{Література}

1. In situ warming in the Antarctic: effects on growth and photosynthesis in Antarctic vascular plants / P.L. Sáez, L.A. Cavieres, J. Galmés, E. Gil-Pelegrín, J.J. Peguero-Pina, D. Sancho-Knapik, L.J. Corcuera. New Phytologist. 2018. Vol. 218. Iss. 4. P. $1406-1418$.

2. Moshynets O.V. Viewing biofilms within the larger context of bacterial aggregations. Biofilms : book/O.V. Moshynets, A.J. Spiers. Rijeka, Croatia : InTech Press, 2016. P. 3-22.

3. Rhizobacterial community structures associated with native plants grown in Chilean extreme environments / M.A. Jorquera, F. Maruyama, A.V. Ogram, O.U. Navarrete, L.M. Lagos, N.G. Inostroza, M. de La Luz Mora. Microbial ecology. 2016. Vol. 72. Iss. 3. P. 633-646.

4. Draft genome sequences of bacteria isolated from the Deschampsia antarctica phyllosphere / F.P. Cid, F. Maruyama, K. Murase, S.P. Graether, G. Larama, L.A. Bravo, M.A. Jorquera. Extremophiles. 2018. Vol. 22. Iss. 3. P. 537-552.

5. Fungal endophytes enhance the photoprotective mechanisms and photochemical efficiency in the Antarctic Colobanthus quitensis (Kunth) Bartl. exposed to UV-B radiation / A. Barrera, R. Hereme, S. Ruiz-Lara, L.F. Larrondo, P.E. Gundel, S. Pollmann, P. Ramos. Frontiers in Ecology. 2020. № 8. P. 122.

6. Root endophytic Penicillium promotes growth of Antarctic vascular plants by enhancing nitrogen mineralization / R. Oses-Pedraza, C. Torres-Díaz, P. Lavín, P. Retamales-Molina, C. Atala, J. Gallardo-Cerda, M.A. Molina-Montenegro. Extremophiles. 2020. Vol. 24. Iss. 5. P. 721-732.

7. Molina-Montenegro M.A., Acuña-Rodríguez I.S., Torres-Díaz C. Antarctic root endophytes improve physiological performance and yield in crops under salt stress by enhanced energy production and $\mathrm{Na}+$ sequestration. Sci Rep. 2020. № 10. P. 5819.

8. Niche differentiation in the composition, predicted function, and co-occurrence networks in bacterial communities associated with Antarctic vascular plants / Q. Zhang, J.J. Acuña, N.G. Inostroza, P. Duran, M.L. Mora, M.J. Sadowsky, M.A. Jorquera. Frontiers in microbiology. 2020. № 11. P. 1036.

9. Сульдина Е.В., Феоктистова Н.А., Богданов И.И. Выделение новых штаммов бактерий Bacillus megaterium и изучение их биологических свойств. Вестник Ульяновской государственной сельскохозяйственной академии. 2020. № 3. С. 60-67.

10. Yanfang N., Wei Y., Lihong C. Diversity and Characterization of Nitrogen-fixing Bacteria in Betula platypylla Rhizosphere in Arxan. Journal of Northeast Forestry University. 2017. P. 05.

11. Adaptive radiation of Pseudomonas fluorescens SBW25 in experimental microcosms provides an understanding of the evolutionary ecology and molecular biology of AL interface biofilm formation / A. Koza, A. Kuśmierska, K. McLaughlin, O. Moshynets, A.J. Spiers. FEMS Microbiology Letters. 2017. Vol. 364. Iss. 12.

12. Crystal violet and XTT assays on Staphylococcus aureus biofilm quantification / Z. Xu, Y. Liang, S. Lin, D. Chen, B. Li, L. Li, Y. Deng. Current microbiology. 2016. Vol. 73. Iss. 4. P. 474-482.

13. Skogman M.E., Vuorela P.M., Fallarero A. Combining biofilm matrix measurements with biomass and viability assays in susceptibility assessments of antimicrobials against Staphylococcus aureus biofilms. The Journal of antibiotics. 2012. Vol. 65. Iss. 9. P. 453-459.

14. Characterization of biofilm formation by Salmonella enterica at the air-liquid interface in aquatic environments / J.A. MedranoFélix, C. Chaidez, K.D. Mena, M. del Socorro Soto-Galindo, N. Castro-del Campo. Environmental monitoring and assessment. 2018. Vol. 190. Iss. 4. P. 1-9. 


\title{
БIОАОГIЧНА БЕЗПЕКА
}

\author{
УДК 504.75.05 \\ DOI https://doi.org/10.32846/2306-9716/2021.eco.6-39.18
}

\section{ОЦІНКА КАНЦЕРОГЕННОГО РИЗИКУ XРОНІЧНОÏ IНТОКСИКАЦIÏ НАСЕАЕННЯ ВІД ЗАБРУДНЕНОГО АТМОСФЕРНОГО ПОВІТРЯ}

\author{
Колісник А.В. \\ Одеський державний екологічний університет \\ вул. Львівська, 15, 65016, м. Одеса \\ Kolisnyk.A.V@gmail.com
}

\begin{abstract}
Для врахування негативних екологічних впливів найрізноманітніших факторів важливо застосовувати підхід, який базується на оцінці ризику несприятливих наслідків. Упродовж тривалого часу оцінка ризику для здоров'я людей, зумовленого забрудненням довкілля, була на відповідальності експертів із токсикології та гігієни. Це було пов'язано з необхідністю врахування великої кількості факторів, які зумовлюють характер впливу шкідливих речовин на організм людини. Нині розроблені методики, які дозволяють отримати приблизні оцінки ризику на основі узагальнених показників, таких як: клас небезпеки, кратність перевищення гранично допустимих концентрацій тощо. Для врахування та аналізу негативного впливу забруднення атмосферного повітря на здоров'я, що може бути реалізовано у хронічних проявах, у роботі застосована лінійно-експоненціальна модель. Метою дослідження є оцінка канцерогенного ризику хронічної інтоксикації від забрудненого атмосферного повітря проживаючого в великих містах Півдня України населення. Об'єкт дослідження - канцерогенний ризик хронічної інтоксикації. Предмет дослідження - вплив забруднювальних речовин атмосферного повітря м. Одеса, м. Ізмаїл, м. Миколаїв, м. Херсон, м. Запоріжжя на безпечність умов перебування населення на відкритому повітрі. Вихідними даними $є$ інформація про концентрації забруднюючих речовин у атмосферному повітрі з офіційних джерел - Регіональних доповідей про стан навколишнього природного середовища в 2017 році (Одеська, Миколаївська, Херсонська, Запорізька області). За результатами оцінки канцерогенного ризику хронічної інтоксикації населення від забрудненого атмосферного повітря міст Півдня України встановлено, що найвищі значення канцерогенного ризику відзначаються для м. Одеса, а найнижчі - для м. Ізмаїл. У 2017 р. найбезпечніші умови перебування на відкритому повітрі характерні для м. Ізмаїлу (9 год.). Інші міста за зменшенням ступеня безпечності розподілилися таким чином: м. Запоріжжя (6 год), м. Миколаїв (5 год.), м. Херсон (4 год.) та м. Одеса (3 год.). Отже, найнебезпечніші умови перебування на відкритому повітрі характерні для м. Одеса. Ключові слова: ризик, хронічна інтоксикація, канцерогенний ризик, забруднюючі речовини, атмосферне повітря.
\end{abstract}

Assessment of carcinogenic risk of chronic intoxication of the population from polluted air. Kolisnyk A.

When you take into account the negative environmental impacts of a variety of factors, it is important to apply an approach based on risk assessment of adverse effects. To take into account the negative environmental impacts of a variety of factors, it is important to apply an approach based on risk assessment of adverse effects. Toxicology and hygiene experts have long been responsible for assessing the risk to human health from environmental pollution. This was due to the need to take into account a large number of factors that determine the nature of the effects of harmful substances on the human body. At present, methods have been developed that allow to obtain approximate risk estimates based on generalized indicators such as: hazard class, multiplicity of exceeding the maximum allowable concentrations, etc. A linear-exponential model is used to take into account and analyze the negative impact of air pollution on health, which can be realized in chronic manifestations. The aim of the study is to assess the carcinogenic risk of chronic intoxication from polluted air to the population residing in large cities of southern Ukraine. The subject of the study is the carcinogenic risk of chronic intoxication. Object - the impact of air pollutants in Odessa, Izmayil, Mykolaiv, Kherson, Zaporizhzhya on the safety of the population while in the open air. The initial data are information on the concentration of pollutants in the air from official sources - Regional Reports on the State of the Environment in 2017 (Odessa, Izmayil, Mykolaiv, Kherson, Zaporizhzhya regions). According to the results of the assessment of carcinogenic risk of chronic intoxication of the population from polluted air in the cities of the South of Ukraine it is established that the highest levels of carcinogenic risk are observed in Odessa, and the lowest in Izmayil. In 2017, the safest conditions for staying outdoors were calculated for the city of Izmayil ( 9 hours). Other cities in order of decreasing security are as follows: Zaporizhzhya (6 hours), Mykolaiv (5 hours), Kherson (4 hours) and Odessa (3 hours). Thus, the most dangerous conditions in the open air are typical for the city of Odessa. Key words: risk, chronic intoxication, carcinogenic risk, pollutants, atmospheric air.

Постановка проблеми. Для оцінки негативних екологічних впливів найрізноманітніших факторів (аварійні ситуації, забруднення хімічними речовинами і радіонуклідами, нераціональна господарська діяльність, природні катастрофи тощо) в останні роки активно розпочали застосовувати підхід, який базується на оцінці ризику несприятливих наслідків. Методи оцінки екологічного ризику не можуть охопити все багатоманіття проблем, пов'язаних з оцінкою екологічного ризику, і описують тільки найважливіші з них. Упродовж тривалого часу оцінка ризику для здоров'я людей, зумовленого забрудненням 


\section{Колісник А.В.}

довкілля, була на відповідальності експертів із токсикології та гігієни. Це було пов'язано з необхідністю врахування великої кількості факторів, які зумовлюють характер впливу шкідливих речовин на організм людини. Нині розроблені методики, які дозволяють отримати приблизні оцінки ризику на основі узагальнених показників, таких як: клас небезпеки, кратність перевищення гранично допустимих концентрацій (ГДК) тощо.

Актуальність дослідження. Відомо, що атмосферне повітря є одним з основних життєво важливих елементів навколишнього природного середовища, а забруднене повітря може спричинити виникнення токсичних ефектів для здоров'я людей. Для врахування та аналізу негативного впливу забруднення атмосферного повітря на здоров'я, що може бути реалізовано у хронічних проявах (в тому числі канцерогенних та імунотоксичних), у роботі застосована лінійно-експоненціальна модель.

Зв'язок авторського доробку з важливими науковими та практичними завданнями. Тематика дослідження відповідає основним напрямам наукової діяльності кафедри екології та охорони довкілля Одеського державного екологічного університету.

Аналіз останніх досліджень та публікацій. Аналізуючи останні дослідження, які пов'язані із темою статті, слід відзначити, що дослідження екологічних ризиків для населення трапляються рідко. Автори досліджень екологічних ризиків для здоров'я населення $[1,2]$ стверджують, що за умови розуміння ризику як усвідомленої небезпеки виникнення подій із визначеними у просторі і часі небажаними наслідками та встановлення його як величини кількісної можна визначити ризик для здоров'я населення як помноження імовірності негативної події на величину можливого збитку від неї. Така форма визначення ризику, на думку авторів, достатньо зручна, тому що дозволяє об'єднати у одному показнику різнорідні дані про об'єкт та суб'єкт небезпеки, одержувати інтегральні оцінки ризику від необмеженої кількості негативних процесів будьякого генезу. Часто для оцінки екологічного ризику від забруднення атмосферного повітря застосовують Методику визначення розміру ризику скорочення тривалості життя під впливом забруднювачів атмосферного повітря [3, 4], в якій оцінка ризику передбачає проведення чотирьох етапів: 1) ідентифікації небезпеки; 2) оцінки експозиції (кількості хімічної речовини, яка доступна для адсорбції (дозою) на обмінних оболонках тіла (легені, шлунково-кишковий тракт, шкіра) протягом певної тривалості впливу); 3) характеристики небезпеки (залежність «доза - ефект»); 4) характеристики ризику. За допомогою цього підходу можна виконати оцінку впливу забруднення атмосферного повітря на скорочення тривалості життя населення.

Виділення не вирішених раніше частин загальної проблеми, котрим присвячусться означена
ОЦІНКА КАНЦЕРОГЕННОГО РИЗИКУ..

стаття. У дослідженні для врахування негативних впливів від забруднення довкілля під час оцінки екологічних ризиків застосована саме лінійно-експоненціальна модель, яка дозволяє отримати точну оцінку ризиків токсичних ефектів для здоров'я людей від забруднення атмосферного повітря на основі відомих та доступних показників, таких як: концентрації забруднюючих атмосферне повітря речовин, їх класи небезпеки, тривалість знаходження в умовах забрудненого атмосферного повітря, параметри, які враховують особливості токсичних властивостей речовин.

Новизна. Полягає у тому, що в дослідженні виконана спроба застосування одного із складних методів, що дозволяє врахувати негативний вплив забрудненого атмосферного повітря на здоров'я населення, який раніше досліджувався лише експертами із токсикології та гігієни.

Методологічне або загальнонаукове значення. Специфікою екологічного ризику $\epsilon$, як правило, нерівномірний його розподіл по території, яка піддалася впливу небезпечного фактора. Розподіл ризику залежить від розподілу несприятливих факторів, які можуть бути статистичними або змінними. Водночас забруднення приземного шару атмосфери промисловими викидами може сильно змінюватися в часі залежно від напрямку і швидкості вітру та інших метеорологічних параметрів. У цьому разі слід врахувати дві крайні ситуації: короткостроковий вплив сильнодіючого фактора та тривалий багаторічний вплив відносно малоінтенсивного фактора. Несприятливі зміни у здоров’ї людей, зумовлені щоденним або професійним контактом із токсичними речовинами, в загальному випадку мають вірогіднісний характер. Це зумовлено значними варіаціями у фізичному стані людей, а також неможливо точно контролювати такі визначальні параметри ризику, як доза, час контакту, специфіка надходження речовини в організм тощо.

Під час проведення оцінок ризику для здоров'я і життя людей все населення ділять на групи за віковою, професійною, соціальною ознаками і виконують оцінку ризику для кожної з цих груп. Вищезазначені обставини роблять процес оцінки ризиків вкрай трудомістким, таким, який потребує обробки великого обсягу вихідної інформації. У науково-технічних літературних джерелах є різні підходи, моделі та методи розрахунку концентрацій шкідливих речовин під час їх міграції у компонентах довкілля.

Виклад основного матеріалу. Для дослідження одного з видів екологічного ризику від забруднення довкілля застосована Методика оцінки ризиків токсичних ефектів для здоров'я людей від забруднення атмосферного повітря. Оцінка ризику, яка виконується на іï основі, припускає реалізацію сценарію, за якого населення піддається впливу токсиканта, концентрація якого в повітрі $c\left(\mathrm{M \Gamma} / \mathrm{M}^{3}\right)$, час експозиції $\tau$ не менше 30 хвилин, а ризик захворюваності є функцією дози токсиканта, який поступив в організм середньостатистичного представника 
групи населення за все життя. Щодо забруднення атмосферного повітря доза токсиканта може бути оцінена на основі даних про концентрацію токсиканта у повітрі та тривалості перебування людей в умовах забрудненого атмосферного повітря [5].

Для вираження ризику хронічної інтоксикації - $\mathrm{R}_{3}$ (у тому числі й канцерогенного ризику), пов'язаного iз забрудненням атмосферного повітря, використовують лінійно-експоненціальну безпорогову модель [6]:

$$
R 3=1-\exp \left(-U R \times \tau \times c^{\beta}\right)
$$

де $U R$ - одиничний ризик - коефіцієнт пропорційності, який пов'язує значення ризику із концентрацією токсиканта;

$c$ - концентрація або доза речовини, яка чинить негативний вплив на організм людини протягом часу експозиції $-\tau$;

$\beta$ - коефіцієнт, який враховує особливості токсичних властивостей речовин.

Параметри рівняння (1) виражаємо у виді, більш зручному для виконання практичних розрахунків [6]:

$$
R 3=1-\exp -0,174 \times\left(\frac{c}{\Gamma Д K_{c \partial} \times K_{3}}\right)^{\beta} \times \tau
$$

де ГДК центрація хімічної речовини у атмосферному повітрі

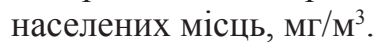

Параметри $\beta$ та $K_{3}$, рекомендовані для розрахунків, наведені в табл. 1. Крім того, незалежно від класу небезпеки речовини, за концентрації, яка не перевищує значення ГДК, $\beta=1,00$ [6].

Таблиця 1

Параметри для розрахунку ризику хронічної інтоксикації, пов'язаного із забрудненням

\begin{tabular}{|c|c|c|c|}
\hline $\begin{array}{c}\text { Клас небезпеки } \\
\text { токсиканта }\end{array}$ & $\begin{array}{c}\text { Характеристика } \\
\text { речовини }\end{array}$ & $\beta$ & $K_{3}$ \\
\hline 1-й & Надзвичайно небезпечні & 2,40 & 7,5 \\
\hline 2-й & Високонебезпечні & 1,31 & 6,0 \\
\hline 3-й & Помірно небезпечні & 1,00 & 4,5 \\
\hline 4-й & Малонебезпечні & 0,86 & 3,0 \\
\hline
\end{tabular}
атмосферного повітря [5]

У дослідженні виконана оцінка канцерогенного ризику хронічної інтоксикації населення від забрудненого атмосферного повітря міст Півдня України: Одеси, Ізмаїла, Миколаєва, Херсона та Запоріжжя в 2017 р. Як вихідні дані для дослідження використані концентрації забруднюючих речовин у атмосферному повітрі з офіційних джерел [7-10].

На першому етапі дослідження на основі методу ГДК [11] розраховуємо показники кратності перевищення ГДК з урахуванням відповідних середньодобових та максимально разових ГДК. Для м. Одеса, м. Миколаїв та м. Херсон встановлено, що пріоритетною забруднюючою речовиною в атмосферному повітрі є формальдегід; для м. Ізмаїл - діоксид азоту; для м. Запоріжжя - пил (за максимальними з разових концентраціями) та діоксид азоту (за середньорічними концентраціями).

На наступному етапі дослідження застосовуємо математичний апарат Методики. Ризик хронічної інтоксикації розраховуємо за формулою (2). При цьому час експозиції $(\tau)$ задаємо змінним від однієї до двадцяти чотирьох годин (на добу) знаходження населення в умовах забрудненого атмосферного повітря. Комплекс ЗР для атмосферного повітря кожного 3 п’яти міст індивідуальний.

Динаміка зміни розрахованих числових значень канцерогенного ризику хронічної інтоксикації, пов'язаного із забрудненням атмосферного повітря, залежно від часу експозиції для кожного з п’яти міст наведена на рисунках $1,3,5,7,9$. Логічно, що зі збільшенням часу експозиції збільшується значення канцерогенного ризику, що пов'язано із прямою залежністю між цими параметрами та відповідає встановленій у Методиці графічній залежності ризику хронічних захворювань, зумовлених забрудненням атмосферного повітря, від кратності перевищення ГДК для речовин різних класів небезпеки.

На рисунках 2, 4, 6, 8, 10 репрезентовані сумарні канцерогенні ризики хронічної інтоксикації залежно від часу експозиції. Сумарний канцерогенний ризик, який не перевищує одиницю, можна вважати допустимим для організму людини, яка знаходиться в умовах відкритого атмосферного повітря і піддається негативному впливу комплексу забруднювальних речовин. Час експозиції може бути як «безпечним» та i «небезпечним» для людини в умовах відкритого атмосферного повітря. Аналізуючи сумарні канцерогенні ризики хронічної інтоксикації залежно від часу експозиції для кожного з міст Півдня України, встановимо безпечні умови для організму людини.

Для м. Одеси (рис. 1) найвищі канцерогенні ризики хронічної дії відзначаються для формальдегіду та оксидів вуглецю. За значеннями сумарного канцерогенного ризику (рис. 2) безпечним є перебування в умовах відкритого атмосферного повітря не більше 3 годин на добу.

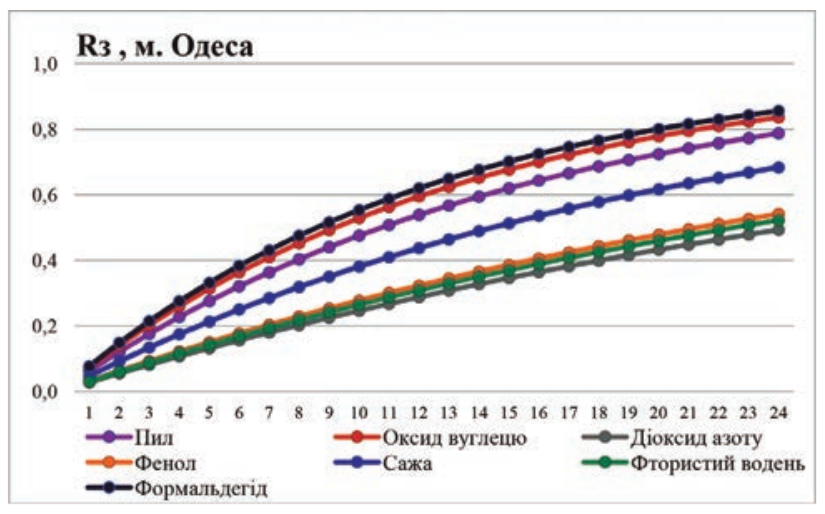

Рис. 1. Зміна канцерогенного ризику хронічної інтоксикачії залежно від часу експозииї (м. Одеса, 2017 р.) 


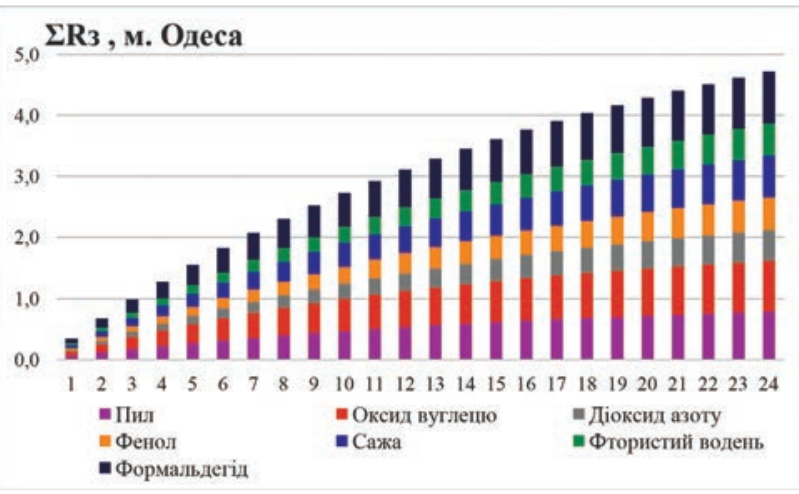

Рис. 2. Сумарний канцерогенний ризик хронічної інтоксикації (м. Одеса, 2017 р.)

Для м. Ізмаїл (рис. 3) найвищі канцерогенні ризики хронічної дії відзначаються для діоксиду сірки. За значеннями сумарного канцерогенного ризику (рис. 4) безпечним є перебування в умовах відкритого атмосферного повітря не більше 9 годин на добу.

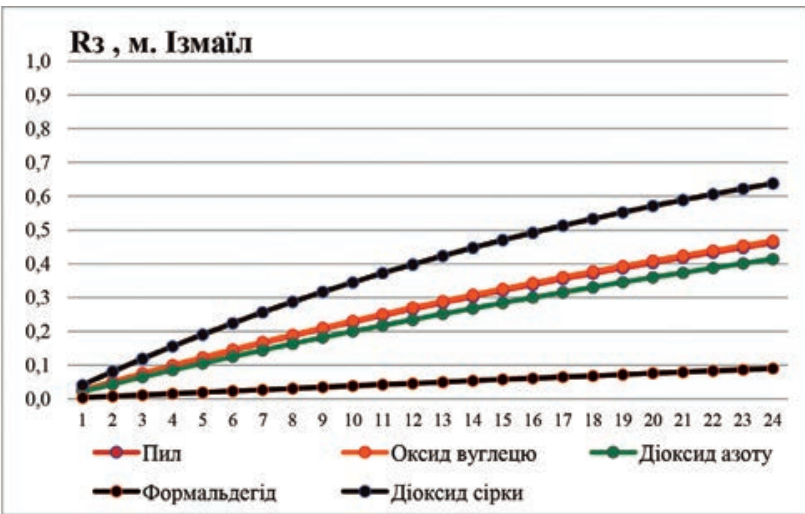

Рис. 3. Зміна канцерогенного ризику хронічної інтоксикаиії залежно від часу експозииї (м. Ізмайл, 2017 р.)

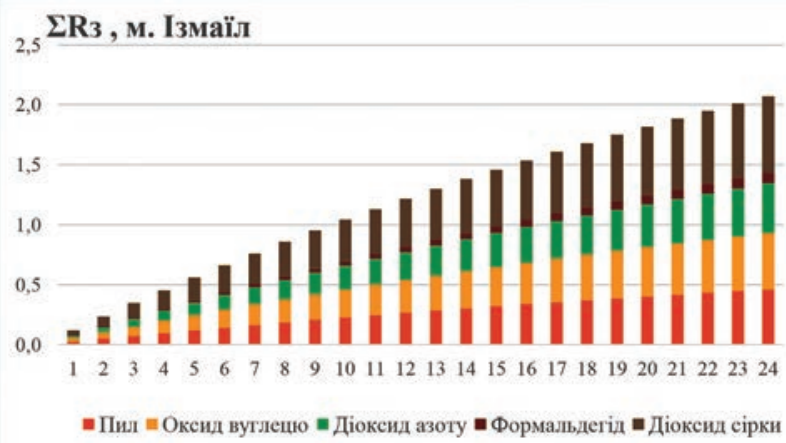

Рис. 4. Сумарний канцерогенний ризик хронічної інтоксикації (м. Ізмаӥл, 2017 р.)

Для м. Миколаїв (рис. 5) найвищі канцерогенні ризики хронічної дії відзначаються для формальдегіду. А за значеннями сумарного канцерогенного ризику (рис. 6) безпечним є перебування в умовах відкритого атмосферного повітря не більше 5 годин на добу.

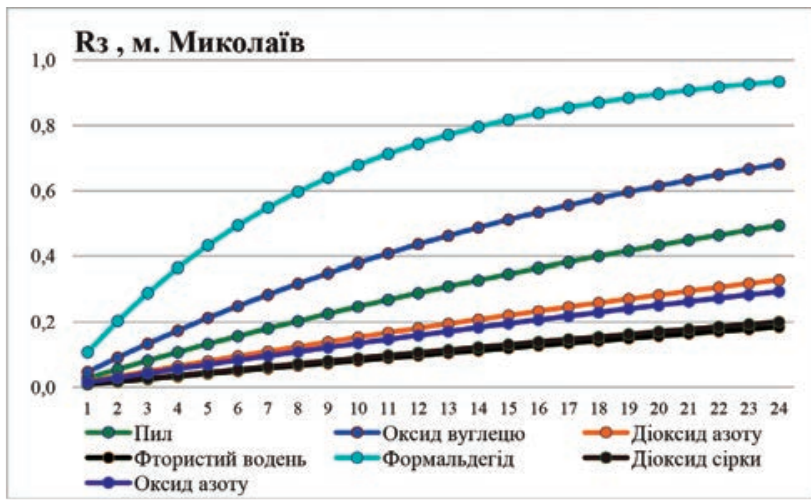

Рис. 5. Зміна канцерогенного ризику хронічної інтоксикації залежно від часу експозищї (м. Миколаїв, 2017 р.)

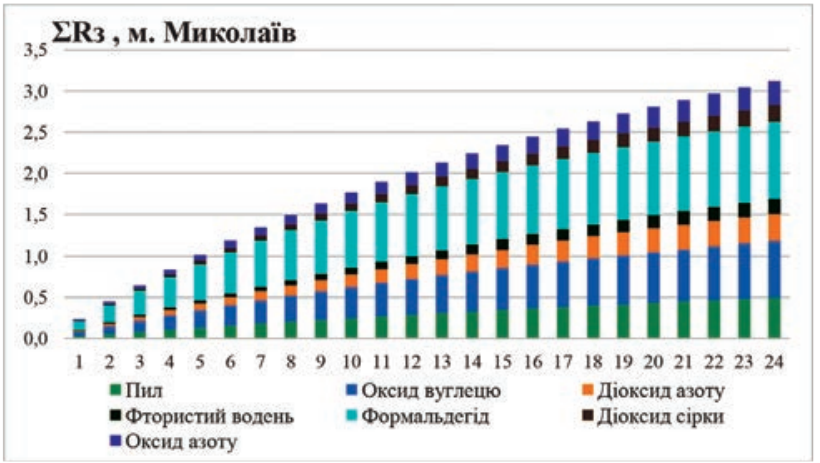

Рис. 6. Сумарний канцерогенний ризик хронічної інтоксикації (м. Миколаїв, 2017 р.)

Для м. Херсон (рис. 7) найвищі канцерогенні ризики хронічної дії відзначаються для формальдегіду. А за значеннями сумарного канцерогенного ризику (рис. 8) безпечним є перебування в умовах відкритого атмосферного повітря не більше 4 годин на добу.

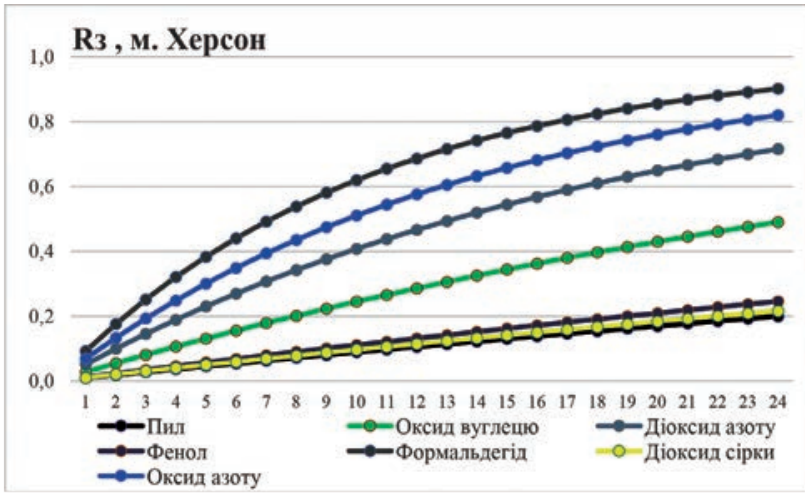

Рис. 7. Зміна каниерогенного ризику хронічної інтоксикаиії залежно від часу експозииії (м. Херсон, 2017 р.)

Для м. Запоріжжя (рис. 9) найвищі канцерогенні ризики хронічної дії відзначаються для формальдегіду. А за значеннями сумарного канцерогенного ризику (рис. 10) безпечним є перебування в умовах відкритого атмосферного повітря не більше 6 годин на добу. 


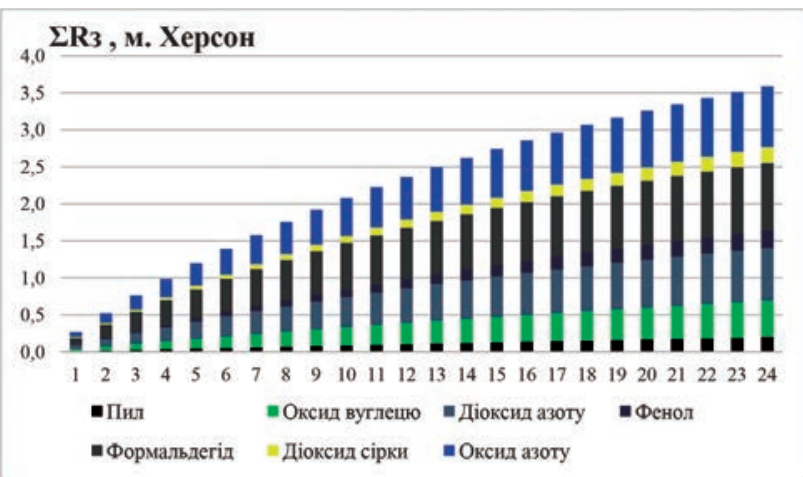

Рис. 8. Сумарний канцерогенний ризик хронічної інтоксикачії (м. Херсон, 2017 р.)

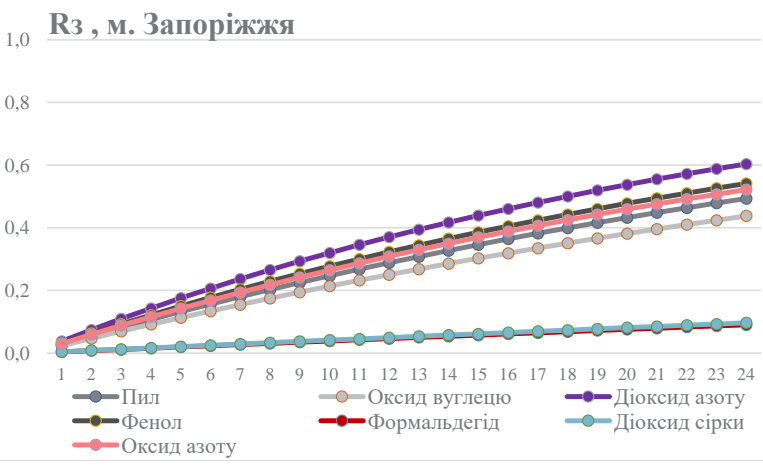

Рис. 9. Зміна канщерогенного ризику хронічної інтоксикачії залежно від часу експозичіi (м. Запоріжжя, 2017 р.)

Результати встановленого часу безпечного перебування людини в умовах відкритого повітря для міст Півдня України (2017 р.) наведені на рис. 11.

Порівнюючи безпечне за часом експозиції перебування людини в умовах відкритого повітря за наявного комплексу забруднюючих речовин у ньому та сумарні канцерогенні ризики хронічної інтоксикації залежно від часу експозиції, встановлюємо, щзо найбезпечніші умови перебування на відкритому

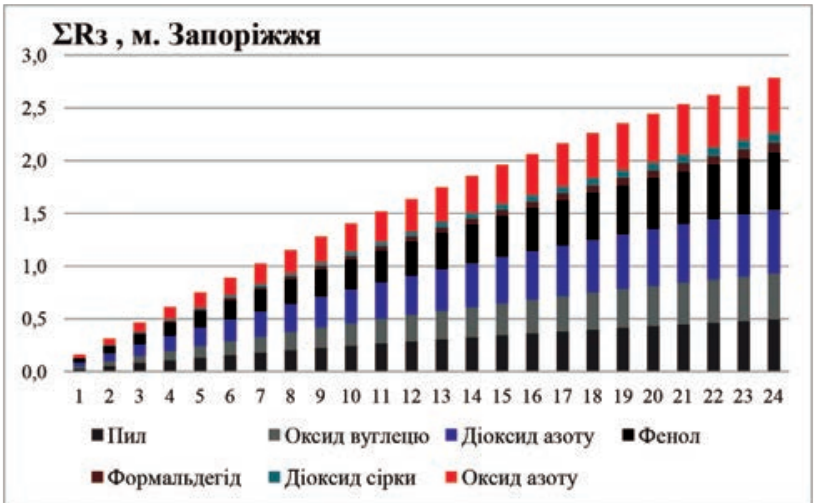

Рис. 10. Сумарний канцерогенний ризик хронічної інтоксикаиії (м. Запоріжжя, 2017 р.)

повітрі характерні для м. Ізмаїлу (9 год.). Інші міста за зменшенням ступеня безпечності розподілилися таким чином: м. Запоріжжя (6 год), м. Миколаїв (5 год.), м. Херсон (4 год.) та м. Одеса (3 год.). Отже, найнебезпечніші умови перебування на відкритому повітрі характерні для м. Одеса.

Головні висновки. За результатами оцінки канцерогенного ризику хронічної інтоксикації від забрудненого атмосферного повітря міст Півдня України слід зробити висновок, що найвищі значення канцерогенного ризику хронічної інтоксикації відзначаються для м. Одеса, а найнижчі - для м. Ізмаїл. Отже, в 2017 р. найбезпечніші умови перебування на відкритому повітрі були характерні для м. Ізмаїл, а найнебезпечніші - для м. Одеса.

Перспективи використання результатів дослідження. Результати дослідження можуть бути використані як приклад можливості застосування Методики оцінки ризиків токсичних ефектів для здоров'я людей від забруднення атмосферного повітря для окремих населених пунктів чи регіонів із метою врахування потенційних небезпек для населення від небезпечного впливу забруднення атмосферного повітря.

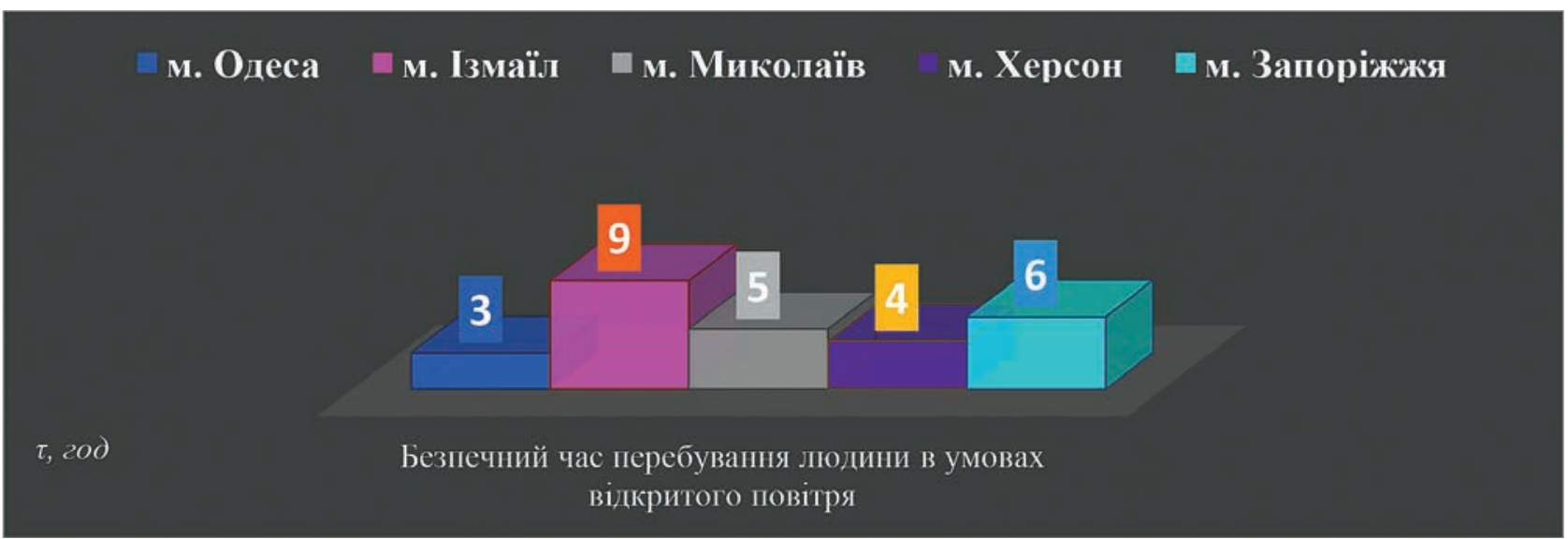

Рис. 11. Безпечний час перебування людини в умовах відкритого повітря за наявного комплексу забруднюючих речовин у ньому для міст Півдня України 


\section{Колісник А.В.}

\section{ОЦНКА КАНЦЕРОГЕННОГО РИЗИКУ...}

\section{Література}

1. Павлов С.Б. Екологічний ризик для здоров'я населення. Медицинские исследования. 2001. Т. 1, С. 16-19.

2. Качинський А.Б., Сердюк А.М. Методологічні основи ризику в медико-екологічних дослідженнях та його значення для екологічної безпеки України. Лікарська справа. 1995. № 3-4. С. 5-15

3. Кузьмина В.А., Екологічна безпека: конспект лекцій. Одеса, 2012. 131 с.

4. Колісник А.В., Снесар А.В., Чернякова О.І. Врахування залежності «доза-ефект» при визначенні скорочення тривалості життя населення від забруднення атмосферного повітря. Екологічна безпека, 2019. Вип. 2(28). С. 75-80.

5. Алымов В.Т., Тарасов Н.П. Техногенный риск: Анализ и оценка. М.: ИКЦ Академкнига, 2005. 118 с.

6. Киселев А.В., Фридман К.Б. Оценка рисков здоровью. СПб.: АО «Дельта», 1997. 100 с.

7. Регіональна доповідь про стан навколишнього природного середовища в Одеській області у 2017 році. Одеса, 2018.270 с.

8. Регіональна доповідь про стан навколишнього природного середовища у Миколаївській області у 2017 році. Миколаїв, 2018. $199 \mathrm{c}$.

9. Регіональна доповідь про стан навколишнього природного середовища у Херсонській області у 2017 році. Херсон, 2018. $238 \mathrm{c}$.

10. Регіональна доповідь про стан навколишнього природного середовища у Запорізькій області у 2017 році. Запоріжжя, 2018. $301 \mathrm{c}$

11. Сафранов Т.А., Колісник А.В. Системний аналіз якості навколишнього середовища: конспект лекцій. Одеса, Одеський державний екологічний університет. 2021. 205 с. 


\title{
ОСОБАИВОСТІ ОРГАНІЗАЦІї ЕКОАОГІЧНО БЕЗПЕЧНОГО ХАРЧУВАННЯ СТУДЕНТІВ ЗА РІЗНИХ ФОРМ НАВЧАННЯ В УMOBAX COVID-19
}

\author{
Мазур Т.Г., Загоруй Л.П., Димань Т.М., Богатко Н.М., Гриневич Н.Є. \\ Білоцерківський національний аграрний університет \\ пл. Соборна, 8/1, 09117, м. Біла Церква, Київська область \\ mazur.tetianag@gmail.com
}

\begin{abstract}
Незадовільний стан харчування студентів призводить до зниження імунного і гуморального захисту організму, збільшення кількості інфекційних та неінфекційних захворювань, передчасного виснаження організму, гальмування фізичного та психічного розвитку молодого організму.

Ситуація, яка склалася нині з поширенням коронавірусної хвороби COVID-19, карантинними обмеженнями для здобувачів освіти, переведенням на дистанційну форму навчання, зумовлює негативну динаміку щодо порушення законів раціонального харчування, добового розпорядку. Малорухливий спосіб життя за таких умов навчання, часті перекуси некорисними продуктами, зорове навантаження і нервово-психічне напруження створюють передумови для появи аліментарних захворювань, набуття зайвої ваги, ожиріння, порушення обміну речовин, психічних і нервових розладів.

За даними Всесвітньої організації охорони здоров'я (ВОО3), на земній кулі понад 800 млн людей хронічно недоїдають і мають певний ступінь білково-енергетичної або білкової недостатності. У разі кількісної та якісної недостатності харчування насамперед страждає імунна система (захисні й адаптивні можливості організму), наслідком чого є високий рівень інфекційної та неінфекційної захворюваності.

Патологія, спричинена недостатнім харчуванням, спостерігається як серед малозабезпечених верств населення, так і серед людей, які мають матеріальні можливості для вільного вибору харчових продуктів, але допускають відхилення від раціонального харчування через недостатне гігієнічне виховання, низьку культуру харчування та відсутність споживчих знань.

Дослідження харчування студентської молоді за різних форм навчання нині є як ніколи актуальним. 3 огляду на зазначене вище, метою дослідження було проаналізувати та порівняти добові харчові раціони студентів за різних форм навчання та провести їх коригування, зважаючи на потребу в енергії та нутрієнтах за умов карантинних обмежень. Ключові слова: екологія харчування, екотрофологія, екологія людини, екологічно безпечне харчування, раціональне харчування, стаціонарне і дистанційне навчання, коронавірусна хвороба COVID-19.
\end{abstract}

Peculiarities of the organization of environmentally safe meals for students in different forms of study in the conditions of COVID 19. Mazur T., Zahoruy L., Dyman T., Bogatko N., Grynevych N.

Unsatisfactory nutritional status of students leads to a decrease in immune and humoral protection of the body, an increase in infectious and non-infectious diseases, premature depletion of the body, inhibition of physical and mental development of the young organism.

The current situation with the spread of coronavirus COVID-19, quarantine restrictions for students, transfer to distance learning causes a negative trend in violation of the laws of nutrition, daily routine. Sedentary lifestyle in such learning conditions, frequent snacks with junk food, visual stress and mental stress creates the preconditions for the emergence of nutritional diseases, weight gain, obesity, metabolic disorders, mental and nervous disorders.

According to the World Health Organization (WHO), more than 800 million people on the globe are chronically malnourished and have some degree of protein-energy or protein deficiency. In the case of quantitative and qualitative malnutrition primarily affects the immune system (protective and adaptive capabilities of the body), resulting in high levels of infectious and non-infectious diseases.

Pathology caused by malnutrition is observed both among the poor and among people who have the financial means to freely choose food, but allow deviations from a balanced diet due to poor hygiene, low food culture and lack of consumer knowledge.

The study of student nutrition in various forms of education is now more relevant than ever. In view of the above, the aim of the study was to analyze and compare the daily diets of students in different forms of education and to adjust them according to the need for energy and nutrients under quarantine restrictions. Key words: food ecology, ecotrophology, human ecology, ecologically safe food, rational food, stationary and distance learning, coronavirus disease COVID-19.

Постановка проблеми. Харчування - це найважливіша фізіологічна потреба організму, яка має великий вплив на життя та здоров'я людини, а саме: забезпечує ріст та розвиток молодого організму; захищає від впливу несприятливих екологічних умов, шкідливих виробничих та побутових чинників; відновлює працездатність; збільшує тривалість активного життя; є методом лікування та профілактики захворювань [3].

Нераціональне харчування суттєво впливає на поширеність аліментарних та аліментарно зумов- лених захворювань. Раціон харчування зі значним умістом насичених жирів та енергоємних продуктів, iз низьким вмістом фруктів і овочів поряд із малорухомим способом життя, палінням, вживанням алкоголю $є$ основною причиною захворювань цивілізації: серцево-судинних захворювань, раку, ожиріння та цукрового діабету [5].

Глобальний економічний вплив COVID-19 може мати наслідки для сільського господарства, виробництва i споживання харчових продуктів. Деякі 
Мазур Т.Г., Загоруй Л.П., Димань Т.М. ...

3 довгострокових наслідків COVID-19 можуть бути викликані страхом перед пандеміями в майбутньому. Це призведе до розроблення стратегій управління ризиками, які можуть вплинути на харчування населення. Адже пандемія, спричинена хворобою COVID-19, має важливий вплив на сільське господарство та ланцюг постачання харчових продуктів, у основному впливаючи на попит на продовольство i, отже, продовольчу безпеку, з великим впливом на найбільш вразливе населення [7]

В умовах пандемії попит на їжу і продовольча безпека сильно постраждали через обмеження мобільності, зниження купівельної спроможності та більший вплив на найбільш вразливі групи населення.

Згідно 3 даними Європейського бюро ВОО3 (Всесвітня організація охорони здоров'я), у 2010 р. населенням Європи було втрачено 136 млн років здорового життя. Причому 41\% цих втрат зумовлені харчуванням, а $38 \%$ - частково зумовлені харчуванням [1].

Зазначене вище свідчить про актуальність і своєчасність вибраної теми дослідження, питання, яке гостро постало нині в суспільстві та потребує негайного вирішення шляхом коригування раціонів, просвітницької діяльності, популяризації здорового й активного способу життя серед школярів, підлітків, студентської молоді та дорослого населення.

Раціональне харчування забезпечує постійність внутрішнього середовища організму і всі його життєві прояви за різних умов праці й побуту, тому дотримання принципів раціонального харчування $€$ необхідною умовою нормалізації і підтримання показників здоров'я здобувачів освіти.

Принципи раціонального харчування:

1. Відповідність надходження енергії та енерговитрат. Енергетична цінність, кількісний та якісний склад раціону мають відповідати енерговитратам організму і забезпечувати його пластичні та фізіологічні функції.

2. Відповідність хімічного складу харчових речовин фізіологічним потребам організму.

3. Максимальна різноманітність раціону. Поживна цінність та властивості їжі мають відповідати індивідуальним потребам і можливостям організму.

4. Оптимальний режим харчування. Режим, тривалість і кратність прийомів їжі, інтервали між ними, розподіл об'єму й енергетичної цінності їжі по окремих іiі прийомах. Тривалість приймання їжі - не менше 15-20 хв. і не більше 30-40 хв.

5. Профілактична спрямованість харчування. Їжа має запобігати захворюванням і підвищувати імунологічний статус організму.

6. Принцип естетичного задоволення. Їжа має бути смачною, приємною, із властивим їй ароматом і вживатися в естетичних умовах.

7. Принцип безпечного харчування. Їжа має бути нешкідливою і безпечною для споживання.

\section{ОСОБАИВОСТІ ОРГАНІЗАЦІЇ...}

Основною ціллю людини за раціонального харчування є забезпечення збереження гомеостазу і функціонування систем організму на високому рівні, нормальний фізичний і психічний розвиток, профілактика аліментарно залежних захворювань.

Дослідження харчування студентської молоді за різних форм навчання нині є як ніколи актуальним . 3 огляду на зазначене вище, метою дослідження було проаналізувати та порівняти добові харчові раціони студентів за різних форм навчання та провести їх коригування, зважаючи на потребу в енергії та нутрієнтах за умов карантинних обмежень.

Для досягнення мети були поставлені такі завдання:

1. Визначити основний обмін та величину основного обміну студентів.

2. Скласти добову хронограму видів індивідуальної діяльності за різних форм навчання.

3. Визначити коефіцієнт фізичної активності на кожний вид індивідуальної діяльності за різних форм навчання.

4. Визначити загальні добові енергетичні витрати за різних форм навчання.

5. Розрахувати індивідуальну потребу в енергії та поживних речовинах за різних форм навчання.

6. Розробити рекомендації для харчування студентів за різних форм навчання.

Виклад основного матеріалу досліджень. У дослідженні взяли участь 40 респондентів (20 чоловічої і 20 жіночої статі) упродовж навчального тижня (з понеділка до п’ятниці) за умов стаціонарного та дистанційного навчання. Проводився щоденний аналіз раціону, фіксувалася добова хронограма фізичної активності, відбувалося зважування та фіксування антропометричних промірів.

Визначення енерговитрат та індивідуальних енергетичних потреб у енергії та нутріснтах за різних форм навчання. Розрахунок основного обміну. Основний обмін (OO) - це затрати енергії на перебіг обмінних процесів у організмі в стані фізичного і психічного спокою. За методикою ФАО ВОО3 основний обмін (ОО) визначається відповідно до віку, статі, маси тіла та зросту. ОО с (середне) для хлопців становив 1825 ккал, для дівчат відповідно 1455 ккал.

Дані щодо середніх добових енерговитрат населення віком 18-29 років наведено в таблиці 1.

Середня величина основного обміну (ВОО), тобто рівень основного обміну метаболічно-активної тканини тіла людини за одну годину, становила 76 (чоловіки) і 61 (жінки) ккал/год.

Для визначення енерговитрат (W) організму використовують формулу: $\mathrm{W}=$ КФА х ВОО х Т, де КФА - коефіцієнт фізичної активності; Т - тривалість певного виду діяльності. Добові енерговитрати розраховували за формулою: $\mathrm{W}=\sum($ КФА $\mathrm{x}$ ВОО $\mathrm{x} \mathrm{T})$. 
Таблиця 1

Добові енерговитрати без фізичної активності

\begin{tabular}{|c|c|c|}
\hline Маса тіла, кг & $\begin{array}{c}\text { Основний обмін } \\
\text { у чоловіків } \\
\text { (18-29 років) }\end{array}$ & $\begin{array}{c}\text { Основний обмін } \\
\mathbf{y} \text { жінок } \\
\text { (18-29 років) }\end{array}$ \\
\hline 50 & 1450 & 1080 \\
\hline 55 & 1520 & 1150 \\
\hline 60 & 1590 & 1230 \\
\hline 65 & 1670 & 1300 \\
\hline 70 & 1750 & 1380 \\
\hline 75 & 1830 & 1450 \\
\hline 80 & 1920 & 1530 \\
\hline 85 & 2010 & 1600 \\
\hline 90 & 2110 & 1680 \\
\hline
\end{tabular}

Для визначення енерговитрат за різних форм навчання було складено добову хронограму видів індивідуальної діяльності студентів. Усереднені дані наведені в таблиці 2.

Аналізуючи дані таблиці 2, можна відзначити, що різниця в енерговитратах за умов стаціонарного та дистанційного навчання становить 799 (чоловіки) і 1034 (жінки) ккал. Виходячи 3 цього, можна ствер- джувати про необхідність коригування харчування за різних умов навчання. Оскільки рухова активність знижена, переважає малорухомий спосіб проведення часу, зростає навантаження на зоровий апарат і нервову систему молоді.

Раціональне харчування передбачає оптимальне співвідношення харчових і біологічно активних речовин. За даними ФАО/ВООЗ, оптимальна кількість основних енергетичних нутрієнтів (білків, жирів і вуглеводів) має відповідно становити 10-11\%, 20-25\%, 65-70\% від енергоцінності раціону [1].

Відповідно до Норм фізіологічних потреб населення України в основних харчових речовинах та енергії, потреба у білках для студентів становить $12 \%$ (у т. ч. тваринних 60\%), для дітей та підлітків - 13\% [1, 2].

Потреба у жирах має становити $30 \%$ від добових енерговитрат. Важливе значення мають рослинні жири - джерело поліненасичених жирних кислот i фосфоліпідів, які необхідні для синтезу клітин i внутрішньоклітинних жирів. Частка рослинних жирів має бути $30 \%$ від загальної кількості спожитих за добу жирів. Тваринні жири в основному є джерелом енергії.

Добова хронограма видів індивідуальної діяльності студентів

\begin{tabular}{|c|c|c|c|c|c|}
\hline \multirow{2}{*}{ Вид діяльності } & \multirow{2}{*}{$\begin{array}{c}\text { КФА (коеф. фізич. } \\
\text { активності) }\end{array}$} & \multicolumn{2}{|c|}{$\begin{array}{c}\text { Робочий день за стаціонарного } \\
\text { навчання (с.н.) } \\
\end{array}$} & \multicolumn{2}{|c|}{$\begin{array}{c}\text { Робочий день за дистанційного } \\
\text { навчання (д.н.) }\end{array}$} \\
\hline & & Тривалість, хв & $\begin{array}{c}\text { Енерговитрати, } \\
\text { чол./жін. ккал }\end{array}$ & Тривалість, хв & $\begin{array}{c}\text { Енерговитрати, } \\
\text { чол./жін. ккал }\end{array}$ \\
\hline \multicolumn{6}{|c|}{ Навчальна діяльність } \\
\hline $\begin{array}{l}\text { Заняття (6 с.н.) } \\
\text { (6 д.н.) }\end{array}$ & $2,2 / 1,2$ & 270 & $752,4 / 603,6$ & 180 & $273,6 / 219,6$ \\
\hline $\begin{array}{l}\text { Перерви (6 с.н.) } \\
\text { (3 д.н.) }\end{array}$ & $3,5 / 1,9$ & 55 & $243,8 / 195,7$ & 30 & $72,2 / 57,95$ \\
\hline Підготовка до занять & 1,8 & 80 & $182,4 / 146,4$ & 50 & $114 / 91,5$ \\
\hline \multicolumn{6}{|c|}{ Особиста гігієна, самообслуговування } \\
\hline Умивання & 1,6 & 15 & $30,4 / 24,4$ & 15 & $30,4 / 24,4$ \\
\hline Душ & 1,8 & 20 & $45,6 / 36,6$ & 30 & $68,4 / 54,9$ \\
\hline $\begin{array}{l}\text { Одягання, роздягання, } \\
\text { гігієна }\end{array}$ & 1,9 & 30 & $72,2 / 57,95$ & 15 & $36,1 / 29,1$ \\
\hline Прийом їжі сидячи & 1,5 & 60 & $114 / 91,5$ & 90 & $171 / 91,5$ \\
\hline Миття посуду & 1,6 & 15 & $28,5 / 24,4$ & 20 & $40,5 / 32,5$ \\
\hline Легке прибирання & 2,7 & 15 & $51,3 / 41,2$ & 20 & $68,4 / 54,9$ \\
\hline $\begin{array}{c}\text { Заняття спортом (футбол, } \\
\text { фітнес) }\end{array}$ & 6,8 & 40 & $344,5 / 622,2$ & - & - \\
\hline \multicolumn{6}{|c|}{ Переміщення } \\
\hline Ходіння по дому & 2,5 & 20 & $63,3 / 50,8$ & 40 & $126,6 / 101,7$ \\
\hline $\begin{array}{c}\text { Прогулянка у звичайному } \\
\text { темпі }\end{array}$ & 3,2 & 25 & $101,3 / 81,3$ & 15 & $60,8 / 48,8$ \\
\hline Ходіння по сходах & 6,2 & 15 & $117,8 / 94,6$ & 5 & $39,3 / 31,5$ \\
\hline \multicolumn{6}{|c|}{ Відпочинок } \\
\hline Спокійно сидячи & 1,2 & 20 & $30,4 / 24,4$ & 40 & $60,8 / 48,8$ \\
\hline $\begin{array}{c}\text { Перегляд гаджетів, } \\
\text { телепередач } \\
\end{array}$ & 1,2 & 140 & $212,8 / 170,8$ & 240 & $364,8 / 292,8$ \\
\hline Читання літератури & 1,7 & 20 & $43,1 / 34,6$ & 50 & $107,7 / 86,4$ \\
\hline $\mathrm{COH}$ & 1 & 300 & $380 / 305$ & 300 & $380 / 305$ \\
\hline Всього & \multicolumn{2}{|c|}{1140 хв (24 год) } & $2813,8 / 2605,5$ & $1140 \mathrm{xB}$ & $2014,6 / 1571,4$ \\
\hline
\end{tabular}




\section{Мазур Т.Г., Загоруй Л.П., Димань Т.М. ...}

Потреба у вуглеводах має становити 60-64\% i забезпечується крохмалем, моно- та дисахаридами. Найбільшої шкоди організму завдає надлишок рафінованого цукру, тому кількість легкозасвоюваних простих вуглеводів має обмежуватися 20\% від загальної кількості спожитих вуглеводів. Уміст незасвоюваних вуглеводів (харчових волокон) має становити 20-30 г на добу (10 г на 1000 ккал).

Співвідношення між масою білків, жирів та вуглеводів для дітей та підлітків, людей похилого віку має бути: 1:0,9:4,6; для дорослої людини відповідно $1: 1: 5,8$. Середня енергетична потреба має становити 2400-2600 ккал.

Добова потреба у водорозчинних вітамінах залежить від енергоцінності раціону: на кожні 1000 ккал енергетичної цінності має надходити: аскорбінової кислоти (вітамін С) - 25 мг; тіаміну (вітамін $\mathrm{B}_{1}$ ) - 0,6 мг; рибофлавіну (вітамін $\mathrm{B}_{2}$ ) - 0,7 мг; піридоксину (вітамін $\left.\mathrm{B}_{6}\right)$ - 0,7 мг; нікотинової кислоти (вітамін РР) - 6,6 мг. Добова потреба у жиророзчинних вітамінах: на кожні 1000 ккал енергетичної цінності має надходити ретинолу (вітамін А) - 1 мг; токоферолу (вітамін Е) - 15 мг.

Харчовий раціон має забезпечувати відчуття насичення, що у свою чергу залежить від обсягу їжі, вмісту жирів і тваринних білків.

Під час складання раціону враховується поєднання страв та продуктів, послідовність вживання страв. Пікантні холодні закуски збуджують апетит, супи посилюють секреторну дію закусок, що необхідно для перетравлювання основної частини раціону - другої страви. Завершується приймання їжі солодкими стравами, які надають відчуття задоволення від спожитої їі.

Обов'язково варто дотримуватися питного режиму, адже нестача рідини в організмі перевантажує серце через підвищення в’язкості крові. Нестача води погіршує виведення токсичних продуктів обміну речовин і ксенобіотиків.

Фізіолого-гігіснічні вимоги до режиму харчування та умов приймання їжі студентами.

Для організму студентів, характерні такі особливості, як:

- незавершені процеси росту та формування організму;

- значні навантаження на зоровий апарат;

- розумова на нервово-психічна напруга;

- різка зміна типу харчування (споживання високорафінованих продуктів, напівфабрикатів, продуктів тривалого зберігання);

- порушення режиму харчування;

- малорухомий спосіб життя (гіпокінезія, гіподинамія).

Наслідками нераціонального харчування студентів є поява захворювань органів травлення, нервові стреси, неврози, втомлюваність, погана засвоюваність матеріалу. А раціональне харчування передбачає особливі вимоги до режиму харчування та умов приймання їжі $[4,5]$.

\section{ОСОБАИВОСТІ ОРГАНІЗАЦІЇ...}

Правильний режим харчування забезпечує: апетит; ретельне пережовування їжі; оптимальне перетравлювання та засвоювання.

Режим харчування передбачає:

- певний час, тривалість, кратність вживання їжі та інтервали між прийомами;

- послідовність вживання страв і прийому їжі;

- розподіл добового раціону впродовж дня (маса, енергетична цінність, якісний склад страв за прийомами їжі);

- інтервал між прийманнями їжі, навчанням, роботою, сном.

Приймання їжі у певний час виробляє умовні рефлекси, забезпечує ритмічність процесів секреції й оптимальне виділення травних соків.

Для підтримання здорового апетиту та оптимальної секреції доцільне 3-4-разове харчування (25\% - сніданок; 15\% - другий сніданок; 35\% обід; 25\% - вечеря) 3 інтервалами між прийомами 4-6 годин та за 2 години до роботи чи навчання, що пов'язане із тривалістю розщеплення і засвоюванням поживних речовин. Вечеряти рекомендується за 2-3 години до сну.

Тривалість споживання страв, яка забезпечує добре пережовування та перетравлення їжі, має становити для сніданку та вечері 20-30 хв, обіду - 40-50 хв, другого сніданку і полуденку - 15-20 хв. На сніданок і вечерю обов'язково мають бути гарячі страви.

3 метою зменшення впливу малорухомого способу життя на організм студентів під час дистанційного навчання необхідно якнайчастіше включати до харчового раціону рослинні продукти, які $є$ природним джерелом корисних для здоров'я харчових волокон.

Відповідно до зазначених вище рекомендацій, приклад оптимального добового набору харчових продуктів для студентів за різних форм навчання наведений у таблиці 3.

Особливості харчування студентів під час розумового навантаження

Під час розумового навантаження, особливо за дистанційного навчання студентів в умовах пандемії, значно зростає розумове та нервово-психічне напруження.

Систематичні нервово-психічні навантаження, незначні фізичні навантаження, ненормований робочий день можуть викликати порушення діяльності центральної нервової та серцево-судинної системи, обміну речовин.

Антистресова направленість харчування передбачає збільшення в раціоні кількості вітамінів (особливо водорозчинних), мікроелементів - овочів, фруктів, хліба з висівками, вареного м'яса. Має бути обмежене споживання екстрактивних речовин - смаженого м'яса, копчених продуктів, гострих страв, солі, шоколаду, кави, чаю.

За умов дистанційного навчання необхідно збільшити споживання вітамінів і мінеральних речовин до $25 \%$ (табл. 4). 
Таблиця 3

Рекомендований оптимальний приклад добового набору харчових продуктів для студентів за різних форм навчання, г/добу

\begin{tabular}{|c|c|c|}
\hline \multirow[b]{2}{*}{ Харчовий продукт } & \multicolumn{2}{|c|}{ Форма навчання } \\
\hline & $\begin{array}{c}\text { Дистанційне } \\
\text { навчання } \\
\text { ккал }\end{array}$ & $\begin{array}{c}\text { Стаціонарне } \\
\text { навчання } \\
\text { ккал }\end{array}$ \\
\hline Хліб житній & 100 & 150 \\
\hline Хліб пшеничний & 280 & 350 \\
\hline Борошно пшеничне & 25 & 25 \\
\hline Макаронні вироби & 15 & 20 \\
\hline Крупа і бобові & 40 & 60 \\
\hline Крохмаль & 5 & 5 \\
\hline Картопля & 300 & 300 \\
\hline Овочі & 325 & 400 \\
\hline Кавуни та дині & 100 & 100 \\
\hline Фрукти та ягоди & 240 & 240 \\
\hline Сухофрукти & 10 & 12,5 \\
\hline Цукор & 75 & 75 \\
\hline Мед & 5 & 5 \\
\hline Олія і маргарин & 15 & 20 \\
\hline Чай & 1 & 1 \\
\hline Какао & 0,5 & 0,5 \\
\hline Кава & 3,5 & 3,5 \\
\hline М'ясопродукти & 200 & 250 \\
\hline Рибопродукти & 60 & 70 \\
\hline Молоко & 450 & 450 \\
\hline Масло вершкове & 25 & 25 \\
\hline Сир м'який & 30 & 30 \\
\hline Сир твердий & 20 & 20 \\
\hline ЯйцЯ & 50 & 50 \\
\hline
\end{tabular}

На основі проведених вище досліджень, а саме порівняння індивідуальних енергетичних затрат за різних форм навчання студентів, виникла гостра необхідність коригування нутрієнтного складу раціону, оскільки за умов дистанційного навчання енергетичні затрати зменшуються в середньому на 800 ккал (чоловіки) і 1030 ккал (жінки). Таке коливання є доволі значним і свідчить про необхідність коригування раціону за обов'язкових умов дотримання принципів раціонального харчування і розумового навантаження.

Підбираючи харчовий раціон, варто враховувати показник основного обміну (індивідуальний чи усереднений) та добові енерговитрати фізично активних студентів. Згідно з проведеними дослідженнями, індивідуальні усереднені показники основного обміну становили 1825 (чоловіки) і 1455 (жінки) ккал; добові енергетичні потреби за умов стаціонарного навчання в середньому становили 2813 (чоловіки) і 2605 (жінки) ккал, а за умов дистанційного навчання - 2014 і 1571 ккал відповідно. 3 огляду на зазначене вище проаналізований індивідуальний денний раціон за умов звичайного стаціонарного навчання та внесені деякі корективи за умов дистанційного (табл. 5).

Із даних таблиці видно, що за умов стаціонарного навчання калорійність раціону становила 3412 ккал. У результаті аналізу цього раціону в нього були внесені корективи, які дали змогу адаптувати його до енергозатрат під час дистанційного навчанні. Важливим при цьому є орієнтація на закони раціонального харчування, дотримання основних рекомендації здорового харчування для підлітків, врахування навантаження на розумову діяльність, малорухомість і напруження зорового апарату.

За цією методикою можна проаналізувати раціон будь якої людини i, враховуючи вищезазначені рекомендації, скоригувати його за індивідуальними параметрами. Такі розрахунки будуть дуже корисними та пізнавальними, олскільки вони не лише математично розраховують потребу, а дають уявлення про склад харчових продуктів, корисні та шкідливі речовини, які можуть там міститися. А поняття про здорове харчування сформує звичку харчуватися правильно і раціонально в майбутньому та бережливо ставитися до свого здоров'я.

Відстеження впливу пандемії на продовольчу систему дозволяє систематично виявляти різні навантаження на продовольчу безпеку, які можна визначити за чотирма параметрами, такими як: наявність, доступ, використання та стабільність. Необхідність реагування на пандемію може сприяти більш широкому визнанню громадськістю використання науки i технологій для підтримки продовольчої безпеки і необхідності споживання екологічно безпечного раціонального харчування.

Таблиця 4

Добова потреба здобувачів освіти у мінеральних речовинах і вітамінах

\begin{tabular}{|c|c|c|c|c|c|c|c|c|c|c|c|c|c|c|c|c|c|}
\hline Групи & $\begin{array}{l}\text { Ca, } \\
\text { мг }\end{array}$ & $\begin{array}{l}\text { P, } \\
\text { мГ }\end{array}$ & $\begin{array}{c}\text { Mg, } \\
\text { MГ }\end{array}$ & $\begin{array}{l}\text { Fe, } \\
\text { мг }\end{array}$ & $\begin{array}{c}\text { Se, } \\
\text { мкг }\end{array}$ & F, мг & $\begin{array}{l}\mathrm{Zn}, \\
\text { мг }\end{array}$ & $\mathbf{J}, \mathbf{\text { мГ }}$ & $\begin{array}{c}\text { A, } \\
\text { мкГ }\end{array}$ & $\begin{array}{c}\text { D, } \\
\text { мкг }\end{array}$ & $\begin{array}{l}\text { E, } \\
\mathbf{M \Gamma}\end{array}$ & $\begin{array}{l}\mathbf{B}_{1}, \\
\text { МГ }\end{array}$ & $\begin{array}{l}\mathbf{B}_{2}, \\
\text { мГ }\end{array}$ & $\begin{array}{l}\mathbf{B}_{6}, \\
\text { мГ }\end{array}$ & $\begin{array}{l}\text { B }_{12} \\
\text { МКг }\end{array}$ & $\begin{array}{l}\mathbf{P P}, \\
\text { МГ }\end{array}$ & $\begin{array}{l}\mathrm{C}, \\
\mathrm{M \Gamma}\end{array}$ \\
\hline $\begin{array}{c}\text { Чоловіки, } \\
\text { 18-29 років, } \\
\text { КФА } 1,4\end{array}$ & 1200 & 1200 & 400 & 15 & 70 & 0,75 & 15 & 0,15 & 1000 & 2,5 & 15 & 1,6 & 2,0 & 2,0 & 3 & 22 & 80 \\
\hline $\begin{array}{c}\text { Жінки, } \\
\text { 18-29 років, } \\
\text { КФА } 1,4\end{array}$ & 1100 & 1200 & 350 & 17 & 50 & 0,75 & 12 & 0,15 & 1000 & 2,5 & 15 & 1,3 & 1,6 & 1,8 & 3 & 16 & 70 \\
\hline
\end{tabular}


Приклад індивідуального (типового) денного раціону за умов стаціонарного та дистанційного навчання студентів

\begin{tabular}{|c|c|c|c|}
\hline \multirow{2}{*}{ г/ккал } & \multicolumn{2}{|c|}{ Форма навчання } & \multirow{2}{*}{ г/ккал } \\
\hline & Стаціонарне навчання & Дистанційне навчання & \\
\hline \multicolumn{4}{|c|}{ Сніданок } \\
\hline $\begin{array}{c}150 / 246 \\
5 / 30\end{array}$ & Гречана каша $з$ вершковим маслом & Сирники із сметаною & $\begin{array}{c}250 / 528 \\
20 / 42\end{array}$ \\
\hline $150 / 356$ & Котлета із свинини & Чорний чай з цукром & $10 / 37$ \\
\hline $20 / 41$ & Чорний хліб & \multirow{3}{*}{ Мармелад } & \multirow{3}{*}{$30 / 90$} \\
\hline $10 / 37$ & Чорний чай 3 цукром & & \\
\hline $20 / 108$ & Шоколадна цукерка & & \\
\hline \multicolumn{4}{|c|}{ Перекус } \\
\hline $150 / 133$ & Банан & Яблуко & $150 / 68$ \\
\hline $20 / 47$ & \multirow[b]{2}{*}{ Бутерброд з маслом і твердим сирим } & Банан & $150 / 133$ \\
\hline $\begin{array}{c}5 / 30 \\
50 / 180\end{array}$ & & Горіхи волоські & $25 / 138$ \\
\hline \multicolumn{4}{|c|}{ Обід } \\
\hline $\begin{array}{c}200 / 78 \\
50 / 150 \\
10 / 19\end{array}$ & Червоний борщ із м’ясом і сметаною & Червоний борщ із м'ясом і сметаною & $\begin{array}{c}200 / 78 \\
50 / 150 \\
10 / 21\end{array}$ \\
\hline $80 / 209$ & Пампушки & Чорний хліб & $20 / 41$ \\
\hline $200 / 76$ & Сік яблучний & Сік морквяний & $200 / 78$ \\
\hline $50 / 132$ & Печиво здобне & Печиво вівсяне & $50 / 98$ \\
\hline $60 / 160$ & Шоколадний батончик & Чорний шоколад & $30 / 143$ \\
\hline \multicolumn{4}{|c|}{ Вечеря } \\
\hline $250 / 1380$ & Пельмені з кетчупом & Молочна вівсяна каша & $300 / 966$ \\
\hline 3412 ккал & & & 2611 ккал \\
\hline 2 л & Вода питна & довж дня) & 2 л \\
\hline
\end{tabular}

\section{Література}

1. Гігієна харчування з основами нутриціології. Підручник у 2 кн. Кн. 1 / Аністратенко Т.І., Білко Т.М., Благодарова О.В. та ін.; За ред. проф. Ципріяна В.І. К.: Медицина, 2007. 528 с.

2. Гігієна харчування з основами нутриціології. Підручник у 2 кн. Кн. 2 / Ципріян В.I., Матасар I.T., Слободкін В.І. та ін.; За ред. проф. Ципріяна В.І. К.: Медицина, 2007. 544 с.

3. Екотрофологія. Основи екологічно безпечного харчування / Димань Т. М. та ін. К.: Лібра, 2006. 304 с.

4. Зубар Н.М. Основи фізіології та гігієни харчування: підручник. К.: Центр учбової літератури, 2010. 336 с.

5. Зубар Н.М., Руль Ю.В., Булгакова М.К. Фізіологія харчування: практикум. Навчальний посібник. К.: Центр учбової літератури, 2013. 208 с.

6. Шкільне харчування має бути безпечним та здоровим, особливо під час карантину: веб-сайт. URL: https://mon.gov.ua/ua/ news/shkilne-harchuvannya-maye-buti-bezpechnim-ta-zdorovim-osoblivo-pid-chas-karantinu-sergij-shkarlet

7. Zurayk, R. (2020). Pandemic and Food Security: A View from the Global South. Journal of Agriculture, Food Systems, and Community Development, 9 (3), 17-21. Веб-сайт. URL: https://doi.org/10.5304/jafscd.2020.093.014 


\title{
ВПАИВ ВИХАОПНИХ ГАЗІВ АВТОТРАНСПОРТУ HA ГЕНЕРАТИВНI ОРГАНИ ПРЕДСТАВНИКIВ РОДУ ACER L.
}

\author{
Сараненко I.I., Шадура К.О. \\ Херсонський державний університет \\ вул. Університетська, 27, 73003, Херсон \\ i.i.saranenko@ukr.net
}

\begin{abstract}
Одним із найпотужніших джерел забруднення довкілля є автотранспорт. Недосконале планування населених пунктів, відсутність або неструктурованість санітарно-захисних зон та зелених смуг досить часто стають основною причиною погіршення їх екологічного стану. Деякі деревні рослини чутливо реагують на зміну екологічних чинників та формують різні відповіді на їхню комплексну дію. Нові особливі властивості, що не притаманні екосистемі, відображають їі емерджентність. За такими ознаками визначають придатність біоіндикації для екологічних досліджень, експертиз, прогнозування поведінки, стану та розвитку екосистем. Найбільшого антропогенного впливу зазнають урбоекосистеми, тому важливим $\epsilon$ контроль за станом навколишнього середовища та своєчасний аналіз забрудненості території міста, у тому числі методами біоіндикації.

Стаття присвячена визначенню впливу вихлопних газів автотранспорту на генеративні органи деревних рослин, представників роду кленових $($ Acer L), які зростають у селі Чорнобаївка Херсонського району поряд з автотрасою Е58. Метою $є$ виявлення біоіндикаційних властивостей генеративних органів деяких представників Acer L. Одночасно апробовано декілька методів оцінювання впливу вихлопних газів на показники плодоношення деревних рослин та вибрано такі, як: кількість суцвіть та плодів на модельних гілках; кількість плодів у суцвітті; ширина і довжина плода, маса 1000 насінин, життєздатність насіння. Визначено, що у досліджуваних видів порівняно з контролем зменшується число суцвіть і кількість плодів на модельній гілці (від 10 до 15\%); довжина (13,3\%) і ширина (21,0\%) плодів, насіння, маса 1000 насінин - на 8,13\%; життєздатність насіння клену гостролистого становить 51,0\%, клену несправжньоплатанового - 68,5\%, клену ясенелистого - 64,3\%; тест-параметром та емерджентною властивістю для фітоіндикації забруднення середовища у моніторингових дослідженнях визначено зниження життєздатності насіння у клена гостролистого.

Найстійкішими виявилися генеративні органи клена ясенелистого та насіння клена несправжньоплатанового. Ключові слова: біоіндикація, емерджентність, генеративні органи, життєздатність, тест-параметр.
\end{abstract}

Influence of vehicle exhaust gases on generative bodies of Acer L. Saranenko I., Shadura K.

One of the most powerful sources of environmental pollution is motor vehicles. Imperfect planning of settlements, lack or unstructured sanitary protection zones and green strips are often the main reason for the deterioration of their environmental condition. Some woody plants are sensitive to changes in environmental factors and form different responses to their complex action. New special properties that are not inherent in the ecosystem, reflect its emergence. Such features determine the suitability of bioindication for ecological research, expertise, forecasting the behavior, state and development of ecosystems. Urban ecosystems have the greatest anthropogenic impact, so it is important to monitor the state of the environment and timely analysis of pollution in the city, including bioindication methods.

This work is devoted to determining the impact of vehicle exhaust gases on the generative organs of woody plants, members of the genus Maple (Acer L), which grow in the village of Chornobaivka, Kherson region near the highway E58. The aim is to identify the bioindication properties of the generative organs of some representatives of Acer L. Simultaneously, several methods of estimating the impact of exhaust gases on fruiting indicators of woody plants were tested and the following were selected: the number of inflorescences and fruits on model branches; the number of fruits in the inflorescence; width and length of the fruit, weight of 1000 seeds, seed viability.

It is determined that in the studied species, in comparison with the control, the number of inflorescences and the number of fruits on the model branch decreases from 10 to $15 \%$; length (13.3\%) and width $(21.0 \%)$ of fruits, seeds, weight of 1000 seeds by $8.13 \%$; seed viability of Acer platanoides L. is $51.0 \%$, Acer pseudopl'atanus L. $-68.5 \%$, Acer negundo L. $-64.3 \%$; test parameter and emergent property for phytoindication of environmental pollution in monitoring studies determined the decrease in seed viability in maple.

The most resistant were the generative organs of Acer negundo L. and seeds of Acer pseudopl'atanus L. Key words: bioindication, emergence, generative organs, viability, test parameter.

Постановка проблеми. Одним із провідних критеріїв стійкості деревних рослин у жорстких екологічних умовах $є$ їх репродуктивна здатність [1-3]. Нормальне функціонування кожної екосистеми включає успішне здійснення процесу іiі самовідновлення [4]. Це пов'язане з тим, що насіннєве розмноження деревних рослин відіграє провідну роль у збереженні генетичної гнучкості та стійкості більшості видів у лісових угрупованнях.

Актуальність дослідження. Дослідження репродуктивного розвитку рослин необхідне для прогнозу- вання їх декоративності, що важливо у підборі асортименту для озеленення промислових підприємств, створення захисних смуг вздовж автомобільних шляхів [5] та загального архітектурного ансамблю міста [6]. Водночас чутливість генеративного розвитку до вихлопних газів робить перспективними пошуки інформативних тест-параметрів для фітоіндикації забруднення середовища у моніторингових дослідженнях [7].

Аналіз останніх досліджень і публікацій. В.П. Безсонова відзначила зниження кількості 


\section{Сараненко I.I., Шадура К.о.}

плодів на модельній гілці деревних рослин, які ростуть у зоні емісій важких металів (марганець, хром, мідь, залізо), збільшення числа плодів, які опали, зниження маси 1000 насінин [8]. 3.В. Грицай встановила, що підвищення концентрації $\mathrm{SO}_{2}$ i $\mathrm{NO}_{2}$ призводить до зниження інтенсивності плодоношення на 44,4\% у Acer platanoides; на 38,5\% - у Acer pseudoplatanus i на 30,8\% - y Acer negindo, а також до зниження маси 1000 насінин у деревних видів роду Асег, що піддавалися дії емісій $\mathrm{SO}_{2}, \mathrm{NO}_{2}$.

Г.Г. Юхневич, І.М. Колесник [9] зазначили, що життєздатність насіння являється найбільш надійним і об'єктивним показником його якості.

К. Кіт, Л. Кілліп, П. Хе [10], С. Волошинська [11] дослідили, що вміст $\mathrm{Pb}$ у рослинах підвищується разом з інтенсивністю автомобільного руху і зменшується по мірі віддалення від дороги.

Яна Зіткова, Їтка Гегрова, Петр Анделц у 2018 році вивчали вплив засолення доріг на ялину європейську. Дослідження проводилося на півночі Чехії у Ліберецькому краї. Пошкодження рослинності проявляється в уповільненні росту, в'яненні, пожовтінні, зменшенні розміру хвої, некрозі кореневої системи, зниженні життєздатності насіння та затримці його проростання [12].

Виділення не вирішених раніше частин загальної проблеми, котрим присвячусться означена стаття. У місті Херсоні та агломерації вздовж автомобільних шляхів насаджені переважно представники кленових та гіркокаштанових. Вплив вихлопних газів на генеративні органи роду Acer L. досліджені мало. Враховуючи масове ушкодження гіркокаштану звичайного мінуючою міллю, доцільно вивчати адаптацію кленових до умов зростання.

Зв'язок авторського доробку із важливими науковими та практичними завданнями. Дослідження проведені у межах комплексного вивчення біоіндикаційних властивостей деревних рослин в умовах міста Херсона та агломерації з метою виявлення інформативних тест-параметрів щодо визначення осередків забруднення повітря та грунтів.

Новизна. Метою роботи $є$ виявлення емерджентних властивостей генеративних органів представників роду кленових та їх придатності для біоіндикації, екологічних досліджень, прогнозування стану і розвитку екосистем.

Методологічне або загальнонаукове значення. Для проведення дослідження апробовано одночасно декілька методів оцінювання впливу вихлопних газів на показники плодоношення деревних рослин.

Проби відбирали з модельних дерев, із південно-східного боку крони, з гілок середнього ярусу, п’ятого порядку галуження. Дослідження інтенсивності плодоношення визначали за методикою Н.Д. Нестеровича [13]. Життєздатність насіння, масу 1000 насінин визначали за державними стандартами $[6,14]$. Результати експерименту опрацьовані статистично. Контрольною ділянкою вибрано парк Слави у місті Херсоні, що знаходиться на значній відстані від автошляхів, де концентрація забруднюючих речовин не перевищує ГДК.

Викладення основного матеріалу. Для проведення дослідження вибрано тест-полігон площею $300 \mathrm{~m}^{2}$, який знаходиться у селі Чорнобаївка Херсонського району поблизу автотраси Е58. У деревному покриві переважають: клен ясенелистий (Acer negundo L.), клен гостролистий (Acer platanoides L.), клен несправжньоплатановий (Acer pseudopl'atanus L.).

У трав'яному покриві: амброзія полинолиста (Ambrosia artemasiifolia L.), гірчак звичайний (Polygonum aviculare L.), гикавка cipa (Berteroa incana (L.) DC.), злинка канадська (Erigeron Canadensis L.), перстач сріблястий (Potentilla argentea L.), буркун лікарський (Melilotus officinalis (L.) Pall), пирій повзучий (Elytrigia repens (L.) Nevski), кульбаба лікарська (Taraxacum officinale Wedd.ex Wigg.), лобода біла (Chenopodium album L.), кропива жалка (Urtica urens L.), тонконіг вузьколистий (Poa angustifolia L.), галінсога дрібноквіткова (Galinsoga parviflora Cav.), конюшина альпійська (Trifolium alpestre L.), лядвенець український (Lotus ucrainicus Klok.), цикорій дикий (Cichorium intybus L.)

Важливим фактором відновлення деревних рослин у лісових екосистемах $є$ інтенсивність плодоношення. Цей показник має велике значення в оцінці стану фітоценозів, у прогнозуванні їх відновлення та розробленні природоохоронних заходів, типового видового складу рослинності для специфічних санітарно-захисних зон.

Наші дослідження впливу на інтенсивність плодоношення деревних рослин роду клен дали змогу встановити, що цей параметр в умовах забруднення у досліджуваних об'єктів знижується. У всіх досліджуваних порід спостерігається зменшення кількості суцвіть на модельній гілці у рослин дослідного варіанту порівняно $з$ контрольним (табл. 1). Цей показник зменшується найбільш суттєво в A.platanoides і становить 66,43\% від контролю. Найбільшу толерантність до забруднення за цим параметром проявляє Acer pseudoplatanus. Число суцвіть на модельній гілці порівняно з контролем становить 80,24\% у клена ясенелистого і 83,87\% у клена несправжньоплатанового.

Число плодів у суцвітті знижується у рослин (табл. 2), які зростали на тест-полігоні, порівняно 3 контрольними деревами. Однак цей параметр, на відміну від попереднього, порівняно 3 контролем падає у клена ясенелистого (на 2,02\%) та у клена несправжньоплатанового (на 4,42\%).

Як результат зниження показників числа суцвіть на модельній гілці та плодів у суцвітті (табл. 3), спостерігається зменшення загальної кількості плодів на модельній гілці дерев, що зростають в умовах забруднення. За ступенем зниження інтенсивності плодоношення досліджені види можна розташувати в такій послідовності: клен ясенелистий > клен несправжньоплатановий > клен гостролистий. 
Вплив вихлопних газів на кількість суцвіть на модельній гілці

\begin{tabular}{|c|c|c|c|}
\hline \multirow{2}{*}{ Вид } & \multicolumn{2}{|c|}{$\begin{array}{c}\text { Кількість суцвіть на } \\
\text { модельній гілці, шт. }\end{array}$} & $\begin{array}{c}\text { \% від } \\
\text { кон- } \\
\text { тролю }\end{array}$ \\
\cline { 1 - 3 } & контроль & тест-полігон & 66,43 \\
\hline Клен гостролистий & $16,15 \pm 0,011$ & $10,73 \pm 0,015$ & 63,87 \\
\hline $\begin{array}{c}\text { Клен несправжньо- } \\
\text { платановий }\end{array}$ & $11,6 \pm 0,068$ & $9,73 \pm 0,045$ & 80,24 \\
\hline Клен ясенелистий & $11,59 \pm 0,083$ & $9,3 \pm 0,056$ & 8 \\
\hline
\end{tabular}

Таблиця 2

Вплив вихлопних газів на кількість плодів у суцвітті

\begin{tabular}{|c|c|c|c|}
\hline \multirow{2}{*}{ Вид } & \multicolumn{2}{|c|}{$\begin{array}{c}\text { Кількість плодів } \\
\text { у суцвітті, шт. }\end{array}$} & $\begin{array}{c}\text { \% від } \\
\text { кон- } \\
\text { тролю }\end{array}$ \\
\cline { 2 - 3 } & контроль & тест-полігон & \\
\hline Клен гостролистий & $7,67 \pm 0,019$ & $7,23 \pm 0,022$ & 94,26 \\
\hline $\begin{array}{c}\text { Клен несправжньо- } \\
\text { платановий }\end{array}$ & $6,79 \pm 0,016$ & $6,49 \pm 0,016$ & 95,58 \\
\hline Клен ясенелистий & $6,93 \pm 0,021$ & $6,79 \pm 0,014$ & 97,98 \\
\hline
\end{tabular}

Згідно 3 літературними джерелами, чинники навколишнього середовища впливають на процеси формування, росту та розвитку плодів і насіння [11, 15]. Дія на ці показники забруднення середовища вивчена недостатньо. Нами проведено дослідження впливу забруднення викидами автотранспорту на деякі морфометричні показники плодів та насіння.

Аналіз отриманих результатів свідчить про зменшення довжини та ширини плодів у всіх досліджених порід в останній стадії росту (табл. 4,5 ).
Вплив вихлопних газів

Таблиця 3

на кількість плодів на модельній гілщі

\begin{tabular}{|c|c|c|c|}
\hline \multirow{2}{*}{ Вид } & \multicolumn{2}{|c|}{$\begin{array}{c}\text { Кількість плодів } \\
\text { на модельній гілці, шт. }\end{array}$} & $\begin{array}{c}\text { \% від } \\
\text { кон- } \\
\text { тролю }\end{array}$ \\
\cline { 1 - 3 } & контроль & тест-полігон & трол \\
\hline Клен гостролистий & $124,44 \pm 0,44$ & $77,33 \pm 0,42$ & 62,14 \\
\hline $\begin{array}{c}\text { Клен несправжньо- } \\
\text { платановий }\end{array}$ & $78,67 \pm 0,46$ & $67,73 \pm 0,32$ & 86,09 \\
\hline Клен ясенелистий & $75,15 \pm 0,61$ & $65,83 \pm 0,58$ & 87,6 \\
\hline
\end{tabular}

Таблиця 4

Вплив вихлопних газів на довжину плода

\begin{tabular}{|c|c|c|c|}
\hline \multirow{2}{*}{ Вид } & \multicolumn{2}{|c|}{ Довжина плода, мм. } & \multirow{2}{*}{$\begin{array}{c}\% \text { від } \\
\text { кон- } \\
\text { тролю }\end{array}$} \\
\hline & контроль & тест-полігон & \\
\hline Клен гостролистий & $44,28 \pm 0,061$ & $33,9 \pm 0,097$ & 76,56 \\
\hline $\begin{array}{c}\text { Клен несправжньо- } \\
\text { платановий }\end{array}$ & $28,64 \pm 0,073$ & $25,62 \pm 0,037$ & 89,46 \\
\hline Клен ясенелистий & $40,62 \pm 0,049$ & $38,22 \pm 0,037$ & 94,04 \\
\hline
\end{tabular}

Таблиця 5

Вплив вихлопних газів на ширину плода

\begin{tabular}{|c|c|c|c|}
\hline \multirow{2}{*}{ Вид } & \multicolumn{2}{|c|}{ Ширина плода, мм. } & \multirow{2}{*}{$\begin{array}{c}\% \text { від } \\
\text { кон- } \\
\text { тролю }\end{array}$} \\
\hline & контроль & тест-полігон & \\
\hline Клен гостролистий & $14,06 \pm 0,029$ & $11,6 \pm 0,024$ & 82,5 \\
\hline $\begin{array}{c}\text { Клен несправжньо- } \\
\text { платановий }\end{array}$ & $12,48 \pm 0,048$ & $9,86 \pm 0,046$ & 79,01 \\
\hline Клен ясенелистий & $9,12 \pm 0,029$ & $6,9 \pm 0,015$ & 75,66 \\
\hline
\end{tabular}

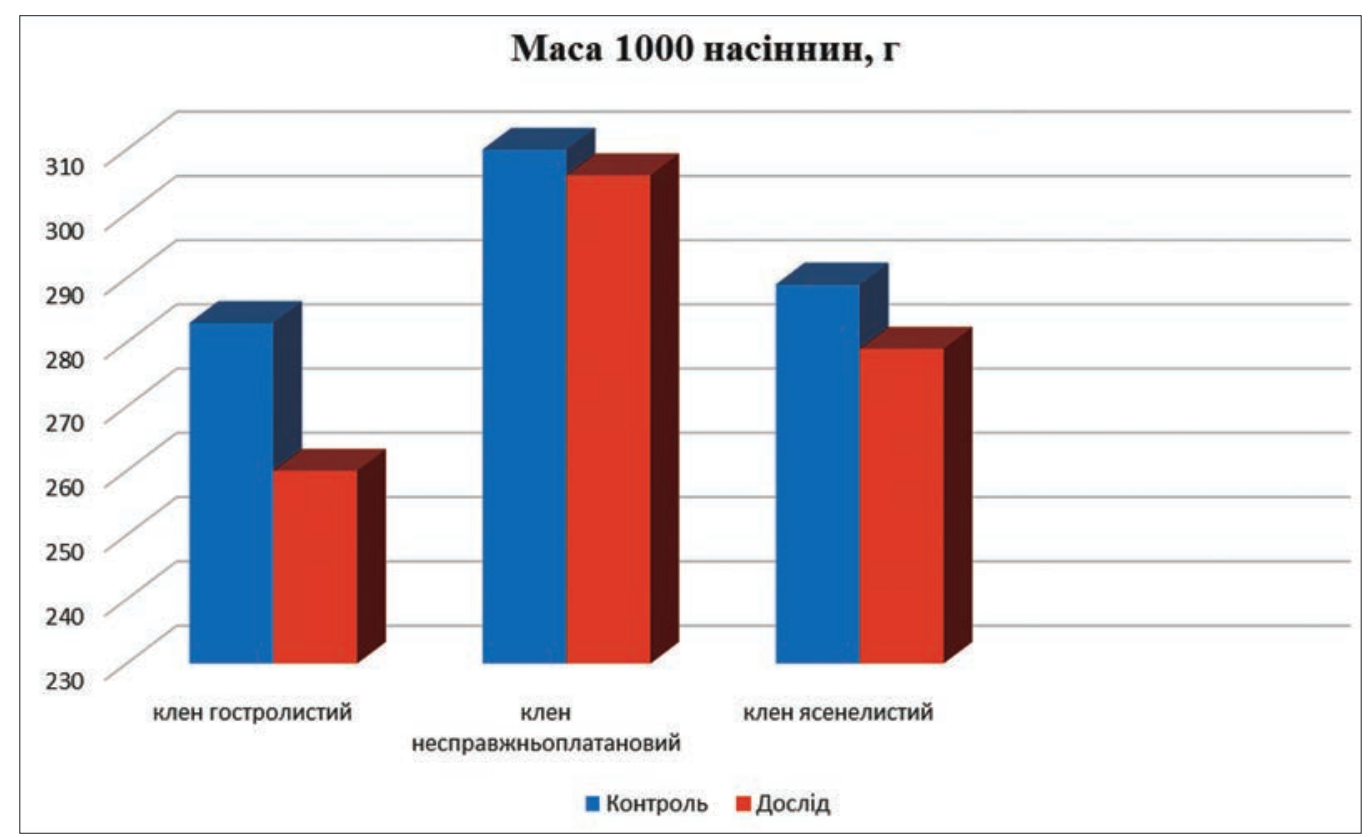

Рис. 1. Вплив вихлопних газів на масу 1000 насінин клена гостролистого, клена несправжньоплатанового, клена ясенелистого 


\section{Сараненко I.I., Шадура К.о.}

У кленів спостерігається збільшення кількості плодів із порушенням розвитку - недорозвиненість крил, редукція одного крила у кленів, аномальні форми крил. Насіння, що знаходилося в цих плодах, було переважно нежиттєздатним.

Для характеристики якості насіння і насіннєвого відновлення важливе значення має така величина, як маса 1000 насінин. Цей параметр у всіх досліджених видів зменшується у дослідному варіанті, порівняно 3 контрольним (рис. 1). Так, у клена несправжньоплатанового маса 1000 насінин порівняно 3 контролем менша на 1,3\%, у клена ясенелистого - на 3,43\%, у клена гостролистого - на 8,13\%.

Дослідження життєздатності насіння показало, що в умовах незабрудненої зони найнижча життєздатність насіння - у клена гостролистого (79,8\%). В умовах дії на рослини викидів автотранспорту життєздатність насіння у всіх порід зменшується, причому цей показник найбільш суттєво падає у клена гостролистого. Найбільшу толерантність до забруднення проявляє насіння клена ясенелистого та клена несправжньоплатанового (рис. 2).

Таким чином, вихлопні гази негативно впливають на показники формування, росту і розвитку плодів у деревних рослин. У досліджених порід знижується інтенсивність плодоношення, зменшуються розміри плодів, насіння, падає маса 1000 насінин, знижується їхня життєздатність. Найбільш чутливим до забруднення середовища за зміною морфометричних показників плодів і насіння є клен гостролистий. Зниження життєздатності насіння у клена гостролистого ми пропонуємо як чутливий тест-параметр для діагностування стану рослин та фітоіндикації забруднення грунтів у моніторингових дослідженнях.
ВПАИВ ВИХАОПНИХ ГАЗІВ АВТОТРАНСПОРТУ...

За сукупністю змін характеристик плодів і насіння дерев в умовах дії на них викидів автотранспорту серед досліджених об'єктів виділили види, які проявляють більшу толерантність до забруднення (клен несправжньоплатановий та клен ясенелистий). Найбільшу чутливість до забруднення за дослідженими показниками проявляє клен гостролистий. Ці дані ми пропонуємо враховувати під час підборі асортименту рослин для озеленення територій, що прилягають до автотрас та промислових комплексів.

\section{Головні висновки.}

1. Зростання рослин роду Acer L. в умовах впливу вихлопних газів призводить до зниження інтенсивності їх плодоношення. У видів, що досліджуються, зменшується число суцвіть і кількість плодів на модельній гілці від 10 до 15\% .

2. У досліджених порід спостерігається зменшення довжини і ширини плодів, насіння, зниження маси 1000 насінин на 8,13\%.

3. Життєздатність насіння клену гостролистого становить 51,0\% від контролю, клену несправжньоплатанового - 68,5\%, клену ясенелистого - 64,3\%.

4. Найбільшу чутливість до забруднення за сукупністю змін показників плодів i насіння проявив клен гостролистий, найменшу - клен несправжньоплатановий.

5. Виявлені емерджентні властивості деревних рослин, які доцільно використовувати як тест-параметри для фітоіндикації забруднення середовища у моніторингових дослідженнях. Найінформативнішим є зниження життєздатності насіння у клена гостролистого.

Перспективи використання результатів дослідження. Виявлені чутливі показники клена гостролистого, які доцільно використовувати як тестпараметри забруднення повітря та грунту.

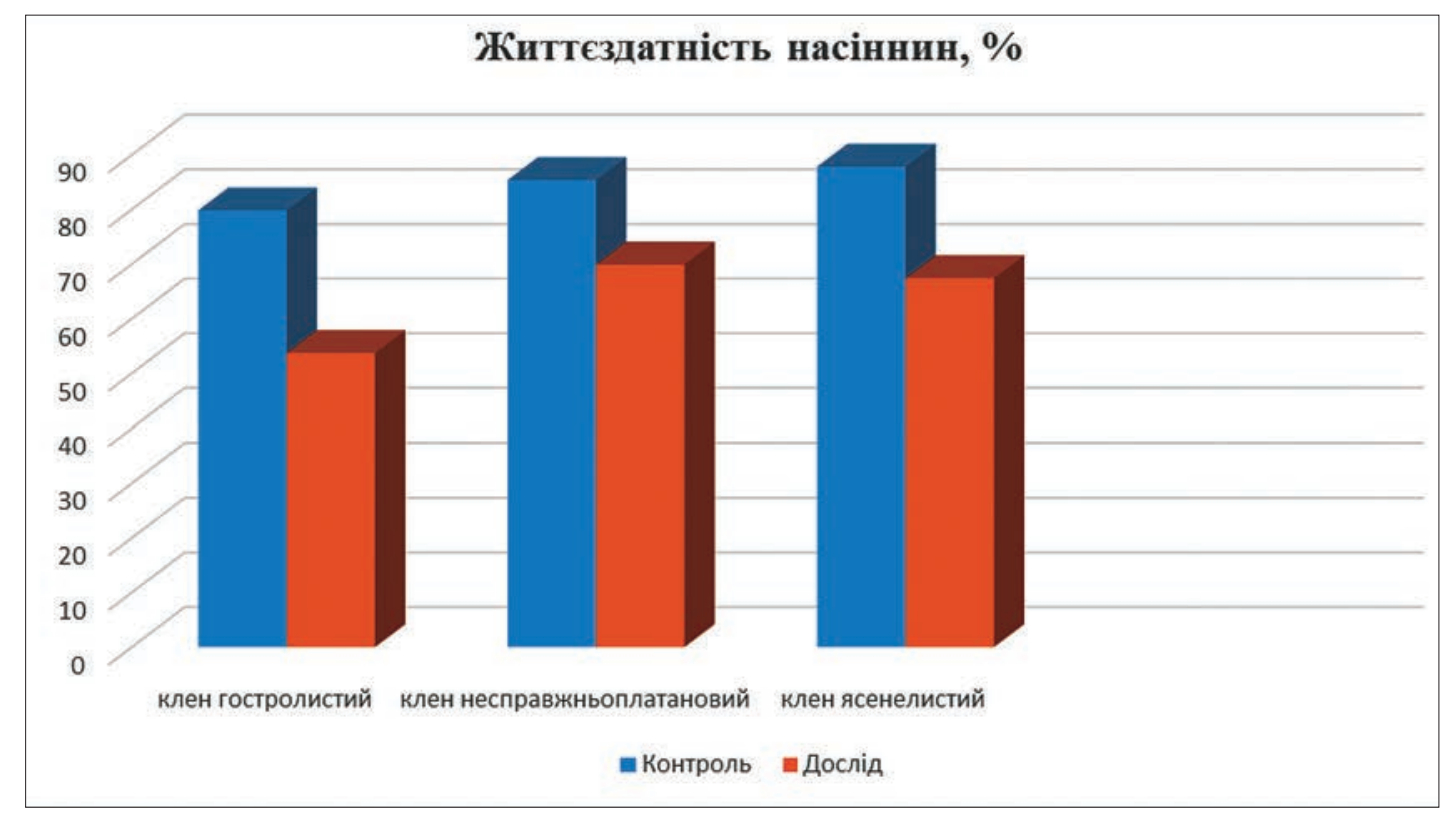

Рис. 2. Вплив вихлопних газів на життєздатність насіння:клена гостролистого, клена несправжньоплатанового, клена ясенелистого 


\section{Література}

1. Бессонова В.П., Юсипова Т.И. Семенное возобновление древесных растенийь и промышленные поллютанты $\left(\mathrm{SO}_{2}\right.$ и $\left.\mathrm{NO}_{2}\right)$. Запорожье, 2001. 193 с.

2. Бессонова В.П., Зайцева І.А. Вміст важких металів у листі дерев і чагарників в умовах техногенного забруднення різного походження. Питання біоіндикаиії та екології. Вип. 13, №2. 2008. URL: http://sites.znu.edu.ua/bioindication/issues/13-2/ bessonova zaiyceva.pdf. (дата звернення: 12.11.2021).

3. Грицай 3.В. Показники плодоношення деревних рослин як чутливі тест-параметри для використання в моніторингових дослідженнях. Фальифейнівські читання. Херсон, 2007. С. 82-86.

4. Цветкова Н.Н., Дубина А.А. Миграция органо-минеральных веществ тяжелых металлов в искусственных дубовых насаждениях степной зоны Украины. Вісник Дніпропетр. ун-ту. Біологія. Екологія. Вип. (9). 2001. С.67-70.

5. Сараненко I.І. Деякі аспекти екологічного моніторингу стану санітарно-захисних зон. Екологічна безпека. Кременчук: КрНУ ім. М. Остроградського, 2010. Вип. 2 (10) С. 36-38.

6. ДСТУ 7243:2011 Якість грунту. Землі техногенно забруднені. Обстеження та використання. [Чинний від 2012-01-01]. Київ, 2012. 16 с. (Інформація та документація).

7. Сараненко I.I. Аналіз стійкості представників роду Aesculus L. до забруднення довкілля в умовах міста Херсона. Екологічні науки 3 (22). Київ: ДЕА, 2018. С. 53-56.

8. ДСТУ 7080:2009. Якість грунту. Проведення польових дослідів. Основні вимоги. [Чинний від 2009-10-27]. Київ, 2009. 10 с. (Інформація та документація).

9. Юхневич Г.Г., Колесник И.М. Микроорганизмы в биоиндикации и биотестировании: лаб. практикум. Гродно: ГрГУ, 2012. $51 \mathrm{c}$.

10. Keith K.E., Killip L., He P. et al. Burkholderia cenocepacia produces a pigment with antioxidant properties using a homogentisate intermediate. Journal of bacteriology. 2007. V. 189, № 24. P. 9057-9065.

11. Волощинська С.С. Біоіндикація стану забруднення довкілля важкими металами (на прикладі автомагістралі «Київ-Варшава»). Вісник ДНУ. Біологія. Екологія. Дніпропетровськ, 2008. Вип. 16, т. 2. С. 24-28.

12. Jana Zítkova, Jitka Hegrova, Petr Andelc. Bioindication of road salting impact on Norway spruce (Picea abies). Transportation Research Part D: Transport and Environment. Volume 59, March 2018, Pages 58-67. URL: https://doi.org/10.1016/j.trd.2017.12.010 (дата звернення: 05.11.2021).

13. Нестерович Н.Д. Плодоношение интродуцированных древесных растений в БССР. Минск: изд-во АН БССР, 1958. 383 с.

14. ДСТУ 8558:2015 Насіння дерев і кущів. Методи визначення посівних якостей (схожості, життєздатності, доброякісності) [Чинний від 2017-01-01]. Київ, 2017. 15 с. (Інформація та документація).

15. Дубина, А.О., Сараненко I.І., Цвєткова Н.М. Розподіл важких металів (Fe, $\mathrm{Mn}, \mathrm{Cu}, \mathrm{Zn}, \mathrm{Ni}, \mathrm{Pb}, \mathrm{Cd}$ ) в грунтах м. Кременчука. Сучасні проблеми біологї екологї та хімії: матеріали міжнар. конф., присвяченої 20-річчю біологічного факультету ЗНУ, 29.03 - 01.04. 2007 р. Запоріжжя: ЗНУ, 2007. С. 466-467. 


\title{
ОЦІНЮВАННЯ РИЗИКУ ДАЯ ЗДОРОВ'Я ДІТЕЙ І ДОРОСАОГО НАСЕАЕННЯ МІСТ ВІД ШКІДАИВОГО ВПАИВУ ВИКИДІВ АВТОТРАНСПОРТУ
}

\author{
Чепель А.Є., Кофанова О.В., Євтєєва Л.І. \\ Національний технічний університет України «Київський політехнічний інститут \\ імені Ігоря Сікорського» \\ пр. Перемоги, 37, 03056, м. Київ \\ allachepel@ukr.net
}

\begin{abstract}
Роботу присвячено вивченню впливу викидів автотранспорту на доросле й дитяче населення міст, яке проживає та/або постійно перебуває в зоні впливу забрудненого повітряного середовища. Актуальність дослідження зумовлена значним зростанням на дорогах великих міст та урбанізованих територій інтенсивності й щільності автотранспортних потоків; нестачею місць для паркування автомобілів; утворенням заторів на дорогах, що призводить до значного підвищення ризику для здоров'я населення від викидів автотранспортних засобів, а отже, і до необхідності кількісного та якісного оцінювання рівня екологічної безпеки дорослого й дитячого населення. Для дослідження впливу викидів автотранспорту на здоров'я людей проведено натурні спостереження за автотранспортними потоками міста (на прикладі Києва). 3 метою кількісного оцінювання ризику для здоров'я людей для дослідження вибрано території, на яких сконцентровано спортивні й дитячі майданчики, дитячі садочки, школи, зони рекреації тощо. Для аналізу використано емпіричні дані постів спостережень Центральної геофізичної обсерваторії імені Бориса Срезневського (м. Київ) щодо рівнів забруднення атмосферного повітря за 2020 р., а саме постів спостережень № 6 (площа Перемоги), № 7 (Бессарабська площа), № 8 (бульвар Лесі Українки, 29) та № 20 (площа Деміївська). Проведений аналіз показав, що на 1000 осіб, які постійно перебувають у районах спостереження, близько 196...259 осіб можуть страждати від хронічної, у тому числі важкої, інтоксикації через вдихання забрудненого повітря. Новизною роботи є теоретичне обгрунтування екологічної безпеки дитячого та дорослого населення міста, які перебувають на спортивних і дитячих майданчиках, у зонах рекреації тощо, під впливом викидів автотранспортних засобів. Практичне значення мають розрахунки ризику для здоров'я населення від впливу таких токсикантів, як сульфур(IV) оксид $\mathrm{SO}_{2}$, нітроген(IV) оксид $\mathrm{NO}_{2}$, формальдегід НС(О)Н. Результати обрахунку ризику для здоров'я людей від забрудненого викидами автотранспорту повітря дають змогу оцінити динаміку неспецифічних токсичних ефектів у разі хронічної інгаляційної інтоксикації дитячого й дорослого населення міста, встановити і спрогнозувати потенційні наслідки такого впливу та на цій основі вибрати дієві запобіжні заходи. Ключові слова: автомобільний транспорт, екологічна безпека, атмосферне повітря, відпрацьовані гази, забруднювальні речовини, ризик для здоров’я населення.
\end{abstract}

Assessment of the risk to the health of children and adults from the harmful effects of the motor transport emissions in cities. Chepel A., Kofanova O., Yevteyeva L.

The work is devoted to the study of the impact of vehicle emissions on the adult and child population living in cities or permanently being in the zone of high air pollution. The relevance of the study is due to a significant increase in large cities and urban areas, the intensity and density of traffic flows, lack of parking spaces, traffic jams, which lead to a significant increase in public health risk from vehicle emissions, and, consequently, leads to the need to quantify the level of environmental safety of both adults and children. For a more detailed study of the impact of motor transport on children's health, firstly, field observations of the city's motor traffic flows were conducted, and secondly, for the quantitative assessment of human health risk, areas where kindergartens and schools, sports and playgrounds, as well as recreational areas are concentrated were selected. The analysis used data from the observation posts of the Borys Sreznevsky Central Geophysical Observatory (Kyiv) on the levels of air pollution in 2020, namely № 6 (Peremogi square), № 7 (Bessarabian square), № 8 (Lesia Ukrainka boulevard, 29), № 20 (Demiivska square). The analysis showed that per 1,000 people who are constantly present in the observation areas, about $196 . .259$ people may suffer from chronic intoxication due to inhalation of polluted air. The novelty of the work includes a theoretical study and practical calculations to confirm the risk to public health from the harmful effects of sulfur (IV) oxide $\mathrm{SO}_{2}$, nitrogen (IV) oxide $\mathrm{NO}_{2}$, formaldehyde $\mathrm{HC}(\mathrm{O}) \mathrm{H}$ on the example of areas affected by negative impact in Kyiv. The study of the potential health risk of air pollution from motor vehicle emissions is important, because this data will allow us to assess the development of nonspecific toxic effects of chronic inhalation intoxication of children and adults in urban areas and choose precautions. Key words: motor transport, ecological safety, atmospheric air, exhaust gases, pollutants, risk for public health.

Вступ. Збільшення кількості автотранспортних засобів (далі - АТЗ), особливо приватного, розширення простору відкритого паркування та збільшення площі для зберігання автомобілів у житлових масивах великою мірою чинять вплив на показники якості атмосферного повітря, підвищують рівень забруднення повітряного простору високоурбанізованих територій. Ситуацію значно погіршує будівництво підземних паркінгів у селітебній зоні, а також зберігання приватного автотранспорту поблизу житлових будинків.

Постановка проблеми. Останніми роками в Україні інтенсивно розвивається будівництво так званих спальних кварталів. Сучасні житлові будинки об'єднуються в масштабні житлові комплекси, які включають різні елементи інфраструктури, зокрема дитячі майданчики та зони рекреації, обладнані ігровими та/або спортивними спорудами. Такі 
майданчики й зони рекреації активно використовуються для прогулянок та ігор із дітьми, занять спортом тощо.

Отже, надзвичайно актуальним завданням $€$ оцінювання ризику та рівнів впливу забрудненого викидами автотранспорту повітря на здоров'я дітей і мешканців будинків, які проживають у районах підвищеного техногенного навантаження.

Метою роботи $є$ визначення рівня впливу викидів припаркованих поблизу будинків автотранспортних засобів на дитячі майданчики та здоров'я мешканців будинків у разі хронічного впливу шкідливого атмосферного повітря.

Зв'язок авторського доробку з важливими науковими та практичними завданнями. Необхідність мінімізації шкідливого впливу автомобілів на здоров'я жителів міст відповідає головним засадам, що визначені в Основних напрямах державної політики України у галузі охорони довкілля, використання природних ресурсів та забезпечення екологічної безпеки (затверджених Постановою Верховної Ради України від 5 березня 1998 р. № 188/98-ВР) та Стратегії державної екологічної політики України на період до 2030 року (затверджена Законом України від 28 лютого 2019 р. № 2697-VIII).

Проведене дослідження щодо шкідливого впливу автотранспорту на здоров'я дітей і дорослого населення міст, яке проживає та/або постійно перебуває в зоні забрудненого атмосферного повітря, дає змогу оцінити реальну ситуацію та на цій основі розробити дієві шляхи зменшення ризику для здоров'я людей, у тому числі за рахунок екологічно сприятливого планування селітебних зон та об'єктів автотранспортної інфраструктури.

Аналіз попередніх досліджень і публікацій. Вплив автотранспорту на якість міського повітряного середовища досліджували провідні вітчизняні й зарубіжні вчені, наприклад Г.О. Татарченко, I.В. Кравченко, М.В. Писаренко, С.Л. Поркуян [1], В.В. Славін, В.В. Томаш [2]. Ризик для здоров'я людей від впливу забрудненого атмосферного повітря досліджено у працях таких учених, як О.О. Борисов [3; 4], І.О. Рабош [5], В.В. Тарасова [6], А.В. Степаненко та А.А. Омельченко [7].

Отже, на сьогодні досліджено й обгрунтовано багато різноманітних способів запобігання впливу автомобільного транспорту на атмосферне повітря й придорожні території. Проте всі запропоновані методи лише зменшують негативний вплив від викидів автомобілів, а не усувають його повністю. Тому зі збільшенням кількості АТЗ кожного року, особливо у приватному секторі, та зі зростанням захворюваності дітей на респіраторні, нервові й навіть онкологічні захворювання проблема захисту атмосферного повітря від негативного впливу автомобілів залишається дуже актуальною.

Виділення не вирішених раніше частин загальної проблеми, котрим присвячусться стаття.
У дослідженнях О.П. Ігнатенко [8], Н.I. Білошицької та співавторів [9] зазначається, що в містах діти становлять до 25\% жителів / мешканців дворових комплексів. І велику частину свого часу (за оцінками, 30-50\%) вони проводять, граючись на дитячих майданчиках і рекреаційних територіях. Навіть у разі відсутності у дворі спеціально обладнаного дитячого чи спортивного майданчика дітлахи граються на тротуарах поблизу під'їдів, на проїзних частинах двора тощо.

За даними ВОО3 [10; 11], приблизно 93\% дітей дихають забрудненим повітрям, що ставить під загрозу їхнє життя і здоров'я, здоров'я наступних поколінь. Головними причинами більшої уразливості дитячого організму щодо негативного впливу забрудненого повітря є те, що діти дихають частіше, ніж дорослі, а також мають невеликий зріст (багато полютантів концентруються саме поблизу земної поверхні). Крім того, жваві дитячі ігри та зайняття спортом потребують багато рухів і, відповідно, надлишкового споживання кисню.

Новизна та загальнонаукове значення. Для оцінки ступеня забруднення територій міста, а також спортивних і дитячих майданчиків, рекреаційних зон тощо використовували натурні спостереження щодо інтенсивності й щільності автотранспортних потоків на дорогах столиці в різні періоди доби, а також емпіричні дані Центральної геофізичної обсерваторії імені Бориса Срезневського (м. Київ, далі - ЦГО) щодо вмісту в атмосферному повітрі основних токсикантів - компонентів викидів автомобілів [12].

Дослідження потенційного ризику для здоров'я населення від забруднення приземного повітряного середовища викидами автотранспорту має вагоме значення, оскільки отримані дані дадуть змогу оцінити факт розвитку неспецифічних токсичних ефектів у разі хронічної інгаляційної інтоксикації дитячого й дорослого населення міст, потенційні наслідки впливу та вибрати запобіжні заходи. Цей напрям дослідження повністю відповідає законам України «Про охорону навколишнього природного середовища» та «Про забезпечення санітарного та епідемічного благополуччя населення», а також іншим законодавчим актам.

Виклад основного матеріалу. 3 огляду на рівень автомобілізації актуальною залишається проблема зберігання індивідуального автотранспорту. У великих містах із досить щільною міською забудовою не завжди в житлових комплексах досить простору, щоб забезпечити всіх мешканців місцями для паркування. Це призводить до того, що автовласники припарковують автомобілі безпосередньо на внутрішній території двора, іноді навіть прямо під вікнами сусідів чи на території поблизу дитячих та/або спортивних майданчиків. Унаслідок такого зберігання АТЗ на замкнутих внутрішніх територіях дворів (так званих дворів «колодязного» типу), навіть віддалених від автомагістралей, формується стійке забруднення атмосферного повітря негативними викидами двигунів 
Чепель А.Є., Кофанова О.В., Свтєєва Л.І.

автотранспорту, що значно загострюється застійними явищами, які виникають на тлі великої кількості поверхів, що огортають територію двора.

Під час роботи двигуна автомобіля в атмосферу викидаються такі шкідливі речовини, як карбон(II) оксид $\mathrm{CO}$, карбон(IV) оксид $\mathrm{CO}_{2}$, оксиди Нітрогену $\mathrm{NO}_{x}$, сульфур(IV) оксид $\mathrm{SO}_{2}$, озон $\mathrm{O}_{3}$, бенз(а)пірен $\mathrm{C}_{20} \mathrm{H}_{12}$, а також дрібнодисперсні тверді частинки РМ. Через тертя шин 3 асфальтом, стирання гальмівних колодок, витоки пального чи мастил тощо досить часто спостерігається потрапляння до навколишнього середовища сполук важких металів, зокрема Плюмбуму, Кадмію тощо, які створюють додаткові загрози здоров'ю людей, особливо дітей [4].

Відпрацьовані гази двигунів АТЗ містять чадний газ (карбон(II) оксид СО), який утворюється під час неповного згоряння палива. Взаємодіючи з гемоглобіном крові, СО утворює стійку сполуку - карбоксигемоглобін, що стає перешкодою для газообміну у клітинах, унаслідок чого в людини спостерігається кисневе голодування. Отже, небезпечний вплив чадного газу полягає в погіршенні здатності крові людини переносити кисень. Вуглекислий газ $\mathrm{CO}_{2}$ не $є$ токсичним, проте його висока концентрація в атмосферному повітрі, особливо в поєднанні з низькою концентрацією кисню, чинить небезпечний вплив на здоров'я людини, викликає проблеми зі сном, запаморочення, головні болі, світлобоязнь та інші негативні прояви.

Зі збільшенням температури двигуна в атмосферу викидаються шкідливі оксиди Нітрогену, зокрема, нітроген(II) оксид NO, який у навколишньому середовищі досить швидко окиснюється до нітроген(IV) оксиду $\mathrm{NO}_{2}$, який є потужним забруднювачем атмосферного повітря та чинником утворення фотохімічного
ОЦІНЮВАННЯ РИЗИКУ ДАЯ ЗДОРОВ'Я ДІТЕЙ...

смогу в містах і на високоурбанізованих територіях. Нітроген(IV) оксид може вражати дихальні шляхи й легені, впливати на них, а також на кількість гемоглобіну у крові людини. У дітей нітроген(IV) оксид спричинює кисневе голодування тканин, збільшує канцерогенний вплив інших токсичних речовин i, як наслідок, може спровокувати появу злоякісних новоутворень.

Бенз(а)пірен $\mathrm{C}_{20} \mathrm{H}_{12}$ належить до поліароматичних вуглеводнів, а отже, є одним із найпотужніших канцерогенів. Потрапляючи до організму людини, він має накопичувальний ефект та постійно «отруює» організм. Доведено, що в місцях накопичення в повітрі бенз(а)пірену збільшується кількість випадків захворювання на рак легень і смертей через нього [13].

Для дослідження впливу викидів АТЗ на здоров'я дітей і мешканців багатоповерхових будинків нами було вибрано території, на яких сконцентрована велика кількість дитячих і спортивних майданчиків, дитячих садочків, шкіл, зон рекреації, а також які розташовані поруч із постами спостереження ЦГО.

Зокрема, у звітах ЦГО зазначено, що такі домішки, як нітроген(IV) оксид $\mathrm{NO}_{2}$, сульфур(IV) оксид $\mathrm{SO}_{2}$ i формальдегід $\mathrm{HC}(\mathrm{O}) \mathrm{H}$ є речовинами, які регулярно перевищують гранично допустимі концентрації (далі - ГДК) у різних частинах міста. Отже, для аналізу ризику для здоров'я населення від забруднення атмосферного повітря зазначеними токсикантами було проаналізовано емпіричні дані ЦГО щодо середньорічних концентрацій домішок за 2020 р. [14] на постах спостережень № 6 (площа Перемоги), № 7 (Бессарабська площа), № 8 (бульвар Лесі Українки, 29), № 20 (площа Деміївська) (рис. 1), на яких спостерігаються максимальні рівні забруднення повітряного середовища (рис. 2-4).

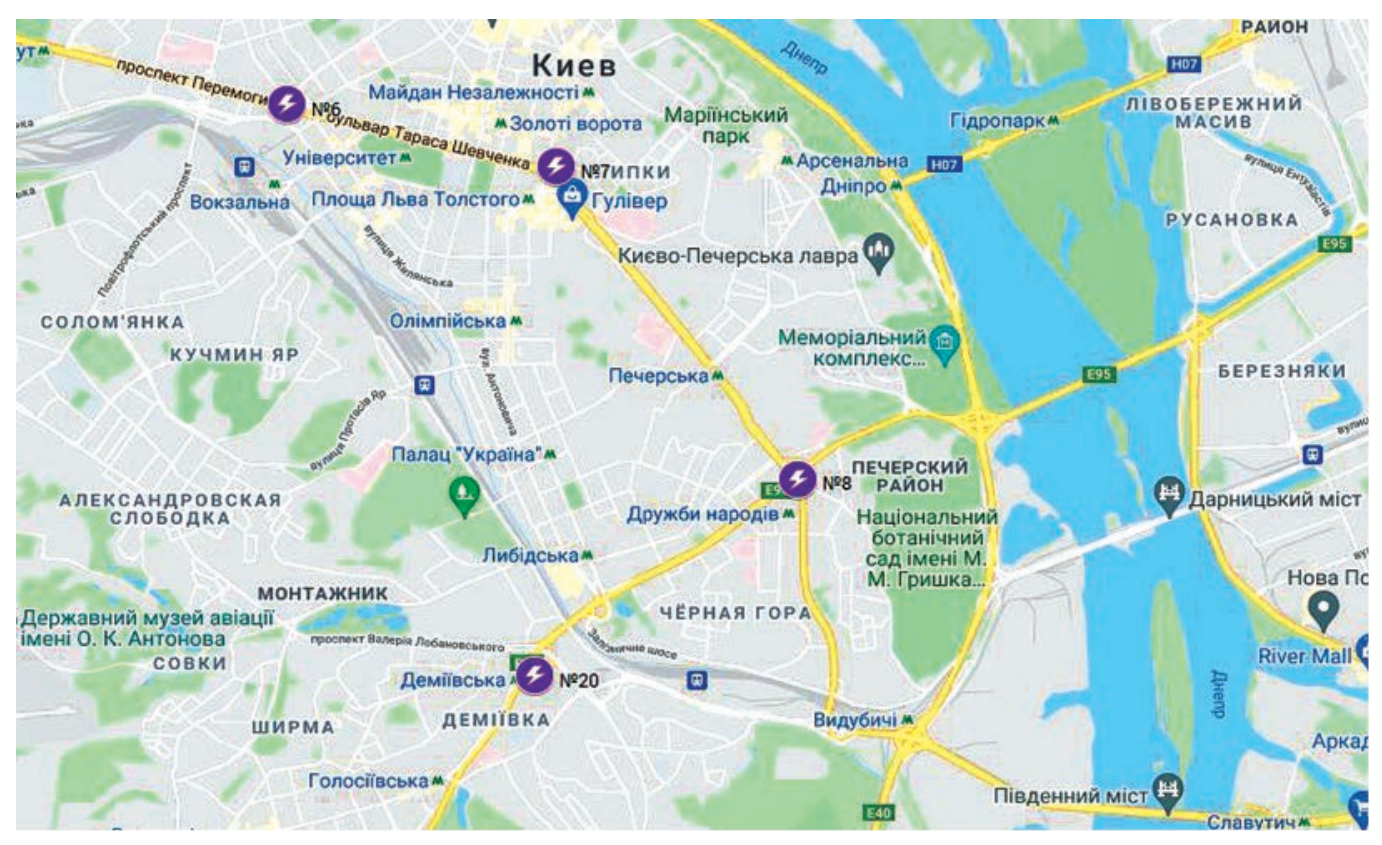

Рис. 1. Розташування постів спостереження ЦГО на карті м. Києва, вибраних для аналізу даних щуодо забруднення атмосферного повітря [14] 


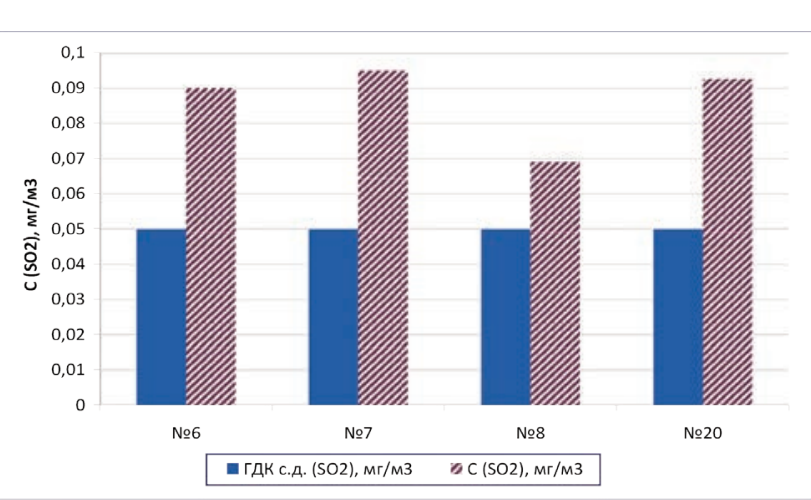

Рис. 2. Рівні забруднення міського атмосферного повітря домішками сульфур (IV) оксиду SO2 на досліджуваних постах спостереження ЦГО, м. Київ

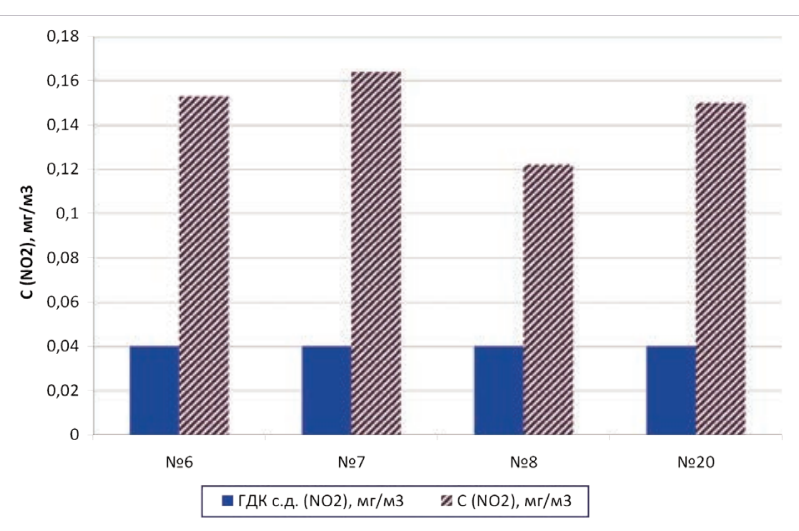

Рис. 3. Рівні забруднення міського атмосферного повітря домішками нітроген(IV) оксиду NO2 на досліджуваних постах спостереження ЦГО, м. Київ

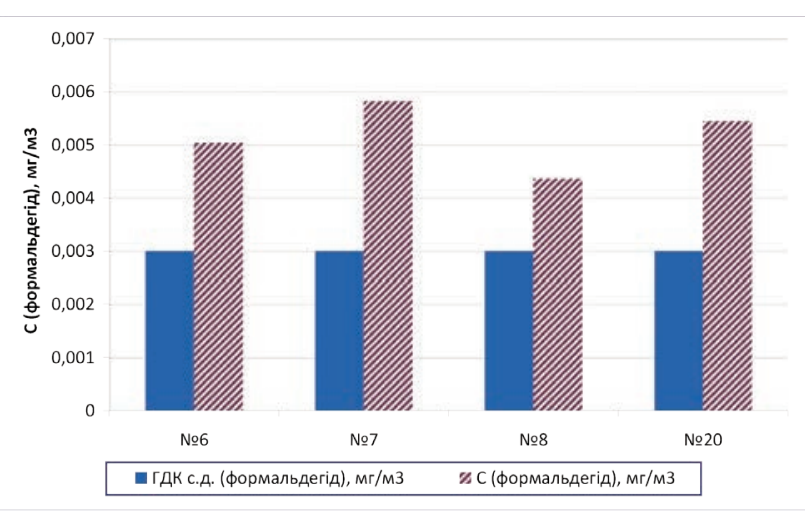

Рис. 4. Рівні забруднення міського атмосферного повітря формальдегідом НС(О)Н на досліджуваних постах спостереження ЦГО, м. Киї

Усі хімічні сполуки тією чи іншою мірою чинять вплив на організм людини. Однак кількісні та якісні характеристики впливу залежать від механізму потрапляння до організму, доз і часу впливу. Аналіз загальної захворюваності серед дітей України показав, що за останні 5 років у структурі загальної захворюваності переважають захворювання органів дихання, хвороби шкіри, нервової системи, органів травлення, виникають злоякісні новоутворення [11; 15]. Тому важливим та актуальним завданням є кількісна оцінка шкідливого впливу, який виникає в разі дії найменшої ефективної дози певного токсиканта (табл. 1).

Таблиця 1

Порівняльна характеристика поширеності захворювань за віковими категоріями дітей та основними класами хвороб, 2020 р. (на 1000 дітей) [15]

\begin{tabular}{|c|c|c|c|}
\hline Вік дитини & $\begin{array}{c}\text { 0-6 } \\
\text { років }\end{array}$ & $\begin{array}{c}7-14 \\
\text { років }\end{array}$ & $\begin{array}{l}15-17 \\
\text { років }\end{array}$ \\
\hline $\begin{array}{c}\text { Інфекційні } \\
\text { та паразитарні хвороби }\end{array}$ & 422,55 & 392,63 & 460,96 \\
\hline Новоутворення & 48,83 & 65,32 & 126,32 \\
\hline $\begin{array}{c}\text { Хвороби крові та } \\
\text { кровотворних органів }\end{array}$ & 218,03 & 102,72 & 164,63 \\
\hline $\begin{array}{l}\text { Хвороби ендокринної } \\
\text { системи }\end{array}$ & 177,34 & 1169,06 & 2485,80 \\
\hline Хвороби нервової системи & 215,27 & 468,64 & 1369,11 \\
\hline Розлади психіки й поведінки & 93,27 & 176,56 & 297,19 \\
\hline $\begin{array}{c}\text { Хвороби ока та його } \\
\text { придаткового апарату }\end{array}$ & 381,29 & 906,10 & 1626,07 \\
\hline $\begin{array}{c}\text { Хвороби вуха та } \\
\text { соскоподібного відростка }\end{array}$ & 285,97 & 294,32 & 423,73 \\
\hline Хвороби системи кровообігу & 54,56 & 212,21 & 609,45 \\
\hline Хвороби органів дихання & 9159,71 & 8674,20 & 10941,08 \\
\hline Хвороби органів травлення & 444,49 & 1181,99 & 2384,65 \\
\hline $\begin{array}{c}\text { Хвороби шкіри й підшкірної } \\
\text { клітковини }\end{array}$ & 582,27 & 516,37 & 955,28 \\
\hline $\begin{array}{c}\text { Хвороби кістково-м’язової } \\
\text { системи та сполучної тканини }\end{array}$ & 208,76 & 1037,34 & 1905,83 \\
\hline Хвороби сечостатевої системи & 186,83 & 285,86 & 1079,24 \\
\hline $\begin{array}{c}\text { Вроджені аномалії } \\
\text { (вади розвитку) }\end{array}$ & 252,07 & 246,71 & 324,74 \\
\hline Травми, отруєння & 352,92 & 654,56 & 951,19 \\
\hline
\end{tabular}

У міжнародній практиці для розрахунку потенційного ризику здоров'ю населення, що пов'язаний iз забрудненням атмосфери, використовують оцінку потенційного ризику за умови хронічного впливу забруднення атмосфери [16].

Імовірність розвитку неспецифічних токсичних ефектів у разі хронічної інтоксикації в заданих умовах визначається за формулою (1):

$$
\text { Risk }=1-\exp \left(\ln (0,84) \times\left(\mathrm{C}(\mathrm{X}) / \Gamma Д \mathrm{~K}_{\mathrm{cд}}(\mathrm{X})\right)^{\mathrm{b}} / \mathrm{K}_{3}\right),
$$

де $\mathrm{C}(\mathrm{X})$ - середньорічна концентрація речовини $\mathrm{X}$, що впливає за проміжок часу;

ГДК ${ }_{\text {с.д. }}(\mathrm{X})$ - гранично допустима концентрація середньодобова;

$\mathrm{K}_{3}$ - коефіцієнт запасу;

b - коефіцієнт, що дає змогу оцінити ізоефективні ефекти домішок різних класів небезпеки [16] (табл. 2).

Оскільки в атмосферному повітрі зазвичай міститься не одна шкідлива домішка, потрібно визначити потенційний ризик комплексного впливу токсикантів на організм людини. Оцінити такий ризик можна за правилом множення ймовірностей із використанням формули (2): 
Чепель А.Є., Кофанова О.В., Свтєєва Л.І.

Таблиця 2

Значення коефіціснтів для речовин за класами небезпеки [16]

\begin{tabular}{|c|c|c|}
\hline $\begin{array}{c}\text { Клас небезпеки } \\
\text { шкдливих речовин }\end{array}$ & $\begin{array}{c}\text { Коефіціснт } \\
\text { запасу } \mathbf{K}_{3}\end{array}$ & Коефіціснт b \\
\hline 1 & 7,5 & 2,35 \\
\hline 2 & 6,0 & 1,28 \\
\hline 3 & 4,5 & 1,0 \\
\hline 4 & 3 & 0,87 \\
\hline
\end{tabular}

Risk $_{\Sigma}=1-\left(1-\right.$ Risk $\left._{1}\right)\left(1-\right.$ Risk $\left._{2}\right)\left(1-\right.$ Risk $\left._{3}\right) \ldots\left(1-\right.$ Risk $\left._{n}\right),(2)$ де $\mathrm{Risk}_{\Sigma}-$ потенційний ризик комплексного впливу шкідливих речовин;

$\mathrm{Risk}_{1}, \mathrm{Risk}_{2}, \ldots$ Risk $_{\mathrm{n}}$ - потенційні ризики впливу кожної окремої домішки.

Для обробки результатів використовуємо рангову шкалу (табл. 3), а також ГДК м. . шкідливих речовин за класами небезпеки (табл. 4). Розраховані дані ризику для здоров'я людей за кожною з речовин та за умов комплексного впливу забруднювачів за вибраними постами спостереження ЦГО наведено в таблиці 5.

Залежність ваги ефектів

Таблиця 3 від величини ризику здоров'ю населення [16]

\begin{tabular}{|c|c|}
\hline Вага ефектів & Risk \\
\hline Рівні мінімального ризику & $<0,1$ \\
\hline Граничні хронічні ефекти & $0,1-0,19$ \\
\hline Важкі хронічні ефекти & $0,2-0,59$ \\
\hline Важкі гострі ефекти & $0,6-0,89$ \\
\hline Смертельні ефекти & $0,9-1,0$ \\
\hline
\end{tabular}

ГДК . . шкідливих речовин за класами небезпеки [17]

\begin{tabular}{|c|c|c|c|}
\hline Речовина & ГДК $_{\text {м. ... }}, \mathbf{м г / \mathbf { M } ^ { 3 }}$ & $\boldsymbol{\Gamma Д К ~}_{\text {с. д.. }}, \mathbf{м г / \mathbf { m } ^ { 3 }}$ & $\begin{array}{c}\text { Клас } \\
\text { небезпеки }\end{array}$ \\
\hline $\begin{array}{c}\text { Сульфур(IV) } \\
\text { оксид } \mathrm{SO}_{2}\end{array}$ & 0,5 & 0,05 & 3 \\
\hline $\begin{array}{c}\text { Нітроген(IV) } \\
\text { оксид } \mathrm{NO}_{2}\end{array}$ & 0,2 & 0,04 & 3 \\
\hline $\begin{array}{c}\text { Формальдегід } \\
\text { НС(О)Н }\end{array}$ & 0,035 & 0,003 & 2 \\
\hline
\end{tabular}

Таблиця 5

Розрахунки ризиків за досліджуваними постами спостереження ЦГО, м. Київ, 2020 р.

\begin{tabular}{|c|c|c|c|c|}
\hline Ризик & ПС № 6 & ПС № 7 & ПС № 8 & ПС № 20 \\
\hline Risk $\left(\mathrm{SO}_{2}\right)$ & 0,068 & 0,071 & 0,052 & 0,070 \\
\hline $\operatorname{Risk}\left(\mathrm{NO}_{2}\right)$ & 0,137 & 0,147 & 0,111 & 0,136 \\
\hline Risk(HC(O)H) & 0,055 & 0,066 & 0,046 & 0,061 \\
\hline Risk $_{\Sigma}$ & 0,240 & 0,259 & 0,196 & 0,246 \\
\hline Вага ефектів & \multicolumn{2}{|c|}{$\begin{array}{c}\text { Важкі хронічні } \\
\text { ефекти }\end{array}$} & $\begin{array}{c}\text { Граничні } \\
\text { хронічні } \\
\text { ефекти }\end{array}$ & $\begin{array}{c}\text { Важкі } \\
\text { хронічні } \\
\text { ефекти }\end{array}$ \\
\hline
\end{tabular}

ОЦІНЮВАННЯ РИЗИКУ ДАЯ ЗДОРОВ'Я ДІТЕЙ...

Отже, на основі проведеного аналізу доходимо висновку, що на 1000 осіб, які постійно перебувають у районах спостереження та вдихають забруднене повітря, 196...259 осіб можуть мати симптоми хронічної інтоксикації, зокрема важкої. Причому найбільші концентрації токсикантів спостерігаються саме на придорожніх територіях, перехрестях тощо, особливо під час утворення заторів, а також у дворах «колодязного» типу, де можливі застійні явища.

Натурні спостереження дворових територій показують, що ці території, як правило, мають невелику площу рекреаційних, «зелених» зон, на них зосереджено багато припаркованих приватних автомобілів, а для благоустрою дворів використано автомобільні шини, диски, вироби з пластмаси тощо. Часто дитячі та/або спортивні майданчики, рекреаційні зони розташовані поблизу стоянок автомобілів. А оскільки покриття більшості дитячих (спортивних) майданчиків грунтове, то на них спостерігається локальне концентрування токсикантів, які разом із пилом створюють ще більшу небезпеку для здоров'я дітей i дорослих. Отже, за нашими спостереженнями, обстежені дворові території м. Києва не відповідають гігієнічним нормам щодо вмісту хімічних речовин у грунті, а також за якістю атмосферного повітря та благоустрою території $[17 ; 18]$.

Головні висновки та перспективи дослідження. Таким чином, для ефективного вирішення проблеми забруднення атмосферного повітря шкідливими домішками, які $\epsilon$ компонентами викидів АТЗ, необхідно застосовувати комбінований підхід, який включає в себе об'ємне планування, екологічні й соціальні аспекти, розрахунок ризиків для здоров'я населення, зокрема дітей, а також встановлення економічних збитків від екологічних ризиків.

Під час планування дворових територій необхідно більше уваги приділяти їх озелененню, адже рослини виконують санітарно-гігієнічну функцію: очищують повітря, здійснюють його іонізацію, захищають від шуму. Потрібно чітко розмежовувати території для дитячого відпочинку, занять спортом, вигулу тварин та не допускати паркування АТЗ поряд iз цими територіями. Звільнення дворових територій від автостоянок, навіть тимчасових, сприятиме значному скороченню викидів шкідливих речовин із відпрацьованими газами автомобілів.

Проведене дослідження в майбутньому може бути використане для прогнозування рівнів забруднення територій міста шкідливими домішками; прогнозування індивідуального ризику для здоров'я дітей i дорослих, які перебувають на територіях ігрових та спортивних майданчиків під впливом забрудненого атмосферного повітря; оцінки ризиків під час планування будівництва автомобільних доріг, селітебних зон, дитячих і спортивних майданчиків, зон рекреації тощо. 


\section{Література}

1. Дослідження забруднення атмосферного повітря відпрацьованими газами автотранспорту в міському середовищі / Г.О. Татарченко, І.В. Кравченко, М.В. Писаренко, С.Л. Поркуян. Вісник Східноукраӥнського національного університету імені Володимира Даля. 2019. № 8. С. 99-104.

2. Славін В.В., Томаш В.В. Зниження шкідливого впливу автомобілів на оточуюче середовище. Вчені записки Таврійського національного університету імені В.І. Вернадського. Серія «Технічні науки». 2018. Т. 29(68). № 6. Ч. 2. С. 162-166.

3. Борисов О.О., Кофанов О.С. Екологічне навантаження з боку автотранспортних потоків на придорожні території рекреаційного призначення. Енергетика: економіка, технологіï, екологія. 2018. № 4. С. 124-133.

4. Борисов О.О., Кофанова О.В. Проблеми вторинної міграції хімічних елементів - інгредієнтів викидів автотранспортних засобів на придорожніх рекреаційних територіях міст. Екологічні науки. 2019. Вип. 1(924). Т. 1. С. 17-21.

5. Рабош І.О., Кофанова О.В. Оцінювання ризиків для здоров'я населення внаслідок забруднення довкілля автотранспортом (на прикладі міста Києва). Енергетика: економіка, технології, екологія. 2018. № 4(54). С. 115-124.

6. Тарасова В.В. Вплив забруднення атмосферного повітря на здоров’я населення. Агросвіт. 2013. № 16. С. 24-28.

7. Степаненко А.В., Омельченко А.А. Забруднення атмосферного повітря та його джерела і наслідки для населення й довкілля. Економіка природокористування: стан, проблеми, перспективи (ЕПК-2016) : збірник наукових праць II Всеукраїнської науково-практичної інтернет-конференції, м. Ірпінь, 29 березня 2016 р. Ірпінь : УДФСУ, 2016. С. $180-196$. URL: http://ir.nusta.edu.ua/jspui/bitstream/doc/354/1/312_IR.pdf.

8. Ігнатенко О.П. Державне регулювання сфери благоустрою населених пунктів : дис. ... докт. наук 3 держ. упр. : 25.00.02. Київ, 2016. $471 \mathrm{c}$.

9. Прибудинкові території: тенденції організації та їх проблеми / Н.І. Білошицька, Г.О. Татарченко, М.В. Білошицький, П.С. Уваров. Вісник Східноукраӥнського начіонального університету імені Володимира Даля. 2019. № 3. С. $39-47$.

10. Загрязнение воздуха и здоровье детей: рекомендуем чистый воздух : резюме. Женева : Всемирная организация здравоохранения, 2018. URL: https://apps.who.int/iris/bitstream/handle/10665/275595/WHO-CED-PHE-18.01-rus.pdf (дата звернення: 08.12.2021).

11. Рекомендации ВО3 по качеству воздуха, касающиеся твердых частиц, озона, двуокиси азота и двуокиси серы. 2006. URL: https://apps.who.int/iris/bitstream/handle/10665/87502/WHO_SDE_PHE_OEH_06.02_rus.pdf?sequence=1\&isAllowed=y (дата звернення: 05.12.2021).

12. Огляд стану забруднення навколишнього природного середовища на території України за даними спостережень гідрометеорологічних організацій у 2020 році / Центральна геофізична обсерваторія імені Бориса Срезневського. Київ, 2021. URL: http://cgo-sreznevskyi.kyiv.ua/data/ukr-zabrud-viz-1/oglyad-stanu-zabrudnennya-2020-sayt.pdf (дата звернення: 07.12.2021).

13. Бензпірен як фактор ризику виникнення онкологічних захворювань / Н.Ю. Шаповаленко, Н.М. Сівкова, І.В. Короткова, Л.В. Степаненко, Т.В. Сахно. Медицина транспорту Украӥни. 2010. № 1. С. $72-76$.

14. Спостереження за забрудненням атмосферного повітря в м. Києві / Центральна геофізична обсерваторія імені Бориса Срезневського. URL: http://cgo-sreznevskyi.kyiv.ua/index.php?fn=lsza\&f=lsza (дата звернення: 01.12.2021).

15. Основні показники здоров'я населення та використання ресурсів охорони здоров’я в Київській області за 2020 рік / КНП КОР «Київський обласний центр громадського здоров’я». Київ, 2021. URL: https://krphc.org.ua/wp-content/uploads/2021/04/ kniga-2020.pdf (дата звернення: 07.12.2021).

16. Караєва Н.А., Варава І.А. Методи і засоби оцінки ризику здоров'ю населення від забруднення атмосферного повітря : практикум. Київ : КПІ ім. Ігоря Сікорського, 2018. 56 с.

17. Про затвердження гігієнічних регламентів допустимого вмісту хімічних і біологічних речовин в атмосферному повітрі населених місць : Наказ Міністерства охорони здоров’я України від 14 січня 2020 р. № 52 / Міністерство охорони здоров’я України. URL: https://zakon.rada.gov.ua/laws/show/z0156-20\#Text (дата звернення: 07.12.2021).

18. Державні санітарні правила охорони атмосферного повітря населених місць (від забруднення хімічними та біологічними речовинами) : Наказ Міністерства охорони здоров’я України від 9 липня 1997 р. № 201 / Міністерство охорони здоров’я України. URL: https://zakon.rada.gov.ua/rada/show/v0201282-97\#Text (дата звернення: 06.12.2021). 


\title{
ЗАГАМЬНІ ПРОБАЕМИ ЕКОАОГIЧНОї БЕЗПЕКИ
}

\author{
УДК 574.3+504.054 \\ DOI https://doi.org/10.32846/2306-9716/2021.eco.6-39.22

\section{МIГРАЦІЯ МАНГАНУ \\ В ГРУНТАХ БІОГЕОЦЕНОЗІВ СТЕПОВОГО ПРИДНІПРОВ'Я (НА ПРИКААДІ ДНІПРОПЕТРОВСЫКОЇ ОБААСТІ)}

\author{
Гунько С.О., Володько Д.А. \\ Дніпровський державний технічний університет \\ вул. Дніпробудівська, 2, 51918, м. Кам’янське, Дніпропетровська область \\ gooonko@gmail.com, dasha79078@gmail.com
}

\begin{abstract}
Результати роботи надали попередню оцінку грунтів за вмістом мангану та дали змогу підійти до складання вичерпної характеристики грунтів Придніпров'я (на прикладі Дніпропетровської області), встановити попередні масштаби забруднення, пізнати шляхи перетворення грунтового покриву області за вмістом Mn, за якими можуть відбуватися їх втрати та виведення з експлуатації; продемонструвати шляхи подальшого дослідження грунтів із метою створення заключної характеристики трофічного ланцюга «Грунт - рослина»; надати прогноз стану марганцю у грунтах Придніпров’я. Вивчення вмісту та динаміки просторового варіювання доступних рухомих форм важких металів у грунтах дає змогу також правильно оцінити забезпеченість ними сільськогосподарських культур, тварин і людини. Результати їх впливу проявляються, вочевидь, не так явно, як інші види деградації грунту або біоти, але важкі метали передаються трофічними ланцюгами з вираженим кумулятивним ефектом, і прояв токсичності може виникати несподівано на їх різних рівнях. Аналіз токсико-екологічних ситуацій, що виникають у районах техногенного впливу, демонструє, що ігнорування елементарних екологічних вимог тягне за собою різкий розлад у функціонуванні природних систем, що призводить до важко виправних, часто незворотних наслідків. Відомо, що грунт має значну ємність поглинання щодо елементів забруднювачів, у грунті відбуваються процеси трансформації різних сполук, у тому числі й екологічно небезпечних, причому можуть відбуватися як перетворення на малотоксичні, інертні або малодоступні рослинам сполуки, так і підвищення відносної токсичності хімічних сполук за рахунок розчинення в кислому середовищі. Дослідження показали, що кількість Мn у природних грунтах, умовно чистих біогеоценозах міститься в таких районах області: 711,34 мг/кг (Нікопольський), 134,85 мг/кг (Синельниківський). Мінімальна кількість мангану (2,21 мг/кг) виявлена в грунтовому горизонті 0-15 см у Верхньодніпровському районі. Найбільша кількість марганцю виявлена в м. Марганець Нікопольського району в грунтовому горизонті $0-15$ см $-145,52$ мг/кг грунту, в грунтовому горизонті 15-50 см - 711,34 мг/кг грунту. Аналогічна картина спостерігається в чорноземі агроценозів, де максимальний вміст Мn приходиться також на верхній грунтовий горизонт. Виключення відзначено у грунтах агроценозу м. Марганець Нікопольського району, де в горизонті 0-15 см міститься 717,97 мг/кг грунту, в горизонті 15-50 см - 731,54 мг/кг грунту; у грунтах Магдалинівського району у горизонті 0-15 см міститься 281,62 мг/кг грунту, в горизонті 15-50 см - 372,25 мг/кг грунту. Ключові слова: вміст мангану, екологічна характеристика, агроценози, коефіцієнт концентрації, закономірності розподілу, техногенне забруднення.
\end{abstract}

Migration of manganese in the soils of biocenosis of steppe Pridnieprovie (on the example of Dnipropetrovsk Oblast). Hunko S., Volodko D.

The results of the work permitted to make a preliminary assessment of manganese content in the soils and start to give a comprehensive description of soils of Pridnieprovie (on the example of Dnipropetrovsk Oblast), ascertain former scales of pollution, discover ways of a regional land cover transformation according to its manganese content, which could cause decrease and removal from an exploitation; demonstrate ways for next studies of soil in order to give the conclusive description of soil-plant food chain; prognosticate state of manganese in soils of Pridnieprovie. The research of active forms of heavy metals content and dynamic of spatial variation in soils allow to correctly assess an ensuring of manganese to agricultural plants, animals and humans. The results of their influences apparently do not demonstrate enough obvious as other types of soil or biota degradation. However, heavy metals move in the food chain with obvious accumulative effect, and toxicity can appear unexpectedly at its different levels. Analysis of toxic-ecological situations, which appear in the areas of a negative technogenic influence, demonstrate: an ignoring of elemental ecological requirements causes a rapid disfunction of biocenosis, which leads to hard remediable and even irrevocable consequences. As is known, soils have a considerable capacity of absorption of contaminating substances. Additionally, processes of different chemical compounds transformation take place in soils, including ecologically dangerous ones: as transformations to low-toxicity, inert and inaccessible compounds for a plant consumption, and increasing relative toxicity of chemical compounds by means of dissolution in acidic fluid. Researches demonstrated, that an amount of manganese in natural soils and conditionally pure biogeocenoses can be found in such districts of Dnipropetrovsk Oblast: 711,34 mg/kg (Nikopolskyi raion), 134,85 mg/kg (Synelnykivskyi raion). A minimal amount of manganese, which is $2,21 \mathrm{mg} / \mathrm{kg}$, was identified in a soil horizon 0-15 sm in Verkhnodniprovskyi raion. The biggest amount of manganese was identified in the city of Marhanets (Nikopolskyi raion) in a soil horizon 0-15 sm - 145,52 $\mathrm{mg} / \mathrm{kg}$, and in another soil horizon 15-50 sm - 711,34 mg/kg. Similar dispersal of manganese can be observed in chernozems of agrocenosises, where the maximal amount of manganese occurred in the high layer of soil horizons. Exceptions were found in the soils of Marhanets' agrocenosises (Nikopolskyi raion), where a horizon 0-15 sm contains $717,97 \mathrm{mg} / \mathrm{kg}$, in a horizon $15-50 \mathrm{sm}-731.54 \mathrm{mg} / \mathrm{kg}$, a horizon $0-15 \mathrm{sm}$ in the soils of Mahdalynivkyi raion contains $281,62 \mathrm{mg} / \mathrm{kg}$, in a horizon 15-50 sm $-372.25 \mathrm{mg} / \mathrm{kg}$. Key words: content of manganese, ecological description, agrocenosis, concentration factor, regularity of dispersal, technogenic pollution. 
Постановка проблеми. У зв'язку із постійним підвищенням надходження важких металів у біосферу та грунт у результаті господарської діяльності людини актуальним є питання охорони навколишнього середовища, в тому числі й грунту. Охорона грунту та навколишнього середовища тісно пов'язана 3 моніторингом. Моніторинг важких металів у грунтах здійснюється як система із трьох взаємодіючих заходів, таких як: спостереження за станом важких металів (надходження, трансформація, виведення), оцінка цього стану та складання прогнозу. Розроблення системи моніторингу викликає необхідність серед численних показників стану важких металів визначити найбільш чутливі, які дають змогу відзначити найбільш слабкі варіації вмісту елементів у грунті, утворені антропогенними факторами.

Одним із найбільш чутливих показників стану важких металів у грунті $є$ рухомі форми металів. Вирішення проблеми пов'язане із проведенням детальних і взаємопов'язаних (у часі та просторі) досліджень про характер варіювання рухомих форм сполук важких металів у грунті. Метою цієї роботи є вивчення вмісту та закономірностей розповсюдження мангану у грунтах біогеоценозів середнього степового Придніпров'я (на прикладі Дніпропетровської області).

Актуальність дослідження. Результати роботи надали попередню оцінку грунтів за вмістом мангану та дали змогу підійти до складання вичерпної характеристики грунтів Придніпров'я (на прикладі Дніпропетровської області), встановити попередні масштаби забруднення, пізнати шляхи перетворення грунтового покриву області за вмістом $\mathrm{Mn}$, за якими можуть відбуватись їх втрати та виведення з експлуатації; продемонструвати шляхи подальшого дослідження грунтів із метою створення заключної характеристики трофічного ланцюга «грунт - рослина»; надати прогноз стану марганцю у грунтах Придніпров'я.

Вивчення вмісту та динаміки просторового варіювання доступних рухомих форм важких металів у грунтах дає змогу також правильно оцінити забезпеченість ними сільськогосподарських культур, тварин і людини [6].

Накопичений досвід [7, 8] свідчить про те, що важкі метали відносяться до найбільш небезпечних для природного середовища хімічних забруднюючих речовин.

Результати їх впливу проявляються, вочевидь, не так явно, як інші види деградації грунту або біоти, але важкі метали передаються трофічними ланцюгами 3 вираженим кумулятивним ефектом, і прояв токсичності може виникати несподівано на їх різних рівнях [13-17].

Аналіз токсико-екологічних ситуацій, що виникають у районах техногенного впливу, демонструє, що ігнорування елементарних екологічних вимог тягне за собою різкий розлад у функціонуванні природних систем, що призводить до важко виправних, часто незворотних наслідків. Відомо, що грунт має значну ємність поглинання щодо елементів забруднювачів, у грунті відбуваються процеси трансформації різних сполук, в тому числі й екологічно небезпечних, причому можуть відбуватися як перетворення в малотоксичні, інертні або малодоступні рослинам сполуки, так і підвищення відносної токсичності хімічних сполук за рахунок розчинення в кислому середовищі $[10,11]$.

Виклад основного матеріалу. У зв'язку з постійним підвищенням надходження важких металів у біосферу та грунт у результаті господарської діяльності людини актуальним є питання охорони навколишнього середовища, в тому числі й грунту [3-5]. Одним із найбільш чутливих показників стану важких металів у грунті є рухомі форми металів, які надходять до трофічних ланцюгів за допомогою рослин. Саме тому вивчення вмісту мангану в грунті та рослинах є актуальним [10, 12].

Манган - елемент 7-ї групи четвертого періоду періодичної системи хімічних елементів Д.І. Менделєєва 3 атомним номером 25 [1]. У ландшафтах відомі двовалентні, тривалентні та чотиривалентні сполуки мангану, які мають різко відмінні властивості. Манган є доволі розповсюдженим елементом. За даними Виноградова та Ферсмана [2], манган займає у таблиці кларків 11-12 місце. Його кларк у літосфері становить 0,09\%.

Відносно багаті за валовим вмістом такі грунтоутворюючі породи, як лесовидні суглинки, глини та леси $\left(6,8 \cdot 10^{-2} \%\right)$ [11].

Манган - елемент інтенсивного біологічного накопичення. До факторів, що впливають на накопичення марганцю у грунті, відносять кліматичні умови, механічний склад грунту, реакцію грунтового розчину, рівень окультуреності та характер рослинності. Не весь манган, що міститься у складі грунту, $\epsilon$ засвоюваним. Залежно від того, чи входить він до складу нерозчинних або розчинних хімічних сполук, чи знаходиться у рухомій формі, марганець по-різному засвоюється рослинами [10].

Рухомі форми мангану складаються з водорозчинних, розчинних у слабких кислотах і легкорозчинних сполук. Вивчення динаміки рухомого та обмінного мангану у грунтах показало [5], що найбільша кількість цих форм спостерігається ранньою весною, коли грунт насичений вологою та в ньому розвиваються анаеробні відновні процеси. За підсихання грунту наприкінці весни відновні сполуки марганцю знову окислюються, розчинність їх знижується. Влітку вміст у грунтах рухомого та обмінного $\mathrm{Mn}$ знову підвищується, що пов'язано з мінералізацією органічних залишків, а також із відновними діями деяких вуглеводів та інших органічних сполук, які виникають у результаті діяльності грунтової мікрофлори на ті зі сполук марганцю, що в інших умовах не відновлюються. 
У роботі досліджувався вміст мангану в умовно чистих степових біогеоценозах i агроценозах Дніпропетровської області. Проби грунту було відібрано на території адміністративних районів області.

Досліджувалися чорнозем південний та чорнозем звичайний. У грунтах визначалися рухомі форми $\mathrm{Mn}$, екстраговані амонійно-ацетатним буфером, $\mathrm{pH}=4,8$. Грунтовий матеріал підготовлено відповідно до методики визначення мікроелементів у грунтах [9]. Результати аналізу наведено в табл. 1.

Відомо [4], що найменша кількість мангану вилучається за допомогою амонійно-ацетатного буферу, $\mathrm{pH}=4,8$. Це саме той манган, який може вивільнити рослина із грунту. Дослідження показали, що кількість Мn у природних грунтах, умовно чистих біогеоценозах міститься в таких районах області: 711,34 мг/кг (Нікопольський), 134,85 мг/кг (Синельниківський). Мінімальна кількість мангану $(2,21$ мг/кг) виявлена у грунтовому горизонті 0-15 см у Верхньодніпровському районі. Найбільша кількість марганцю виявлена в м. Марганець Нікопольського району у грунтовому горизонті 0-15 см - 145,52 мг/кг грунту, у грунтовому горизонті 15-50 см - 711,34 мг/кг грунту.

Аналогічна картина спостерігається в чорноземі агроценозів, де максимальний вміст Mn приходиться також на верхній грунтовий горизонт. Виключення відзначено у грунтах агроценозу м. Марганець Нікопольського району, де в горизонті 0-15 см міститься 717,97 мг/кг грунту, в горизонті 15-50 см - 731,54 мГ/кГ грунту; у грунтах Магдалинівського району у горизонті 0-15 см міститься 281,62 мг/кг грунту, в горизонті 15-50 см - 372,25 мг/кг грунту.

Дослідження вмісту марганцю у грунтах конкретних районів показало нижче наведені результати.

Царичанський район. Вміст мангану в чорноземі звичайному варіює в межах 3,3-3,5 мг/кг грунту. Вміст мангану в чорноземі звичайному агроценозів знаходиться в межах 1,3-4,8 мг/кг грунту. Спостерігається накопичення Mn у верхньому горизонті 0-15 см. Розрахований коефіцієнт співвідношення «грунт - порода» $\mathrm{K}_{\text {Сгп }}$ (табл. 1) для грунтів степу $\left(\mathrm{K}_{\mathrm{Cгп}}=0,9\right)$. Фіксується винесення металу 3 верхніх грунтових горизонтів. У грунтах агроценозу $\left(\mathrm{K}_{\mathrm{Cгп}}=3,7\right)$ відбувається інтенсивне накопичення у верхньому грунтовому горизонті.

Нікопольський район. Вміст мангану в чорноземі південному становить 6,8-12,4 мг/кг грунту. Вміст $\mathrm{Mn}$ в генетичних горизонтах агроценозів варіює в межах 29,3-30,8 мг/кг грунту. К Сгп для грунтів степу $\left(\mathrm{K}_{\mathrm{Cг}}=1,8\right)$, характеризує акумуляцію металу в кореневонасиченому шарі з максимальним вмістом на глибині 0-15 см. Для грунтів агроценозу $\left(\mathrm{K}_{\mathrm{Cгп}}=\right.$ 0,9) спостерігається винесення металу з верхнього грунтового горизонту.

м. Марганецьь Нікопольського району. Вміст Mn в чорноземі звичайному змінюється від 145,0 до 711,3 мг/кг грунту, а в агроценозах коливається в межах 324,0-382,6 мг/кг грунту. Підраховані $\mathrm{K}_{\text {Сгп }}$ для грунтів степу $\left(\mathrm{K}_{\mathrm{Cг \Pi}}=0,2\right)$ та для грунтів агроценозу $\left(\mathrm{K}_{\mathrm{C} п \Pi}=1,2\right)$ вказують на те, що в степу відбува-

Таблиця 1

Міграція мангану (рухома форма*) у грунтах умовно чистих біогеоценозів та агроценозів Дніпропетровської області

\begin{tabular}{|c|c|c|c|c|c|}
\hline Моніторинговий район & $\begin{array}{c}\begin{array}{l}\text { Найменування } \\
\text { грунту }\end{array} \\
\end{array}$ & $\begin{array}{c}\text { Тип } \\
\text { біогеоценозу } \\
\end{array}$ & $\begin{array}{c}\text { Грунтовий } \\
\text { горизонт, см }\end{array}$ & $\begin{array}{c}\text { Концентрація } \\
\text { мангану, мг/кг грунту }\end{array}$ & $\mathbf{K}_{\mathrm{C} \Gamma \Pi}$ \\
\hline \multirow{4}{*}{ Царичанський } & \multirow{4}{*}{$\begin{array}{c}\text { чорнозем } \\
\text { звичайний }\end{array}$} & \multirow{2}{*}{ степ } & $0-15$ & 3,3 & \multirow{2}{*}{0,9} \\
\hline & & & $15-50$ & 3,5 & \\
\hline & & \multirow{2}{*}{ агроценоз } & $0-15$ & 4,8 & \multirow{2}{*}{3,7} \\
\hline & & & $15-50$ & 1,3 & \\
\hline \multirow{4}{*}{ Нікопольський } & \multirow{4}{*}{ чорнозем південний } & \multirow{2}{*}{ степ } & $0-15$ & 12,4 & \multirow{2}{*}{1,8} \\
\hline & & & $15-50$ & 6,8 & \\
\hline & & \multirow{2}{*}{ агроценоз } & $0-15$ & 29,3 & \multirow{2}{*}{0,9} \\
\hline & & & $15-50$ & 30,8 & \\
\hline \multirow{4}{*}{$\begin{array}{l}\text { Нікопольський } \\
\text { м. Марганець }\end{array}$} & \multirow{4}{*}{$\begin{array}{l}\text { чорнозем } \\
\text { звичайний }\end{array}$} & \multirow{2}{*}{ степ } & $0-15$ & 145,5 & \multirow{2}{*}{0,2} \\
\hline & & & $15-50$ & 711,3 & \\
\hline & & \multirow{2}{*}{ агроценоз } & $0-15$ & 382,6 & \multirow{2}{*}{1,2} \\
\hline & & & $15-50$ & 324,0 & \\
\hline \multirow{4}{*}{ Верхньодніпровський } & \multirow{4}{*}{$\begin{array}{c}\text { чорнозем } \\
\text { звичайний }\end{array}$} & \multirow{2}{*}{ степ } & $0-15$ & 2,2 & \multirow{2}{*}{0,3} \\
\hline & & & $15-50$ & 6,7 & \\
\hline & & \multirow{2}{*}{ агроценоз } & $0-15$ & 30,6 & \multirow{2}{*}{0,6} \\
\hline & & & $15-50$ & 54,5 & \\
\hline \multirow{4}{*}{ Кам’янський } & \multirow{4}{*}{$\begin{array}{c}\text { чорнозем } \\
\text { звичайний }\end{array}$} & \multirow{2}{*}{ степ } & $0-15$ & 14,5 & \multirow{2}{*}{2,6} \\
\hline & & & $15-50$ & 5,5 & \\
\hline & & \multirow{2}{*}{ агроценоз } & $0-15$ & 13,9 & \multirow{2}{*}{0,8} \\
\hline & & & $15-50$ & 16,4 & \\
\hline
\end{tabular}

* - екстрагуючий розчин: амонійно-ацетатний буфер, $\mathrm{pH}=4,8$ 
ється винесення, а в агроценозі - акумуляція металу у верхніх грунтових горизонтах 15-50 см.

Верхньодніпровський район. Вміст марганцю в чорноземі звичайному коливається в межах 2,2-6,7 мг/кг грунту. Вміст Mn в генетичних горизонтах агроценозів варіює від 30,6 до 54,5 мг/кг грунту. К Сгп для грунтів степу $\left(\mathrm{K}_{\mathrm{Cг \Pi}}=0,3\right)$, спостерігається винесення металу в грунтовому горизонті 15-50 см у грунтах різнотравно-кострицево-ковилевого степу. У грунтах агроценозу $\left(\mathrm{K}_{\mathrm{Cгп}}=0,6\right)$ так само відбувається винесення мангану $з$ верхнього грунтового горизонту.

Кам'янський район. Вміст марганцю в чорноземі звичайному коливається від 5,5 до 14,5 мг/кг грунту. Вміст Mn в генетичних горизонтах агроценозів

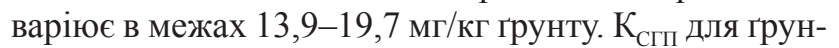
тів степу $\left(\mathrm{K}_{\mathrm{Cгп}}=2,6\right)$, у грунтах степу відбувається значне накопичення металу у верхньому гумусовому горизонті 0-15 см. У грунтах агроценозу $\left(\mathrm{K}_{\mathrm{Cг \Pi}}=0,8\right)$, навпаки, спостерігається винесення мангану з верхніх грунтових горизонтів.

Головні висновки. Визначений вміст мангану у грунтах рухомої форми умовно чистих біогеоценозів і агроценозів 4 адміністративних районів Дніпропетровської області. Вміст Мn у грунтах різнотравно-кострицево-ковилевого степу варіює в межах 2,2-711,3 мг/кг грунту у Верхньодніпровському та Нікопольському (м. Марганець) районах відповідно. Концентрація мангану у грунтах агроценозів варіює в межах 1,3-382,6 мг/кг грунту у Царичанському та Нікопольському (м. Марганець) районах відповідно. Встановлено, що чорнозем звичайний відрізняється більш високим вмістом мангану порівняно з чорноземом південним. Доведене інтенсивне накопичення мангану у верхньому грунтовому горизонті Царичанського $\left(\mathrm{K}_{\mathrm{Cг \Pi}}=3,7\right)$, Нікопольського $\left(\mathrm{K}_{\mathrm{Cг \Pi}}=1,8\right)$ та Кам'янського $\left(\mathrm{K}_{\mathrm{Cг \Pi}}=2,6\right)$ районів.

\section{Література}

1. Беус А.А., Грабовская Л.И., Тишкова Н.В. Геохимия окружающей среды. Москва: Недра, 1976. 248 с.

2. Виноградов А.П. Геохимия редких и рассеянных элементов в почвах. М.: Наука, 1982. 322 с.

3. Гунько С.О. Закономірності розподілу кадмію в едафотопах урбанізованих територій м. Кам’янське. Автореф. дис. канд. біол. наук, Дніпро, 2021. 25c.

4. http://www.dnu.dp.ua/docs/ndc/dissertations/D08.051.04/autoreferat_6046399d5c7c2.pdf

5. Гунько С.О. Закономірності розподілу кадмію в едафотопах урбанізованих територій м. Кам'янське. Дисертація на здобуття наукового ступеня кандидата біологічних наук за спеціальністю 03.00.16 «Екологія». - Дніпровський національний університет імені Олеся Гончара, Дніпро, 2021.

6. http://www.dnu.dp.ua/docs/ndc/dissertations/D08.051.04/dissertation_606016a359ebb.pdf

7. Гунько С.О., Володько Д.А. Дослідження розподілу мангану в грунтах Дніпропетровської області. Perspectives of development of science and practice. Abstracts of XIII International Scientific and Practical Conference. Prague, Czech Republic. 2021. 55-56. DOI: 10.46299/ISG.2021.II.XIII

8. Дмитрук Ю.М. До питання методики геохімічної характеристики грунтового покриву екосистем. Агроекологічний журнал. 2004. № 4. С. 56-63.

9. Дмитрук Ю.М. Еколого-геохімічний аналіз міграції і вмісту важких металів у грунтах елементарних ландшафтів. Ірунтознавство. 2004. № 5(3-4). С. 26-42.

10. Дмитрук Ю.М. Біогеохімічна класифікація біогеоценозів (педоцентричний підхід). Екологія та ноосферологія. 2006. № 17(1-2). C. 86-90.

11. Костишин С.С., Руденко С.С., Морозова Т.В.Основи загальної екології: практичний курс. Чернівці: Книги, 2008.238 с.

12. Цвєткова Н.М., Тагунова Е.О. Геохімічні бар'єри в розподілі мангану в едафотопах Присамар'я Дніпровського. Вісник Дніпропетровського університету. Біологія, екологія. 2015. 23(1). С. 3-9.

13. Чмиленко Ф.А., Смитюк Н.М. О содержании подвижных форм тяжелых металлов в почве г. Днепропетровска. Вісник ДНУ. Біологія. Екологія. 2001. № 9(2). С. 128-131.

14. Gunko S.O., Tsvetkova N.M., Neposhivaylenko N.O. The interpolation of cadmium in soils urbanized territory of steppe Dnieper region using geoinformation modeling methods. Biosystems Diversity. 2018. 26(2). 145-153. doi: 10.15421/011823

15. Huang L., Liua F., Tan W., Hu H., Wang M.K.. Geochemical characteristics of selected elements in ironmanganese cutans and matrices of Alfisols in central China. J. Geochem. Explor. 2009. 103(1). 30-36.

16. Lin C., Wang J., Liu S., He M., Liu X. Geochemical baseline and distribution of cobalt, manganese, and vanadium in the Liao River Watershed sediments of China. Geosciences Journal. 2013. 17(4). 455-464.

17. Mundus S., Lombi E., Holm P.E., Zhang H., Husted S. Assessing the plant availability of manganese in soils using Diffusive Gradients in Thin films (DGT). Geoderma. 2012. 183-184, 92-99.

18. Obrador A., Alvarez J.M., Lopez-Valdivia L.M., Gonzalez D., Novillo J., Rico M.I. Relationships of soil properties with Mn and $\mathrm{Zn}$ distribution in acidic soils and their uptake by a barley crop. Geoderma. 2007. 137. 432-443.

19. Peiyue L., Qian H., Howard K.W.F., Wu J., Lyu X. Anthropogenic pollution and variability of manganese in alluvial sediments of the Yellow River, Ningxia, northwest China. Environ. Monit. Assess. 2014. 186(3). 1385-1398. 


\title{
ВИЗНАЧЕННЯ ФІЗИКО-ХIMIЧНИХ ПАРАМЕТРІВ ВУГІАЬНОГО ВІДВАИУ ДТЕК ШУ "ГЕРОЇВ КОСМОСУ"
}

\author{
Красовський С.А., Ковров О.С., Клімкіна I.I. \\ Національний технічний університет «Дніпровська політехніка» \\ пр. Д. Яворницького, 19, 49005, м. Дніпро \\ kpacka0@gmail.com, kovrov.o.s@nmu.one,klimkina.i.i@nmu.one
}

\begin{abstract}
Вугільна промисловість займає одне із провідних місць в українському енергетичному та економічному секторах, але, незважаючи на цінність цієї галузі, вона здійснює негативний вплив на навколишнє середовище. Разом із вугіллям на земну поверхню також виймаються гірські породи, які складуються на спеціально відведеній території, утворюючи вугільні відвали. Накопичення відвалів гірських порід $є$ великою екологічною проблемою гірничодобувної промисловості. Вугільні відвали негативно впливають на навколишнє середовище, забруднюючи атмосферу, літосферу та гідросферу. На всіх етапах існування породних відвалівіз моменту видачі відвальної маси на поверхню до згасання внутрішніх та зовнішніх фізико-хімічних, мінералоутворюючих, біологічних та інших процесів - відбувається поступове внутрішнє нагрівання породних мас, окислення нестійких сполук, вилуговування активних елементів, кислотне стікання новоутворених розчинів, повітряна та водна ерозія схилів відвалів тощо. Зараз в українській частині Донбасу нараховується 1185 відвалів порід шахт. Відвали та шламонакопичувачі містять близько 1,3 млрд т порід із щорічним поповненням близько 60 млн т. Ці території займають великі площі і потребують рекультивації в майбутньому. 3 кожним роком збільшуються території та об’єми відвалів вуглевидобування. Метою цього дослідження є фізико-хімічний аналіз відвалу вуглевидобування ДТЕК ШУ «Героїв Космосу», а саме визначення рН та електропровідності субстрату, вмісту поживних речовин, концентрації рухомих форм елементів і вмісту потенційно активних важких металів та інших токсичних елементів. У статті приведені результати, отримані методом мас-спектрометрії з індуктивно-зв'язаною плазмою (ІЗП-МС). Отримані результати свідчать про те, що цей субстрат містить низьку концентрацію поживних речовин та має високий вміст потенційно активних важких металів та інших токсичних елементів. ICP-MS аналіз потенційно активних і рухомих форм мікроелементів у пробах, взятих із вугільного відвалу, дав змогу встановити, що концентрація таких елементів, як Co, $\mathrm{As}, \mathrm{Cu}, \mathrm{Pb}, \mathrm{Mn}$ та $\mathrm{Zn}$, перевищує норми ГДК в 59, 38, 47, 11,5, 2,5 та 25 разів відповідно. Ключові слова: вугільний відвал, фізико-хімічні показники, метод мас-спектрометрії з індуктивно-зв'язаною плазмою, важкі метали, ГДК.
\end{abstract}

Determination of physico-chemical characteristics of the coal dump "Heroiv Kosmosy". Krasovskyi S., Kovrov O., Klimkina I.

The coal industry occupies one of the leading positions in the Ukrainian energy and economic sectors, but it has a negative impact on the environment. Along with coal, rocks that are stored in a specially designated area, forming coal dumps, which are removing to the earth's surface. The accumulation of rock dumps is a major environmental problem for the mining industry. Coal dumps have a negative impact on the environment. They are polluting the atmosphere, lithosphere and hydrosphere. At all stages of the existence of coal dumps - from the moment of dumping to the surface to the extinction of internal and external physico-chemical, mineral-forming, biological and other processes - there is a gradual internal heating of waste masses, oxidation of unstable compounds, leaching of active elements, acid drainage, air and water erosion of dump slopes, etc. There are 1185 dumps of rocks of mines in the Ukrainian part of Donbass. Coal dumps contain about 1.3 billion tons of rocks with an annual replenishment of about 60 million tons. These areas occupy large areas and need reclamation in the future. The territory and volumes of coal mining dumps increase every year. The purpose of this study was to perform a physico-chemical analysis of the coal dump "Heroiv Kosmosy", namely to determine the $\mathrm{pH}$ and electrical conductivity of the substrate, nutrient content, concentration of mobile forms of elements and content of potentially active heavy metals and other toxic elements. The paper presents the results obtained by mass spectrometry with inductively coupled plasma (ISP-MS). The obtained results presents that this substrate contains a low concentration of nutrients and a high content of potentially active heavy metals and other toxic elements. ICP-MS analysis of "potentially active" and mobile forms of trace elements in samples revealed that the concentration of elements such as Co; $\mathrm{As} ; \mathrm{Cu} ; \mathrm{Pb} ; \mathrm{Mn}$ and $\mathrm{Zn}$ exceed the TLV (Threshold limit value) by 59; 38; 47; 11.5; 2.5 and 25 times, respectively. Key words: coal dump, physico-chemical analysis, inductively coupled plasma mass-spectrometry (ICP-MS), heavy metals, TLV.

Постановка проблеми. Нині вугільна промисловість відіграє важливу роль в економічному та енергетичному секторах. Світові запаси вугілля перевищують 860 млн т, за оцінками, цього може вистачити на наступні 112 років активного користування [1]. Попри те, що вугілля залишається важливим джерелом енергії та його експлуатація сприяє розвитку низки національних економік, вугільна промисловість залишає по собі негативні зміни навколишнього середовища [2]. Ці зміни стосуються всіх сфер планети. Під час утворення вугільних відвалів під головну лінію впливу потрапляє літосфера. Для побудови вугільних відвалів необхідні великі території, під час створення яких паралельно забруднюється атмосфера і гідросфера. Дані свідчать, що на територіях вугільних відвалів також зменшується біологічна активність [3]. Видобуток корисних копалин - це тимчасове користування земельними ресурсами, тому дуже важливо досягти екологічної стійкості в гірничому процесі. У цьому разі виникає потреба у розробленні рекультивації земель - стратегії, яка спрямована на уникнення або зменшення впливу гірничої промисловості на навколишнє середовище. 
Актуальність дослідження. Вугільна промисловість займає провідне місце в українському економічному та енергетичному секторах. За 2020 рік українські шахтарі дістали на поверхню близько 18,9 млн т вугілля. Це супроводжується приблизним утворенням 60 млн т гірських порід, які складуються на спеціальних територіях, утворюючи відвали [4]. Ці відвали вуглевидобування мають високу концентрацію важких металів та потенційно токсичних мікроелементів. Ці території мають низький pH, низькі органічні показники та дефіцит рослинного покриву. Одним із методів вирішення цієї проблеми є рекультивація відвалів вуглевидобування, тобто повне або часткове відновлення земель. Таким чином, визначення фізико-хімічних параметрів породної маси відвалів вуглевидобування є ключовим етапом в оцінці перспектив їх рекультивації.

Зв'язок авторського доробку із важливими науковими та практичними завданнями. Авторами досліджено фізико-хімічні характеристики відвалу вуглевидобування ДТЕК ШУ «Героїв Космосу». Результати досліджень дають змогу розробити дієві заходи з рекультивації відвалів вуглевидобування через покращення фізико-хімічних показників породної маси.

Аналіз останніх досліджень та публікацій. Одним із наслідків підземного видобутку вугілля є утворення вугільних відвалів. Негативні наслідки включають проблеми стійкості схилів, ерозію, порушення землі та ландшафту, забруднення поверхневих вод, зміну $\mathrm{pH}$ та забруднення повітря через пил та спалювання вугільних частинок, що залишаються у гірській породі, що може призвести до зміни екосистеми та неможливості використання землі після шахт [5]. Відвали часто містять велику кількість лужних речовин, металів, лужноземельних металів, сульфідів та інших компонентів, що призводять до забруднення прилеглих територій та підземних вод неорганічними солями [6]. Низький або високий $\mathrm{pH}$ субстрату перешкоджає розвитку рослинності. Крім того, дренаж із цих грунтів може бути збагачений $\mathrm{Fe}, \mathrm{Al}, \mathrm{Mn}$, мікроелементами ( $\mathrm{Pb}, \mathrm{Cu}, \mathrm{Ni}, \mathrm{U}, \mathrm{As}, \mathrm{Zn})$ і сульфатом, що негативно впливає на навколишнє середовище [7]. Поживні речовини 3 вугільних відвалів вилуговуються через прискорені темпи ерозії, тому продуктивний профіль грунту повністю зруйнований, тому відвали не мають підтримуючих та продуктивних властивостей для закріплення рослин [8]. Таким чином, після детального вивчення фізико-хімічних характеристик вугільного відвалу вуглевидобування буде можливість підібрати найоптимальніший метод рекультивації.

Виділення не вирішених раніше частин загальної проблеми, котрим присвячусться означена стаття. Виконаний аналіз фізико-хімічних характеристик відвалу вуглевидобування ДТЕК ШУ «Героїв Космосу», на основі якого можна у подальшому підібрати методи для рекультивації цієї території.

Новизна. Під час експерименту встановлено фізико-хімічні показники відвалу вуглевидобування ДТЕК ШУ «Героїв Космосу», визначено концентрації потенційно активних важких металів та порівняно з нормами гранично-допустимих концентрацій, визначено фізико-хімічні властивості породної маси, на основі яких можна обгрунтувати метод рекультивації для покращення загальної екологічної ситуації на території шахти.

Методологічне або загальнонаукове значення. Полягає у комплексному аналізі таких фізико-хімічних показників грунту, як: $\mathrm{pH}$, питома електропровідність грунту (ЕС), вміст потенційно активних важких металів, інших токсичних елементів та рідких металів. Для інтактної проби грунту визначено додатково кількісний вміст поживних речовин для рослин, а саме іонів $\mathrm{NO}_{3}^{-}, \mathrm{NH}_{4}^{+}, \mathrm{PO}_{4}{ }^{3-}$, методом спектрофотометрії i концентрації рухомих форм елементів, отриманих шляхом водної витяжки та екстракції амонійно-ацетатним буфером $(\mathrm{pH}=7)$ і амонійно-ацетатним розчином із додаванням лимонної кислоти $(\mathrm{pH}=5)$.

Викладення основного матеріалу. У роботі досліджували фізико-хімічні параметри відвалу вуглевидобування шахти «Героїв Космосу». Субстратом слугувала порода 3 відвалу шахти. Проведено комплексний аналіз фізико-хімічних показників, таких як: $\mathrm{pH}$, питома електропровідність грунту (EC), кількісний вміст органічної речовини та іонів $\mathrm{NO}_{3}^{-}, \mathrm{NH}_{4}^{+}, \mathrm{PO}_{4}{ }^{3-}$, а також вміст потенційно активних важких металів та інших токсичних елементів. Зразки з відвалу були доведені до повітряно-сухого стану, після чого зробили грунтово-водні витяжки у співвідношенні 1:10. pH водної витяжки визначали за ГОСТ 17.5.4.01-84, питому електропровідність - за ДСТУ ISO 11265:2001. Для визначення вмісту органічних речовин у грунті використовували метод сухого спалювання за ДСТУ Б В.2.1-16:2009.

Визначили концентрації водорозчинних форм хімічних елементів рухомих форм (співвідношення «грунт - амонійно-ацетатний буфер» (рН7), амонійно-ацетатний розчин + аскорбінова кислота (pH5) у співвідношенні 1:50.

Наступним визначали кількісний вміст іонів $\mathrm{NO}^{3-}, \mathrm{NH}_{4}^{+}, \mathrm{PO}_{4}{ }^{3-}$ фотометричним методом відповідно до німецьких стандартів «DIN-Norm». Вміст $\mathrm{NO}_{3}^{-}$визначали відповідно до методики DIN 38405-9. Нітрати через додавання розчину концентрованих сірчаної та фосфорної кислот реагують із 2,6-диметилфенолом 3 утворенням 4-нітро-2,6-диметилфенолу. Останній надає розчину оранжевого забарвлення, оптичну щільність якого вимірюють при довжині хвилі 338 нм.

Концентрацію іонів $\mathrm{NH}_{4}^{+}$визначали за індофеноловим методом згідно 3 DIN 38406-5. В основі 
методу лежить реакція аміаку з фенолом у присутності окислювача гіпохлориту натрію. Продуктом реакції $\epsilon$ індофенол, який у лужному середовищі забарвлює розчини у синій колір. Оптичну щільність розчинів вимірюють при довжині хвилі 625 нм.

Вміст іонів $\mathrm{PO}_{4}^{3-}$ визначали за DIN EN ISO 6878. В основі цього методу лежить здатність фосфат-іонів утворювати 3 молібдатом амонію фосфорномолібденову гетерополікислоту (ФМГПК) - стійку у кислому середовищі і забарвлену у жовтий колір сполуку. Інтенсивність забарвлення жовтої ФМГПК слабка, тому для визначення фосфору використовували іiі відновлену форму, інтенсивно забарвлену у синій колір. Оптичну щільність розчинів вимірювали при довжині хвиль 880 нм. Під час додавання відновника, Mo(VI), що входить до складу ФМГПК, переходить до $\mathrm{Mo}(\mathrm{V})$ з утворенням «фосфор-молібденової сині». Вільні Mo(VI) і Мо(V), що не входять до складу ФМГПК, також утворюють забарвлені у синій колір з'єднання. Щоб уникнути відновлення Мо(VI), що входить до складу молібденово-кислого амонію, процедуру відновлення ФМГПК проводили у м'яких умовах. Як відновник використовували аскорбінову кислоту у присутності антімонілтартрату калію $\mathrm{K}(\mathrm{SbO}) \mathrm{C}_{4} \mathrm{H}_{4} \mathrm{O}_{6}$, який прискорює утворення відновленої форми ФМГПК і сприяє іiі стійкості. Утворення пофарбованого у синій колір комплексу відбувається у слабокислому середовищі. Головним компонентом, що заважає під час фотометричного визначення фосфору, є $\mathrm{Fe}(\mathrm{III})$, для усунення впливу якого здійснювали його відновлення до $\mathrm{Fe}(\mathrm{II})$. Вміст потенційно активних форм мікроелементів визначали на підставі методу мас-спектрометрії 3 індуктивно-зв'язаною плазмою (ICP-MS). Аналіз фізико-хімічних властивостей субстрату наведено в таблиці 1.

Таблиця 1

Фізико-хімічні показники субстрату

\begin{tabular}{|c|c|c|c|c|}
\hline \multirow{2}{*}{$\mathbf{p H}$} & \multirow{2}{*}{ EП мS/см } & \multicolumn{3}{|c|}{ Поживні речовини } \\
\cline { 3 - 5 } & & $\begin{array}{c}\mathbf{N O}^{-} \\
\mathbf{M}\end{array}$ & $\begin{array}{c}\mathbf{N H}^{+} \\
\mathbf{M}\end{array}$ & $\begin{array}{c}\mathbf{P O}^{3-}{ }_{4} \\
\mathbf{M \Gamma}\end{array}$ \\
\hline 7,68 & 1200 & 0,007 & 0,11 & 0,016 \\
\hline
\end{tabular}

Таблиця 2

Концентрація потенційно активних та рухомих форм важких металів та інших токсичних елементів у субстраті

\begin{tabular}{|c|c|c|c|c|c|c|}
\hline Назва & $\mathrm{Co}$ & $\mathrm{As}$ & $\mathrm{Cu}$ & $\mathrm{Pb}$ & $\mathrm{Mn}$ & $\mathrm{Zn}$ \\
\hline С мг/кг & 296,8 & 76,6 & 140,9 & 122,5 & 3740 & 572,3 \\
\hline
\end{tabular}

Головні висновки: У статті наведено результати фізико-хімічного аналізу субстрату з відвалу вуглевидобування ДТЕК ШУ «Героїв Космосу», які свідчать про низький вміст поживних речовин та високу концентрацію потенційно активних важких металів та інших токсичних речовин, що спонукає підібрати у майбутньому найоптимальніші методи рекультивації території.

Перспективи використання результатів дослідження. Отримані результати дають змогу підібрати у майбутньому найоптимальніші варіанти технічного та біологічного етапу рекультивації вугільного відвалу, що дає можливість повернення промислової території до сільськогосподарського користування.

\section{Подяка/Acknowledge}

Автор висловлює щиру вдячність проф., д-ру Герману Хайльмайєру за надання можливості проведення досліджень на базі лабораторії Інституту біології Технічного Університету «Фрайберзька гірнича академія» (м. Фрайберг, Німеччина).

The authors express special thanks to Prof. Dr. Hermann Heilmeier for the support and possibility to use the technical equipment of the Institute of Bioscience, TU Bergakademie Freiberg.

Представлені дослідження виконано в рамках проєкту DAAD «EcoMining: розроблення інтегрованої програми аспірантів для сталої гірничодобувної та екологічної діяльності» та співпраці між Технічним університетом «Фрайберзька Гірнича Академія», Фрайберг, Німеччина, та Національним технічним університетом «Дніпровська політехніка», Дніпро, Україна (2019-2022).
Показано, що рН грунту з ділянки рекультивації становить 7,68, значення питомої електропровідності $1200 \mu \mathrm{S} /$ см. Результати спектрофотометричного аналізу забезпеченості субстрату елементами живлення рослин свідчать про недостатню кількість нітратної (від 0,007 мг/кг)

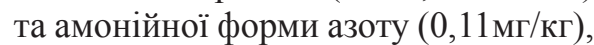
а також фосфатів $(0,016$ мг/кг). У таблиці 2 показана концентрація потенційно активних та рухомих форм важких металів та інших токсичних елементів.

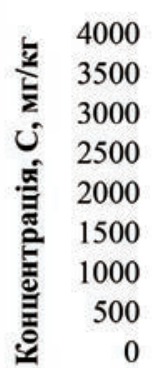

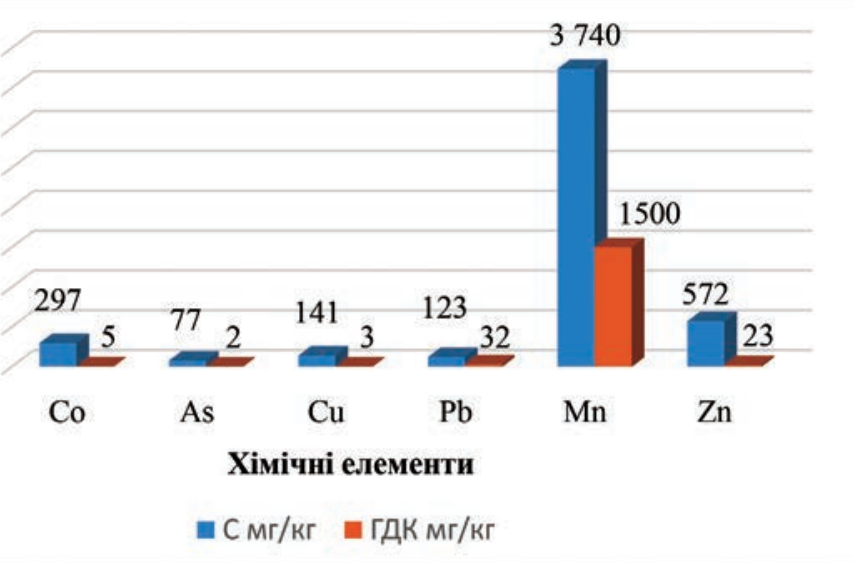

Рис. 1. Концентрація важких металів та інших токсичних елементів порівняно з ГДК 
Presented research was supported in the frame Activities" and cooperation between Technische Universität of theDAAD project"EcoMining:DevelopmentofIntegrated Bergakademie Freiberg, Germany, and Dnipro University PhD Program for Sustainable Mining \& Environmental of Technology, Dnipro, Ukraine (2019-2022).

\section{Література}

1. BP Global Group (2012) BP statistical review of world energy 2012, 48 p. http://www.bp.com/assets/bp_internet/globalbp/ globalbp_uk_english/reports_and_publications/statistical_energy_review_2011/STAGING/local_assets/pdf/statistical_review_ of_world_energy_full_report_2012.pdf

2. Zhengfu B, Hilary I, John D, Frank O, Sue S (2010) Environmental issues from coal mining and their solutions. Min Sci Technol 20:0215-0223

3. Sun H, Li M, Li D (2011) The vegetation classification in coal mine overburden dump using canopy spectral reflectance. Comput Electron Agric 75:176-180

4. Видобуток і збагачення вугілля URL : https: // energo.dtek.com/ business / coal industry/

5. Zhengfu B, Hilary I, John D, Frank O, Sue S (2010) Environmental issues from coal mining and their solutions. Min Sci Technol 20:0215-0223

6. Zhengquan Jiang, Lei Li. Environmental Problems and Resources Utilization on Coal Slag[J]. Research of Environmental Sciences, 1998,11(3):57-59.(in Chinese)

7. Zhou, C., Liu, G., Yan, Z., Fang, T., and Wang, R.: Transformation behavior of mineral composition and trace elements during coal gangue combustion, Fuel, 2012 p. № 97, 644-650.

8. Chaulya, S.K., Singh, R.S., Chakraborty, M.K., Srivastava, B.K., 2000. Quantification of stability improvement of a dump through biological reclamation. Geotechnical and Geological Engineering 18, 193-207. 


\title{
МІСЫКЕ САДІВНИЦТВО В УМОВАХ АЬВІВСЫКОЇ УРБОЕКОСКСТЕМИ: МОЖАИВОСТІ ТА ПЕРЕВАГИ
}

\author{
Луцишин О.3., Гілета Л.А. \\ Відокремлений структурний підрозділ «Педагогічний фаховий коледж \\ Львівського національного університету імені Івана Франка» \\ вул. Ген. Тарнавського, 107, 79016, м. Львів \\ olena.lutsyshyn@Inu.edu.ua, ljuba.gileta@gmail.com
}

Розглянуто зелену зону Львівської урбоекосистеми - найбільшого міста Західної України, яка представлена системою територій із зеленими насадженнями на незабудованих відкритих просторах у межах міста або приміської зони, що мають екологічне, економіко-господарське, рекреаційне та естетичне значення і можуть використовуватися для розвитку міського садівництва.

Описане у світовій практиці міське садівництво є популярною діяльністю серед жителів економічно розвинених держав, де функціонально використовують зелений простір. Він має потенціал надавати основні екосистемні послуги, підтримуючи при цьому добробут містян, i сприяє розвитку біорізноманіття у межах великих міст.

Враховуючи численні переваги міського садівництва, необхідною умовою його розвитку в містах України $є$ розташування садів і городів у зручній для відвідування мешканців, бажано центральній частині. Потенціал для розвитку міського садівництва у межах Львівської урбоекосистеми є достатньо потужним. Зокрема, в парку Залізна Вода, що розташований у центральній частині міста, біля руїн теплиць Рерінга, на місці колишнього розсадника, об'єднання громадських організацій «Плато», «Екотерра», «Пермакультура в Україні» прагнуть створити розвинутий публічний простір.

Досліджено, що розвиток міського садівництва в межах парку Залізна Вода поблизу теплиць Рерінга можливий також завдяки грунтовим ресурсам. Для їх оцінки вибрано три дослідні ділянки, в межах яких із верхньої частини гумусового горизонту (з глибини 10-20 см) відібрано проби грунту для лабораторно-аналітичних досліджень.

Описано результати досліджень, що свідчать про високий потенціал розвитку міського садівництва в межах Львівської урбоекосистеми на ділянці поряд із теплицями Рерінга та екологічні переваги такого рішення. Ключові слова: міське садівництво, зелена зона, Львівська урбоекосистема, теплиці Рерінга.

City gardening in the conditions of Lviv urban ecosystem: opportunities and benefits. Lutsyshyn O., Hileta L.

The green zone of Lviv (the largest city of Western Ukraine) urban ecosystem is considered. It includes a system of green areas in undeveloped open spaces within the city or suburban area, which have ecological, economic, recreational, and aesthetic value and can be used for urban horticulture.

Urban gardening is described. This is a popular activity among the inhabitants of economically developed countries, where green space is functionally used. It has the potential to provide basic ecosystem services while maintaining the well-being of citizens and contributing to the development of biodiversity within large cities.

Due to the advantages of urban, the location of gardens and orchards is a necessary condition for its development in the cities of Ukraine. They should be located in a convenient place for residents to visit, preferably in the central part. Lviv urban ecosystem has the potential for the development of urban horticulture. For example, the developed public space is planned to be created on the site of the former nursery of public organizations "Plateau", "Ecoterra", "Permaculture in Ukraine", which is located in Zalizni Vody Park, the central part of the city.

The development of urban gardening within Zalizni Vody Park (near the Rering greenhouses) is also possible due to soil resources. Three research sites were selected for soil assessment. Samples from the upper part of the humus horizon (from a depth of 10-20 cm) were taken for laboratory and analytical research.

The results of research and environmental benefits of the solution are described. According to the research, the development of urban gardening within the Lviv urban ecosystem on the site near the Rering greenhouses has a high potential. Key words: city gardening, green zone, Lviv urban ecosystem, Rering greenhouses.

Постановка проблеми. Міське садівництво - глобальний тренд урбанізованих екосистем, що з кожним роком охоплює все більшу територію та кількість прихильників. Враховуючи масштаби забудови, цей напрям набуває стрімкого розвитку на території Львівської урбоекосистеми. Відповідно, постає питання науково-обгрунтованого аналізу можливостей і переваг міського садівництва в межах Львова.

Актуальність досліджень. Дедалі частіше людина, перебуваючи в суєті міста, активних робочих буднів, постійного психологічного навантаження, відчуває потребу втечі від хаосу та шукає затишку в поєднанні із природою. Особливо цю необхідність мають люди, робота яких пов'язана 3 активним розумовим навантаженням. Саме вони хочуть на деякий час замінити працю інтелектуальну на фізичну або просто відпочити на природі, милуючись іiї красою та затишком. Але не кожен має можливість виїжджати за межі міста. Частковим вирішенням такої потреби $є$ новий тренд у сільському господарстві - сіті-фермерство. Городи на терасах чи стінах (вертикальні сіті-ферми) - близьке майбутнє великих міст України. Окрім того, що людина відволікається від буденних справ, вона має змогу власноруч виростити екологічно чисту продукцію. А для тих людей, які потребують більше простору, 
вирішенням питання можуть стати виокремленні території під садівництво у парках.

Аналіз останніх досліджень і публікацій. Дослідженням міського садівництва в межах урбанізованих екосистем впродовж тривалого часу займаються європейські вчені $[3 ; 4 ; 5 ; 7]$. Проте такі дослідження мало описані у вітчизняних наукових доробках, особливо з погляду природничих наук. Варто відзначити працю [1], у якій висвітлюються питання концепції «місто-сад» у сучасному баченні взаємозв’ язку між урбанізацією, зміною міської екології та громадським здоров'ям. Тому дослідження міського садівництва має значний потенціал.

Викладення основного матеріалу. Місто Львів найбільше місто Західної України, адміністративний центр Львівської області, національно-культурний та освітньо-науковий осередок країни, великий промисловий центр і транспортний вузол. За кількістю населення Львів займає сьоме місце в країні (станом на 1 липня 2021 року населення Львова становило 717486 жителів).

У межах Львівської урбоекосистеми виділяється зелена зона, тобто система територій із зеленими насадженнями на незабудованих відкритих простоpax у межах міста або приміської зони, що мають екологічне, економіко-господарське, рекреаційне та естетичне значення і можуть використовуватися також для розвитку міського садівництва.

Основою зеленої зони є деревні насадження стабілізатори життєвого середовища, які збагачують атмосферне повітря киснем, поглинають вуглекислий газ, виділяють леткі речовини - фітонциди, активно впливають на формування мікроклімату (збільшують вологість повітря, захищають від вітру і сонячної радіації). Дерева, кущі та квіткові рослини займають важливе місце в архітектурно-художній виразності міста і є невіддільним (невід'ємним) компонентом сучасного містобудування. Вдале поєднання різних рослин дає змогу значно зменшити шкідливі санітарні фактори урбанізації.

Зелену зону міста формують лісопаркові та паркові масиви, природоохоронні території, сільськогосподарські угіддя та зелені елементи міст. Вони створюють найбільш цілісний гігієнічний і комфортабельний простір для життя і діяльності людини.

Лісопарк або буферний парк - лісовий масив 3 елементами паркового благоустрою для масового відпочинку населення. Основними лісопарковими масивами Львівської урбоекосистеми є «Погулянка», «Зубра», «Білогорща», Винниківський, Замарстинівський і лісопарк «Кортумова Гора», який охоплює схили однойменної гори, є геологічною пам'яткою природи місцевого значення.

Лісопарки Львова розміщені переважно на околицях міста або у його старих районах. Вони характеризуються значними площами та переважанням у їх межах природних насаджень, переважно дуба, сосни, бука та інших дерев.
Парк - самостійний архітектурно-організаційний комплекс площею понад 2 га, який виконує санітарно-гігієнічні функції та призначений для короткочасного відпочинку населення. Паркові масиви Львова розташовані переважно у нових районах міста, мають невеликі площі та були закладені в середині минулого століття. У парках Львівської урбоекосистеми переважають клени, каштани, тополі, дуби, липи, в'язи, осокори. Також є екзотичні породи: дуб червоний, тюльпанове дерево, гінкго, магнолія, тис ягідний та інші.

У межах Львова $є$ сім паркових масивів: «Боднарівка», «Горіховий гай», «Левандівський», «Піщані озера», «Скнилівський», «Святоюрський» та парк імені Папи Римського Іоанна Павла II.

До зелених елементів міста Львова відносяться численні сквери. Загалом сквер - це озеленена ділянка громадського користування для відпочинку на території населеного пункту, яка відіграє і декоративну роль. У кожному з районів міста $є$ різна кількість скверів, так, у Галицькому районі - 36 скверів; в Залізничному 5 скверів; до Личаківського адміністративного району міста належать 14 скверів; у Сихівському районі міста розташовано 3 сквери; у Франківському районі міста розташовано 5 скверів; до Шевченківського району міста Львова належать 8 скверів.

На території Львівської урбоекосистеми функціонує понад тридцять об'єктів природо-заповідного фонду: ботанічні та геологічні пам'ятки природи, ботанічні сади, парки-пам'ятки садово-паркового мистецтва та регіональний ландшафтний парк. Із них три об'єкти природно-заповідного фонду загальнодержавного значення - ботанічний сад Львівського національного лісотехнічного університету, ботанічний сад Львівського національного університету імені Івана Франка, пам'ятка садово-паркового мистецтва «Стрийський парк». Шість об’єктів природно-заповідного фонду мають місцеве значення. У їх складі:

1) регіональний ландшафтний парк «Знесіння»;

2) старий ботанічний сад Львівського національного університету імені Івана Франка;

3) ботанічний сад Львівського національного медичного університету імені Данила Галицького;

4) два парки-пам'ятки садово-паркового мистецтва: імені Івана Франка та Снопківський;

5) дендропарк імені Бенедикта Дибовського.

Сади і парки Львова створювалися впродовж кількох століть. Найвдаліший період у їх формуванні XIX століття. Причиною збереження куточків природи $\epsilon$ складний рельєф місцевості та менталітет львів'ян. Сучасну систему озеленення міста можна назвати кільцево-радіальною. Зелені клини, сформовані з паркових насаджень, утворюють екологічні коридори. Кожна із зелених зон міста, залежно від типу зеленої зони та іï розмірів, виконує різні функції [1].

До різноманіття цих функцій впродовж останнього часу органічно додається міське садівництво.

Міське садівництво є популярною діяльністю серед жителів розвинених держав, де функціонально 


\section{Луцишин О.3., Гілета Л.А.}

використовують зелений простір. Він має потенціал надавати основні екосистемні послуги, підтримуючи при цьому добробут містян, і сприяє розвитку біорізноманіття у межах великих міст.

Важливо зазначити, що міське садівництво інтенсивно розвивається впродовж останніх десятиліть, допомагаючи людям повернути природу до міст, зробивши життя більш здоровим і стійким. Завдяки міському садівництву нові покоління садівників перетворюють міський ландшафт у стійке середовище.

Міське садівництво $є$ частиною міського сільського господарства, має соціальні, економічні та екологічні переваги для міст. Екологічно стійка урбанізація також немислима без міського та приміського сільського господарства [5].

Міське садівництво - це слаборозвинений напрям, який здатний генерувати економію енергії, допомагати пом'якшити міський клімат і зменшити кількість водного стоку, а також забезпечувати жителів органічними продуктами [3]. Міське садівництво допомагає людству зрозуміти себе як частину планетарної екологічної системи [4].

Безсумнівно, міське садівництво сприяє оздоровленню навколишнього середовища, стимулює суспільне життя і сприяє сталому розвитку. Воно має кілька корисних аспектів: фізичний і матеріальний, емоційний і соціальний, розумовий і освітній, встановлення з'єднання із природою і розширення обізнаності про сталий розвиток.

Щоб зробити перший крок у цьому напрямі, необхідно правильно вибрати ділянку, врахувати кліматичні особливості та рельєф місцевості, дослідити грунтовий покрив. Не менш вагомим $є$ правильний підбір вирощуваних культур і якості садивного матеріалу (насіння, розсади, саджанців). Важливо вивчити історію вибраного місця. Кращим варіантом буде територія, не порушена антропогенним пресингом, яка не забудувалася, не забруднена, iз повнопрофільними грунтами.

Під час закладання саду необхідно правильно облаштувати межі, які доповнюватимуть його. Це можуть бути штучні огорожі, але значно ефективніше й гармонійніше виглядатимуть природні бар'єри із самшиту, плюща, барбарису, бузку, жасмину тощо. Живопліт можна застосувати і для поділу території на функціональні зони.

Облаштовуючи сад для відпочинку, слід звернути увагу

\section{МІСЬКЕ САДІВНИЦТВО..}

на естетичний фактор, гармонійність у поєднанні кольорів, відтінків, світла, тіней.

Перед закладанням саду чи городу необхідно оцінити рельєф території, глибину залягання грунтових вод, провести аналіз грунту (встановити гранулометричний склад, визначити величину $\mathrm{pH}$, вміст гумусу, мікроелементів тощо).

Зважаючи на численні переваги міського садівництва, необхідною умовою його розвитку в містах України є розташування міських садів і городів у зручній для відвідування мешканців, бажано центральній частині. Така територіальна можливість для розвитку міського садівництва $є$ у межах Львівської урбоекосистеми. У парку Залізна вода, що розташований у центральній частині міста (рис. 1), біля руїн теплиць на місці колишнього міського розсадника, об'єднання громадських організацій «Плато», «Екотерра», «Пермакультура в Україні» прагнуть створити розвинутий публічний простір.

Вибір цієї ділянки зумовлений насамперед вдалим територіальним розташуванням, це місце до початку розвитку міського садівництва у Львові було у доволі занедбаному стані. Ця локація пов'язана із діяльністю відомого львівського садівника Арнольда Рерінга (1840-1913 рр.), поруч із нею він жив та працював над облаштування парку Залізна Вода.

Розвиток міського садівництва в межах парку Залізна Вода поблизу теплиць Рерінга можливий і завдяки грунтовим ресурсам. Для їх оцінки вибрано три дослідні ділянки, в межах яких із верхньої частини гумусового горизонту (з глибини 10-20 см)

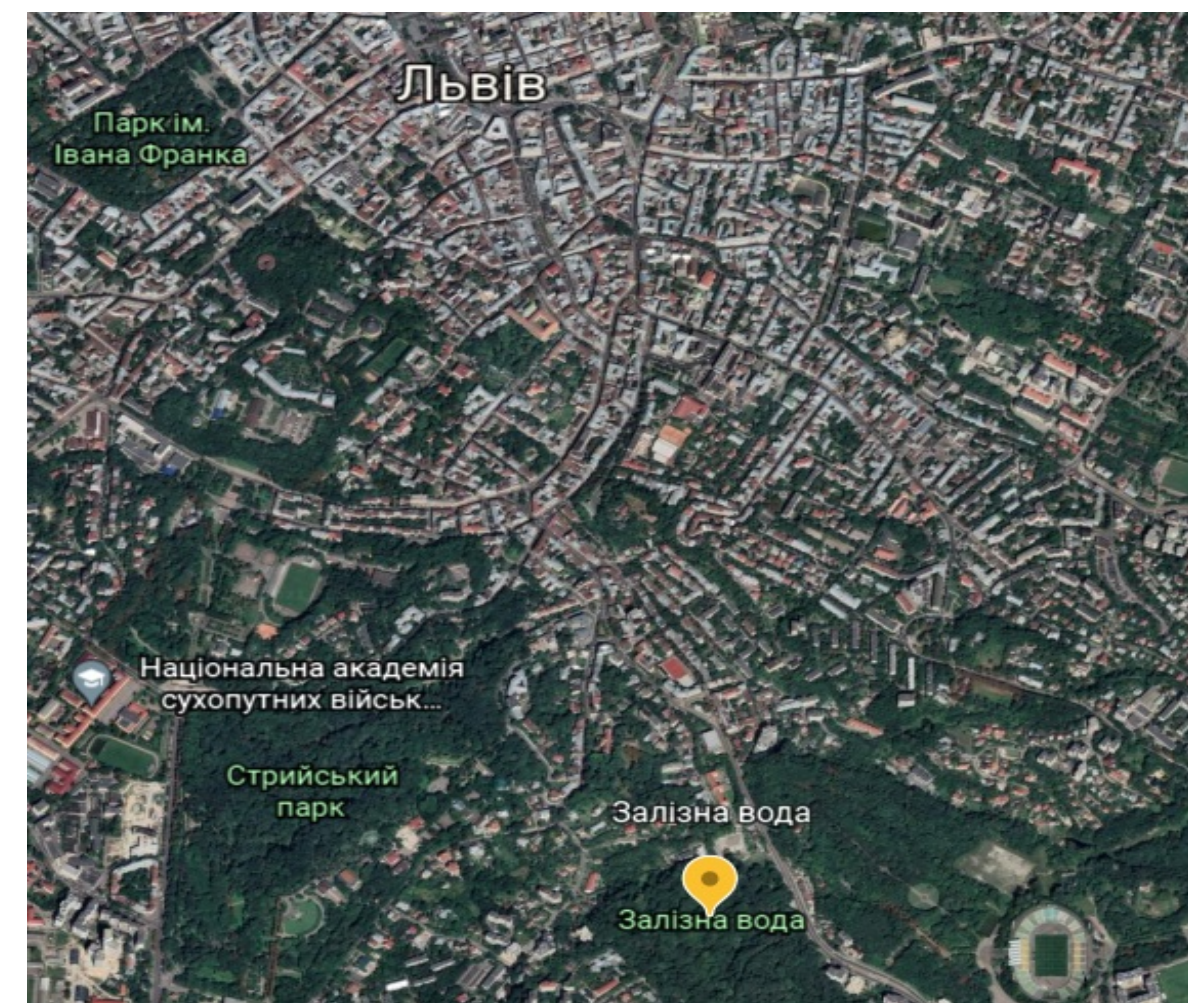

Рис. 1. Фрагмент аерофотознімка цуентральної частини м. Львова 
відібрано проби грунту для лабораторно-аналітичних досліджень. Дослідна ділянка № 1 - грядка в межах колишніх теплиць; № 2 - південна частина території під виноградником; № 3 - ділянка під інвазійними видами дерев. Відбір проб грунту та подальші дослідження проведено восени 2021 року згідно із загальноприйнятими методиками ГОСТ і ДСТУ в Україні.

Лабораторно-аналітичні дослідження виконано в лабораторії Екології землекористування Відокремленого структурного підрозділу «Педагогічний фаховий коледж Львівського національного університету імені Івана Франка». У відібраних зразках грунту визначено гранулометричний склад, вміст гумусу, реакцію грунтового розчину, ступінь насичення грунтів основами, карбонатність, забезпечення грунтів азотом і фосфором. Дослідження проведено у трьохкратній повторності та вирахувано середні значення. Результати лабораторно-аналітичних досліджень відібраних зразків грунту наведено у таблиці 1 .

3 огляду на вимогливість рослин до фізичних властивостей грунтів, важливе значення має гранулометричний склад. Від нього залежать водно-фізичні властивості, гумусовий стан грунтів, тепловий режим. Для встановлення гранулометричного складу грунтів у зразках визначено вміст фізичної глини (частинок розміром менше 0,01 мм). Зразок грунту 3 ділянки № 1 - легкосуглинкового гранулометричного складу, вміст фізичної глини $-21,62 \%$; зразки грунту з ділянок № 2 і 3 - супіщані, вміст фракції розміром менше 0,01 мм становить 16,81 і 19,45\% відповідно.

Реакція грунтового розчину має суттєвий вплив на властивості грунту та рослини. Адже підвищена кислотність $є$ причиною токсичної дії на рослини іонів $\mathrm{Al}^{3+}, \mathrm{Fe}^{3+}, \mathrm{Mn}^{2+}$, знижується біологічна активність грунту, пригнічуються процеси нітрифікації, амоніфікації, фіксації азоту з атмосфери. На лужних грунтах погіршуються фосфатний режим живлення рослин. Реакція грунтового розчину досліджуваних зразків - нейтральна, значення рН близьке до 7,0.

Біологічна активність грунтів перебуває в прямій кореляційній залежності від органічної речовини та її специфічної речовини - гумусу. Грунти з високим вмістом гумусу здатні продукувати урожай якісний і в більшій кількості.

Показники вмісту гумусу у відібраних зразках оцінено за класифікацією Л.О. Грішиної та Д.С. Орлова. У межах грядки середній вміст гумусу в грунті ста- новить 10,36\% та оцінюється як дуже високий; під виноградником та інвазійними видами дерев значення в межах 6-10\%, вміст - високий (табл. 1).

Досліджувані зразки грунту містять невелику кількість карбонатів $\left(\mathrm{CaCO}_{3}\right)$. Вміст карбонатів у грунті може мати важливе значення під час вибору гербіцидів і раціональних методів внесення добрив.

Азот засвоюється рослинами переважно у формі мінеральних сполук 3 іонами $\mathrm{NH}_{4}^{+}, \mathrm{NO}_{3}^{-}$, що утворюються в процесі мінералізації органічних речовин або вносяться 3 добривами. За нестачі азоту для живлення плодових рослин послаблюється їхній ріст, зменшується нагромадження біомаси і порушується співвідношення між надземною та кореневою системами (листя стає дрібне, блідого зеленого забарвлення, швидко опадає). За надмірного азотного живлення плодових культур спостерігається подовження вегетації, весною квіти більш чутливі до приморозків, листя і плоди часто уражуються хворобами [2]. Вміст рухомих форм азоту в грунтовому зразку з ділянки № 2 становить 161 мг/кг і оцінюється як низький. Для грунтових зразків ділянок № 1 i № 3 характерний підвищений вміст азоту 245,0 і 238,0 мг/кг відповідно.

Фосфор у рослинах відіграє роль у забезпеченні процесів метаболізму. Його нестача у грунті викликає послаблене коренеутворення, пагони стають тонкі, листя - дрібне, набуває неприродного темно-зеленого забарвлення 3 пурпуровим і бронзовим відтінками; затримується розпускання бруньок. Оптимальне живлення рослин фосфором сприяє швидкому вступу їх у період плодоношення, стимулює формування і дозрівання плодів, підвищує морозостійкість [2]. Вміст рухомого фосфору в усіх відібраних зразках грунту знаходиться в межах 101-150 мг/кг, оцінюється як підвищений (табл. 1).

Результати досліджень свідчать про високий потенціал розвитку міського садівництва в межах Львівської урбоекосистеми на ділянці поряд із теплицями Рерінга. Нині тут висаджують різноманітні культури - звичні нам гарбузи, помідори, квасолю, редиску, полуницю. Із цікавих - сахалінська гречка та спаржева квасоля сорту Вінга, яка має метрові стручки.

Міське садівництво в межах Львівської урбоекоситеми має низку переваг, серед яких насамперед необхідно відзначити екологічні. Адже вибране місце, яке, хоч і локалізується практично у центральній частині міста, було сильно захаращене та забруднене побутовими та будівельними відходами. Проте

Результати лабораторно-аналітичних досліджень грунтів

Таблиця 1

\begin{tabular}{|c|c|c|c|c|c|c|c|}
\hline $\begin{array}{c}\text { № } \\
\text { ділянки }\end{array}$ & $\begin{array}{r}\text { Фізична } \\
\text { глина, \% }\end{array}$ & $\mathrm{pH}_{\mathrm{H} 2 \mathrm{O}}$ & Гумус, \% & $\begin{array}{c}\text { Сума } \\
\text { ввібраних основ, } \\
\text { ммоль/100 г грунту }\end{array}$ & $\mathrm{CaCO}_{3}, \%$ & $\mathbf{N}_{\text {зая }}, \mathbf{M \Gamma / K \Gamma}$ & $\begin{array}{c}\mathrm{P}_{2} \mathrm{O}_{5}, \text { Мг/кг } \\
\text { (за методикою } \\
\text { Чирікова) } \\
\end{array}$ \\
\hline 1. & 21,62 & 7,3 & 10,36 & 48,0 & 9,02 & 245,0 & 116,0 \\
\hline 2. & 16,81 & 7,1 & 6,65 & 47,4 & 9,02 & 161,0 & 127,0 \\
\hline 3. & 19,45 & 7,1 & 8,79 & 47,6 & 8,61 & 238,0 & 120,0 \\
\hline
\end{tabular}



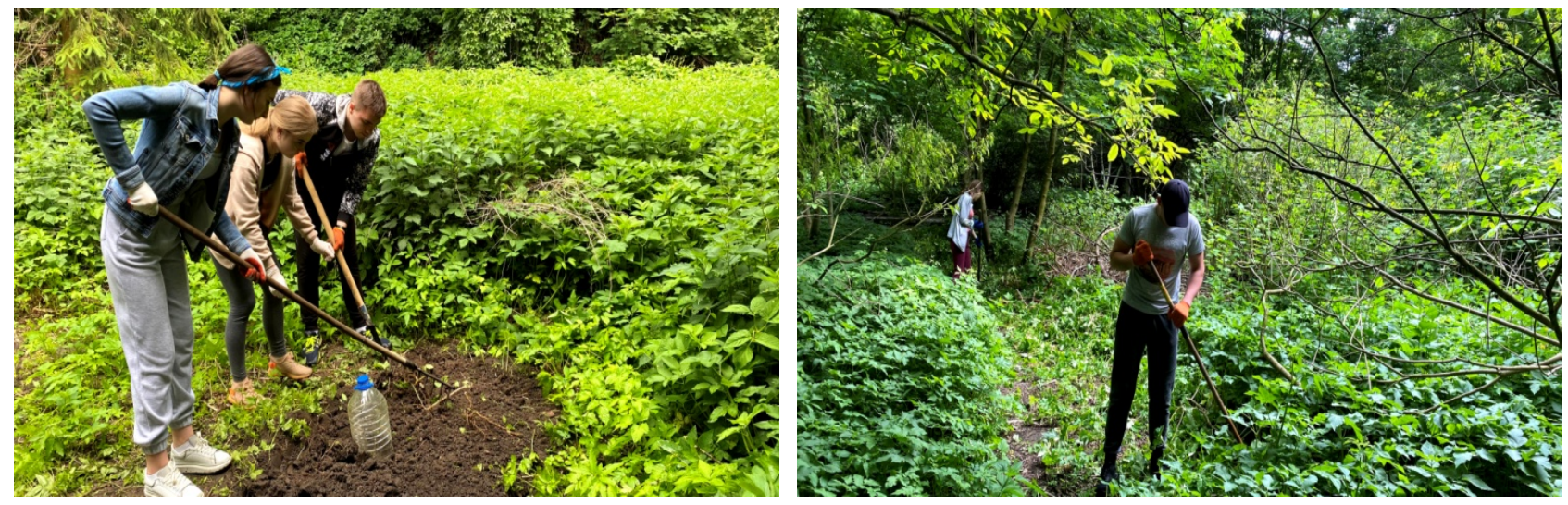

Рис. 2. Облагородження теплищь Рерінга

вже на початку закладання саду-городу територію почали розчищати та облагороджувати, в тому числі i студенти-екологи ВСП «Педагогічний фаховий коледж Львівського національного університету імені Івана Франка» (рис. 2).

Цей проєкт також сприятиме екоосвіті, адже, за словами екоактивістів, міський сад-город створюють для того, щоби приваблювати людей, розповідати їм про пермакультуру, про органічне садівництво, фермерство, про природоорієнтовані рішення.

Важливо відзначити соціальну та рекреаційну функції міського садівництва в межа Львова. Соціальна функція полягає у співпраці людей різного віку та статі, їх спілкуванні та взаємодії задля досягнення поставленої мети. Рекреаційна функція $\epsilon$ не менш важливою, адже дає змогу містянам, що завантажені зазвичай розумовою працею, відпочити на природі, докладаючи фізичну працю для влаштування та підтримання у належному стані саду-городу.

Головні висновки. Міське садівництво, до якого належить квітникарство, вирощування фруктів, овочів, стає все більш популярним і трендовим хобі жителів урбосистем. Не винятком є місто Львів, у якому для розвитку сіті-фермерства є сприятливі соціально-економічні умови та природні чинники. Зокрема, проведені власні дослідження фізико-хімічних властивостей грунтів свідчать про достатнє забезпечення грунтів гумусом і рухомими формами азоту та фосфору.

Місто Львів - не тільки культурний, науковий чи туристичний осередок, воно славиться парками, скверами, територіями природно-заповідного фонду. Навіть невеликий сад, який може бути облаштований в одній із таких місцин, буде прихистком від шуму, хаосу, повсякденної суєти жителів міста.

Для облаштування міського саду в парку Залізна Вода об’єдналися громадські організації: «Плато», «Екотерра», «Пермакультура в Україні». Ініціатори відновлюють покинуту, захаращену територію колишніх теплиць Рерінга, при цьому використовують екологічні технології для вирощування культур. Це чудовий приклад для наслідування.

Перспективи використання результатів досліджень. Лабораторно-аналітичні дослідження грунту можуть стати основою для подальшого детального вивчення природних умов території майбутнього громадського простору, який облаштовують громадські організації міста Львова.

\section{Література}

1. Гілета Л.А. Вплив туристично-рекреаційної діяльності на стан зелених зон Львівської урбоекосистеми Географія та туризм: науковий журнал / ред. кол. С.А. Лісовський (гол. ред.) та ін. Київ: Альфа-ПІК, 2019. Вип. 51. С. 34-44.

2. Заморський В.В., Яковенко Р.В., Яковенко О.В. Плодівництво: навч. посібн. Вид. 2-ге, доповнене. Умань: Видавець «Сочінський М.М.», 2019. 404 с.

3. Clinton N., Stuhlmacher M., Miles A., Aragon N.U., Wagner M. A. Global Geospatial Ecosystem Services Estimate of Urban Agriculture, Earth's Future 6 (2018), 40-60.

4. Müller C., Auf der Suche nach einem neuen Natur-Kultur-Verhältnis, Degrowth in Bewegung (en), (2016) 33, 1-10.

5. Smit J., Nasr J. Urban agriculture for sustainable cities : using wastes and idle land and water bodies as resources, Environment and Urbanization 4 (1992) 2, 141-152.

6. Кіптенко В.К. Роль рекреаційної діяльності і туризму в підвищенні якості життя міського населення похилого віку на засадах сталого розвитку. - Звіт про науково-дослідну роботу. URL: https://zenodo.org > zvit-16050-02-2018-full text.

7. Tresch S, Frey D., Le Bayon R.C., Mader P. Moretti Direct and indirect effects of urban gardening on aboveground and belowground diversity influencing soil multifunctionality Sci. Rep., 9 (2019). URL: https://www.nature.com/articles/s41598-019-46024-y\#Abs1. 


\title{
ВНЗНАЧЕННЯ НАПРЯМІВ ЕКОАОГІЧНИХ ПРОБАЕМ, ВИСВITАЕНИХ У РЕГIОНААЬНИХ ЗМI, НА ПРИКААДІ МИКОААСВА
}

\author{
Маркіна Л.М., Жолобенко Н.Ю., Ушкац С.Ю., Плахтіна О.І. \\ Національний університет кораблебудування імені адмірала Макарова \\ пр. Героїв України, 9, 54025, м. Миколаїв \\ markserg@ukr.net, svitlana.ushkats@nuos.edu.ua, nataliya.zholobenko@nuos.edu.ua
}

\begin{abstract}
Поширення екологічної інформації на теренах інформаційного простору України, а також на телебаченні, радіо, шпальтах друкованих видань має сформувати у населення нову екологічну свідомість, і саме цим займається особливий жанр журналістики - екожурналістика, що пропонує шляхи вирішення зазначених проблем, поточних подій та тенденцій, пов'язаних iз навколишнім середовищем (НC), а особисто журналіст бере на себе соціальну відповідальність за формування екологічної свідомості населення. У статті розглянуто та проаналізовано основні регіональні екологічні проблеми міста Миколаєва та області за соціологічним рейтингом. Представлено основні загальноукраїнські та місцеві засоби масової інформації (ЗМI) та простежено, які нагальні та класичні екологічні питання висвітлюються у засобах масової інформації міста. Визначено, що містян турбує практичне вирішення екологічних проблем та ухвалення місцевого та державного бюджету для їх подолання. Досліджено, що екологічна тематика має недостатнє висвітлення в засобах масової інформації через низьку кваліфікацію екожурналістів та слабку зацікавленість аудиторії, однією з причин якої є недостатня екологічна освіченість, а також відсутність необхідних рубрик у виданнях та витіснення екологічної тематики політичними й економічними новинами. Для вирішення цих питань необхідно активізувати підвищення комунікації журналістів та екоактивістів з гілками місцевої та державної влади для раціонального вирішення екологічних питань як міста Миколаєва, так й країни загалом. На державному рівні необхідно забезпечувати підтримку та захист журналістів, які розслідують екологічні проблеми, для створення та вкорінення довіри до них як із боку суспільства, так і з боку держави. Ключові слова: екологічні проблеми, екожурналістика, довкілля, навколишне середовище, публікації, інтернет-видання, засоби масової інформації, забруднення.
\end{abstract}

Determination of directions of environmental problems covered in regional media on the example of Mykolayev. Markina L., Zholobenko N., Ushkats S., Plakhtina O.

Dissemination of environmental information in the information space of Ukraine, as well as on television, radio, print media, should form a new environmental consciousness in the population, and this is what a special genre of journalism - ecojournalism, which offers ways to solve these problems, current events and trends. related to the environment, and personally, the journalist assumes social responsibility for the formation of environmental awareness of the population. The article considers and analyzes the main regional environmental problems of the city of Mykolayiv and the region by sociological rating. The main all-Ukrainian and local mass media are presented and it is traced which urgent and classical ecological issues are covered in the city mass media. It is determined that the citizens are concerned about the practical solution of environmental problems and the adoption of local and state budgets to overcome them. It was studied that environmental issues are insufficiently covered in the media due to low qualifications of environmental journalists and low audience interest, one of the reasons for which is insufficient environmental education, as well as lack of necessary sections in publications and displacement of environmental issues by political and economic news. To solve these issues, it is necessary to intensify the increase of communication between journalists and environmental activists with the branches of local and state authorities for the rational solution of environmental issues, both in the city of Mykolayiv and the country as a whole. At the state level, it is necessary to provide support and protection for journalists who investigate environmental issues in order to create and instill trust in them, both on the part of society and the state. Key words: ecological problems, ecojournalism, environment, environment publications, online publications, mass media, pollution.

Постановка проблеми. Екологічну ситуацію нині в Україні можна охарактеризувати як кризову, що формувалася протягом тривалого періоду через нехтування об'єктивними законами розвитку і відтворення природно-ресурсного комплексу України [1]. У 2019 році серед європейських країн, де фактор екологічного благополуччя держави $\epsilon$ надважливим, вона посіла 5-те місце за рівнем смертності через низький ступінь екологічної безпеки, де цим чинником нехтують та висувають на перше місце проблеми економічного та політичного характеру [2]. За даними рейтингу рівня екологічної ефективності «The Environmental Performance Index», який онов- люється один раз на 2 роки та у якому беруть участь 180 країн, у 2016 році Україна посіла 44 місце, у 2018 - 109, а у 2020 році - 60 місце серед усіх учасниць дослідження $[3,4]$. До вирішення цієї проблеми необхідно підходити комплексно, починаючи 3 екологічного виховання, що бракує українському суспільству. Основні знання та поширення необхідної інформації про важливі екологічні проблеми мають сформувати у населення нову екологічну свідомість, де важливе місце займає екологічна журналістика [5, 6] та кваліфіковані журналісти [7].

Актуальність. Засновниками екологічної журналістики в Україні вважають науковців Д. Прилюка, 
А. Москаленка. Сьогодні їхню справу продовжують українські журналістикознавці: В. Різун, В. Іванов, Д. Олтаржевський, значних зусиль для вивчення ефективності впливу газетного тексту, його стилістичних особливостей докладають Н. Непийвода, О. Пономарів, А. Мамалига. На особливу увагу заслуговує вивчення розмаїття жанрових форм у журналістиці, які досліджує В. Шкляр. У 1996 році заснована Всеукраїнська екожурналістська асоціація («ВЕЖА»), засновниками якої стали А.П. Глазовий, B.В. Козак, А.М. Комська, А.Є. Конечников, I.М. Малахов, А.К. Михайлик [8].

В останні роки матеріали цього напряму почали активно заповнювати інформаційний простір на телебаченні, радіо, шпальтах друкованих видань, сторінках глобальної мережі Інтернет. Але у вітчизняних медіа все ще залишаються недостатньо розкритими актуальні екологічні теми: вирубки лісів, браконьєрства, нераціонального використання природних ресурсів, поводження з відходами, забруднення повітря, питання якості продуктів харчування тощо [9].

Екологічні публікації у ЗМІ потребують високого рівня фахової майстерності: журналіст має не просто описати проблему, а зробити попередній грунтовний аналіз - зібрати та класифікувати дані, висвітлити їі важливість та запропонувати можливі шляхи подолання, стимулювати населення діяти або приймати певні рішення, контролювати діяльність влади, роботу підприємств, що забруднюють довкілля, та інформувати громаду про права, затверджені законодавством України [10].

Водночас робота екожурналіста вимагає високого рівня знань як журналістики, так і екології, тож проблема української екожурналістики у тому, що професійних журналістів-екологів менше, ніж журналістів широкого профілю. Але у порівнянні з минулим десятиліттям спостерігаються й позитивні зміни, так, в Україні з'явився якісний екологічний контент, а самі громадяни стають більш екосвідомими, та все ще залишаються проблеми екоманіпуляцій і використання теми довкілля в комерційних і політичних цілях, що мають відвернути увагу суспільства від реальної проблеми. Насамперед підіймаються штучно створені екологічні проблеми, що висвітлюються локально в окремих аспектах, вигідно маніпулюючи свідомістю людей в тих чи інших регіонах, а реальні проблеми, що становлять загрозу для українців десятиліттями, залишаються незмінними [10].

Актуальність цього дослідження зумовлена визначенням загальних тенденцій висвітлення в 3МI екологічних проблем України та міста Миколаєва і передбачають перспективи розвитку екологічної журналістики в країні та області для вирішення регіональних екологічних проблем.

Зв'язок авторського доробку із важливими науково-практичними завданнями. Необхідно визначити та дослідити особливості екологічної проблематики, досвід, характер, жанрові форми висвітлення екологічних питань в Україні та місті Миколаєві, ставлення населення до екологічних проблем.

Аналіз останніх досліджень i публікацій. Сюжети, пов'язані з охороною довкілля, частіше з'являються на сторінках друкованих 3МІ та нових інтернет-порталів, створюються й розвиваються тематичні екологічні інтернет-проєкти. Сторінки спеціалізованих електронних видань зазвичай $є$ органом тієї чи іншої екологічної організації, тому насамперед переслідують мету популяризації власних поглядів, а вже потім намагаються розміщувати на сайті новини та добірки цікавої екологічної інформації. Загалом значна увага приділяється таким темам, як засмічення міста, проблемам біосферних заповідників, пожеж та незаконної вирубки дерев, безвідповідального ставлення до природи та бездіяльності влади тощо [11]. Окремо можна відзначити регіональні видання, Інтернет-версії яких несуть інформацію про себе, свою спрямованість, рекламу, містять матеріали свіжих номерів та архіви, де можна знайти публікації на екотематику [12]. I хоча ця тематика $\epsilon$ актуальною, на жаль, вона досі не займає відповідного місця у засобах масової інформації за відсутності об'єктивності [13]. Адже доволі часто розслідування є суб'єктивним або підтримує тільки одну сторону конфлікту. Також вважається, що привернути увагу аудиторії до проблем екології можна лише негативом, але відсутність екологічного позитиву - серйозний недолік загальної преси. Поверхове ставлення до проблеми, викривлення фактів, некоректність подання інформації через брак часу для вивчення проблеми, недостатність екологічної освіти та якісних джерел інформування також вважаються недоліками. Через відсутність рубрик теми в багатьох матеріалах повністю не розкриті, деякі з них друкуються не в повному обсязі, спорадично трапляється позитивна та оптимістична інформація, яка би стосувалася охорони довкілля. Акцент робиться на глобальність і катастрофічність проблеми, а не на шляхи іiі вирішення. Автори екоматеріалів мають певні труднощі, стикаючись зі специфікою їх підготовки. Недостатня інформованість, нечітке володіння термінологією та стилістикою $є$ основними помилками, які $є$ в матеріалах про екологію [14].

Журналісти, які спеціалізуються на екологічній тематиці в 3МI, щодня стикаються з багатьма нагальними проблемами, такими як: дефіцит коштів, залежність від рекламодавців, власників ЗМІ, політична цензура тощо. Головними бар'єрами у професійній діяльності екологічного журналіста $є$ неоперативне отримання інформації від офіційних установ та екологічного руху, недостатне усвідомлення завдань і значення журналістської роботи представниками екологічних структур, брак інформації, незрозумілі коментарі фахівців, низький рівень захищеності журналістів, особливо тих, хто займається питаннями екологічної та ядерної безпеки $[15,16]$. 
Непрофесійна робота із фактами, зайве прагнення до сенсаційності в подачі матеріалу можуть не тільки заплутати читача, викликати паніку, але й нададуть привід чиновникам, відповідальним за вирішення екологічних проблем, зайвий раз підкреслити некомпетентність журналістів і громадськості та ігнорувати думку громадян у прийнятті екологічно важливих рішень. 3 іншого боку, компетентне й коректне висвітлення існуючих проблем може вплинути на їх позитивне вирішення.

Виділення не вирішених раніше частин загальної проблеми, котрим присвячусться стаття. Визначення екологічних заходів країни та міста на базі встановлення особливостей створення інформаційного поля довкола екологічних проблем.

Новизна. Практичною новизною є визначення найпоширеніших екологічних проблем міста Миколаєва для правильного висвітлення 3 метою швидкого їх вирішення.

Методи дослідження: функціональний аналіз та моніторинг у дослідженні сучасного стану висвітлення екопроблем в 3МI, соціальне спостереження, опитування та узагальнення результатів досліджень.

Викладення основного матеріалу. Метою та завданням дослідження було визначення особливості екологічної проблематики, дослідження досвіду, характеру, жанрових форм висвітлення екологічних питань в Україні, ставлення населення до проблем, пов'язаних з екологічною темою, в Україні та місті Миколаєві. Для цього проведено аналіз екологічних публікацій регіональних та загальноукраїнських засобів масової інформації, дослідження сучасних змін довкілля на прикладі регіональних ЗМІ.

Для дослідження використовувались методи моніторингу електронних сайтів, медіа, аналіз контенту 3MI, використані наукові статті та дослідження, журналістські матеріали та екологічні публікації в загальноукраїнських і регіональних медіа. У роботі розглядалися публікації загальноукраїнських новинних ресурсів: «Українська правда», «Обозреватель», «Сегодня», «24 канал», «ТСН», «Страна.иа», «РБК Україна», «УНІАН», «Гордон», «Новое время», «ЛІГА», «Укрінформ», «Знай.uа», «Тиждень иа», «Дзеркало тижня», «Інтерфакс», 3 регіональних

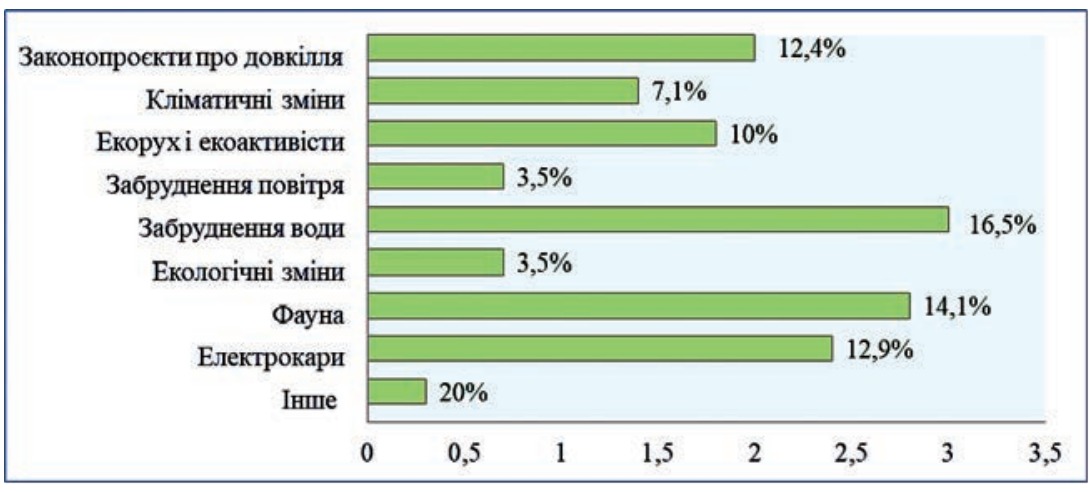

Рис. 1. Екологічні проблеми, які висвітлюють Інтеренет-видання України видань: «Преспутности. Нет», «.0512», «Никвести», «Новости Н», «Корабелов. Инфо». Матеріали екологічних публікацій показали, що відомі Інтернет-видання присвячують питанням екології лише $1 \%$ публікацій, 3 яких розподіл основних наведено на рис. 1.

Інтернет-видання багато уваги приділяють законопроєктам про довкілля, адаптації до змін клімату, екологічним надзвичайним ситуаціям, екоруху та екоактивістам. Трапляються матеріали про зміни біорізноманіття, забруднення повітря, води тощо. Дослідження екологічних публікацій у регіональних виданнях показало іншу картину. Регіональні видання мало освітлюють екологічні теми, які торкаються усієї країни, але багато уваги приділяють екологічним проблемам регіонального рівня. Найбільш екологічним виданням виявилися Інформаційне інтернет-видання Миколаєва «Преступности Нет» та інформаційно-аналітичне інтернет-видання Миколаєва «Никвести».

Найбільш популярною темою на сторінках сайту $\epsilon$ практичне вирішення проблем міста та ухвалення бюджету для вирішення екологічних проблем регіону. Лідерами серед тем опинилися й місцеві підприємства - Заводи «Екотранс» та Миколаївський глиноземний завод, яких звинуватили у забрудненні довкілля шляхом незаконного викиду відходів від виробництва.

Місто Миколаїв - портове місто, тому багато публікацій присвячено забрудненню акваторії, браконьєрству, риболовству, забрудненню Кінбурзької коси та Тилігульського лиману. Сторінки містять чимало репортажів незаконної вирубки дерев, екологічних заходів екоактивістів міста. Також розглядаються теми забруднення повітря, що зараз є актуальною не тільки для Миколаєва, а й для України та світу загалом (рис. 2).

Що стосується інших видань, то, наприклад, «Корабелов. Инфо» публіковує новини про Миколаївський глиноземний завод та природні зміни: засухи, забруднення води, акваторію, акцентуючи увагу на проблеми певного регіону міста, де саме розташований завод і більшість селищ. Новини Миколаєва «.0512» опубліковують більшу частину інформації у стилі блогу чи афіш, «Новости-Н» публікують новини у жанрі інтерв'ю, коментарів або прогнозів від експертів-екологів, ці дописи стосуються не лише Миколаєва, а й усієї країни загалом.

3 метою дослідження громадської думки та ставлення населення до екологічних питань в Україні та області, визначення рівня обізнаності респондентів та знайдення шляхів покращення ситуації 3 інформуванням громадян проводилось опитування та анкетування. За допомогою GoogleФорми було 
розроблено та розіслано в додаток Viber, Telegram, соціальну мережу Facebook та на електроні пошти анкету-опитування думки мешканців міста щодо висвітлення екологічних проблем у ЗМІ, яка містила 10 запитань із кількома варіантами відповідей. GoogleФорма анкети, відповіді та результати анкетування 121 респондента наведено на рис. 3-11.

Перші два питання про вік та стать респондентів показали більшу занепокоєність заявленою проблематикою молоді та жінок. Найбільш активними та небайдужими виявилися студенти віком від 18 до 23 років, а дітей молодше 18 років ці питання не зацікавили взагалі, жоден не взяв участі в опитуванні. Несподіваною виявилася повна байдужість до питань екології майже $15 \%$ респондентів, та це дало надію, що близько $80 \%$ цікавляться нагальними екологічними питаннями.

На запитання «Звідки ви отримуєте інформацію про екологічні проблеми України, області?» більшість респондентів вказали, що це соціальні мережі, телебачення та ролики в YouTube. 3 іншого вони додали інтернет, онлайн-медіа, статті, семінари та професійну діяльність (рис. 5).

Найбільш ефективними засобами екологічної просвіти, на думку більшості опитуваних, $\epsilon$ соціальні мережі, рекламні ролики та засоби масової інформації, а друковані видання майже ніхто не читає, інше взагалі ніхто не вибрав (рис. 6).

На запитання «Які основні питання, пов'язані із проблемами екології, найчастіше висвітлю- ються в 3МІ?» на першому місті респонденти вказали проблеми вирубки лісів та зелених насаджень, на другому - кліматичні проблеми, потім проблеми забруднення світового океану та проблеми поводження $з$ відходами. Також вони відзначили, що засоби масової інформації торкаються питань забруднення атмосфери і проблем промислового забруднення, знищення біорізноманіття, проблем енерго- та ресурсозбереження, стічних вод, пожеж та питань природно-заповідного фонду (рис. 7).

Опитуваним було запропоновано оцінити, наскільки екологічні питання є важливими. Майже $40 \%$ респондентів зазначили, що ці питання $є$ дуже важливими, трохи більше 30\% вважають, що ці питання критичні

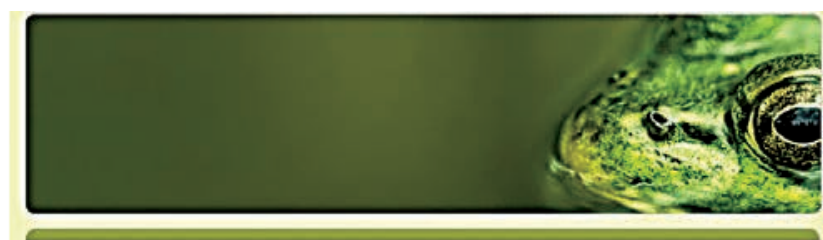

Анкета опитування думки мешканців міста щодо висвітлення екологічних проблем в 3MІ (розішліть будь ласка цю анкету своїм близьким та друзям)

Шановний респонденте!

Кафедра техногенної та цивільної безпеки Національного університету

кораблебудування імені адмірала Макарова проводить дослідження громадськоі Аумки на тему: «Ставлення громадськості до екологічних проблем висвітлених в 3Mls.

Ми маемо на меті дізнатись про ставлення респондентів до екологічних питань в Україні та області, визначити рівень обізнаності респондентів, знайти шляхи покращення ситуації з інформуванням громадян.

Саме тому Ваші відповіді на запитання є дуже важливими. Сподіваємось на плідну cniвпрацю та дякуемо Вам заздалегідь.

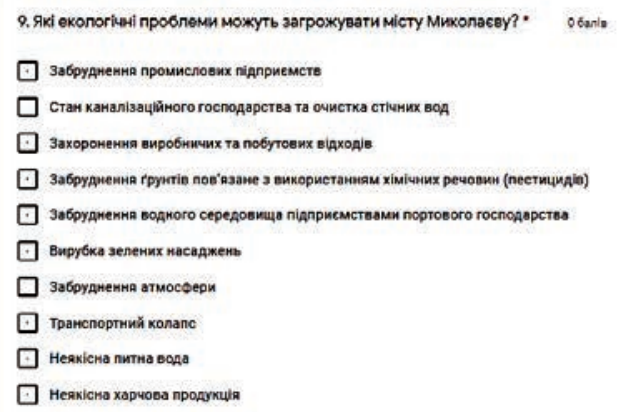

10. чи знеете ви прізвица/М'я відомих екожурналістів, вчених або обалія exовктиістів? *

$\square$ Tá

$\square$ ні

Мозете вказати, кого саме

Mapicram

Pис. 3. GooglеФорма анкети опитування думки мешканців міста щзодо висвітлення екологічних проблем у ЗМІ 

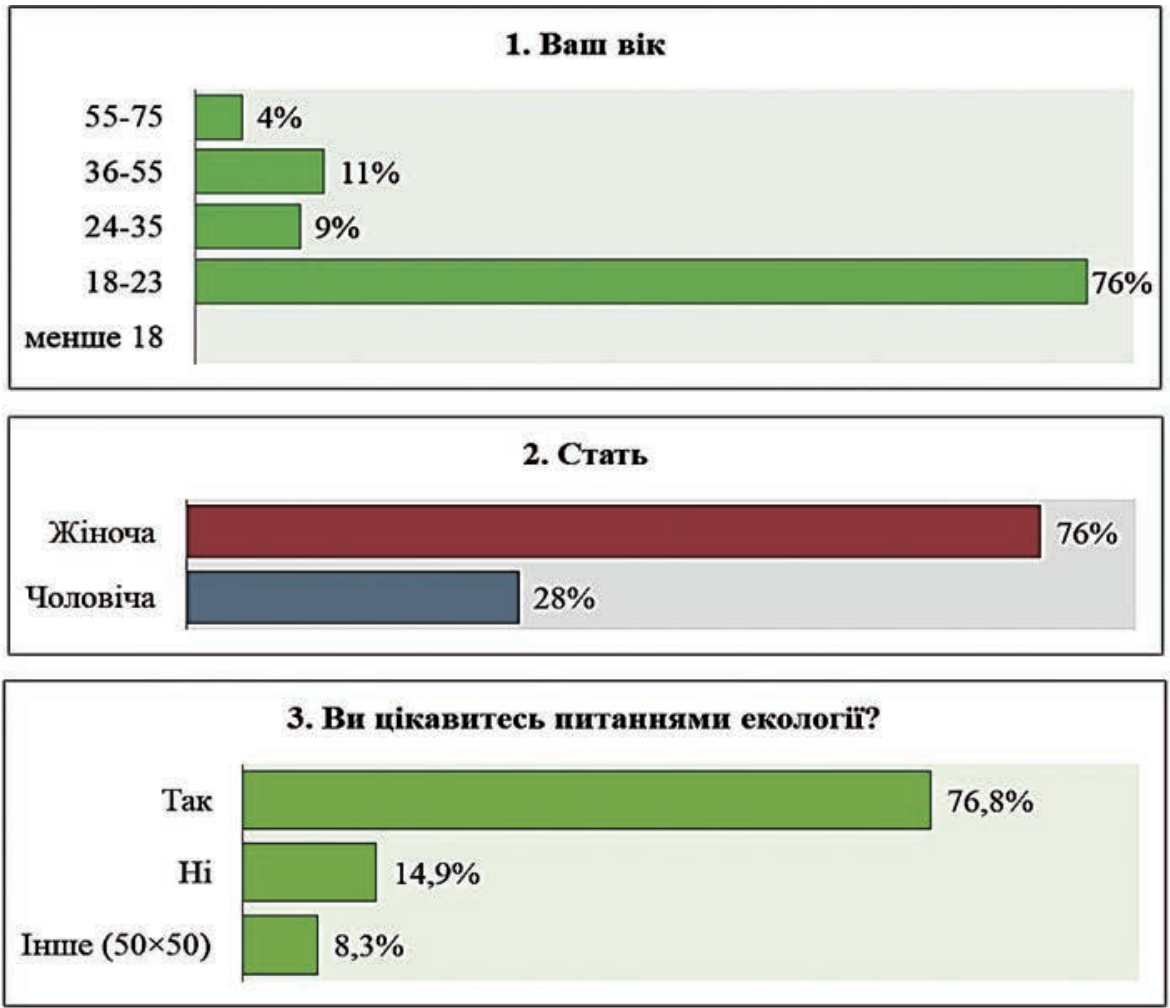

Рис. 4. Перші три питання анкети опитування мешканців міста Миколаєва

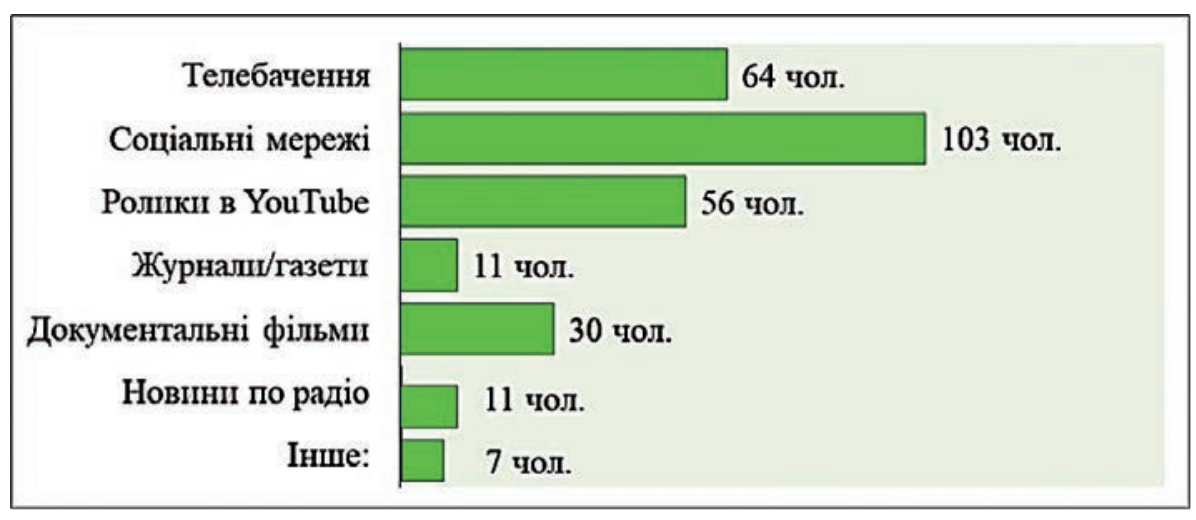

Рис. 5. Питання № 4. Звідки ви отримуєте інформацію про екологічні проблеми Украӥни, області?

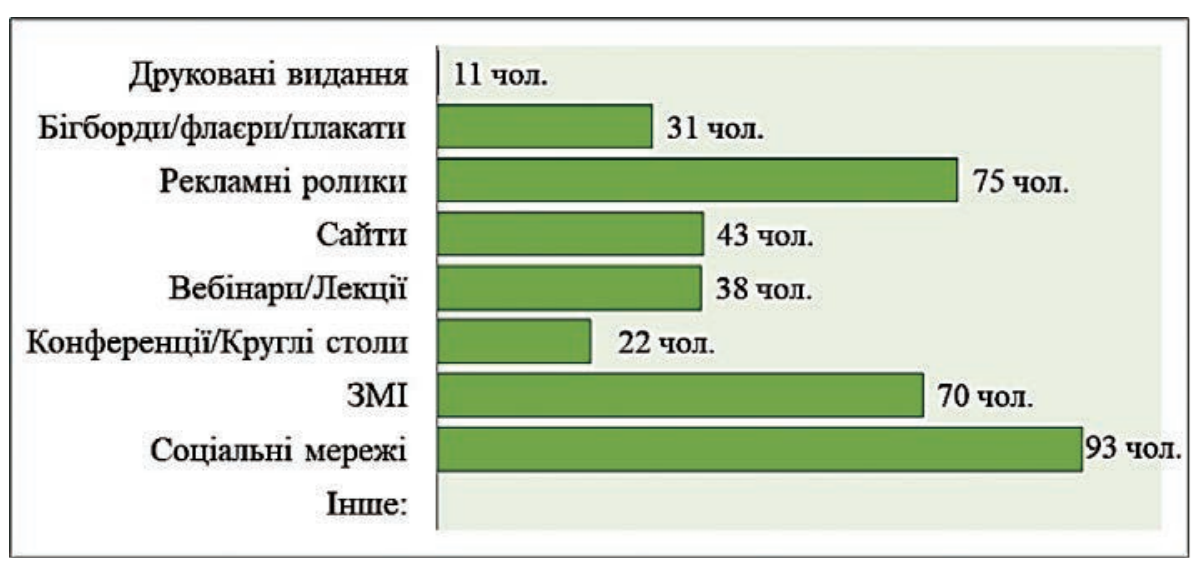

Рис. 6. Питання № 5. Які засоби екологічної просвіти, на Вашу думку, найбільш ефективні? 


\section{Маркіна Л.М., Жолобенко Н.Ю., Ушкац С.Ю. ..}

для виживання людства, приблизно 7\% думають, що такі питання $\epsilon$, а понад 4\% припускають, що питання важливі, але не першочергові. I лише 19\% думають, що екологічні питання не важливі (рис. 8).

На запитання «Чи вважаєте Ви, що проблеми зміни клімату можуть призвести до глобальних проблем життєдіяльності людини?» майже $80 \%$ опитуваних відповіли, що така проблема може загрожувати знищенню людства. На жартівливе запитання «Нi, людина - Цар природи» було отримано несподіваний результат - $0 \%$ відповідей (рис. 9), що свідчить про початкову стадію розуміння біоцентризму, запропонованого В.I. Вернадським.

\section{ВИЗНАЧЕННЯ НАПРЯМІВ ЕКОЛОГІННИХ ПРОБАЕМ...}

Анкетування проводилося в місті Миколаєві, тому респондентам було запропоновано запитання «Які екологічні проблеми можуть загрожувати місту Миколаєву?». На нього опитувані надали найбільшу кількість відповідей, що говорить про небайдужість містян. Найголовнішими проблемами визначили незадовільну якість питної води, стан каналізаційного господарства та очистку стічних вод і проблеми, пов'язані із захороненням виробничих та побутових відходів. На другому місці - забруднення промисловими підприємствами та забруднення водного середовища підприємствами портового господарства. Також було приділено увагу забрудненню атмосфери

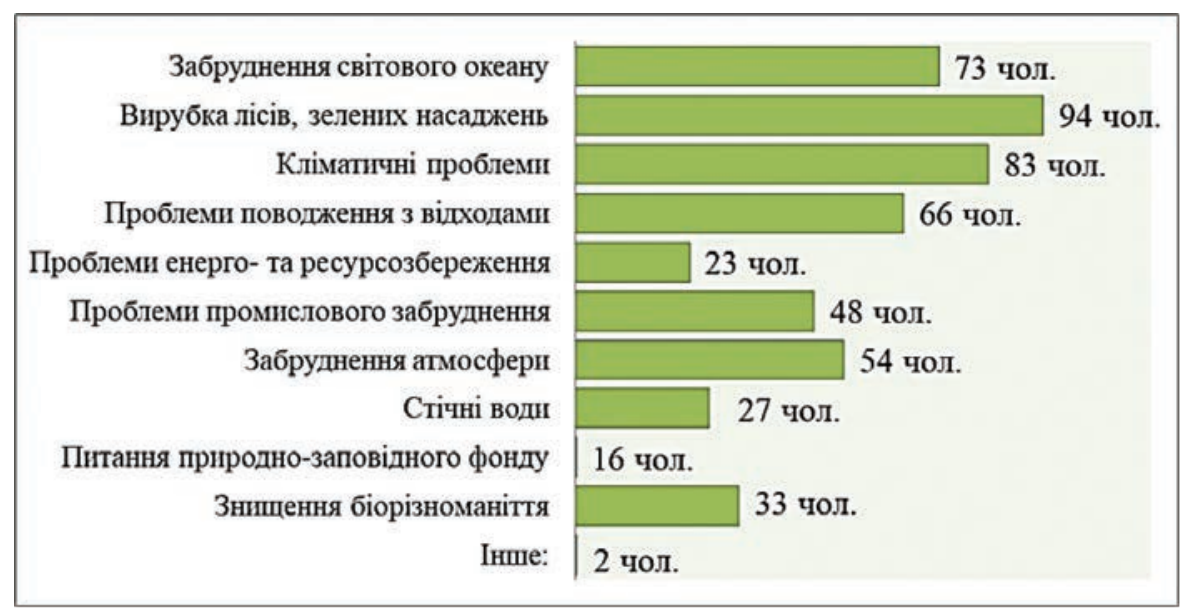

Рис. 7. Питання № 6. Які основні питання, пов'язані з проблемами екології, найчастіше висвітлюються в 3 МI?

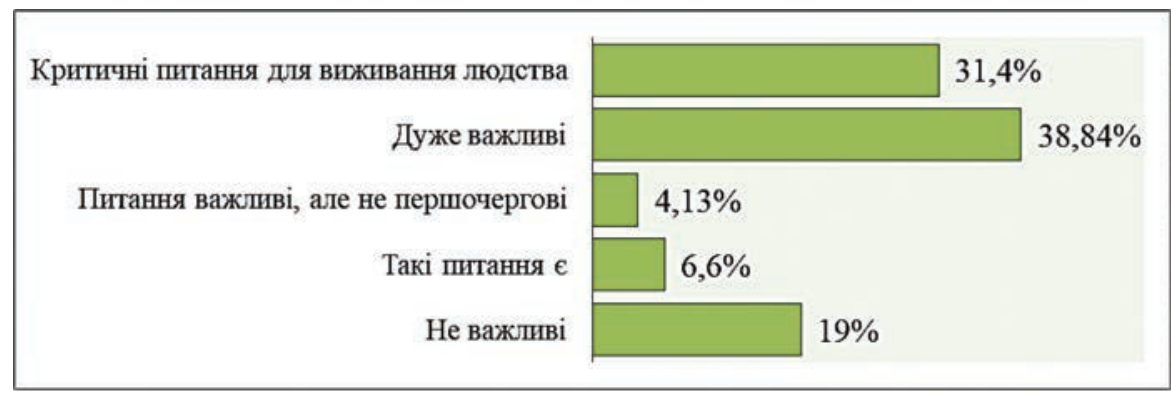

Рис. 8. Питання № 7. Очуініть, наскільки екологічні питання є важливими

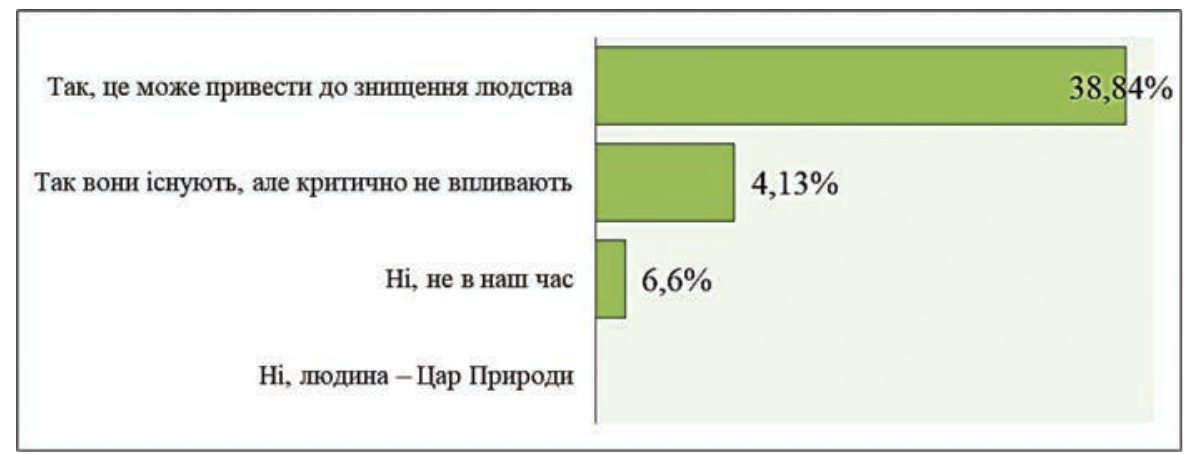

Рис. 9. Питання № 8. Чи вважаєте Ви, щчо проблеми зміни клімату можуть призвести до глобальних змін життедіяльності людини? 


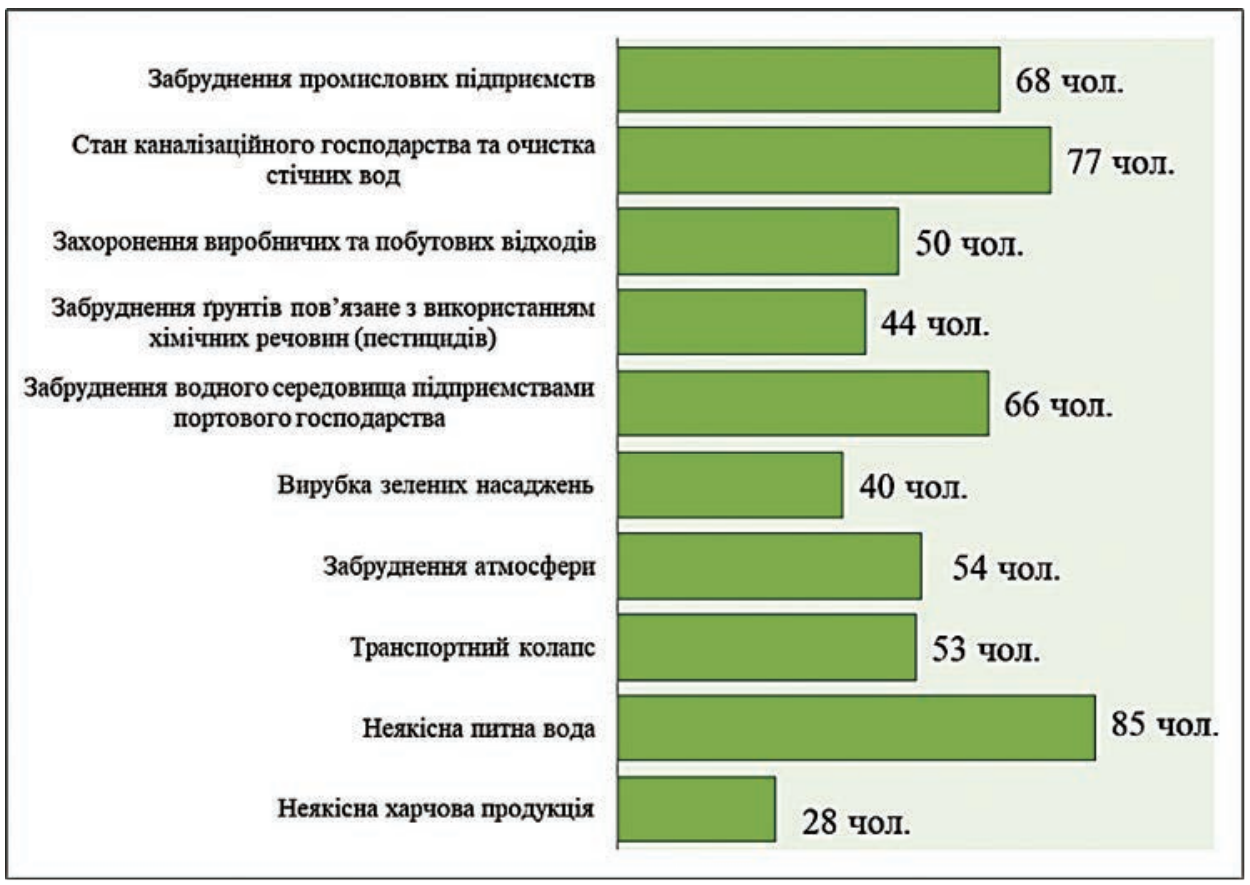

Рис. 10. Питання № 9. Екологічні проблеми,

щзо можуть загрожувати місту Миколаєву

та грунтів, що пов'язане з використанням хімічних речовин (пестицидів), вирубці зелених насаджень, транспортному колапсу та неякісній харчовій продукції (рис. 10).

I3 запропонованих десяти тем екологічного напряму майже всі питання $є$ актуальними для міста, що $\epsilon$ важливим поштовхом для влади і громади в пошуках їх вирішення.

Наприкінці респондентам було запропоновано запитання «Чи знаєте ви прізвища/ім'я відомих екожурналістів, вчених або екоактивістів?». Більшість опитуваних (66,2\%) відзначили, що вони не знають таких людей. 29,75\% вказали, що знають, але не можуть назвати їх ім'я, і лише 4,13\% вказали прізвище відомої шведської екологічної активістки Грети Тунберг, яка отримала міжнародну популярність і визнання за просування думки про неминучу екзистенційну кризу для людства внаслідок зміни клімату, та вказали українську екоактивістку Юлію Мархель, президента всеукраїнського молодіжного руху Let's do it Ukraine.

Головні висновки. Екологічні розслідування та екоаналіз є актуальними напрямами в журналістиці. Її стрімкий розвиток та прогрес зумовлені важливістю цієї сфери діяльності для забезпечення безпеки життєдіяльності людини. Визначено, що екологічна тематика має недостатнє висвітлення у ЗМІ через низку причин: недостатню кваліфікацію журналістів, низьку зацікавленість аудиторії, домінування політичних та економічних новин над екологічною тематикою. Незважаючи на появу нових екологічних видань, поступове підвищення екологічної свідомості українців, екожурналістика все ще має низку проблем: у глобальних інтернет-виданнях екологічна тема висвітлюється недостатньо, опубліковані матеріали можуть містити у собі агресивну та нав' язливу рекламу та екоманіпуляції. Треба активізувати підвищення комунікації журналістів та екоактивістів із гілками влади для раціональнішого вирішення екопитань, забезпечувати підтримку й захист журналістів, які розслідують екопроблеми.

Місто Миколаїв є промисловим центром зі своїми портами, підприємствами, багатогалузевим сільським господарством тощо, що є прямим джерелом негативного впливу на довкілля. I саме тому дуже важливо розвивати місцеву екологічну журналістику та продовжувати висвітлення зазначених проблем для впливу на свідомість населення, що ігнорує або байдуже до важливих екологічних питань, а також впроваджувати та вдосконалювати відповідне законодавство.

1. Жити можна, але не скрізь. Що розповів екологічний рейтинг областей України https://focus.ua/ratings/473439-zhit-mozhno-no-ne-vezde-chto-rasskazal-ekologicheskij-rejting-oblastej-ukrainy-2021.

2. Надимили: Україна ввійшла у ТОП-5 країн Европи за смертністю через низький рівень екології (2021) https://dn.vgorode.ua/news/sobytyia/416754-nadymyly-ukrayna-voshla-v-top-5-stran-evropy-po-smertnosty-yz-za-ekolohyy.

3. Бєляков О.О Сучасні проблеми розвитку екологічної журналістики в Україні: бібліогр., Культура народов Причерноморья, 2017. C. $149-152$. 


\section{Маркіна Л.М., Жолобенко Н.Ю., Ушкац С.Ю. ... ВИЗНАЧЕННЯ НАПРЯМІВ ЕКОАОГЧНИХ ПРОБАЕМ...}

4. Українські онлайн-3МI ігнорують тему екології: інфографіка (2021) https://news.liga.net/world/news/ ukrainskie-onlayn-smi-ignoriruyut-temu-ekologii-infografika-imi.

5. Шаргородська А.Ф. Екологічна проблематика в сучасній українській журналістиці: Методичні вказівки та завдання для студентів третього курсу спеціальності «журналістика», Одеса: ОРІДУ НАДУ, 2016. 48 с.

6. Всеукраїнська еко журналістська асоціація (2021) https://clarity-project.info/rgf/11f9ff13b1890c67291630ddf7bc8af2.

7. Екологічні проблеми в Україні та як з ними боротись (2021) https://kalamar.ua/ekologichni-problemi-v-ukrayini-ta-yak-znimi-borotis/.

8. Екологічна журналістика: актуальність в умовах сьогодення (2021) https://h.ua/story/151288/.

9. Грета, електрокари та пластикові пакети: як пишуть про екологію онлайн-медіа (2021) https://imi.org.ua/monitorings/ greta-elektrokary-ta-plastykovi-pakety-yak-pyshut-pro-ekologiyu-onlajn-media-i30067.

10. Чому екоманіпуляції і хайп на екотренді дуже небезпечні і відводять увагу суспільства від реальної довкіллєвої проблематики? (2021) https://ecolog-ua.com/news/chomu-ekomanipulyaciyi-i-hayp-na-ekotrendi-duzhe-nebezpechni-i-vidvodyat-uvagususpilstva-vid.

11. Медіа, що пишуть про екотеми: чому це важливо (2021) https://www.thelede.media/istorii/2020/07/31/1974/.

12. Матус С.А., Левіна Г.М., Карпюк Т.С., Денищик О.Ю. Аналітичний звіт. «Базове дослідження стану та напрямів розвитку екологічної політики України та перспектив посилення участі організацій громадянського суспільства у розробці та впровадженні політик, дружніх до довкілля». Київ, 2019. 117 с.

13. Панченко С.А. Роль регіональної преси у зростанні соціально-комунікативного попиту на екологічну інформацію / С. А. Панченко // Держава та регіони. Науково-виробничий журнал. Серія : Соціальні комунікації. 2012. № 1 (28). С. $101-104$.

14. Халепи української екожурналістики (2021) https://ms.detector.media/mediaosvita/post/8604/2011-11-22-khalepy-ukrainskoiekozhurnalistyky/.

15. Державний екологічний контроль: на порозі перезавантаження (2021) https://www.pravda.com.ua/ columns/2021/09/17/7307487/.

16. 5 причин замовчування екологічних проблем у 3MI https://akulamedia.com/kirovograd-5-prichin-zamovchuvannjaekologichnih-problem-u-zmi. 


\title{
УДК 504 \\ DOI https://doi.org/10.32846/2306-9716/2021.eco.6-39.26 \\ ГАОБАИЬНІ ЕКОАОГІЧНІ ПРОБАЕМИ З ТОЧКИ ЗОРУ АСТРОЕКОАОГIї
}

\author{
Хом'як I.B. \\ Житомирський державний університет імені Івана Франка \\ вул. Велика Бердичівська, 40, 10005, Житомир \\ ecosystem_lab@ukr.net
}

\begin{abstract}
У публікації розглядаються нові можливості для теоретичної та прикладної екології, які з'являються із розвитком іiї розділу астроекології. Ці інструменти та теоретичні моделі можуть стати ключовими елементами в поступі людства в напрямі подолання екологічної кризи. Незважаючи на більш як півстоліття пошуків та дискусій, реальних результатів вирішення глобальних екологічних проблем не помітно. Це підштовхує розширювати наш погляд на екологію та генеровані нею теоретичні конструкції, а також позбавлятися від зашореності та «земного шовінізму» під час розгляду практичних екологічних завдань. Сучасна астроекологія надає нові ефективні методи для моніторингу та вирішення проблем екологічної кризи. Насамперед це стосується дистанційного зондування Землі. Ми можемо не лише відстежувати такі аномальні явища, як рівень забруднення, фізичні параметри, в тих частинах біосфери, які є недоступними або важкодоступними для наземних досліджень, проводити моніторинг стану конкретних екосистем у режимі реального часу, а й вивчати та картографувати їхню різноманітність. Щоб уникнути хибних рішень під час розв'язання проблем із довкіллям, потрібно враховувати і ті фактори, які генеруються за межами окремих локальних екосистем чи біосфери загалом. Дослідження впливу космічної погоди на окремі біосистеми чи на всю поведінку планети є важливими елементами нашого розуміння глобальних біосферних процесів, які дозволяють нам розробити більш ефективні засоби для подолання екологічної кризи. Також необхідною $є$ ревізія основних екологічних правил і законів з позиції астроекології, що дозволить уникнути хибних узагальнень, які можуть призвести до помилок у наших відносинах із навколишнім середовищем. Астроекологія працює в більш жорстких умовах, які не допускають панування суб'єктивних поглядів на взаємодію організмів із середовищем. Наприклад, під час підбору надійних біосигнатур чітко відфільтровуються другорядні ознаки, які із земного погляду здаються достатніми. Ключові слова: екологічна криза, астробіологія, біосигнатури, космічна погода, дистанційне зондування.
\end{abstract}

Global environmental problems in terms of astroecology. Khomiak I.

In this article, we consider new opportunities for theoretical and applied ecology that emerged with the development of astroecology. Astroecology gives us tools and theoretical models that can become key elements for a system of measures to overcome the environmental crisis. We have more than half a century of searching and discussing the problem of the ecological crisis. However, today we cannot see real results in solving global environmental problems. The situation pushes us to expand our view of ecology. We must take a fresh look at the theoretical constructions and get rid of narrow-mindedness and "earthly chauvinism" when considering practical environmental problems. Modern astroecology provides new effective methods of monitoring and solving problems of ecological crisis. First of all, this applies to remote sensing of the Earth. We can not only track the distribution of different types of pollution. We can measure physical parameters where it is impossible or difficult to reach from the earth's surface, monitor the state of specific ecosystems in real time, study and map their diversity. We need to take into account factors that arise outside of individual local ecosystems or the biosphere as a whole to avoid making wrong decisions when dealing with environmental issues. Research into the impact of space weather on individual biosystems or on the entire behaviour of the planet is a very important element of our understanding of global biosphere processes. This will help develop more effective means of overcoming the environmental crisis. We need a revision of basic environmental rules and laws in terms of astrology. This will avoid erroneous generalizations that could lead to errors in our relationship with the environment. Astroecology works in harsh conditions that do not allow subjective views on the interaction of organisms with their environment. For example, selecting reliable biosignatures to look for signs of life. Key words: ecological crisis, astrobiology, biosignatures, space weather, remote sensing.

Вступ. Усвідомлення екологічної кризи в 60-70-х роках ХХ століття та численні дискусії навколо неї не наблизили нас до їі подолання. Разом iз боротьбою проти загрозливих змін у навколишньому середовищі потрібно оцінити ऑï стратегію. Адже серія помилкових рішень не лише відтерміновує подолання проблеми, а й може іï поглибити. Вже нині на локальному рівні ми бачимо багато випадків, породжених нашими непродуманими кроками [1]. Так, спостерігається зникнення раритетних компонентів біоти під час введення строгої заповідності, в результаті заміни оселищного підходу на строгий заповідний режим в інтерпретації закону від 2017 року [2]. Наприклад, у Поліському природному заповіднику після введення певного режиму охорони зникли деякі рідкісні види. Також під загрозою опинились степові екосистеми, частина 3 яких нездатна функціонувати на малих площах без численних популяцій копитних. На іншому кінці нашої планети ми можемо спостерігати, як насадження дерев у заплавах пересихаючих пустельних річок призвело до повного їх знищення. Важливе питання: чи не мають ці локальні провали своє відображення на глобальному рівні?

Огляд попередніх підходів. Рішення проблем довкілля, які приймаються на державному та 


\section{Хом'як I.B.}

міжнародному рівнях, завжди $є$ політичними. В демократичних спільнотах політик, щоб утриматися на владному Олімпі, мусить спиратися на ідеї найбільш популярні серед його виборців. Звичайно, він може лише імітувати підтримку цих ідей чи намагатися змінити суспільну думку, але в загальному розрізі його діяльність не може відходити на критичну відстань від основних електоральних трендів. Однак відсоток людей, здатних відносно повно оцінити суть екологічної проблеми, незначний. Оскільки популярність певних ідей формується за законами функціонування мемів [3], то немає ніяких гарантій, що рішення, до якого підштовхує політика його електорат, буде оптимальним і раціональним. Такі рішення можуть бути прийняті лише консенсусом висококваліфікованих дослідників. Однак якщо вони будуть іти в розріз із політичними інтересами представників влади чи громадськості, то будуть проігноровані. 3 іншого боку, діяльність учених-екологів залежить від волі політиків чи донорів із громадських організацій. Отже, і у них виникає та сама залежність від громадської думки. Це спонукає замість пошуків справді дієвих способів розв'язання екологічних проблем намагатися сподобатися максимальному числу дотичних до результатів дослідження громадян.

Ще однією з проблем на цьому шляху є «земний шовінізм». Ми часто розглядаємо нашу біосферу як замкнену систему, ізольовану від космічних впливів та законів і принципів, за якими функціонує Всесвіт [4]. Це часто можна спостерігати у дослідників, які протягом тривалого періоду вивчають один невеликий за площею регіон. 3 часом їхня картина світу починає викривлятися, що підштовхує до хибних висновків та інтерпретації фактів, які спостерігаються. Метод погляду на проблему зі сторони, моделювання іiі не як окремого замкнутого на собі світу, а як частину чогось більшого, завжди приносили гарні результати і робили дослідження більш ефективним і продуктивним. На жаль, нині нами досліджена лише одна біосфера, що заставляє нас робити глобальні висновки на основі одиничних локальних прикладів. Однак методи математичного моделювання [5], космічного моніторингу та побудови моделюючих експериментів [6;7] і спостережень, які використовує астроекологія, дозволяють поглянути на проблему екологічної кризи зі сторони [8].

Мета та завдання дослідження - проаналізувати можливості методів астроекології, зробити більш ефективними зусилля, спрямовані на подолання екологічної кризи.

Матеріали та методи досліджень. Матеріалами дослідження $є$ архів публікацій, екологічного спрямування, провідних астробіологічних журналів світу. Проведено тематичний та статистичний аналіз статей у спеціалізованих фахових журналах "Astrobiology" [9], "Astrobiology Magazine" [10], "International Journal of Astrobiology" та інших [11].

\section{ГАОБААЬНІ ЕКОАОГІЧНІ ПРОБАЕМИ...}

Результати досліджень та їхнс обговорення. Сучасна астроекологія, 3 одного боку, $є$ розділом астробіології, а з іншого - класичної екології. У віддаленій перспективі вона буде зосереджена на інтерпланетарних питаннях взаємозв'язку надорганізмових біосистем із навколишнім середовищем. Натепер астроекологія переживає перші етапи становлення як самостійна наука. До розряду астроекологічних належать дослідження угруповань видів екстримофілів [12], панспермії [13], моделювання біосигнатур [14], дистанційного зондування Землі [15] та впливу факторів космічного середовища на біосферу та іiі елементи [16]. Дослідження основних публікацій вказує на те, що сучасна астроекологія має три важливі частини. Перша спрямована на вивчення впливу космічної погоди на функціонування земного життя на різних рівнях організації. Друга зосереджена на використанні досліджень окремих компонентів біосфери за допомогою системи методів космічного моніторингу стану земного довкілля. Третя - це власне класична астроекологія, яка займається питаннями впливу позаземних умов середовища на ймовірне виникнення та еволюцію життя, моделювання екзоекосистем, екзобіосфер та пошук відповідних ним біосигнатур [17].

Вплив змін у стані космічного середовища, яке оточує нашу планету, на процеси в її біотичних системах тривалий час ігнорувався. Причиною цьому була складність для дослідження та моделювання системи взаємодії між окремими компонентами «космічної погоди» та реакціями на них біосистем. Незважаючи на роботи біофізиків А.Л. Чижевського [18], С.Е. Шноля [19] та багатьох інших, ідея про потребу дослідження цього взаємозв'язку не набула популярності. Заважала старту масштабних досліджень і глибинна світоглядна проблема. Вона викликана антропоцентричним поглядом на світ. Людині вкрай важко визнавати існування сил, які здатні визначати долю частини іiі оточення, але на які вона не зможе вплинути в осяжному майбутньому. Водночас накопичувалося велике число фактів, коли зміни в активності космічного опромінення викликали реакцію на рівні зв'язків між окремими організмами. Ця реакція проявлялася спочатку на популяційному рівні, а вже потім відбивалася на динаміці екосистем [20]. Так, натепер науковим консенсусом визнається вплив зміни циклів сонячної активності на структуру окремих популяцій і флуктуації в екосистемах. При цьому йдеться не лише про загальне число енергії, яке періодично змінюється, а про інтенсивність іï потоку в окремих частинах електромагнітного спектра чи в корпускулярній радіації [19]. Дослідження показали, що не всі популяційні хвилі пояснюються моделлю Лотки-Вольтера [21]. Більш докладний статистичний аналіз вказує на синхронізацію популяційних хвиль із сонячною активністю. Наприклад, у разі зміни активності Сонця в певних частинах спектра та потоку іонів від нього 
змінюється концентрація окремих речовин у продуцентах. Це автоматично запускає зміни у всіх популяціях трофічної мережі, пов'язаних із ними. Натепер під час прийняття рішення про зміни чисельності ареалу популяції потрібно обов'язково враховувати цикли сонячної активності. Так, наприклад вважають некоректними висновки про становище раритетних або інвазійних видів, якщо спостереження за структурою їхніх популяцій тривало менше 10-12 років $[20 ; 22]$. Саме через такий час вносяться корективи про належність видів до охоронних переліків (національних та міжнародних червоних списків).

Останніми роками все більш широкого вжитку набувають методи космічного зондування землі 3 природоохоронною метою. Йдеться не лише про глобальні зміни клімату, опустелювання, лісистість тощо. Сучасні методи GIS-моделювання дозволяють працювати на більш тонкому рівні. Порівняння супутникових знімків у певних частинах спектра в поєднанні із дослідженнями екосистем на поверхні Землі дозволяє досить точно визначати їхній тип та стан. Це дозволяє будувати картографічні моделі залежності поширення певних оселищ від умов середовища та їхньої стадії динаміки. Такий напрям відкриває нові перспективи в охороні природи та раціональному природокористуванні. Наприклад, з його допомогою можна оптимізувати ведення лісового господарства. Адже ми в режимі реального часу можемо не лише визначати певні проблеми лісових насаджень (пожежі, поширення шкідників та хвороб), а й планувати лісогосподарську діяльність та перевіряти іiі відповідність (визначати наявність раритетних оселищ у зоні рубки, встановлювати потребу в санітарній рубці та ії ефективність, контролювати площі та якість рубок) [23]. Те саме можна робити і в інших сферах: під час виготовлення документів ОВД та контролю за дотриманням законодавства на їхній основі, плануванні розбудови природоохоронних територій, моніторингу ефективності сільськогосподарських робіт, озеленення міст, боротьбі iз поширеннями інвазійних видів-трансформерів [20].

Сучасна астроекологія дозволяє поглянути на біосферу не як на ізольовану в межах однієї планети систему із людиною в її основі, а як на частину динамічного Всесвіту [24]. Наукове вирішення проблем має перевірений роками алгоритм. Після накопичення фактичного матеріалу та його попереднього аналізу обирається ряд кроків, побудованих на основі прийнятих консенсусом учених теорій. На відміну від філософії, наукові теорії побудовані на обмеженому матеріалі й не поширюються на інші феномени за його межами. На жаль, ми часто спостерігаємо, що сьогоднішні рішення екологічних проблем приймаються не в результаті наукового консенсусу, а через популяризацію випадкових ідей людьми, далекими від екологічних досліджень.

Разом із тим в екології, незважаючи на більш як півторавікову історію, наявні «теорії», де невелике число спостережень стало основою для загальних екологічних законів. Натепер накопичилися численні винятки із цих правил, але вони продовжують кочувати підручниками з екології та беруться до уваги під час прийняття рішень, пов'язаних з окремими аспектами екологічної кризи. Це явище зумовлене когнітивним феноменом під назвою «земний шовінізм». Особливості астроекології в тому, що вона вимушена старанно його уникати. Намагаючись вийти у своїх теоретичних та експериментальних дослідженнях за межі типових умов земної біосфери, вона виробляє правила, які можуть стати універсальними екологічними законами [25]. Тестування екологічних теорій у сфері досліджень астроекології призводить до вдосконалення екології як науки і підвищення іiі спроможності в подоланні проблем із довкіллям [26-27].

Висновки. Сучасна астроекологія надає нові ефективні методи для моніторингу та вирішення проблем екологічної кризи.

Для надійного та швидкого вирішення екологічних проблем необхідне розширення погляду на відносини між біосистемами та їхнім довкіллям за межі локальних екосистем та біосфери Землі.

Необхідною є ревізія екологічних правил і законів з позиції астроекології, що дозволить уникнути хибних узагальнень, які можуть призвести до помилок під час подолання глобальної екологічної кризи.

\section{Література}

1. Хом'як І.В., Демчук Н.С., Василенко О.М. Фітоіндикація антропогенної трансформації екосистем на прикладі Українського Полісся. Екологічні науки. 2018. № 3. С. 113-118.

2. Хом’як І.В., Костюк В.С., Гарбар О.В., Демчук Н.С., Андрійчук Т.В., Власенко Р.П., Гарбар Д.А., Онищук І.П., Шпаковська Л.В., Омельчук М.О. Особливості розміщення оселищ із різним ступенем антропогенної трансформації. Екологічні науки. 2021. № 7. C. 67-71.

3. Dawkins Richard. The Selfish Gene. 3rd edition. Oxford : Oxford University Press, 2006. 192 p.

4. Meehl G.A., Arblaster J.M., Matthes K., Sassi F. van Loon H. Amplifying the Pacific climate system response to a small 11-year solar cycle forcing. Science. 2009. No. 5944. P. 1114-1118.

5. Черняєва О.П., Хом’як I.В. Тератрансформаційний потенціал Elymus repens (L.) GOULD. Сталий розвиток країни в рамках Європейської інтеграції : тези Всеукраїнської науково-практичної конференції здобувачів вищої освіти і молодих учених. Житомир. 2021. С. 18.

6. Лещенко Д., Хом'як I.В. Рекультиваційний та тератрансформаційний потенціал Carex hirta L. Сталий розвиток краӥни в рамках Європейської інтегращії : тези Всеукраїнської науково-практичної конференції здобувачів вищої освіти і молодих учених. Житомир. 2021. С. 54. 


\section{Хом'як I.B.}

7. Золенко I., Хом'як I.В. Перспективи використання Tusilago farfara L. з метою тератрансформації та рекультивації. Сталий розвиток країни в рамках Європейської інтеграчії : тези Всеукраїнської науково-практичної конференції здобувачів вищої освіти і молодих учених. Житомир. 2021. С. 32.

8. Бондар С.С., Хом’як І.В. Тератрансформаційні стратегії освоєння незаселених субстратів. Сталий розвиток краӥни в рамках Європейської інтеграції : тези Всеукраїнської науково-практичної конференції здобувачів вищої освіти і молодих учених. Житомир. 2021. С. 16.

9. Astrobiology. URL: http://astrobiology.com/ (дата звернення: 22.11.2021).

10. Astrobiology magazine. URL: https://phys.org/partners/astrobiology-magazine (дата звернення: 21.11.2021).

11. International Journal of astrobiology. URL: https://www.cambridge.org/core/journals/international-journal-of-astrobiology (дата звернення: 20.11.2021).

12. Billi D., Viaggiu E., Cockell C.S., Rabbow E., Horneck G., Onofri S. Damage escape and repair in dried Chroococcidiopsis spp. from hot and cold deserts exposed to simulated space and martian conditions. Astrobiology, 2010. No. 1. P. 65-73.

13. Mautner Michael N. Seeding the Universe with Life: Securing Our Cosmological Future. The Society for Life in Space (SOLIS). 2000. URL: http://panspermia-society.com. (дата звернення: 23.11.2021).

14. Seager S., Schrenk M., Bains W. An astrophysical view of Earth-based metabolic biosignature gases. Astrobiology. 2012. No. 1. P. 61-82.

15. Begni G., Escadafal R., Fontannaz D., Hong-Nga Nguyen A.T. Remote sensing: a tool to monitor and assess desertification. Les dossiers thématiques du CSFD. Issue 2. Montpellier: Agropolis international, 2005. 44 p.

16. Cade W.B., Christina Chan-Park. The Origin of "Space Weather". Space Weather. 2015. No. 2. P. 99-103.

17. Хом'як I.В., Шамоніна M.I. Тератрансформаційний потенціал представників роду осокові (Сагех). Сталий розвиток країни в рамках Свропейської інтеграиії : тези Всеукраїнської науково-практичної конференції здобувачів вищої освіти і молодих учених. Житомир. 2021. С. 12.

18. Чижевский А.Л. Земное эхо солнечных бурь. Москва : Мысль, 1973. 352 с.

19. Шноль С.Э. Космофизические факторы в случайных процессах. Stockholm : Svenska fysikarkivat, 2009. 388 c.

20. Хом'як І.В. Вплив інвазій видів-трансформерів на динаміку рослинності перелогів Українського Полісся. Біоресурси і природокористування. 2018. № 1-2. С. 29-35.

21. Hofbauer J., Sigmund K. Dynamical Systems and Lotka-Volterra Equations. Evolutionary Games and Population Dynamics. New York : Cambridge University Press, 1998. P. 1-54.

22. Khomiak Ivan, Harbar Oleksandr, Demchuk Nataliia, Kotsiuba Iryna, Onyshchuk Iryna. Above-graund phytomas dynamics in autogenic succession of an ecosystem. Forestry ideas. 2019. No. 1. P. 136-146.

23. Guo Huadong, Huang Qingni, Li Xinwu, Sun Zhongchang, Zhang Ying. Spatiotemporal analysis of urban environment based on the vegetation-impervious surface-soil model. Journal of Applied Remote Sensing. 2013. No. 8. 084597.

24. Krissansen-Totton J., Bergsman D.S., Catling D.C. On Detecting Biospheres from Chemical Thermodynamic Disequilibrium in Planetary Atmospheres. Astrobiology. 2016. No. 1. P. 39-67.

25. Mautner Michael N. Life in the Cosmological Future: Resources, Biomass and Populations. Journal of the British Interplanetary Society. 2005. No. 58. P. 167-180.

26. Ribicky, K.R., Denis, C. On the Final Destiny of the Earth and the Solar System. Icarus. 2001. No. 1. P. $130-137$.

27. Mauldin J.H. Prospects for Interstellar Travel, Prospects for Interstellar Travel Univelt. San Diego : AAS Publications, 1992.93 p. 


\title{
АГРОКАІМАТИЧНА ОЦІНКА ПОСУШАИВОСТІ ВЕГЕТАЦІЙНОГО ПЕРІОДУ В ПРИЧОРНОМОРСЫКІЙ ЗОНІ НАДЗВИЧАЙНО НИЗЫКОї ВОДНОСТІ
}

\author{
Польовий А.М. ${ }^{1}$, Овчарук В.А. ${ }^{1}$, Вольвач О.В. ${ }^{1}$, Кущенко Л.В. ${ }^{1}$, Толмачова А.В. ${ }^{1}$ \\ ${ }^{1}$ Одеський державний екологічний університет \\ вул. Львівська, 15, 65016, м. Одеса \\ alla.tolmach@ukr.net rada.d.4109001@gmail.com
}

\begin{abstract}
Посуха - це одне з найнебезпечніших природних явищ, екстремальні прояви якого спричиняють значні матеріальні збитки, насамперед у сільськогосподарському виробництві. Натепер у південних областях України, які входять до зони недостатньої водності, складається дуже напружена ситуація щодо забезпеченості водними ресурсами. Метою статті $є$ визначення сучасних умов посушливості періоду активної вегетації сільськогосподарських культур на території окремих районів Херсонської області, а також визначення майбутніх тенденцій змін умов зволоження. Для досягнення мети було проведено комплексну оцінку сучасних умов посушливості вегетаційного періоду із застосуванням традиційних агрометеорологічних показників посух - гідротермічного коефіцієнта Селянінова, показників посушливості Шашко й Уланової. Також був проведений аналіз тенденції посушливості території за методом гармонійних вагів. Розрахунки виконувалися для двох станцій - Велика Олександрівка (північна частина області, басейн річки Інгулець) і Бехтери (південно-західна частина області, де річок немає). Аналіз отриманих результатів дозволяє зробити висновок, що на території дослідження практично щорічно спостерігаються посухи різної інтенсивності. Для дослідження динаміки показника посушливості гідротермічного коефіцієнта й визначення тенденції його мінливості було використано метод гармонійних вагів. Принцип методу гармонійних вагів полягає в тому, що значення часового ряду зважують так, щоб пізніші спостереження мали більшу вагу, тобто вплив пізніших спостережень повинен сильніше відбиватися на тенденції врожайності, ніж вплив більш ранніх. Найсприятливішим був 2010 р., найпосушливішими - 2011 і 2017 рр. 3 початку досліджуваного періоду лінії тренду для двох станцій практично паралельні. 32016 р. спостерігається зменшення трендової компоненти, що свідчить про поступове зростання посушливості досліджуваної території. Можливе зменшення величин гідротермічного коефіцієнта на території Херсонської області щороку на 0,01 у порівнянні з нинішніми значеннями. Ключові слова: посуха, показники посушливості, вегетаційний період, гідротермічний коефіцієнт, водні ресурси.
\end{abstract}

Agroclimate assessment of vegetation drought period in the extremely insufficient low water content in the Black sea zone. Polevoy A., Ovcharuk V., Volvach O., Kushchenko L., Tolmachova A.

Drought is one of the most dangerous natural phenomenon, extreme manifestations of which cause significant material damage, especially in agricultural production. Now in the southern regions of Ukraine, which are part of the zone of insufficient water, is very intense the situation regarding the availability of water resources. The purpose of this article is determination of modern conditions of aridity of the period of active vegetation crops in some areas of Kherson area, as well as determining future trends in changes in humidification conditions. To achieve this goal, a comprehensive assessment of modern conditions of drought of the growing season with the use of traditional agrometeorological indicators of drought - hydrothermal Selyaninov coefficient, drought indicators Shashko and Ulanova was made. The analysis of the tendency of aridity of the territory by the method of harmonic scales was made too. Calculations were performed for two stations - Velyka Oleksandrivka (northern part of the region, Ingulets river basin) and Bekhtery (southern the western part of the region, where there are no rivers). Analysis of the obtained results allows us to conclude that the study area is almost annual droughts of various intensity are observed. To study the dynamics of the dryness index of SCC and determination tendencies of its variability the method of harmonic scales was used. The principle of the method of harmonic scales is that the value of time the number is weighed so that later observations have more weight, i.e. the impact of later observations should have a stronger effect on trends yields than the effects of earlier ones. The most favorable was 2010, the most arid - 2011 and 2017. Since the beginning of the study period, trend lines for two stations almost parallel. Since 2016, there has been a decrease in the trend components, indicating a gradual increase in drought the study area. It is possible to reduce the values of SCC on the territory Kherson region annually by 0.01 compared to current values. Key words: drought, drought indicators, vegetation period, hydrothermal coefficient, water resources.

Постановка проблеми. Посухи є складовою частиною клімату Землі, вони зазвичай починаються без попередження, не визнають кордонів, економічних і політичних відмінностей. Посуха це одне 3 найнебезпечніших природних явищ, екстремальні прояви якого спричиняють значні матеріальні збитки, загибель людей, домашніх і диких тварин, завдають шкоди навколишньому середо- вищу, призводять до негативних соціальноекономічних наслідків [1-3].

Під посухою в агрометеорологічному аспекті розуміють складне природне явище, внаслідок якого рослини потерпають від нестачі вологи, спричиненої посиленим випаровуванням або тривалим бездощовим періодом. У результаті порушується водний баланс рослини, вона в'яне, урожайність виявля- 
Польовий А.М., Овчарук В.А., Вольвач О.В. ...

ється мінімальною, а за тривалих та інтенсивних посух рослини гинуть ще до періоду формування врожаю [4].

В умовах глобального потепління необхідний моніторинг посух із метою діагностики умов їх виникнення та розвитку в кожному конкретному році, а також визначення тенденції їх змін у часі.

Актуальність дослідження. За оцінками фахівців Українського гідрометеорологічного центру [5], уже в сучасних умовах понад $30 \%$ кращих посівних земель щорічно відчувають дефіцит вологи. У роки сильних посух втрати зернових культур у цілому по Україні сягають 5 ц / га, а в степових областях - до 10-15 ц / га. В останні роки все частіше бувають випадки повної загибелі урожаїв.

Агрономічною наукою та практикою розроблено багато заходів боротьби проти посушливих явищ. Зокрема, це снігозатримання, лісосмуги, пари. Головним заходом у такому переліку традиційно є зрошення.

Дослідження посушливості проводилося для території Херсонської області. Херсонська область - одна 3 найпосушливіших в Україні, тут землеробство без перебільшення можна назвати ризикованим. Кожного року відбувається збільшення суми активних температур, а кількість середньорічних опадів зменшується, що призводить до зменшення кількості продуктивної вологи в грунті. Тому зрошення в Херсонській області $\epsilon$ необхідністю. Однак за сучасних змін клімату в південних областях України, які входять до зони недостатньої водності, складається дуже напружена ситуація щодо забезпеченості водними ресурсами [6].

Агротехнічні заходи вирішують тактичні завдання боротьби з посушливістю, однак зі стратегічного, а отже, з агрономічного й агрокліматичного боку доцільніша адаптація характеру землеробства до конкретних умов посушливості з урахуванням набору сільськогосподарських культур, спеціалізації сільськогосподарського виробництва тощо.

Для вирішення задачі необхідно знання закономірностей формування посушливих явищ - де, коли, в якій формі й $з$ якою інтенсивністю вони спостерігаються. У роботі зроблено аналіз посушливих явищ за останні роки на території Херсонської області.

Зв'язок авторського доробку з важливими науковими й практичними завданнями. Дослідження виконувалось у межах науково-дослідної роботи Одеського державного екологічного університету «Комплексний метод імовірнісно-прогностичного моделювання екстремальних гідрологічних явищ на річках Півдня України для забезпечення сталого водокористування в умовах кліматичних змін». Також тематика досліджень відповідає основним напрямам наукової діяльності кафедри агрометеорології та агроекології та кафедри гідрології суші Одеського державного екологічного університету.

Аналіз останніх досліджень і публікацій. Натепер існують чисельні дослідження як україн-
АГРОКАІМАТИЧНА ОЦІНКА ПОСУШАИВОСТІ...

ських, так і зарубіжних кліматологів, агрометеорологів, гідрологів, агрономів стосовно походження, розвитку й поширення посух, причому вони стосуються як сучасних умов, так і майбутніх, що очікуються з урахуванням змін клімату.

Представники Одеського державного екологічного університету активно досліджують питання. Серед праць слід відзначити роботи В.М. Хохлова у співавторстві 3 Н.С. Срмоленко [7] і грунтовне дослідження, проведене І.Г. Семеновою та представлене в монографічному виданні [8]. Зокрема, наявні оцінки просторово-часового розподілу стандартизованого індексу опадів SPI для території України показали, що в період 1980-2009 рр. спостерігалася тенденція до збільшення кількості посух порівняно $з$ періодом 1950-1979 рр., а максимум повторюваності посух спостерігався в Миколаївській, Херсонській, Одеській і Вінницькій областях [8].

У сумісній роботі І.Г.Семенової та А.М.Польового [9] представлені результати аналізу просторово-часового розподілу посух у теплі сезони періоду 2021-2050 pр. по території України, отримані 3 використанням даних кліматичного моделювання в рамках кліматичних сценаріїв RCP4.5 та RCP6.0. Найбільш посушливими за обома сценаріями очікуються 2044-2048 рр., коли в ряді областей сезонна посуха може досягнути екстремальної інтенсивності.

Результати дослідження впливу змін клімату на водні ресурси України [10], виконаного для сценаpiïв RCP4.5 RCP8.5, свідчать про те, що за період 2021-2050 pр. зменшення водних ресурсів відбуватиметься по всій рівнинній території, на півдні й південному сході досягне $60 \%$, а в Північно-Західному Причорномор'ї - до 50\%.

Фахівці Полтавської державної аграрної академії в роботі [11] відзначають, що в останні десятиліття в Україні відзначається небезпечна тенденція збільшення повторюваності посух. Вони пропонують ряд заходів з адаптації аграрного виробництва до нових кліматичних умов.

Виділення не вирішених раніше частин загальної проблеми, котрим присвячусться означена стаття. Метою статті $є$ визначення сучасних умов посушливості періоду активної вегетації сільськогосподарських культур на території окремих районів Херсонської області, а також майбутніх тенденцій змін умов зволоження.

Новизна представленого дослідження полягає в тому, що вперше для аналізу тенденції посушливості території за показником гідротермічного коефіцієнта (далі - ГТК) застосовано метод гармонійних вагів, який не тільки дозволяє врахувати вплив пізніших досліджень, а й спрогнозувати кількісну зміну показника на наступні роки.

Методологічне або загальнонаукове значення полягає в комплексній оцінці сучасних умов посушливості вегетаційного періоду із застосуванням традиційних агрометеорологічних показників посух. 
Викладення основного матеріалу. Натепер існує вже близько 150 індексів посухи. Цілий ряд показників посухи рекомендований Комплексною програмою боротьби з посухою Всесвітньої метеорологічної організації [12].

За інформацією Українського гідрометцентру в Україні районування та оцінка посушливості території здійснюється за гідротермічним коефіцієнтом Селянінова (ГТК), який являє собою відношення суми опадів за період із температурами повітря вище $10^{\circ} \mathrm{C}$ $\sum P$ до суми температур повітря вище $10^{\circ} \mathrm{C} \sum T$, зменшеної в 10 разів, і визначається за формулою [4; 5]:

$$
\Gamma T K=\frac{\Sigma P}{0,1 \Sigma T},
$$

де ГТК - це інтегральний показник гідротермічного режиму, що враховує тепло й вологу. Він вживається як показник вологозабезпеченості або умов сприятливості для вирощування сільськогосподарських культур.

Крім ГТК використовується ще низка показників зволоження. Серед них показник посушливості $\mathrm{Md}$ Д.І. Шашко [4], що являє собою відношення суми опадів $\Sigma P$ до суми середніх добових значень дефіциту тиску водяної пари $\Sigma d$ :

$$
M d=\frac{\Sigma P}{\Sigma d} .
$$

Для оцінки загальних посух (атмосферних і грунтових) Є.С. Уланова запропонувала використовувати коефіцієнт зволоження:

$$
K_{1}=\frac{W_{s}+\Sigma O_{V-V I}}{0,01 \Sigma T_{V-V I}},
$$

де $W_{\text {s }}$ - запаси продуктивної вологи в метровому шарі грунту під час стійкого переходу середньої добової температури повітря через $5^{\circ} \mathrm{C}$ навесні, мм; $\sum_{O V-V I}$ - сума опадів за травень - червень, мм; $\sum T_{V-V I}-$ сума середніх добових температур повітря за травень - червень [4].

Усі розглянуті критерії належать до класичних i тривалий час використовуються в агрокліматичних дослідженнях.

3 урахуванням досліджень зміни клімату й використанням великої кількості вихідних даних фахівцями Українського гідрометцентру було побудовано нову карту агрокліматичного зонування території України для періоду активної вегетації всіх сільськогосподарських культур (травень - вересень) за показником ГТК5-9 (рис. 1). Період спостережень використаний для розрахунків 1961-2013 рр. [5].

Як можна бачити, на території Північного й Південного Степу України значення ГТК за період активної вегетації попадають у градацію від 0,71 до 1, що відповідає середньо посушливим умовам. Лише південні райони Херсонської області й північно-західні райони Криму, а також невелика територія півдня сучасного Мелітопольського району Запорізької області за значеннями ГТК характеризуються як сильно посушливі.

Треба відзначити, що наведена карта-схема агрокліматичного районування території України за показником посушливості ГТК добре узгоджується 3 наведеною на рис. 2 картою-схемою гідрологічного районування України [13].

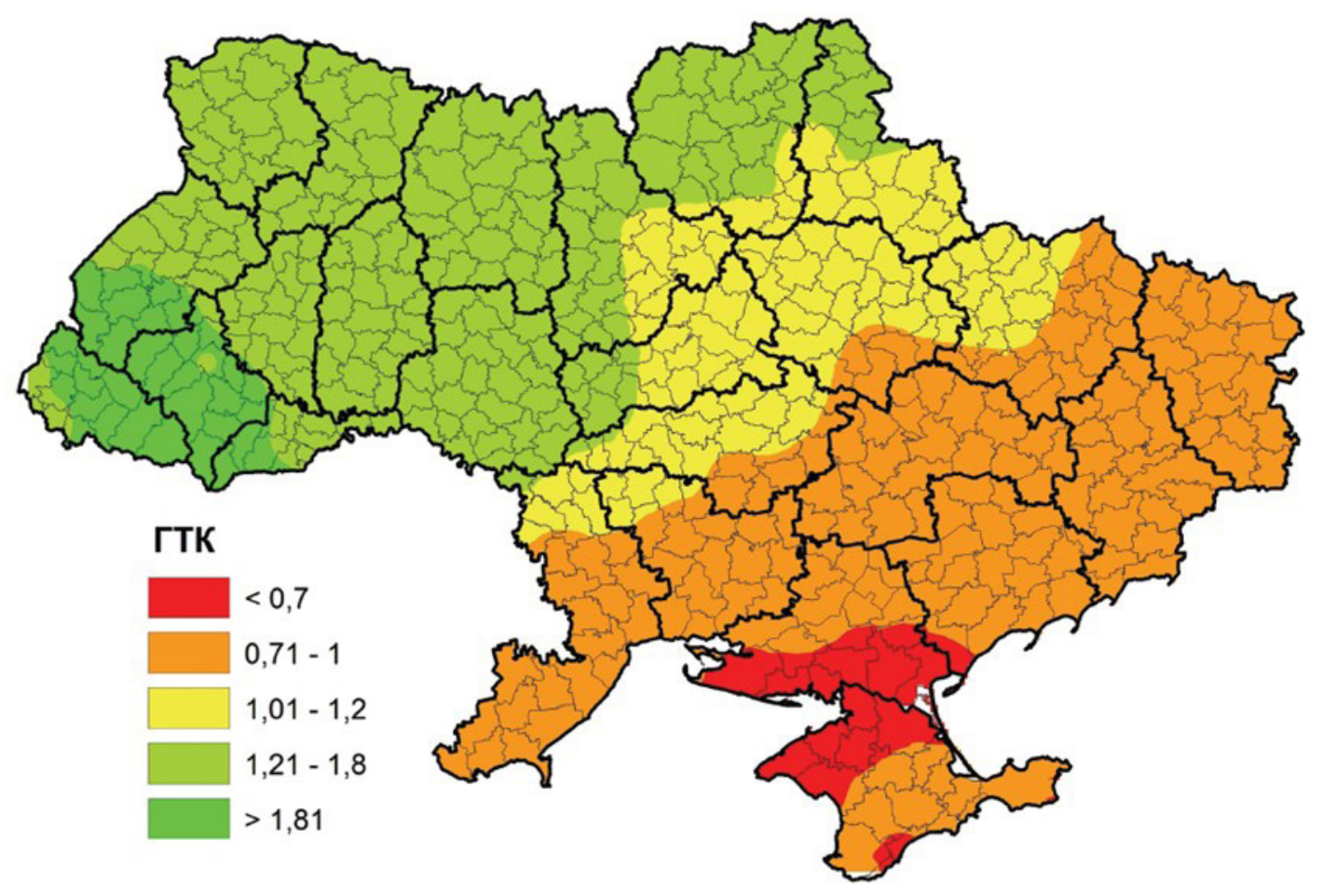

Рис. 1. Карта-схема розподілу значень ГТК ${ }_{5-9}$ за період 1961-2013 рр. [5] 


\section{Польовий А.М., Овчарук В.А., Вольвач О.В. .}

Відповідно до такого районування території із середньо й сильно посушливими умовами (за показником ГТК) перебувають у зоні недостатньої водності, а території, які характеризуються як сильно посушливі, належать до Причорноморської зони надзвичайно низької водності. У цілому ці території належать до басейнів Дунаю, річок Причорномор'я, Південного Бугу, Сіверського Дінця, річок Приазов'я та Криму, де нестача й майбутній дефіцит водних ресурсів $є$ нагальною проблемою, яка стає все актуальнішою в умовах змін клімату [6].

Дослідження посушливості проводилося для території Херсонської області. Як вхідна інформація було використано дані про середньодекадну температуру повітря та декадну суму опадів за період 2004-2018рр. Як досліджувані пункти було вибрано дві метеорологічні станції: Велика Олександрівка, яка характеризує північну частину області й знаходиться в басейні річки Інгулець, і Бехтери (південно-західна частина області). Річок у районі немає, життєдіяльність регіону забезпечує Краснознам'янський канал.

У табл. 1 представлені результати розрахунків для станції Велика Олександрівка. Тут чисельник - інтенсивність посухи за ГТК, знаменник - за $\mathrm{Md}$. Як можна бачити з таблиці, перехід через $10^{\circ} \mathrm{C}$ навесні (початок періоду активної вегетації сільськогосподарських культур) у районі метеостанції Велика Олександрівка відбувається в середньому 11 квітня, а перехід через $10^{\circ} \mathrm{C}$ восени (кінець періоду активної вегетації) - 15 жовтня.

У середньому за період 2004-2018 pр. накопичується сума активних температур $3612^{\circ} \mathrm{C}$ і сума опадів

\section{АГРОКАІМАТИЧНА ОЦІНКА ПОСУШАИВОСТІ..}

295 мм. Оцінка рівня прояву засушливості за показником ГТК виконувалась за такими градаціями: дуже сильна (екстремальна) посуха (ГТК $\leq 0,40)$; сильна посуха $(Г Т К=0,41-0,7)$; середня посуха $($ ГТК $=$ $0,71-1)$; слабка посуха $(Г T К=1,01-1,2)$; достатне зволоження (ГТК $=1,21-1,8)$; волого $(Г T К ~ \geq 1,81)$.

Можна бачити, що середньобагаторічне значення ГТК для станції Велика Олександрівка становить 0,83 , що характеризується як середньопосушливі умови. Однак 8 із 15 досліджених років за величиною ГТК були із сильною посухою (53\% всіх випадків), 3 роки були із середньою посухою (20\% від загальної кількості досліджених років), 3 роки були зі слабкою посушливістю (20\% років) і лише один рік із 15 характеризується надмірним зволоженням. Таким чином, за показником ГТК за всі досліджені роки найбільш посушливими були 2012 та 2017 рp.

Також була зроблена спроба оцінити ступінь інтенсивності посухи в період активної вегетації за показником зволоження Д.І. Шашко, критерії якого були такими: відсутність посухи (напівволога зона з $M d \geq 0,41$ ); слабка посуха (напівпосушлива зона з $M d=0,40-0,31$ ); середня посуха (посушлива зона $3 M d=0,30-0,20$ ); сильна посуха (дуже посушлива зона з $M \mathrm{~d}=0,19-0,10)$; дуже сильна посуха (напівсуха напівпустельна зона з $M d \leq 0,09$ ).

Для розрахунку показника $M d$ було визначено суму середньодекадних дефіцитів вологості грунту, яка в середньому для умов станції Велика Олександрівка становить 1475 мм. Середньобагаторічне значення критерію $M d$ становить 0,22 , що характеризує

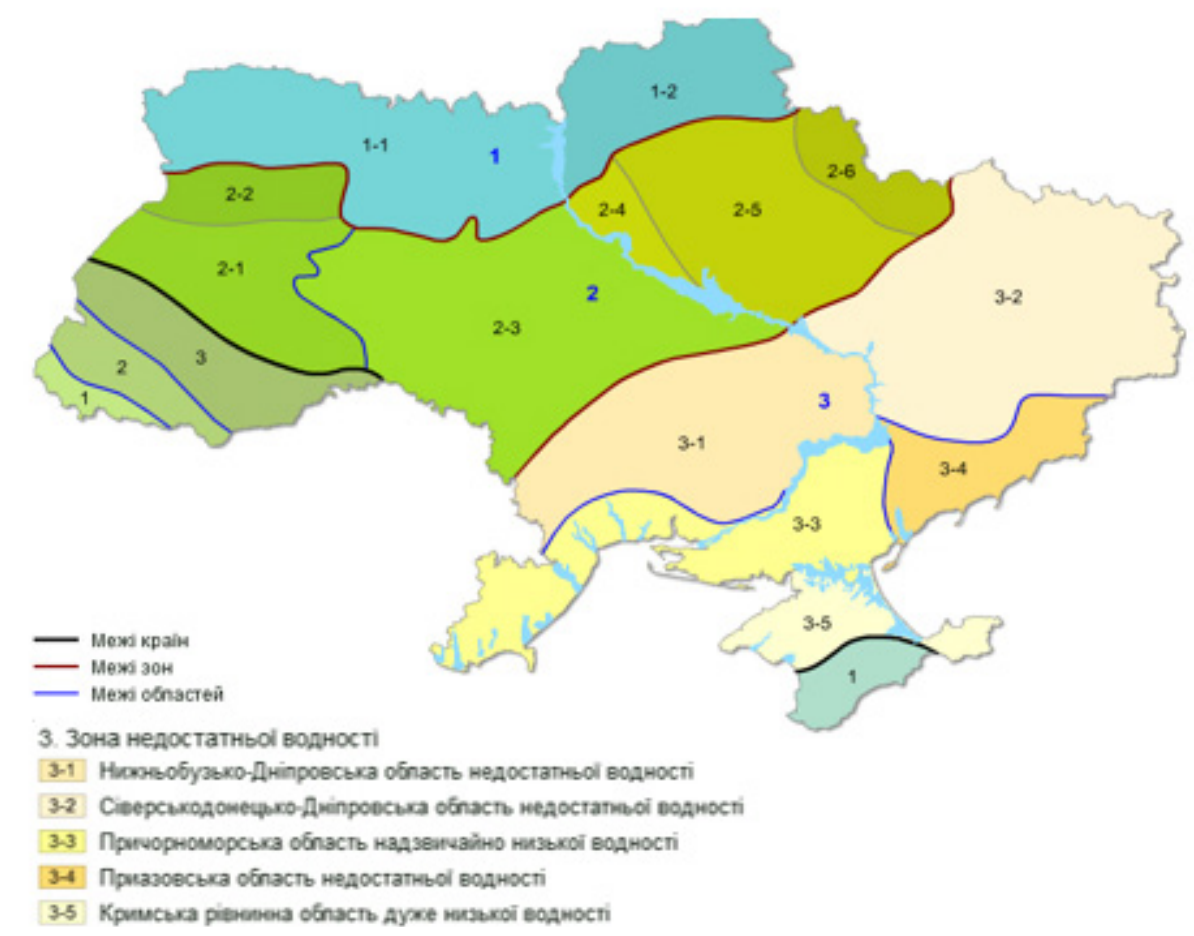

Рис. 2. Карта-схема гідрологічного районування Украӥни [13] 
Таблиця 1

Розрахунок показників посушливості на станції Велика Олександрівка

\begin{tabular}{|c|c|c|c|c|c|c|c|c|}
\hline \multirow{2}{*}{ Рік } & \multicolumn{2}{|c|}{$\begin{array}{c}\text { Дати переходу через } \\
10^{\circ} \mathrm{C} \\
\end{array}$} & \multirow{2}{*}{$\begin{array}{c}\text { Сума } \\
\text { температур } \\
\text { вище } 10^{\circ} \mathrm{C}\end{array}$} & \multirow{2}{*}{$\begin{array}{l}\text { Сума опа- } \\
\text { дів, мм }\end{array}$} & \multirow{2}{*}{$\begin{array}{c}\text { Сума } \\
\text { дефіцитів } \\
\text { вологи, мм }\end{array}$} & \multirow{2}{*}{ ГТК } & \multirow{2}{*}{ Md } & \multirow{2}{*}{$\begin{array}{c}\text { Інтенсивність } \\
\text { посухи }\end{array}$} \\
\hline & навесні & восени & & & & & & \\
\hline 2004 & 12 квітня & 09 жовтня & 3134 & 659 & 894 & 2,1 & 0,74 & волого / відсутня \\
\hline 2005 & 10 квітня & 13 жовтня & 3561 & 239 & 1325 & 0,67 & 0,18 & сильна / сильна \\
\hline 2006 & 09 квітня & 12 жовтня & 3475 & 211 & 1232 & 0,61 & 0,17 & сильна / сильна \\
\hline 2007 & 21 квітня & 14 жовтня & 3661 & 222 & 1736 & 0,61 & 0,13 & сильна / сильна \\
\hline 2008 & 07 квітня & 22 жовтня & 3560 & 340 & 1302 & 0,96 & 0,26 & середня / середня \\
\hline 2009 & 18 квітня & 22 жовтня & 3365 & 245 & 1490 & 0,73 & 0,16 & середня / сильна \\
\hline 2010 & 03 квітня & 02 жовтня & 3646 & 407 & 1364 & 1,1 & 0,30 & слабка / середня \\
\hline 2011 & 20 квітня & 12 жовтня & 3487 & 182 & 1445 & 0,52 & 0,13 & сильна / сильна \\
\hline 2012 & 08 квітня & 30 жовтня & 4243 & 200 & 1894 & 0,47 & 0,11 & сильна / сильна \\
\hline 2013 & 10 квітня & 30 жовтня & 3738 & 402 & 1460 & 1,07 & 0,28 & слабка / середня \\
\hline 2014 & 12 квітня & 17 жовтня & 3663 & 252 & 1586 & 0,69 & 0,16 & сильна / сильна \\
\hline 2015 & 14 квітня & 10 жовтня & 3463 & 270 & 1431 & 0,78 & 0,19 & середня / сильна \\
\hline 2016 & 02 квітня & 09 жовтня & 3416 & 375 & 1415 & 1,1 & 0,26 & слабка / середня \\
\hline 2017 & 13 квітня & 20 жовтня & 3665 & 179 & 1699 & 0,49 & 0,11 & сильна / сильна \\
\hline 2018 & 02 квітня & 29 жовтня & 4107 & 249 & 1857 & 0,61 & 0,13 & сильна / сильна \\
\hline Середнє & 11 квітня & 15 жовтня & 3612 & 295 & 1475 & 0,83 & 0,22 & середня / середня \\
\hline
\end{tabular}

середню посушливість. Можна бачити, що в більшості випадків показники посушливості за обома критеріями збігаються, особливо це стосується сильних посух. За критерієм $M d 10$ років із 15 (67\%) характеризуються сильно посушливими умовами. В одному 3 досліджених років посуха була відсутня, це був 2004 р., який за значенням ГТК вважається вологим. Чотири 315 досліджених років характеризуються середньопосушливими умовами, це становить $27 \%$ усіх випадків.

Оскільки для сільськогосподарських культур найбільшу небезпеку становить загальна посуха, тобто поєднання атмосферної та грунтової засух, для визначення посушливості території крім показників ГТК і $M d$ було визначено коефіцієнт зволоження Є.С. Уланової, який ураховує саме запаси продуктивної вологи в грунті. За таким показником 4315 досліджених років характеризуються відсутністю посухи й нормальним зволоженням, також 4 досліджених роки були із середньою посухою. В обох випадках це становить $27 \%$ загальної кількості років. Сильні й дуже сильні посухи за критерієм Уланової спостерігалися в 7 роках, що становить 47\% випадків, тобто можна сказати, що половина досліджуваних років характеризується наявністю сильних посух.

Розбіжність у чутливості всіх застосованих критеріїв дуже несуттєва, і за усіма критеріями посухи, що спостерігалися в районі Великої Олександрівки протягом вегетаційного періоду 2012 й 2017 pp., характеризуються як найбільш інтенсивні.

Станція Бехтери знаходиться в другому дуже посушливому агрокліматичному районі Херсонської області, де знаходяться найбільші зрошувані площі. Представляє інтерес визначення кількості й інтенсивності посух протягом вегетаційного періоду й у районі станції. Результати розрахунків критеріїв ГТК і $M d$ надаються в табл. 2.

Період активної вегетації в середньому починається в районі Бехтер 12 квітня, а закінчується 18 жовтня. У середньому за цей період накопичується сума активних температур, що становить $3677^{\circ} \mathrm{C}$, а середньобагаторічна сума опадів становить 241 мм. Середньобагаторічне значення ГТК 0,66 дозволяє характеризувати досліджувану територію як сильно посушливу, але протягом 15 років величини ГТК коливалися від 0,34-0,37 (екстремальна посуха) у 2015 та 2011 рр. до 1,16-1,17 (слабка посушливість) у 2004 та 2010 рр.

315 досліджених років за величиною ГТК були 2 роки зі слабкою посухою (13\% всіх випадків), 7 років були із сильною посухою (47\% від загальної кількості досліджених років), 4 роки були із середньою посушливістю (27\% років) і два роки з 15 характеризуються екстремальною посушливими умовами (також 13\%).

Аналіз показника посушливості $M d$ Шашко дозволяє зробити висновок, що середньобагаторічне значення такого критерію становить 0,19, що відповідає сильній посушливості. За таким показником територія дослідження характеризується як і за показником ГТК. Вісім із 15 років характеризуються як сильно посушливі, це становить понад половину випадків, 4 роки були середньопосушливими, по одному року було із сильною посухою, слабкою посухою та взагалі 3 нормальним зволоженням (без посух).

Порівняння посушливих умов за обома показниками свідчить про те, що вони досить чітко визначають сильні й дуже сильні посухи. Так, у дев'яти роках із 15 за обома показниками умови характеризуються як сильно й екстремально сильно посушливі. 
Польовий А.М., Овчарук В.А., Вольвач О.В. ... АГРОКАІМАТИЧНА ОЦІНКА ПОСУШАИВОСТІ..

Таблиця 2

Розрахунок показників посушливості на станції Бехтери

\begin{tabular}{|c|c|c|c|c|c|c|c|c|}
\hline \multirow{2}{*}{ Рік } & \multicolumn{2}{|c|}{$\begin{array}{c}\text { Дати переходу через } \\
10^{\circ} \mathrm{C}\end{array}$} & \multirow{2}{*}{$\begin{array}{c}\text { Сума } \\
\text { температур } \\
\text { вище } 10^{\circ} \mathrm{C}\end{array}$} & \multirow{2}{*}{$\begin{array}{c}\text { Сума } \\
\text { опадів, мм }\end{array}$} & \multirow{2}{*}{$\begin{array}{c}\text { Сума } \\
\text { дефіцитів } \\
\text { вологи, мм }\end{array}$} & \multirow{2}{*}{ ГТК } & \multirow{2}{*}{ Md } & \multirow{2}{*}{$\begin{array}{c}\text { Інтенсивність } \\
\text { посухи }\end{array}$} \\
\hline & навесні & восени & & & & & & \\
\hline 2004 & 13 квітня & 14 жовтня & 3278 & 381 & 936 & 1,16 & 0,41 & слабка / відсутня \\
\hline 2005 & 11 квітня & 14 жовтня & 3596 & 183 & 1241 & 0,51 & 0,15 & сильна / сильна \\
\hline 2006 & 14 квітня & 14 жовтня & 3484 & 141 & 1202 & 0,41 & 0,12 & сильна / сильна \\
\hline 2007 & 20 квітня & 25 жовтня & 3756 & 155 & 1466 & 0,41 & 0,11 & сильна / сильна \\
\hline 2008 & 10 квітня & 27 жовтня & 3669 & 315 & 1244 & 0,86 & 0,25 & середня / середня \\
\hline 2009 & 19 квітня & 26 жовтня & 3613 & 177 & 1304 & 0,49 & 0,14 & сильна / сильна \\
\hline 2010 & 03 квітня & 03 жовтня & 3694 & 431 & 1118 & 1,17 & 0,39 & слабка / слабка \\
\hline 2011 & 19 квітня & 13 жовтня & 3490 & 128 & 1251 & 0,37 & 0,10 & дуже сильна / сильна \\
\hline 2012 & 13 квітня & 30 жовтня & 4080 & 269 & 1446 & 0,66 & 0,19 & сильна / сильна \\
\hline 2013 & 10 квітня & 30 жовтня & 3738 & 267 & 1313 & 0,71 & 0,20 & середня / середня \\
\hline 2014 & 11 квітня & 20 жовтня & 3723 & 322 & 1403 & 0,87 & 0,23 & середня / середня \\
\hline 2015 & 14 квітня & 13 жовтня & 3587 & 121 & 1358 & 0,34 & 0,09 & $\begin{array}{c}\text { дуже сильна / } \\
\text { дуже сильна }\end{array}$ \\
\hline 2016 & 02 квітня & 11 жовтня & 3700 & 335 & 1265 & 0,91 & 0,26 & середня / середня \\
\hline 2017 & 26 квітня & 25 жовтня & 3558 & 201 & 1332 & 0,56 & 0,15 & сильна / сильна \\
\hline 2018 & 02 квітня & 31 жовтня & 4191 & 195 & 1684 & 0,46 & 0,12 & сильна / сильна \\
\hline Середнє & 12 квітня & 18 жовтня & 3677 & 241 & 1304 & 0,66 & 0,19 & сильна / сильна \\
\hline
\end{tabular}

Середньобагаторічне значення критерію $\mathrm{K}_{\mathrm{y}}$, що становить 16 , також характеризує досліджуваний район як сильно посушливу територію, як і за попередніми показниками. Дуже посушливі умови за таким показником відзначалися в 6 роках $(40 \%$ випадків), сильні посухи - у 7 роках (47\% випадків), по одному року були із середньою посушливістю та 3 нормальним зволоженням. Для станції Бехтери також слід відзначити дуже добре збігання ступеня посушливості території за різними критеріями.

Як вже зазначалося, ступінь зволоження вегетаційного періоду, особливо в умовах Півдня України, суттєво впливає на ріст, розвиток і формування врожаїв сільськогосподарських культур. Також ступінь зволоження впливає на інтенсивність емісії парникових газів із грунту. Визначено, що найбільш інтенсивна емісія $\mathrm{N}_{2} \mathrm{O}$ спостерігалась у періоди високого рівня зволоження грунту, коли створювались анаеробні умови в грунті [14]. Тому питання дослідження умов посушливості й зволоження актуальне в багатьох аспектах.

Для дослідження динаміки показника посушливості ГТК і визначення тенденції його мінливості нами було використано метод гармонійних вагів. Такий метод широко використовується для аналізу часових рядів, а в агрометеорології його першим запропонував А.М. Польовий [15].

$\mathrm{y}$ методах прогнозу за таким часовим рядом робиться припущення щодо виду тренду. Форма тренду та його параметри визначаються в результаті найкращої (за будь-яким зі статистичних критеріїв) функції із числа тих, що є. У порівнянні з такими методами метод гармонійних вагів має ту перевагу, що тут необхідності в таких припущеннях немає.
Принцип методу гармонійних вагів полягає в тому, що значення часового ряду зважують так, щоб пізніші спостереження мали більшу вагу, тобто вплив пізніших спостережень повинен сильніше відбиватися на тенденції врожайності, ніж вплив більш ранніх.

На рис. 3 представлена динаміка величин ГТК для станцій Велика Олександрівка й Бехтери, а також лінії тренду. Можна бачити, що криві ходу значень ГТК для обох станцій протягом досліджуваного періоду дуже схожі, а максимальні й мінімальні значення ГТК спостерігаються в одні й ті ж роки. Так, найсприятливішими були для обох станцій умови 2010 р., коли величини ГТК наближалися до значення 1,21 , що характеризує умови достатнього зволоження. Також досить сприятливим у районі Бехтер був 2004 р., але водночас у районі Великої Олександрівки спостерігалися умови надмірного зволоження, які могли бути несприятливими для вирощування деяких сільськогосподарських культур. Найбільш посушливими для обох станцій виявилися 2011 та 2017 рр., коли значення ГТК не перевищували 0,5 .

Також можна бачити, що 3 початку досліджуваного періоду лінії тренду для двох станцій практично паралельні. 32016 р. спостерігається зменшення трендової компоненти, що свідчить про поступове зростання посушливості досліджуваної території.

За допомогою методу гармонійних вагів можна визначити тенденцію досліджуваної величини на наступний рік, виходячи 3 різної ваги перших та останніх величин досліджуваного часового ряду. Нами було визначено величини тенденцій. Для обох територій вони від'ємні й становлять $-0,01$. Це означає, що можливе зменшення величин ГТК на території Херсонської області щороку на 0,01 у порівнянні 


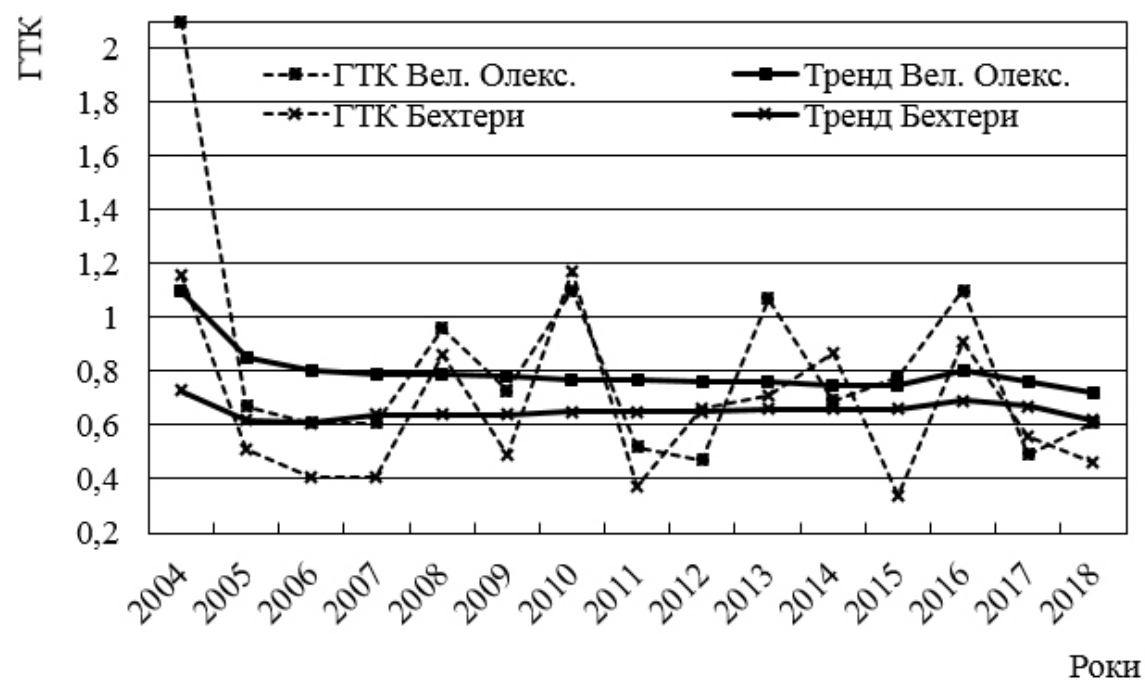

Рис. 3. Динаміка щзорічних значень ГТК і лінії тренду на станціях Велика Олександрівка й Бехтери

3 нинішніми значеннями. Це досить суттєве зменшення (наприклад, 0,01 - це різниця між показником середньої $(\Gamma T К=0,71)$ і сильної $(\Gamma T К=0,70)$ посухи.

Головні висновки. Ураховуючи означене, можна зробити висновок, що умови періоду активної вегетації на території Скадовського й Бериславського районів Херсонської області, що належать до Причорноморської зони надзвичайно низької водності, за теперішнього часу $€$ середньо й сильно посушливими. Крім того, спостерігається тенденція до зростання посушливості досліджуваної теритоpiï. Оскільки сільськогосподарське виробництво на території традиційно орієнтоване на використання зрошення, необхідно вживати заходи щодо запобігання за нинішніх умов і за умов, що очікуються у зв'язку зі змінами клімату, втрат майбутніх урожаїв.

Перспективи використання результатів дослідження. Отримані результати будуть використані під час подальшого виконання науково-дослідної роботи кафедр гідрології суші й агрометеорології та агроекології Одеського державного екологічного університету. Перспективні аналогічні дослідження в умовах реалізації відомих кліматичних сценаріїв змін клімату, а також визначення можливостей майбутнього зрошення за умов, коли водні ресурси зазнають негативного впливу змін клімату.

\section{Література}

1. Dynamics of Socioeconomic Exposure, Vulnerability and Impacts of Recent Droughts in Argentina / G. Naumann, W.M. Vargas, P. Barbosa, V. Blauhut, J. Spinoni, J.V. Vogt. Geosciences. 2019. Vol. 9 (1). P. 39. DOI: 10.3390/Geosciences 9010039.

2. Edwards B., Gray M., Hunter B. The social and economic impacts of drought. Australian Journal of Social Issues. 2019. Vol. 54. Issue 1. P. 22-31. DOI: https://doi.org/10.1002/ajs4.52.

3. Chen X., Su Y., Fang X. Social impacts of extreme drought event in Guanzhong area, Shaanxi Province, during $1928-1931$. Climatic Change. 2021. No. 164. P. 27. DOI: https://doi.org/10.1007/s10584-021-02978-5.

4. Польовий А.М. Сільськогосподарська метеорологія : підручник. Одеса : «ТЕС», 2012. 629 с.

5. Адаменко Т.І. Агрокліматичне зонування території України з врахуванням зміни клімату. Київ : ТОВ «РІА» БЛІЦ, 2014.18 с.

6. Мінімальний та екологічний стік річок у зоні недостатньої водності України / Л.В. Кущенко, В.А. Овчарук, О.М. Прокоф'єв, М.В. Гопцій, Г.М. Андреєвська. Екологічні науки. 2021. № 2 (35). С. 30-36. DOI: https://doi.org/10.32846/2306-9716/2021. есо.2-35.5.

7. Хохлов В.М., Єрмоленко Н.С. Просторово-часова мінливість посух в Східноєвропейському секторі в умовах глобальних змін клімату. Украӥнський гідрометеорологічний журнал. 2012. № 11. С. 128-134.

8. Семенова І.Г. Синоптичні та кліматичні умови формування посух в Україні : монографія. Харків : ФОП Панов А.М., 2017. $236 \mathrm{c}$.

9. Семенова І.Г., Польовий А.М. Прогностичний розподіл посух теплого сезону по території України у 2021-2050 pp. Bicнuк ХарківськогоначіональногоуніверситетуіменіВ.Н.Каразіна. Серія«Геологія.Географія. Екологія». 2020.Вип.53.С.169-179.

10. Лобода Н.С., Божок Ю.В. Шляхи визначення можливої гідрологічної посухи за метеорологічними даними в умовах змін клімату для річок північно-західного Причорномор'я. Геополітика та екогеодинаміка регіонів. 2014. Т. 10. Вип. 1. С. $281-289$.

11. Посухи в контексті змін клімату України / В.М. Писаренко, П.В. Писаренко, В.В. Писаренко, О.О. Горб, Т.О. Чайка. Вісник Полтавської державної аграрної академії. 2019. Вип. 1. С. 134-146. DOI: 10.31210/visnyk2019.01.15.

12. Керівництво для підготовки Планів управління посухами. Розробка і впровадження в контексті Водної Рамкової Директиви ЄС. Глобальне водне партнерство Центральної та Східної Свропи, 2015. 48 c. https://www.gwp.org/globalassets/global/gwpcee_files/idmp-cee/idmp-guidelines-ukrainian-web.pdf. 
Польовий А.М., Овчарук В.А., Вольвач О.В. ... АГРОКАІМАТИЧНА ОЦІНКА ПОСУШАИВОСТІ...

13. Руденко Л.Г., Чабанюк В.С., Бочковська А.І. Національний атлас України. Київ : Інститут географії Національної академії наук України і Товариство з обмеженою відповідальністю «Інтелектуальні системи ГЕО», 1999-2000. UPL: https://atlas.igu.org.ua/elektr_versiya.html.

14. Польовий А.М., Божко Л.Ю. Моделювання динаміки емісії парникових газів $\left(\mathrm{CO}_{2}, \mathrm{~N}_{2} \mathrm{O}\right)$ із грунтів агроекосистем. Вісник Харківського національного університету імені В.Н. Каразіна. Серія «Геологія. Географія. Екологія». 2021. Вип. 54. С. 329-344. DOI: https://doi.org/10.26565/2410-7360-2021-54-25.

15. Полевой А.М. Прикладное моделирование и прогнозирование продуктивности посевов. Ленинград : Гидрометеоиздат, 1988. 319 с. 


\title{
ПОВОДЖЕННЯ З ВІДХОДАМИ
}

УДК 502.174:332.142.6 (043.5)

DOI https://doi.org/10.32846/2306-9716/2021.eco.6-39.28

\section{АНАМІЗ СУЧАСНОГО ДОСВІДУ ТА НАПРЯМІВ ВИРІШЕННЯ ПРОБАЕМ УПРАВАIННЯ ТВЕРДИМИ КОМУНАМЫНИМИ ВІДХОДАМИ}

\author{
Коцюба І.Г., Лефтер Ю.О., Нонік Л.Ю., Сльнікова Т.О., Герасимчук О.Л. \\ Державний університет «Житомирська політехніка» \\ вул. Чуднівська, 103, 10005, Житомир \\ chaszmin30@gmail.com,olena_1409@ukr.net
}

\begin{abstract}
Розглянуто світовий досвід у вирішенні питань управління твердими комунальними відходами. Актуальність проблеми зумовлена зростанням кількості відходів, які накопичуються не лише на поверхні грунту, але й у надмірних кількостях у водах світового океану. Виділено провідні шляхи зменшення об’ємів відходів, управління відходами та долучення місцевих муніципалітетів до їх реалізації.

Метою статті $є$ аналіз та оцінка міжнародного досвіду у вирішенні екологічних проблем, що пов'язані зі зростанням та утилізацією твердих відходів. Для досягнення поставленої мети використані наукові методи статистичного аналізу і порівняння.

Результати. Проаналізовано досвід європейських країн та США у сфері поводження із твердими відходами. Встановлено, що захоронення як спосіб утилізації відходів втрачає свою актуальність, і частка країн, які його застосовують, поступово зменшується. Натомість зростає кількість відходів, що використовуються як джерело вторинної сировини для виробництва нових товарів. Значна частина країн СС використовує відходи як джерело енергії. Актуальними є також методи компостування та рециклінгу. Розглянуто питання поводження зі пластиковими відходами і використання біопластику та переробленого пластику як пакувальних матеріалів. Розглянуто загальнодержавну проблему накопичення відходів в Україні, яка потребує системного та нагального вирішення.

Висновки. Основним завданням України, спираючись на вагомий досвід європейських країн у сфері поводження з відходами та комплексного вирішення практичних питань управління потоками відходів, $\epsilon$ організація раціонального поводження з відходами, що відповідає сучасним еколого-економічним та ресурсним вимогам, використання відходів як джерела сировини, забезпечення екологічної безпеки, перехід від полігонного захоронення відходів до їх промислової переробки. Ключові слова: довкілля, тверді відходи, пластик, утилізація відходів, переробка відходів, поводження з відходами.
\end{abstract}

Analysis of current experience and directions of solving problems of solid municipal waste management. Kotsiuba I., Lefter Yu., Nonik L., Yelnikova T., Herasymchuk O.

The world experience in solving the issues of solid waste management and administration has been reviewed. The urgency of the problem is due to the growing amount of waste that accumulates not only on the soil surface, but also in excessive amounts in the waters of the oceans. Leading ways to reduce waste, manage waste and involve local municipalities in their implementation have been identified.

The aim of the article is to analyze and evaluate international experience in solving environmental problems related to the growth and disposal of solid waste. Scientific methods of statistical analysis and comparison were used to achieve this goal.

Results. The experience of European countries and the United States in the field of solid waste management is analyzed. It is established that landfilling as a method of waste disposal is losing its relevance and the share of countries that use it is gradually decreasing. Instead, the amount of waste used as a source of secondary raw materials for the production of new goods is growing. Many EU countries use waste as an energy source. Composting and recycling methods are also relevant. The issues of plastic waste management and the use of bioplastics and recycled plastics as packaging materials are considered. The national problem of waste accumulation in Ukraine, which needs a systemic and urgent solution, is considered.

Conclusions. The main task of Ukraine, based on the significant experience of European countries in the field of waste management and comprehensive solutions to practical issues of waste flow management, is the organization of waste management that meets modern environmental, economic and resource requirements, use of waste as a source of raw materials ensuring environmental safety, the transition from landfill to their industrial processing. Key words: environment, solid waste, plastic, waste disposal, waste processing, waste management.

Постановка проблеми. Зростаюча кількість відходів є ключовою екологічною, соціальною та економічною проблемою людства. Лише в країнах Європейського союзу щорічно утворюється близько 3 млрд т відходів, що становить майже 6 т твердих відходів на кожного європейця $[1,2]$. Водночас у країнах СС відзначається послаблення зв'язку між економічним зростанням та виробництвом відходів
[1]. Управління відходами стає дедалі складнішим, оскільки стандарти на захоронення та спалювання ТКВ стали більш жорсткими. Отже, зменшення кількості утворення відходів $є$ ефективним варіантом у досягненні мети ефективного управління відходами.

Актуальність дослідження. У всьому світі проблема утилізації відходів із кожним роком стає все більш актуальною. Поховання на сміттєвих полігонах 
Коцюба І.Г., Лефтер Ю.О., Нонік Л.Ю....

(звалищах) має суттєвий недолік - вилучення з господарського обороту значних земельних територій. Важливим етапом визнання токсичних властивостей, небезпечного впливу на здоров'я людства та на екосистеми стійких органічних забруднювачів стало підписання Стокгольмської конвенції про стійкі органічні забруднювачі (2001) [3]. Усвідомлюючи нагальність вирішення глобальної проблеми накопичення відходів, Україна підписала (2001) та ратифікувала (2007) Стокгольмську конвенцію. Угода про асоціацію між Україною та ЄС у тому числі відображає спільні зусилля у вирішенні питань поводження з відходами [4].

Аналіз останніх досліджень i публікацій. Проблема накопичення, поводження та утилізації відходів досліджується у працях зарубіжних та вітчизняних науковців. Так Р. Гейєр, Дж. Джамбек, К. Лаванда $[5,6]$ проаналізували ситуацію поводження із пластиковими відходами в різних краінах. Можливість використання ТПВ як цінної енергетичної сировини досліджували Д. Мойя, Ч. Альдас, Г. Лопес, Й. Малінаускайте, Х. Йоухара, П. Станчев $[7,8]$. Серед вітчизняних науковців Є. Михайлова, Г. Панчева, Г. Резніченко, І. Коцюба, Ю. Подчашинський, С. Лико, С. Лук'янова присвятили свої дослідження питанням поводження із твердими побутовими відходами, прогнозування та моделювання їх накопичення в Україні $[9,10]$.

Виділення не вирімених раніше частин загальної проблеми, котрим присвячується означена cmammя. Проблема продукування, накопичення відходів та поводження 3 ними набуває планетарного масштабу. Наукові дослідження головним чином спрямовані на пошук шляхів зменшення числа від-

\section{АНААІЗ СУЧАСНОГО ДОСВІДУ...}

ходів, які продукує людина у процесі життєдіяльності, а також на ефективне управління ТКВ. Проте більшість досліджень мають розрізнений характер, а узагальнення сучасного міжнародного досвіду та напрямів вирішення проблем управління ТКВ знаходиться поза увагою науковців.

Методологічне або загальнонаукове значення. Метою написання статті $є$ розгляд та проведення оцінки міжнародного досвіду у вирішенні екологічних проблем, що пов'язані зі зростанням та утилізацією твердих комунальних відходів. Для реалізації поставленої мети використані наукові методи статистичного аналізу і порівняння.

Виклад основного матеріалу. Незважаючи на докладені зусилля, 3 одного боку, науковців, а 3 іншого - урядів провідних держав світу, у тому числі країн $\mathrm{CC}$, спостерігається поступове зростання утворення ТКВ. За даними Євростату, ситуація в державах-членах $\mathrm{CC} є$ різною (рис. 1) $[1,2]$. Найбільше ТКВ утворюється у Данії (781 кг/ людину), а найменше - у Польщі (315 кг/людину) та Румунії (272 кг/людину).

Так, загалом у ЄС у 2019 році $30 \%$ відходів перероблено, $17 \%$ компостовано, $28 \%$ спалено і $24 \%$ захоронено. Слід відзначити, що поступово зменшується частка захоронених відходів та збільшується число країн, що повністю відмовляються від захоронення як методу поводження з відходами.

У таблиці 1 узагальнено досвід європейських країн у сфері безпечного поводження із твердими комунальними відходами.

Аналіз даних вказує на те, що більшість країн $Є С$ сортує та переробляє ТКВ із метою отримання цінної сировини та енергії. Щоб досягти цілей сталого роз-

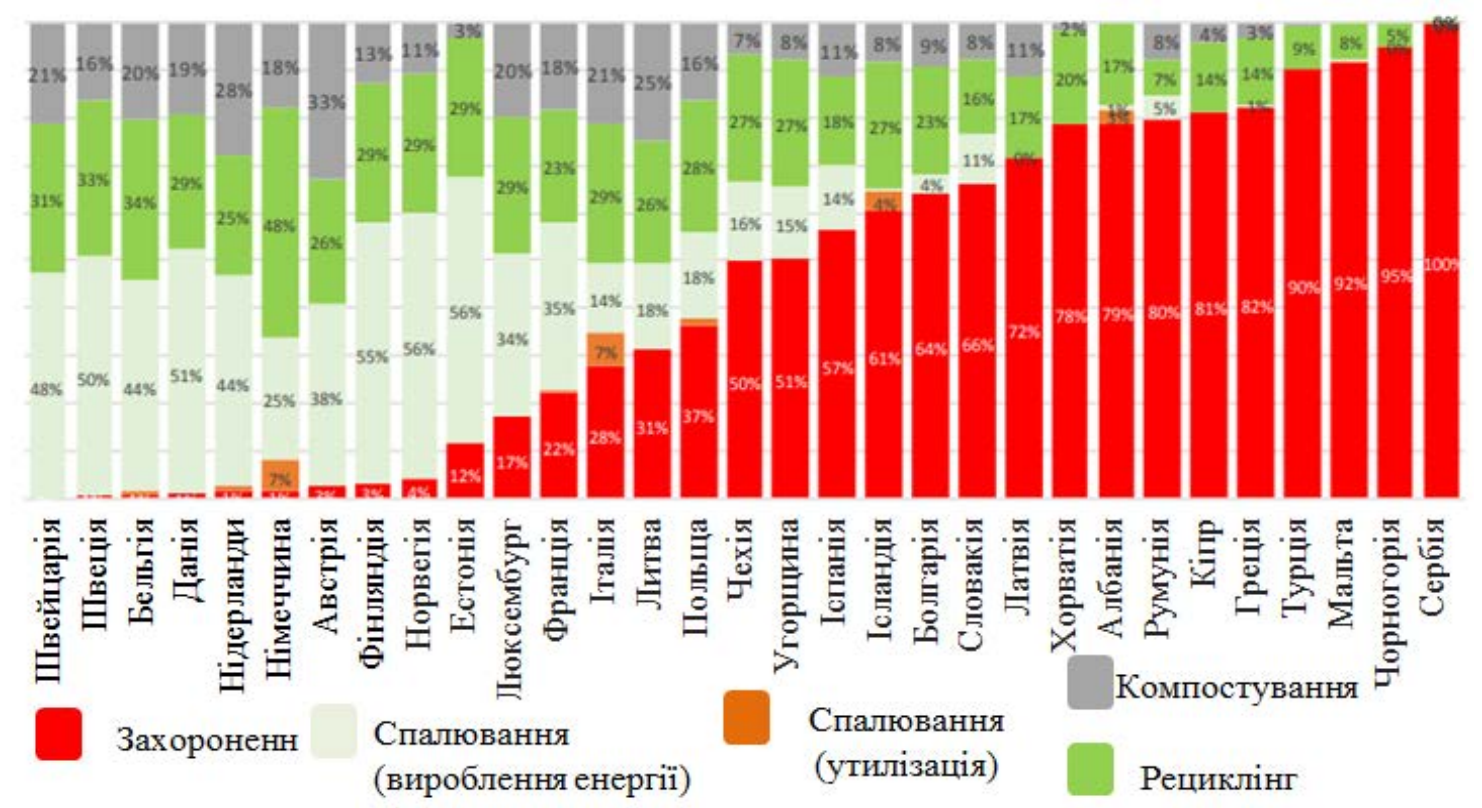

Рис. 1. Структура поводження з відходами в краӥнах СС (станом на 2019 р.) Джерело: дані Євростату [11] 
Досвід свропейських країн в управлінні відходами

\begin{tabular}{|c|l|}
\hline Країна & \multicolumn{1}{|c|}{ Особливості } \\
\hline Німеччина & $\begin{array}{l}\text { Відмова від полігонів твердих побутових відходів. Кошти інвестуються у такі методи поводження } \\
\text { 3 відходами, як сортування, спалювання та переробка. Утилізація відходів здійснюєтья шляхм їх } \\
\text { сортування та подальшої переробки. Відходи, які не підлягають переробці, спалюються з отриманням } \\
\text { тепла та електроенергії. Впроваджена нова система збору сміття жодних санкцій не передбачає. }\end{array}$ \\
\hline Швейцарія & $\begin{array}{l}\text { Заборонені сміттєві полігони. Кошти інвестуються у такі методи поводження з відходами, як сортування, } \\
\text { спалювання та переробка. Сортування відхдів. Повторно використовуються відходи жерстяних банок } \\
\text { та скла. Політикою Швейцарії передбачається штрафування за викидання невідсортованих відходів. }\end{array}$ \\
\hline Франція & $\begin{array}{l}\text { Система утилізації відходів передбачає сортування відходів на дві фракції: вторинну сировину } \\
\text { та інші відходи. Передбачаються урни для одягу. Не передбачає покарань чи заохочень. }\end{array}$ \\
\hline Швеція & $\begin{array}{l}\text { Відмова від полігонів твердих побутових відходів. Кошти інвестуються у такі методи поводження } \\
\text { з відходами, як сортування, спалювання та переробка. Сортування відходів по фракціях, а також } \\
\text { спалювання з отриманням тепла та електроенергії. Є 32 сміттєспалювальні заводи. Політика країни } \\
\text { спрямована на інформаційну кампанію. Перевага віддається переробці відходів. }\end{array}$ \\
\hline Польща & $\begin{array}{l}\text { У країні здійснюється обов'язкове сортування сміття усіма жителями на 5 компонентів, які згодом } \\
\text { утилізуються як вторинна сировина. Відходи, які неможливо переробити, захоронюються на полігонах } \\
\text { ТПВ, на яких передбаченні системи дегазації полігонів з отриманням тепла та електроенергії. } \\
\text { Передбачається переробляти та готувати до повторного використання не менше 50\% відходів у країні. }\end{array}$ \\
\hline \multirow{2}{*}{ Словенія } & $\begin{array}{l}\text { Всі відходи забирає місцева муніципальна компанія. Проте лише за змішані та органічні відходи } \\
\text { платить житель. Доступ до загальнодоступних контейнерів для сміття забезпечується за допомогою } \\
\text { електронної картки жителя. Мешканці індивідуальних будинків мають свої власні контейнери для } \\
\text { відходів та сплачують за відходи залежно від обсягів контейнерів. Менше 5\% відходів захоронюються. }\end{array}$ \\
\hline
\end{tabular}

витку, економічного зростання та чистого довкілля, більшість держав розробляють національні програми та стратегії поводження з відходами.

Наприклад, Департаментом навколишнього природного середовища та продовольчих і сільськогосподарських справ Великобританії розроблено Стратегію поводження з відходами до 2050 року "Our waste, our resources: a strategy for England" [12]. Стратегія передбачає збереження запасів матеріальних ресурсів до 2050 року шляхом зменшення відходів, сприяння ефективному використанню ресурсів та, як наслідок, переходу до кругової економіки.

Однією 3 найбільш поширених у міжнародній практиці є модель координаційного агента як відокремленої структури або неприбуткової компанії 3 винятковими або частковими правами для поводження 3 відходами, що утворюються на певній території. Модель поєднує в собі тенденцію міських органів влади досягти цільових показників із переробки відходів і зменшення їх поховання на полігонах у найбільш економний спосіб [2].

У міжнародних корпораціях постає питання зменшення частки матеріалів пакування під час «передачі» іiі споживачам. До цієї ініціативи долучаються великі корпорації, в тому числі LSDH, Auchan Retail France, Danone, L'Oréal, Biscuits Bouvard, Coca-Cola European Partners, Nestlé France та Unilever, Carrefour, які підписали договір про поетапну відмову від пластикової упаковки у своїх магазинах. Документ спрямований на зменшення кількості використання пластику більш ніж на 140 т на рік $[11,12,14]$.

Компанії вживають конкретних заходів для запобігання утворенню відходів: одноразові картонні коробки та ящики для упаковки замінюються на багаторазові пластикові; використовуються презентаційні дисплеї, «готові до продажу», в яких упаковка призначена для більш тривалого використання; дерев'яні піддони (вагою 20 кг) на складах замінюються на піддони 3 переробленого картону вагою лише 3,3 кг тощо. Це дасть змогу зменшити використання пластику на понад 120 т на рік $[12,14]$.

Щороку європейці утворюють 25 млн т пластикових відходів, менше третини $з$ яких потрапляють на переробку [2, 11]. Більшість відходів потрапляють у води морів та океанів (табл. 2), що є небезпечним для морських мешканців. Тому актуальним $є$ питання розроблення наукових, управлінських та економічних засад збереження водних об'єктів від антропогенного впливу. Так, недержавна екологічна організація зі штаб-квартирою у Нідерландах The Ocean Cleanup [13] запустила систему очистки океану від пластику System 001. Розробники планують, що впродовж 5 років можна буде усунути $50 \%$ забруднення, а до 2040 року - 90\%. Проте очищення поверхні океану від пластику не є повним вирішенням проблеми, адже різний пластик плаває на різних глибинах в океані, як бачимо з таблиці 2. Для того щоб зупинити процес потрапляння пластику в океан, необхідно витратити 95\% зусиль, а щоб очистити - $5 \%$.

Одночасно планується зменшення шкоди довкіллю шляхом утилізації відходів та відмови від використання пластикового посуду та пакування. У Франції, Аргентині, Японії, Австралії, Сгипті, Італії та інших країнах світу були введені обмежувальні заходи щодо поліетиленових пакетів. Введена заборона на безкоштовні ПЕ-пакети 3 невеликими уточненнями: дозволені тонкі пакети без ручок, що використовуються для упаковки сирих продуктів і напівфабрикатів. Досвід 
Частка різних видів морського сміття $(\geq 5 \mathrm{~mm})$

в його загальному складі, в товщі води, на дні, на поверхні і на пляжах, \% *

\begin{tabular}{|c|c|c|c|c|c|}
\hline Види морського сміття & Загальний склад, \% & У товщі води, \% & На дні, \% & На поверхні, \% & На пляжах, \% \\
\hline Біотичний & 1,3 & & & & \\
\hline Рибальство (метал) & 1,3 & & & & \\
\hline Рибні запаси & 3,1 & & 10,74 & & \\
\hline Склокераміка & 3,2 & 5,63 & & & 4,02 \\
\hline Метал & 3,71 & 9,59 & 8,77 & & \\
\hline Різні типи & 4,8 & & & 6,58 & 5,71 \\
\hline Папір / картон & 1,7 & & & & \\
\hline Мотузка & 1,5 & & 3,7 & & \\
\hline Текстиль / тканини & 1,2 & & & & \\
\hline Деревина & 2,3 & & & 3,57 & \\
\hline Пачки цигарок & 2,9 & & & & \\
\hline Пластик, всього & 59,74 & 51,75 & 47,06 & 76,87 & 57,67 \\
\hline \multicolumn{6}{|l|}{ В тому числі: } \\
\hline Рибальство (пластик) & 8,03 & 22,93 & 11,97 & 3,21 & 8,29 \\
\hline Пластикові волокна & 7,05 & & & & \\
\hline Поліетиленова плівка & 8,4 & & & & \\
\hline Пластмаса в гранулах & 1,3 & & & & \\
\hline Пінополістирол & 4,6 & & & 3,0 & 7,05 \\
\hline Інше & 4,0 & & & & \\
\hline
\end{tabular}

Складено на основі даних LITTERBASE. URL: http://litterbase.awi.de/

* Порожня клітинка означає, що частка цього виду сміття вкрай незначна в цьому стовпці

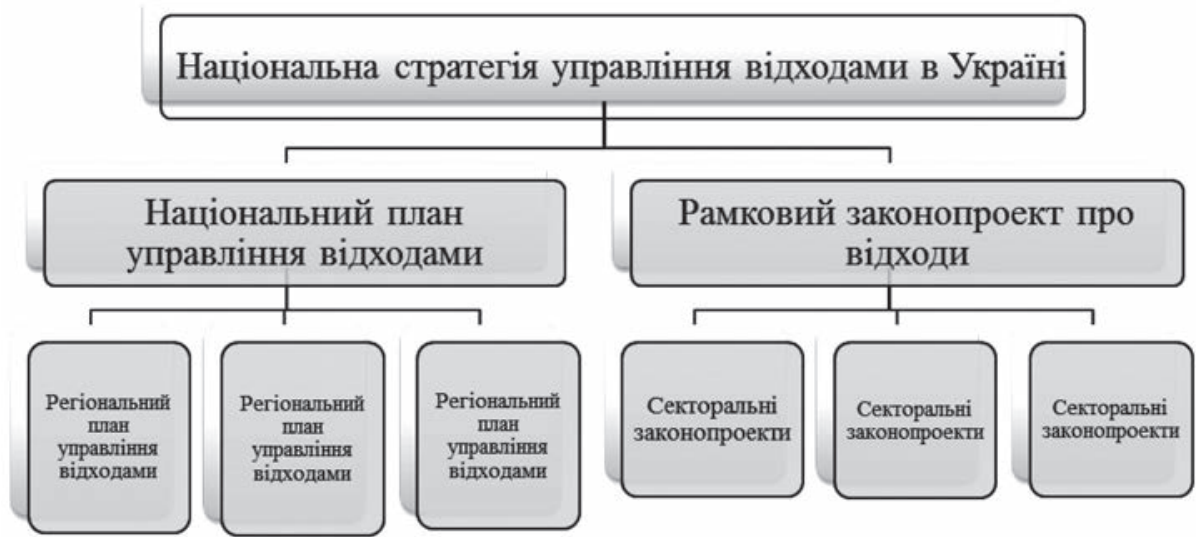

Рис. 2. Інструменти реалізащиї стратегії управління відходами в Украӥні до 2030 року

цих країн показує, що споживання пакетів різко падає $[2,12,14]$. Спостерігається збільшення біорозкладного пластику, споживання якого становить всього близько 0,1-0,2\% від загального споживання пластмаси в ЄС. Щорічному зростанню споживання біопластику сприяє переповненість звалищ, законодавча база, викиди парникових газів, збільшення сміття в морі. Розвиток сучасних технологій спрямований не лише на переробку відходів упаковки, але і на зниження іiі ваги [13 ].

У 2006 році в США було розроблено технологію, яка передбачає виробництво пластикових пляшок із стовідсотково використаного поліетилену, причому $25 \%$ - це пластикові відходи зі «сміттєвого острова» в Тихому океані. Відомі транснаціональні компанії, такі як Coca-Cola та PepsiCo, поступово переходять на випуск своїх безалкогольних напоїв у тарі iз біопластику та переробленого пластику. Компанія PepsiCo в тестовому режимі планує виготовити 200 тисяч пляшок виключно з біопластику [13].

В Україні тільки за 2019 рік накопичилося майже 53 млн м ${ }^{3}$ ТКВ, або понад 10 млн т, більшість із яких було захоронено на 6 тис. сміттєзвалищ і полігонів загальною площею майже 9 тис. га. Інструментами реалізації Національної стратегії визначено затверджений Кабінетом Міністрів України у лютому 2019 року Національний план управління відходами до 2030 року [15], який передбачає розроблення регіональних планів управління відходами до 2030 року (рис. 2). Реалізація цієї стратегії передбачає адаптацію 
національного законодавства до вимог європейського законодавства та впровадження рамкового закону «Про управління відходами» [4].

Документ має комплексний характер та є основою для прийняття усіх секторальних законів у цій сфері, визначає правові, організаційні, економічні засади та правові механізми контролю для забезпечення захисту довкілля і здоров'я людини з метою впровадження заходів для зменшення утворення відходів, зниження негативних наслідків від управління відходами, сприяння їх повторному використанню і відновленню як вторинної сировини та енергетичних ресурсів.

Висновки. Таким чином, сучасний міжнародний досвід пропонує безліч ефективних рішень із вирішення проблеми накопичення ТКВ та впровадження сучасних технологій їх реалізації. Відходи можна розглядати як ресурс, із якого можна отримати певну споживчу користь, що є ключовим для вирішення проблеми і формує новий досвід у сфері управління ТКВ. Наявний досвід потребує адаптації до умов кожної держави та вимагає проведення постійних наукових досліджень у сфері поводження з відходами. Проблема утворення та управління ТКВ в Україні залишається гострою і потребує нагального вирішення. Законодавча база перебуває у стадії реформування та повністю не сформована. Органи виконавчої влади та місцевого самоврядування ОТГ, які мають вирішувати наявні проблеми та формувати систему управління комунальними відходами на місцевому рівні в територіальних об'єднаних громадах як міських територій громади, так сільської місцевості, не мають для цього необхідних знать, досвіду та розробленого методичного забезпечення.

\section{Література}

1. Європейський комітет статистики. Municipal waste by waste management operations. Municipal Waste Generation, European Environment Agency assessment URL: http://themes.eea.europa.eu/IMS/IMS/ISpecs/ISpecification20041007131809/ IAssessment1183020255530/view_content.

2. EUROSTAT and European Environment Agency statistics. URL: http://epp.eurostat.ec.europa.eu/statistics_explained/index.php/ National accounts \%E2\%80\%93 GDP.

3. Стокгольмська конвенція про стійкі органічні забруднювачі. URL: https://zakon.rada.gov.ua/laws/show/995_a07.

4. Угода про асоціацію України з СC. URL: https://eu-ua.org/tekst-uhody-pro-asotsiatsiiu.

5. Geyer R.; Jambeck J.R., Lavender K.. Production, use, and fate of all plastics ever made. Science Advances, e1700782, $2017.1-5$. DOI: $10.1126 /$ sciadv. 1700782

6. Джамбек Дж.Р., Гейер Р., Уилкокс К., Зиглер Т.Р., Перриман М., Андради А., и Ло К. Л. Пластиковые отходы поступают с суши в океан. Наука, 347 (6223), 2015. 768-771. URL: https://slacc.org.uk/wp-content/uploads/2017/12/10.-Jambeck2015.pdf

7. Moya, D., Aldás, C., López, G., Kaparaju, P. (2017). Municipal solid waste as a valuable renewable energy resource: a worldwide opportunity of energy recovery by using Waste-To-Energy Technologies. Energy Procedia, 134, 286-295:DOI:10.1016/j. egypro.2017.09.618

8. Malinauskaite, J., Jouhara, H., Czajczyńskab, D., Stanchev, P., Katsou, E., Rostkowski, P. Municipal solid waste management and waste-to-energy in the context of a circular economy and energy recycling in Europe. Energy, 141, 2017. 2013-2044. URL: https://doi.org/10.1016/j.energy.2017.11.128

9. Коцюба І.Г., Подчашинський Ю.О., Лико С.М., Лук’янова С.М. Математичне моделювання та прогнозування обсягів накопичення твердих комунальних відходів міста. Науково-технічний збірник "Вісник Начіонального транспортного університету”. Київ, 2017 року. Вип. № 2/2017. С. 34-41.

10. Михайлова Є.О., Панчева Г.М., Резніченко Г.М. Ефективні механізми поводження з твердими побутовими відходами в Україні. Комунальне господарство міст, 2019, том 5, випуск 151, с. 37-44. DOI 10.33042/2522-1809-2019-5-151-37-44

11. Municipal waste by waste management operations. Eurostat: website. URL: http://appsso.eurostat.ec.europa. $\mathrm{eu} / \mathrm{nui} /$ show.do?query=BOOKMARK_DS-150766_QID_2C32EBFE_UID_3F171EB0\&layout=TIME,C,X, 0 ;GEO,L,Y,0;WST_OPER,L,Z,0;UNIT,L,Z, 1 ;INDICATÖRS,C,Z,2; \&zSelection=DS 150766 INDICATORS, OBS_FLAG;DS-150766-WST_OPER,GEN;DS-150766UNIT,THS_T;\&rank

12. Department for Environment Food \& Rural Affairs. Our waste, our resources: a strategy for England. URL:https://assets.publishing. service.gov.uk/government/uploads/system/uploads/attachment_data/file/765914/resources-waste-strategy-dec-2018.pdf.

13. Recycling international: портал. URL: http://www.recyclinginternation.com.

14. Carrefour: Combating waste. URL: http://www.carrefour.com/content/combating-waste.

15. Тверді побутові відходи в Україні: потенціал розвитку. Сценарії розвитку галузі поводження 3 твердими побутовими відходами. Підсумковий звіт. IFC, Група Світового банку. Київ. 104 c. URL:https:/www.ifc.org/wps/wcm/ connect/504c5765-89d4-4be1-916e-ea27aa94feaf/22. 


\title{
ПРИРОДНО-ЗАПОВІДНИЙ ФОНД УКРАЇНИ
}

УДК 502.43:528.921

DOI https://doi.org/10.32846/2306-9716/2021.eco.6-39.29

\section{ОСОБАИВОСТІ РОЗПОДИУ ТЕРИТОРІЙ I ОБ'СКТІВ ПРИРОДНО-ЗАПОВІДНОГО ФОНДУ ПОАТАВСЫКОÏ ОБААСТI В УМОВАХ НОВОГО АДМІНІСТРАТИВНО-ТЕРИТОРІАМЬНОГО УСТРОЮ УКРАӤНИ}

\author{
Голік Ю.С., Смоляр Н.О. ${ }^{1}$, Остапенко П.О. ${ }^{2}$, Чепурко Ю.В. ${ }^{1}$ \\ ${ }^{1}$ Національний університет «Полтавська політехніка імені Юрія Кондратюка» \\ пр. Першотравневий, 24, 36011, м. Полтава \\ golik38@i.ua, smolarnat@ukr.net, juliakorzh2003@gmail.com; \\ ${ }^{2}$ Громадська організація «Товариство дослідників України» \\ вул. Ломоносова, 81, 03022, м. Київ \\ ostapenkopavlo@gmail.com
}

\begin{abstract}
У статті представлено результати дослідження розподілу об'єктів природно-заповідного фонду Полтавської області в контексті змін адміністративно-територіального устрою України в межах укрупнених чотирьох новоутворених районів та 60 територіальних громад. Надано кількісні значення та картографічні матеріали щодо показника заповідності територій районів і територіальних громад Полтавської області. Станом на 1 січня 2021 року природно-заповідна мережа Полтавської області налічує 393 об’єкти загальною площею 14 2789,76 гектарів, що визначає показник заповідності 4,966\%. Це об’єкти восьми категорій природно-заповідного фонду України, деякі зі своєю диференціацією: національні природні парки, регіональні ландшафтні парки, заказники (ботанічні, ландшафтні, гідрологічні, лісові, загальнозоологічні, орнітологічні, ентомологічні), ботанічний сад, заповідні урочища, пам’ятки природи (комплексні, ботанічні, геологічні, гідрологічні, зоологічні), дендропарки, парки - пам’ятки садово-паркового мистецтва.

Наведено результати аналізу змін показника заповідності окремих районів до і після ухвалення постанови «Про утворення та ліквідацію районів». Аналіз показників заповідності новостворених чотирьох районів показує, що за нового адміністративно-територіального устрою України показник заповідності чотирьох районів значно вирівнявся (у межах 3,7-6,3\%) порівняно із ситуацією за старого адміністративно-територіального устрою, де показник заповідності у 25 районах коливався в досить широкому діапазоні - від 0,8\% у Гребінківському районі до 17,932\% у Диканському, що вказує на вдалий раціональний розподіл не тільки колишніх територіальних одиниць, а й об’єктів природно-заповідної мережі в межах районів.

Зазначено, що за умов нового адміністративно-територіального устрою України площа територій і об'єктів природно-заповідного фонду в межах окремих територіальних громад значно відрізняється. Найвищими вони $є$ в таких територіальних громадах: Кобеляцькій - 20,646\%, Диканській - 17,832\%, Кременчуцькій - 16,020\%, Градизькій - 15,898\%, Кам’янопотоківській 14,724\%, Лютенській - 14,528\%, Пирятинській - 14,408\%, Оболонській - 13,606\%, Гадяцькій- 12,092\% та Великобудищанській - 10,148\%. Це пов'язано з функціонуванням у їхньому складі локальних природно-заповідних мереж національних природних і регіональних ландшафтних парків. У деяких новостворених громадах показник заповідності відсутній, це - Пришибська, Ромоданівська та Гоголівська територіальні громади, для яких актуальним $є$ вивчення можливостей і ресурсів для створення природно-заповідних об'єктів.

Означено основні проблеми розвитку об’єктів та територій природно-заповідного фонду, напрями їх вирішення шляхом подальшої оптимізації природно-заповідної мережі Полтавської області в умовах збалансованого розвитку. Ключові слова: природно-заповідний фонд, територіальні громади, адміністративно-територіальний устрій, Полтавська область, показник заповідності, екологічне картографування, збалансований розвиток.
\end{abstract}

Peculiarities of distribution of objects and territories of the nature reserve fund of Poltava region in the conditions of the new administrative-territorial structure. Holik Yu., Smolyar N., Ostapenko P., Chepurko Iu.

The article presents the results of the study of distribution of objects of natural reserve fund of Poltava region in the context of changes in the administrative-territorial structure of Ukraine within the enlarged four newly districts and 60 territorial communities. Quantitative values and cartographic materials on the indicator of protected areas of districts and territorial communities of Poltava region are provided. As of January 1, 2021 natural-reserve network of Poltava region includes 393 objects with a total area of 142789,76 ha, which determines the index of protection by $4,966 \%$. These are objects of eight categories of natural-reserve fund of Ukraine, some of their differentiation: national nature parks, regional landscape parks, sanctuaries (botanical, landscape, hydrological, forest, generalzoological, ornithological, entomological), botanical gardens, protected tracts, natural monuments (complex, botanical, geological, hydrological, zoological), dendroparks, parks - monuments of landscape art.

The results of the analysis of changes in the indicator of the protected areas before and after the adoption of the Decree "On the formation and liquidation of districts" are given. An analysis of the four districts again shows that under the new administrativeterritorial structure of Ukraine, the rate of protection of the four districts has significantly leveled and is in the range 3,7-6,3\% compared 
to the situation in the old administrative-territorial structure, where the rate of protection in 25 areas varied quite widely - from $0,8 \%$ in Grebenkovsky area to $17,932 \%$ in Dikansky, which indicates not only a successful rational distribution of the former territorial units but also objects of nature reserve and conservation.

It is noted that under the new administrative-territorial structure of Ukraine, the area of territories and objects of the natural reserve fund within individual territorial communities differ significantly. They are high in these territorial communities: Kobelyatska20,646\%, Dikanska - 17,832\%, Kremenchug - 16,020\%, Gradizh - 15,898\%, Kamennopotokivska - 14,724\%, Lyutenska - 14,528\%, Pyriatynska $-14,408 \%$, Obolon $-13,606 \%$, Gadyach $-12,092 \%$ and Velikobudyshchenska $-10,148 \%$. This is due to the functioning within their local nature reserve networks of national nature and regional landscape parks. In some newly communities there is no indicator of conservation, these are Prishibskaya, Romodanovskaya and Gogolevskaya territorial communities, for which it is relevant to study the opportunities and resources for the creation of natural-reserve objects.

The main problems of development of objects and territories of the natural reserve fund and the directions of their solution by further optimization of the natural reserve network of Poltava region under the conditions of sustainable development are marked. Key words: natural-reserved fund, territorial communities, administrative-territorial structure, Poltava region, reserve index, ecological mapping, balanced development.

Постановка проблеми. У 2020 р. в Україні відбулися зміни адміністративно-територіального устрою. Верховною Радою України було ухвалено постанову № 3650 «Про утворення та ліквідацію районів». У Полтавській області з колишніх 25 районів утворено чотири нові укрупнені райони, які мають приблизно однакові показники, як за територією, так і за кількістю населення. Вони включили в себе 60 новоутворених окремих територіальних громад. Але питання щодо територіального розподілу в цих умовах територій і об'єктів природно-заповідного фонду Полтавської області залишалися невизначеними й актуальними.

Метою статті $\epsilon$ аналіз розподілу територій та об'єктів природно-заповідного фонду (далі - ПЗФ), визначення особливостей розподілу показника заповідності за територіальними громадами (далі - ТГ) Полтавської області в умовах нового адміністративно-територіального устрою (далі - АТУ) України, окреслення завдань подальшої оптимізації локальних природно-заповідних мереж (далі - ПЗМ) на виконання завдань національних i європейських природоохоронних стратегій.

Матеріал та методи дослідження. Об'єктом дослідження є система природно-заповідних територій і об'єктів Полтавської області, яка сформована на основі статистичних даних Департаменту екології та природних ресурсів Полтавської ОДА, картографічних матеріалів i статистичних даних сучасного стану земельних угідь Держземагенства в Полтавській області, матеріалів про ПЗФ регіону, зокрема й монографічних зведень із вміщеними переліками територій і об'єктів ПЗФ області [1-2; 4-7], та результатів оригінальних багаторічних (1994-2020 рр.) комплексних созологічних досліджень. У процесі оброблення й аналізу вихідних матеріалів було використано наукові методи систематизації: польовий, статистичний, аналітичний. Для оцінки стану ПЗФ області, адміністративних районів та новоутворених ТГ використано показник заповідності території.

\section{Аналіз останніх досліджень і публікацій}

Одним із головних напрямів екологічної політики України є розвиток природоохоронних територій. ПЗФ охороняють як національне надбання, щодо якого встановлено особливий режим охорони, відтворення й використання. Україна розглядає цей фонд як складову частину світової системи природних територій та об'єктів, що перебувають під особливою охороною. Розвиток системи природоохоронних територій $є$ важливою передумовою для забезпечення збалансованого розвитку країни [8].

Відомості про ПЗФ Полтавської області в різні періоди його формування й оптимізації наводяться в низці монографій, довідників, науково-популярних видань [1-7; 9-10].

Збереження природи Полтавщини - завдання не одного покоління природодослідників, природоохоронців та природолюбів. На Полтавщині набутий вагомий досвід природозаповідання, який пов'язаний 3 іменами таких відомих учених, як В.І. Вернадський, С.О. Іллічевський, В.Ф. Ніколаєв, M.I. Гавриленко, Д.С. Івашин, Р.В. Ганжа, О.А. Стасілюнас, Т.Л. Андрієнко, О.М. Байрак та інші. I натепер ця справа в області здійснюється сучасниками у кращих традиціях природоохоронної роботи.

Новизна проведеного дослідження. Уперше проведено розподіл територій і об'єктів ПЗФ Полтавської області та створено картографічні матеріали (карти розподілу показника заповідності) за окремими і новими укрупненими районами щодо нового АТУ України.

Виклад основного матеріалу дослідження. ПЗФ Полтавської області станом на 1 січня 2021 р. налічує 393 об'єкти загальною площею 142 789,76 га. Показник заповідності становить 4,966\%.

ПЗФ області представляють: національні природні парки - 2 (площа - 22 792,62 га); регіональні ландшафтні парки - 5 (площа - 53 056,45 га); заказники загальнодержавного значення - 20 (площа 41 226,9 га) та місцевого значення - 159 (площа 38 492,31 га); пам'ятки природи загальнодержавного значення - 1 (площа - 145 га) та місцевого значення - 137 (площа - 1739,03 га); ботанічний сад загальнодержавного значення - 1 (площа -18 га); дендрологічні парки загальнодержавного значення 2 (площа - 20,9 га) та місцевого значення - 1 (площа 7,64 га); парки-пам' ятки садово-паркового мистецтва загальнодержавного значення - 4 (площа - 442,5 га) та місцевого значення - 13 (площа - 179,64 га); заповідні урочища - 48 (площа - 7 116,2 га). 
Таблиця 1

Склад і структура природно-заповідного фонду Полтавської області станом на 1 січня 2021 р.

\begin{tabular}{|c|c|c|c|}
\hline \multirow{2}{*}{ Категорія і назва об’єкта ПЗФ } & \multicolumn{2}{|c|}{ Кількість } & \multirow{2}{*}{$\begin{array}{c}\text { Площа } \\
\text { загальна, га }\end{array}$} \\
\hline & $\mathbf{A}$ & Б & \\
\hline Національні природні парки & & 2 & 22792,62 \\
\hline Заказники: & 159 & 20 & 79719,21 \\
\hline ботанічні & 38 & 1 & 5853,34 \\
\hline ландшафтні & 53 & 9 & 52186,13 \\
\hline гідрологічні & 52 & 7 & 16048,84 \\
\hline лісові & 3 & & 2373,7 \\
\hline загальнозоологічні & 7 & 1 & 2399,2 \\
\hline орнітологічні & 2 & 2 & 690,7 \\
\hline ентомологічні & 4 & & 167,3 \\
\hline Регіональні ландшафтні парки & 5 & & 53056,45 \\
\hline Гадяцький & & & 12803,3 \\
\hline Диканський & & & 11945 \\
\hline Кагамлицький & & & 28,15 \\
\hline Кременчуцькі плавні & & & 5080 \\
\hline Нижньоворсклянський & & & 23200 \\
\hline Ботанічний сад & & 1 & 18 \\
\hline Заповідні урочища & 48 & & 7116,2 \\
\hline Пам'ятки природи: & 137 & 1 & 1884,03 \\
\hline комплексні & 13 & & 115,34 \\
\hline ботанічні & 110 & 1 & 1713,02 \\
\hline геологічні & 9 & & 45,85 \\
\hline гідрологічні & 3 & & 2,4 \\
\hline зоологічні & 2 & & 7,42 \\
\hline Дендропарки & 1 & 2 & 28,54 \\
\hline $\begin{array}{c}\text { Парки - пам'ятки садово-парко- } \\
\text { вого мистецтва }\end{array}$ & 13 & 4 & 622,14 \\
\hline Разом за об’єктами ПЗФ & 363 & 30 & $142789,76^{*}$ \\
\hline
\end{tabular}

А-території й об'єкти ПЗФ місцевого значення, Б-території й об'єкти ПЗФ загальнодержавного значення; позначено * - з урахуванням площ територій і об' єктів ПЗФ, що входять цілком або частково до складу інших.

Загалом, ПЗМ Полтавської області репрезентують об'єкти восьми категорій ПЗФ України, деякі зі своєю диференціацією: національні природні парки, регіональні ландшафтні парки, заказники (ботанічні, ландшафтні, гідрологічні, лісові, загальнозоологічні, орнітологічні, ентомологічні), ботанічний сад, заповідні урочища, пам'ятки природи (комплексні, ботанічні, геологічні, гідрологічні, зоологічні), дендропарки, парки - пам'ятки садово-паркового мистецтва.

Розподіл об’єктів ПЗФ у відсотках щодо районів Полтавської області до ухвалення постанови Кабінету Міністрів України «Про утворення та ліквідацію районів» від 17 липня 2020 р. наведено на карті 1.

Улітку 2020 р. в Україні відбулися значні адміністративно-територіальні зміни. Верховна Рада України ухвалила постанову № 3650 «Про утво- рення та ліквідацію районів». У Полтавській області було ліквідовано 25 районів та утворено чотири нові, а саме: Кременчуцький, Лубенський, Миргородський та Полтавський. Території нових районів Полтавської області є значно укрупненими порівняно $з$ попередніми межами. Кременчуцький, Лубенський та Миргородський райони, хоча й мають різну кількість територіальних громад у своєму складі - 12, 7 та 17 відповідно, але їхня площа $\epsilon$ майже ідентичною та становить 6,11 тисяч км ${ }^{2}$, 5,48 тисяч км ${ }^{2}$ та 6,29 тисяч км² відповідно. Четвертий Полтавський район $\epsilon$ найбільш гіпертрофованим, у своєму складі має 24 територіальні громади та площу 10,86 тисяч км², що майже вдвічі більше за територію Лубенського району [11]. Зауважимо, що межі нових районів визначені за зовнішніми кордонами територій сільських, селищних та міських ТГ, що входять до того чи іншого району. Укрупнення районів пояснюється одним із кроків децентралізації в Україні [12]. У загальному вигляді показники розподілу за територіальними громадами та у складі районів зведено в таблиці 2.

Розподіл показників заповідності за новими районами Полтавської області наведено нижче на карті 2. Аналіз показників заповідності новостворених чотирьох районів показує, що за нового АТУ України показник заповідності районів значно вирівнявся (у межах 3,7-6,3\%) порівняно із ситуацією, відображеною на карті 1 , де показник заповідності коливався в досить широкому діапазоні - від 0,8\% у Гребінківському районі до 17,932\% у Диканському, що вказує на раціональний розподіл колишніх територіальних одиниць і об'єктів ПЗФ у межах районів. Так, показник заповідності

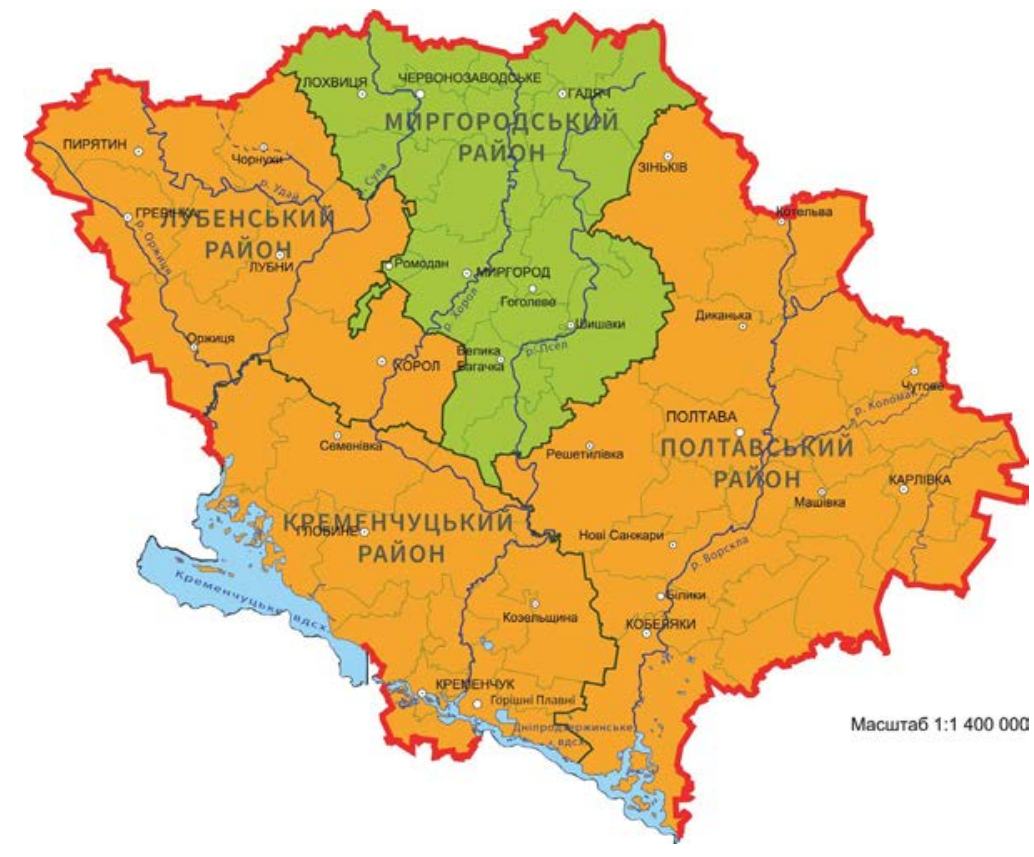

Карта 1. Показник заповідності територій районів Полтавської області станом на 1 січня 2021 р. 
Характеристика показника заповідності за новоствореними територіальними громадами

Таблиця 2

Полтавської області

\begin{tabular}{|c|c|c|c|c|c|}
\hline $\begin{array}{c}\text { Назва } \\
\text { району }\end{array}$ & № TГ & Назва ТГ & Площа ТГ, га & $\begin{array}{c}\text { Площа ПЗФ, } \\
\text { га }\end{array}$ & $\begin{array}{c}\text { Показник } \\
\text { заповідності }\end{array}$ \\
\hline \multirow{12}{*}{ 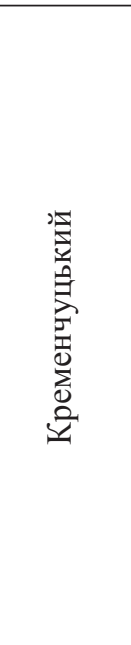 } & 1 & Глобинська & 119810 & 978,7 & 0,817 \\
\hline & 2 & Горішньоплавнівська & 37340 & 1604,7 & 4,298 \\
\hline & 3 & Градизька & 126110 & 20049,5 & 15,898 \\
\hline & 4 & Кам'янопотоківська & 26640 & 3922,5 & 14,724 \\
\hline & 5 & Козельщинська & 73050 & 1593,6 & 2,182 \\
\hline & 6 & Кременчуцька & 13610 & 2180,33 & 16,020 \\
\hline & 7 & Новогалещинська & 19310 & 485,4 & 2,514 \\
\hline & 8 & Оболонська & 47170 & 6417,97 & 13,606 \\
\hline & 9 & Омельницька & 22370 & 506 & 2,262 \\
\hline & 10 & Піщанська & 28400 & 145 & 0,511 \\
\hline & 11 & Пришибська & 17000 & - & - \\
\hline & 12 & Семенівська & 80300 & 914,64 & 1,139 \\
\hline & \multicolumn{2}{|c|}{ У Кременчуцькому районі } & 611100 & 38798,33 & 6,349 \\
\hline \multirow{7}{*}{ 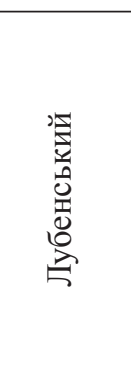 } & 13 & Гребінківська & 58830 & 476 & 0,809 \\
\hline & 14 & Лубенська & 107030 & 1669,4865 & 1,560 \\
\hline & 15 & Новооржицька & 45370 & 191 & 0,421 \\
\hline & 16 & Оржицька & 75390 & 3647,83 & 4,839 \\
\hline & 17 & Пирятинська & 93280 & 13439,96 & 14,408 \\
\hline & 18 & Хорольська & 106320 & 1604,545 & 1,509 \\
\hline & 19 & Чорнухинська & 61940 & 2015,1 & 3,252 \\
\hline & \multicolumn{2}{|c|}{ У Лубенському районі } & 548100 & 23043,91 & 4,204 \\
\hline \multirow{18}{*}{ 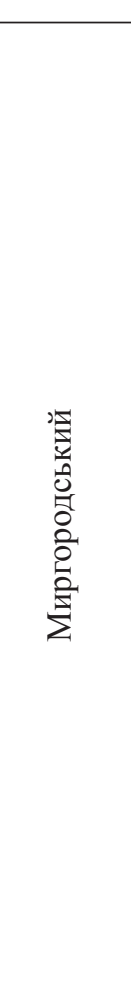 } & 20 & Білоцерківська & 31060 & 1274,7 & 4,104 \\
\hline & 21 & Великобагачанська & 41450 & 846,82 & 2,043 \\
\hline & 22 & Великобудищанська & 38480 & 3904,8524 & 10,148 \\
\hline & 23 & Великосорочинська & 40370 & 90 & 0,222 \\
\hline & 24 & Гадяцька & 20330 & 2457,5974 & 12,092 \\
\hline & 25 & Гоголівська & 18880 & 0,02 & 0 \\
\hline & 26 & Заводська & 20320 & 1421,3 & 6,995 \\
\hline & 27 & Комишнянська & 51750 & 5,52 & 0,011 \\
\hline & 28 & Краснолуцька & 25410 & 1580,7182 & 6,221 \\
\hline & 29 & Лохвицька & 81800 & 3100,01 & 3,790 \\
\hline & 30 & Лютенська & 37440 & 5439,182 & 14,528 \\
\hline & 31 & Миргородська & 61720 & 1261,5 & 2,044 \\
\hline & 32 & Петрівсько-Роменська & 21510 & 515 & 2,394 \\
\hline & 33 & Ромоданівська & 9710 & - & - \\
\hline & 34 & Сенчанська & 35400 & 221,72 & 0,626 \\
\hline & 35 & Сергіївська & 16380 & 452,35 & 2,762 \\
\hline & 36 & Шишацька & 77320 & 896,02 & 1,159 \\
\hline & \multicolumn{2}{|c|}{ У Миргородському районі } & 629300 & 23467,31 & 3,718 \\
\hline
\end{tabular}


Продовження таблиці 2

\begin{tabular}{|c|c|c|c|c|c|}
\hline $\begin{array}{c}\text { Назва } \\
\text { району }\end{array}$ & № ТГ & Назва ТГ & Площа ТГ, га & $\begin{array}{c}\text { Площа ПЗФ, } \\
\text { га } \\
\end{array}$ & $\begin{array}{c}\text { Показник } \\
\text { заповідності }\end{array}$ \\
\hline \multirow{24}{*}{ 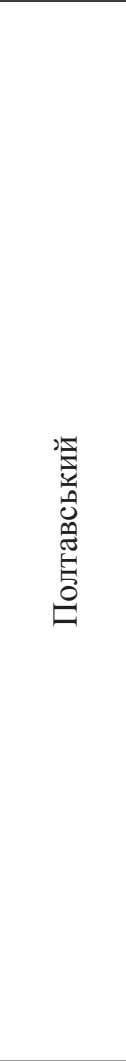 } & 37 & Білицька & 38890 & 57,8 & 0,149 \\
\hline & 38 & Великорублівська & 38970 & 1053,1 & 2,702 \\
\hline & 39 & Диканська & 68280 & 12176 & 17,832 \\
\hline & 40 & Драбинівська & 26050 & 301 & 1,155 \\
\hline & 41 & Зіньківська & 106700 & 722,89 & 0,678 \\
\hline & 42 & Карлівська & 33450 & 354,1 & 1,059 \\
\hline & 43 & Кобеляцька & 121860 & 25159 & 20,646 \\
\hline & 44 & Коломацька & 18870 & 428 & 2,268 \\
\hline & 45 & Котелевська & 40450 & 805,02 & 1,990 \\
\hline & 46 & Ланнівська & 26870 & 585,3 & 2,178 \\
\hline & 47 & Мартинівська & 25760 & 52,7 & 0,205 \\
\hline & 48 & Мачухівська & 24780 & 166,6 & 0,672 \\
\hline & 49 & Машівська & 39180 & 47,2 & 0,120 \\
\hline & 50 & Михайлівська & 43200 & 2077,4 & 4,809 \\
\hline & 51 & Нехворощанська & 28480 & 1878,7 & 6,597 \\
\hline & 52 & Новосанжарська & 67290 & 3337,3 & 4,960 \\
\hline & 53 & Новоселівська & 25750 & 654,7 & 2,543 \\
\hline & 54 & Опішнянська & 30510 & 988,89 & 3,241 \\
\hline & 55 & Полтавська & 54870 & 264,18 & 0,482 \\
\hline & 56 & Решетилівська & 110210 & 2866,2 & 2,601 \\
\hline & 57 & Скороходівська & 32500 & 115,7 & 0,356 \\
\hline & 58 & Терешківська & 19750 & 5 & 0,025 \\
\hline & 59 & Чутівська & 53450 & 3109,24 & 5,817 \\
\hline & 60 & Щербанівська & 10080 & 274,29 & 2,721 \\
\hline \multicolumn{3}{|c|}{ Усього в Полтавському районі } & 1086200 & 57480,21 & 5,291 \\
\hline \multicolumn{3}{|c|}{ Усього в Полтавській області } & 2874700 & 142789,76 & 4,9666 \\
\hline
\end{tabular}

в цих умовах для трьох районів фактично зрівнявся (Лубенський район - 4,204\%, Полтавський 5,291\%, Кременчуцький - 6,349\%), а Миргородський район поступається ім незначним чином $-3,718 \%$. Усе це надає однакові стартові можливості районам для досягнення європейського рівня заповідності.

Аналіз результатів проведеного дослідження показав, що за останні 25 років показник заповідності в Полтавській області зріс майже у 12 разів (з 0,4 до 4,966\%) [4]. За такого показника заповідності площа територій і об’єктів ПЗФ у межах окремих ТГ значно відрізняється. Найвищими вони є у Кобеляцькій ТГ 20,646\%, Диканській ТГ - 17,832\%, Кременчуцькій ТГ - 16,020\%, Градизькій 은 Кам'янопотоківській - 14,724\%, Лютенській ТГ - 14,528\%, Пирятинській ТГ - 14,408\%,

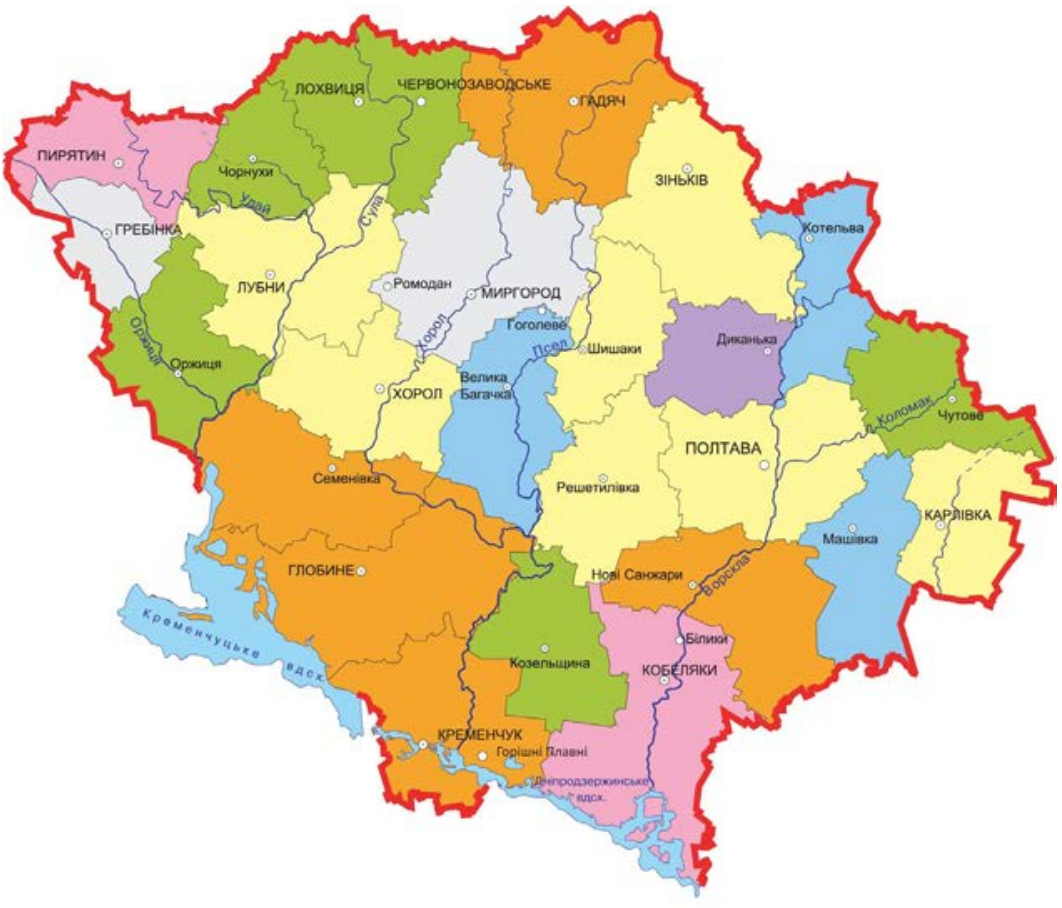

Карта 2. Показник заповідності за чотирма новими районами Полтавської області (легенда до карти 2 аналогічна карті 1) 


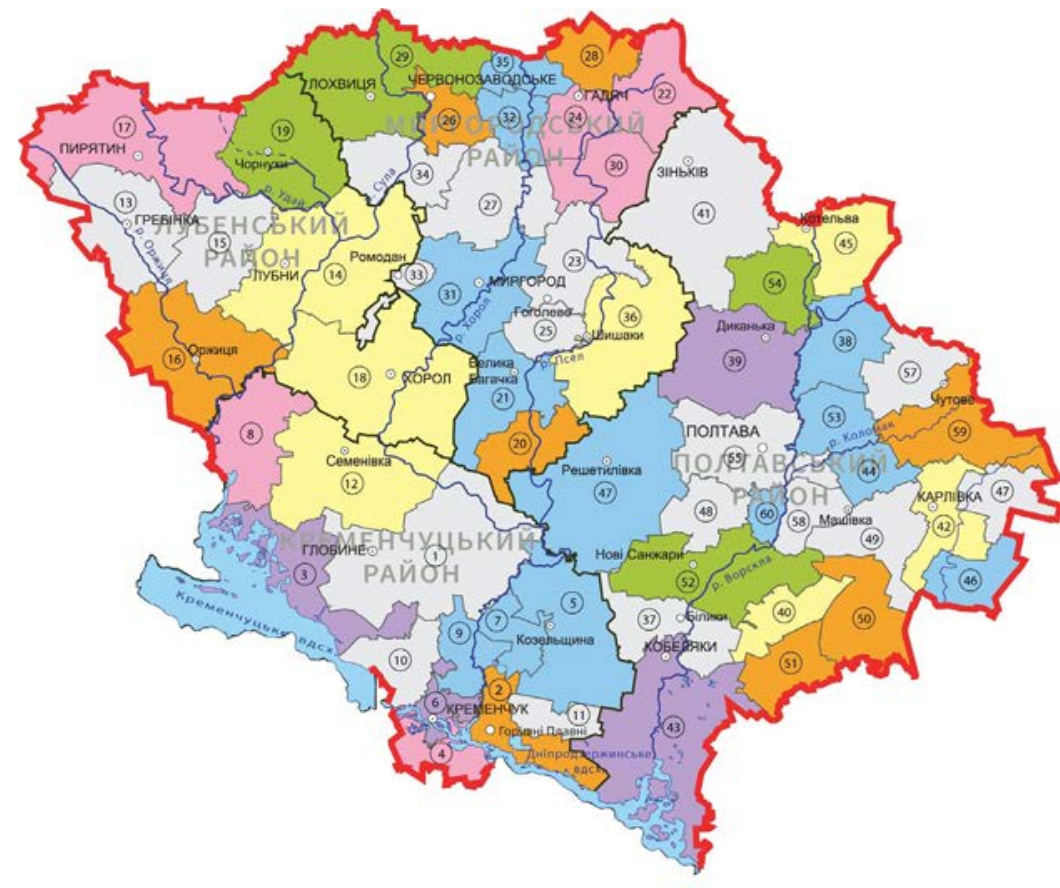

Карта 3. Показник заповідності за новоутвореними об'єднаними територіальними громадами Полтавської області (легенда до карти 3 аналогічна карті 1).

Оболонській ТГ - 13,606\%, Гадяцькій ТГ - 12,092\%, Великобудищанській ТГ - 10,148\%. Це пов'язано зі «спадщиною» від колишнього районного розподілу, завдяки функціонуванню в їхньому складі локальних ПЗМ національних природних і регіональних ландшафтних парків, які дозволили об'єднати щільно розміщені об'єкти різних категорій у значні за площею території та забезпечити більш ефективну охорону різноманітних природних комплексів із їхнім біорозмаїттям. Водночас у деяких громадах показник заповідної «спадщини» фактично відсутній - у Пришибській ТГ, Ромоданівській ТГ та Гоголівській ТГ.

Нумерацію і назви окремих ТГ наведено в таблиці 2

Основними проблемами розвитку ПЗМ Полтавської області на сучасному етапі є: недостатнє охоплення природозаповіданням екологічно сталих комплексів за наявності відповідних ресурсів і можливостей; загальний показник заповідності в області є нижчим за національний (4,966\% проти $6,77 \%)$ і європейський (12-21\%); нерівномірність охоплення охороною в межах природно-заповідних об'єктів області та, як наслідок, низький показник заповідності у значної кількості новоутворених ТГ (0,011-3\% за середнього в області 4,966\%); фактично відсутне фінансування наукових досліджень щодо оптимізації ПЗМ області; недостатне сприяння місцевих органів самоврядування розширенню ПЗМ на місцевому рівні та відповідно низькі обсяги фінансування природозаповідання й утримання об'єктів ПЗФ із місцевих бюджетів; нерозвинута система інформування місцевого населення щодо умов використання та ведення господарської діяльності на територіях ПЗФ. Основними причинами виникнення цих проблем, на нашу думку, залишаються: неналежна поінформованість і низький рівень екологічної свідомості місцевого населення; потреба у фінансуванні заходів щодо охорони та розвитку об'єктів ПЗФ; не досить ефективна діяльність у сфері оптимізації ПЗМ області та розбудови регіональної екомережі.

Нині основна увага повинна бути націлена на подальшу оптимізацію ПЗМ області в нових умовах утворених ТГ і районів, насамперед у ТГ iз низьким показником заповідності. «Спадщина» результатів багаторічних комплексних созологічних досліджень біорозмаїття в Полтавській області дозволяє сподіватись на можливість використання напрацювань для подальшої оптимізації регіональної ПЗМ завдяки створенню нових, розширення й об'єднання площ наявних об'єктів.

Зважаючи на те, що в сучасній ПЗМ Полтавщини зберігаються й охороняються типові й унікальні природні комплекси, які репрезентують практично всі структурні компоненти біорозмаїття регіону, основною тенденцією природозаповідання в Полтавській області є створення значних за площею об'єктів (за наявності ресурсів і можливостей) на основі критеріїв унікальності та репрезентативності біорозмаїття, виходячи 3 концепції забезпечення охороною середовищ існування живих організмів, їх угруповань, біотопів і екосистем загалом.

Головні висновки. Загалом ПЗМ Полтавської області є досить репрезентативною щодо кількісних (393 об’єкти восьми категорій) та якісних характеристик (показник заповідності - 4,966\%, незначно поступається національному). Однак у розрізі новостворених ТГ Полтавської області, утворених відповідно до засад нового АТУ України, показник заповідності є вкрай нерівномірним, а для деяких - ця характеристика навіть відсутня. Тому головними тенденціями розвитку ПЗФ ТГ Полтавської області на сучасному етапі $є$ : екосистемний підхід до заповідання (збереження середовищ існування); створення об'єктів на значних площах (із метою включення більшої кількості екосистем); об'єднання щільно розміщених об'єктів у більші за площею території згідно 3 концепцією регіональної екомережі; створення об'єктів поліфункціонального призначення; під час створення об'єктів урахування критеріїв як унікальності, так і репрезентативності; підвищення показника заповідності в області, нових районах i також усіх ТГ як індикатора стану збереженості 
Голік Ю.С., Смоляр Н.О., Остапенко П.О. ...

природи в контексті забезпечення збалансованого розвитку регіону.

Перспективи використання результатів проведеного дослідження

Розроблені у процесі проведеного дослідження картографічні матеріали планується використати

\section{ОСОБАИВОСТІ РОЗПОДІАУ ТЕРИТОРІЙ..}

під час створення нової редакції «Екологічного атласу Полтавської області». Одержані дані будуть надані до Департаменту екології та природних ресурсів Полтавської області для використання 3 метою підвищення ефективності розбудови регіональної ПЗМ

\section{Література}

1. Атлас адміністративно-територіального устрою Полтавської області. Підтримка належного врядування в місцевих громадах як складової реформи децентралізації : проєкт Координатора проєктів ОБСЄ в Україні ; Міністерство розвитку громад та територій України ; Товариство дослідників України / за заг. ред. П.О. Остапенка. 2 вид., доп. Київ, 2021. 18 с.

2. Інформаційно-аналітичні матеріали міністерства енергетики та захисту довкілля України з питання «Аналіз площ природно-заповідного фонду України в розрізі адміністративно-територіальних одиниць за 2019 р.». 2020. 104 с.

3. Заповідна краса Полтавщини / Т.Л. Андрієнко та ін. Полтава : IBA «Астрея», 1996. 184 с.

4. Еталони природи Полтавщини. Розповіді про заповідні території Полтавщини / О.М. Байрак та ін. Полтава : Верстка, 2003. $212 \mathrm{c}$.

5. Голік Ю.С., Чепурко Ю.В. Новітня оцінка екологічного стану Полтавської області. Проблеми екологічної безпеки : збірник наукових праць XVIII Міжнародної науково-практичної конференції, м. Кременчук, 6-8 жовтня 2020 р. Кременчук, 2020. C. 32-35.

6. Довкілля Полтавщини : монографія / за заг. ред. Ю.С. Голіка, О.Е. Ілляш. Полтава : Копі-центр, 2014. 256 с.

7. Екологічна енциклопедія : у 3-х т. / редкол. : А.В. Толстоухов (гол. ред.) та ін. Київ : ТОВ «Центр екологічної освіти та інформації», 2008.

8. Полтавщина : енциклопедичний довідник / за ред. В.А. Кудрицького. Київ : Українська енциклопедія, 1992.1022 с.

9. Природно-заповідний фонд Полтавщини : реєстр-довідник / автор і укл. Н.О. Смоляр. Полтава : ШвидкоДрук, 2014.149 с.

10. Природно-заповідний фонд Української РСР : реєстр-довідник заповідних об'єктів / за ред. М.А. Воїнственського. Київ : Урожай, 1986. С. 111-129.

11. Природоохоронні території Української РСР / за ред. Д.І. Проценко. Київ : Урожай, 1993. 176 с.

12. Регіональна екомережа Полтавщини / за заг. ред. О.М. Байрак. Полтава : Верстка, 2010. 214 с. 


\title{
ЗБЕРЕЖЕННЯ БIОАОГІЧНОГО I МАНДШАФТНОГО РІЗНОМАНIТТЯ
}

\author{
УДК 502(477.81) \\ DOI https://doi.org/10.32846/2306-9716/2021.eco.6-39.30
}

\section{ПРИРОДНИЙ ФЕНОМЕН ПОАІССЯ РІВНЕНЩИНИ}

\author{
Герман Н.В. \\ Рівненський державний гуманітарний університет \\ вул. С. Бандери, 12, 33028, м. Рівне \\ german.natalia.rdgu@gmail.com
}

\begin{abstract}
У статті здійснено комплексний аналіз основних складових частин природного феномену Полісся Рівненщини, що актуалізується нагальною потребою підвищення ефективності збереження та популяризації цього регіону. 3'ясовано, що його провідним природним ресурсом є ліс, а показник лісистості - один із найвищих в Україні. У лісах Полісся Рівненщини переважають хвойні лісові масиви, а сосна звичайна є домінантною породою дерев. 3 огляду на це місцеві ліси характеризуються високим рівнем фітонцидності та мають яскраво виражену лікувально-оздоровчу функцію. Акцентовано, що внаслідок малодоступності для людини та іiі діяльності частина лісів регіону зберегла свій первісний вигляд, а тому є винятковою. Свідченням цього $є$ набуття ними у 2020 р. статусу пралісів, квазіпралісів і природних лісів. Наголошено, що надзвичайно вагоме значення мають місцеві болота; вони - унікальна система, що є джерелом живлення не лише водойм, але і флори та фауни. Вказано, що неповторними природними об'єктами Полісся Рівненщини є екосистеми заплав річки Прип'ять, що були сформовані впродовж тривалої еволюції, нині вони $є$ домівкою для рідкісних і вразливих видів тварин, рослин, птахів і комах. Визначено, що ще одним феноменом природи Полісся Рівненщини є багаті родовища граніту. Місцева будівельна сировина $з$ нього має настільки високі показники якості, що не лише конкурує з відповідними видобувними породами на українському ринку, але й експортується за кордон. Зазначено, що базальтові стовпи Полісся Рівненщини - це водночас і унікальне геологічне явище, вияв древнього вулканізму, що вражає монументальністю й бездоганністю природних форм, i ексклюзив із погляду видобування та використання базальтової сировини в Україні. Окреслено, що дорогоцінним мінеральним ресурсом Полісся Рівненщини є бурштин, потенційні можливості використання якого є надзвичайно розмаїтими. Підсумовано, що все це в сукупності дає підстави для твердження про універсальну винятковість природи Полісся Рівненщини. Ключові слова: Полісся Рівненщини, лісовий ландшафт, болотний масив, річка Прип’ять, граніт, базальтові стовпи, бурштин.
\end{abstract}

Natural phenomenon of Polissya, Rivne region. Herman N.

The article provides a combined analysis of the main components of natural phenomenon of Polissya, Rivne region, that actualized by urgent necessity to increase the efficiency of preservation and promotion of this region. It has been found, that its leading natural resource is forest, and indicator of forest cover is one of the highest in Ukraine. In the forests of Polissya, Rivne region coniferous forests dominate, and Scots pine is the dominant species of trees. Due to this, local forests are characterized by high level of phytoncide and have an obvious therapeutic and health-improving function. It is emphasized, that because of inaccessibility for people and their activities, the part of the region's forests has retained its original appearance and is, therefore, exceptional. Evidence of this is their acquisition in 2020 of the status of primeval (virgin), quasi-virgin and natural forests. It is emphasized, that local swamps have extremely significant value; they are a unique system, which is a source of power not only for reservoirs, but also for flora and fauna. It is stated, that the unique natural objects of Polissya, Rivne region are ecosystems of floodplains of the river Pripyat, that were formed during the long evolution: today they are home for the rare and vulnerable species of animals, plants, birds and insects. Highlighted, that another natural phenomenon of Polissya Rivne region are rich granite deposits. Local constructional raw stuff from it has such high indicators of quality, that competes with the appropriate mining breeds not only in Ukrainian market, but also is exported abroad. It is noted, that the basalt pillars of Polissya Rivne region is, at the same time, a unique geological phenomenon, disclosure of ancient volcanism, which amazes with its monumentality and perfection of natural forms, and exclusive in terms of extraction and using of basalt raw materials in Ukraine. It is outlined, that precious mineral resource of Polissya Rivne region is amber, and potential opportunities of using amber are extremely diversified. It is summed up, that all this in together gives grounds for the assertion about universal exclusivity of nature of Polissya, Rivne region. Key words: Polissya Rivne region, forest landscape, swamp massif, Pripyat river, granite, basalt pillars, amber.

Постановка проблеми. Полісся-географічнийта історико-етнографічний регіон, що розташований на території чотирьох сучасних сусідніх держав: України (північні райони Волинської, Рівненської, Житомирської, Київської, Чернігівської та Сумської областей), Білорусі (південна частина Брестської області), Польщі (східна смуга Підляшшя) та Росії (південний захід Калузької області).

У IX - X ст. Полісся було контактною зоною слов'ян - племінних союзів дреговичів, волинян, древлян, а також балтського союзу ятвягів. Саме тому його називають прабатьківщиною слов'ян та прадавньою колискою слов'янства. Перша письмова згадка про Полісся, датована 1274 р., міститься

в Галицько-Волинському літописі. Того року, як ішлося в ньому, князь Мстислав Данилович, син Данила Романовича Галицького, «ішов був од [города] Копиля, пустошачи по Поліссі» [5, с. 429]. Етимологія назви «Полісся» безпосередньо пов'язана зі словом «ліс» і означає територію дрімучих лісів. Показовим у цьому контексті є запис ГалицькоВолинського літопису за 1234 р., у якому йшлося про боротьбу Данила Галицького із чернігівськими князями за Київ. Вони покликали на допомогу половців, i, як свідчить літописець, «коли половці прийшли до Києва і грабували землю Руську, то Данило хотів вийти [з Києва] додому лісовою стороною, бо Данило знесилився був». Як твердять 
Герман Н.В.

фахівці, описана у літописі безпечна «лісова сторона» і була Поліссям [5, с. 391].

Нині Полісся - унікальний природний регіон Європи, якому певною мірою притаманні первісний вигляд лісів, величезні масиви боліт, густа сітка річок, а збережені ландшафти дикої природи є домівкою для багатьох рідкісних і вразливих видів тварин, рослин, птахів і комах. 3 огляду на це 2019 р. зусиллями Українського товариства охорони птахів впроваджено міжнародний транскордонний проєкт «Полісся - дика природа без кордонів». Його учасниками стали природоохоронні інституції України, Білорусі, Польщі, Німеччини та Великобританії, а стратегічною метою підвищення природоохоронного статусу регіону [1]. А вже восени 2020 р. відбулося обговорення питання номінування прикордонних територій Українського Полісся у програму «Світова природна спадщина ЮНЕСКО» [3]. Отже, на складниках природної унікальності Полісся, зокрема Полісся Рівненщини, зупинимося докладніше.

Актуальність дослідження. Зв'язок авторського доробку із важливими науковими та практичними завданнями. Нині існуе чимало загроз для Полісся, пов'язаних із негативними наслідками діяльності людини: масштабні вирубки, часті пожежі, зневоднення територій, зокрема осушення боліт, незбалансоване полювання, неекологічний збір ягід, недбале ставлення до довкілля тощо. Все це руйнує універсальну екосистему Полісся. Тому саме в осягненні цінності, природного феномену його складника - Полісся Рівненщини, а також необхідності його збереження та популяризації полягає актуальність цієї статті.

Аналіз останніх досліджень i публікацій. Численні студії вітчизняних дослідників засвідчують посилений інтерес до проблемного поля природної унікальності Полісся Рівненщини. Так, питання породного складу лісових масивів цієї місцевості та їх використання у рекреації та туризмі фахово інтерпретовані у публікаціях М. Мельнійчука і В. Чабанчук [6;12]. Грунтовне дослідження місця та ролі боліт і водойм Полісся Рівненщини в контексті функціонування і збереження біорозмаїття регіону проведено Т. Журій [3], Л. Ступчук [11] і В. Шрамовичем [13]. Розгляд стану та технології видобування невід'ємної ланки природного феномену Полісся Рівненщини родовищ базальту - міститься у публікації І. Гнатюк i С. Іванова [2]. 3'ясуванню й окресленню значення базальтових стовпів як одного 3 атрибутів природної винятковості Полісся Рівненщини присвячені статті А. Калька, В. Шкіринця і Н. Волненко [4], а також В. Одарченко [8]. Докладну інформацію про поліський бурштин як коштовний камінь і корисну копалину регіону викладено у праці В. Мельничука і М. Криницької [7].

Виділення не вирішених раніше частин загальної проблеми, котрим присвячусться означена стаття. Незважаючи на низку грунтовних наукових розвідок, присвячених окремим аспектам природного феномену Полісся Рівненщини, відсутність комплексного дослідження органічної неповторності цього регіону спонукала авторку до більш докладного студіювання вказаної теми.
ПРИРОДНИЙ ФЕНОМЕН ПОАІССЯ РІВНЕНЩИНИ

Новизна. У статті здійснено збір, систематизацію, аналіз основних показників природної унікальності Полісся Рівненщини: лісових ландшафтів, болотних масивів, заплав річки Прип'ять, а також гранітних, базальтових і бурштинових родовищ.

Методологічне або загальнонаукове значення. Акцентована увага на обгрунтуванні регіону Полісся Рівненщини як видатного зразка екологічних, біологічних і геологічних процесів.

Викладення основного матеріалу. Уже в самій назві географічного макрорегіону Полісся вказано один із його провідних природних ресурсів - ліс. У цьому контексті Рівненщина є цьому яскравим підтвердженням. За оцінкою фахівців, лісистість Полісся Рівненщини є однією з найвищих в Україні: вона становить $46,7 \%$, що є в 3 рази більшим від середнього показника по країні. До найбільш заліснених належать Рокитнівський, Березнівський, Сарненський, Володимирецький і Дубровицький райони Рівненської області [6, с. 344].

Структура лісів Полісся Рівненщини за групами порід виглядає таким чином: хвойні $(65,4 \%)$, м'яколистяні $(23,8 \%)$ і твердолистяні $(10,8 \%)$ [10, с. 16]. Домінантною породою хвойних є сосна звичайна (Pinus sylvestris L.), яка займає 69,7\% вкритих лісовими насадженнями лісових ділянок Полісся Рівненщини (334 067,3 га). Значні лісові масиви займають береза повисла (Betula pendula Roth.) 15,4\% (73 982,4 га), дуб звичайний (Quercus robur L.) 4,3\% (20 566,9 га) та вільха чорна (Alnus glutinosa (L.) Gaerth.) - 9,9\% (47 404,7 га), а також ялина Європейська (Picea abies) - 0,4\% (1824,5 га) і граб звичайний (Carpinus betulus L.) - 0,2\% (5127,3 га). Всі інші породи дерев Полісся Рівненщини становлять $0,1 \%$ [6, с. 344].

Наголосимо, що видовий склад і вікова структура лісових ландшафтів Полісся Рівненщини визначають важливу рекреаційну, зокрема лікувально-оздоровчу, функцію. Так, висока фітонцидність, тобто здатність вбивати чи пригнічувати ріст і розвиток бактерій, мікроскопічних грибів та інших форм мікроорганізмів, притаманна для соснових борів, де в 2 рази менше бактерій, ніж у мішаних зелених насадженнях. У широколистяно-соснових лісах спостерігається зменшений вміст у повітрі шкідливих газів і радіоактивних речовин. Водночас такі породи дерев, як клен, липа, тополя тощо характеризуються помітною шумознижувальною здатністю. Для порівняння: якщо в $1 \mathrm{~m}^{3}$ міського повітря міститься 30-40 тисяч бактерій та мікроорганізмів, то в лісовому повітрі їх знаходиться не більше 400. Зокрема, фітонциди сосни звичайної та крушини ламкої вбивають збудників туберкульозу, кишкової палички, а берези і тополі зменшують кількість мікробів золотистого стафілококу [12, с. 149-150].

2020 p. на Поліссі Рівненщини, а саме у Висоцькому, Володимирецькому, Дубровицькому, Зарічненському, Рафалівському, Рокитнівському та Остківському лісництвах фахівцям вдалося виявити 1556 га унікальних лісів, що збереглися завдяки природним бар'єрам та важкій доступності. Вони росли без втручання людини, зберегли свою природну структуру i видовий склад. Тому саме 
природний шлях розвитку цих лісових масивів забезпечив їхню стійкість. Ці ліси - еталонні з погляду історичного фітоценогенезу (процесу формування та розвитку) заболочених лісів. Вони отримали статус пралісів, квазіпралісів та природних лісів, а тому перебувають нині під охороною дії Закону України № 2063 - VIII від 23 травня 2017 р. «Про внесення змін до деяких законодавчих актів України щодо охорони пралісів згідно з рамковою конвенцією про охорону та сталий розвиток Карпат» [1].

На території Рівненщини знаходяться й найбільш цінні масиви боліт Полісся. Так, у Рівненському природному заповіднику представлені болота всіх типів, що $\epsilon$ на Українському Поліссі. Болотний масив «Переброди» має рідкісний для України процес розвитку - периферійно-оліготрофний, тобто розвиток болота, наростання шару торфу і збіднення живлення тут відбуваються з периферії до центру [9]. Водночас болотні масиви Полісся Рівненщини є надзвичайно важливими з погляду підтримання водного балансу, оскільки, як губки, адсорбують і накопичують надлишок води, а впродовж засушливих сезонів звільняють ці запаси, компенсуючи водний дефіцит. Тому болота Полісся Рівненщини - це унікальна система, що є джерелом живлення не лише водойм, але і флори та фауни регіону $[1 ; 13]$.

Основним водним ресурсом Полісся Рівненщини $€$ річка Прип'ять. Вона належить до останніх великих річок Свропи, що майже не зазнали серйозного втручання людини. Про це свідчать неспрямленість русла, відсутність дамб, незмінність течії. Для неї дотепер характерна велика кількість меандрів і рукавів, а широка заплава зумовлює неповторний характер місцевості [3]. Тому невипадково річку Прип’ять ще називають «європейською Амазонкою».

Саме екосистеми заплав Прип'яті, що були сформовані впродовж тривалої еволюції і складаються 3 боліт, луків, лісів та інших екосистем із широкомасштабними гідрологічними та екологічними процесами та характерною сезонною динамікою, i $є$ одним із феноменів Полісся Рівненщини [3]. Вони - притулок для рідкісних і вразливих видів тварин (лось, рись), птахів (свищ євразійський (Mareca penelope), брижач (Calidris pugnax), очеретянка прудка (Acrocephalus paludicola), підорлик великий (Aquila clanga)), рослин (рододендрон жовтий (Rhododendron luteum), росичка (Drosera), зозульки травневі (Dactylorhiza majalis)), а також комах.

Ще однією ексклюзивною рисою Полісся Рівненщини $є$ те, що воно багате родовищами будівельних матеріалів - піску, глини, вапняку, крейди, будівельного каменю тощо. Зокрема, у структурі будівельної сировини Полісся Рівненщини вагоме місце посідає такий вид будівельних корисних копалин, як граніт - одна 3 найміцніших гірських магматичних порід. Його поклади пов'язані із ПівнічноЗахідним мегаблоком Українського кристалічного щита (УЩ), де переважають палеопротерозойські габро-діорит-гранітні породи. Для цього будівельного матеріалу характерні витримування температури до $600{ }^{\circ} \mathrm{C}$, висока щільність, стійкість до механічних ушкоджень і несприятливих умов навколишнього природного середовища [2, с. 17].
На території Полісся Рівненщини розвідано більше 20 родовищ граніту: 15 - у Сарненському, 6 - у Рокитнівському, а також по декілька у Березнівському та Корецькому районах. Граніти переважно дрібно- та середньозернисті, хоча трапляються й більш тверді кристалічні породи. Залежно від особливостей навколишнього природного середовища, що яскраво простежуються 3 півночі на південь Рівненщини, колір граніту змінюється від сірого до рожево-коричневого [2, с. 14]. Так, одним iз найбільших родовищ граніту в Рівненській області є кар'єр «Крута Слобода», що знаходиться поблизу смт Томашгород у Рокитнівському районі. Його площа становить 77 га, а розвідані запаси - 8 млн м³. Будівельна сировина 3 нього має настільки високі показники якості, що не лише конкурує з видобувними породами граніту на українському ринку, але й експортується за кордон, зокрема в Литву, Латвію і Польщу [2, с. 17].

Крім того, геологічним феноменом Полісся Рівненщини є родовища базальту - так звані базальтові стовпи з Костопільського району. Це - пам'ятка древнього вулканізму на Поліссі, поетично описана академіком П.А. Тутковським: «Як ліс величезних правильних кристалів, як мовчазне військо зачарованих кам'яних велетнів підноситься перед вами ця величезна природна колонада... Треба самому бачити iii, щоб оцінити своєрідну красу і поетичну розкіш цього майже нікому невідомого куточка України, одного 3 найцікавіших місць нашого краю, гідного уваги любителів природи і туристів» [4, с. 167].

Науковцями з'ясовано, що на венд-рифейському етапі протерозойської ери докембрію (600-650 млн років тому) в цій місцевості відбулося виверження вулкану, лава з якого застигала у вигляді шестигранних (рідше - чотиригранних або восьмигранних) стовпів. Виливання вулканічної лави відбувалося багаторазово впродовж тривалого геологічного періоду. Саме тому в родовищах базальту на Поліссі Рівненщини виділяють до десяти базальтових потоків; базальтові стовпи залягають один над одним, засвідчуючи значну різноманітність форм і кутів залягання. Висота базальтових стовпів коливається від 3 до 30 м, а ширина - від 6 до 120 см [4, с. 168].

Водночас феномен базальтових стовпів Полісся Рівненщини пояснюється тим, що видобуток базальтової сировини обмежується лише родовищами цього регіону, а отже, в межах України вони $\epsilon$ винятковими. Справа в тому, що суцільні базальтові покриви у вигляді стовпів - трапи - виявлені на території Рівненської i Волинської областей. Вони залягають під 20-50-метровим шаром осадових порід, і лише в кар'єрах Рівненщини базальти виходять на поверхню, що й зумовлює їх активне видобування. Так, найбільша кількість базальтових кар'єрів знаходиться в околицях сіл Злазне, Базальтове (урочище Іванова Долина), Берестовець, Великий Мидськ (біля хутора Мутвіца), Гутвин і Рудня Костопільського району Рівненської області [4, с. 168-169]. Відомо, що з базальтової сировини, видобутої з місцевих кар'єрів, викладена бруківка площ Парижа, Брюсселя, Відня, Берліна і Варшави. Нині ж на основі базальту виготовляють теплоза- 
Герман Н.В.

хисне покриття для космічних кораблів, тканину для пожежних костюмів і скафандрів, використовують для виробництва турбоактивних двигунів тощо [8].

Не можемо обійти увагою ще один природний феномен Полісся - бурштин. Це - унікальний автохтонний коштовний камінь органічного походження, що відрізняється від більш поширеного прибалтійського бурштину різноманітнішим кольоровим спектром, а тому більше цінується. За даними прогнозних ресурсів щодо наявності бурштинової сировини на Поліссі, Україна посідає друге місце у світі. Значні його запаси знаходяться й на Поліссі Рівненщини. Так, згідно 3 результатами пошуково-оцінюваних робіт, що проводилися Рівненською геологічною експедицією, прогнозні ресурси бурштину на окремих ділянках лише в Дубровицькому, Сарненському та Володимирецькому районах Рівненської області становлять більше 1500 т. Для порівняння: згідно з офіційними даними за 2013 р. річний видобуток бурштину в Рівненській області становив 4,5 т [7, с. 4-5]. Вражає і різновекторність сфер його застосування: ювелірна справа, образотворче та декоративно-прикладне мистецтво, парфумерна, фармацевтична та лакофарбова галузі, лікувальна та релігійно-обрядова практика, а також царина економіки, де бурштин виступає як надійний засіб розміщення капіталу [7, с. 5]. У сукупності це дає підстави для твердження про унікальність бурштину як дорогоцінного мінерального ресурсу 3 численними потенційними можливостями його використання.

Головні висновки. Отже, ключовим природним феноменом Полісся Рівненщини є лісові ландшафти. Їхня лісистість $є$ однією з найвищих в Україні. У них переважають хвойні лісові масиви, а сосна звичайна $€$ домінантною породою дерев. 3 цим пов'язані високий рівень їх фітонцидності та яскраво виражена лікувально-оздоровча функція. Крім того, внаслідок малодоступності для людини частина лісів регіону зберегла свій первісний вигляд, а тому є винятковою. Це підтверджується набуттям нею 2020 р. статусу пралісів, квазіпралісів і природних лісів. На території Рівненщини знаходяться й найбільш цінні масиви боліт, окремі з яких мають рідкісний для України процес розвитку. Водночас місцеві болота є надзвичайно важливими 3 погляду підтримання водного балансу в регіоні, а також забезпечення життєдіяльності його флори і фауни. Неповторними природними об'єктами Полісся Рівненщини є екосистеми заплав річки Прип'ять, що були сформовані впродовж тривалої еволюції: нині вони є домівкою для рідкісних і вразливих видів тварин, рослин, птахів і комах. Ще одним феноменом природи Полісся Рівненщини є те, що воно багате родовищами будівельних матеріалів, зокрема, одне 3 вагомих місць у цій структурі посідає граніт. Місцева будівельна сировина 3 нього має настільки високі показники якості, що не лише конкурує з відповідними видобувними породами на українському ринку, але й експортується за кордон. Базальтові стовпи Полісся Рівненщини - це водночас і унікальне геологічне явище, вияв древнього вулканізму, що вражає монументальністю й бездоганністю природних форм, і ексклюзив із погляду видобування та використання базальтової сировини в Україні. Дорогоцінним мінеральним ресурсом Полісся Рівненщини є бурштин, потенційні можливості використання якого $\epsilon$ надзвичайно розмаїтими. Все це в сукупності дає підстави для твердження про універсальну винятковість природи Полісся Рівненщини.

Перспективи використання результатів дослідження авторка вбачає в розробленні не лише теоретичних документів роз'яснювального характеру (наприклад, для державних інституцій або органів місцевого самоврядування), але й практичних, зокрема тематичних еколого-природничих матеріалів для навчально-виховної роботи у школі та 3ВО.

\section{Література}

1. Болото на вагу золота: чому важливо зберегти Прип'ятське Полісся. URL: https://manevychi.rayon.in.ua/topics/ 388225-hraniteli-polissia-iak-vprovadzhuiutsia-novi-vidnosini-mizh-liudinoiu-i-prirodoiu (дата звернення 27.11.2021).

2. Гнатюк І., Іванов Є. Родовища граніту у Рівненській області: стан, технологія видобування, екологія. Вітчизняна наука на зламі епох: проблеми та перспективи розвитку: матеріали XXV Всеукраїнської науково-практичної інтернет-конференції (16-17 вересня 2016 р.): збірник наукових праць. Вип. 25. Переяслав-Хмельницький, 2016. С. 14-17.

3. Журій Т. Територія Рівненського природного заповідника може стати світовою природною спадщиною ЮНЕСКО. URL: https://www.visti.rovno.ua/news/teritoriya-rivnenskoho-prirodnoho-zapovidnika-mozhe-stati-svitovoyu-prirodnoyuspadshchinoyu-yunesko (дата звернення 29.11.2021).

4. Калько А.Д., Шкіринець В.М., Волненко Н.П. Геологічні об’єкти Рівненщини як складова створення геопарків. Психологопедагогічні основи гуманізачії навчально-виховного прочесу в школі та ВНЗ : збірник наукових праць. Рівне : МЕГУ ім. акад. С. Дем’янчука. 2017. № 19 (1). С. 165-174.

5. Літопис руський / Пер. з давньорус. Л.С. Махновця; відп. ред. О.В. Мишанич. - К.: Дніпро, 1989. 591 с.

6. Мельныйчук М. М., Чабанчук В. Ю. Породний склад лісів Полісся Рівненщини (на прикладі Висоцького лісгоспу). Географические аспекты устойчивого развития регионов: II международная научно-практическая конференция (Гомель, 23-24 марта 2017 г.) : [материалы]. Гомель : ГГУ им. Ф. Скорины, 2017. С. 343-348.

7. Мельничук В.Г., Криницька М.В. Бурштин Полісся. Довідник. Рівне: НУВГП, 2018. 236 с.

8. Одарченко В. Поліська Етна - «Базальтові стовпи». URL: https://www.radiosvoboda.org/a/1189090.html (дата звернення 01.12.2021).

9. Рівненський природний заповідник. Україна Інкогніта. URL: https://ukrainaincognita.com/rivnenska-oblast/sarnenskyi-raion/ sarny/rivnenskyi-pryrodnyi-zapovidnyk (дата звернення 01.12.2021).

10. Стратегія розвитку Рівненської області на період до 2027 року. Рівне, 2020. 160 c. URL: https://www.minregion.gov.ua/ wp-content/uploads/2020/05/strategiya-rozvytku-rivnenskoyi-oblasti-na-period-do-2027-roku-.pdf (дата звернення 01.12.2021).

11. Ступчук Л. У чому цінність Полісся... URL: https://day.kyiv.ua/uk/article/naprykinci-dnya/u-chomu-cinnist-polissya (дата звернення 02.12.2021)

12. Чабанчук В., Мельнійчук М. Використання поліських лісових ландшафтів Рівненщини у рекреації та туризмі. Наукові записки Тернопільського начіонального педагогічного університету імені Володимира Гнатюка. Серія: Географія. 2015. № 2. C. 147-152.

13. Шрамович В. Як Україна перетворюється на сухе болото. URL: https://www.bbc.com/ukrainian/features-53989097 (дата звернення 29.11.2021) 


\title{
ІНДУКЦІЯ ЗАХИСНИХ РЕАКЦІЙ У РОСАИН ZEA MAYS L. (РОАСЕAE) В УМОВAХ ПОСУХИ
}

\author{
Зубровська О.М. \\ Криворізький ботанічний сад Національної академії наук України \\ вул. Маршака, 50, 50089, м. Кривий Ріг, Дніпропетровська область \\ zubrovska@ukr.net
}

\begin{abstract}
В умовах глобального потепління в помірних широтах прогнозується зростання частоти й інтенсивності посух, які вважаються одним із найбільш руйнівних екологічних стресорів для рослин. У зв'язку з цим особливо актуальним $є$ з'ясування адаптивних процесів та пошук засобів підвищення неспецифічної стійкості рослин, які зростають у подібних кліматичних умовах. У статті наведено результати досліджень із вивчення посухи на ростові та фізіолого-біохімічні показники 22-добових рослин Zea mays L. (Роасеае), гібриду Бліц 160 MB (середньостиглий), районованого у степовій зоні України. У вегетаційних дослідах показано, що короткочасна грунтова посуха пригнічувала ростові процеси у вегетативних органах рослин (особливо у надземній частині). Встановлено, що дефіцит вологи в середовищі зростання викликав посилення вільнорадикальних реакцій i, як наслідок, зумовлював зниження вмісту хлорофілів $a$ (в 1,4 раза) і $b$ (в 1,3 раза), їх співвідношення, а також кількості каротиноїдів (в 1,25 раза). Передпосівна обробка «Антистресом» сприяла кращому росту рослин $Z$. mays в умовах стресу (активніше формувалася коренева система, зростав показник коренезабезпечення) і помітно зменшувала прояви пероксидного окиснення ліпідів (рівень ТБК-активних сполук зменшувався на 40\%). Однак повного відновлення морфометричних показників рослин не відбулося. Виявлено позитивний вплив біостимулятора на розвиток фізіологічних процесів у рослин: за нормального рівня зволоженості збільшувалися показники вмісту пігментів (от 16 до 40\%), а в умовах дефіциту вологи в середовищі зростання рівень хлорофілів і каротиноїдів менше відрізнявся від норми, причому рівень каротиноїдів відновлювався майже до контрольних значень. Зроблено припущення, що індуковане «Антистресом» зростання співвідношення хлорофілів $a / b$ і збільшення вмісту каротиноїдів у 22-добових рослин $Z$. mays в умовах дефіциту вологи може слугувати ознакою високої потенційної інтенсивності фотосинтезу і підтверджує комплексний характер формування реакції-відповіді на стрес на іматурній стадії розвитку рослин. Ймовірно, протекторна роль регулятору росту передусім зумовлена стимуляцією розвитку кореневої системи та активуванням систем антиоксидантного захисту рослин, зокрема за рахунок підвищення рівня каротиноїдів, що може привести до нормалізації водного обміну, поліпшення процесів транспірації і фотосинтезу у тканинах листків кукурудзи. Ключові слова: посуха, Zea mays, хлорофіли, каротиноїди, ТБК-активні сполуки, біостимулятор.
\end{abstract}

Induction of protective reactions in plants of Zea mays L. (Poaceae) under drought conditions. Zubrovska $\mathbf{O}$.

Under the conditions of the global warming in the middle latitudes, an increase in the frequency and intensity of droughts is expected, and the droughts are considered one of the most destructive environmental stressors for plants. In this regard, explanation of the adaptive processes and searching for ways to increase the nonspecific resistance of plants growing in such climatic conditions is of prime importance. The paper presents the results of study of the drought impact on the growth and physiological-biochemical indicators of 22-day-old plants of Zea mays L. (Poaceae), Blitz 160 IS hybrid, released in the steppe zone of Ukraine. Vegetation experiments showed that short-term soil drought inhibited the processes of growth in the vegetative organs of plants (most notably, in the aboveground part). It is found that moisture deficit in the growing environment caused the enhancement of free-radical reactions and, as a consequence, contribute to reduction of the content of chlorophylls $a$ (1.4 times) and $b$ (1.3 times), their ratio, as well as the number of carotenoids (1.25 times). Seed incrustation by "Antistress" promoted the better growth of $Z$. mays plants under stress (more active formation of the root system, increase in the root supply indicator) and significantly reduced the manifestations of lipid peroxidation (the level of TBA-reactive compound decreased by 40\%). However, no complete recovery of morphometric parameters of the plants occurred. Positive effect of the biostimulator on the development of physiological processes in plants has been recorded: at the normal humidity level the indicators of the pigment content increased (from 16 to 40\%), while under the conditions of moisture deficit in the growing environment the level of chlorophylls and carotenoids was less different from the normal level, and the level of carotenoids almost restored to control values. It is suggested that "Antistress"-induced increase in $a / b$ chlorophyll ratio and carotenoid content in 22-day-old Z. mays plants under the conditions of moisture deficit may serve as a sign of high potential intensity of photosynthesis and confirms the integrated nature of the response to stress at the immature stage of the plant development. Probably, the protective role of the growth regulator is primarily conditioned by the stimulation of root system development and activation of the plant antioxidant protection systems, in particular, by increasing the level of carotenoids, which, in turn, can lead to normalization of water metabolism, and improvement of the processes of transpiration and photosynthesis in the tissues of maize leaves. Key words: drought, Zea mays, chlorophylls, carotenoids, TBA-active compounds, biostimulator "Antistress".

Постановка проблеми та актуальність дослідження. Глобальне потепління, зумовлене впливом техногенних і природних циклічних процесів, супроводжується зростанням кількості катастрофічних атмосферних явищ та загальним порушенням кліматичної рівноваги. У помірних широтах прогно- зується збільшення частоти й інтенсивності посух, що поступово перетворить зони гарантованого рослинництва у регіони ризикованого землеробства [1]. Посуха вважається одним із найбільш руйнівних екологічних стресорів для рослин, який суттєво пригнічує їхній ріст та розвиток [2]. Головними наслідками 


\section{Зубровська О.М.}

iii згубної дії є розвиток пероксидного окиснення ліпідів, зниження швидкості поділу і розтягування клітин, зменшення розмірів листків і продихового апарату, видовження пагону і проліферація коренів, порушення фотосинтезу, транспірації, ферментативної активності тощо [3]. Рослини реагують на посуху специфічно, а їх стійкість у стресових умовах зумовлена функціонуванням різноманітних фізіолого-біохімічних процесів. Тому саме фізіологічна пластичність визначає діапазон виживання рослин і їх продуктивності [4]. Кукурудза (Zea mays L.) завдяки екологічній пластичності, здатності фотосинтезувати за $\mathrm{C}_{4}$-типом [5], ефективно використовувати елементи живлення і високим кормовим якостям займає одне із провідних місць у світовому землеробстві.

Одним $з$ екологічно безпечних та економічних шляхів підвищення продуктивності й захисту сільськогосподарських рослин в умовах глобального потепління $є$ застосування регуляторів росту різноманітної природи, таких як препарати з алелопатично активними сполуками [6], бактеріями [7], фунгіцидами [8], сіліцієвмісні препарати [9]. Саме тому нас зацікавив новий регулятор росту «Антистрес» (ПП «ВКФ Імпторгсервіс», Україна) із підвищеною адаптогенною дією, активні компоненти якого швидко включаються у різноманітні фізіологічні процеси рослин і підвищують їхню стійкість до несприятливих факторів довкілля. Нині використання цього біостимулятора в екологічному землеробстві і фізіологічні механізми його впливу на рослини в посушливих умовах досліджені недостатньо. Отже, метою нашої роботи було вивчення впливу передпосівної обробки насіння «Антистресом» на динаміку ростових процесів, вміст пігментів і перебіг вільнорадикальних реакцій у рослин кукурудзи за дії грунтової посухи.

Матеріали і методи дослідження. Досліди проводили на 22-добових рослинах кукурудзи L. гібриду Бліц 160 MB. Частину насіння попередньо витримували 3 год. у розчині регулятора росту в рекомендованих виробником концентраціях. Далі все насіння пророщували у термостаті при $+24^{\circ} \mathrm{C}$, висаджували у 2-літрові ємності із стерилізованим піском і вирощували в лабораторних умовах за I.А. Григорюком [10]: температура $+20 /+17^{\circ} \mathrm{C}$ (день/ніч), фотоперіод 16/8 год. (день/ніч), освітлення 690 мкмоль квантів/ $\left(\mathrm{m}^{2} \bullet \mathrm{c}\right)$, відносна вологість повітря $65 \pm 5 \%$, вологість субстрату $60 \%$ від повної вологоємності (щоденно поливали розчином Кнопа по 50 мл на ємність). Грунтову посуху моделювали шляхом припинення поливу 14-добових рослин впродовж 4 наступних діб до моменту зниження вологоємності субстрату вдвічі. Потім полив відновлювали, і рослини зростали в нормальних умовах до 22-ї доби (іматурна стадія розвитку). Морфометричні показники рослин оцінювали за загальноприйнятими методами [11]. Посухостійкість оцінювали за показником коренезабезпечення (Мк/Мл), який відображає співвідно-

\section{ІНДУКЦІЯ ЗАХИСНИХ РЕАКЦІЙ..}

шення маси коренів і надземної частини [12]. Вміст пігментів у листках визначали за A.R. Wellburn [13] iз використанням диметилсульфоксиду, концентрацію ТБК-активних продуктів - за М.М. Мусієнко [14]. Повторність у межах окремого варіанту досліду становила 50 рослин, аналітична повторність 4-кратна. Статистичну обробку даних проводили за методами параметричної статистики [15] за рівня значущості $p \leq 0,05$.

Виклад основного матеріалу. Посушливість клімату пригнічує функціональну активність органів рослин і гальмує їх ростові процеси. Так, короткочасна грунтова посуха у 22-добових рослин $Z$. mays призводила до скорочення на 20\% довжини і коренів, і надземної частини, а їх маса знизилася на 16 та 26\% відповідно (табл. 1). Відзначимо, що першочергово пошкоджувалися корені, бо навіть після налагодження поливу через відмирання кореневих волосків репараційні процеси уповільнювалися, а функціональна активність кореневої системи повністю не поновлювалася.

Інкрустація насіння «Антистресом» покращувала ростові показники рослин на 5-13\% відносно таких без обробки, як у контрольних умовах, так і за водного дефіциту. При цьому інтенсивніше збільшувалася маса коренів (табл. 1), чому, ймовірно, сприяла наявність у складі біостимулятора Mapc-EL, диметилсульфоксиду, флуору і калію, які опосередковано активували роботу різноманітних ферментів і брали участь у синтезі білків та вуглеводів. Оскільки посухостійкість різних видів рослин залежить від співвідношення розмірів поверхні листків і кореневої системи, нами показано, що у гібриду Бліц 160 МВ в посушливих умовах показник коренезабезпечення (Мк/Мл) зменшувався на $8 \%$ відносно контролю (табл. 1). Натомість обробка насіння регулятором росту сприяла збільшенню цього показника у 1,24 раза.

Успішність адаптації рослин за дії стресорів значною мірою залежить від оптимального функціонування асиміляційного апарату. Фотосинтез основний метаболічний процес, що забезпечує утворення біомаси рослин, продуктивність якого залежить від вмісту у листках фотосинтетичних пігментів, їх складу і співвідношення [16]. Більшість дослідників показали, що посуха призводить до зниження кількості хлорофілів у рослинах $[17 ; 18]$. На рис. 1 відображено, що за дефіциту вологи у рослин $Z$. mays сумарний рівень хлорофілів зменшувався, що відбувалося переважно за рахунок хлорофілу $a$, вміст якого у 1,4 раза був нижчим за контрольні показники, тоді як кількість хлорофілу $b$ знижувалася у 1,3 раза. Встановлене, вочевидь, пов'язане з генерацією активних форм кисню, що призводить до пошкодження молекул пігментів, та інгібуванням активності ключових ферментів синтезу хлорофілів [19].

Каротиноїди захищають молекули хлорофілу від фотоокиснення, підтримуючи життєздатність рослин у стресових умовах [20]. Як нами показано, 
Вплив грунтової посухи на морфометричні показники $Z$. mays (*- статистично достовірна різниця до контролю при $p \leq 0,05$ )

\begin{tabular}{|c|c|c|c|c|c|}
\hline \multirow{3}{*}{ Варіант } & \multicolumn{2}{|c|}{ Надземна частина } & \multicolumn{2}{|c|}{ Корені } & \multirow{3}{*}{ Мк/Мл } \\
\hline & Maca, $\Gamma$ & Довжина, см & Maca, $\Gamma$ & Довжина, см & \\
\hline & $\mathbf{M} \pm \mathbf{m}$ & $\mathbf{M} \pm \mathbf{m}$ & $\mathbf{M} \pm \mathbf{m}$ & $\mathbf{M} \pm \mathbf{m}$ & \\
\hline Контроль & $0,57 \pm 0,01$ & $24,0 \pm 0,62$ & $0,69 \pm 0,02$ & $23,8 \pm 6,08$ & 1,21 \\
\hline Контроль + Антистрес & $0,60 \pm 0,01^{*}$ & $24,4 \pm 1,10^{*}$ & $0,79 \pm 0,01^{*}$ & $26,2 \pm 3,74^{*}$ & 1,31 \\
\hline Посуха & $0,45 \pm 0,01 *$ & $20,3 \pm 1,03 *$ & $0,50 \pm 0,02 *$ & $19,8 \pm 7,13^{*}$ & 1,11 \\
\hline Посуха + Антистрес & $0,48 \pm 0,01^{*}$ & $21,0 \pm 1,16^{*}$ & $0,66 \pm 0,02 *$ & $20,7 \pm 2,75^{*}$ & 1,38 \\
\hline
\end{tabular}

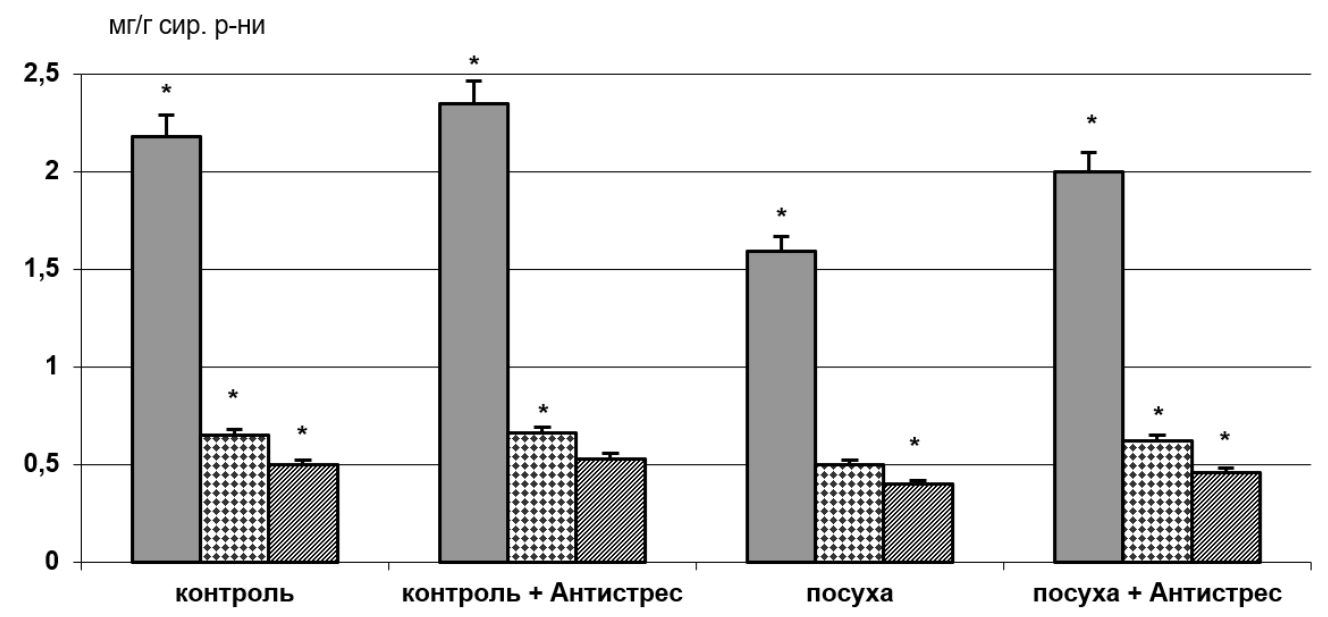

\section{口хлорофіл а Фхлорофіл b चкаротиноїди}

Pис. 1. Вміст пігментів (мг/2 сирої речовини) у листках Z. тауs на 22-гу добу росту; * - статистично достовірна різниця відносно контролю за $p \leq 0,05$

кількість сумарних каротиноїдів у листках Z. mays за дії посухи знижувалася на 25\% відносно контролю (рис. 1). Встановлене вказує на порушення роботи світлозбираючого комплексу пігментних систем, у результаті чого пригнічуються ростові процеси рослин.

Загальною тенденцією позитивного впливу «Антистресу» за дефіциту вологи було збільшення вмісту пігментів у гібриду Бліц 160 МВ. Так, кількість хлорофілів $a$ і $b$ у листках зростала в 1,2 раза порівняно з варіантом без регулятора росту (рис. 1). Вміст каротиноїдів збільшувався суттєвіше (майже наближався до рівня контролю), що в посушливих умовах сприяло захисту фотосинтетичної системи, адже каротиноїди є попередниками багатьох антиоксидантних сполук та абсцизової кислоти - «гормону стресу» [21].

Важливим показником збалансованості фотосинтезу є співвідношення між кількістю хлорофілів $a$ i $b$, яке в умовах стресу використовують як маркер стійкості рослинного організму [3]. В умовах короткочасної грунтової посухи співвідношення хлорофілів $a / b$ і співвідношення між сумарним вмістом хлорофілів та каротиноїдів у листках $Z$. mays знизилося від 5 до 12\% відносно контролю (табл. 2). Тоді як у варіантах із біостимулятором їх показники зростали, що може вказувати на високу потенційну інтенсивність фотосинтезу і підтверджує комплексний характер формування захисних реакцій на посуху на іматурній стадії розвитку.

Однією із причин зниження вмісту хлорофілів у посушливих умовах є утворення активних форм кисню, які викликають пероксидне окиснення ліпідів (ПОЛ) i, як наслідок, пошкодження самих молекул хлорофілу [22]. У наших дослідженнях нестача вологи у грунті індукувала незначне збільшення інтенсивності ПОЛ у вегетативних органах необроблених рослин. Так, кількість ТБК-активних сполук у листках $Z$. mays зростала лише у 1,3 раза, а в кореневій системі - у 1,5 раза (рис. 2), що може свідчити про високу толерантність і стійкість гібриду до впливу посухи.

Обробка насіння Z. mays «Антистресом» у посушливих умовах відчутно зменшувала прояви окиснювального стресу (рис. 2), а протекторна дія препарату помітніше проявлялась у коренях, про що свідчить на 40\% менша кількість ТБК-активних сполук відносно варіанту без інкрустації. Очевидно, індукція регулятором росту резистентності до посухи може бути зумовлена присутністю у складі препарату диметилсульфоксиду, який стабілізує 
Співвідношення фотосинтетичних пігментів у листках Z. mays на 22-гу добу росту (* - статистично достовірна різниця до контролю при $p \leq 0,05$ )

\begin{tabular}{|c|c|c|c|c|}
\hline \multirow{2}{*}{ Варіант } & \multicolumn{2}{|c|}{ Сума хлорофілів, мг/г сир. p-ни } & \multicolumn{2}{|c|}{ Індекси співвідношенн різних пігментів } \\
\cline { 2 - 5 } & $\mathbf{M} \pm \mathbf{m}$ & $\mathbf{V}, \mathbf{\%}$ & $\mathbf{C h l} a / \mathbf{C h l} b$ & $\sum$ хл. / $\sum$ кар. \\
\hline Контроль & $2,83 \pm 0,077$ & 10,89 & 3,35 & 5,66 \\
\hline Контроль + Антистрес & $3,01 \pm 0,027^{*}$ & 15,19 & 3,56 & 5,68 \\
\hline Посуха & $2,09 \pm 0,012^{*}$ & 3,05 & 3,18 & 5,22 \\
\hline Посуха + Антистрес & $2,62 \pm 0,035^{*}$ & 6,73 & 3,23 & 5,70 \\
\hline
\end{tabular}

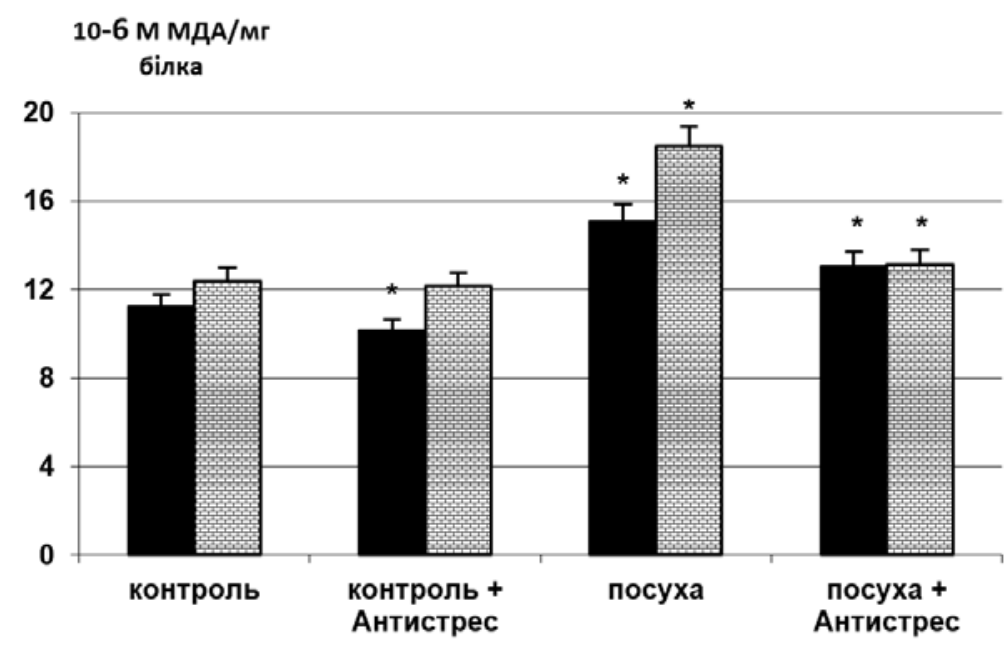

Шнадземна частина

Фкорені

Pис. 2. Вміст ТБК-активних сполук у 22-добових рослин Z. тауs в умовах грунтової посухи, 10-6 М МДА/мг білка

(* - статистично достовірна різниця до контролю при $p \leq 0,05)$

бар'єрну функцію тонопласту і стимулює активність ферментів антиоксидантного захисту [23; 24].

Головні висновки. Підсумовуючи, зазначимо, що передпосівна обробка «Антистресом» в умовах грунтової посухи сприяла кращому росту рослин Z. mays і помітно зменшувала прояви стресового впливу у гібрида Бліц 160 МВ. Встановлено позитивний вплив біостимулятора на розвиток фізіологічних процесів: за нормального рівня зволоження збільшувалися показники вмісту пігментів, а в умовах дефіциту вологи у грунті рівень хлорофілів і каротиноїдів меншою мірою відхилялися від норми. Очевидно, протекторна роль «Антистресу» передусім зумовлена стимуляцією розвитку кореневої системи й активуванням систем антиоксидант- ного захисту, в тому числі за рахунок підвищення рівня каротиноїдів у листках, що нормалізує водний обмін, покращує процеси транспірації і фотосинтезу в тканинах листків Z. mays.

Перспективи використання результатів дослідження. Відзначимо, що доцільно було би продовжити дослідження на наступних етапах розвитку рослин для 3'ясування можливостей нівелювання «Антистресом» стресового впливу посухи на генеративну сферу кукурудзи й отримання стабільного врожаю. Встановлені результати дадуть змогу доповнити та оновити список районованих сортів кукурудзи, які виявляють толерантність до нестачі вологи у середовищі зростання і найкращу продуктивність в умовах посушливого степу.

\section{Література}

1. Meehl G.A., Stocker T.F., Collins W.D., Friedlingstein P., Gaye T., Gregory J.M., Kitoh A., Knutti R., Murphy J.M., Noda A., Raper S.C.B., Watterson I.G., Weaver A.J., Zhao Z.C. Global Climate Projections. Climate Change 2007: the physical science basis. Contribution of Working Group I to the Fourth Assessment Report of the Intergovernmental Panel on Climate Change. Cambridge, U.K., 2007, № 10. P. 747-846.

2. Farooq M., Hussain M., Wahid A., Siddique K.H.M. Drought Stress in Plants: An Overview. Plant Responses to Drought Stress. Springer-Verlag-Berlin-Heidelberg, 2012. P. 1-15. DOI: 10.1007/978-3-642-32653-0-1.

3. Fathi A., Barari Tari D. Effect of Drought Stress and its Mechanism in Plants. Intern. J. Life Sci. 2016. V. 10(1). P. 1-6. DOI: 10.3126/ijls.v10i1.14509. 
4. Пятыгин С.С. Стресс у растений: физиологический подход. Журнал общей биологии. 2008. Т. 69(4). С. $294-298$.

5. Cohen A.C., Travaglia C.N., Bottini R., Piccoli P.N. Participation of abscisic acid and gibberellins produced by endophytic Azospirillum in the alleviation of drought effects in maize. Botany. 2009. V. 87. P. 455-462. DOI: 10.1139/B09-023.

6. Дідик Н.П., Закрасов О.В., Росіцька Н.В., Харитонова І.П. Аклімація рослин кукурудзи до посухи після обробки насіння алелопатично активними речовинами. Физиол. растений и генетика. 2014. Т. 46(5). С. 449-454.

7. Максимов И.В., Веселова С.В., Нужная Т.В., Сарварова Е.Р., Хайруллин Р.М. Стимулирующие рост растений бактерии в регуляции устойчивости растений к стрессовым факторам. Физиол. растений. 2015. T. 62(6). С. 763-775. DOI: 10.7868/ S0015330315060111.

8. Zeun R., Scalliet G., Oostendorp M. Biological activity of sedaxane - a novel broad-spectrum fungicide for seed treatment. Pest Management Sci. 2013. V. 69. P. 527-534. DOI: 10.1002/PS.3405.

9. Заіменко Н.В., Дідик Н.П., Дзюба О.І., Закрасов О.В., Росіцька Н.В., Вітер А.В. Індукція захисних реакцій на посуху у рослин кукурудзи анальцимом за різних зволоженості й типу грунту. Физиол. и биохим. культ. растений. 2013. Т. 45(1). C. $35-44$.

10. Григорюк И.А., Ткачев В.И., Савинский С.В., Мусиенко Н.Н. Современные методы исследований и оценки засухо- и жароустойчивости растений. Методическое пособие. Киев, 2003. 139 с.

11. Большой практикум по физиологии растений. Минеральное питание. Физиология клетки. Рост и развитие: учеб. пособие для студ. биол. спец. вузов / ред. Б.А. Рубин. М., 1978. 408 с.

12. Косаківська І.В., Бабенко Л.М., Васюк В.А., Войтенко Л.В. Вплив гіпертермії та грунтової посухи на ріст, вміст фотосинтетичних пігментів і мікроструктуру епідермісу листка Triticum spelta L. Bісник ХНАУ. Серія Біологія. 2017. Т. 3(42). C. 81-91.

13. Wellburn A.R. The spectral determination of chlorophylls a and $b$, as well as total carotenoids, uning various solvents of different resolution II. Plant Physiol. 1994. V. 144. P. 307-313.

14. Мусієнко М.М., Паршикова Т.В., Славний П.С. Спектрофотометричні методи в практиці фізіології, біохімії та екології рослин. Київ, 2001. 200 с.

15. Єгоршин О.О., Лісовий М.В. Математичне планування польових дослідів та статистична обробка експериментальних даних. Харків, 2005. 193 с.

16. Андрианова Ю.Е., Тарчевский И.А. Хлорофилл и продуктивность растений. М., 2000. 135 с.

17. Mafakheri A., Siosemardeh A., Bahramnejad B., Struik P.C., Sohrabi Y. Effect of drought stress on yield, proline and chlorophyll content in three Chickpea cultivars. Austral. J. Crop Sci. 2010. V. 4(8). P. 580-585.

18. Абрамова Э.А., Иванищев В.В. Содержание фотосинтетических пигментов и аскорбиновой кислоты в проростках вики в присутствии хлорида никеля. Научные ведомости. Серия Естест. науки. 2012. Т. 19(128). С. 152-155.

19. Padmaja K., Prasad D.D.K., Prasad A.R.K. Inhibition of chlorophyll synthesis in Phaseolus vulgaris Seedlings by cadmium acetate. Photosynthetica. 1990. V. 24. P. 399-405.

20. Казнина Н.М. Физиолого-биохимические и молекулярно-генетические механизмы устойчивости растений семейства Pоасеае к тяжелым металлам: дис. ... докт. биол. наук. Петрозаводск, 2016. 358 с.

21. Ястреб Т.О. Індукування посухостійкості рослин проса дією екзогенних саліцилової і янтарної кислот. Вісник XНАУ. Серія Біологія. 2012. Т. 2(26). С.92-97. http://nbuv.gov.ua/UJRN/Vkhnau_biol_2012_2_11.

22. Banyai J., Karsai I., Balla K., Kiss T., Bedo Z., Lang L. Heat stress response of wheat cultivars with different ecological adaptation. Cer. Res. Com. 2014. V. 42(3). P. 413-425. DOI: 10.1556/CRC.42.2014.3.5.

23. Нурминский В.Н. Влияние мембранотропных соединений на стабильность и электрофизиологические свойства вакуолярных мембран: автореф. дис. ... канд. биол. наук. Иркутск, 2003. 20 с.

24. Sasidharan R., Vosenek L., Pierik R. Cell wall modifying proteins mediate plant acclimatization to biotic and abiotic stresses. Crit. Rev. in Plant Sci. 2011. V. 30. P. 548-562. DOI: 10.1080/07352689.2011.615706. 


\title{
УЧАСТЬ ІНВАЗІЙНИХ ВИДІВ РОСАИН У ФОРМУВАННІ РОСАИННИХ УГРУПОВАНЬ У ПРОЦЕСІ ВІДНОВАЮВААЬНИХ СУКЦЕСІЙ
}

\author{
Клименко Т.К., Ісмагілова А.Є. \\ Дніпровський державний технічний університет \\ вул. Дніпробудівська, 2, 51918, м. Кам'янське, Дніпропетровська область \\ kugeltat@gmail.com
}

\begin{abstract}
Сукцесія - це процес, під час якого рослинні види-домінанти поступово змінюються. Під час сукцесії відбувається зміна типу стратегії із збільшенням частки конкурентоспроможних видів. Інвазивні види рослин краще розповсюджуються і впроваджуються у ті ландшафти, де наявні антропогенні порушення, при цьому ризик вторгнення тим більший, чим більшою $€$ фрагментація ландшафту. Небезпека нашестя оселенців для ландшафтів пов'язана також із скороченням видового розмаїття. Моніторингові ділянки для спостереження за процесом сукцесії, а також для вивчення впливу рослинних інвазій на процеси відновлення екосистем знаходяться у лівобережній частині м. Кам’янського, на намивних пісках (ділянка № 1, відновлення відбувається на вкрай бідних субстратах) і на місці створення дренажного каналу (ділянка № 2, знаходиться під потужним рекреаційним впливом). Процеси відновлення відбуваються вже понад 40 років. На обох ділянках спостережень частка інвазивних видів рослин у загальній надземній фітомасі є доволі істотною - 42 та $38 \%$ на першій та другій ділянках відповідно. Їх вагома частка у надземній фітомасі на обох ділянках спостереження свідчить про те, що рослинні угруповання, які там сформувалися, незважаючи на тривалий час сукцесійних змін, перебувають у неврівноваженому стані. Серед рослинних інвазій домінують Ambrosia artemisiifolia L. та Conyza canadensis (L.) Cronq. - це види-малорічники, надзвичайно життєздатні, які мають високі адаптивні властивості завдяки своєї невибагливості, а також високому репродуктивному потенціалу. Це типові представники піонерної рослинності на порушених землях, які через свою низьку ценотичну та конкурентну потужність у процесі розвитку сукцесії мають поступатися іншим видам. Проте вони продовжують домінувати в угрупованнях, не поступаються аборигенним видам рослин і таким чином уповільнюють швидкість сукцесійних процесів. Ключові слова: чужорідні види, рослинні інвазії, відновлювальна сукцесія, урбофітоценози, урбоекосистеми.
\end{abstract}

Participation of invasive plant species in the formation of plant communities during regenerative successions. Klymenko T., Ismagilova A.

Succession is the process through which dominant plant species gradually change. Throughout the course of succession there is a change in the type of strategy that is followed by an increase in the quantity of competitive species. Invasive plant species are better reinforced and introduced into landscapes where there is anthropogenic damage. Therefore, higher level of fragmentation of a landscape causes greater risk of invasion. Alien species invasion also correlates with the declining biodiversity. Monitoring sites for the observation of the succession, as well as for studying the impact of plant invasions on ecosystem restoration processes are located on the left bank of Kamianske, on alluvial sands (section №1 where restoration occurs on extremely poor substrates) and at the site of drainage channel (section № 2 which is under the strong recreational influence). Recovery processes have been taking place for over 40 years. In both areas of observation, the share of invasive plant species in the total aboveground phytomass is quite significant - 42 and $38 \%$ in the first and second areas, respectively. Their significant share in the aboveground phytomass in both areas of observation indicates that the plant communities that have formed there, despite a long period of successional changes, are in an unstable state. Ambrosia artemisiifolia L. and Conyza canadensis (L.) Cronq. are dominant among plant invasions. Those two species are annual plants with high adaptive characteristics since they require low maintenance and have great reproductive potential. They are typical examples of pioneer plant species of damaged soils and would yield to other species throughout the development of succession due to low cenotic activity and competitiveness. Invasive plant species continue to dominate in groups, they are resistant to fall under the pressure of native plant species, and thus slow down the succession processes. Key words: alien species, plant invasions, regenerative succession, urban phytocenosis, urban ecosystems.

Постановка проблеми. Антропогенно перетворені екосистеми, як і природні, не втрачають своєї здатності надавати екосистемні послуги, тобто вони впливають на регуляцію екологічних процесів, забезпечують організми ресурсами, а також задовольняють культурні та духовні потреби людини. На можливість надавати ці послуги значною мірою впливає генетичне, видове та екосистемне біологічне різноманіття [1]. Урбоекосистеми характеризуються значними змінами у видовому складі біоценозів, зокрема присутністю чужорідних видів рослин $[2,3]$.

Для оцінки екологічного стану сучасних урбоекосистем і прогнозування траєкторії їх розвитку особ- ливо важливими є дослідження сукцесій у техногенних ландшафтах, оскільки такі сукцесії відбуваються у незамкнених умовах, не залежать від історичного розвитку рослинності і є моделями сучасних глобальних процесів трансформації середовища [4].

Актуальність дослідження. Важливість вивчення відновлювальних сукцесій полягає у тому, що це допомагає краще оцінювати сталість природних систем до техногенного впливу, а також дає змогу оцінити здатність порушених ландшафтів до самовідновлення [5].

Зв'язок авторського доробку із важливими науковими та практичними завданнями. Дослідження 
виконані на базі кафедри екології та охорони навколишнього середовища Дніпровського державного технічного університету («Екологічна оцінка антропогенного впливу на ландшафти Дніпровської агломерації», номер держреєстрації 0118U006760).

Аналіз останніх досліджень і публікацій. Будьяка сукцесія індивідуальна, склад рослинних популяцій динамічний, тобто сукцесія - це процес, під час якого рослинні види, які присутні в угрупованнях, можуть ставати домінантами у різний час. Положення видів залежить від їх біологічних особливостей. Важливим є вивчення видових стратегій, а також міжвидових взаємодій [6]. Рання сукцесія характеризується високою часткою нових оселенців, але з часом загальне видове багатство знижується. Під час сукцесії відбувається зміна типу стратегії із збільшенням частки конкурентоспроможних видів [7, 8].

Негативний влив інвазивних рослин на довкілля $\epsilon$ очевидним і доведеним численними дослідженнями багатьох авторів. Вони вливають на компоненти середовища існування організмів (змінюють водний, поживний та інші режими грунтів та їх структуру, сприяють процесам деградації місцезростань), на самі організми в угрупованнях, а також наносять суттєву шкоду суспільству (знижують врожаї, вливають на стан здоров'я людини, змінюють привабливість природних та культурних ландшафтів тощо) [9]. Інвазивні види рослин краще розповсюджуються і впроваджуються у ті ландшафти, де наявні антропогенні порушення. Такі ландшафти потім стають «стартовим майданчиком» для вторгнення видів-чужинців у сусідні природні непорушені ландшафти. Часто впровадження одного-двох видів чужорідних рослин призводить до подальшого вторгнення інших видів-оселенців [17], тобто антропогенні порушення $\epsilon$ одним із факторів, який сприяє інвазіям видів-чужинців, при цьому ризик вторгнення тим більший, чим більшою є фрагментація ландшафту [10, 11]. Небезпека нашестя оселенців для ландшафтів пов'язана також із скороченням видового різноманіття [12].

Існує багато досліджень, які вивчали вплив неоднорідності ресурсів та навколишнього середовища на успіх чужорідних видів рослин. Нові умови у порушених середовищах будуть істотно відрізнятися від початкових, i, за винятком ранніх сукцесійних видів та/або універсальних видів, більшість місцевих видів не будуть адаптовані до них. Це викликає конкурентний дисбаланс, який може сприяти розселенню чужорідних видів у цих рудеральних місцезростаннях $[13,14]$. Інвазії чужорідних видів можуть значно впливати на перебіг сукцесійних процесів і навіть їх блокувати [15]. Вважається, що чужорідні види можуть істотно домінувати на початкових стадіях сукцесій, але з часом їх участь у формуванні угруповання стає менш вагомою. Але деякі види-чужинці на різних стадіях сукцесій несприятливо впливають на перебіг відновлювальних процесів: підтримують високий рівень синантропізації і гальмують спрямовану зміну рослинних угруповань $[16,17,18]$. Домінування видів-трансформерів в угрупованні супроводжується відносно низьким видовим багатством [17].

Виділення не вирішених раніше частин загальної проблеми, котрим присвячусться означена стаття. Спостереження за процесом сукцесії відтворюють реальну картину процесів відновлення, саме тому такий моніторинг на постійних моніторингових ділянках є дуже важливим джерелом інформації щодо закономірностей динаміки екосистем на початкових і подальших стадіях сукцесії.

Наукова новизна. Для оцінки процесів відновлення, а також участі у цих процесах інвазивних видів рослин було вибрано показники надземної фітомаси, оскільки вони доволі точно відображають процеси відновлення біологічної продуктивності порушених екосистем.

Метою роботи $є$ аналіз участі інвазивних видів рослин у формуванні рослинних угруповань у процесі відновлювальної сукцесії.

Матеріали і методи роботи. Для вивчення надземної фітомаси використовувався метод укосів у період максимального розвитку травостою [19]. У серпні 2019 року на моніторингових ділянках № 1 та № 2 за допомогою рамки (площею $0,25 \mathrm{~m}^{2}$ ) у 10-кратній повторності надземна частина рослин зрізалася на рівні грунту. Укоси розбиралися за окремими ботанічними групами: однодольні та дводольні неінвазивні, інвазивні рослини. Проводився підрахунок кількості особин у кожній із зазначених груп. Рослинні зразки висушували до повітряно-сухого стану, а потім у сушильній шафі - до абсолютно сухого стану за температури менше $105^{\circ} \mathrm{C}$, після чого зважували на електронних вагах.

Викладення основного матеріалу. Моніторингові ділянки для спостереження за процесом сукцесії, а також для вивчення впливу рослинних інвазій на процеси відновлення екосистем знаходяться у лівобережній частині м. Кам’янського: ділянка № 1 - на пустирі, який утворений на місці намивання пісків для будівництва лівобережних житлових масивів (будівництво не відбулося), ділянка № 2 - поряд із лівобережним дренажним каналом, який розташований вздовж житлових мікрорайонів і створений під час намивання пісків у процесі будівництва для дренажу грунтових вод. Забудова лівобережної частини міста відбувалася впродовж 1974-1985 років, тобто процеси відновлення відбуваються вже понад 40 років.

Проте масштаб порушень території істотно впливає на процес сукцесії - ділянка № 1 розташована на місцях суцільного намиву піску на великих площах під майбутню забудову. Територія іiі засмічена будівельним і побутовим сміттям, процеси відновлення відбуваються вкрай повільно, проєктивне покриття не перевищує 30-35\%, видовий склад збіднений, переважають рудеральні терофіти, яскраво виражена інвазія злинки канадської. 


\section{Клименко Т.К., Ісмагілова А.G.}

Моніторингова ділянка № 2, навпаки, розташована поряд із дренажним каналом, де масштаб порушень $\epsilon$ набагато меншим і де процеси відновлення відбувалися набагато швидше - проєктивне покриття 80-100\%, спостерігається істотне різноманіття переважно видів-псамофітів. Серед інвазивних видів рослин виявлені амброзія полиннолиста та злинка канадська.

Статистичні показники надземної фітомаси на ділянках спостереження за процесом сукцеciï № 1 та № 2 наведено у табл. 1. Провідна роль у формуванні рослинного угруповання на ділянці № 1 належить Conyza canadensis L. Загальний запас надземної фітомаси в межах цієї ділянки - 40,8 г/м², неістотно переважають дводольні рослини (рис. 1), їхя надземна фітомаса становить у середньому 58\% від загальної і коливається від 5,4 до 36 г абсолютно сухої маси на квадратний метр.

На відміну від ділянки № 1, на другій ділянці спостереження за процесом сукцесії розвинений густий
УЧАСТЬ ІНВАЗІЙНИХ ВИДІВ РОСАИН...

травостій, який сформований різнотрав'ям із загальною середньою фітомасою 51,5 г/м м $^{2}$ Спостерігається відносне переважання дводольних рослин, їх частка за біомасою коливається в межах від 25 до 75\% і в середньому становить $59,5 \%$.

Надземна фітомаса неінвазивних рослин на ділянці № 1 коливалась у межах від 10 до 40 г/ $\mathrm{m}^{2}$ i в середньому становила 23,7 г/ $\mathrm{m}^{2}$, а на ділянці № 2 межі коливання надземної фітомаси неінвазивних рослин - 19,3-48,8 г/м² за середнього значення цього показника 32 г/Mㄹ (рис. 2). На обох ділянках спостережень частка інвазивних видів рослин у загальній надземній фітомасі є доволі істотною 42 та 38\% на першій та другій ділянках відповідно.

У всіх квадратах укосів на ділянці № 1 (відносно рання стадія сукцесії) злинка канадська є абсолютним домінантом, на неї припадає 42\% надземної

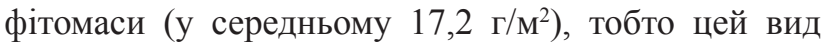
$\epsilon$ особливо активним і формує угруповання. Проте

Таблиця 1

Статистичні показники надземної фітомаси на ділянках спостереження за процесом сукцесії № 1 та № 2

\begin{tabular}{|c|c|c|c|c|}
\hline Вид, місце відбору & Mean $\pm \mathrm{SD}, \Gamma / \mathbf{M}^{2}$ & Min, $\Gamma / \mathbf{M}^{2}$ & Max, $\Gamma / \mathbf{M}^{2}$ & $\mathrm{CV}, \%$ \\
\hline \multicolumn{5}{|c|}{$\begin{array}{l}\text { Ділянка спостереження за процесом сукцесії № } 1 \text { (відносно рання стадія сукцесії) } \\
\mathrm{n}=10\end{array}$} \\
\hline Загальна фітомаса & $40,8 \pm 11,0$ & 15,42 & 52,91 & 27,0 \\
\hline Однодольні & $17,3 \pm 6,4$ & 10,02 & 30,08 & 37,0 \\
\hline Дводольні & $23,6 \pm 9,7$ & 5,40 & 35,86 & 41,2 \\
\hline Дводольні неінвазивні & $8,0 \pm 3,9$ & 4,05 & 16,05 & 49,1 \\
\hline Conyza canadensis L. Cronq. & $17,2 \pm 8,6$ & 5,40 & 26,84 & 50,1 \\
\hline \multicolumn{5}{|c|}{$\begin{array}{l}\text { Ділянка спостереження за процесом сукцесії № } 2 \text { (відносно пізня стадія сукцесії) } \\
\mathrm{n}=13\end{array}$} \\
\hline Загальна фітомаса & $51,5 \pm 19,1$ & 25,55 & 94,16 & 37,0 \\
\hline Однодольні & $20,9 \pm 4,8$ & 14,50 & 30,40 & 23,1 \\
\hline Дводольні & $30,7 \pm 17,3$ & 6,25 & 70,15 & 56,4 \\
\hline Дводольні неінвазивні & $12,1 \pm 5,9$ & 4,05 & 23,43 & 48,8 \\
\hline Ambrosia artemisiifolia $\mathrm{L}$. & $19,8 \pm 13,7$ & 5,35 & 45,03 & 69,2 \\
\hline Conyza canadensis (L.) Cronq. & $8,0 \pm 2,2$ & 4,83 & 11,07 & 27,6 \\
\hline
\end{tabular}

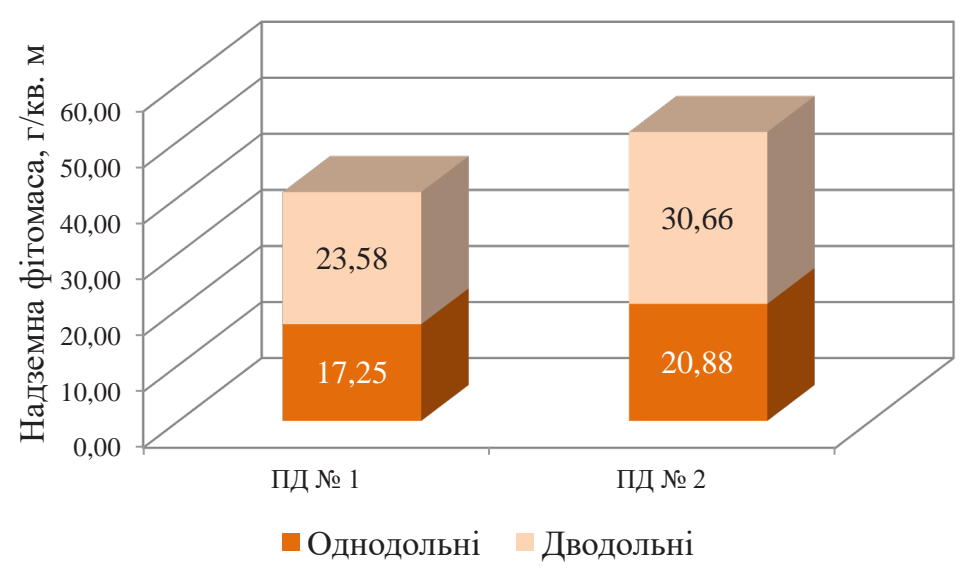

Рис. 1. Наземна фітомаса однодольних і дводольних рослин на ділянках спостереження за процеесом сукиесї 


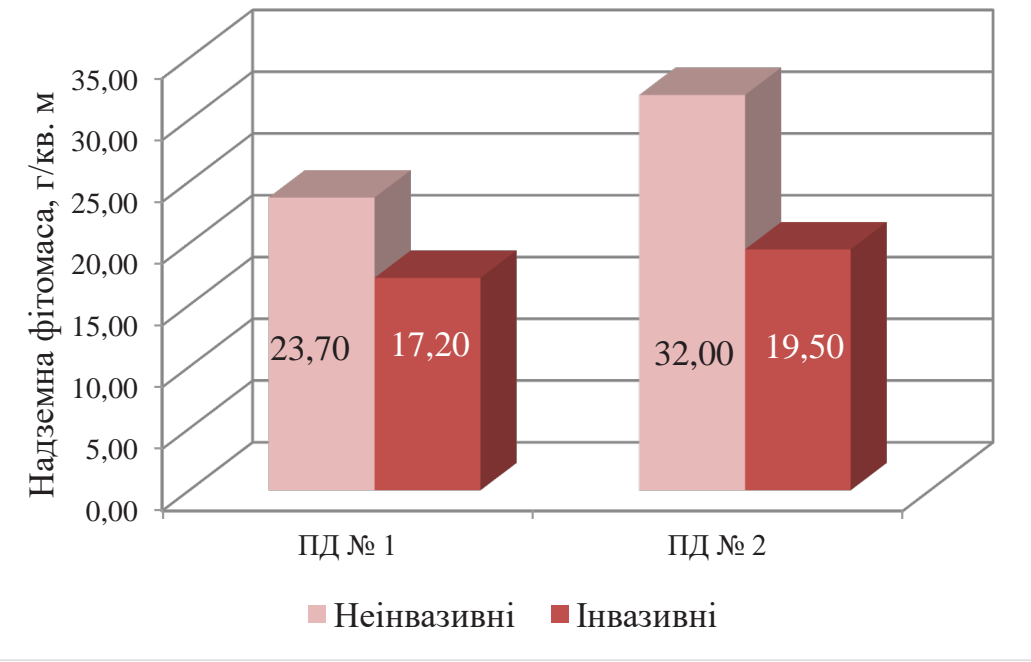

Рис. 2. Наземна фітомаса неінвазивних та інвазивних рослин на ділянках спостереження за процесом сукиесї

Таблиця 2

Біоекологічна характеристика інвазивних видів Ambrosia artemisifolia L. Ta Conyza canadensis (L.) Cronq.

\begin{tabular}{|c|c|c|c|c|c|c|}
\hline Вид & Трофо-морфа & $\begin{array}{c}\text { Гігро- } \\
\text { морфа }\end{array}$ & Геліо-морфа & Тип запилення & $\begin{array}{c}\text { Тип } \\
\text { дисемінації }\end{array}$ & Цено-морфа \\
\hline Ambrosia artemisifolia $\mathrm{L}$. & $\mathrm{Og}-\mathrm{MgTr}$ & $\mathrm{MsKs}$ & $\mathrm{ScHe}$ & $\mathrm{Anph}$ & $\mathrm{Bal}$ & $\mathrm{Ru}$ \\
\hline $\begin{array}{c}\text { Conyza canadensis }(\mathrm{L} .) \\
\text { Cronq. }\end{array}$ & $\mathrm{Og}-\mathrm{MgTr}$ & $\mathrm{MsKs}$ & $\mathrm{ScHe}$ & $\mathrm{Ent}(\mathrm{Ah})$ & Anch & $\mathrm{Ru}$ \\
\hline
\end{tabular}

слід звернути увагу на доволі високу варіативність показника фітомаси рослин цього виду - загалом частка маси злинки у загальній фітомасі коливається від 15 до 62\%. Амброзія полиннолиста на цій ділянці виявлена не була, що пояснюється їі відносно більшою вибагливістю до субстрату - на первинних ареалах вона віддає перевагу відносно багатим, добре зволоженим грунтам [20]. Очевидно, що умови зростання на ділянці спостереження № 2 більше відповідають іiі вимогам, оскільки вона була виявлена у 10 квадратах із 13, а частка надземної фітомаси рослин цього виду коливається від 13,5 до 47,8\% від загальної. Злинка канадська була виявлена на цій ділянці у 7 квадратах із 13, а іiі відносне вагове багатство не перевищує $22 \%$.

Амброзія полиннолиста завдяки своєму високому адаптаційному потенціалу швидко розширює свій ареал на 6-20 км у рік, за що вважається надзвичайно інвазивним видом [21]. Цей вид $є$ мезофітом, нітрофілом, віддає перевагу багатим на органіку грунтам, помірно та добре освітленим ділянкам, вважається теплолюбним. Але завдяки своїй екологічній пластичності може рости на бідних, вологих та затінених ділянках. Амброзія вважається антропохором, але іiі насіння також може добре розповсюджуватися по воді, саме тому вона так поширена на піщаних насипах. Завдяки високій швидкості розповсюдження, здатності швидко адаптуватися та своїй алелопатичній дії амброзія є дуже потужним конкурентом. Розповсюдження амброзії пов'язують також із урбанізацією, переважно вона поширена на деградованих місцезростаннях [22-26]. Злинка канадська - північноамериканська однорічна рослина, яка зустрічається у всіх провінціях Канади, окрім Ньюфаундленда. Це бур'ян садів, виноградників, ріллі, зустрічається на узбіччі доріг. Утворює сходи до жовтня, кількість насіння на одну особину може перевищувати 200 тис. [27]. Біоекологічна характеристика обох видів інвазивних рослин наведена у табл. 2. Їх вагома частка у надземній фітомасі на обох ділянках спостереження свідчить про те, що рослинні угруповання, які там сформувалися, незважаючи на тривалий час сукцесійних змін, перебувають у неврівноваженому стані. Але якщо на ділянці № 1 невисока швидкість сукцесії зумовлена особливостями субстрату (намивний пісок), то вагома участь інвазивних видів рослин у формуванні рослинного угруповання на ділянці № 2 може бути пояснена високим антропогенним навантаженням, оскільки вздовж дренажного каналу здійснюється постійний інтенсивний пішохідний потік і наявні високі рекреаційні навантаження.

Висновки. Ambrosia artemisiifolia L. та Conyza canadensis (L.) Cronq. - це види-малорічники, надзвичайно життєздатні, які мають високі адаптивні властивості завдяки своїй невибагливості, а також 


\section{Клименко Т.К., Ісмагілова А.G.}

високому репродуктивному потенціалу. Це типові представники піонерної рослинності на порушених землях, які через свою низьку ценотичну та конкурентну потужність у процесі розвитку сукцесії мають поступатися іншим видам. Проте, якщо відновлення відбувається на вкрай бідних субстратах

\section{УЧАСТЬ ІНВАЗІЙНИХ ВИДІВ РОСАИН...}

або ділянка знаходиться під потужним антропогенним впливом, інвазійні види рослин продовжують домінувати в угрупованнях, не поступаються аборигенним видам рослин і таким чином уповільнюють швидкість сукцесійних процесів.

\section{Література}

1. Cadotte, M.W., Yasui, S.L.E., Livingstone, S. et al. Are urban systems beneficial, detrimental, or indifferent for biological invasion?. Biol Invasions, 2017. 19, 3489-3503. https://doi.org/10.1007/s10530-017-1586-y.

2. Čeplová, N., Lososová, Z., \& Kalusová, V. (2017). Urban ornamental trees: a source of current invaders; a case study from a European City. Urban Ecosystems, 20(5), 1135-1140. https://doi.org/10.1007/s11252-017-0665-2.

3. Salomon C. J. Invasion ecology goes to town: from disdain to sympathy. Biol Invasions 2017. 19, 3471-3487. https://doi.org/10.1007/s10530-017-1588-9.

4. Гусев А.П., Шпилевская, Н.С., \& Веселкин, В.Д Особенности сукцессии растительности на склонах карьера строительных песков (месторождение песков «Осовцы», Гомель) . Веснік ВДУ. 2014. № 6(84). С. 21-26.

5. Гусев А.П. Потенциал самовосстановления геосистем и его оценка на основе фитоиндикации . Вестн. Белорус. государств. ун-та. Сер. 2. 2010. № 1. C. 77-81.

6. Pickett S.T.A. Population patterns through twenty years of oldfield succession. Vegetatio, 1982. 49, 45-59. https://doi.org/10.1007/BF00051566.

7. Dölle M., Bernhardt-Römermann M., Parth A., \& Schmidt, W. Changes in life history trait composition during undisturbed old-field succession. Flora-Morphology, Distribution, Functional Ecology of Plants, 2008. 203(6), 508-522. https://doi.org/10.1016/j.flora.2007.07.005.

8. Robinson G.R., Handel S.N. Directing spatial patterns of recruitment during an experimental urban woodland reclamation. Ecological applications, 2000, 10 (1), 174-188. https://doi.org/10.1890/1051-0761(2000)010[0174:DSPORD]2.0.CO;2.

9. Dickie I.A., Bennett B.M., Burrows L.E. et al. Conflicting values: ecosystem services and invasive tree management. Biol Invasions, 2014. 16, 705-719 https://doi.org/10.1007/s10530-013-0609-6.

10. Гусев А.П. Особенности сукцессий растительности в ландшафтах, нарушенных деятельностью человека (на примере юго-востока Белоруссии). Сибирский экологический журнал. 2012. № 2. С. 231-236.

11. Гусев А.П. Пространственно-временные изменения структуры ландшафтов юго-востока Белоруссии и их экологические последствия (на примере инвазий растений). Вестник Воронежского государственного университета. Серия: география, геоэкология. 2014. No1. С. 18-23.

12. Hejda M., Pyšek P., Jarošík V. Impact of invasive plants on the species richness, diversity and composition of invaded communities. Journal of ecology, 2009. 97(3), 393-403 https://doi.org/10.1111/j.1365-2745.2009.01480.x.

13. Vilà M., Ibáñez I. Plant invasions in the landscape. Landscape Ecol, 2011. 26, 461-472 https://doi.org/10.1007/s10980-011-9585-3

14. Davis M. A. et al. Invasion biology. Oxford University Press on Demand, 2009. https://books.google.com.ua/.

15. Шварц Е.А. Сохранение биоразнообразия: сообщества и экосистемы / Е.А. Шварц. М.: Т-во научных изданий КМК, 2004.112 с.

16. Гусев А.П. Особенности начальных стадий восстановительной сукцессии в антропогенном ландшафте (на примере юго-востока Белоруссии). Экология. 2009. №3. С. 174-179.

17. Гусев А.П. Чужеродные виды-трансформеры как причина блокировки восстановительных процессов (на примере юговостока Беларуси). Российский журнал прикладной экологии, 2016, 3 (7). С. 10-14.

18. Gusev A.P. The Impact of Invasive Canadian Goldenrod (Solidago Canadensis L.) on Regenerative Succession in Old Fields (the Southeast of Belarus). Russian Journal of Biological Invasions. 2015. Vol. 6. No2. P. 74-77.

19. Родин Л. Е., Базилевич Н. И. Динамика органического вещества и биологический круговорот зольных элементов и азота в основных типах растительности земного шара. М.; Л.: Наука, 1965. 253 с.

20. Bassett I. J., Crompton C. W. The Biology of Canadian Weeds: 55.: Ambrosia trifida L.. Canadian Journal of Plant Science. 62(4): 1003-1010. https://doi.org/10.4141/cjps82-148.

21. Vrbničanin S., Janjić V. Ambrozija (Ambrosia artemisiifolia L.): poreklo, biologija, ekologija i genetička varijabilnost. Biljni lekar, XXXIX (1), 36-44, 2011.

22. Fumanal B., Chauvel B., Sabatier A., Bretagnolle F. Variability and cryptic heteromorphism of Ambrosia artemisiifolia seeds: What consequences for its invasion in France? Annals of Botany, 100, 305-313, $2007 \mathrm{https} / / \mathrm{doi} . \mathrm{org} / 10.1093 / \mathrm{aob} / \mathrm{mcm} 108$.

23. Choi B. S., Song D. Y., Kim C. G., Song B. H., Woo S. H., Lee C. W. Allelopathic effects of common ragweed (Ambrosia artemisiifolia var. elatior) on the germination and seedling growth of crops and weeds. Korean Journal of Weed Science, 30, 34-42, 2010 https://doi.org/10.5660/KJWS.2010.30.1.034.

24. Lehoczky E, Szabó R, Nelima MO, Nagy P, Béres I. Examination of common ragweed's (Ambrosia artemisiifolia L.) allelopathic effect on some weed species. Communications in Agricultural and Applied Biological Sciences. 2010 ;75(2):107-111. PMID: 21542474 .

25. Brandes,D., Nitzsche J. Biology, introduction, dispersal, and distribution of common ragweed (Ambrosia artemisiifolia L.) with special regard to Germany. Nachrichtenblatt des Deutschen Pflanzenschutzdienstes, 58, 286-291, 2006 http://www.digibib.tu-bs. $\mathrm{de} /$ ?docid $=00016647$.

26. Chollet D., Drieu Y., Molines J., Pauget J. Comment lutter contre l'ambroisie a feuilles d'armoise. Perspectives Agricoles, 1999. 250, 78-82.

27. Susan E. Weaver. The biology of Canadian weeds. 115. Conyza canadensis. Canadian Journal of Plant Science. 81(4): 867-875. https://doi.org/10.4141/P00-196. 


\title{
СЕЗОННI РИТМИ РОЗВИТКУ РОСАИН DRACOCEPHALUM MOLDAVICA ЗА IHTРОДУКЦIї В УМОВАХ ЦЕНТРААЬНОГО ПОАІССЯ УКРАЇНИ
}

\author{
Котюк Л.А. ${ }^{1}$, Іващенко І.В. ${ }^{1}$, Рахметов Д.Б. ${ }^{2}$, Борисюк Б.В. ${ }^{1}$ \\ ${ }^{1}$ Поліський національний університет \\ Старий бульв., 7, 10008, м. Житомир \\ ${ }^{2}$ Національний ботанічний сад імені М.М. Гришка Національної академії наук України \\ вул. Тімірязєвська, 1, 01014, м. Київ \\ kotyuk-la@ukr.net,kalateja@ukr.net, Bborisuk1@gmail.com,rjb2000.16@gmail.com
}

\begin{abstract}
Встановлено тривалість фаз розвитку рослин Dracocephalum moldavica та вплив абіотичних умов на перебіг життєвого циклу рослин за інтродукції в Центральному Поліссі України. Загальна тривалість життєвого циклу змієголовника молдавського в умовах Полісся України становила від 134 (2009 р.) до 142 (2013 р.) діб, найбільш тривала фаза квітування - від 29 (2011 р.) до 44 (2009 р.) діб. Для проходження повного циклу розвитку, від посіву до відмирання рослин D. moldavica, необхідна сума активних температур у середньому $2534,0^{\circ} \mathrm{C}$ : мінімальна $-2210,3^{\circ} \mathrm{C}\left(2011\right.$ р.), максимальна $-2651,7^{\circ} \mathrm{C}(2010$ р.); ефективних температур - у середньому $1168,1^{\circ} \mathrm{C}$ (від $930,3^{\circ} \mathrm{C}$ до $\left.1311,7^{\circ} \mathrm{C}\right)$. Виявлено пряму кореляційну залежність між сумою ефективних температур і тривалістю фаз вегетації рослин D. moldavica, що виражається високим коефіцієнтом кореляції $(\mathrm{r}=0,97)$, тоді як між сумою опадів і тривалістю фаз вегетації коефіцієнт кореляції дещо менший $(\mathrm{r}=0,65)$. Виявлена залежність тривалості вегетації рослин від суми ефективних температур, яка описується рівнянням: $\mathrm{y}=0,97 \cdot \mathrm{x}^{0,61}$, доводить, що температура є лімітуючим фактором для росту і розвитку рослин $D$. moldavica. Недостатня кількість опадів і запасу вологи у грунті вплинула на інтенсивність появи сходів та розвиток рослин упродовж фаз сходів та стеблування, а високі літні температури й відсутність опадів спричинили укорочення тривалості квітування та плодоношення. Встановлено, що біологічні потреби інтродуцента у тривалості вегетаційного періоду й термічного режиму повністю відповідають природним умовам Центрального Полісся України, що підтверджує перспективність впровадження у культуру рослин $D$. moldavica в цьому регіоні. Дослідження малопоширеного виду рослин Dracocephalum moldavica забезпечують збагачення біологічної різноманітності регіону за рахунок нового інтродуцента, сприяють розширенню сировинної бази цінних ароматичних рослин. Ключові слова: Dracocephalum moldavica, інтродукція, фази розвитку рослин, сума активних і ефективних температур.
\end{abstract}

Seasonal rhythm of development of Dracocephalum Moldavica introduced in Central Ukrainian Polissya. Kotiuk L., Ivashchenko I., Rakhmetov D., Borysiuk B.

The duration of phases of Dracocephalum moldavica plant development and the influence of abiotic conditions on the course of plant life cycle during introduction in the Central Ukrainian Polissya have been established. The total duration of the life cycle of the Moldavian dragonhead under the conditions of Ukrainian Polissya was from 134 (2009) to 142 (2013) days, the longest flowering phase lasted from 29 (2011) to 44 (2009) days. To go through the full cycle of development, from sowing to the death of D. moldavica plants, the required amount of active temperatures averages $2534,0^{\circ} \mathrm{C}$ : minimum $-2210,3^{\circ} \mathrm{C}(2011)$, maximum $-2651,7^{\circ} \mathrm{C}(2010)$; effective temperature is on average $1168,1 \mathrm{C}$ (from $930,3^{\circ} \mathrm{C}$ to $1311,7^{\circ} \mathrm{C}$ ). There is a direct correlation between the sum of effective temperatures and the duration of vegetation phases of D. moldavica plants, which is expressed by a high correlation coefficient $(\mathrm{r}=0.97)$, while between the sum of precipitation and the duration of vegetation phases the correlation coefficient is slightly lower $(\mathrm{r}=0.65)$. The dependence of the duration of plant vegetation on the sum of effective temperatures, which is described by the equation: $\mathrm{y}=0.97 \mathrm{x}$ 0.61 , proves that temperature is a limiting factor for the growth and development of $D$. moldavica plants. Insufficient rainfall and soil moisture affected the intensity of germination and plant development during the germination and stemming phases, high summer temperatures and lack of rainfall shortened the duration of flowering and fruiting period. It has been established that the biological needs of the introducer in the duration of the vegetation period and thermal regime fully correspond to the natural conditions of Central Polissya of Ukraine, which confirms the prospects of D. moldavica introduction in plant culture in this region. Research poorly distributed species Dracocephalum moldavica provides the biological variety enrichment due to the new introduced plant, facilitate the extension of raw material base of valuable aromatic plants. Key words: Dracocephalum moldavica, introduction, phases of plant development, amount of active and effective temperatures.

Постановка проблеми. Завдяки своїм унікальним біологічним і біохімічним властивостям одним із найбільш поширених видів в умовах культури Євразійського континенту рослин родини Lamiaceae є змієголовник молдавський (Dracocephalum moldavica L., 1753). Змієголовник молдавський - це однорічна трав'яна рослина заввишки 30-80 см зі стрижневою кореневою системою, ортотропним чотиригранним стеблом, супротивно розміщеними листками та китицеподібними суцвіттями $[1,2,3]$.

Рослини D. moldavica належать до СвропейськоСибірського генетичного центру походження $[1,2]$, у природі трапляються у Середній Азії, Росії, Монголії, Китаї та Північній Америці, їх уведено в культуру в Європі та Азії як медонос, лікарську рослину $[4,5,6]$. Як ефіроолійну рослину змієголовник молдавський культивували ще 330 -х років 19 -го століття 
Котюк Л.А., Іващенко І.В., Рахметов Д.Б. ...

в умовах Криму, Молдови, Сибіру, Поволжя [7]. ${ }^{\circ}$ Сновні площі змісголовника молдавського в Україні нині зосередженні на Півдні та Поділлі $[8,9]$.

Актуальність дослідження. Фітомасу рослин D. moldavica вживають із лікувальною метою: як протизапальний та заспокійливий засіб, при застуді, головному болю $[10,11]$, болях у суглобах, невралгії, ревматизмі, тахікардії, гіпертонічній хворобі, безсонні $[12,13,14]$. Надземну частину змієголовника молдавського використовують у кондитерській галузі $[15,16]$, для виготовлення абсенту, вермуту, квасу, компоту, ароматизації чаю та оцту. Фітосировина D. moldavica годиться як приправа до страв 3 м'яса, риби, овочів $[2,17]$. У рослинній сировині $D$. moldavica виявлено вітаміни, ліпіди, протеїни, цукри, дубильні речовини, макро- та мікроелементи [14]. Особливо цінна ефірна олія, яку синтезує рослина, ііі використовують у харчовій галузі, фармації, парфумерії, косметології [18, 19].

Зв'язок авторського доробку із важливими та практичними завданнями. Зважаючи на те, що природні запаси фітосировини лікарських, ефіроолійних, ароматичних рослин скорочуються із року в рік, важливим $\epsilon$ уведення в культуру нових видів рослин. Вивчення адаптаційних можливостей малопоширеного інтродуцента змієголовника молдавського забезпечить покращення технологічних процесів його культивування (встановлення термінів посіву, збирання урожаю) в умовах Центрального Полісся України.

Аналіз останніх досліджень і публікацій. Відомо, що адаптивні властивості інтродуцентів залежать від абіотичних чинників природно-кліматичної зони. Важливим показником динаміки сезонного розвитку рослин $є$ температурний поріг фенологічних фаз розвиту, який об'єктивно відображає залежність біоритмів від температурного режиму, а тому його застосовують як порівняльний критерій під час аналізу у розробках, пов'язаних з адаптацією інтродуцентів. Сума активних температур слугує показником забезпеченості теплом за вегетаційний період [5]. Встановлено, що у разі нестачі вологи й світла подовжується тривалість вегетації рослин, а продуктивність та кількісні показники виходу ефірної олії змієголовника молдавського різко знижуються [20, 21].

За відомостями Г. Паршиної (2009) [22] і С. Тоцкої зі співавторами (2013) [23], тривалість життевого циклу рослин $D$. moldavica в умовах Алма-Атинської та Московської областей становила 140 та 150 діб. В умовах Херсонської області [7] вегетативний період рослин $D$. moldavica становив у середньому 120-130 діб, Лісостепу Київської області - до 140 діб [5], у Західному Поділлі (Тернопільська обл.) - 140-150 діб [9]. В умовах Ставропольського краю період від повних сходів до початку цвітіння змієголовника молдавського становив 105-115 діб [24], Центральної Якутії - 96-106 діб [25], Білорусі 92-105 діб [26].

\section{СЕЗОННІ РИТМИ РОЗВИТКУ РОСАИН...}

С.В. Овечко (2003) відзначає, що для нормального розвитку змієголовника молдавського в умовах Півдня України необхідно від 2600 до $3500^{\circ} \mathrm{C}$ активних температур [27]. За повідомленням В.В. Чумакової та В.Ф. Чумакова (2018), сума температур за період вегетації рослин в умовах Ставропольського краю становила $2400-2900^{\circ} \mathrm{C}$, а відносна вологість варіювала у межах 37-79\% [24]. В умовах Лісостепу Західного Сибіру (Новосибірськ) сума активних температур, необхідних для розвитку рослин $D$. Moldavica, становила $2262-3153^{\circ} \mathrm{C}$, ефективних $-941-1673^{\circ} \mathrm{C}$ [28].

Виділення не вирішених раніше частин загальної проблеми, котрим присвячусться зазначена стаття. Зважаючи на обмеженість відомостей щодо адаптивних властивостей рослин D. moldavica при введенні у культуру в умовах Центрального Полісся України, мета наших досліджень полягала у встановленні впливу абіотичних чинників на сезонні ритми розвитку інтродуцента.

Упродовж 2008-2013 років вивчали вплив температури, кількості опадів та відносної вологості на проходження фаз розвитку змієголовника молдавського в умовах ботанічного саду Поліського національного університету, який розташований у зоні Центрального Полісся України. Нами зроблено розрахунок суми активних і ефективних температур, вищих за $+10^{\circ} \mathrm{C}$, за різними міжфазними періодами та життєвого циклу змієголовника молдавського загалом.

Методологічне або загальнонаукове значення. Предмет досліджень - рослини змієголовника молдавського (Dracocephalum moldavica L.). Використовували насінний матеріал із колекції малопоширених ароматичних рослин відділу культурної флори Національного ботанічного саду імені М.М. Гришка НАН України. Рослини культивували на колекційних ділянках ботанічного саду Поліського національного університету. Досліди закладали на відкритій ділянці, добрива і полив не застосовували. Насіння висівали упродовж третьої декади квітня першої декади травня на глибину 1,5 см за схемою $45 \times 30$ см. Догляд за рослинами полягав у видаленні бур'янів і розпушуванні міжрядь.

Особливості розвитку рослин вивчали згідно із загальноприйнятими методиками Т.А. Работнова (1950, 1960) [29], А.А. Уранова, О.В. Смирнової (1969) [30], I.M. Бейдемана (1974) [31] та Д.Б. Рахметова (2011) [32]. У дослідженнях використано показники середніх добових значень температури повітря, суму активних температур розраховували за формулою: $\sum t_{\text {aкm }}=t * n$, де $t$ - активна середньодобова температура за період, ${ }^{\circ} \mathrm{C}$; $n$ - кількість днів у періоді. Сума ефективних температур за цей же період розраховується як: $\sum t_{e \phi}=(t-B)$ * $n$, де В - біологічний мінімум, ${ }^{\circ} \mathrm{C}[33,34]$.

Отримані дані обробляли статистично $з$ використанням програми Microsoft Excel 10.

Виклад ${ }^{\circ}$ Сновного матеріалу. Результати досліджень свідчать, що загальна тривалість 
життєвого циклу змієголовника молдавського в умовах Центрального Полісся України упродовж шести років досліджень становила: у 2008 році 139 діб, у 2009 - 138, 2010 - 134, у 2011 - 140, у 2012 - 137, у 2013 - 142 доби, а в середньому - 138 діб, що узгоджується 3 відомостями інших дослідників [5, 21].

Встановлено, що в умовах культури сходи змієголовника з'являлися за досить широкого діапазону сум активних і ефективних температур: від 88,7 i $28,7^{\circ} \mathrm{C}$ (2009 р.) до 314,1 та $134,1^{\circ} \mathrm{C}$ (2013 р.) (рис. $\left.2-3\right)$. За результатами аналізу інших абіотичних чинників встановлено, що у першій декаді травня 2009 року випала достатня кількість опадів, що забезпечило зростання показника відносної вологості повітря. Упродовж квітня та першої половини травня 2013 року опади були майже відсутні, що й спричинило затримку сходів на 9 діб (рис. 1, табл. 1).

Упродовж фази стеблування рослин D. moldavica діапазон суми активних та ефективних температур становив від 216,5 й $76,5^{\circ} \mathrm{C}$ (2008 р.) до 682,5 (2013 р.) i $318,5^{\circ} \mathrm{C}$ (2011 р.) (див. табл.1). У березні - травні 2008 року випало 325,1 мм опадів, у 2011 - 58,2, у 2013 - 118 мм опадів. Очевидно, у 2011 та 2013 роках запас вологи у грунті був недостатнім, що спричинило подовження тривалості цього періоду від 14 до 37 діб (див. рис. 1).

Діапазони суми активних та ефективних температур під час бутонізації рослин D. moldavica становили: від 276,8 i $126,8^{\circ} \mathrm{C}$ (2011 р.) до 584,5 i $294,5^{\circ} \mathrm{C}$ (2009 р.), а показники водозабезпеченості були вищими, що спричинило подовження тривалості фази - від 15 до 29 діб (див. рис. 1-3, табл. 1).

Упродовж фази квітування рослин D. moldavica мінімальні суми активних та ефективних температур встановлено 2011 року $\left(538,7\right.$ та $\left.248,7^{\circ} \mathrm{C}\right)$, максимальні - $777,5^{\circ} \mathrm{C}-2009$ року та $428,3^{\circ} \mathrm{C}-2010$ року. Визначено, що 3 підвищенням температури тривалість фази скорочувалася у 1,5 раза (від 29 діб у 2011 році до 44 діб у 2009 році) (див. рис. 1-3, табл. 1). Встановлено максимальну кількість опадів упродовж фази (191,9 мм) 2011, мінімальну (37,4 мм) 2013 року.

Діапазони суми активних температур упродовж фази плодоношення інтродуцента $D$. moldavica становили від $339,2^{\circ} \mathrm{C}$ (2013 р.) до $878,9^{\circ} \mathrm{C}$ (2008 р.), а ефективних температур відповідно - від 129,2 i $383,7^{\circ} \mathrm{C}$. Тривалість періоду плодоношення варіювала відповідно - від 21 до 43 діб, що було зумовлено майже повною відсутністю опадів у серпні 2013 року (див. рис. 1-3, табл. 1).

Встановлено, що відмирання рослин D. moldavica відбувалося за 20,4 (2008 р.) - 178,5 C (2012 р.) активних температур та за 0,4 (2008 р.) - 78,6 ${ }^{\circ} \mathrm{C}$ (2009 р.) ефективних температур, тривалість цього періоду становила від 8 до 11 діб. Упродовж фази максимальну кількість опадів встановлено 2008 року (123,7 мм), повну відсутність - 2009 року (див. рис. 1-3, табл. 1).

За повідомленням М.Ю. Грязнова і С.А. Тоцкої (2019), змієголовник молдавський Собливо вимогливий до водозабезпечення під час проростання насіння, у подальшому - досить посухостійкий [15], що узгоджується з нашими дослідженнями.

В умовах Центрального Полісся України упродовж життєвого циклу рослин D. moldavica кількість опадів варіювала від 201,5 мм (2013 р.) до 441,1 мм (2010р.), в середньому за роки досліджень - 337,0 мм (рис. 1), що виявилося достатнім для нормального росту та розвитку рослин.

Встановлено, що в умовах Центрального Полісся України для проходження повного циклу розвитку, від посіву до відмирання змієголовника молдавського, сума активних температур становила у середньому $2534,0^{\circ} \mathrm{C}$; мінімальна $-2210,3^{\circ} \mathrm{C}$ (2011р.), максимальна - $2651,7^{\circ} \mathrm{C}$ (2010 р.). Рослини для життєвого циклу потребували у середньому $1168,1^{\circ} \mathrm{C}$ ефективних температур (від 930,3 до $1311,7^{\circ} \mathrm{C}$ ).

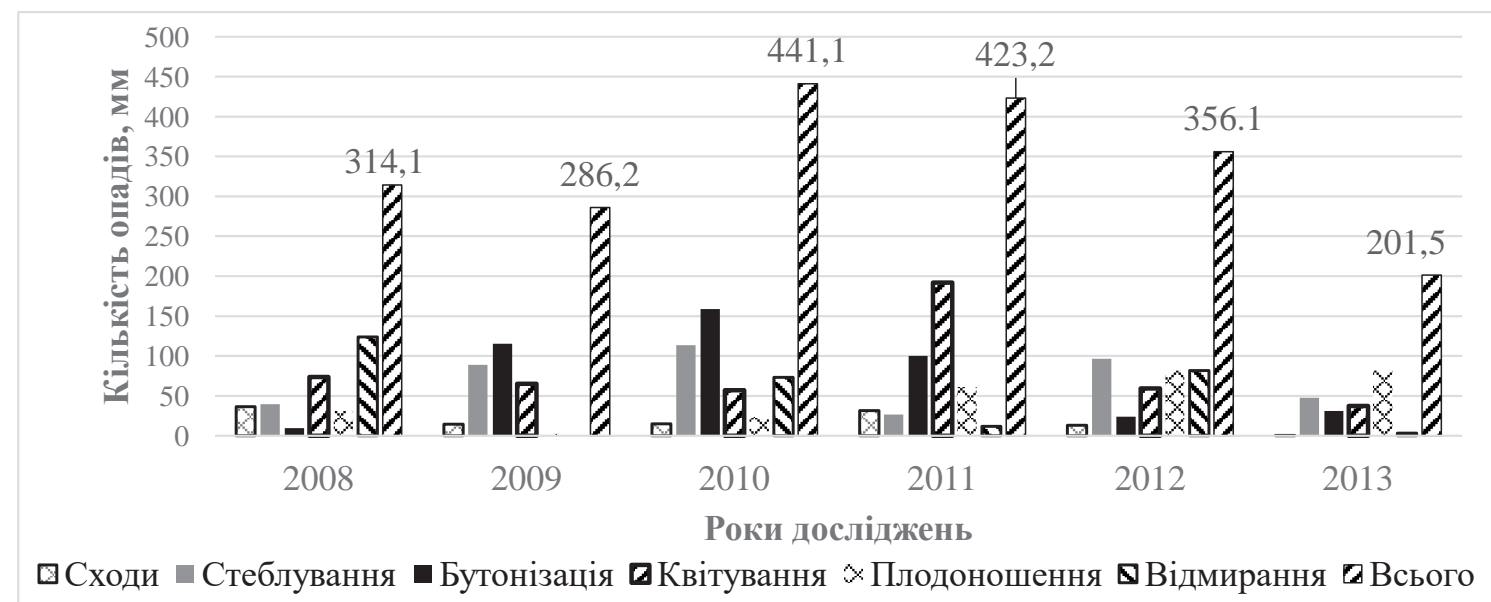

Рис. 1. Кількість опадів упродовж вегетаційного періоду рослин D. moldavica в умовах Центрального Полісся Украӥни 


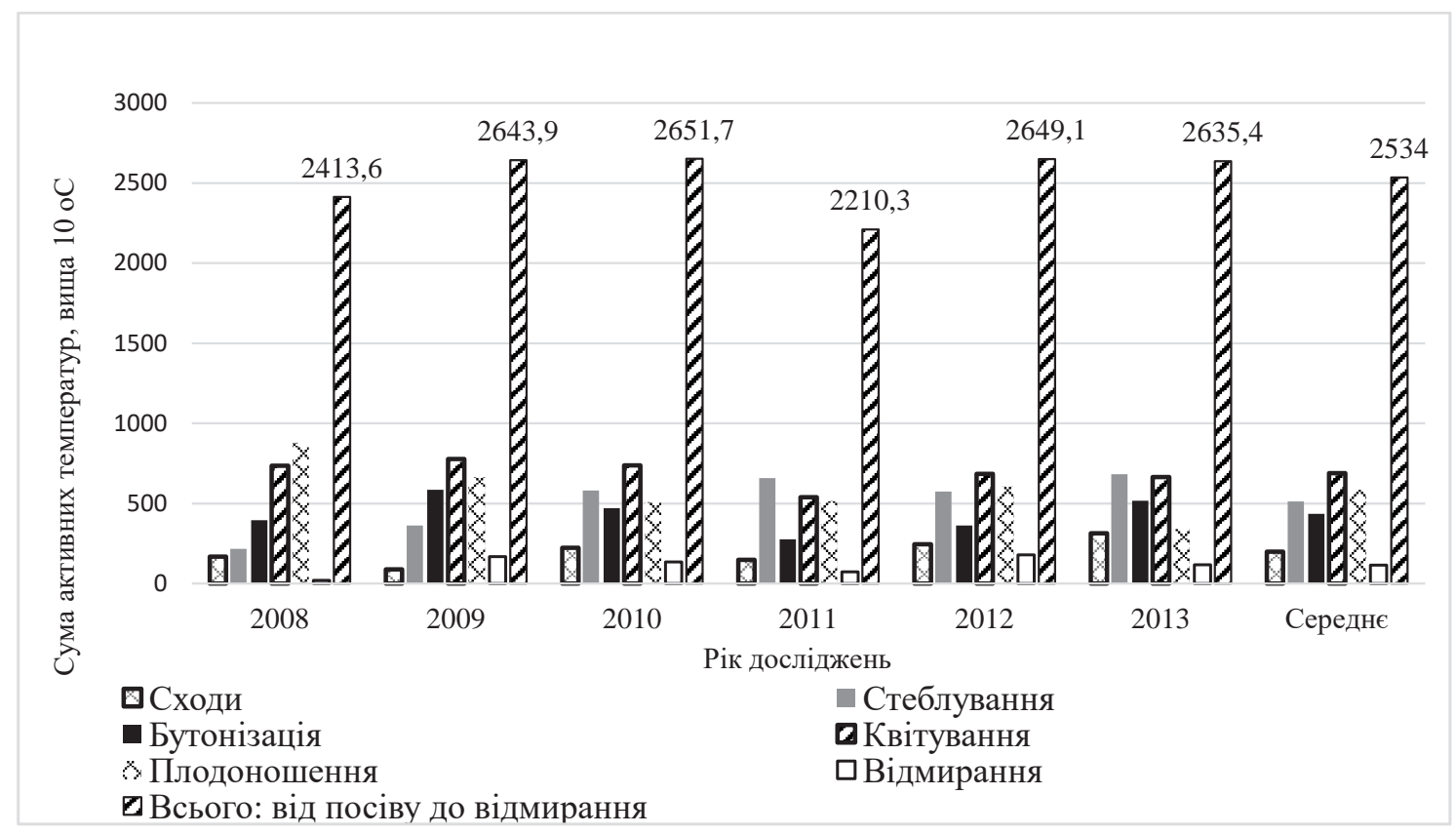

Pис. 2. Сума активних температур, вища $10^{\circ} \mathrm{C}$, необхідна для проходження фаз розвитку D. moldavica в умовах Центрального Полісся України

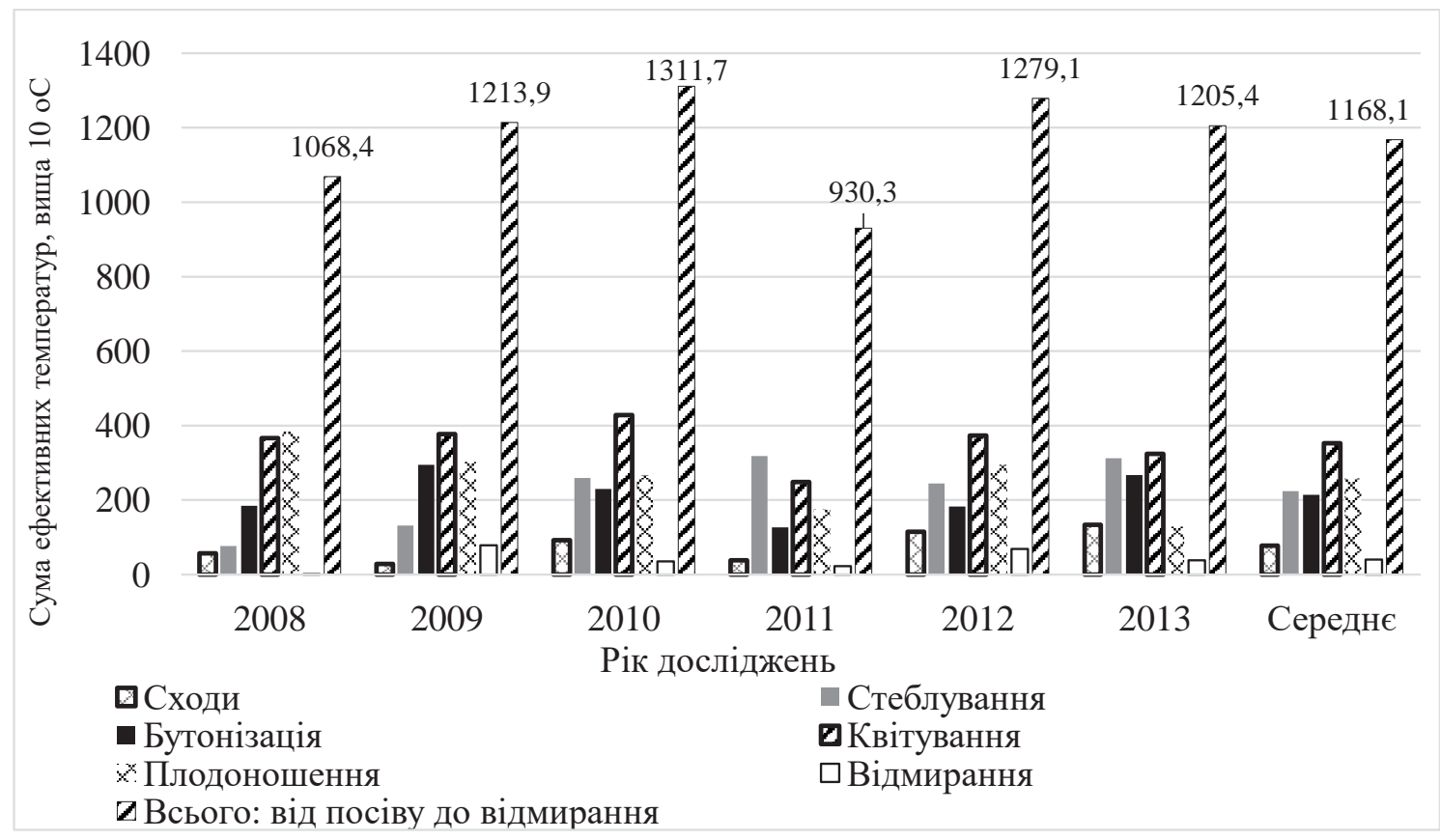

Рис. 3. Сума ефективних температур, вища $10^{\circ} \mathrm{C}$, необхідна для проходження фаз розвитку D. Moldavica в умовах Центрального Полісся Украӥни

Під час аналізу показників вологості повітря протягом вегетаційного періоду змієголовника молдавського відзначено динамічні зміни у бік зростання цього показника 3 квітня по вересень. Так, середньомісячні показники відносної вологості повітря у квітні становили $61,9 \%$, у травні - 66,3, у червні 69,7, у липні - 74,2, у серпні-70,9, у вересні-74,3 \%. За роками досліджень середні показники вологості за місяць змінювалися здебільшого на 5-10\%, щодекади - на 5-20\% (див. табл. 1).
За результатами досліджень встановлено пряму кореляційну залежність між сумою ефективних температур i тривалістю фаз вегетації рослин D. moldavica, що виражається високим коефіцієнтом кореляції $(\mathrm{r}=0,97)$, тоді як між сумою опадів і тривалістю фаз вегетації коефіцієнт кореляції менший $(\mathrm{r}=0,65)$ (рис. 3$)$.

Залежність тривалості вегетації рослин від суми ефективних температур, яка описується рівнянням: $\mathrm{y}=0,97 \cdot \mathrm{x}^{0,61}$, доводить, що температура $є$ лімітуючим 
Таблиця 1

Характеристика умов вегетації рослин D. moldavica за інтродукції в Центральному Поліссі України

\begin{tabular}{|c|c|c|c|c|c|}
\hline Рік & Фази розвитку & $\begin{array}{c}\text { Сума ефективних } \\
\text { температур, }{ }^{\circ} \mathrm{C}\end{array}$ & $\begin{array}{c}\text { Відносна вологість } \\
\text { повітря, \% }\end{array}$ & $\begin{array}{l}\text { Кількість } \\
\text { опадів, мм }\end{array}$ & $\begin{array}{c}\text { Тривалість фаз } \\
\text { вегетації, діб }\end{array}$ \\
\hline \multirow{7}{*}{2008} & Сходи & 57,3 & 65,6 & 36,4 & 14 \\
\hline & Стеблування & 76,5 & 72,3 & 39,5 & 14 \\
\hline & Бутонізація & 184,3 & 67,6 & 9,7 & 21 \\
\hline & Квітування & 366,2 & 67,3 & 73,8 & 37 \\
\hline & Плодоношення & 383,7 & 64,6 & 31 & 43 \\
\hline & Відмирання & 0,4 & 93,3 & 123,7 & 10 \\
\hline & Коефіцієнт кореляції * & 0,99 & $-0,6$ & $-0,3$ & - \\
\hline \multirow{7}{*}{2009} & Сходи & 28,7 & 64,6 & 14,6 & 8 \\
\hline & Стеблування & 131,6 & 72,0 & 88,9 & 23 \\
\hline & Бутонізація & 294,5 & 69,5 & 115,1 & 29 \\
\hline & Квітування & 377,5 & 69,5 & 65,2 & 44 \\
\hline & Плодоношення & 303 & 71,9 & 2,4 & 25 \\
\hline & Відмирання & 78,6 & 68,4 & 0 & 9 \\
\hline & Коефіцієнт кореляції * & 0,92 & 0,5 & 0,6 & - \\
\hline \multirow{7}{*}{2010} & Сходи & 92 & 60,8 & 15 & 13 \\
\hline & Стеблування & 259,8 & 71,0 & 113,5 & 32 \\
\hline & Бутонізація & 229,5 & 74,4 & 158,8 & 24 \\
\hline & Квітування & 428,3 & 72,5 & 57,2 & 31 \\
\hline & Плодоношення & 267 & 67,8 & 23,5 & 24 \\
\hline & Відмирання & 35,1 & 78,0 & 73,1 & 10 \\
\hline & Коефіцієнт кореляції * & 0,91 & 0,1 & 0,3 & - \\
\hline \multirow{7}{*}{2011} & Сходи & 38,5 & 70,2 & 31,5 & 15 \\
\hline & Стеблування & 318,5 & 60,2 & 26,6 & 35 \\
\hline & Бутонізація & 126,8 & 74,7 & 100,1 & 15 \\
\hline & Квітування & 248,7 & 77,0 & 191,9 & 29 \\
\hline & Плодоношення & 174,8 & 72,1 & 61,1 & 37 \\
\hline & Відмирання & 23 & 74,3 & 12 & 9 \\
\hline & Коефіцієнт кореляції * & 0,84 & $-0,4$ & 0,2 & - \\
\hline \multirow{7}{*}{2012} & Сходи & 115,5 & 63,4 & 13,0 & 12 \\
\hline & Стеблування & 244,2 & 69,3 & 96,4 & 34 \\
\hline & Бутонізація & 182,4 & 68,8 & 23,7 & 18 \\
\hline & Квітування & 373,8 & 69,4 & 59,2 & 31 \\
\hline & Плодоношення & 294,7 & 73,3 & 81,9 & 31 \\
\hline & Відмирання & 68,5 & 73,3 & 81,9 & 11 \\
\hline & Коефіцієнт кореляції * & 0,89 & 0,3 & 0,6 & - \\
\hline \multirow{7}{*}{2013} & Сходи & 134,1 & 56,9 & 0,4 & 18 \\
\hline & Стеблування & 312,5 & 72,1 & 47,8 & 37 \\
\hline & Бутонізація & 267,2 & 72,1 & 31 & 25 \\
\hline & Квітування & 324,4 & 73,4 & 37,4 & 34 \\
\hline & Плодоношення & 129,2 & 75,5 & 81,5 & 21 \\
\hline & Відмирання & 38 & 78,0 & 3,4 & 8 \\
\hline & Коефіцієнт кореляції & 0,96 & 0,0 & 0,5 & - \\
\hline
\end{tabular}

Примітка: * - Враховано значення коефіцієнтів кореляції між показниками, що характеризують умови вегетації рослин по роках дослідження: $n=6, r_{0} \geq 0,82$, достовірно при $p=0,05$.

фактором для росту і розвитку рослин D. moldavica.

Головні висновки. Встановлено вплив абіотичних умов на тривалість життєвого циклу рослин Dracocephalum moldavica за інтродукції в Центральному Поліссі України:

- загальна тривалість життєвого циклу змієголовника молдавського в умовах Полісся України становила від 134 (2009 р.) до 142 (2013 р.) діб;
- для проходження повного циклу розвитку, від посіву до відмирання змієголовника молдавського, необхідна сума активних температур у середньому $2534,0^{\circ \mathrm{C}}$ : мінімальна - 2210,3 ${ }^{\text {оC }}$ (2011 р.), максимальна - 2651,7º $(2010$ р.); ефективних температур - у середньому $1168,1^{\text {о C }}$ (від 930,3 ${ }^{\circ \mathrm{C}}$ до $1311,7^{\circ \mathrm{C}}$ );

- недостатня кількість опадів і запасу вологи у грунті вплинула на темпи появи сходів та інтенсивність роз- 


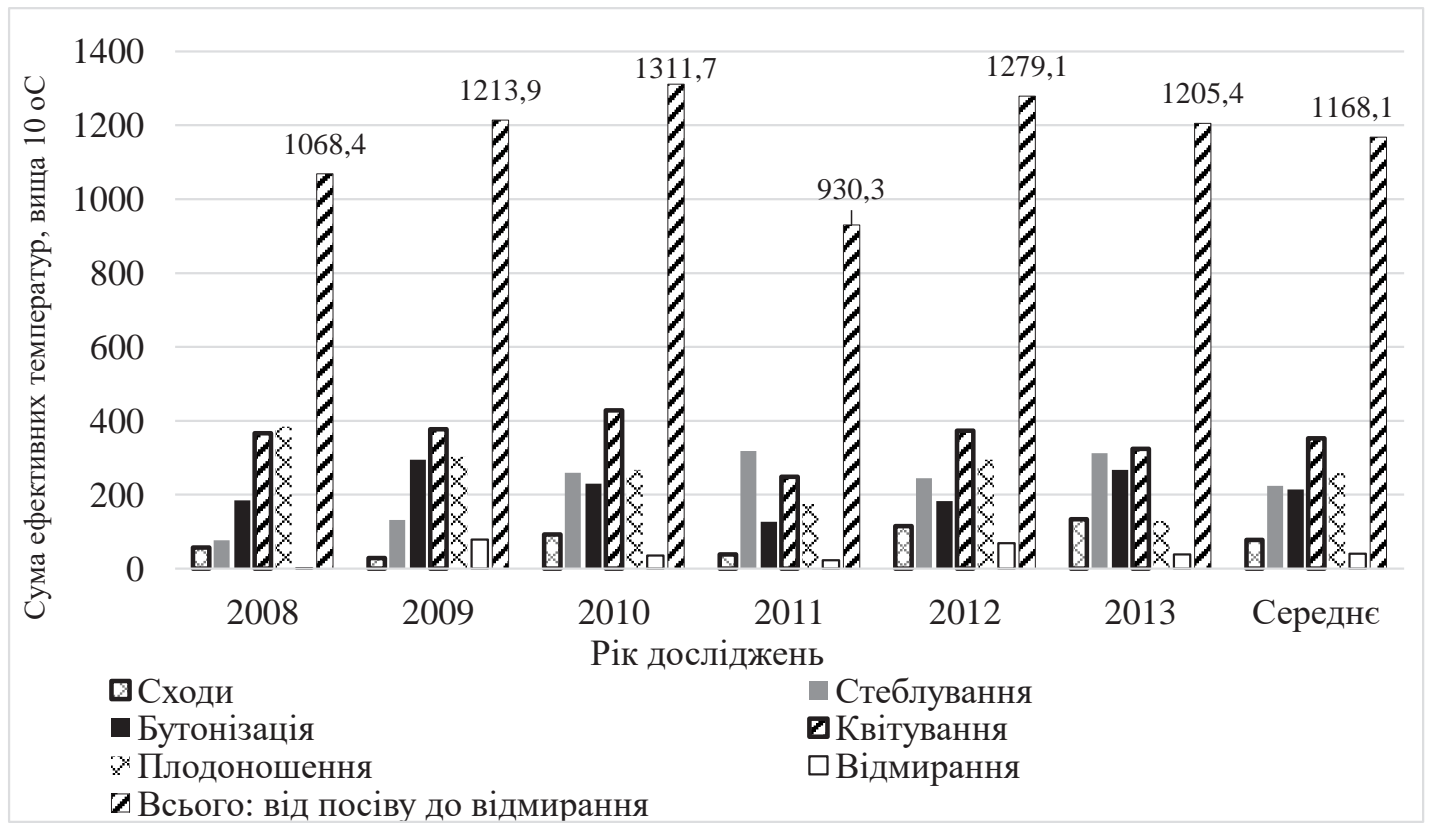

Рис. 3. Залежність тривалості вегетаиії рослин D. тоldavica від суми ефективних температур в умовах Центрального Полісся Украӥни

витку рослин упродовж фаз сходів та стеблування, а високі літні температури й відсутність опадів призвели до скорочення тривалості цвітіння та плодоношення.

Перспективи використання результатів дослідження. Біологічні потреби інтродуцента щодо три- валості вегетаційного періоду, термічного та водного режиму повністю відповідають природним умовам Центрального Полісся України, що підтверджує перспективність впровадження у культуру рослин D. moldavica в цьому регіоні.

\section{Література}

1. Балабас Г.М. Интродукция лекарственных, ароматических и технических растений. М. : Наука, 1965. 425 с.

2. Ц Цвелёв Н.Н. Семейство Губоцветные (Lamiaceae, или Labiatae). Жизнь растений: в 6 т. М., 1981. Т. 5. Ч. 2. С. $404-412$.

3. Котюк Л.А. Морфологічні ${ }^{\circ}$ Собливості Dracocephalum moldavica L. у зв'язку з інтродукцією у ботанічному саду ЖНАЕУ. Сучасна фітоморфологія. Львів, 2013. Т. 4. С. 293-297. DOI: https://doi.org/10.5281/zenodo.161402

4. Dziki D., Mis A., Gladyszewska B., Laskowski J., Kwiatkowski S., Gawlik-Dziki U. Physicochemical and grinding characteristics of dragonhead seeds. International Agrophysics, 2013. Vol. 27 (4). P. 403-408. DOI: 10.2478/intag-2013-0010.

5. Свиденко Л.В. Биология роста и развития некоторых эфирномасличных растений в условиях Херсонской области. Бюлл. Никит. ботан. сада,1998. Вып. 80. С. 98-100.

6. Работягов В.Д., Бакова Н.Н., Хлыпенко Л.А., Голубева Т.Ф. Эфиромасличные культуры и пряноароматические растения для использования в фитотерапии. Ялта, 1998. $82 \mathrm{c.}$

7. Овечко С.В. Біологічні ${ }^{\circ}$ Собливості розвитку Dracocephalum moldavica L. в умовах Херсонської області. Заповідна сnрава: стан, проблеми, перспективи. Херсон: Айлант, 1999. С. 72-74.

8. Котюк Л.А., Рахметов Д.Б. Біологічні ${ }^{\circ}$ Собливості Dracocephalum moldavica L. при інтродукції в умовах Житомирського Полісся. Проблеми експериментальної ботаніки та біотехнології: збірник наукових праць. Київ: Фітосоціоцентр, 2012. Вип. 1. С. 101-109.

9. Шанайда М.І., Пасемків Ю.А., Корабльова О.А., Рахметов Д.Б. Результати інтродукційних та фітохімічних досліджень видів роду Dracocephalum L. (D. grandiflorum L. та D. moldavica L.) у Північному Лісостепу та на Західному Поділлі України. Інтродукиія рослин. 2008. № 2. С. 65-71.

10. Tan M., Cheng-hui H., Wen J., Cheng Z., Ning Y., Wei H., Zhong-gao G., Jian-guo X. Development of solid lipid nanoparticles containing total flavonoid extract from Dracocephalum moldavica L. and their therapeutic effect against myocardial ischemiareperfusion injury in rats. Int. J. Nanomedicine. 2017. Vol. 12. P. 3253-3265. DOI: 10.2147/IJN.S131893

11. Yu H., Liu M.., Liu Y., Qin L., Jin M., Wang Z. Antimicrobial Activity and Mechanism of Action of Dracocephalum moldavica L. Extracts Against Clinical Isolates of Staphylococcus aureus. Front. Microbiol. 2019. Vol. 10. P. 1249. DOI: 10.3389/ fmicb.2019.01249

12. SalamoneA.,Zizzo G. V., Scarito G. The antimicrobial activity of water extracts from Labiatae. Acta Hortic, 2006. Vol. 723.P.465-470. DOI: 10.17660/ActaHortic.2006.723.67

13. De Martino L., De Feo V., Nazzaro F. Chemical composition and in vitro antimicrobial and mutagenic activities of seven Lamiaceae essential oils. Molecules, 2009. Vol. 14. P. 4213-4230. DOI:10.3390/molecules 14104213

14. Cvijovic V., Djukic D., Mandis L., Acamovic-Djokovic G., Pesakovic M. Composition and antimicrobial activity of essential oils of some medicinal and spice plants. Chemistry of Natural Compounds, 2010. Vol. 46 (3). P. 481-482. DOI:10.1007/s10600-010-9652-z 
15. Грязнов М. Ю., Тоцкая С. А. Новый сорт Dracocephalum moldavica L. слелекции ФГБНУ ВИЛАР. Овощи Росии. 2019. № 3 (47). C. 65-67.

16. Wójtowicz A., Oniszczuk A., Oniszczuk T, Oniszczuk T., Kocira S., Wojtunik K., Mitrus M., Kocira A., Widelski J., Skalicka-Woźniak K. Application of Moldavian dragonhead (Dracocephalum moldavica L.) leaves addition as a functional component of nutritionally valuable corn snacks. J. Food Sci. Technol. 2017. Vol. 54. P. 3218-3229. DOI: https://doi.org/10.1007/s13197-017-2765-7

17. Кораблева О. А., Рахметов Д. Б. Полезные растения в Украине: от интродукции до использования. К.: Фитосоциоцентр, 2012. $171 \mathrm{c}$.

18. Weremczuk-Jeżyna I., Grzegorczyk-Karolak I, Frydrych B., Królicka A., Wysokińska H. Hairy roots of Dracocephalum moldavica: rosmarinic acid content and antioxidant potential. Acta Physiologiae Plantarum. 2013, Vol. 35, Issue 7, P. 2095-2103. DOI 10.1007/ s11738-013-1244-7

19. Котюк Л.А. Вміст аскорбінової кислоти і каротину у сировині пряно-ароматичних рослин родини Lamiaceae Lindl. Біологічні Cтудіï/Studia Biologica, 2013. T. 7, № 2. С. 83-90. DOI: https://doi. org/10.309.70/sbi.0702.292

20. Аутко А.А., Рупасова Ж.А., Аутко А.А., Кухарева Л.В. Биоэкологические ${ }^{\circ}$ Собенности выращивания пряноароматических лекарственных растений. Минск: Тонпик, 2003. 160 с.

21. Alael S., Melicyan A., Kobraee S., Alael S., MelicyanA., Kobraee S. Mahna N. Effect of different soil moisture levels on morphological and physiological characteristics of Dracocephalum moldavica. Agricultural communications, 2013. Vol. 1/1. P. 23-26.

22. Паршина $\Gamma^{\circ}$ Собенности развития Dracocephalum moldavica L. при интродукции в Алматинской области. Вісник Київського університету. Серія: Інтродукція та збереження рослинного різноманіття, 2009. Вип. 22/24. С. 13-14.

23. Тоцкая С.А., Коротких И.Н., Хазиева Ф.М. Послеуборочное дозревание семян змееголовника молдавського (Dracocephalum moldavica L.). Вопросы биологической, медииинской и фармацевтической химии, 2013. № 5. С. $25-27$.

24. Чумакова В.В., Чумаков В.Ф. Агробиологическая и фитохимическая характеристика сорта змееголовника молдавского Эгоист. Сельскохозяйственный журнал. 2018. №2 (11). С. 2-32.

25. Егорова П.С. К интродукции Dracocephalum moldavica L. (змееголовника молдавского) в Якутском ботаническом саду. Вестник КрасГАУ. 2017. №5. С. 117-122.

26. Савич И.М., Тычина И.Н. ${ }^{\circ}$ Собенности развития видообразцов змееголовника молдавского (Dracocephalum moldavica L.) в условиях Центрального ботанического сада Национальной академии наук Беларуси. Материалы Международной научной конференции, посвященной 85-летию Центрального ботанического сада НАН Беларуси (6-8 июня 2017 года, г. Минск). Ч. 1. Минск: Медисонт, 2017. С. 241-243.

27. Овечко С.В. Биологические ${ }^{\circ}$ Собенности и хозяйственно ценные признаки Dracocephalum moldavica $\mathrm{L}$. в условиях нижнего Приднепровья Херсонской обл. : дисс ... канд. биол. наук: 03.00.05. Ялта, 2003. $161 \mathrm{c.}$

28. Сарлаева И.Я., Байкова Е.В., Васильева О.Ю. Теплообеспеченность однолетних декоративных растений в Лесостепи Западной Сибири. Успехи современной науки и образования. 2016. №12, Том 7. С. 188-197.

29. Работнов Т.А. Жизненный цикл многолетних травянистых растений в луговых ценозах. Труды БИНАН СССР. Сер. 3. Геоботаника. М.: АН СССР, 1950. Вып. 6 (7). 204 с.

30. Уранов А.А., Смирнова О. В. Классификация и ${ }^{\circ}$ Сновные черты развития популяций многолетних растений. Бюлл. МОИП. Отд. биол. 1969. Вип. 79 (1). С. 19-135.

31. Бейдеман И.Н. Методика изучения фенологии растений и растительных сообществ. Новосибирск: Наука, 1974.156 с.

32. Рахметов Д.Б. Теоретичні та прикладні аспекти інтродукції рослин в Україні. К.: Аграр Медіа Груп, 2011. 398 с.

33. Павлова М.Д. Практикум по агрометеорологии. Л.: Гидрометеоиздат, 1974. 210 с.

34. Польовий А.М., Божко Л.Ю., Ситов В.М., Ярмольська О.С. Практикум з сільськогосподарської метеорології. Одеса: ТЕС, $2001.400 \mathrm{c}$. 


\title{
СИНАНТРОПНI РОСАИНИ В УРБАНОФАОРI МICТА НОВИЙ РОЗДІА АЬВІВСЬКОЇ ОБААСТІ
}

\author{
Павлишак Я.Я., Кречківська Г.В. \\ Дрогобицький державний педагогічний університет імені Івана Франка \\ вул. Шевченка, 23, 82100, м. Дрогобич, Львівська область \\ pavlyshak2210@ukr.net, gkrechkivska@gmail.com
}

\begin{abstract}
Втручання людини у природні комплекси та їх трансформація зумовили появу синантропної рослинності. Синантропізація рослинного покриву стала одним із найнебезпечніших наслідків діяльності людини і виявляється у збідненні та уніфікації флори. Антропогенну трансформацію флори супроводжує експансія та занесення адвентивних видів. Із кожним роком збільшується кількість неаборигенних рослин, розширюється спектр їхніх місцезростань, наростають темпи заносу, поширення та ступінь натуралізації.

У статті наведені результати дослідження синантропної фракції флори міста Новий Розділ Львівської області. Складено конспект урбанофлори рослин та систематизовано їх по родинах, класах, відділах. Встановлено систематичний, біоморфологічний, географічний, еколого-ценотичний аналіз флори. Проаналізовано життєві форми рослин за характером розташування бруньок відновлення щодо поверхні землі та снігового покриву.

На території дослідження виявлено 116 синантропних видів, 62 з яких є апофітами, 54 - адвентами. Синантропні види об’єднують у 101 рід, 30 родин та 2 відділи. До відділу Magnoliophyta класу Magnoliopsida належать 103 види, 90 родів і 27 родин, до класу Liliopsida - 12 видів, 10 родів і 2 родини; до відділу Equisetophyta - один вид Equisetum arvense. У списку найбільш насичених синантропними видами родин $є$ : Asteraceae $(23,2 \%)$, Poaceae $(9,5 \%)$, Fabaceae $(8,6 \%)$, Brassicaceae $(6,8 \%)$, Caryophylaceae (5,2\%), Lamiaceae (5,2\%), Scrophulariaceae (4,3\%), Apiaceae (4,3\%), Polygonaceae (4,3\%), Rosaceae $(3,4 \%)$.

За ступенем натуралізації переважає група епекофітів (51,8\%), за способом проникнення - ксенофітів $(59,2 \%)$.

Найбільша кількість адвентивних видів трапляється вздовж доріг, біля смітників, на закинутих місцях. Серед видів виявлено переважання видів середземноморського походження. Ключові слова: синантропна флора, структурний аналіз, археофіти, кенофіти, апофітні види, адвентивні види.
\end{abstract}

Synanthropic plants in the urban flora of Novy Rozdil, Lviv region. Pavlyshak Y., Krechkivska G.

Human intervention in natural complexes and their transformation led to the emergence of synanthropic vegetation. Synantropization of vegetation has become one of the most dangerous consequences of human activity and is manifested in the impoverishment and unification of the flora, which leads to undesirable evolutionary consequences. Anthropogenic transformation of flora is accompanied by expansion and introduction of adventitious species. Every year the number of non-native plants increases, the range of their habitats expands, the rates of drift, spread and degree of naturalization increase.

The results of the research of synantropic flora of Novy Rozdil, Lviv region.

In the research, the investigated species were systematized into families. Also, the abundance and life forms were determined. A systematic, biomorphological, geographical, ecologically-cenotical analysis of the flora was established. The key role of the different plant life forms by the type of root sestems and position of revival buds about the blanket of snow in restore vegetation of grasslands were definited.

There are 116 synanthropic species on the studied. The synanthropic flora includes 62 species of olien plants and 54 species of apophytes. The synantropic species contain 101 genera, 30 families and 2 divisions. The Magnoliophyta division of the Magnoliopsida class contains 103 specious, 92 genera, and 27 families, the Liliopsida class contains 12 species, 10 genera and 2 families. The Equisetophyta devision contains a single species Equisetum arvense. The families which are the most saturated of synanthropic species: Asteraceae (23.2\%), Poaceae (9.5\%), Fabaceae (8.6\%), Brassicaceae (6.8\%), Caryophylaceae $(5,2 \%)$, Lamiaceae $(5,2 \%$.), Scrophulariaceae (4,3\%), Apiaceae (4,3\%), Polygonaceae $(4,3 \%)$, Rosaceae $(3,4 \%)$.

The degree of naturalization is dominated by a group of epecophytes $(51,8 \%)$, by the way of penetration - xenophytes $(59,2 \%)$.

The largest number of adventions species occus along roads, near garbage, on abandoned sites. The domination of species with Mediterranean origin among alien species has detected. Key words: synanthropic flora, structural analysis, arheophytes, kenophytes, apophytes species, adventitious species.

Постановка проблеми. Посилення урбанізації, ущільнення мережі шляхів сполучення, розширення площ розорюваних земель, структура ландшафту та стан навколишнього середовища зазнали великих змін. Синантропна флора на сучасному етапі свого розвитку представлена сукупністю складних комплексів рослинності; флористичний склад, тривалість існування та напрям розвитку зумовлені природними особливостями регіону.

Актуальність дослідження. Розвиток синантропної рослинності призвів до змін у місцевій природній флорі та втрати нею своїх специфічних особливостей, зокрема зменшення різноманітності аборигенних видів [2; 3]. Особливо виражений він у містах, де вплив людини надзвичайно інтенсивний та багатогранний за кількістю факторів, оскільки у містах концентрується значна частина населення, що чинить антропогенний тиск на довкілля, внаслідок чого міське середовище перетворюється на зону екологічного лиха, а це позначається несприятливими умовами для біотичного різноманіття. Рекреаційна та інтенсивна перетворююча діяльність, 
забруднення навколишнього середовища промисловими відходами, знаходять повне своє відображення у структурі рослинних угруповань [3]. Тому дослідження синантропної фракції флори - надзвичайно актуальна проблема.

Зв'язок авторського доробку із важливими науковими та практичними завданнями. Тема дослідження відповідає основним напрямам наукової діяльності кафедри біології та хімії ДДПУ імені Івана Франка і виконувалася в межах науково-дослідної теми: «Моніторинг стану природних, техногенно змінених та урбанізованих екосистем Передкарпаття». Вивчення структури синантропної флори дасть змогу досліджувати, прогнозувати та регулювати можливі зміни у рослинних угрупованнях і тим самим зберегти цінний генофонд та природні запаси фіторесурсів.

Результати проведеного дослідження можуть знайти широке застосування для збереження природної фіторізноманітності, відновлення та збереження унікальних і типових рослинних угруповань.

Аналіз останніх досліджень i публікацій. Українські вчені багато уваги приділяють вивченню синантропної рослинності, дослідженню окремих міст, районів. Дослідження рудеральних і сегетальних угруповань Українського Розточчя провела М.I. Сорока [14]. Вивчені особливості синантропної фракції урбанофлор м. Львова [9], м. Кіровограда [1] тощо. Впродовж 2016-2020 pр. проводилося дослідження синантропної фракції Дрогобицького району, Самбірського та Турківського районів.

Виділення не вирішених раніше частин загальної проблеми, котрим присвячусться означена стаття. Метою дослідження було встановлення видового складу синантропних рослин в урбанофлорі міста Новий Розділ Львівської області.

Новизна. Детальних досліджень синантропної рослинності міста Новий Розділ та його околиць не проводилося. Встановлено видовий склад синантропних рослин досліджуваної території, складено конспект урбанофлори. Уперше наводиться таксономічний аналіз території дослідження.

Поширення видів рослин вивчали загальноприйнятим методом флористичних досліджень (маршрутним методом та методом пробних ділянок). Види рослин визначали за визначником [6]. Приналежність видів до категорії синантропних визначено за В. Протопоповою [11]. Для аналізу синантропної фракції використано історико-географічну класифікацію J. Kornas [16]. Первинні ареали видів визначено за флористичним районуванням земної кулі А.Л. Тахтаджяна [15], життєві форми за Х. Раункієром [13]. Рясність визначали окомірним методом за шкалою Друде [7].

Метою роботи $\epsilon$ вивчення синантропних рослин в урбанофлорі міста Новий Розділ Львівської області.

Виклад основного матеріалу. Дослідження проводилися протягом 2019-2021 рр. Дослідженнями були охоплені придорожні екотопи вздовж автомобільних шляхів, внутрішньоміські зелені насадження загального користування: парки, сквери, пустирі, ділянки напівприродної рослинності.

Під час флористичного обстеження виявлено 116 видів синантропних рослин, які об'єднані у 101 рід, 30 родин, 3 класи та належать до двох відділів. Усі виявлені види відносяться до відділу Magnoliophyta - 99,1\%, при цьому число родин становить 96,7\%. Відділ Equisetophyta представлений 1 родиною та 1 видом $(0,9 \%)$ (табл. 1$)$.

Таблиця 1

Таксономічна структура урбанофлори

\begin{tabular}{|c|c|c|c|c|}
\hline \multirow{2}{*}{ Відділ, клас } & \multicolumn{2}{|c|}{ Родина } & \multicolumn{2}{c|}{ Вид } \\
\cline { 2 - 5 } & $\begin{array}{c}\text { абс. } \\
\text { к-сть. }\end{array}$ & $\mathbf{\%}$ & $\begin{array}{c}\text { абс. } \\
\text { к-сть. }\end{array}$ & $\%$ \\
\hline Equisetophyta & 1 & 3,3 & 1 & 0,9 \\
\hline Magnoliophyta: & 29 & 96,7 & 115 & 99,1 \\
\hline в т. ч. Magnoliopsida & 27 & 90,0 & 103 & 88,8 \\
\hline Liliopsida & 2 & 6,7 & 12 & 10,3 \\
\hline Всього: & 30 & 100 & 116 & $\mathbf{1 0 0}$ \\
\hline
\end{tabular}

Як свідчать отримані результати, на теритоpii дослідження найбільша частина видів $(28,4 \%)$ зростає досить рясно (Myosotis arvensis L., Chamaerion angustifolium L., Elytrigia repens L., Mentha arvensis L.). Рясно ростуть 19,8\% рослин (Impatiens parviflora L., Sanguisorba officinalis L., Poa compressa L. Papaver rhoeas L.), дуже рясно 8,6\% (Heracleum sibiricum L., Capsella bursa-pastoris L., Equisetum arvense L., Acer negundo L.), рідко 15,5\% (Euphorbia peplus L. Verbascum densiflorum L., Anchusa arvensis L., Oenothera biennis L.), поодиноко - 24,1\% (Echium vulgare L., Descurainia Sophia L., Amaranthus retroflectus L., Portulaca oleracea), a $3,4 \%$ змикаються надземними частинами (Polygonum aviculare L., Polygonum hydropiper L.).

Флористичний аналіз видового складу виявив домінування родини Asteraceae, 27 видів, або 23,2\%. Типовими представниками у рудеральних екотопах є Stenactis annua L., Lactuca serriola L., Artemisia absinthium L., Cichorium intubus L. тощо. Родина Poaceae займає друге місце - 11 видів або 9,5\%. Це Elytrigia repens L., Setaria glauca L., Echinochloa crusgalli (L.) P. Beauv та інші. Третє місце належить родині Fabaceae - 10 видів (8,6\%).

Родина Brassicaceae становить 6,8\%. Такі родини, як Caryophylaceae та Lamiaceae, представлені однаковою кількістю видів, що становить 5,2\%. Родини Scrophulariaceae, Apiaceae, Polygonaceae становлять 4,3\%, a Rosaceae - 3,4\%.

Двадцять родин (із видовим спектром 1-3) представляють 29 (25,0\%) видів. Причому велика частка малочисельних родин є характерною ознакою синантропної флори.

Серед видів флори у результаті досліджень встановлено групу адвентивних рослин, що становить 
Павлишак Я.Я., Кречківська Г.В.

46,6\% (54 види), та апофітів - 53,4\% (62 види) Адвентивними видами є Amaranthus retroflectus L., Oenothera biennis L., Bromus mollis L., Chenopodium album L., Acer negundo L., Cichorium intubus L., Artemisia absinthium L. тощо.

Відбувається адвентизація через вторгнення кенофітів як цілеспрямованими, так і стихійними впливами. Згідно 3 класифікацією синантропних видів [11], адвентивні рослини за часом занесення поділяються на археофіти та кенофіти.

За нашими дослідженнями, за часом занесення переважають ксенофіти - 30 видів (55,6\%). До них належать Acer negundo L., Amaranthus retroflectus L., Heracleum sibiricum L., Impatiens parviflora L., Solidago canadensis L.

Археофіти становлять 24 види (44,4\%). Серед них нами виявлено: Sonchus arvensis L., Artemisia absinthium L., Portulaca oleracea L., Senecio vulgaris L., Lactuca serriola Torner, Capsella bursa-pastoris L., Rauschert Descurainia sophia (L.) Lactuca serriola L., Lamium album L., Myosotis arvensis (L.) Hill. Переважають за способом занесення ксенофіти (види, несвідомо занесені людиною) - 32 види (59,2\%). До них належать: Sisymbrium loselii L., Lamium album L., Centaurea cyanus L., Carduus nutans L., Artemisia absinthium L., A. annua L., Anthemis arvensis L. Ксенофітам значно поступаються ергазіофіти (види, свідомо завезені, що згодом здичавіли й поширюються спонтанно) - 16 видів, або 29,6\%. Це Robinia pseudoacacia L., Lupinus polyphyllus Lindl. тощо.

Аколютофіти (види, занесені людиною неумисно, поширюються завдяки тому, що природні екосистеми $є$ антропогенно порушеними, а умови антропогенних екосистем найсприятливіші для їх зростання) представлені незначною кількістю - 6 видами (11,1\%). До них належать Bromus mollis L., Cichorium intubus L., Capsella bursa-pastoris L.

Біля смітників, на закинутих місцях, уздовж доріг зустрічається найбільша кількість адвентив-

\section{СИНАНТРОПНІ РОС ИИН В УРБАНОФАОРІ..}

них видів. Добре натуралізувалася значна кількість адвентивних рослин та зайняла свою нішу в рудеральних угрупованнях, утворюючи групу епекофітів.

За ступенем натуралізації адвентивні рослини поділено на чотири групи. Переважають епекофіти, що натуралізувалися у повністю трансформованих екотопах,-28 видів (51,8\%): Amaranthus retroflectus L., Artemisia absinthium L., Portulaca oleracea L., Galinsoga parviflora Cav., Lamium album L., Myosotis arvensis (L.) Hill., Lepidium ruderale L. тощо. На ергазіофіти припадає 16 видів (29,6\%): Acer negundo L., Robinia pseudoacacia L., Brassica napus L.

Вищу ступінь натуралізації становлять агріофіти, які зростають у природних та напівприродних угрупованнях, їх є 8 видів (14,8\%): Stenactis annua Nees, Saponaria officinalis L., Salix fragillis L., Vicia angustifolia Reichard, Oenothera biennis L. Ефемерофіти - види зі слабким ступенем натуралізації, які часом з'являються у невеликій кількості в різних місцях. Ефемерофіти утримуються у флорі короткий проміжок часу, нараховують 2 види $(3,7 \%)$.

Аналіз походження видів дає змогу стверджувати, що більшість видів флори - це вихідці iз Середземномор'я $(22,4 \%, 26$ видів): Lolium temulentum L., Urtica dioica L., Raphanus raphanistrum L., Sisymbrium loselii L., Anthemis cotula L. та ін). Друге місце за чисельністю займають види євразійської групи, що становлять 17,2\% (20 видів): Echium vulgare L., Ranunculus repens L., Equisetum arvense L., Rumex confertus L.

До голарктичної групи належать 19 видів (Euphorbia peplus L., Lolium perenne L., Aethusa cynapium L., Barbarea vulgaris R.Br), або 16,3\%. Європейська група налічує 17 видів, що становить 14,6\% (Lotus corniculatus L., Arctium lappa L., Anisantha tectorum L., Anchusa arvensis L. тощо).

До північноамериканської групи належить 12 видів (10,3\%): Stenactis annua L., Chamaerion angustifolium L. тощо.

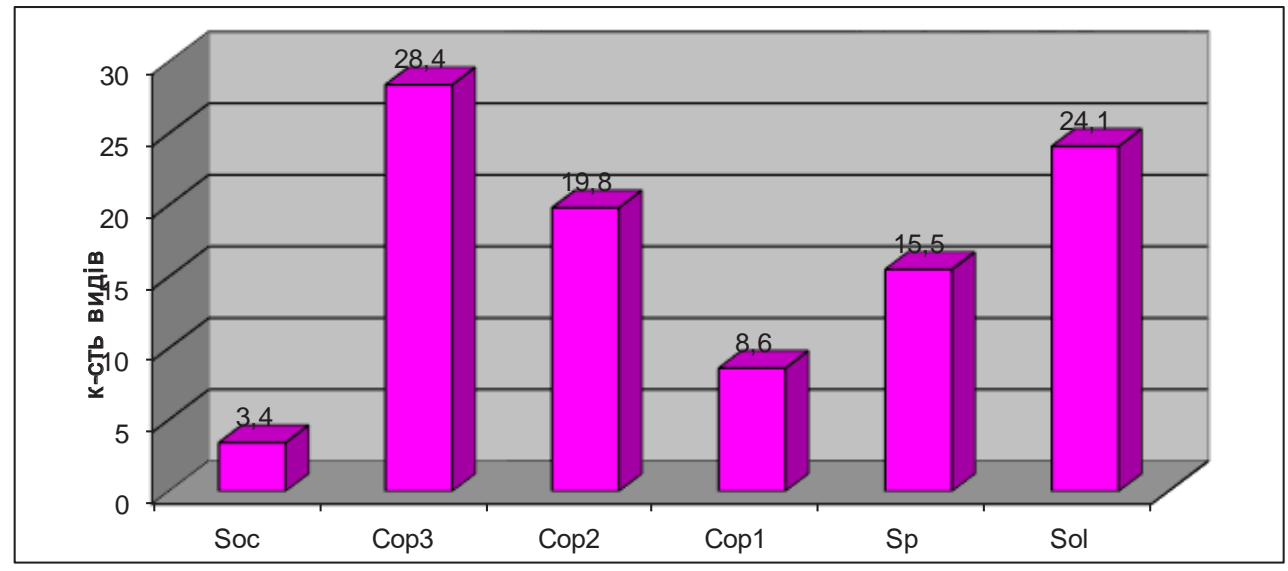

Діаграма 1

Рясність урбанофлори міста Новий Розділ 
Сім видів (6,0\%) - середземноморсько-ірано-туранського походження: Conium maculatum L., Cichorium intubus L., Xanthium stramorium L. тощо. Представниками ірано-туранської групи є 8 видів (6,9\%): Galium aparine L., Setaria glauca L., Avena fatua L., Lamium album L., а також 6 видів (5,2\%) азійської групи (Impatiens parviflora, Echinochloa crusgalli (L.) P. Beauv, Polygonum aviculare L. та ін). Південноамериканська група представлена одним видом, що становить 0,8\% (Galinsoga parviflora Cav).

У спектрі життєвих форм за Раункієром переважають терофіти (51,7\%; 60 видів). Збільшення частки терофітів у флорах урбанізованих територій пов'язано 3 їх високою здатністю до натуралізації за рахунок інтенсивного насіннєвого розмноження, наявністю відкритих порушених місць існування, які підходять для їх зростання. Дещо меншою кількістю представлені гемікриптофіти (49 видів; 42,2\%).

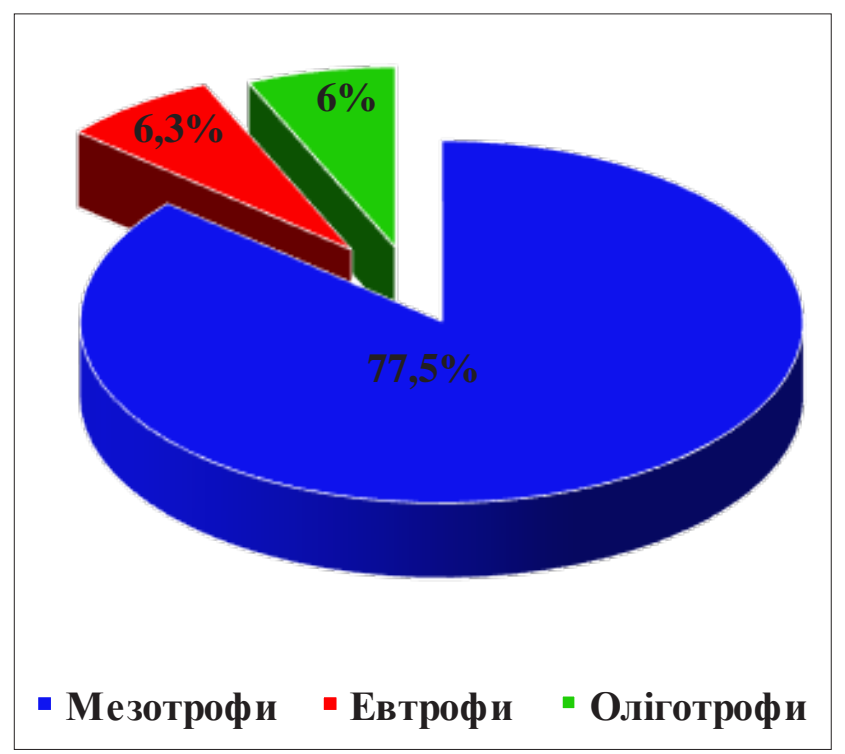

Розподіл рослин щчодо поживності грунту

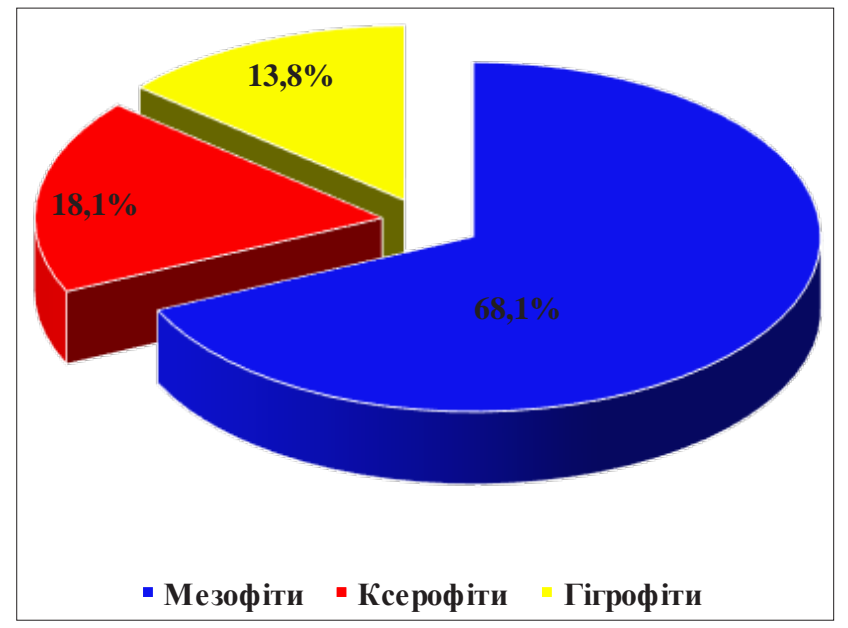

Діаграма 3

Екологічні групи рослин щэодо води
Фанерофіти та криптофіти налічують по три види, що становить 2,6\%. Серед криптофітів - Rumex acetosella L., Aegopodium podograria L. Lathyrus pratensis L. тощо. Хамефіти становлять 0,9\%. Високе різноманіття терофітів та зменшення ролі хамефітів, криптофітів - характерна властивість урбанофлор загалом [1].

Проведений екологічний аналіз щодо родючості грунту, вологості та освітлення. У флорі найчисельнішою є група мезотрофних видів. Ця група складається загалом із 90 видів (77,5\% від загальної кількості видів). Група еутрофних видів є менш чисельною та дуже вимогливою до поживних речовин (19 видів, 6,3\%): Matricaria perforata Merat., Setaria glauca L., Sonchus asper (L.) Hill., Sonchus arvensis L. тощо. Група оліготрофів найбідніша та об'єднує лише 7 видів (6,0\%): Lepidium ruderale L., Portulaca oleracea L. (діаграма 2).

Окрім багатства грунтів, на розподіл видів значно впливає рівень зволоження. В екологічному спектрі за відношенням до рівня зволоження простежується тенденція до мезофітинізації та ксеромезофітинізації.

Переважають представники екологічної групи мезофітів - 79 видів, що становить 68,1\%: Elytrigia repens L., Plantago lanceolata L., Plantago major L., Chelidonium majus L., Berteroa incana (L.) DC тощо. Ксерофіти налічують 21 вид (Ononis arvensis L., Sonchus arvensis L., Senecio vulgaris L., Achillea millefolium L. тощо), частка яких становить $18,1 \%$.

Останнє місце у спектрі груп щодо води посідають гігрофіти (16 видів, 13,8\%): Xanthium stramorium L., Heracleum sibiricum L., Ranunculus repens L., Galinsoga parviflora Cav., Geum urbanum L. тощо (діаграма 3).

Екологічний спектр видів рослин урбанофлори щодо світлового режиму включає такі геліоморфи: геліофіти, що $є$ найчисленнішою групою (50,4\%), оскільки найпоширенішим осередками цих рослин є відкриті антропогенно змінені екотопи (Vicia angustifolia L., Cichorium intubus L., Lathyrus pratensis L., Ambrosia artemisiifolia L. тощо).

Сціогеліофіти становля 35,6\% (Artemisia vulgaris L., Mentha arvensis L., Salix fragilis L. тощо). Група геліосциофітів представлена видами, що становлять 9,5\% (Acer negungo L., Urtica dioica L., Aegopodium podograria L. тощо). Найменший відсоток припадає на сціофіти (4,5\%): Lamium album L., Impatiens parviflora DC., Oxalis acetosella L.

Головні висновки. Основу урбанофлори становлять представники відділу Magnoliophyta - 99,1\%. Аналіз систематичної структури спектру провідних родин флори представлений: Asteraceae - 23,2\%, Poaceae - 9,5\% та Fabaceae - 8,6\%. Апофітна фракція становить 53,4\%, адвентивна фракція - 46,6\%.

За походженням переважають види iз Середземномор'я (22,4\%), що відповідає загальним закономірностям синантропізації флори України. У спектрі життєвих форм переважають терофіти. 
Павлишак Я.Я., Кречківська Г.В.

У результаті проведеного екологічного аналізу щодо родючості грунту переважають мезотрофні види (77,5\%; 90 видів); стосовно зволоження - мезофіти (79 видів, 68,1\%), щодо світла - геліофіти, що є найчисленнішою групою $(50,4 \%)$.
СИНАНТРОПНІ РОСАИНИ В УРБАНОФАОРІ..

Перспективи використання результатів дослідження. Дані досліджень урбанофлори міста Новий Розділ Львівської області є основою практичних заходів для збереження природної фіторізноманітності та їі відновлення.

\section{Література}

1. Аркушина Г.Ф. Особливості синантропної складової урбанофлори Кіровограда. Синантропізація рослинного покриву України (м. Переяслав-Хмельницький, 27-28 вересня 2012 року). Київ-Переяслав Хмельницький, 2012. С. 9-10.

2. Бурда Р.І., Пашкевич Н.А., Бойко Г.В. Чужорідні види охоронних флор Лісостепу України. Київ: Наук. думка, 2015.114 с.

3. Бурда Р.И. Антропогенная трансформация флоры. К. : Наук. думка, 1991. 168 с.

4. Бурда Р.І. Концепція сучасної науки про сегетальні бур'яни. Агроекологічний журнал. 2002. №1. С. 3-11.

5. Бурда Р.І., Патика В.П. Моніторинг фітобіоти сегетальних екосистем. Вісник аграрної науки. 2002. № 7. С. 59-63.

6. Доброчаева Д.Н., М.И. Котов Определитель высших растений Украины. К.: Наук. думка, 1987. 548 с.

7. Друде О. Екологія рослин: підручник. Київ : «Фіона-К». 2003. 208 с.

8. Кучерявий В.П. Урбоекологія, фітомеліорація: витоки і шляхи розвитку. Науково- технічний журнал. 2011.2 (4) 25-30.

9. Кучерявий В.О., Соломаха В.А., Соломаха Т.Д. Синтаксономія рудеральної рослинності м. Львова. Украйнський ботанічний журнал. 1991. Т. 48. № 3. С. 48-55.

10. Мар'юшкіна В.Я. Адвентизація рослинності як наслідок спонтанної та цілеспрямованої інтродукції. Інтродукція рослин. 2002. № 1. C. 49-60.

11. Протопопова В. В. Синантропная флора Украины и пути ее развития. К . : Наук. Думка, 1991. 204 с.

12. Павлишак Я.Я., Гойванович Н.К. Синантропна флора Передкарпаття (Дрогобицький район) та ії аналіз. Науковий вісник Львівського лісотехнічного університету. 2017. Випуск 27(6). С. 38-41.

13. Раункиер Х. Жизненные формы высших растений и их изучение. Полевая геоботаника. М. : 1964. С. 146-205.

14. Сорока М.I. Рослинність Українського Розточчя. Львів: Світ, 2008. 432 с.

15. Тахтаджян А.Л. Система магнолиофитов. Л : Наука, 1987. 439 с.

16. Kornas J. Geographically historical classification of synanthropic plants.Warsaw, 1968. Vol. 25. P. 33-41. 


\title{
ДИНАМІКА ВІДНОВАЮВАНОЇ РОСАИННОСТІ ПIЩАНИХ КАР'СРІВ ЖИТОМИРСЬКОГО ПОАІССЯ
}

\author{
Хом'як І.В., Гарбар Д.А., Андрійчук Т.В., Костюк В.С., Власенко Р.П. \\ Житомирський державний університет імені Івана Франка \\ вул. Велика Бердичівська, 40, 10005, Житомир \\ ecosystem_lab@ukr.net
}

\begin{abstract}
Стаття присвячена проблемі відновлення природних екосистем у районі покинутих піщаних кар'єрів на територіїЦентрального Полісся. В ній розглядається формування фітоценотичного різноманіття на різних елементах території виробки після припинення активної господарської діяльності. Розглядаються окремі аспекти динаміки формування рослинного покриву в різних умовах середовища та впливу на неї прямих і опосередкованих антропогенних факторів. Результати дослідження можуть послужити основою для покращення теоретичних моделей динаміки екосистем. Це дослідження має неабияке значення для підвищення ефективності та модернізації підходів до рекультивації. В тому числі розглядається можливість використання природних процесів формування рослинності. Обговорюється питання зміни пріоритетів процесу рекультивації - від повернення господарського потенціалу до отримання пакета екосистемних послуг. У результаті дослідження встановлено, що рослинність закинутих піщаних кар'єрів Центрального Полісся належить до 12 класів, 20 порядків, 29 союзів, 58 асоціацій за класифікацією Браун Бланке. Рослинність досліджуваної території перебуває на відносно ранніх стадіях відновлення природної рослинності та належить до двох типів сукцесійних серій: заростання перелогів та відновлення в місці активного видобутку піску. Відновлення природних екосистем відбувається високими темпами відповідно до описаних раніше теоретичних моделей. Головний атрактор динаміки пов'язаний із закономірним зростанням надземної фітомаси рослинних угруповань. Описані рослинні угруповання часто мають широкі екотони ділянки із численними незайнятими еконішами, що робить їх вразливими до проникнення інвазійних видів-трансформерів. Такі інвазії часто закінчуються формуванням катастрофічного клімаксу і перешкоджають повноцінному формуванню аборигенних фітоценозів. Ключові слова: рекультивація, природні екосистеми, інвазійні види-трансформери.
\end{abstract}

Dynamics of restoration vegetation of sand quarries of Zhytomyr Polissya. Khomiak I., Harbar D., Andriichuk T., Kostiuk V., Vlasenko R.

The article discusses the process of restoration of natural ecosystems in the area of abandoned sand quarries in Central Polissya. The formation of phytocenotic diversity on various elements of abandoned sand quarries after cessation of active human activity is considered here. We discuss some aspects of the dynamics of vegetation formation in different environmental conditions and the impact on it of direct and indirect anthropogenic factors. The results of the study can be the basis for improving theoretical models of the dynamics of natural ecosystems. This study is of great importance for improving the efficiency and modernization of modern approaches to the reclamation of disturbed areas. We consider the possibility of using natural processes of vegetation formation during the restoration of natural ecosystems and reclamation. We are discussing the issue of changing the priorities of the reclamation process. We propose to move from restoring the economic potential of the disturbed areas to receiving a package of ecosystem services after the restoration of natural ecosystems. It was studied that the vegetation of abandoned sand quarries in Central Polissya belongs to 12 classes, 20 orders, 29 unions, 58 associations according to the Brown Blanke classification. The vegetation of the study area is in the relatively early stages of restoration of natural vegetation. Ecosystem dynamics belong to two types of succession series: overgrowth of fallows and restoration in the place of active sand mining. Restoration of natural ecosystems occurs as described in previous theoretical models. The main attractor of dynamics is formed by the natural growth of aboveground phytomass of plant communities. The phytocenoses described by us have wide ecotone areas and are vulnerable to the penetration of invasive species of transformers. Key words: reclamation, natural ecosystems, invasive species of transformers.

Постановка проблеми. Відновлення природних екосистем після порушення їхньої структури та цілісності є однією із найбільш актуальних проблем сьогодення. Ця проблема може виникати в межах різних ландшафтів та під дією різних факторів [1]. Такі розриви в «плівці життя» (за В.І. Вернадським) ведуть за собою негативні наслідки не лише локального масштабу [2]. Вони через опосередкований вплив на сусідні екосистеми створюють регіональні екологічні проблеми. В результаті інтегруючої взаємодії в кінцевому результаті це стає глобальною проблемою. Коли сума цих порушень досягає критичної межі, тоді функціонування та основні параметри біосфери міняються, що несе загрози існуванню людства.

Актуальність досліджень. Плануючи свою діяльність щодо відновлення природних екосистем, потрібно мати загальні уявлення про екосистемну динаміку та про те, як вона проявляється в конкретних умовах середовища. Для цього потрібно мати загальні теоретичні моделі та перевіряти їх на конкретних прикладах [3]. Лише після цього на основі теоретичних моделей можна вибудовувати прогностичні алгоритми та планувати діяльність відповідно до поставлених цілей.

Огляд попередніх підходів. Коли в ХХ столітті почалося обговорення та виникла практика відновлення території після порушень, то не йшлося про відновлення природних екосистем. Зазвичай ціллю рекультивації було відновлення господарського потенціалу території. Насамперед планувалася діяльність, спрямована на відновлення сільськогосподарських угідь або лісів промислового призна- 
Хом'як І.В., Гарбар Д.А., Андрійчук Т.В. ...

чення [4]. Відлуння цього підходу спостерігається на законодавчому рівні. Наприклад, у статті 52 Закону України «Про охорону земель» [5].

Натепер є усвідомлення, що відновлена територія може дати набагато більше ніж лісова плантація чи агроекосистеми. Ідеться про цінність екосистемних послуг. Саме тому з'являються не лише нові методології рекультивації, але й нові цілі [6]. Новою ціллю для рекультивації $\epsilon$ відновлення природних екосистем, які не будуть експлуатуватися, за винятком використання їхнього рекреаційного потенціалу [7]. При цьому велику увагу приділяють процесам природного відновлення порушених екосистем [8].

Для того щоб регенерація природних оселищ відповідала поставленим цілям та була максимально ефективною, необхідно створювати моделі динаміки відновлення екосистем та прогнози їхнього розвитку в різних умовах. Цьому сприяє проведення численних досліджень, в яких інтегруються геоботанічні методи роботи на місцевості із геологічними розвідками та використанням методів дистанційного зондування поверхні [9].

Мета та завдання дослідження - вивчення якісних змін у рослинному покриві під час відновлення природних екосистем у різних умовах середовища на території піщаних кар'єрів Житомирського Полісся. Відповідно до мети було поставлено такі завдання: описати і класифікувати рослинні угруповання покинутих піщаних кар'єрів; встановити залежність між умовами середовища та типом рослинних угруповань; визначити часові рамки щодо виникнення певних типів угруповань у конкретних умовах середовища.

\section{Матеріали та методи досліджень.}

Матеріалами є стандартні геоботанічні описи, зроблені в покинутих піщаних кар'єрах на території Центрального Полісся в період із 2004 по 2021 роки. Описи виконувалися за стандартною методикою стаціонарним і напівстаціонарним методами [10]. Класифікація рослинних угруповань здійснювалася за принципами школи Браун Бланке [11] відповідно до Продромусу рослинності України [12]. Рівень антропогенної трансформації встановлювався синфітоіндикаційним методом за шкалою ДідухаХом'яка [13]. Показник динаміки визначався за оригінальною методикою, розробленою лабораторією теорії екосистем Житомирського державного університету імені Івана Франка [14].

Результати досліджень та їхнє обговорення.

Рослинність досліджуваної території належить до 12 класів, 20 порядків, 29 союзів, 58 асоціацій. Синтаксономічна схема, згідно із системою Браун Бланке, має такий вигляд:

Lemnetea de Bolós et Masclans 1955: Lemnetalia minoris de Bolós et Masclans 1955: Lemnion minoris de Bolós et Masclans 1955: Lemnetum minoris Soó 1927, Spirodeletum polyrhizae W. Koch 1954, Lemnetum gibbae Miyawaki et J. Tx 1960; Stratiotion Den
Hartog et Segal 1964: Hydrocharitetum morsus-ranae Langendonck 1935, Lemno-Hydrocharitetum morsusranae Oberdorfer. 1957.

Potamogetea Klika in Klika et Novak 1941: Potamogetalia Koch 1926: Ceratophyllion demersi Den Hartog et Segal ex Passarge 1996: Ceratophylletum demersi Corillion 1957, Ceratophylletum submersi Soó 1928; Nymphaeion albae Oberd 1957: MyriophylloNupharetum Koch 1926, Numpharo lutei-Nymphaetum albae Tomasz 1977; Potamogion Libberd 1931: Potametum natantis Hild 1959.

Phragmiti-Magnocaricetea Klika in Klika et Novak 1941: Nasturcio-Glicerietalia Pignatti 1953: GlycerioSparganion fluitans Br.-Bl et Siss in Boer 1942: Glycerietum fluitantis Nowiński 1930; Oenathetalia aquaticae Hejny ex Balátová-Tuláčková et al. 1993: Eleocharito palustris-Sagittarion sagittifoliae Passarge 1964: Glycerio fluitantis-Oenanthetum aquaticae Eggler 1933, Oenantheto aquaticae-Roripetum amphibiae Lohmeyer 1950, Eleocharitetum palustris Savič 1926, Alopecuro-Alismatetum plantaginis-aquaticae Slavniæ Bolbrinker 1984; Phragmitetalia Koch 1926: Phragmition Koch 1926: Phragmitetum australis Savič 1926, Typhetum angustifoliae Pignatti 1953, Typhetum latifoliae Nowiński 1930, Iridetum pseudocaori Eggler 1933, Schoenoplectetum lacustris Chouard 1924, Acoretum calami Dagys 1932, Glycerietum maximae Nowiński 1930 corr. Sumberová, Chytrý et Danihelka in Chytrý 2011; Magnocaricetalia Pignatti 1953: Magnocaricion elatae Koch 1926: Caricetum elatae Koch 1926, Carici elatae-Calamagrostietum canescentis Jílek 1958; Magnocaricion gracilis Géhu 1961: Caricetum vesicariae Chouard 1924, Caricetum acutiformis Eggler 1933, Caricetum gracilis Savič 1926, Carici acutaeGlycerietum maximae Jilek et Valisek 1964.

Scheuchzerio palustris-Caricetea fuscae Tx. 1937: Caricetalia fuscae Koch 1926: Caricion fuscae Koch 1926: Calamagrostietum neglectae Steffen 1931, Caricetum nigrae Braun 1915; Scheuchzerietalia palustris R.Tx et Nordhagen 1937: Scheuchzerion palustris Nordhagen 1936: Polytricho communisMolinietum caeruleae Hadač et Váňa 1967, Sphagno fallacis-Phragmitetum australis (Jeschke 1961) Passarge 1999, Menyantho trifoliatae-Sphagnetum teretis (Waren 1926) Dierssen 1982, Carici-Menyanthetum Soó 1955.

Oxycocco-Sphagnetea Br.-B1. et Tüxen ex Westhoff et Paschier 1946: Sphagnetalia medii Kästner \& Flössner 1933: Sphagnion medii Kästner and Flössner 1933: Drosero rotundifoliae-Sphagnetum Konishchuk 2009, Ledo-Sphagnetum fusci Du-Rietz 1921.

Molinio-Arrhenatheretea R.Tx 1937: Galietalia veri Mirk. et Naum. 1986: Agrostion vinealis Sipaylova, Mirk., Shelyag et V.Sl. 1985: Agrostio vinealis-Calamagrostietum epigeioris (Shelyag et al. 1981) Shelyag, V.S1. et Sipaylova 1985, Agrostietum vinealis-tenuis Shelyag et al. 1985, Poo angustifoliaeArrhenatheretum elatiori Shevchyk et V.Sl. in Shevchyk et al., 1996, Potentillo argenteae-Poetum angustifoliae 
Solomakha 1996, Achillea submiefolium-Dactyletum glomeratae Smetana, Derpoluk, Krasova 1997; Molinetalia Koch. 1926: Mentho longifoliae-Juncion inflexi T. Müller et Görs ex de Foucault 2009: Juncetum effusi (Pauca 1941) Soó 1947.

Epilobietea angustifolii Tx. et Preising ex von Rochow 1951: Galeopsio-Senecionetalia sylvatici Passarge 1981: Epilobion angustifolii Oberd. 1957: Rubo-Chamaenerietum angustifolii Hadač et al. 1969, Calamagrostietum epigii Juraszek 1928.

Robinietea Jurco ex Hadac et Sofron 1980: Cheledonio-Robinietalia Jurco ex Hadaĉ et Sofron 1980: Balloto nigrae-Robinion pseudoacaciae Hadač et Sofron 1980: Cheledonio-Pinetum sylvestris (Gorelov 1997) Davydov comb. nova prov.; CheledonioRobinion Hadaĉ et Sofron in Chytrý 2013: CheledonioRobinietum Jurco 1963; Chelidonio-Acerion negundo L. Ishbirdin et A. Ishbirdin 1991: Cheledonio-Aceratum negundi L. Ishbirdin et A. Ishbirdin 1991; Sambucetalia racemosae Oberd. ex Doing 1962: Sambuco-Salicion capreae Tx. et Neum et Oberd.1957: Salicetum capreae Schreier 1955.

Salicetea purpurea Moor 1958: Salicetalia purpureae Moor 1958: Salicion albae de Soó 1951: Salici-Populetum Meijer Drees 1936, Populetum nigroalbae Slavnić 1952.

Franguletea Doing ex Westhoff in Westhoff et Den Held 1969: Salicetalia auritae Doing 1962: Salicion cinereae Th.Müll et Görs ex Pass 1961: Salicetum pentandro-cinereae Pass 1961.

Artemisietea vulgaris Lohmeyer et al. ex von Rochow 1951: Agropyretalia intermedio-repentsis Th.Müll et Görs 1969: Convolvulo-Agropyrion repentis Görs 1966: Agropyretum repentis Felföldy 1942, Poo compressae-Tussilaginetum farfarae R. Tx. 1931; Onopordetalia acanthii Br.-Bl. et Tx. ex Klika et Hadač 1944: Arction lappae R.Tx 1937: Echio-Verbascetum Sissingh 1950; Dauco-Melilotenion Görs ex Rostański et Gutte 1971: Berteroëtum incanae Sissingh et Tideman ex Sissingh 1950, Dauco-Picridetum hieracioidis Görs 1966; Onopordion acanthii Br.-Bl et al. 1926: PotentiloArtemisietum absintii Faliński 1965.

Polygono arenastri-Poëtea annuae Rivas-Martínez 1975: Polygono arenastri-Poëtalia annuae Tx. in Géhu et al. 1972 corr. Rivas Martínez et al. 1991: Saginion procumbentis Tüxen et Ohba in Géhu et al. 1972: Herniarietum glabrae (Hohenester 1960) Hejný et Jehlík 1975, Poetum annuae Gams 1927.

Plantagenetea majoris Tx. et Preising ex von Rochow 1951: Potentillo-Polygonetalia avicularis R. Tx. 1947: Plantagini-Prunellion Eliáš 1980: Juncetum tenuis Schwick. 1944.

Рослинність досліджуваної території перебуває на відносно ранніх стадіях відновлення природної рослинності. За цією ознакою іiі можна розділити на дві групи сукцесійних серій: рослинності перелогів та рослинності виробки. В кожній групі добре помітна велика кількість екотонних ділянок.
Водна рослинність, розташована на дні кар'єрів, належить переважно до мезотрофного або до оліго-мезотрофного типу. Евтрофні водойми, заселені представниками класу Lemnetea, трапляються рідко. Вони присутні лише в сильно антропізованих неглибоких кар'єрах зі значним біогенним забрудненням. Найчастіше трапляються угруповання асоціації Potametum natantis. Лише на півночі Центрального Полісся частішають випадки трапляння асоціації Numpharo lutei-Nymphaetum albae. Прибережноводна рослинність розташована широкими смугами навколо водойм. Найчастіше це асоціація Phragmitetum australis. Мезотрофні та оліготрофні болотні угруповання формуються в кар'єрах на північній межі Центрального Полісся.

Угруповання злаковників займають найбільшу площу досліджуваної території. В межах виробітку вони трапляються невеликими фрагментами, розташовані і практично суцільним масивом за його межами. Переважно це мезофітні та мезоксерофітні луки порядку рослинних угруповань Galietalia veri. Мезофітні та мезогіргофітні луки трапляються набагато рідше. Лише під час прокладання грунтових доріг над ділянками із водонепроникними глинами формується асоціація Juncetum effusi. Навколо кар'єрів величезні площі займають угруповання класу Epilobietea angustifolii.

Оселища, що сформовані фанерофітами, зазвичай перебувають на ранніх стадіях формування. На перелогах віддалених від насаджень корінних лісів формуються угруповання, близькі до асоціації Salicetum capreae класу Robinietea. На схилах кар'єру формування суцільного деревного покриву відбувається за нестандартною схемою. Тут він утворюється раніше, ніж суцільний покрив злаковників. Це відповідає спостереженням Яна Фроза (Frouz Jan) та його колег $[12 ; 15]$. За умов інвазії Robinia pseudoacacia L. формуються угруповання порядку Cheledonio-Robinietalia. Ще однією формою похідних лісів є молоді вербово-тополеві насадження класу Salicetea purpurea. На більш ранніх стадіях утворюються ценози типових верболозів (клас Franguletea). В таких угрупованнях переважають різні представники роду Salix за участю флори класів похідних лісів.

Рудеральні оселища представлені угрупованнями класів Artemisietea vulgaris, Polygono arenastriPoёtea annuae та Plantagenetea majoris. Це переважно пирійники, полинники [16; 17; 18] та угруповання, утворені під дією надмірного витоптування в районі грунтових доріг і стежок. Рудеральні угруповання містять неповноцінні упаковки еконіш, тому вони найбільш вразливі до вторгнення інвазійних видів [19]. Наприклад, в угруповання класу Artemisietea vulgaris часто проникає Solidago canadensis L.

\section{Висновки.}

Рослинність закинутих піщаних кар'єрів Центрального Полісся належить до 12 класів, 20 порядків, 29 союзів, 58 асоціацій. 
Хом'як І.В., Гарбар Д.А., Андрійчук Т.В. ...

Рослинність досліджуваної території перебуває на відносно ранніх стадіях відновлення природної рослинності та належить до двох типів сукцесійних серій: перелогів та виробки.

\section{ДИНАМІКА ВІДНОВАЮВАНОЇ РОСАИННОСТІ...}

Рослинні угруповання часто мають ознаки екотонів та численні незайняті еконіші, що робить ї вразливими до проникнення інвазійних видів-трансформерів.

\section{Література}

1. Хом'як І.В. Особливості антропогенного впливу на природну динаміку екосистем Українського Полісся. Екологічні науки. 2018. № 1. С. 69-73.

2. Вибрані наукові праці академіка В.І. Вернадського: Геохімія живої речовини / редакційна рада НАН України, Коміс. 3 наук. спадщини акад. В.І. Вернадського, Нац. б-ка України ім. В.І. Вернадського, Ін-т зоології ім. І.І. Шмальгаузена, Ін-т геохімії навколиш. середовища. Київ : Наук. думка, 2012. Т. 4. 504 с.

3. Ivan Khomiak, Oleksandr Harbar, Nataliia Demchuk, Iryna Kotsiuba, and Iryna Onyshchuk. Above-graund phytomas dynamics in autogenic succession of an ecosystem. Forestry ideas. 2019. No. 1. P. 136-146.

4. Логинов Б.И., Попа Ю.Н., Козак А.В. Методические рекомендации по лесной рекультивации загазованной поверхности угольных шахт Донбасса. Киев : Изд. УСХА, 1990. 8 с

5. Закон України «Про охорону земель». URL: https://zakon.rada.gov.ua/laws/show/962-15\#Tехt (дата звернення: 12.12.2021).

6. Швіндлерман С.П., Зацепіна Д.Я., Голубнича С.В., Федорова В.В. Стасенко В.А. Фітооптимізація техногенних ландшафтів. Донецьк : Видавництво Донецького держ. ун-ту, 1999. 275 с.

7. Macdonald S. Ellen, Landhäusser Simon M., Skousen Jeff, Franklin Jennifer, Frouz Jan, Hall Sarah, Jacobs Douglass F., Quideau Sylvie. Forest restoration following surface mining disturbance: challenges and solutions. New Forests. 2015. No 5. P. 703-732.

8. Frouz Jan, Mudrák Ondřej, Reitschmiedová Erika, Walmsley Alena, Vachová Pavla, Šimáčková Hana, Albrechtová Jana, Moradi Jabbar, Kučera Jiř́i. Rough wave-like heaped overburden promotes establishment of woody vegetation while leveling promotes grasses during unassisted post mining site development. Journal of Environmental Management. 2018. No. 205. P. 50-58.

9. Bren A., Khomiak I., Khomiak O. Application of a comprehensive analysis of renevable vegetation of sand quarries. Sustainable development of the country in the framework of European integration: Abstracts of the All-Ukrainian scientific-practical conference of applicants for higher education and young scientists. Zhytomyr. 2021. P. 74.

10. Юнатов А.А. Типы и содержание геоботанических исследований. Пробные площади и экологические профили. В кн. Полевая геоботаника, т. 3. Ленинград : Изд-во АН СССР, 1972. С. 7-38.

11. Braun-Blanquet J. Grundzüge der Vegetationskund. In: Pflanzensoziologie. Berlin : Verlag von Julius Springer, 1964. 865 S.

12. Дубина Д.В., Дзюба Т.П., Смельянова С.М., Багрікова Н.О., Борисова О.В., Борсукевич Л.М., Винокуров Д.С., Гапон С.В., Гапон Ю.В., Давидов Д.А., Дворецький Т.В., Дідух Я.П., Жмуд О.І., Козир М.С., Коніщук В.В., Куземко А.А., Пашкевич Н.А., Рифф Л.Е., Соломаха В.А., Фельбаба-Клушина Л.М., Фіцайло Т.В., Чорна Г.А., Чорней I.І., Шеляг-Сосонко Ю.Р., Якушенко Д.М. Продромус рослинності України / за ред. Д.В. Дубина, Т.П. Дзюба. 2019. Київ : Наукова думка, $782 \mathrm{c.}$

13. Хом'як І.В., Василенко О.М., Гарбар Д.А., Андрійчук Т.В., Костюк В.С., Власенко Р.П., Шпаковська Л.В., Демчук Н.С., Гарбар О.В., Онищук І.П., Коцюба І.Ю. Методологічні підходи до створення інтегрованого синфітоіндикаційного показника антропогенної трансформації. Екологічні науки. 2020, № 5 (32). Т. 1 . С. 136-141.

14. Khomiak I., Onishchuk I., Demchuk N. Phytoindicators of ecosystem dynamics in Ring-banc Ukrainian Polissia. ScienceRise: Biological Science. 2018 No. 4. P. 25-30.

15. Kapets N.V., Barsukov O.O., Vynokurov D.S., Khomyak I.V. Pioneer lichen communities of the Teteriv River Basin (Ukraine). Acta Botanica Hungarica 2018. No. 3-4. P. 331-355.

16. Хом'як І.В., Шамоніна М.I. Тератрансформаційний потенціал представників роду осокові (Саrex). Сталий розвиток країни в рамках Європейської інтеграції : тези Всеукраїнської науково-практичної конференції здобувачів вищої освіти $\mathrm{i}$ молодих учених. Житомир. 2021. С. 12.

17. Черняєва О.П., Хом’як I.В. Тератрансформаційний потенціал Elymus repens (L.) GOULD. Сталий розвиток краӥни в рамках Європейської інтеграції : тези Всеукраїнської науково-практичної конференції здобувачів вищої освіти і молодих учених. Житомир. 2021. С. 18.

18. Лещенко Д., Хом’як I.В. Рекультиваційний та тератрансформаційний потенціал Carex hirta L. Сталий розвиток краӥни 8 рамках Європейської інтегращиї : тези Всеукраїнської науково-практичної конференції здобувачів вищої освіти і молодих учених. Житомир. 2021. С. 54.

19. Хом'як І.В. Вплив інвазій видів-трансформерів на динаміку рослинності перелогів Українського Полісся. Біоресурси $i$ природокористування. 2018. № 1-2. С. 29-35. 


\section{ІННОВАЦІЙНІ АСПЕКТИ ПІДВИЩЕННЯ ЕКОАОГІЧНОї БЕЗПЕКИ}

УДК 628.16

DOI https://doi.org/10.32846/2306-9716/2021.eco.6-39.36

\section{РОЗРОБАЕННЯ ТА ЗАПРОВАДЖЕННЯ "ЗЕАЕНИХ" ТЕХНОАОГІЙ РЕВІТАМІЗАЦІї ЗАБРУДНЕНИХ ВОД, ПОВІТРЯ ТА ПОРУШЕНИХ ІРУНТІВ I ЗАПОБІГАННЯ ЇХ ВИСНАЖЕННЮ З ВИКОРИСТАННЯМ ВІДНОВАЮВАМЬНИХ ПРИРОДНИХ РЕСУРСІВ ТА ЕНЕРГІї СОНЦЯ}

Бондар О.І. ${ }^{1}$, Коцар О.М. ${ }^{2}$, Филипчук В.Л. ${ }^{3}$, Курилюк М.С. ${ }^{4}$, Лі Цзюнь ${ }^{5}$

${ }^{1}$ Державна екологічна академія післядипломної освіти та управління вул. Митрополита Василя Липківського, 35, корп. 2, 03035, м. Київ

${ }^{2}$ Товариство з обмеженою відповідальністю «Український науково-дослідний центр «ПОТЕНЦІАЛ-4» вул. Кибальчича, 13А, оф. 7, 02225, м. Київ

${ }^{3}$ Національний університет водного господарства та природокористування вул. Соборна, 11, 33028, м. Рівне

${ }^{4}$ Українська технологічна академія пров. Куренівський, 19/5, оф. 200, 04073, м. Київ БДослідне підприємство «ВОДЕНЬ» вул. Гагаріна, 39, 33003, м. Рівне dei2005@ukr.net; e-kotsar@ukr.net, v.l.fylypchuk@nuwm.edu.ua, atol.rosa@gmail.com, lee_rivne@qq.com

Водні, повітряні та грунтові екосистеми України, а також світу нині зазнають забруднення та виснаження внаслідок антропогенного навантаження, знищення лісів та зміни клімату.

В Україні 29,2\% стічних вод забруднені. Щорічно промисловістю у поверхневі води скидається понад 500 млн м³ забруднених вод без їх очищення. Приміром, річка Прип’ять дає 80\% забруднень головній водній артерії України - річці Дніпро, де зосереджені три чверті водних ресурсів країни. Значно забруднені в Україні повітря і грунти.

Головна причина забруднення водойм недостатньо очищеними зворотними водами - незадовільний стан каналізаційних очисних споруд (КОС) населених пунктів, промислових та сільськогосподарських підприємств, а також використання морально та фізично застарілих технологій, обладнання для очищення стічних вод, відсутність амортизаційних вкладень і безсистемність капітальних ремонтів мереж та споруд водоочищення. Зокрема, використання «старих» полів фільтрації є основними чинниками незадовільного екологічного стану навколишнього середовища, особливо грунтів та грунтових вод, у багатьох регіонах України. Зменшення запасів прісної води як в Україні, так і у світі, зростаюче забруднення поверхневих вод завдяки скиду у водойми недостатньо очищених стічних вод призводить до погіршення стану водних екосистем, а також повітря і грунтів.

Здійснювати скидання стічних (зворотних) вод у водойми, з одного боку, потрібно, бо ж вода повертається у природне середовище, але з іншого - не завжди безпечно для водної, повітряної та грунтової екосистем. Зокрема, водні ресурси ріки Дніпро використовуються надзвичайно нераціонально: понад 50\% чистої водопровідної води використовується для технологічних потреб, хоча близько 90\% їх (технологічних потреб) можна задовольняти за рахунок повторного використання води в системах технічного водопостачання промислових та комунальних підприємств.

Витрати свіжої води у промисловості та в сільському господарстві в загальному їі споживанні становлять в Україні 54\%, у тому числі у промисловості - 46\%; води водопровідної (питної) якості, що використовується в житлово-комунальному господарстві, $-46 \%$.

Нині в Україні вже гостро відчувається дефіцит водних ресурсів, що виник насамперед завдяки зростанню господарської діяльності та нераціональному використанню води. 3 водних джерел води береться більше, ніж повертається в природне середовище. Так, річний стік Дніпра за останні роки зменшився на понад 19\%, що призвело до виникнення проблем у риболовстві, пароплавстві, зникнення окремих видів річної флори та фауни, а також погіршення стану рекреаційних зон (берегової зони відпочинку).

Безповоротне водоспоживання досягає 37\% від усієї взятої в господарство України природної води.

Погіршення екологічного стану грунтів в Україні зумовлене недотриманням нормативів сівозмін, глибокою оранкою, зловживанням мінеральними добривами тощо.

За останні 25 років у грунтах України вміст гумусу зменшився на 25\%, тобто втрати біогумусу сягають вже більше $1 \%$ щороку.

Безповоротне водоспоживання досягає 37\% від усієї забраної води в господарства України.

Питома забезпеченість водними ресурсами в Україні найнижча в СНД і становить усього 1,0 тис. м³/особу на рік. За запасами водних ресурсів (у розрахунку на одиницю площі й одного мешканця) Україна займає одне з останніх місць серед країн Свропи. 
Цей показник тісно пов'язаний із реальними витратами води і свідчить про нераціональне використання водного ресурсу України. У розрахунку на одного мешканця України річні витрати води становлять близько 90 м³. На одного мешканця міста на побутові потреби витрачається близько 289 літрів води на добу. У країнах Європейського Союзу цей показник становить нижче 100 літрів на добу. Ключові слова: «зелена» технологія; водні ресурси; технологія «Ревітал»; «Біоплато»; вищі водні рослини (ВВР), відновлювальні природні ресурси; фільтраційно-регенераційне біоплато гідропонного типу (ФРБГТ); екосистеми, безмембранне опріснення, солонуваті води.

Development and implementation "green" technologies revitalization polluted water, air and soil with violations of renewable natural resources and energy of sun and depletion of prevention. Bondar A., Kotsar E., Fylypchuk V., Kuryliuk M., Li Jun

Aquatic, air and soil ecosystems of Ukraine and the world are subject to pollution and depletion due to anthropogenic pressure, deforestation and climate change.

In Ukraine, $29.2 \%$ of wastewater is discharged contaminated. Every year, the industry discharges more than $500 \mathrm{million}^{3}$ of polluted water into surface water without treatment. In particular, the Pripyat River provides $80 \%$ of pollution to the main waterway of Ukraine - the Dnieper River, where three quarters of the country\&apos;s water resources are concentrated. Air and soils in Ukraine are significantly polluted.

The main cause of water pollution by insufficiently treated return waters is the unsatisfactory state of operation of sewage treatment plants (SSC) of settlements, industrial and agricultural enterprises, as well as the use of obsolete wastewater treatment technologies, lack of depreciation and unsustainable sewerage. . In particular, the use of "old" filtration fields are the main reasons for the unsatisfactory ecological condition of the environment in many regions of Ukraine. Declining freshwater reserves, both in Ukraine and in the world, and increasing pollution of surface waters due to the discharge of insufficiently treated wastewater into water bodies leads to the deterioration of aquatic ecosystems, as well as air and soil.

Discharge of used wastewater (return) into reservoirs on the one hand is necessary because water is returned to nature, but on the other hand, their discharge is not always safe for aquatic, air and soil ecosystems. For example, the water resources of the Dnieper River are used extremely irrationally: more than $50 \%$ of clean tap water is spent on technological needs, although about $90 \%$ of them (technological needs) can be met by reusing water in industrial and municipal water supply systems.

The consumption of fresh purified water in industry in its total consumption is $56 \%$ in Ukraine; water of drinking (drinking) quality is used in housing and communal services $46 \%$, in industry $31 \%$ and in agriculture $23 \%$.

Ukraine is already experiencing an acute shortage of water resources, which arose primarily due to the growth of economic activity and irrational use of water. More water is taken from water sources than is returned. Thus, the annual runoff of the Dnieper decreased by more than $19 \%$, which led to problems in fishing, shipping, as well as the disappearance of certain species of annual flora and fauna, as well as recreational areas (coastal recreation area).

Irreversible water consumption reaches $37 \%$ of all water taken to the economy of Ukraine.

Deterioration of the ecological condition of soils in Ukraine is due to non-compliance with the standards of modification, deep plowing, abuse of mineral fertilizers, etc.

Over the last 25 years, the content of humus in soils in Ukraine has decreased by $25 \%$, ie, the loss of biohumus reaches more than $1 \%$ annually.

Irreversible water consumption reaches $37 \%$ of all abstracted water from Ukrainian farms.

The specific supply of water resources in Ukraine is the lowest in the CIS and is only 1.0 thousand $\mathrm{m}^{3} /$ person per year. Ukraine ranks last among European countries in terms of water resources per unit area and per capita.

This indicator is closely related to real water consumption and indicates the rational or irrational use of water resources in Ukraine. Per capita in Ukraine, the annual water consumption is about $90 \mathrm{~m}^{3}$. Approximately 289 liters per day are spent per capita on household needs. Key words: "green" technology; aquatic resources; Revital technology; Bioplato; higher aquatic plants (VVR), renewable natural resources; filtration-regeneration bioplateau of hydroponic type (FRBGT); ecosystems, membraneless desalination, brackish water.

Постановка проблеми. Актуальним є створення та запровадження інноваційних «зелених» технологій ревіталізації забруднених прісних солонуватих вод, повітря та грунтів, які у разі використання відновлювальних природних ресурсів і енергії сонця забезпечать відновлення нормативної якості води в забруднених водоймах, покращать стан атмосферного повітря та родючість грунтів.

Аналіз останніх досліджень і публікацій. Розглянуті теоретичні засади впровадження технологій ревіталізації забруднених прісних та солонуватих вод, а також повітря та грунтів за класифікацією Л.А. Кульського [1], які можна умовно розділити на чотири групи за ступенем дисперсності (рис. 1).

Аналіз існуючого стану. Стічні води населених пунктів у своєму складі мають широкий спектр органічних та неорганічних домішок різного фазово-дисперсного та хімічного складу. Відповідно до класифікації домішок академіка Л.А. Кульського забруднення можуть мати розмір від іонів та молекул до грубодисперсних частинок, тобто мають виражений багатокомпонентний стан.

Так, мінеральні та органічні домішки I групи мають розміри $10^{-2}-10^{-4}$ см (завислі речовини, планктон, суспензії, емульсії, бактеріальні завислі речовини, гідробіонти активного мулу та інші біологічні утворення). Вилучення цих домішок, тобто відділення їх від забрудненої води, може бути досягнуто шляхом використання фізичних процесів, які базуються на різній питомій вазі води та домішок цієї групи дисперсності.

До II групи домішок води належать органічні та мінеральні речовини, які мають розміри $10^{-7}-10^{-8} \mathrm{M}-$ це різні типи гідрофільних і гідрофобних колоїдних систем, високомолекулярні речовини й детергенти, віруси. Їх вилучення може забезпечуватися фазово-дисперсним переходом із другої в першу групу застосуванням коагулянтів, 
флокулянтів та інших прийомів, внаслідок чого руйнуються колоїдні системи і створюються сприятливі умови для наступного розподілу фаз.

До III групи домішок води належать молекулярно розчинені речовини, які мають розміри $10^{-8}-10^{-9}$ м. Це, зокрема, молекулярні органічні розчини, гази, органічні електроліти; найбільш ефективним для їх вилучення з води є окиснення, у тому числі біоокислення, адсорбція.

До IV групи домішок належать дисоційовані на іони мінеральні та органічні речовини, гази, електроліти, які мають розміри $10^{-9}-10^{-10} \mathrm{M}, \mathrm{i}$ технологія очищення води від них базується на здійсненні фазоводисперсних переходів із використанням хімічних процесів утворення осадів, введенням реагентів, відділенням іонів від води на мембранах тощо.

Мета роботи - обгрунтування технології очищення багатокомпонентних стічних прісних та солонуватих вод населених пунктів, яка забезпечить високу якість очищеної води за низьких затрат на глибоке очищення води, мінімальної кількості утворення вторинних продуктів, а також визначення сфери застосування «зеленої» технології «Ревітал» яка базується на таких основних принципах:

- Забруднені води є гетерогенними системами, в яких одночасно присутні домішки всіх груп дисперсності, тому головним принципом технології
«Ревітал» $є$ забезпечення умов фазово-дисперсних переходів шляхом максимального використання фізичних процесів кавітації для розподілу фаз.

- Пріоритетом у технології «Ревітал» для руйнування колоїдних систем $€$ використання фізикохімічних процесів, які не потребують застосування коагулянтів та органічних флокулянтів, зокрема, із сольовими «хвостами» хлоридів, сульфатів та фосфатів.

- Для коригування $\mathrm{pH}$, окислювально-відновлювальної потужності $\mathrm{rH}$ та окисно-відновного потенціалу (ОВП-Еh) зворотних та забруднених поверхневих вод технології «Ревітал» використовуються фізико-хімічні процеси, які не потребують застосування хімічних реагентів та складних у використанні (обслуговуванні) мембранних технологій типу гіперфільтрації (RO) та ультрафільтрації (УФ).

- Для біодеструкції та біоокислення розчинених молекулярних та дисоційованих на іони органічних домішок, звільнення від іонів неорганічних солей у технології «Ревітал» використовують факультативні мікроорганізми, зокрема ті, які містяться у біопрепараті типу «БіоСан» або в аналогах, за значно менших енерговитрат на забезпечення їх життєдіяльності, ніж під час використання аеробних мікроорганізмів.

- Для забезпечення нормативних санітарногігієнічних показників технічної води, отриманої

Кааснфікація забруднювяльних речовнн у прнроднкх $\mathbf{i}$ стічних водах

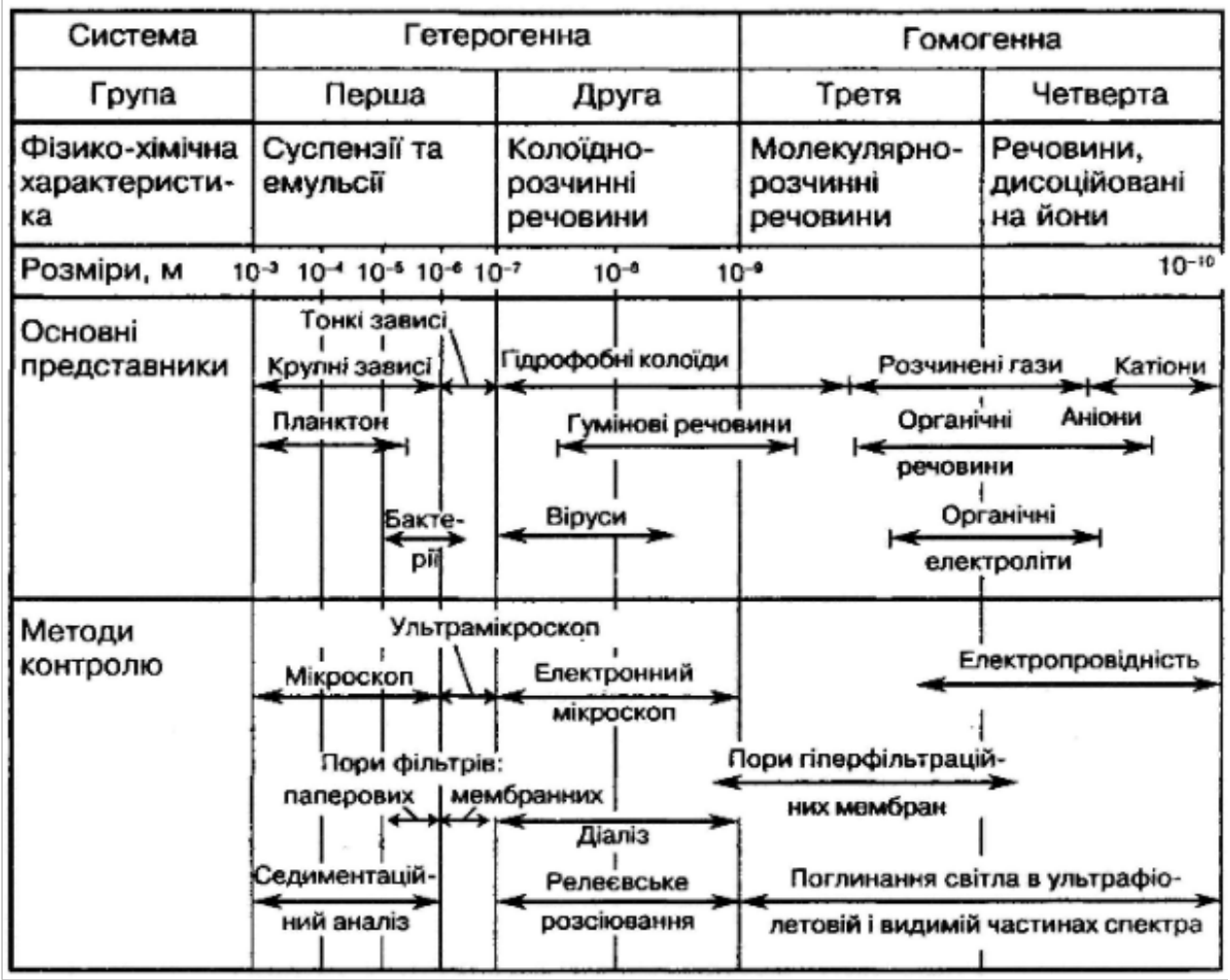

Рис. 1. Класифікачія забруднюючих речовин у природних і стічних водах відповідно до їх фазово-дисперсного стану за класифікаџією Л.А. Кульського 
Бондар О.І., Коцар О.М., Филипчук В.Л. ...

шляхом обробки стічних вод по технології «Ревітал», використовують «зелені» реагенти на основі перекису водню, стабілізованого надоцтовою кислотою, зокрема типу «Дезосепт Форте», продукти розкладу якого безпечні для рослин, тварин, мікрофлори грунтів та гідробіонтів водних екосистем і без утворення парникових газів.

- Для доокислення органічних багатокомпонентних домішок ПАР і СПАР та знезараження води за технологією «Ревітал» використовується реагент Фентона, який сприяє додатковому видаленню зі стічних вод поліфосфатів і комплексному знезараженню води, продукти розкладу якого також екологічно безпечні для рослин, тварин, мікрофлори грунтів та гідробіонтів водних екосистем і навколишнього атмосферного повітря.

- Для оптимізації процесів механічного зневоднення осадів, які утворюються у процесах обробки забруднених вод за технологією «Ревітал», використовується флокулянт із дезінфікуючим (біоцидним) ефектом, наприклад типу ПГМГ-ГХ (полігексаметиленгуанідін гідрохлорид), який біологічно розкладається, що дозволяє отримувати біосубстрат, який не містить патогенних і умовно патогенних мікроорганізмів та життєздатних яєць гельмінтів, придатний для покращення удобрювальних та структурно-механічних властивостей грунтів під час вирощування декоративних, вищих водних енергетичних рослин (ВВР) та інших технічних культур.

- Для вилучення іонів мінеральних солей використовують синергетичний очисний комплекс типу «Біоплато», або «ФРБГТ» (фільтраційно-регенераційне біоплато гідропонного типу) з інертним субстратом, на якому прикріплюється біоценоз мікроорганізмів, із висадженими вищими водними енергетичними рослинами (очеретом, міскантусом тощо), які цілорічно внутрішньогрунтово зрошуються попередньо підготовленою за технологією «Ревітал» стічною та освітленою циркуляційною водою біоплато.

- Наземна надлишкова біомаса вищих водних енергетичних рослин (очерету, рогозу, міскантусу, ейхорнії, пістії, папірусу, верби енергетичної тощо) використовується у технології «Ревітал» після щорічного (сезонного) іiі видалення, наприклад, осіння як корисний вторинний ресурс (як трав'яне борошно або біопаливо - відновлюване джерело енергії в котлах та на БіоTЕС, а також як сировина в промисловості під час виробництва бетонних блоків, целюлози тощо) та для отримання біосубстрату під час компостування разом із механічно або гравітаційно зневодненим осадом каналізаційних очисних споруд (КОС).

- Вищі водні рослини (ВВР), що є відновлювальними природними ресурсами для очищення води та складовим елементом «зеленої» технології «Ревітал», збагачують воду й атмосферу киснем (водяною парою - транспірація через ВВР), поглинають вуглекислий (парниковий) газ, пил і смог,
РОЗРОБАЕННЯ ТА ЗАПРОВАДЖЕННЯ «ЗЕ ЕНИХ»...

покращуючи екологічний стан атмосферного повітря, та створюють естетичний зелений ландшафт в основі очисних споруд стоків .

- «Зелена» технологія «Ревітал» орієнтована на вивільнення робочої сили (операторів очисних споруд) низького рівня та покращення шкідливого середовища на станціях очищення стічних вод із використанням відновлювальних природних ресурсів.

\section{Викладення результатів досліджень.}

Забруднення, що знаходяться в багатокомпонентних стічних водах, можна віднести до гетерогенної або гомогенної системи, кожна 3 яких зумовлює вибір процесів для їх вилучення. Тому всі процеси очищення таких стічних вод можна поділити на дві головні групи: процеси перетворення домішок та розподілу домішок і води, кожну з яких доцільно поділити на дві підгрупи. Перша група включає підгрупи процесів для зміни фазово-дисперсного стану домішок і для знешкодження домішок; друга підгрупа - процеси для розподілу фаз концентрування домішок. Впровадження комплексу процесів та методів, розроблених за базою об'єднаних принципів у технології «Ревітал» на основі класифікації Л.А. Кульського, дозволяють розв'язати проблему ресурсозбереження та охорони довкілля від забруднення стічними водами, використовуючи їх повторно, з отриманням біосубстрату для поліпшення стану грунтів, отриманням вторинної сировини для промисловості, зменшуючи капітальні та експлуатаційні витрати на охорону довкілля від забруднення та виснаження, вивільнення робочої сили (операторів очисних споруд) низького рівня під час експлуатації водоочисних комплексів, запобігання негативному суб'єктивному впливу непідготовленого персоналу на роботу очисних споруд.

Вибір технології очищення багатокомпонентної стічної води може починатись із застосуванням будь-якої підгрупи процесів, але обов'язковим $\epsilon$ перехід від нижчої до більш вищої підгрупи процесів (рис. 1). У загальному вигляді вибір процесів для очищення стічної води від забруднюючих компонентів однієї групи має починатися з використання процесів для концентрування домішок води, особливо у тому разі, якщо такі домішки можуть бути повторно використані у основному виробництві або утилізовані. Після цього проводиться перехід до процесів знешкодження і далі до переводу домішок у інший фазово-дисперсний стан та розподілу фаз. У разі необхідності можна починати із процесів знешкодження або після концентрування можливо зразу перейти до процесів розподілу фаз. При цьому потрібно відзначити, що здебільшого для процесів розподілу фаз обов'язковими є попередні процеси для зміни фазово-дисперсного стану домішок, а для процесів знешкодження та зміни фазово-дисперсного стану домішок води обов“язковими можуть бути попередні процеси для концентрування домішок води. 


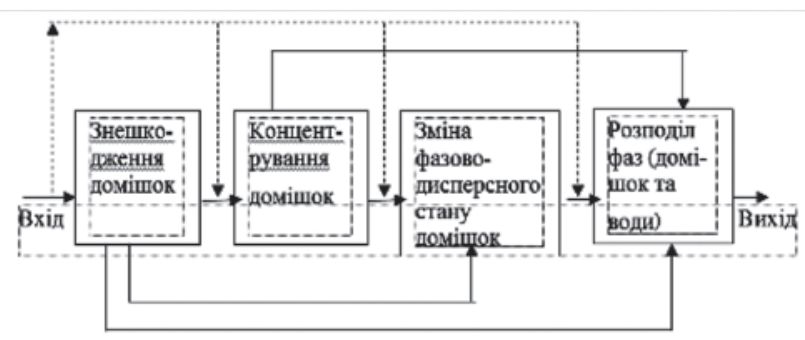

Рис. 1. Послідовність вибору прочесів для очищення багатокомпонентних прісних і солонуватих природних і стічних вод

Узагальнена схема ревіталізації зворотних прісних та солонуватих вод за «зеленою» технологією «Ревітал» наведена на рис. 2.

На технологію «Ревітал» (заявник ФОП Коцар О.М.) видано позитивний санітарно-гігієнічний висновок Міністерства охорони здоров'я України.

«Зелену» технологію «Ревітал» апробовано в лабораторних умовах та запроваджено на багатьох об'єктах України, зокрема на КО населених пунктів у Київській, Львівській, Сумській областях, на молокозаводах, м'ясопереробних підприємствах, заводах iз виробництва солоду, фармацевтичних та комунальних підприємствах тощо.

Усереднений склад міських стічних вод, очищених за технологією «Ревітал» зворотних вод та вимоги для якості зворотних вод під час скиду у водойми та використання на технічні потреби наведені в таблиці.

\section{Висновки}

Розроблення та впровадження технологій ревіталізації забруднених вод, повітря та порушених грунтів сприяє поліпшенню стану водних, повітряних та грунтових екосистем із використанням відновлювальних природних ресурсів та енергії сонця.

Технологія «Ревітал» орієнтована на вивільнення робочої сили низького рівня (вивільнення операторів очисних споруд стічних вод) та на покращення шкідливого середовища на станціях очищення стічних вод із використанням відновлювальних природних ресурсів, самопромивних гідроавтоматизованих фільтраційно-регенераційних біоплато гідропонного типу (ФРБГТ) та самопромивних блочно-модульних установок (гідророботів, прояснювачів, фільтрів).

Технологія «Ревітал» може бути адаптована до будь-яких кліматичних умов, для водоочисних станцій різної (заданої) продуктивності у багатьох регіонах світу, а також функціонувати тривалий термін в автономному «безлюдному» режимі.

Синергетичне використання технології «Ревітал» у комплексі із гідроавтоматизованими фільтраційнорегенераційними біоплато гідропонного типу (ФРБГТ) та самопромивними гідророботами, прояснювачами, фільтрами може використовуватися на станціях безмембранного опріснення та глибокого очищення солонуватих вод.

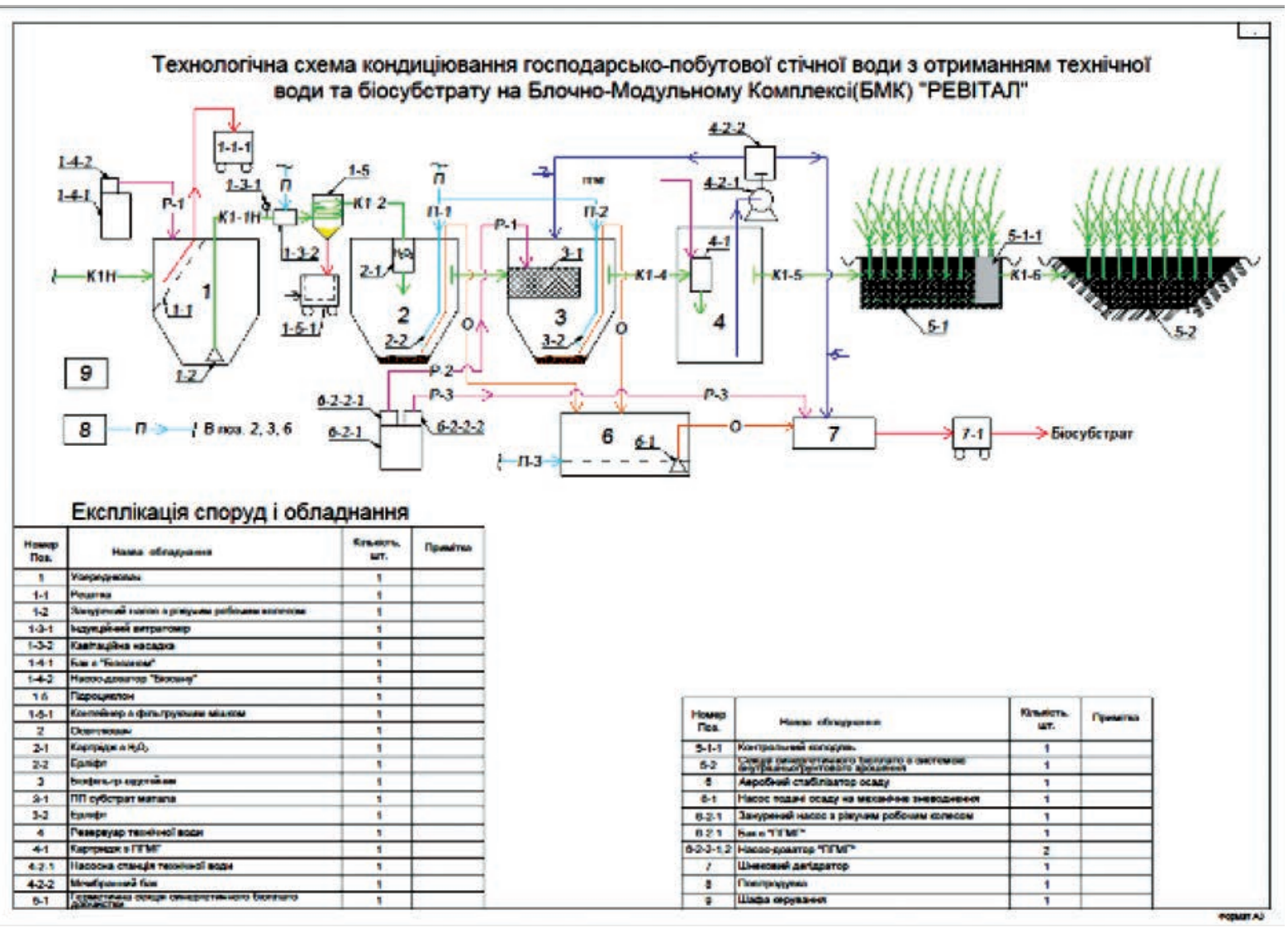

Рис. 2. Узагальнена схема ревіталізаџії зворотних прісних та солонуватих вод за «зеленою» технологісю «Ревітал» 
Усереднений склад міських стічних вод, очищених за «зеленою» технологією «Ревітал» зворотних вод та вимоги для якості зворотних вод під час скиду у водойми (господарсько-питного та рекреаційного призначення) та використання на технічні потреби (під час зрошення та поливу)

\begin{tabular}{|c|c|c|c|c|c|}
\hline \multirow[b]{2}{*}{ № } & \multirow[b]{2}{*}{ Показник } & \multicolumn{4}{|c|}{ Значення показників якості } \\
\hline & & $\begin{array}{c}\text { у стічній } \\
\text { воді на вході } \\
\text { в КОС }\end{array}$ & $\begin{array}{c}\text { у ревіта-лізованій } \\
\text { зворотній воді за } \\
\text { технологісю «Ревітал» } \\
\text { (зворотна вода після } \\
\text { біоплато-КОС) }\end{array}$ & $\begin{array}{c}\text { нормативні у } \\
\text { зворотних водах } \\
\text { (під час викорис- } \\
\text { тання для технічних } \\
\text { потреб КОС та під } \\
\text { час зрошення }\end{array}$ & $\begin{array}{c}\text { нормативні у } \\
\text { зворотних водах під } \\
\text { час їх водовідведення } \\
\text { у водойми госп.- } \\
\text { питного та } \\
\text { рекреаційного } \\
\text { призначення }\end{array}$ \\
\hline 1 & $\mathrm{pH}$, од. & $6,5-9,0$ & $6,5-8,5$ & $6,5-8,5$ & $6,5-8,5$ \\
\hline 2 & Завислі речо-вини, мг/дм ${ }^{3}$ & 300,0 & 8,0 & 15,0 & 15,0 \\
\hline 3. & Сухий залишок, мг/дм³ & 1300,0 & 850,0 & 1000,0 & 1000,0 \\
\hline 4 & Сульфати, мг/дм³ & 480,0 & 400,0 & 450,0 & 450,0 \\
\hline 5 & Хлориди, мг/дм ${ }^{3}$ & 380 & 280,0 & 350,0 & 350,0 \\
\hline 6 & БСК $_{5}$, мГ $\mathrm{O}_{2} /$ дм $^{3}$ & 300,0 & 12,0 & 15,0 & 15,0 \\
\hline 7 & $\mathrm{XCK,} \mathrm{мг} \mathrm{O}_{2} /$ дм $^{3}$ & 350,0 & 49,0 & 80,0 & 80,0 \\
\hline 8 & Азот амонійний, мг/дм ${ }^{3}$ & 20,0 & 1,3 & 2,0 & 2,0 \\
\hline 9 & СПАР, мг/дм ${ }^{3}$ & 7,0 & 0,4 & 0,5 & 0,5 \\
\hline 10 & Нітрити, мг/дм ${ }^{3}$ & 0,3 & 2,1 & 3,3 & 3,3 \\
\hline 11 & Нітрати, мг/дм ${ }^{3}$ & 5,0 & 45,0 & 45,0 & 45,0 \\
\hline 12 & Фосфати, мг/дм ${ }^{3}$ & 8,0 & 2,5 & 3,5 & 3,5 \\
\hline 13 & Залізо загальне, мг/дм³ & 2,5 & 0,1 & 0,3 & 0,3 \\
\hline 14 & Жири, мг/дм ${ }^{3}$ & 20,0 & відс. & відс. & відс. \\
\hline 15 & Нафтопродукти, мг/дм³ & 5,0 & 0,1 & 0,3 & 0,3 \\
\hline 16 & $\begin{array}{c}\text { Індекс лактозопозитивних } \\
\text { паличок }\end{array}$ & Не визн. & Не більше 5000 & Не більше 5000 & Не більше 5000 \\
\hline 17 & $\begin{array}{l}\text { Життєздатні яйця } \\
\text { гельмінтів }\end{array}$ & Не визн. & відсутні & відсутні & відсутні \\
\hline
\end{tabular}

\section{Література}

1. Коцар О.М. Запровадження енергоефективних екобезпечних технологій очищення забруднених вод / О.М. Коцар, Г.О. Діренко. Праці Ін-ту електродинаміки НАН України. Спец. випуск. 2004. С. 114-118.

2. Коцарь Е.М. Свойства высших водных растений с позиций их использования для очистки загрязненных вод в инженерно-биологических сооружениях V Міжнародна науково-практична конференція «Екологічна безпека: проблеми і шляхи вирішення», 7-11 вересня, 2009 р., Алушта : Зб. наук. ст. у 2-х т. Т. 2 /УкрНДІЕП. Х.: Райдер, 2009. С. 312-315.

3. Коцарь Е.М. Использование высшихводныхрастений в практике очистки сточных вод и поверхностногостока Сантехніка, опалення, кондиціювання. 2006. № 4 (28). С. 12-15.

4. Коцар О.М. Використання вищих водяних рослин для кондиціювання зворотних вод в закритому біоплато гідропонного типу Наук. зап. Терноп. держ.пед. ун-ту. Сер. Біологі. 2001. 4(15). С. 133-134.

5. Олена Коцар. Екомодернізація підприємств. Журнал «ЕCOBUSINESS. Екологія підприємства» № 2, 2019 р.

6. Коцар О.М. «Зелена модернізація виробництва як важлива складова сталого розвитку України» / Матеріали науково-практичної конференції «Меліорації та водовикористання з нагоди 130-річчя першого водопроводу міста Мелітополя» 2019 p. 52 c.

7. Bondar A., Fylypchuk V., Kuryliuk N., Ayaya Aniyefiok. «DEEP PURIFICATION OF WATER IN FILTRATION-REGENERATION BIOPLATO OF HYDROPONIC TYPE». UDC 504.4:528.71:628.35 Kyiv, 2017. State Ecological Academy of Postgraduate Education and Management 35, Metropolitan Vasyl Lipkivsky Str., 03035, Kyiv, National university of water and environmental engineering 11, Soborna st., 33000, Rivne. Науково-практичний журнал «Екологія водних ресурсів» Екологічні науки № 16-17. C. $39-45$. 


\title{
ОСВIТА ДАЯ СТАИОГО РОЗВИТКУ
}

\author{
УДК 378:504.03 \\ DOI https://doi.org/10.32846/2306-9716/2021.eco.6-39.37
}

\section{ОСОБАИВОСТІ ФОРМУВАННЯ У СТУДЕНТСЫКОї МОАОДІ ЗНАНЬ ПРО ЗМІНИ КАIМАТУ}

\author{
Дух О.І., Цицюра Н.І., Галаган О.К. \\ Кременецька обласна гуманітарно-педагогічна академія імені Тараса Шевченка \\ вул. Ліцейна, 1, 47003, м. Кременець, Тернопільська область \\ olja_dykh@ukr.net
}

Розкрито особливості формування у студентської молоді знань про зміни клімату. Проаналізовано досвід зарубіжних та вітчизняних учених із питань формування кліматичної грамотності.

Висвітлено особливості інтеграції кліматичних знань в освітній простір закладу вищої освіти через діяльність еколого-просвітницького центру «ЕКОХАБ КREMENETS» та окреслено основні напрями його діяльності: проведення відкритих лекцій «Філософія «Zero Waste», або Крок до зменшення відходів», «Zero Waste у навчальних закладах» для студентів, школярів та вчителів регіону; організація виставки сучасних екологічних видань та дружніх до навколишнього середовища екотоварів (eco-friendly), альтернативних одноразовим речам; проведення майстер-класів із сортування побутових відходів, вечорів екологічних ігор із студентською молоддю.

Представлено досвід роботи та визначено шляхи формування знань про зміни клімату, такі як: організація еколого-просвітницьких центрів; впровадження в інформаційний простір закладу вищої освіти концепції «Zero Waste»; інтеграція питань зміни клімату у зміст компонент освітніх програм; співпраця екоорганізацій та закладів освіти; синергія між навчанням і дослідженнями зміни клімату; введення у зміст освітніх програм вибіркових освітніх компонентів «Екологічний стиль життя», «Освіта для сталого розвитку», «Екологічна грамотність», «Сталий розвиток».

Розкрито освітній потенціал та методику використання настільних екологічних ігор «Зелене місто майбутнього», «Мережа життя», «Екополія», «Кеep Cool», «ЕкоМемо», «Водний слід», «Екобатл» як спосіб привернення уваги молоді до проблеми кліматичних змін та особливостей сталого розвитку, формування вміння співпрацювати в команді та розробляти узгоджені стратегії боротьби зі зміною клімату.

Вважаємо, що поширення успішного досвіду закладів освіти у формуванні стійкого екологічного світогляду та кліматичної грамотності майбутніх фахівців дасть змогу освітній галузі ефективно реалізовувати цілі сталого розвитку. Ключові слова: зміна клімату, освіта з питань зміни клімату, кліматична грамотність, еколого-просвітницький центр, «Zero Waste», студентська молодь.

Peculiarities of forming the student youth's knowledge about climate change. Dukh O., Tsytsyura N., Galagan $O$.

Peculiarities of forming knowledge about climate changes in student youth's have been revealed. The foreign and domestic scientists' experience on forming climate literacy has been analyzed.

The peculiarities of integration of climatic knowledge into the educational space of a higher education institution through the activities of the ecological and educational center 'ECOHUB KREMENETS' have been highlighted and the main directions of its activities have been outlined: conducting open lectures 'Philosophy of 'Zero Waste', or The step to reduce waste', 'Zero Waste' in educational institutions' for students, schoolchildren and teachers of the region; organization of an exhibition of modern ecological publications and environmentally friendly (eco-friendly) products, alternatives to disposable items; conducting of master classes on sorting household waste, parties of ecological games with student youth.

The experience of work has been presented and the ways of forming knowledge about climate changes have been determined: organization of ecological-educational centers; introduction of 'Zero Waste' concept into the information space of a higher education institution; integration of climate change issues into the content of educational programme components; cooperation of environmental organizations and educational institutions; synergies between learning and researching of climate change; introduction of selective educational components 'Environmental lifestyle', 'Education for constant development', 'Environmental literacy', 'Constant development' into the content of educational programs.

The educational potential and methods of using board ecological games 'Green City of the Future', 'Life Network', 'Ecopolis', 'Keep Cool', 'EcoMemo', 'Water Trail', 'Ecobattle' as a way drawing youngsters' attention to the problem of climate changes and the peculiarities of constant development, forming the ability to work in a team and develop coordinated strategies to combat climate change have been revealed.

We believe that dissemination of educational institutions' successful experience in forming the future professionals' constant environmental worldview and climate literacy will allow the education sector to effectively implement the goals of constant development. Key words: climate change, climate change education, climate literacy, environmental education center, 'Zero Waste', student youth.

Постановка проблеми. Глобальні зміни клімату на міжнародному рівні названо найбільшою загрозою для природи і людства [1]. Оскільки освіта загалом є одним з основних засобів формування знань, умінь та навичок, то освіту з питань зміни клімату визнано ключовою частиною міжнародної реакції на глобальні кліматичні зміни [2]. У 2010 році створено програму «Освіта з питань зміни клімату 


\section{Дух О.І., Цицюра Н.I., Галаган О.К.}

для сталого розвитку» (ЮНЕСКО), яка спрямована на використання інноваційних підходів до викладання і навчання, підвищення кліматичної грамотності суспільства та мотивування молоді змінити власну поведінку. Згідно з доповіддю, опублікованою ЮНЕСКО, освіта не готує молодь достатньою мірою до адаптації, вжиття заходів і реагування на зміни клімату та екологічні кризи. У межах дослідження «Навчайтеся заради нашої планети» проаналізовані навчальні плани і програми майже у 50 країнах у всіх регіонах. Більше половини з них не згадують про зміну клімату, і тільки в $19 \%$ йдеться про біорозмаїття [3; 4]. Крім цього, такі національні цілі сталого розвитку, як «якісна освіта» та «пом'якшення наслідків зміни клімату», не містять завдань та індикаторів, які стосуються освіти з питань зміни клімату [5]. Тому необхідність формування кліматичної грамотності у молодого покоління постала як виклик перед освітньою системою та громадськими об'єднаннями України.

Аналіз останніх досліджень i публікацій. Державною програмою США $з$ дослідження глобальних змін (USGCRP) визначено кліматично грамотну людину, яка «розуміє основні принципи кліматичної системи Землі, вміє оцінювати науково достовірну інформацію про клімат, змістовно розповідає про його зміни і приймає виважені та відповідальні рішення щодо дій, які можуть вплинути на клімат» [6]. Тенденції міжнародних досліджень учених щодо впровадження кліматичної освіти спрямовані на вивчення освітніх стратегій та підходів до підвищення кліматичної грамотності [7]; спілкування та навчання кліматичної грамотності [8]; підвищення кваліфікації вчителів із кліматичної грамотності та освіти $[9,10]$; освітні заходи щодо зменшення наслідків глобального потепління та зміни клімату $[11,12]$. Впровадження знань про зміну клімату в закордонних університетах в основному здійснюється через навчання та дослідження паралельно з висвітленням питань зміни клімату у програмі бакалаврів, магістрів, докторантів. Розгляд цієї теми відбувається шляхом проведення навчальних та дослідницьких заходів, семінарів та конференцій, за допомогою громадських ініціатив тощо [13]. Погляди вітчизняних науковців і громадськості вказують на те, що формальна освіта в Україні не відповідає на сучасні кліматичні виклики та не спроможна сформувати знання і вміння в молоді для вирішення проблем зміни клімату [14].

Виділення не вирішених раніше частин загальної проблеми, котрим присвячусться означена стаття. У статті висвітлено інформацію щодо можливостей освітніх закладів формувати у студентської молоді знання про зміни клімату. Пріоритетні завдання покладаються саме на освітню галузь, оскільки вона визнана ключовою частиною міжнародної реакції на глобальні зміни та є одним із найпотужніших і перевірених засобів формування світогляду молоді.

\section{ОСОБАИВОСТІ ФОРМУВАННЯ...}

Новизна. Висвітлено особливості інтеграції кліматичних знань в освітній простір закладу вищої освіти через діяльність еколого-просвітницького центру «ЕКОХАБ KREMENETS» та представлено основні напрями його роботи. Розкрито освітній потенціал настільних екологічних ігор «Зелене місто майбутнього», «Мережа життя», «Екополія», «Кеep Cool», «ЕкоМемо», «Водний слід», «Екобатл».

Методологічне або загальнонаукове значення. Поширення успішного досвіду закладів освіти у формуванні стійкого екологічного світогляду та кліматичної грамотності майбутніх фахівців дасть змогу освітній галузі ефективно реалізовувати цілі сталого розвитку.

Виклад основного матеріалу. Освіту в інтересах сталого розвитку (ОСР) на законодавчому рівні визначено одним з основних інструментів державної екологічної політики в Україні, що дасть змогу встановити методологічні основи та запровадити безперервну екологічну освіту [15]. Вивчення такого аспекту, як «зміна клімату», передбачене в освітніх характеристиках програм ОСР [16]. Однак освіта 3 питань зміни клімату не представлена належним чином ні в офіційних документах про вищу освіту, ні у національних цілях Порядку денного у сфері сталого розвитку до 2030 року [14].

Вивчення вітчизняних науково-педагогічних праць і досліджень, у яких розглядаються системи освіти зарубіжних країн, показало, що проблема екологізації освітнього простору в умовах сталого розвитку на тлі сучасних глобалізаційних процесів не набула ознак завершеного й ретельного розгляду: не узагальнено теоретичні засади екологізації освітнього процесу вищої школи; не відображено процес практичної підготовки майбутнього вчителя до реалізації функцій освіти для сталого розвитку в умовах реформування Нової української школи; не виокремлено для українського освітнього контексту елементів позитивного вітчизняного та зарубіжного досвіду підготовки вчителя в умовах сталого розвитку.

3 огляду на важливість формування екологічної свідомості вчителів Нової української школи та необхідність екологізації освітнього простору, у Кременецькій обласній гуманітарно-педагогічній академії ім. Тараса Шевченка був створений Регіональний еколого-просвітницький центр «ЕКОХАБ КREMENETS». Діяльність центру спрямована на впровадження концепції «Zero Waste» («нуль марнування») в освітній простір закладу вищої освіти, переосмислення світогляду та повсякденної поведінки молоді, формування усвідомлення, що захист клімату є найважливішим завданням кожної людини.

Регіональний еколого-просвітницький центр реалізує свою діяльність шляхом:

- проведення відкритих лекцій «Філософія «Zero Waste», або Крок до зменшення відходів», «Zero Waste у навчальних закладах» для студентів, школярів та вчителів регіону; 
- організації виставки сучасних екологічних видань та дружніх до навколишнього середовища екотоварів (eco-friendly), альтернативих одноразовим речам;

- проведення майстер-класів із сортування побутових відходів;

- проведення вечорів екологічних ігор із студентською молоддю.

Важливою складовою частиною, яку варто врахувати під час формування кліматичної грамотності у студентської молоді, $€$ наскрізний акцент на зміні клімату в освітніх компонентах освітніх програм; включення у навчальні програми питань сталого розвитку, пов'язаних зі зміною клімату, синергія між навчанням і дослідженнями зміни клімату [13]. Учасниками еколого-просвітницького центру «ЕКОХАБ КREMENETS» КОГПА ім. Тараса Шевченка запропоновано та розроблено вибіркові освітні компоненти «Екологічний стиль життя», «Освіта для сталого розвитку», «Екологічна грамотність», «Сталий розвиток», метою яких є формування у здобувачів вищої освіти високого рівня екологічної свідомості. Ці курси дають змогу зрозуміти особистий вплив на клімат планети в локальному і глобальному масштабі, формують практичні екологічні навички та спонукають молодь організувати безпечну для довкілля майбутню професійну діяльність.

Нині одним із найпотужніших чинників підвищення рівня кліматичної грамотності української молоді та протидії глобальним кліматичним змінам є громадські екологічні організації. Такі об'єднання, як «Кременецька екологічна ліга», «Українська кліматична мережа», «Зелена хвиля», «Екодія», «Колегія екологічної освіти «Світ Освіт», організовують форуми, серії тренінгів, навчальних проєктів із метою підвищення рівня обізнаності молоді щодо зміни клімату.

Для успішного впровадження питань екологічної освіти та кліматичних знань важливо зосередитися на особисто значущій та актуальній інформації з використанням активних методів навчання [7]. Одним із таких методів $\epsilon$ ігрові технологї̈ навчання. Використання екологічних ігор ми розглядаємо як компонент неформальної освіти 3 питань сталого розвитку, як ненав'язливий спосіб донесення інформації про зміну клімату, що дає змогу зрозуміти суть проблеми грунтовніше та приймати екологічно правильні, безпечні для довкілля рішення (таблиця 1). В учасників гри формується розуміння сучасних

Освітній потенціал настільних екологічних ігор

Таблиця 1

\begin{tabular}{|c|c|}
\hline Назва гри & Зміст гри та основні освітні цілі \\
\hline $\begin{array}{c}\text { Зелене місто } \\
\text { майбутнього }{ }^{1}\end{array}$ & $\begin{array}{c}\text { Гравці отримують знання про те, як їхні повсякденні дії у зонах «Житлова», «Транспорт», «Відпочинок», } \\
\text { «Школа», «Покупки» можуть стати підсилюючим чи пом’якшуючим чинником зміни клімату. Учасники } \\
\text { гри обговорюють важливі екологічні проблеми, з якими вони стикаються у повсякденному житті, вчаться } \\
\text { вести дискусії, відстоювати свою позицію та приймати обгрунтовані рішення. }\end{array}$ \\
\hline Мережа життя ${ }^{1}$ & $\begin{array}{c}\text { Під час гри учасники вивчають основні поняття у сфері біорізноманіття, будують харчові мережі, } \\
\text { створюють стабільну екосистему, знайомляться із подіями, які спричинені людською діяльністю, } \\
\text { зокрема зі змінами клімату. У гравців формуються знання про основні загрози біорізноманіттю та } \\
\text { вміння пояснити причинно-наслідкові взаємозв’язки у природі. }\end{array}$ \\
\hline Екополія ${ }^{2}$ & $\begin{array}{c}\text { Під час гри учасники працюють над знищенням «Великої тихоокеанської сміттєвої плями» та } \\
\text { створенням сміттєпереробного заводу. Кожен гравець має змогу розробляти свої стратегії будівництва } \\
\text { екологічних міст. В учасників формуються знання про рециклювання та утилізацію відходів. }\end{array}$ \\
\hline Keep Cool ${ }^{1}$ & $\begin{array}{c}\text { Учасники під час гри представляють конкуруючі групи країн, які мають завдання реалізувати власні } \\
\text { політичні та економічні цілі, при цьому втримуючи баланс безпечного рівня парникових газів. Гра є } \\
\text { практичною демонстрацією труднощів міжнародних відносин у вирішенні глобальної проблеми зміни } \\
\text { клімату, вона стимулює учасників на активну дискусію, формує вміння співпрацювати в команді та } \\
\text { спільно розробляти узгоджені стратегії зменшення ризиків стихійних лих. }\end{array}$ \\
\hline ЕкоМемо ${ }^{3}$ & $\begin{array}{c}\text { В учасників гри формується здатність передбачити та оцінити довгостроковий вплив особистих } \\
\text { рішень та дій на розвиток «сміттєвих стихійних лих» регіону. Гравці дізнаються про те, що } \\
\text { відбувається з відходами після сортування, роблять спроби розробити стратегії зменшення } \\
\text { індивідуального «сміттєвого сліду». }\end{array}$ \\
\hline Водний слід ${ }^{1}$ & $\begin{array}{c}\text { Під час гри в учасників формується розуміння особистого впливу на клімат планети. Учасники } \\
\text { дізнаються, скільки води затрачається на виготовлення різних продуктів харчування, спільно } \\
\text { обговорюють переваги певних страв і сезонних місцевих продуктів, усвідомлюють необхідність } \\
\text { бережливого ставлення до водних ресурсів. }\end{array}$ \\
\hline Екобатл ${ }^{1}$ & $\begin{array}{c}\text { Під час гри учасники отримують знання про раціональне використання природних ресурсів. Гравці } \\
\text { виступають в ролі «марнотратця», «сумлінного громадянина», «громадського активіста», «блогера» } \\
\text { або «інспектора», виконуючи при цьому важливу місію. Під час гри відбувається обговорення } \\
\text { прикладів марнування енергії та ресурсів і способів їх збереження. }\end{array}$ \\
\hline
\end{tabular}

Промоутери навчальних екологічних ігор:

${ }^{1}$ ГО Український Екологічний клуб «Зелена хвиля».

${ }^{2}$ Світлана Розсохач, фіналістка «Zero Waste Academy 2020-2021».

${ }^{3}$ Наталія Стегній, екоактивістка. 


\section{Дух О.І., Цицюра Н.I., Галаган О.К.}

змін клімату як антропогенного явища, що виникає внаслідок збільшення викидів парникових газів. Розвиваються пізнавальні, емоційні та поведінкові компетентності.

Хорошою новацією у впровадженні ігрових технологій навчання є створення комп'ютерних багатокористувацьких версій екологічних ігор. Наприклад, Keep Cool Mobile, яка $є$ аналогом настільної гри Keep Cool, має низку оновлених можливостей, дає змогу працювати із 50 гравцями одночасно та надає динамічний досвід. Звісно, потрібно враховувати,

\section{ОСОБАИВОСТІ ФОРМУВАННЯ...}

що ефективність освітнього аспекту цих ігор значною мірою буде залежати від фасилітатора.

Головні висновки. Ефективне формування у студентської молоді знань про зміни клімату пропонуємо здійснювати через організацію еколого-просвітницьких центрів, упровадження в інформаційний простір закладу вищої освіти концепції «Zero Waste», інтеграцію питань зміни клімату у зміст компонент освітніх програм, співпрацю екоорганізацій та закладів освіти, використання екологічних ігор із просвітницькою метою.

\section{Література}

1. Шевченко О. Проблема глобальної зміни клімату в контексті міжнародної безпеки Актуальні проблеми міжнародних відносин. 2017. Вип. 130. С. 24-38.

2. Climate change education for sustainable development: the UNESCO climate change initiative. 2010. 19 p. URL: https://unesdoc.unesco.org/ark:/48223/pf0000190101/ (дата звернення: 27.11.2021).

3. Екологічна освіта має стати основним компонентом навчальних програм усіх країн до 2025 року/ Профспілка працівників освіти і науки України URL: https://pon.org.ua/novyny/8746-ekologchna-osvta-maye-stati-osnovnim-komponentom-navchalnihprogram-ush-krayin-do-2025-roku.html (дата звернення: 27.11.2021).

4. UNESCO declares environmental education must be a core curriculum component by 2025/ UNESCO. URL: https://en.unesco. org/news/unesco-declares-environmental-education-must-be-core-curriculum-component-2025 (дата звернення: 27.11.2021).

5. Цілі сталого розвитку: Україна. Завдання та індикатори. Міністерство економічного розвитку і торгівлі України. URL: https://www.undp.org/content/dam/ukraine/docs/SDGreports/SDG\%20leaflet\%20ukr_F.pdf (дата звернення: 27.11.2021).

6. U.S. Global Change Research Program. Climate literacy: The essential principles of climate sciences. Washington, DC: U.S. Global Change Research Program. 2009. URL: http://www.globalchange.gov/resources/educators/climate-literacy (дата звернення: 27.11.2021).

7. Martha C. Monroe, Richard R. Plate, Annie Oxarart, et al. Chaves Identifying effective climate change education strategies: a systematic review of the research. Environmental Education Research. 2019. N 25:6, P. 791-812.

8. Leuzinger S., Borrelle S.B., Jarvis R. M. Improving Climate-Change Literacy and Science Communication Through Smart Device Apps. Front. Educ. 2019. V 4. P. 138.

9. Hestness E., McDonald R. C., Breslyn W. et al. Science Teacher Professional Development in Climate Change Education Informed by the Next Generation Science Standards. Journal of Geoscience Education. 2014. N 62 (3). 319-329.

10. Li C. J., Monroe M. C., Oxarart A., Ritchie T. Building teachers' self-efficacy in teaching about climate change through educative curriculum and professional development. Applied Environmental Education \& Communication. 2021. N 20 (1). 34-48.

11. Bush D., Sieber R., Seiler G., Chandler M. University level teaching of Anthropo-genic climate change via student inquiry. Studies in Science Education. 2017. 53(2). P. 113-136.

12. Bush D., Sieber R., Seiler G., Chandle, M.. Examining educational climate change technology: How group inquiry work with realistic scientific technology alters classroom learning. Journal of Science Education and Technology. 2018. 27(2). $147-164$.

13. Leal Filh, W., Sima M., Sharif, A. et al. Handling climate change education at universities: an overview. Environ Sci Eur . 2021. N 33. P. 109. URL: https://doi.org/10.1186/s12302-021-00552-5 (дата звернення: 27.11.2021).

14. Халаїм О.О. Освіта з питань зміни клімату в університетах України та світу. Екологічна освіта для сталого розвитку з питань зміни клімату у дошкільній, середній, позашкільній та вищій освіті України. 2020. С. 15-19.

15. Закон України «Про Основні засади (стратегію) державної екологічної політики України на період до 2030 року» від 28.02.2019 № 2697-VIII /Верховна Рада України. URL: https://zakon.rada.gov.ua/laws/show/2697-19 (дата звернення: 27.11.2021).

16. Підготовка вчителів до викладання питань сталого розвитку. Навчально-методичні матеріали для викладачів вищих педагогічних навчальних закладів та системи після дипломної педагогічної освіти: посібник / О.І. Пометун та ін. Київ : Педагогічна думка, 2015. 120 с. 


\section{ВIДОМОСТI ПРО АВТОРIB}

Андрійчук Тамара В'ячеславівна (Житомир) - кандидат біологічних наук, старший викладач кафедри екології та географії, Житомирський державний університет імені Івана Франка;

Батальцев Євген Володимирович (Суми) - кандидат технічних наук, асистент кафедри екології та природозахисних технологій, Сумський державний університет;

Безпальченко Віолета Михайлівна (Херсон) - кандидат хімічних наук, доцент, доцент кафедри хімії, екології та безпеки життєдіяльності, Херсонський національний технічний університет;

Блінова Наталія Костянтинівна (Сєвєродонецьк) - кандидат біологічних наук, доцент, доцент кафедри хімічної інженерії та екології, Східноукраїнський національний університет імені Володимира Даля;

Богатко Надія Михайлівна (Біла Церква) - доктор ветеринарних наук, завідувач кафедри ветеринарносанітарної експертизи та лабораторної діагностики, Інститут післядипломного навчання керівників і спеціалістів ветеринарної медицини Білоцерківського національного аграрного університету;

Бондар Олександр Іванович (Київ) - доктор біологічних наук, член-кореспондент Національної академії аграрних наук України, заслужений діяч науки і техніки України, Державна екологічна академія післядипломної освіти та управління;

Борецька Ірина Юріївна (Львів) - аспірантка кафедри екології, Львівський національний університет імені Івана Франка;

Борисюк Борис Васильович (Житомир) - кандидат сільськогосподарських наук, доцент, доцент кафедри загальної екології, Поліський національний університет;

Вербицький Сергій Тарасович (Львів) - кандидат фізико-математичних наук, провідний науковий співробітник, завідувач відділу сейсмічності Карпатського регіону, Інститут геофізики імені С. І. Субботіна Національної академії аграрних наук України;

Власенко Руслана Петрівна (Житомир) - доцент кафедри екології та географії, Житомирський державний університет імені Івана Франка;

Володько Дар'я Анатоліївна (Кам'янське) - здобувач освіти другого (магістерського) рівня, Дніпровський державний технічний університет;

Вольвач Оксана Василівна (Одеса) - кандидат географічних наук, доцент, доцент кафедри агрометеорології та агроекології, Одеський державний екологічний університет;

Гаєвський Валерій Ростиславович (Рівне) - кандидат технічних наук, доцент кафедри хімії та фізики, Національний університет водного господарства та природокористування;

Галаган Оксана Костянтинівна (Кременець) - кандидат біологічних наук доцент кафедри біології, екології та методик їх навчання, Кременецька обласна гуманітарно-педагогічна академія імені Тараса Шевченка;

Гарбар Діана Анатоліївна (Житомир) - кандидат біологічних наук, доцент кафедри екології та географії, Житомирський державний університет імені Івана Франка;

Гах Тетяна Олександрівна (Полтава) - аспірант, Національний університет «Полтавська політехніка імені Юрія Кондратюка»;

Герасимчук Олена Леонтіївна (Житомир) - кандидат педагогічних наук, доцент кафедри екології, Державний університет «Житомирська політехніка»;

Герман Наталія Володимирівна (Рівне) - кандидат педагогічних наук, доцент, професор кафедри екології, географії і туризму, Рівненський державний гуманітарний університет;

Гілета Любов Андріївна (Львів) - кандидат географічних наук, викладач-методист, Відокремлений структурний підрозділ «Педагогічний фаховий коледж Львівського національного університету імені Івана Франка»;

Глодова Любов Михайлівна (Косів) - науковий співробітник лабораторії екологічного моніторингу, Національний природний парк «Гуцульщина»;

Голік Юрій Степанович (Полтава) - кандидат технічних наук, професор університету, завідувач кафедри теплогазопостачання, вентиляції та теплоенергетики, Національний університет «Полтавська політехніка імені Юрія Кондратюка»;

Гриневич Наталія Євгеніївна (Біла Церква) - доктор ветеринарних наук, професор, завідувач кафедри іхтіології та зоології, Білоцерківський національний аграрних університет;

Груша Михайло Михайлович (Київ) - кандидат біологічних наук, доцент кафедри біології, Національний медичний університет імені О. О. Богомольця;

Гунько Світлана Олександрівна (Кам'янське) - кандидат біологічних наук, доцент кафедри екології та охорони навколишнього середовища, Дніпровський державний технічний університет; 
Джумеля Ельвіра Анатоліївна (Львів) - доктор філософії, асистент кафедри програмного забезпечення, Національний університет «Львівська політехніка»;

Джура Наталія Миронівна (Львів) - кандидат біологічних наук, доцент, доцент кафедри екології, Львівський національний університет імені Івана Франка;

Димань Тетяна Миколаївна (Біла Церква) - доктор сільськогосподарських наук, професор кафедри загальної екології та екотрофології, Білоцерківський національний аграрний університет;

Дух Ольга Ігорівна (Кременець) - кандидат біологічних наук доцент кафедри біології, екології та методик їх навчання, Кременецька обласна гуманітарно-педагогічна академія імені Тараса Шевченка;

Дячок Василь Володимирович (Львів) -доктор технічних наук, професор, професор кафедри екології та збалансованого природокористування, Інститут сталого розвитку імені В'ячеслава Чорновола Національного університету «Львівська Політехніка»;

Свтєєва Любов Іванівна (Київ) - кандидат технічних наук, старший викладач, Національний технічний університет України «Київський політехнічний інститут імені Ігоря Сікорського»;

Сльнікова Тетяна Олександрівна (Житомир) - кандидат технічних наук, доцент кафедри екології, Державний університет «Житомирська політехніка»;

Жиленко Тетяна Іванівна (Суми) - кандидат фізико-математичних наук, доцент, доцент кафедри математичного аналізу та методів оптимізації, Сумський державний університет;

Жолобенко Наталя Юріївна (Миколаїв) - здобувач кафедри техногенної та цивільної безпеки, Національний університет кораблебудування імені адмірала Макарова;

Загоруй Людмила Петрівна (Біла Церква) - кандидат ветеринарних наук, доцент кафедри харчових технологій і технологій переробки продукції тваринництва, Білоцерківський національний аграрний університет;

Закорчевна Наталя Борисівна (Київ) - кандидат економічних наук, завідувачка кафедри водних екосистем і біоресурсів, Державна екологічна академія післядипломної освіти та управління;

Захаренко Микола Олександрович (Київ) - доктор біологічних наук, професор, членкореспондент Національної академії аграрних наук України, професор кафедри ветеринарної гігієни імені професора А. К. Скороходька, Національний університет біоресурсів і природокористування України;

Зубровська Ольга Миколаївна (Кривий Ріг) - кандидат біологічних наук, науковий співробітник відділу природної та культурної флори, Криворізький ботанічний сад Національної академії наук України;

Іващенко Ірина Вікторівна (Житомир) - кандидат біологічних наук, доцент, доцент кафедри захисту рослин, Поліський національний університет;

Ігнатишин Адальберт Васильович (Львів) - інженер відділу сейсмічності Карпатського регіону, Інститут геофізики імені С. І. Субботіна Національної академії наук України;

Ігнатишин Василь Васильович (Львів) - кандидат фізико-математичних наук, старший науковий співробітник відділу сейсмічності Карпатського регіону, Інститут геофізики імені С. І. Субботіна Національної академії наук України, доцент кафедри географії та туризму, Закарпатський угорський інститут імені Ференца Ракоці II;

Ігнатишин Моніка Бейлівна (Львів) - провідний інженер відділу сейсмічності Карпатського регіону, Інститут геофізики імені С. І. Субботіна Національної академії наук України;

Іжак Тібор Йосипович (Берегове) - кандидат географічних наук, $\mathrm{PhD}$, доцент кафедри географії та туризму, Закарпатський угорський інститут імені Ференца Ракоці II;

Ісмагілова Анастасія Євгеніївна (Кам'янське) - магістр кафедри екології та охорони навколишнього середовища, Дніпровський державний технічний університет;

Клименко Тетяна Карлівна (Кам'янське) - доцент, доцент кафедри екології та охорони навколишнього середовища, Дніпровський державний технічний університет;

Клімкіна Ірина Іванівна (Дніпро) - кандидат біологічних наук, доцент кафедри екології та технологій захисту навколишнього середовища, Національний технічний університет «Дніпровська Політехніка»;

Ковров Олександр Станіславович (Дніпро) - доктор технічних наук, професор кафедри екології та технологій захисту навколишнього середовища, Національний технічний університет «Дніпровська Політехніка»;

Козій Іван Сергійович (Суми) - кандидат технічних наук, доцент, докторант кафедри екології та природозахисних технологій, Сумський державний університет;

Колісник Алла Вікторівна (Одеса) - кандидат географічних наук, доцент кафедри екології та охорони довкілля, Одеський державний екологічний університет;

Костюк Віталій Степанович (Житомир) - кандидат біологічних наук, старший викладач кафедри екології та географії, Житомирський державний університет імені Івана Франка;

Котюк Людмила Анатоліївна (Житомир) - доктор біологічних наук, доцент, завідувач кафедри загальної екології, Поліський національний університет; 
Кофанова Олена Вікторівна (Київ) - доктор педагогічних наук, кандидат хімічних наук, професор, Національний технічний університет України «Київський політехнічний інститут імені Ігоря Сікорського»;

Коцар Олена Михайлівна (Київ) - кандидат технічних наук, академік Міжнародної Академії Природничих наук в м. Ганновері (Німеччина), Український науково-інженерний центр Потенціал-4;

Коцюба Ірина Григорівна (Житомир) - доктор технічних наук, доцент кафедри екології, Державний університет «Житомирська політехніка»;

Кочмарський Володимир Зіновійович (Рівне) - кандидат фізико-математичних наук, професор кафедри гідроенергетики, теплоенергетики та гідравлічних машин, Національний університет водного господарства та природокористування;

Красовський Володимир Васильович (Хорол) - кандидат біологічних наук, старший науковий співробітник, директор, Хорольський ботанічний сад;

Красовський Сергій Анатолійович (Дніпро) - аспірант кафедри екології та технологій захисту навколишнього середовища, Національний технічний університет «Дніпровська політехніка»;

Кречківська Галина Володимирівна (Дрогобич) - кандидат біологічних наук, доцент кафедри біології та хімії, Дрогобицький державний педагогічний університет імені Івана Франка;

Крилова Ірина Іванівна (Київ) - кандидат юридичних наук, доктор наук державного управління, професор кафедри водних екосистем і біоресурсів, Державна екологічна академія післядипломної освіти та управління;

Крот Ольга Петрівна (Харків) - доктор технічних наук, доцент кафедри безпеки життедіяльності та інженерної екології, Харківський національний університет будівництва та архітектури;

Кудіна Софія Володимирівна (Київ) - студентка IV курсу факультету хімічних та біофармцевтичних технологій, Київський національний університет технологій та дизайну;

Кузнсцов Сергій Іванович (Херсон) - кандидат технічних наук, доцент кафедри хімії, екології та безпеки життедіяльності, Херсонський національний технічний університет;

Курбатова Інна Миколаївна (Київ) - доктор біологічних наук, доцент, професор кафедри біології тварин, Національний університет біоресурсів і природокористування України;

Курилюк Микола Степанович (Київ) - доктор біологічних наук, академік Української технологічної академії, асоційованої при ЮНЕСКО, науковий співробітник, Державна екологічна академія післядипломної освіти та управління;

Кущенко Лілія Вікторівна (Одеса) - здобувач наукового ступеня $\mathrm{PhD}$, Одеський державний екологічний університет;

Лазарєв Свген Сергійович (Київ) - студент VI курсу теплоенергетичного факультету, Національний технічний університет України «Київський політехнічний інститут імені Ігоря Сікорського»

Ластовецька Людмила Олегівна (Київ) - студентка IV курсу факультету хімічних та біофармцевтичних технологій, Київський національний університет технологій та дизайну;

Лефтер Юлія Олександрівна (Житомир) - аспірант кафедри екології, Державний університет «Житомирська політехніка»;

Лі Цзюнь (Рівне - Шаньдун, КНР) - науково-технічний консультант, член-кореспондент Української технологічної академії (УТА), асоційованої при ЮНЕСКО, Дослідне підприємство «ВОДЕНЬ».

Луцишин Олена Зіновіївна (Львів) - кандидат географічних наук, викладач вищої категорії, Відокремлений структурний підрозділ «Педагогічний фаховий коледж Львівського національного університету імені Івана Франка»;

Мазур Тетяна Григорівна (Біла Церква) - кандидат ветеринарних наук, доцент кафедри загальної екології та екотрофології, Білоцерківський національний аграрний університет;

Макаренко Наталія Олексіївна (Суми) - провідний фахівець кафедри екології та природозахисних технологій, Сумський державний університет;

Малєєв Володимир Олексійович (Херсон) - кандидат сільськогосподарських наук, доцент, доцент кафедри хімії, екології та безпеки життєдіяльності, Херсонський національний технічний університет;

Малицький Дмитро Васильович (Львів) - доктор фізико-математичних наук, професор, завідувач відділу, Карпатське відділення Інституту геофізики імені С. І. Субботіна Національної академії наук України;

Маркіна Людмила Миколаївна (Миколаїв) - доктор технічних наук, професор, завідувачка кафедри техногенної та цивільної безпеки, Національний університет кораблебудування імені адмірала Макарова;

Маслак Валерія Ігоревна (Київ) - студентка IV курсу факультету хімічних та біофармцевтичних технологій, Київський національний університет технологій та дизайну;

Матіс Євгенія Олегівна (Харків) - здобувач зі спеціальності 183 Технології захисту навколишнього середовища, Харківський національний університет будівництва та архітектури;

Медведсв Олександр Валентинович (Львів) - провідний інженер-конструктор, Філія «Науково-дослідний інститут автомобілебудування «Еталон»; 
Нонік Людмила Юріївна (Житомир) - аспірант кафедри екології, Державний університет «Житомирська політехніка»;

Овчарук Валерія Анатоліївна (Одеса) - доктор географічних наук, доцент, директор науковонавчального гідрометеорологічного інституту, доцент кафедри гідрології суші, Одеський державний екологічний університет;

Остапенко Павло Олегович (Київ) - кандидат географічних наук, голова, Громадська організація «Товариство дослідників України»;

Павлишак Ярослава Ярославівна (Дрогобич) - кандидат сільськогосподарських наук, доцент кафедри біології та хімії, Дрогобицький державний педагогічний університет імені Івана Франка;

Паславський Михайло Михайлович (Львів) - кандидат технічних наук, асистент кафедри інформаційних технологій, Національний лісотехнічний університет України;

Плахтіна Оксана Ігорівна (Миколаїв) - бакалавр, Національний університет кораблебудування імені адмірала Макарова;

Польовий Анатолій Миколайович (Одеса) - доктор географічних наук, професор, академік Академії наук вищої школи ВШ України, завідувач кафедрою агрометеорології та агроекології, Одеський державний екологічний університет;

Прекрасна Євгенія Петрівна - кандидат біологічних наук, старший науковий співробітник, Державна установа «Національний Науковий Антарктичний центр»;

Рахметов Джмал Бахлул огли (Київ) - доктор сільськогосподарських наук, професор, заступник директора з наукової роботи (інноваційний розвиток), Національний ботанічний сад імені М. М. Гришка Національної академії наук України;

Романенко Олександр Вікторович (Київ) - доктор біологічних наук, професор, завідувач кафедри біології, Національний медичний університет імені О. О. Богомольця;

Романюк Ольга Іванівна (Львів) - кандидат хімічних наук, старший науковий співробітник, Відділення фізико-хімії горючих копалин Інституту фізико-органічної хімії і вуглехімії імені Л. М. Литвиненка Національної академії наук України;

Руда Марія Віталіївна (Львів) - кандидат технічних наук, доцент кафедри екологічної безпеки та природоохоронної діяльності, Національний університет «Львівська політехніка»;

Русин Ірина Богданівна (Львів) - кандидат біологічних наук, доцент, докторант кафедри екології та збалансованого природокористування, Інститут сталого розвитку імені В'ячеслава Чорновола Національного університету «Львівська Політехніка»;

Сараненко Інна Іванівна (Херсон) - кандидатка біологічних наук, доцентка, доцент кафедри географії та екології факультету біології, географії та екології, Херсонський державний університет;

Семенченко Оксана Олександрівна (Херсон) - кандидат технічних наук, доцент, доцент кафедри хімії, екології та безпеки життєдіяльності, Херсонський національний технічний університет;

Скарга Вікторія Вікторівна (Сєвєродонецьк) - завідувач навчальної лабораторії дисциплін професійного циклу підготовки, Східноукраїнський національний університет імені Володимира Даля;

Смоляр Наталія Олексіївна (Полтава) - кандидат біологічних наук, доцент кафедри прикладної екології та природокористування, Національний університет «Полтавська політехніка імені Юрія Кондратюка»;

Степова Олена Валеріївна (Полтава)- доктор технічних наук, доцент, завідувач кафедри прикладної екології та природокористування, Національний університет «Полтавська політехніка імені Юрія Кондратюка»;

Толмачова Алла Вікторівна (Одеса) - кандидат географічних наук, завідувач лабораторії грунтознавства та екології рослин, Одеський державний екологічний університет;

Трунова Інна Олександрівна (Суми) - кандидат технічних наук, доцент, доцент кафедри екології та природозахисних технологій, Сумський державний університет;

Тупицька Ольга Миколаївна (Київ) - кандидат біологічних наук, доцент, доцент кафедри біохімії і фізіології тварин імені акаденіка М. Ф. Гулого, Національний університет біоресурсів і природокористування України;

Тягній Людмила Михайлівна (Полтава) - аспірант, Національний університет «Полтавська політехніка імені Юрія Кондратюка»;

Ушкац Світлана Юріївна (Миколаїв) - кандидат фізико-математичних наук, викладач кафедри техногенної та цивільної безпеки, Національний університет кораблебудування імені адмірала Макарова;

Фатесв Антон Ігорович (Київ) - кандидат технічних наук, старший науковий співробітник відділу енерготехнологічного використання твердого палива, Інститут теплоенергетичних технологій Національної академії наук України;

Филипчук Віктор Леонідович (Рівне) - доктор технічних наук, професор кафедри охорони праці та безпеки життєдіяльності, Національний університет водного господарства та природокористування; 
Филипчук Віктор Леонідович (Рівне) - доктор технічних наук, професор кафедри охорони праці та безпеки життедіяльності, Національний університет водного господарства та природокористування;

Філатьєва Ельвіра Миколаївна (Сєвєродонецьк) - здобувач, Східноукраїнський національний університет імені Володимира Даля;

Хом'як Іван Владиславович (Житомир) - кандидат біологічних наук, доцент кафедри екології та географії, Житомирський державний університет імені Івана Франка;

Цицюра Неля Іванівна (Кременець) - кандидат біологічних наук доцент кафедри біології, екології та методик їх навчання, Кременецька обласна гуманітарно-педагогічна академія імені Тараса Шевченка;

Чепель Алла Євгеніївна (Київ) - аспірантка, Національний технічний університет України «Київський політехнічний інститут імені Ігоря Сікорського»;

Чепурко Юлія Володимирівна (Полтава) - аспірантка кафедри прикладної екології та природокористування, Національний університет «Полтавська політехніка імені Юрія Кондратюка»;

Черняк Таїсія Василівна (Хорол) - завідувач сектору дендрології, розмноження рослин та еколого-освітньої діяльності, науковий співробітник, Хорольський ботанічний сад;

Шадура Ксенія Олександрівна (Херсон) - здобувачка ступеня вищої освіти «бакалавр», спеціальності 101 Екологія 4 року навчання факультету біології, географії та екології, Херсонський державний університет;

Шибанова Алла Миколаївна (Львів) - кандидат технічних наук, доцент, доцент кафедри екологічної безпеки та природоохоронної діяльності, Національний університет «Львівська політехніка»;

Юнгін Ольга Серігївна (Київ) - кандидат біологічних наук, доцент кафедри біотехнології шкіри та хутра, Київський національний університет технологій та дизайну

Ясинецький Андрій Олексійович (Київ) - кандидат технічних наук, старший науковий співробітник відділу екологічних проблем енергетики, Інститут теплоенергетичних технологій Національної академії наук України. 
HOTATKU 
Наукове видання

\section{ЕКОЛОГІЧНІ НАУКИ}

- Екологія і виробництво

- Екологія водних ресурсів

- Екологія та економіка природних ресурсів

- Теоретична екологія

- Біологічна безпека

- Загальні проблеми екологічної безпеки

- Зміна клімату

- Поводження з відходами

- Природно-заповідний фонд України

- Збереження біологічного та ландшафтного різноманіття

- Інноваційні аспекти підвищення екологічної безпеки

- Освіта для сталого розвитку

Адреса редакції:

Державна екологічна академія післядипломної освіти та управління вул. Митрополита Василя Липківського, 35, корпус 2, Київ, 03035; тел. +3809942867 00;

www.ecoj.dea.kiev.ua e-mail: info@ecoj.dea.kiev.ua

Видавничий дім «Гельветика»

Свідоцтво суб' єкта видавничої справи ДК № 6424 від 04.10.2018

Україна, 65101, м. Одеса, вул. Інглезі, 6/1

Тел. +38 (048) 70938 69, +38 (095) 93448 28, +38 (097) 7230608

E-mail: mailbox@helvetica.ua

Підписано до друку 26.11.2021. Формат 64х84/8.

Папір офсетний. Гарнітура Times New Roman. Цифровий друк.

Ум. друк. арк. 26,04. Тираж 100. Замовлення № 0222/045.

Ціна договірна. Віддруковано з готового оригінал-макета 